\title{
IUCN
}

Conservation and sustainable use of biodiversity in the islands and lagoons of northern Sri Lanka

Devaka Weerakoon, Sampath De A. Goonatilake, Tharanga Wijewickrama, Arjan Rajasuriya, Naalin Perera, Terney

Pradeep Kumara, Gyan De Silva, Sriyanie Miththapala and Ananda Mallawatantri

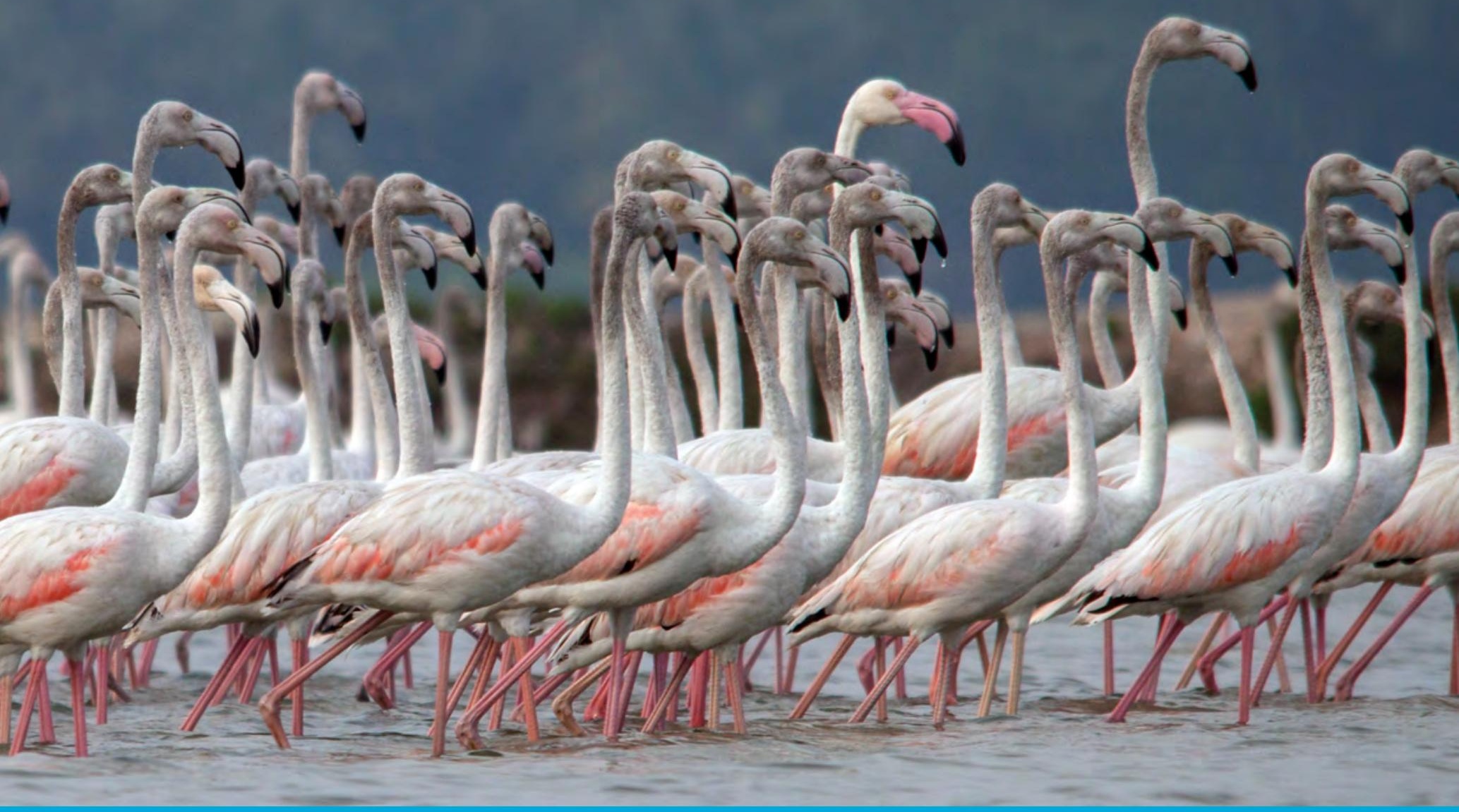

INTERNATIONAL UNION FOR CONSERVATION OF NATURE 



\section{Conservation and sustainable use of biodiversity in the islands and lagoons of northern Sri Lanka}

Devaka Weerakoon, Sampath De A. Goonatilake, Tharanga Wijewickrama, Arjan Rajasuriya, Naalin Perera, Terney

Pradeep Kumara, Gyan De Silva, Sriyanie Miththapala and Ananda Mallawatantri 
The designation of geographical entities in this book, and the presentation of the material, do not imply the expression of any opinion whatsoever on the part of MFF or IUCN concerning the legal status of any country, territory, or area, or of its authorities, or concerning the delimitation of its frontiers or boundaries.

The views expressed in this publication do not necessarily reflect those of MFF or IUCN.

MMF and IUCN are pleased to acknowledge the support of its Framework Partners who provide core funding: Ministry for Foreign Affairs of Finland; Government of France and the French Development Agency (AFD); the Ministry of Environment, Republic of Korea; the Norwegian Agency for Development Cooperation (Norad); the Swedish International Development Cooperation Agency (Sida); the Swiss Agency for Development and Cooperation (SDC) and the United States Department of State.

This publication has been produced by Mangroves for the Future (MFF) with the financial support of Sida, Norad, Danida and the Royal Norwegian Embassy in Thailand.

Published by: $\quad$ IUCN Sri Lanka Country Office, Colombo, Sri Lanka

Copyright: $\quad$ (c) 2020 IUCN, International Union for Conservation of Nature and Natural Resources

Reproduction of this publication for educational or other noncommercial purposes is authorized without prior written permission from the copyright holder provided the source is fully acknowledged.

Reproduction of this publication for resale or other commercial purposes is prohibited without prior written permission of the copyright holder.

Citation: Weerakoon, D., Goonatilake, S. De A., Wijewickrama, T., Rajasuriya, A., Perera, N., Kumara, T.P., De Silva, G., Miththapala, S. and Mallawatantri, A. (2020). Conservation and sustainable use of biodiversity in the islands and lagoons of northern Sri Lanka. Colombo, Sri Lanka: IUCN Sri Lanka Country Office. xx+330.

ISBN: $\quad$ 978-2-8317-2088-3 (PDF)

DOI: $\quad$ https://doi.org/10.2305/IUCN.CH.2020.18.en

Cover photograph: Greater flamingos (Phoenicopterus roseus), Mannar Island (๑ Niroshan Mirando

Available at: $\quad$ IUCN Sri Lanka

53, Horton Place

Colombo 7

Sri Lanka

www.iucn.org/srilanka

www.iucn.org/resources/publications 


\section{Table of contents}

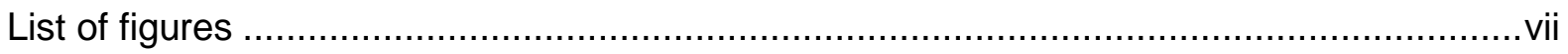

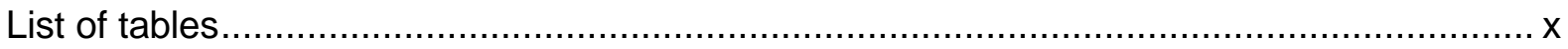

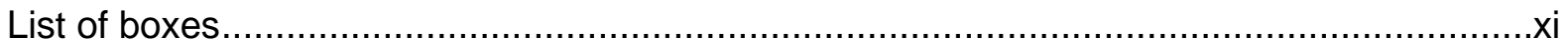

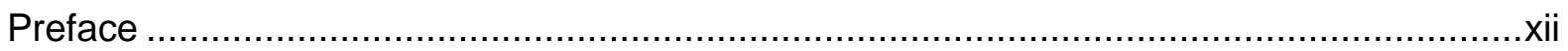

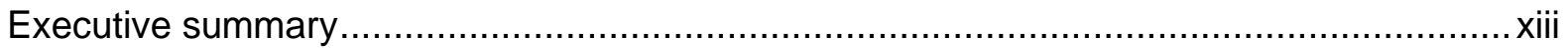

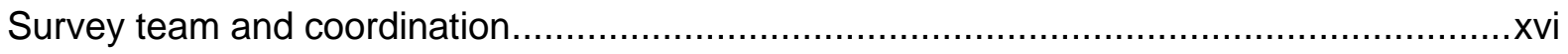

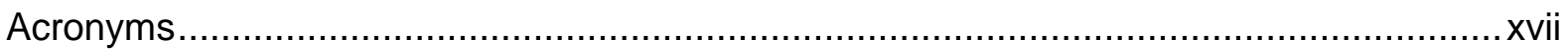

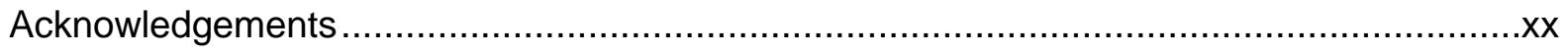

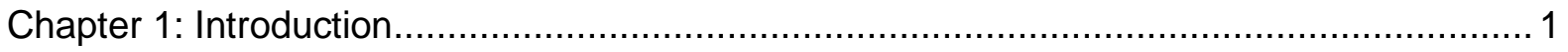

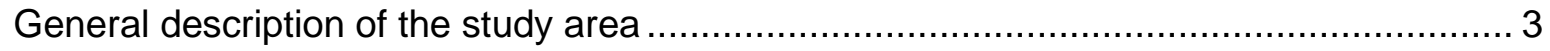

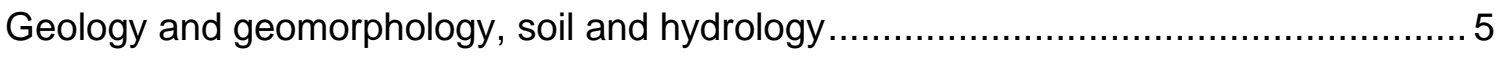

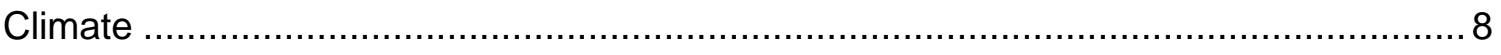

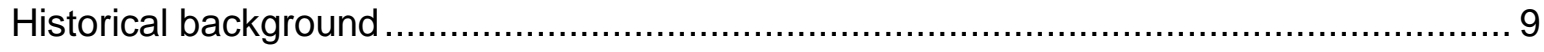

Area of paleontological and bio-geographical significance ................................... 9

Area of prehistoric human migration (Palaeolithic, Mesolithic and Megalithic) .............. 10

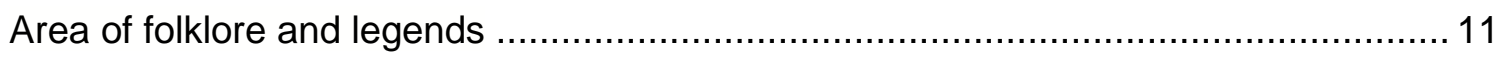

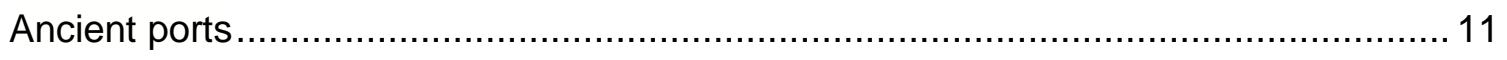

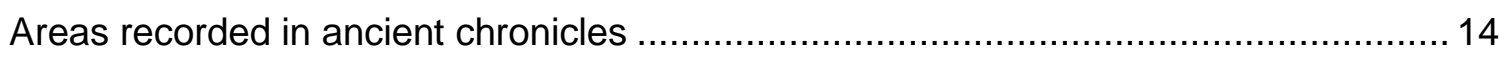

Areas of historical colonial ruins and buildings (Portuguese and Dutch Forts and

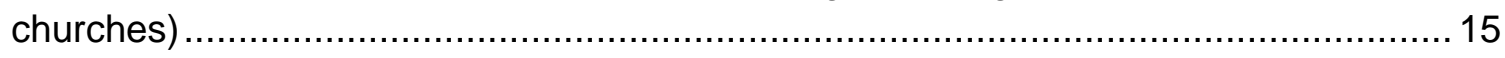

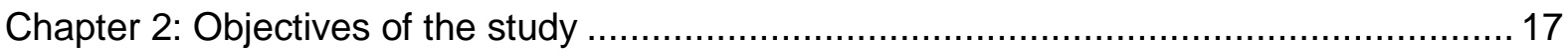

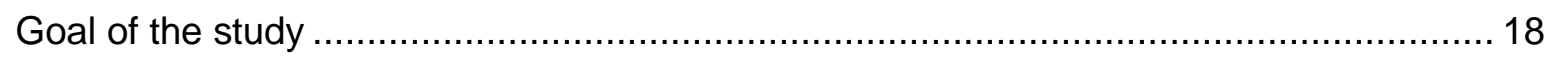

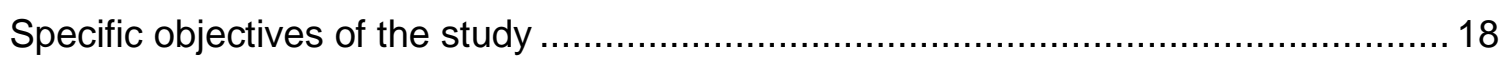

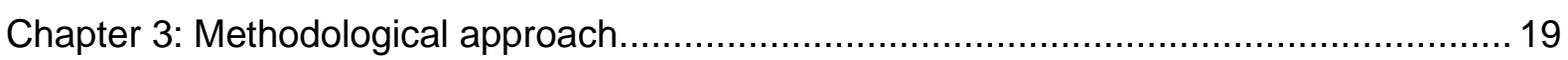

Methodology used for the terrestrial biodiversity survey ........................................ 20

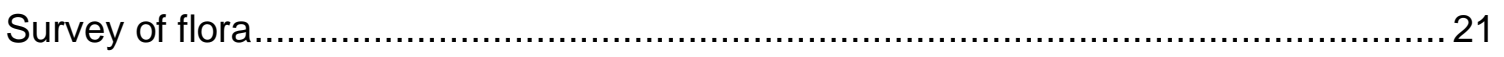

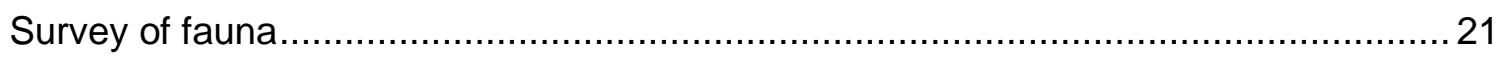

Methodology used for the marine biodiversity survey ........................................... 22

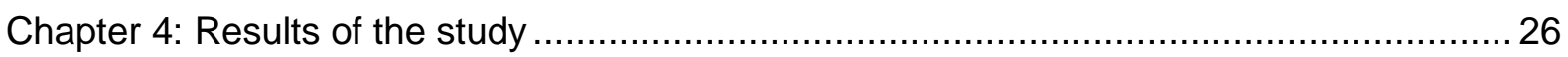

Ecosystem diversity in the study area........................................................... 27

Terrestrial and coastal ecosystem diversity ...................................................... 27 
Terrestrial species diversity 42

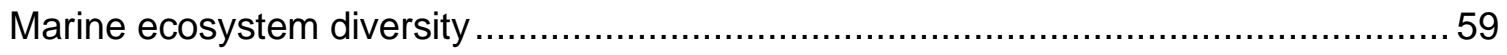

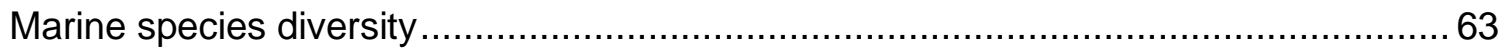

Chapter 5: Threats to natural resources and biodiversity in the study area ....................... 70

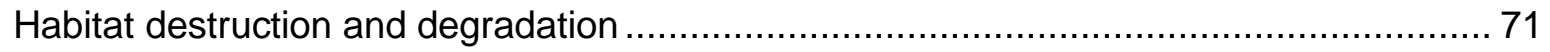

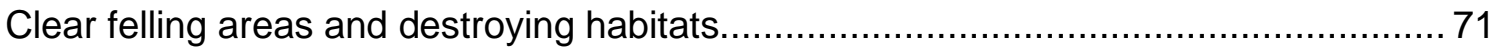

Changing the physical configuration of lagoons and estuaries ................................ 71

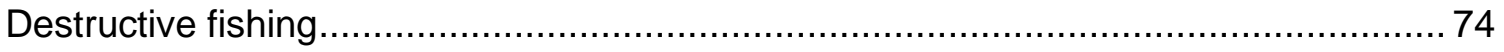

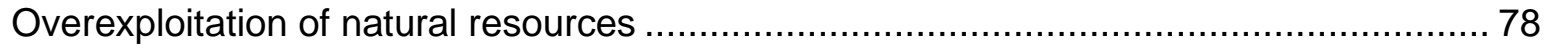

Pollution 87

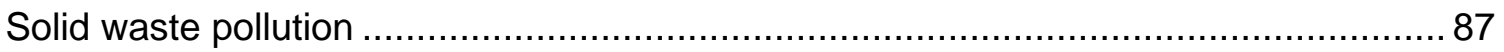

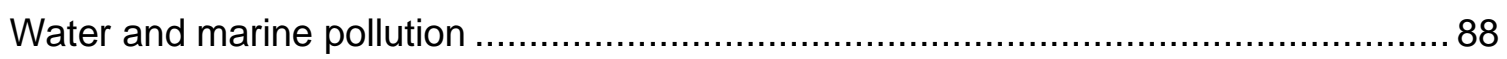

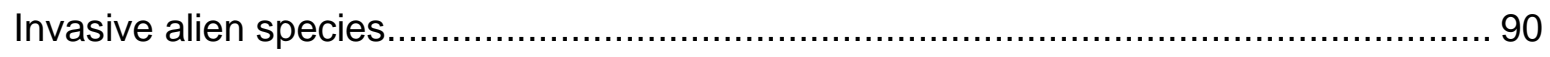

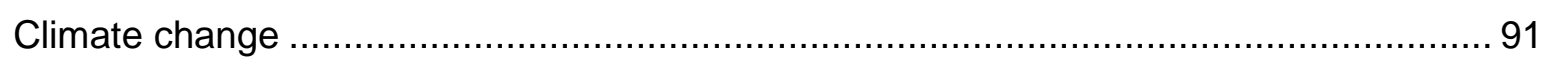

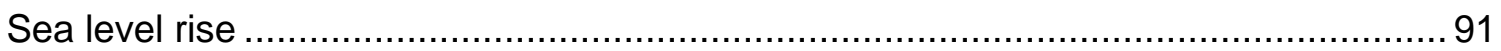

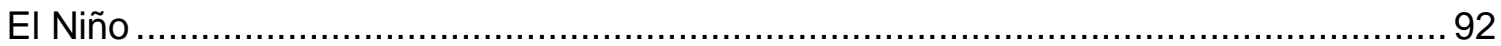

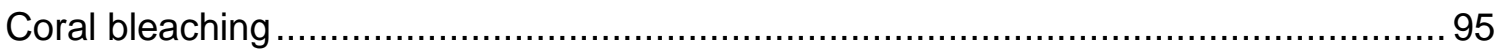

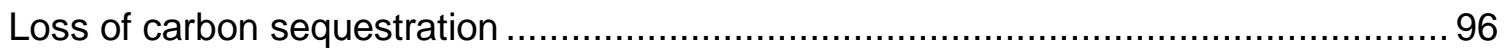

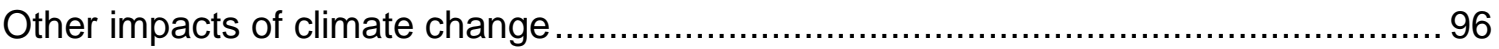

Chapter 6. Recommendations for the sustainable management of natural resources and the

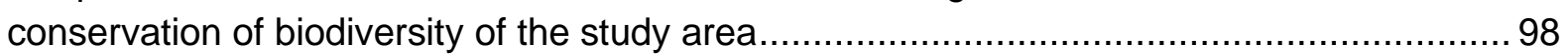

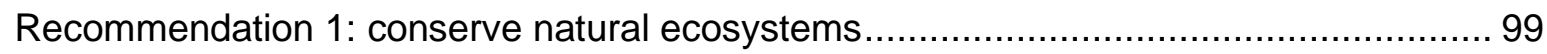

Recommendation 2: carry out further detailed studies of the biodiversity of the region.. 106

Recommendation 3: shift to an inter-sectoral approach to management....................... 107

Recommendation 4: manage solid waste and other forms of pollution......................... 108

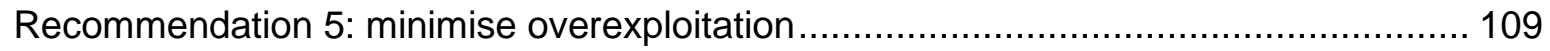

Recommendation 6: control invasive alien species (IAS) ..................................... 109

Recommendation 7: mitigate and adapt to climate change .................................... 111

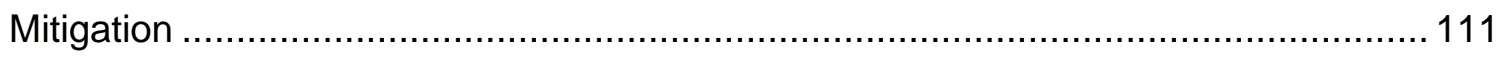

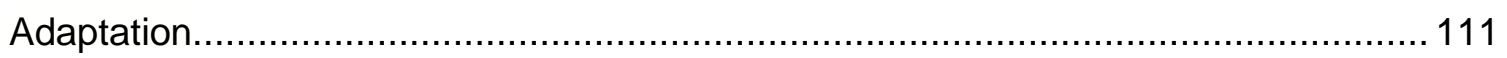

Recommendation 8: ensure adherence to environmental laws ................................. 112

Recommendation 9: carry out extensive awareness programmes about the area's natural wealth ......................................................................................... 113

Recommendation 10: ensure responsible tourism ............................................... 113

Prevent over-visitation and overexploitation .................................................. 114

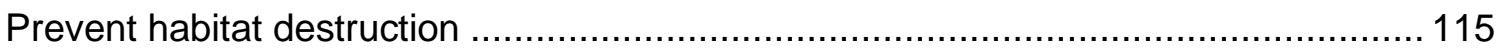

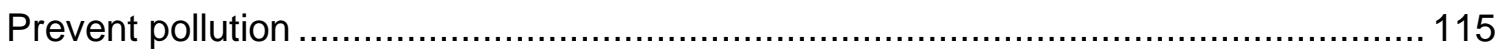


Prevent the spread of IAS 116

Use green building practices during construction ............................................. 116

Ensure mitigation and adaptation to climate change .......................................... 117

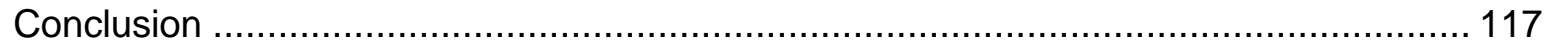

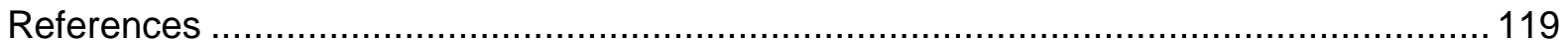

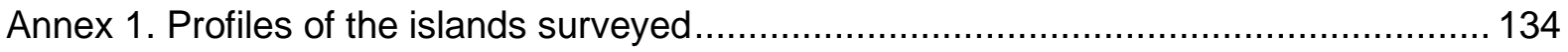

Analaitivu Island (Sinhala: Annaladoova; Dutch: Rotterdam) .................................... 135

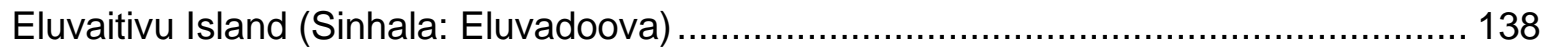

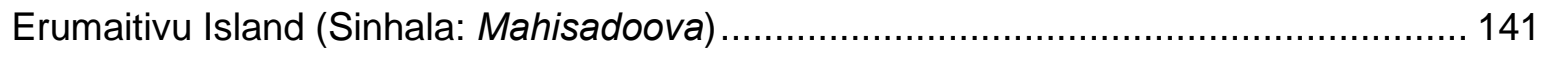

Iranaitivu North Island (Sinhala: Erandoowa; Dutch: Enkhuizen) .............................. 145

Iranaitivu South Island (Sinhala: Uoona Duwa; Dutch: Hoorn) ................................ 148

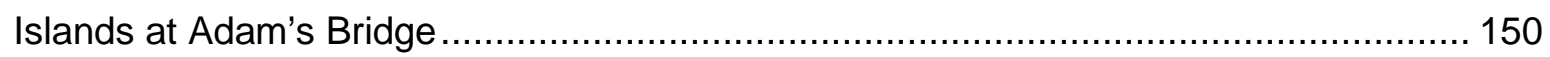

Kachchativu Island (Pali: Kachchatheetha; Sinhala: Kachchadoova)........................... 152

Kakerativu Island (Sinhala: Sakkaradoova; Dutch: Calienye) .................................... 155

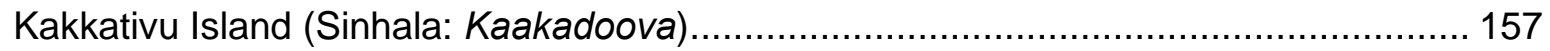

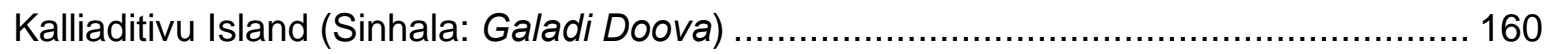

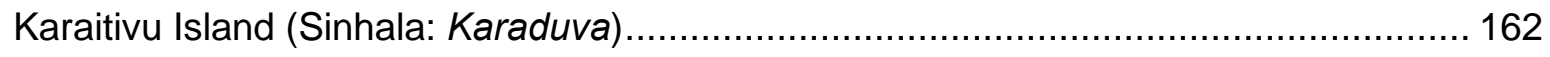

Kayts or Velanai Island (Sinhala: Uruthota or Bellana; Dutch: Leiden)........................ 165

Kurikadduwan Island (Sinhala: Kiralakatuvana) ............................................... 168

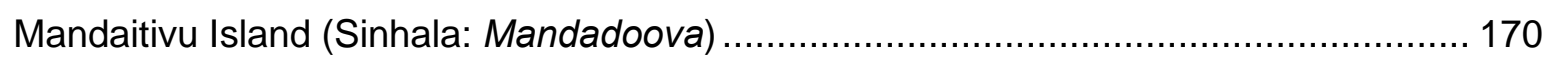

Mannar Island (Sinhala: Mannaram Doopatha, Tamil: Mannār) ................................. 173

Nainativu Island (Sinhala: Nagadeepa; Dutch: Haarlem) .......................................... 177

Neduntivu Island (Sinhala: Maedundoova; Dutch: Delft) ......................................... 179

Palaitivu Island (Sinhala: Paludoova; Dutch: Galue) ............................................ 182

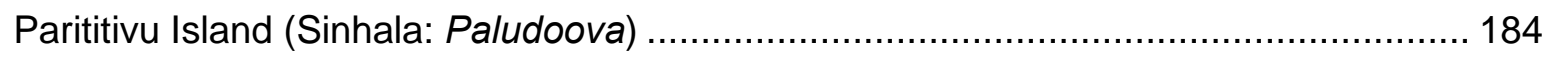

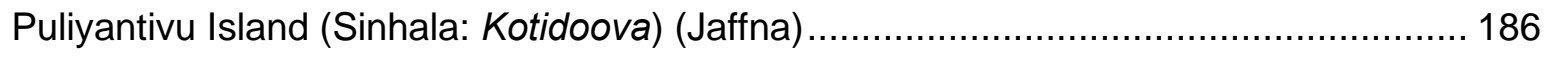

Puliyantivu Island (Sinhala: Kotidoova) (Mannar) ................................................. 188

Pungudutivu Island (Sinhala: Punguthdeepa; Dutch: Middleberg) .............................. 190

Annex 2. Profiles of coastal stretches surveyed ........................................................ 193

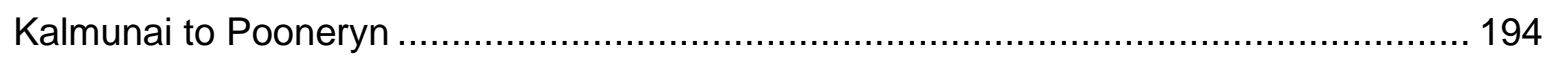

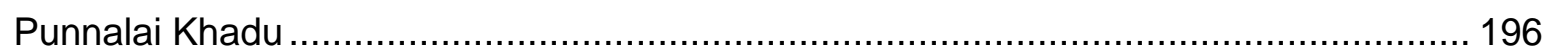

Northern coastal stretch of the Jaffna Peninsula (from Thiruvadinilayam - Dambakolapatuna

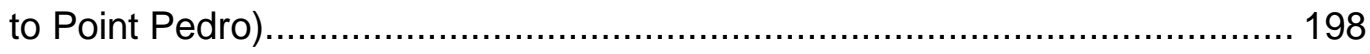

Eastern coastal stretch of the Jaffna Peninsula (Manatkadu to Chundikulam) ............... 202

North-east coast (between Chundikulam to Kokkiliai Lagoon) .................................. 204

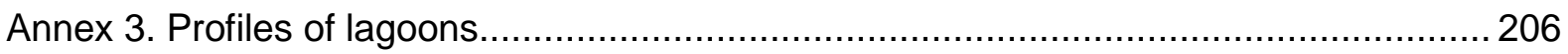

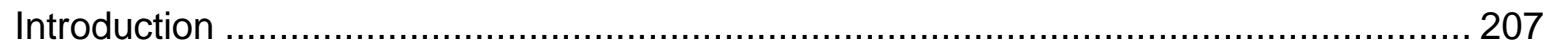




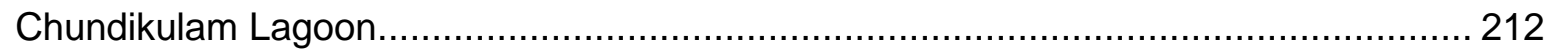

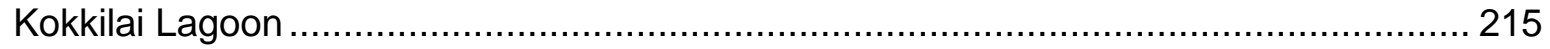

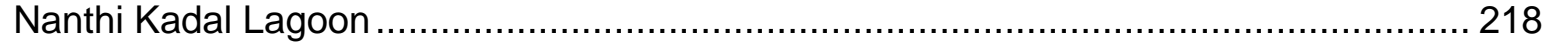

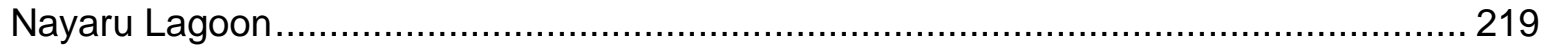

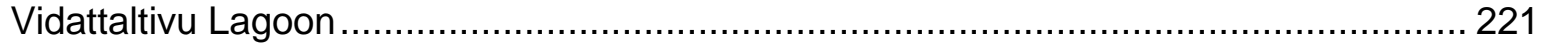

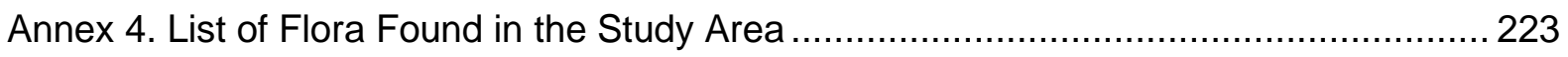

Annex 5. List of Fauna Found in the Study Area ........................................................ 261

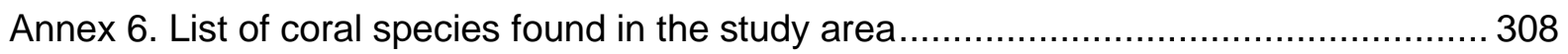

Annex 7. List of reef fish species found in the study area ............................................ 311

Annex 8. List of invertebrates recorded during the survey and beach collection from

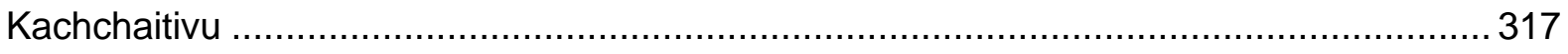

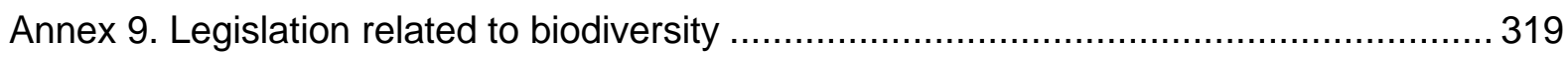




\section{List of figures}

Figure 1.Study area showing the islands in northern Sri Lanka ..................................... 4

Figure 2. The continental shelf and bathymetry around Sri Lanka .................................. 6

Figure 3. Adam's Bridge and its surrounds.................................................................. 7

Figure 4. The migration of megafauna to Sri Lanka, during the Pleistocene period ............. 10

Figure 5. Kudiremalai Point .................................................................................. 11

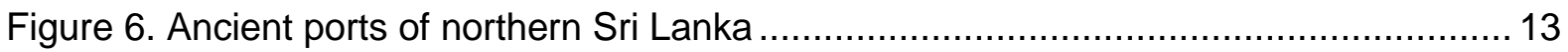

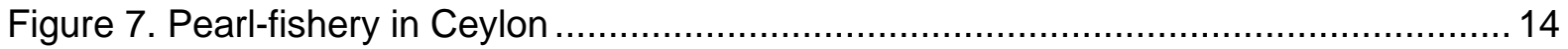

Figure 8. Sunset at Hammenhiel Fort, seen from Karaitivu .............................................. 16

Figure 9. Sunset over Jaffna Lagoon ................................................................... 18

Figure 10. Islands, coastal stretches and lagoons in the Northern Province, sampled during

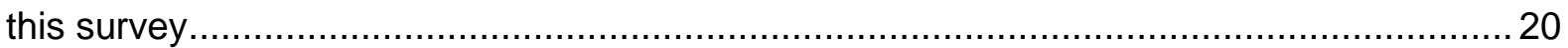

Figure 11. Coral reef areas sampled in Palk Bay and Palk Strait .................................... 23

Figure 12. Top: examining the island map, Iranaitivu South; bottom: field assessment

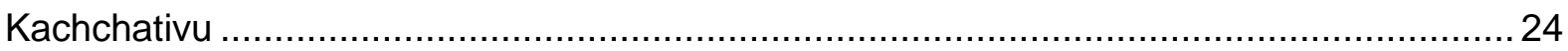

Figure 13. Top: the team disembarking at Palaitivu; bottom: returning from marine surveys 25

Figure 14. Top: arid mixed evergreen forests, Kakerativu Island; bottom: palmyra woodlands,

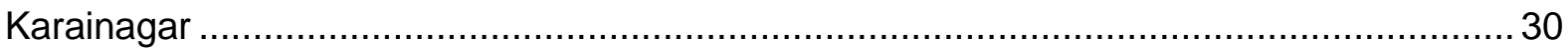

Figure 15. Top: beach front scrub, Kakerativu Island; bottom: coral rock and seashore

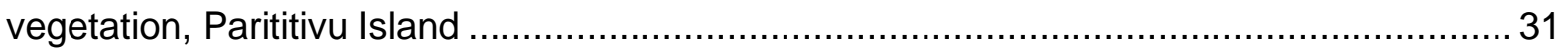

Figure 16. Top: sand dune scrub; bottom: sandy seashore vegetation............................ 33

Figure 17. Top: mangroves and associates, Puliyantivu Island; bottom: salt marshes, Kayts

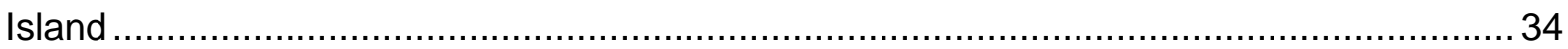
Figure 18. Top: mat of cyanobacteria in a tidal flat, Mannar Island; bottom; a common redshank (a common winter visitor) feeding on invertebrates on a submerged tidal flat, Mannar Island

Figure 19. Top: greater flamingo and Eurasian wigeon (both migrants), Kayts Lagoon; bottom:

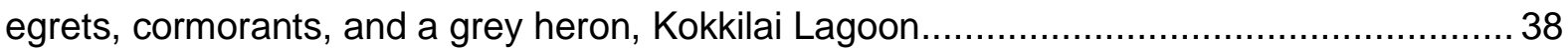
Figure 20. Top: wet pasture lands, Iranaitivu North Island; bottom: dry pasturelands, Punnalai

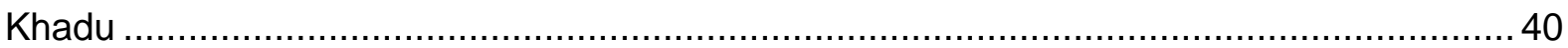

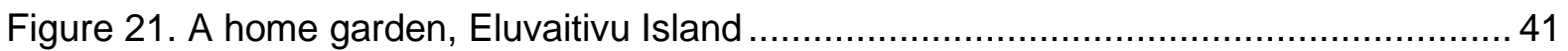

Figure 22. Map of terrestrial, marine and coastal ecosystems of the study area................. 41 Figure 23. Bay cedar (Suriana maritima) listed in the 2012 Red List as Critically Endangered,

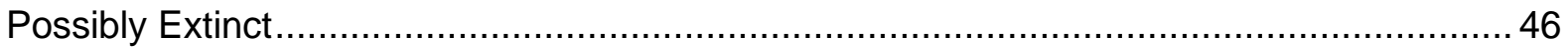
Figure 24.Top: octopus bush (Tournefortia argentea), an Endangered species; bottom: Sesamum prostratum listed as Critically Endangered ............................................... 47 Figure 25. Top: sea trumpet (Cordia subcordata), an Endangered species; bottom: beach gardenia (Guettarda speciosa), listed as Vulnerable ................................................ 48 Figure 26. Top: the ubiquitous palmyra (Borassus flabellifer); bottom: baobab (Adansonia digitata), protected by the Antiquities Ordinance ..................................................... 49 Figure 27. Top: Avicennia marina, the dominant mangrove species of the area, Mandaitivu; bottom: Suaeda maritima

Figure 28. Top: bright babul blue (Azanus ubaldus), a Critically Endangered species, restricted to the north and north-west of the island; bottom: large salmon Arab (Colotis fausta), listed as Vulnerable. 54 
Figure 29. Top: Sri Lankan chameleon (Chamaeleo zeylanicus); bottom: Bibron's sand skink

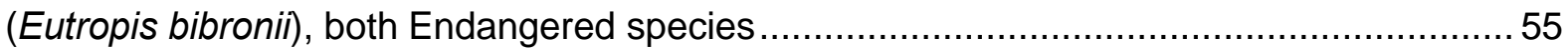

Figure 30. Top: Indian courser (Cursorius coromandelicus), a Critically Endangered species; bottom: Siberian stonechat (Saxicola maurus), a rare winter vagrant................................ 56

Figure 31. Top: crab-plover (Dromas ardeola); bottom: Indian spot-billed duck (Anas poecilorhyncha), both rare breeding residents of the northern region .............................5 57 Figure 32. Top: Delft ponies (Equus caballus); bottom: feral donkeys (Equus asinus)......... 58 Figure 33. Top: algae species Sargassum and Turbinaria spp.; bottom: soft coral Sarcophyton

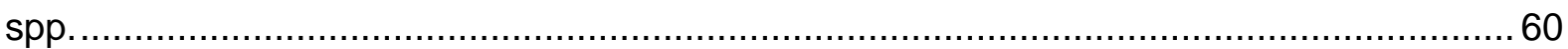

Figure 34. Top: branching coral (Acropora formosa), Kiranchi; bottom: foliose coral (Montipora aequituberculata), Palaitivu.

Figure 35. Top: massive coral (Platygyra sinensis), Iranaitivu; bottom: tabulate coral (Acropora latistella in the foreground and $A$. formosa in the background), Palaitivu...........................62 Figure 36. Top: coral reef, off Point Pedro; bottom: seagrass meadow, Vankalai, Gulf of Mannar 64

Figure 37. Top: Montipora hispida, Arippu; bottom: from left to right: Indo-Pacific sergent (Abudefduf vaiginensis), Indian vagabond butterflyfish (Chaetodon decussatus), blubberlip snapper (Lutjanus rivulatus), Andaman butterflyfish (Chaetodon andamanensis), Point Pedro 68

Figure 38. Top: melon-headed whale (Peponocephala electra); bottom: spinner dolphins (Stenella longirostris)

Figure 39. Top: road built across a mangrove ecosystem, Mandaitivu; bottom: mangroves

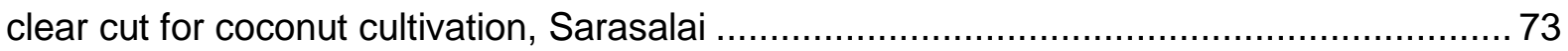

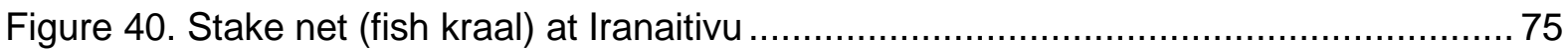

Figure 41. Stake net (fish kraal) fixed on reefs using metal pipes.................................. 76

Figure 42. Scuba diving equipment used for chank and sea cucumber harvesting ............. 77 Figure 43. Top: fisherman with a boat showing how propellers have damaged seagrasses, Mannar; bottom: fishermen using banned mono-filament nets, Vallaipadu ......................... 79 Figure 44. Top: a dead marine turtle, Casuarina Beach, Karainagar; bottom: discarded by-

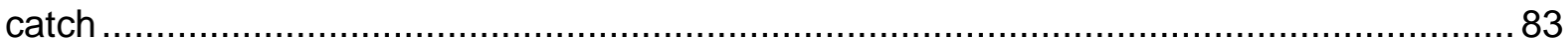

Figure 45. Top: discarded by-catch, including spider conchs, sea urchins and Murex shells;

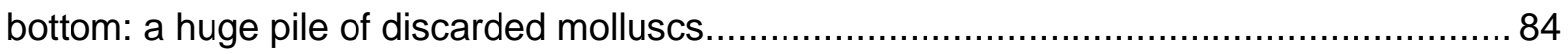

Figure 46. Top: a skin diver holding a sacred chank he has picked up, Vankalai, Mannar;

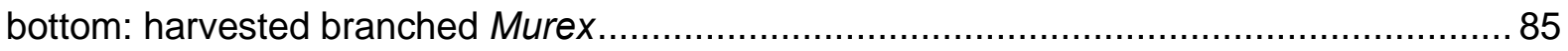

Figure 47. Top: killed dugong, caught off Battalangudu, photographed in Mollikulam; bottom: drying sea cucumbers, Pallimunai, Mannar .................................... 86 Figure 48. Top: solid waste pollution in seagrass meadows in the Gulf of Mannar; bottom: solid waste near Kora kulam, Mannar Island, where rare winter visitors are found ..................... 89 Figure 49. Top: mesquite (Prosopis juliflora) growing in Vankalai Sanctuary; bottom: feral dogs

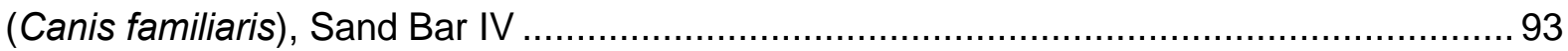

Figure 50. Top: a nesting brown noddy (Anous stolidus) on Sand Bar Island III; bottom: gullbilled tern (Sterna nilotica) in Iranaitivu, both rare breeding residents ............................. 94

Figure 51. Predicted sea level rise in northern Sri Lanka .............................................. 95

Figure 52. Map of existing conservation areas, areas proposed under the ISEA and areas

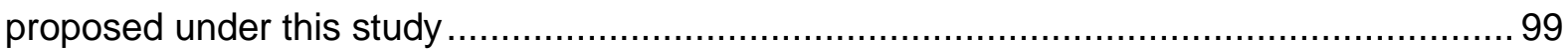

Figure 53. Diagram showing the different organisations and the different categories of areas

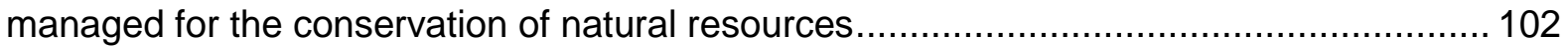

Figure 54. Top: fishermen, Kokkilai Lagoon; bottom: toddy tapping, Delft ....................... 118 
Figure 55. Map of Analaitivu Island, showing ecosystems, land use and

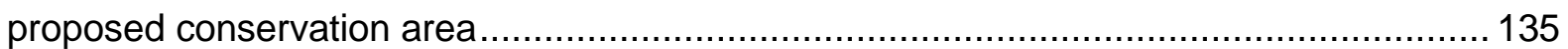

Figure 56. Map of Eluvaitivu Island, showing ecosystems and land use........................... 138

Figure 57. Map of Erumaitivu Island, showing ecosystems and land use ........................ 141

Figure 58. Map showing the proposed conservation area encompassing Erumaitivu and

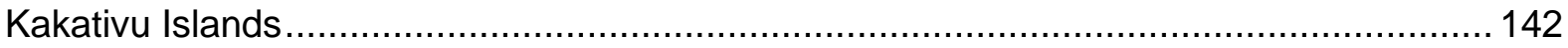

Figure 59. Map of the Iranaitivu North and Iranaitivu South islands, ecosystems, land use and

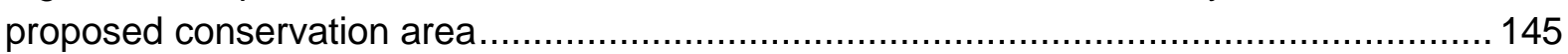
Figure 60. Map of the Adam's Bridge Islands showing existing protected area boundary.. 150 Figure 61. Map of Kachchativu Island, ecosystems, land use and proposed conservation area 152

Figure 62. Kachchativu Church, where an annual festival is held, with pilgrims from both India

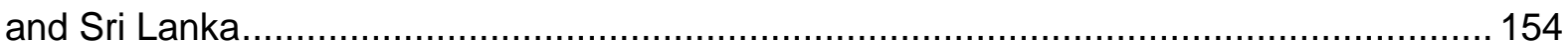

Figure 63. Map of Kakerativu Island, showing ecosystems, land use and proposed

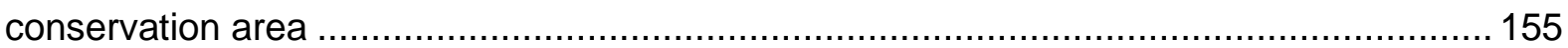

Figure 64. Map of Kakkativu Island, showing ecosystems and other land use ................. 157

Figure 65. Map showing the proposed conservation area encompassing Erumaitivu and

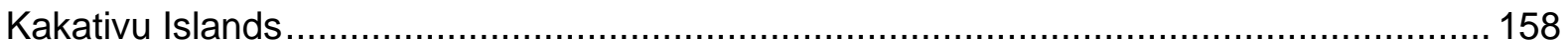

Figure 66. Map of the Kalliaditivu Island, showing ecosystems and other land use ........... 160 Figure 67. Map of the Karaitivu Island, showing ecosystems, land use and proposed

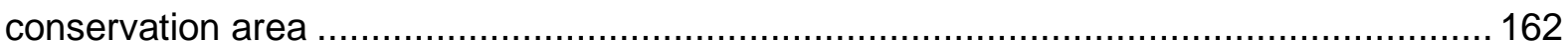

Figure 68. Map of Kayts Island, showing ecosystems, other land use and important bird

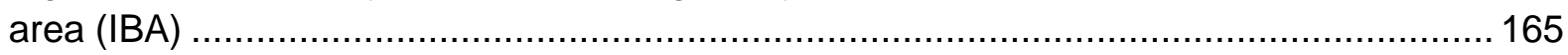

Figure 69. Migrant black-headed gulls (Chroicocephalus ridibundus) in Kayts ................. 167

Figure 70. Map of Kurikadduwan Island, showing ecosystems and land use .................... 168

Figure 71. Map of Mandaitivu Island, showing ecosystems, land use and proposed

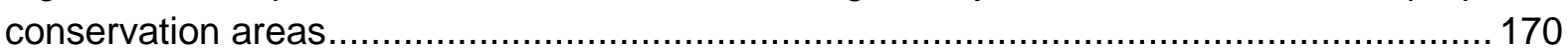

Figure 72. Map of Mannar Island, showing ecosystems and other land use ..................... 173

Figure 73. Top: Dutch Fort, Mannar Island; Bottom, the oldest (reported to be over 700 years old) and the largest individual baobab (Adansonia digitata) tree in Sri Lanka, found at Pallimunai, Mannar Island

Figure 74. Map of Nainativu Island, showing ecosystems, land use and proposed

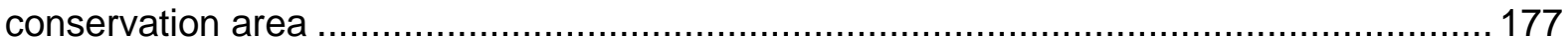

Figure 75. Map of Neduntivu Island, showing ecosystems, land use and proposed

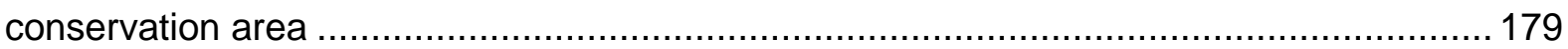

Figure 76. Map of Palaitivu Island, showing ecosystems, land use and proposed conservation

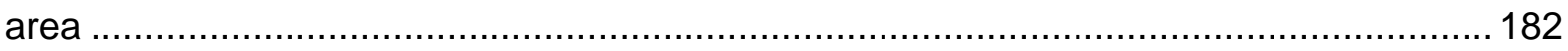

Figure 77. Map of Parititivu Island, showing ecosystems and land use .......................... 184

Figure 78. Map of Puliyantivu Island (Jaffna), showing ecosystems and land use ............ 186

Figure 79. Map of Puliyantivu Island (Mannar), showing ecosystems and land use ......... 188

Figure 80. Map of Pungudutivu Island, showing ecosystems and land use ...................... 190

Figure 81. Map of the coastal stretch from Kalmunai to Pooneryn, showing ecosystems and

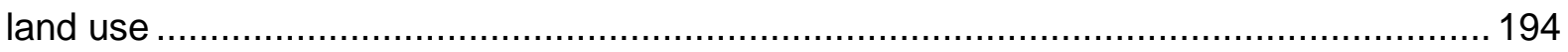

Figure 82. Map of the coastal stretch at Punnalai Khadu, showing ecosystems and land use

Figure 83. Map of the northern coastal stretch of the Jaffna Peninsula (from ThiruvadinilayamDambakolapatuna to Point Pedro), showing ecosystems and land use. 198 
Figure 84. Top: Dambakolapatuna Viharaya and bottom: Keerimalai tank, both found in the

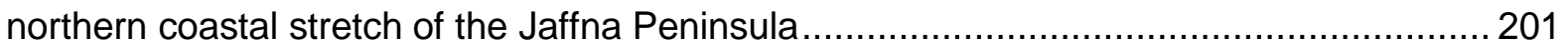

Figure 85. Map of the eastern coastal stretch of Manatkadu to Chundikulam, showing ecosystems, land use and existing protected areas ...................................................... 202

Figure 86. Map of the north-east coast (between Chundikulam to

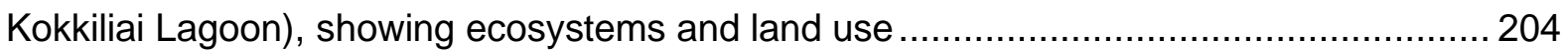

Figure 87. Map of the lagoons of the northern coastline ........................................... 208

Figure 88. Map of Chundikulam Lagoon its surrounds, showing ecosystems, land use and

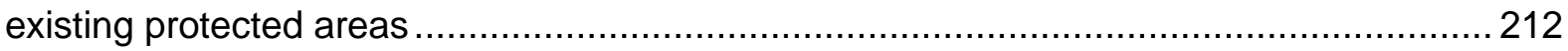

Figure 89. Map of Kokkilai Lagoon its surrounds, showing ecosystems and land use ....... 215

Figure 90. Map of Nanthi Kadal Lagoon its surrounds, showing ecosystems and land use 218

Figure 91. Map of Nayaru Lagoon its surrounds, showing ecosystems and other land use 219

Figure 92. Map of Vidattaltivu Lagoon and its surrounds, showing ecosystems, land use and existing protected area. 221

\section{List of tables}

Table 1. Districts, divisional secretariats and grama niladhari divisions in the study area...... 4

Table 2. Air temperature and rainfall variations within the northern districts ........................ 8

Table 3. Taxonomic guides and other publications used for species identification and

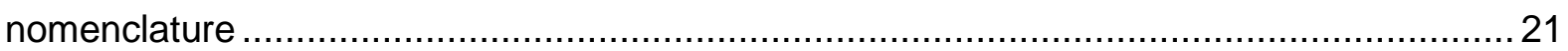

Table 4. Summary of flora recorded during the field survey.......................................... 42

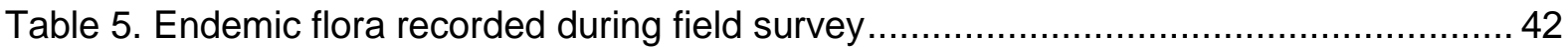

Table 6.Threatened flora recorded during field survey ................................................ 43

Table 7. Summary of fauna recorded during the field survey ........................................ 51

Table 8. Conservation status of the faunal species recorded in the study area ...................52

Table 9. Summary of marine species recorded during the field survey.............................. 63

Table 10. Conservation status of whales and dolphins found in the northern waters of Sri Lanka

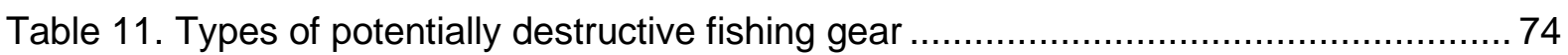

Table 12. List of invasive alien flora found in the study area............................................ 90

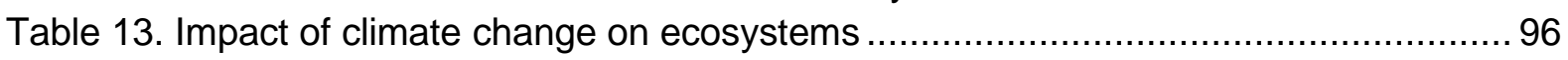

Table 14. Areas proposed in this study as conservation areas, justification for their

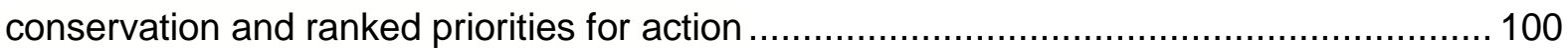

Table 15. Types of areas managed for conservation and brief details............................ 102

Table 16. Names of the five lagoons detailed in this report their extents. ......................... 208

Table 17. Ecological and livelihoods value of two major lagoons in the Jaffna Peninsula.. 209 


\section{List of boxes}

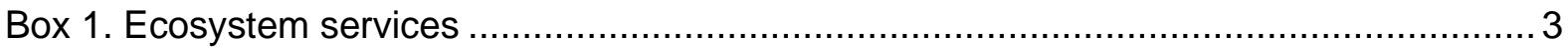

Box 2. Changing the ebb and flow of tides in a lagoon destroys it ................................. 72

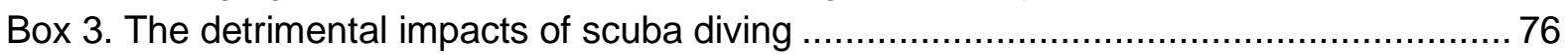

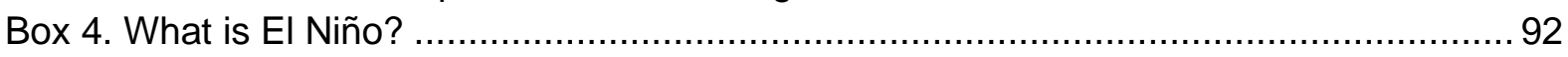

Box 5. The importance of coastal ecosystems in carbon sequestration............................. 96

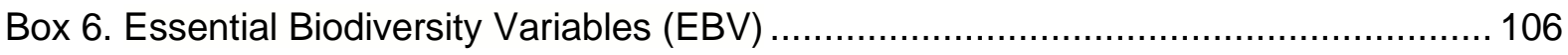

Box 7. The need for marine archaeological expeditions .............................................. 107

Box 8. The characteristics of IAS and their impacts on natural ecosystems ..................... 110

Box 9. The role of ecosystems in climate change mitigation............................................ 111

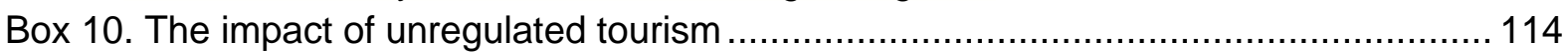




\section{Preface}

Coastal communities in many parts of Asia are particularly vulnerable to the impacts of climate change, with increased severity of extreme weather events directly affecting the lives of millions of people and damaging the ecosystems and resources they rely on for everyday survival.

This report has been produced as part of the Mangroves for the Future (MFF) initiative. MFF is a unique partner-led initiative to promote investment in coastal conservation for sustainable development. Co-chaired by IUCN and UNDP, MFF works to restore the health of coastal eco-systems as a contribution to building resilience in coastal communities in Asia. The emphasis is on generating knowledge, empowering local communities and governments, and working to promote policy solutions that will support best practice in integrated coastal management.

Moving forward, MFF will increasingly focus on building resilience of coastal communities by promoting ecosystem-based approaches and by showcasing the climate change adaptation and mitigation benefits that can be achieved with healthy mangrove forests and other types of coastal vegetation.

Healthy coastal ecosystems play a major role in helping coastal communities to adapt to climate change impacts. Mangroves and other coastal vegetation support biodiversity conservation and enable improvements in livelihoods and human well-being, while also providing cost-effective risk reduction against such threats as coastal erosion, storm surges and tsunamis. Mangroves also offer potential for mitigating climate change impacts through their high carbon storage capacity, thereby contributing to the Reducing Emissions from Deforestation and Degradation (REDD+) process.

At the same time, MFF is working to improve the effectiveness of governance and management of coastal resources by promoting models of co-management, payment for ecosystem services and similar resource-sharing mechanisms that will benefit traditional coastal communities. This is particularly important given that conservation may often appear to have high opportunity costs when other uses of natural areas (notably aquaculture) are more profitable in the short term, and that the local communities most affected by natural resource decision making may not have a voice.

This report is one of many which highlight ecosystem-based approaches being developed and tested around Asia. It is being produced and shared by MFF in order to serve as a resource and learning tool for coastal management practitioners, but also to help in raising awareness of the many issues and challenges which surround the protection of Asia's coastlines and the communities they support. 


\section{Executive summary}

After the 30-year long civil war was over, the Government of Sri Lanka commenced an accelerated programme to develop the Northern Province. If not carefully planned, such a programme will result in the loss of biodiversity and the consequent loss of services that ecosystems provide humans. Therefore, documenting the biodiversity found within coastal, nearshore and offshore islands of the Northern Province was identified as a need that would help both planners and conservation biologists alike.

IUCN (International Union for Conservation of Nature) with the Urban Development Authority, Sri Lanka Tourism Development Authority, and the Marine Environment Protection Authority, conducted a baseline assessment of the biodiversity of the coastal and offshore areas islands in the Northern Province.

\section{Goal of this study}

To assess the biodiversity of the coastal islands, as well as the lagoon ecosystems, in the North, to support the formulation of a strategic development planning framework that considers the need for environmental safeguards and conservation of biodiversity; and also to assess the resource base to promote sustainable tourism.

\section{Objectives}

To a) document site-specific information on habitats and species; b) identify comprehensive studies that are essential to further understand the resource base; c) identify the potential for sustainable tourism for the islands and lagoons in the northern coastal belt; d) define potential carrying capacities and identifying types and levels of development appropriate for specific sites; e) detail the drivers of anthropogenic change facing this area; f) provide recommendations for the conservation of certain areas with high biodiversity value and to redress the drivers of change, and e) propose actions and improvements for the areas assessed.

This report presents the results of a rapid biodiversity assessment of a $949 \mathrm{~km}$ stretch from Mannar to the Kokkilai Lagoon, including 22 coastal islands, five coastal stretches and four lagoons, extending across four districts (Jaffna, Mannar, Kilinochchi and Mullaittivu), 20 Divisional Secretariats Divisions and 264 Grama Niladhari Divisions. For terrestrial ecosystems, assessments were carried out during November 2015 and March 2016, and for marine surveys in the coastal waters of Palk Bay and Palk Strait, during November 2015 and March 2016. The results of this assessment are shown below:

\section{Diversity}

Natural terrestrial ecosystem diversity

Arid mixed evergreen forests; palmyra woodlands; seashore scrublands; dead coral beaches; sand dune scrublands; sandy seashores; mangroves and associates; salt marshes; tidal flats; lagoons and estuaries.

\section{Semi-natural ecosystem diversity}

Wet and dry pasturelands.

Man-made ecosystems

Home gardens.

Diversity of flora

Total number of species=342; number of tree species $=102$; number of shrub species=53; number of climber species $=59$; number of herbaceous species $=111$; number of epiphyte species $=3$; number of endemic species $=7$; number of Threatened species $=33$ 
Bay cedar, a rare coastal shrub, was found for the third time in Sri Lanka, after 125 years; also the octopus bush, a rare plant, and Sesamum prostratum, hitherto recorded only from the east coast.

$$
\text { Diversity of fauna }
$$

Total number of species=349; number of endemic species= 9; number of Threatened species=26; number of migrant birds $=78$

The famous Mannar ponies and donkeys.
Marine ecosystem diversity
Fringing coral reefs were found in the Palk Bay and Palk Strait along the northern coast of the Jaffna
Peninsula, around the islands and from Devil's Point to Kiranchi. The only offshore patch reef is the
Maldiva Bank, in the south-eastern section of the Palk Bay. The main seagrass meadows in the North
are found in the Palk Bay from Mannar Island to Kiranchi, along the coast and among the islands of the
Jaffna Peninsula.
Marine species diversity (selected species only)
Number of species of hard corals=86; number of species of seagrasses=11; number of species of reef
fish=172; number of species of sea cucumber=6; number of species of seaweeds=5; number of species
of molluscs=12; number of species of crustaceans=7; number of species of echinoderms=4; number of
species of Threatened corals=5; number of species of Threatened seagrasses=1; number of species of
Threatened reef fish=1
Notable species

\section{Threats to ecosystems and species}

\section{Habitat destruction}

Mangroves: for example, in Chirutivu, Sarasalai and Nagarkovil, Vidattaltivu and Thondaimanaru.

Sand dunes: for example, in Manatkadu and Pooneryn.

Improper construction of roads, across lagoons blocking the through-flow of water: for example, reconstruction of the Jaffna-Pannai road has blocked the free flow of water in the northern part of the Jaffna Lagoon; the road constructed for Mandaitivu village; the barrage in Thondaimanaru Lagoon, Arialai bridge, across part of the Jaffna Lagoon; cross-roads across other parts of the Thondaimanaru Lagoon, as well as in Kayts and Uppu Aru Lagoons.

\section{Over-exploitation}

Destructive and illegal fishing practices: for example, push and pull nets; trammel nets; use of nets on coral reefs; gill nets; purse seine, spearfishing and fish kraals are all being used in the area.

Waste from by-catch: Many fishers target specific species and non-target species are accidentally caught in the net and discarded.

Targeted over-harvesting of species: for example, Indian chanks (Silavatturai and Arrippu); branched murex (the Gulf of Mannar, Silavatturai, Arrippu, Vankalai and Mannar Island) and sea cucumbers (Mannar Island).

Poaching: Dugongs are harpooned (the Gulf of Mannar, Palk Bay and Palk Strait).

Boat propellers: cause damage to seagrass meadows in shallow areas where boats are constantly moving (the Gulf of Mannar, Palk Bay and among the islands near the Jaffna Peninsula).

\section{Pollution}

Solid waste pollution: Waste is dumped by roadsides, or in open land. Observed in marine surveys of Valvettithurai, Point Pedro and Manatkadu and the Gulf of Mannar; in the coastal stretches from Pooneryn to Sangupiddy and Valvettithurai to Point Pedro, Mullaittivu, and Pudumathalan Beach; the banks of Thondaimanaru Lagoon, Jaffna Lagoon near Vaddukkoddai, Arialai in Kayts and on Mannar Island.

Water pollution is found in Navanthurai, Pannai, Guru Nagar, Columbuthurai and Pasaiyur, where there is pollution from agrochemicals and dumping of sewage into the lagoon. 
Species of IAS flora= 5; species of IAS fauna= Feral dogs, feral cats and Tilapia.

\section{Climate change}

Inundation due to climate change (through predictive modelling): Periya Kalapu and Vankalai

Lagoon, Palaitivu, Parititivu, part of the Chundikulam Lagoon and a part of coastline could be inundated by 2025 .

Coral bleaching was observed in Mandaitivu.

\section{Recommendations}

Recommendation 1: Conserve natural ecosystems
Areas for conservation were proposed, and detailed, with maps, in the report.
Recommendation 2: Carry out further region in-depth, detailed biodiversity assessment
studies
The specific studies needed are discussed in the report. These studies are needed for formulation of
management plans that do not degrade ecosystems.
Recommendation 3: Shift to an inter-sectoral approach to management
Forge and implement multi-stakeholder platforms to ensure a holistic approach.
Recommendation 4: Manage solid waste and other forms of pollution
Establish a solid waste management programme to ensure that the generation of waste is minimised,
separated, and disposed of responsibly. Water and air quality and noise standards must also be
maintained according to the regulations of the National Environmental Act.
Recommendation 5: Minimise over-exploitation

With the Department of Fisheries and Aquatic Resources and the Department of Wildife Conservation, create awareness regarding fishing gear and species for which there are restrictions.

Recommendation 6: Control Invasive Alien Species (IAS)
Formulate a plan for managing identified IAS, which should include training for government officers, as
well as management and monitoring.

Recommendation 7: Mitigate the impacts of and adapt to climate change

Actively promote stringent energy conservation measures; developing Iranaitivu North, Iranaitivu South, Eluvaitivu, Kachchativu, Karaitivu, Delft, Paraitivu and Analaitivu as emission free islands; and adapt to climate change by routinising climate-proofing in development and livelihoods-related projects, protecting and restoring ecosystems; and making agriculture sustainable.

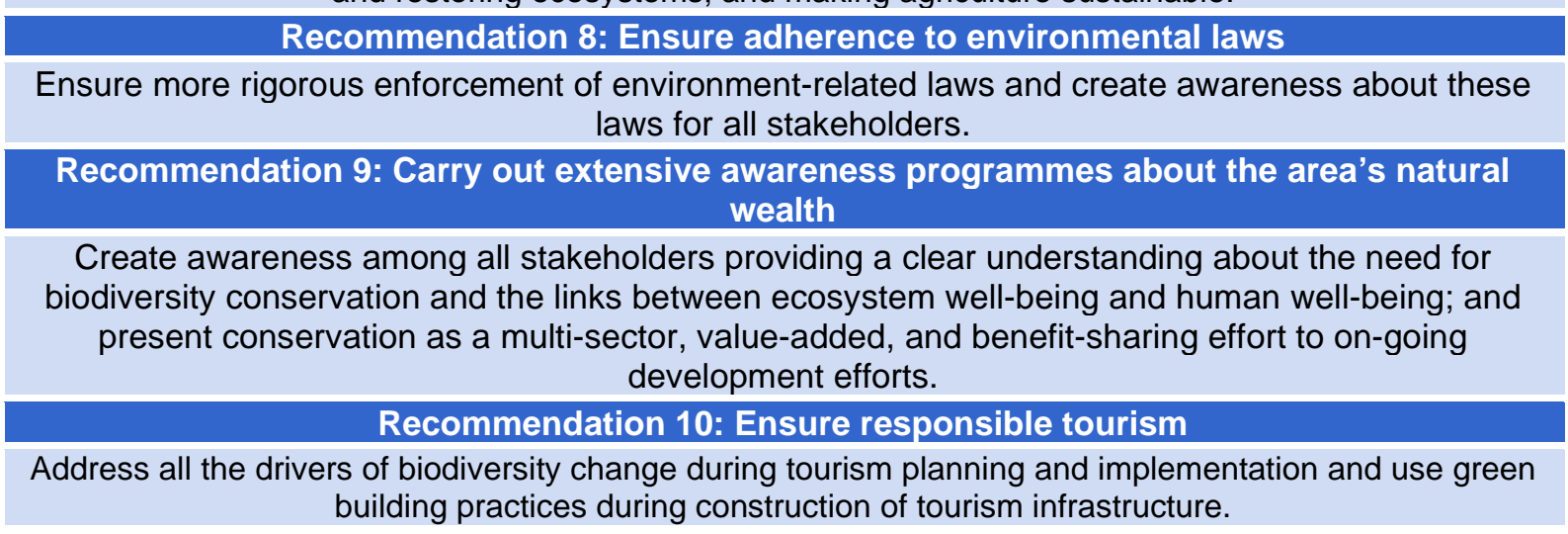

The northern coastal stretch from Mannar to Kokkilai has been untouched by development for over 30 years, retaining some pristine ecosystems, a suite of range-restricted species and has several feeding areas for migrating birds which provide communities in these coastal areas with life-sustaining ecosystem services. It is imperative, therefore, that future development is planned in an integrated manner, ensuring that sensitive ecosystems and species of concern are conserved, retaining life-sustaining ecosystem services. 


\section{Survey team and coordination}

\section{Survey team}

Prof. Devaka Weerakoon (Team Leader, Terrestrial Biodiversity)

Mr. Sampath De A. Goonatilake (Terrestrial Fauna and Archaeology)

Mr. Tharanga Wijewickrama (Terrestrial Flora)

Mr. Arjan Rajasuriya (Team Leader, Marine Biodiversity)

Mr. Naalin Perera (Terrestrial and Marine Biodiversity)

Dr. Terney Pradeep Kumara (Marine Biodiversity)

Mr. Gyan De Silva (Marine Biodiversity)

\section{Oversight}

Dr. Ananda Mallawatantri

Dr. Shamen Vidanage

\section{Coordination}

Dr. Damith Chandrasekara

Mr. Kapila Gunarathne

\section{Technical support}

Ms. Harini Nishshanka

Ms. Matheesha Katuwawala

Mr. Anuka Vithanage

Mr. Sampath Bandara

Ms. Chameli Liyanage

\section{GIS mapping}

Ms. Sandamali Pathirage

\section{Photographs}

Mr. Sampath de A Goonatilake

Mr. Naalin Perera

Mr. Arjan Rajasuriya

Dr. Terney Pradeep Kumara

Ms. Kumudini Ekaratne

Mr. Luxhsmanan Nadaraja

Mr. Milinda Wattegedara

Mr. Niroshan Mirando

Mr. Susantha Udagedera

Ms. Anouk Illangakoon

Dr. Sriyanie Miththapala 


\section{Acronyms}

\begin{tabular}{|c|c|}
\hline ASTER & Advanced Space borne Thermal Emission and Reflection Radiometer \\
\hline BOBLME & Bay of Bengal Large Marine Ecosystem \\
\hline BP & Before Present \\
\hline $\mathrm{BrR}$ & Breeding resident \\
\hline BrRWV & Breeding Resident/Winter Visitor \\
\hline BRW & Black and Red Ware \\
\hline CBD & Convention on Biological Diversity \\
\hline CC\&CRMD & Coast Conservation and Coastal Resources Management Department \\
\hline CEA & Central Environmental Authority \\
\hline CGF & Conservator General of Forests \\
\hline COD & Chemical Oxygen Demand \\
\hline Cos & Conservation Status \\
\hline $\mathrm{CR}$ & Critically Endangered \\
\hline CR (PE) & Critically Endangered (Possibly Extinct) \\
\hline CZMP & Coastal Zone Management Plan \\
\hline DD & Data Deficient \\
\hline DFAR & Department of Fisheries and Aquatic Resources \\
\hline DMC & Disaster Management Center \\
\hline DSD & Divisional Secretariat Division \\
\hline DWC & Department of Wildlife Conservation \\
\hline $\mathrm{EbA}$ & Ecosystem-based adaptation \\
\hline EIA & Environmental Impact Assessment \\
\hline EN & Endangered \\
\hline END & Endemic \\
\hline ENSO & El Niño-Southern Oscillation \\
\hline EX & Exotic \\
\hline FARA & Fisheries and Aquatic Resources Act \\
\hline $\mathrm{FCO}$ & Forest Conservation Ordinance \\
\hline FD & Forest Department \\
\hline FFPO & Flora and Fauna Protection Ordinance \\
\hline GIS & Geographical Information Systems \\
\hline GISD & Global Invasive Species Database \\
\hline GoM & Gulf of Mannar \\
\hline
\end{tabular}




\begin{tabular}{|c|c|}
\hline HIV & Human Immunodeficiency Virus \\
\hline IAS & Invasive Alien Species \\
\hline IBA & Important Bird Area \\
\hline IEE & Initial Environmental Examination \\
\hline IN & Indigenous \\
\hline IPCC & Intergovernmental Panel on Climate Change \\
\hline ISEA & Integrated Strategic Environment Assessment \\
\hline IUCN & International Union for Conservation of Nature \\
\hline LC & Least Concern \\
\hline MASL & Mahaweli Authority of Sri Lanka \\
\hline MEA & Millennium Ecosystem Assessment \\
\hline MEPA & Marine Environment Protection Authority \\
\hline MFF & Mangroves for the Future \\
\hline MoE & Ministry of Environment \\
\hline MoMD\&E & Ministry of Mahaweli Development and Environment \\
\hline MSDW & Ministry of Sustainable Development and Wildlife \\
\hline MSP & Multi-Stakeholder Platforms \\
\hline NARA & National Aquatic Resources Research and Development Agency \\
\hline NE & Not Evaluated \\
\hline NGO & Non-Governmental Organisation \\
\hline NOAA & National Oceanic and Atmospheric Administration \\
\hline NSAP & Sri Lanka National Strategy and Action Plan \\
\hline NT & Near Threatened \\
\hline ORCA & Ocean Resources Conservation Association \\
\hline PM & Passage Migrant \\
\hline $\mathrm{R}$ & Resident \\
\hline RAP & Rapid Assessment Programmes \\
\hline SLLR\&DC & Sri Lanka Land Reclamation and Development Corporation \\
\hline SLTDA & Sri Lanka Tourism Development Authority \\
\hline SpS & Species status \\
\hline STAP & Scientific and Technical Advisory Panel \\
\hline STP & Sewage Treatment Plants \\
\hline SU & Status Unknown \\
\hline SV & Summer Visitor \\
\hline TEEB & The Economics of Ecosystems Biodiversity \\
\hline Ubr & Uncertain Breeding Resident \\
\hline
\end{tabular}




$\begin{array}{ll}\text { UDA } & \text { Urban Development Authority } \\ \text { UNEP } & \text { United Nations Environment Programme } \\ \text { UNFCCC } & \text { United Nations Framework Convention on Climate Change } \\ \text { UNICEF } & \text { United Nations International Children's Emergency Fund } \\ \text { UWV } & \text { Uncertain Winter Visitor } \\ \text { Va } & \text { Vagrant } \\ \text { VCWV } & \text { Very Common Winter Visitor } \\ \text { VES } & \text { Visual Encounter Survey } \\ \text { VOC } & \text { Volatile Organic Chemicals } \\ \text { VU } & \text { Vulnerable } \\ \text { WCMC } & \text { World Conservation Monitoring Centre } \\ \text { WGS } & \text { World Geodetic System } \\ \text { WV } & \text { Winter Visitor } \\ \text { Wva } & \text { Winter Vagrant } \\ \text { WWF } & \text { World Wide Fund for Nature }\end{array}$




\section{Acknowledgements}

We are immensely grateful to the Urban Development Authority (UDA), Coast Conservation and Coastal Resources Management Department (CC\&CRMD) and Department of Fisheries and Aquatic Resources (DFAR) for participating in the survey and for the facilities provided for fieldwork.

We are also grateful to the Sri Lanka Navy for their help in providing sea transport to islands. The assistance provided by members of local communities is highly appreciated and we gratefully acknowledge the financial support of Sida, Norad, Danida and the Royal Norwegian Embassy in Thailand.

We are grateful to out two external reviewers, Prof. Siril Wijesundara and Mr. Leslie Joseph for the constructive comments to improve this document. 


\section{Chapter 1: Introduction}

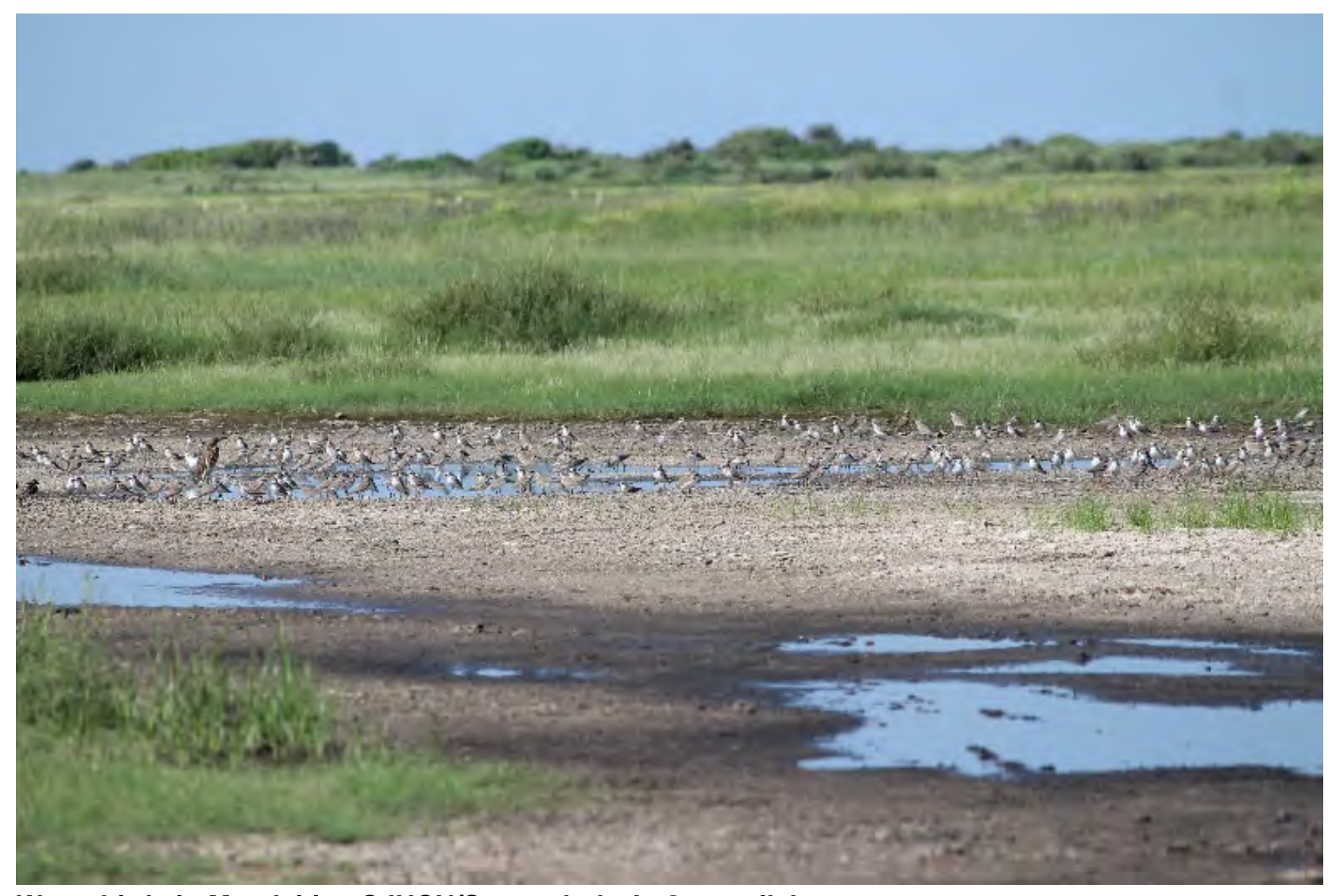

Water birds in Mandaitivu @ IUCN/Sampath de A. Goonatilake 
Sri Lanka is a moderate-sized continental island, listed as the $25^{\text {th }}$ largest island in the world extending over $65,610 \mathrm{~km}^{2}$ (Calder, 2009). In addition to the main island, there are also 61 islands located within the territorial waters of Sri Lanka, totalling a land area of $337.77 \mathrm{~km}^{2}$ (KRI, 2004). These islands vary in extent from $0.0001 \mathrm{~km}^{2}$ (Pigeon Island, in the north-east) to $1.26 \mathrm{~km}^{2}$ (Mannar Island, in the north-west). Of these islands, $28(45.9 \%)$ are in the Northern Province (KRI, 2004). Of those in the Northern Province, 19 are in the Jaffna District and 16 in the Jaffna Peninsula (KRI, 2004). Many of these islands support a characteristic biodiversity (both terrestrial and marine) resulting in the declaration of several protected areas - such as Adam's Bridge National Park and Delft Island National Park — in the area (MSDW, 2015).

Some of the smaller islands have not been inhabited by people, but are being used transiently by fishermen, as fishing camps. Some of the medium-sized islands have been inhabited in the past but were abandoned during the three-decade long armed conflict that persisted in the northern region of Sri Lanka. Yet others - such as Mannar, Delft, Kayts and Mandaitivu, which are large, have been inhabited for a long time, and there are many archaeological monuments found on these islands representing different periods of history.

However, other than the larger islands, the biodiversity of the rest of the islands remains largely unexplored, especially because these islands were inaccessible during the armed conflict that prevailed in the area until 2009.

The Northern Province also encompasses $40 \%$ of Sri Lanka's coastline and is endowed with rich coastal and offshore resources. The coast itself is composed of a rich assemblage of marine ecosystems, such as coral reefs, seagrass meadows, tidal flats, beaches, lagoons, estuaries and mangroves. Parts of these ecosystems are characteristic species assemblages, some of which can only be encountered in this region. Some of these species included birds — such as the spot-billed duck (Anas poecilorhyncha), crab plover (Dromas ardeola), longtailed shrike (Lanius schach), Indian courser (Cursorius coromandelicus); butterflies - such as the yellow pansy (Junonia hierta hierta), bright babul blue (Azanus ubaldus), crimson tip (Colotis danae), large salmon Arab (Colotis fausta), and joker (Byblia ilithyia); and marine mammals - such as the dugong (Dugong dugon). Many of the species that are restricted to the Northern Province are found in coastal and nearshore habitats. Therefore, the coastal and nearshore areas in the Northern Province function as critical habitats for many species of fauna and flora. However, these ecosystems and their species remain understudied, for the same reasons listed in the previous paragraph. The coastal area is also rich in archaeological monuments and traditional legends. The area is also very beautiful.

After the three-decade long civil war was over, the Government of Sri Lanka commenced an accelerated programme to develop the Northern Province. If not properly planned, these developmental projects will result in the loss of biological diversity and, in particular, the consequent loss of services that ecosystems provide (Box 1). 


\section{Box 1. Ecosystem services}

'Ecosystem services are the benefits people obtain from ecosystems. These include provisioning services such as food and water; regulating services such as flood and disease control; cultural services such as spiritual, recreational, and cultural benefits; and supporting services, such as nutrient cycling, that maintain the conditions for life on Earth' (MEA, 2005). Ecosystem services directly and indirectly affect human survival and quality of life (TEEB, 2017).

One of the important considerations in any plan that looks towards economic and social development of the North, is that it must place a heavy emphasis on promoting livelihood options of coastal communities through new business opportunities that are focused on sustainable use of coastal resources - such as nature-based, sustainable tourism. Such a focus will ensure the resilience of coastal ecosystems, which will, in turn, reduce the vulnerability of coastal communities in the face of impending changes brought about by climate change. It will also ensure the sustainability of the livelihoods of coastal communities. This is also in line with the concept, adopted by the present government, of a Blue-Green Economy, which places heavy emphasis on building resilient marine ecosystems, as a means of achieving global sustainability, climate mitigation and poverty eradication.

Therefore, documenting the biodiversity that is found within coastal and nearshore areas, as well as the offshore islands of the Northern Province, was identified as a timely need. Such documentation will help both planners and conservation biologists alike, as then, the development that is planned for the Northern Province can be carried out in a manner that sustains these coastal resources.

To achieve the above, IUCN, International Union for the Conservation of Nature, together with the Urban Development Authority (UDA), Sri Lanka Tourism Development Authority (SLTDA), and the Marine Environment Protection Authority (MEPA) collaborated to conduct a baseline assessment of the biodiversity of the coastal areas in the Northern Province, as well as of the offshore islands.

\section{General description of the study area}

There are 43 islands located in the region of the Gulf of Mannar and the Palk Strait. Most of these islands were omitted from the national development agenda during the internal civil war. Because most of the islands are uninhabited and have untouched clear blue seas and golden beaches, a great opportunity exists to develop these islands, in a well-planned and sustainable manner, as nature-tourism destinations.

The study area covers a $949 \mathrm{~km}$ stretch from Mannar to the Kokkilai Lagoon, including 22 coastal islands, five coastal stretches and four lagoons (see Figure 1). 


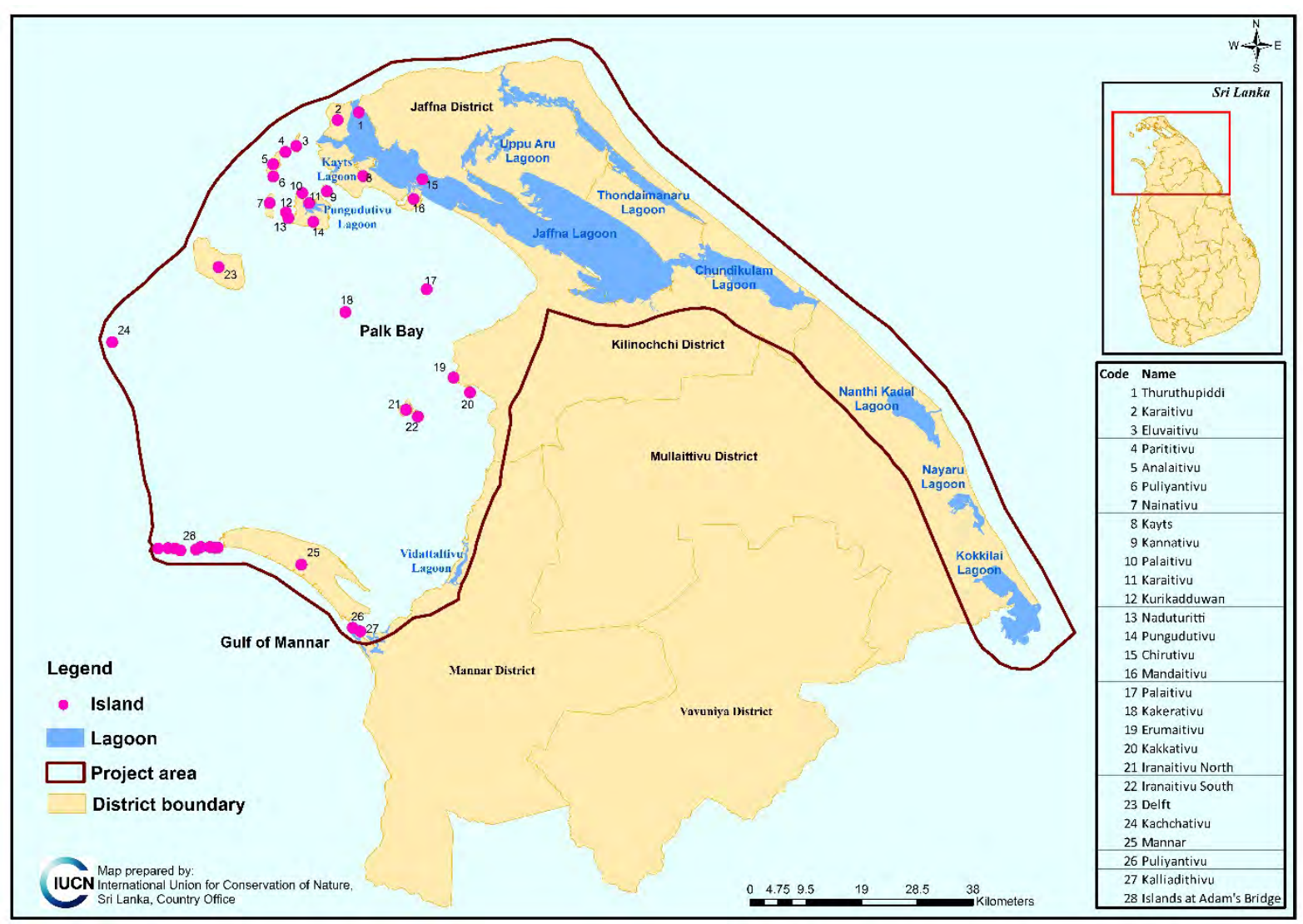

Figure 1.Study area showing the islands in northern Sri Lanka

This surveyed area extends across four districts (Jaffna, Mannar, Kilinochchi, Mullaittivu), 20 Divisional Secretariat Divisions and 264 Grama Niladhari Divisions, as shown in Table 1.

Table 1. Districts, divisional secretariats and grama niladhari divisions in the study area

\begin{tabular}{|c|c|c|}
\hline Districts & Divisional secretariats & No. of grama niladhari \\
\hline \multirow{13}{*}{ Jaffna } & Delft & 6 \\
\hline & Island South (Velanai) & 30 \\
\hline & Jaffna & 14 \\
\hline & Karainagar & 9 \\
\hline & Kayts (Island North) & 15 \\
\hline & Kopay (Valikamam East) & 2 \\
\hline & Nallur & 2 \\
\hline & Thenmaradchchi (Chavakachcheri) & 11 \\
\hline & Vadamaradchi East & 17 \\
\hline & Vadamaradchi North & 18 \\
\hline & Valikamam North (Tellippalai) & 7 \\
\hline & Valikamam South-west (Sandilipay) & 7 \\
\hline & Valikamam West (Chankanai) & 8 \\
\hline \multirow{4}{*}{ Kilinochchi } & Kandavalai & 3 \\
\hline & Karachchi & 1 \\
\hline & Panchchilaipalai & 5 \\
\hline & Poonakary & 15 \\
\hline
\end{tabular}




\begin{tabular}{|l|l|r|r|}
\hline \multicolumn{1}{|c|}{ Districts } & \multicolumn{1}{|c|}{ Divisional secretariats } & No. of grama niladhari \\
\hline Mannar & Mannar & 40 \\
\cline { 2 - 3 } & Mantai West & 12 \\
\hline Mullaittivu & Maritime Pattu & 24 \\
\hline Total & & 20 & 246 \\
\hline
\end{tabular}

\section{Geology and geomorphology, soil and hydrology}

\section{Geology}

The dominant tertiary sedimentary rocks from the Miocene age are thick limestone deposits that are found underlying the Jaffna Peninsula, the islands surrounding it, and the northwestern coastal zone of the country (Kehelpannala, 2007). These beds are fossiliferous and Wayland and Davies (1923) have dated fossils from the Puttalam-Jaffna limestone as being Upper Miocene age.

The Jaffna series extends from near Puttalam on the west coast, and widens toward the North, to cover the Jaffna Peninsula (Kehelpannala, 2007). Southward, the limits of this limestone can be seen in outcrops of Precambrian rock found at Madhu Road Station on the Mannar railway line; north of Mankulam on the Jaffna road; and between Mankulam and Mullaittivu. Generally, the Jaffna series comprises fossiliferous limestone which contains chert ${ }^{1}$ nodules and is hard, compact, and off-white to greyish-coloured (Erb, 1963). This is capped by a series of areno-argillaceous ${ }^{2}$ beds (Erb, 1963). In the Kudiremalai area these latter beds are overlain by resistant, red sandstone (Erb, 1963). Wadia (1945) states that the Jaffna limestone appears to be similar in age to the Quilon and Workalli beds of the Quilon (south-west) coast of Travancore and Cochin in India, that belong to the Middle Miocene period (Erb, 1963).

\section{Coastal geomorphology}

Sri Lanka is situated on a continental shelf that surrounds the island, on which is also situated the Indian subcontinent (Madduma Bandara, 2007) (Figure 2). This continental shelf has an average width of $20 \mathrm{~km}$, narrowest in the south, and widens north of the Kalpitiya Peninsula to its widest surrounding the Jaffna Peninsula (Madduma Bandara, 2007). The shallowest part of the continental shelf is in the Palk Strait where Adam's Bridge and Pedro Banks are located. The area around Palk Bay has a shallow and flat basin with an average depth of around 9-15 $\mathrm{m}$ (Madduma Bandara, 2007). The outer margin of the shelf is approximately along the 100fathom line $(182.88 \mathrm{~m})$ and from there the bottom drops off rapidly to over 1,828.8 metres. In fact, seas around Sri Lanka are, except for the Palk Strait, oceanic in nature. On the west, the Gulf of Mannar is over 1,820 metres deep.

\footnotetext{
1 fine-grained sedimentary rock composed of microcrystalline or cryptocrystalline silica

${ }^{2}$ A combination of a sedimentary rock composed of sand, as well as clay
} 


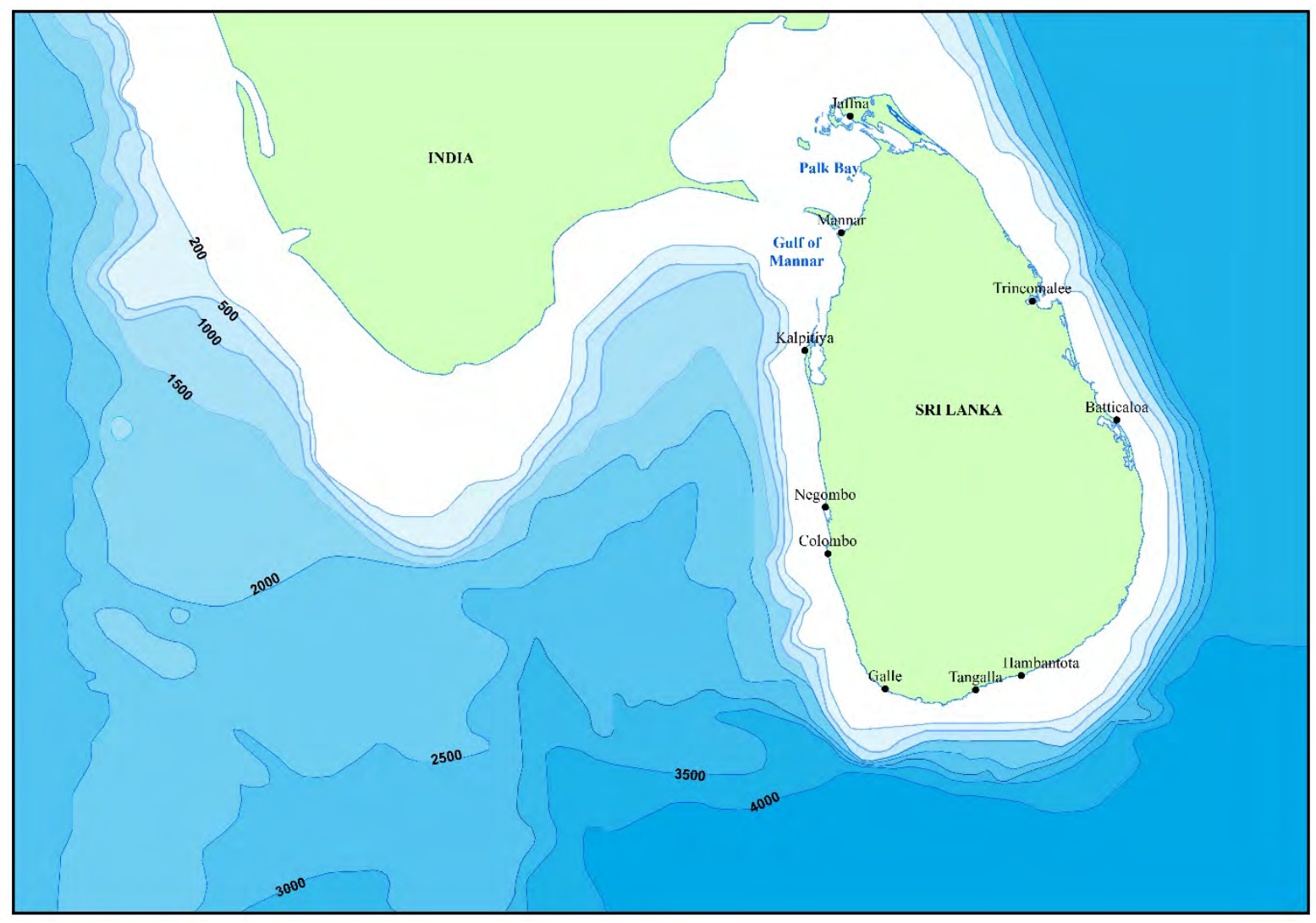

Figure 2. The continental shelf and bathymetry around Sri Lanka

(Source: Ariyawansa, 2007)

Adam's Bridge is a chain of limestone islands covered with sand, as well as sand islands, stretching from India's Pamban Island (also known as Rameshawaram Island) to Sri Lanka's Mannar Island (Figure 3). Adam's Bridge, therefore, forms a causeway joining Sri Lanka and India, which are, at this point, approximately $32 \mathrm{~km}$ apart. The depth of water over the submerged part of Adam's Bridge averages well under $11 \mathrm{~m}$, and this, in combination with the strong, monsoon-controlled currents, results in the formation of numerous shifting sand bars, which are characteristic of the area. Another elevation in the continental shelf extends from north-east of the Jaffna Peninsula to the vicinity of Karaikal and Calimere Point in India and is known as Pedro Bank.

South of Adam's Bridge, between Mannar Island and Karaitivu Island, a third rise in the shelf forms the once famous pearl fishing banks. The surface of the shelf at this point and elsewhere in the Palk Strait area, as evidenced by fragments of rock brought to the surface by trawlers operated by the fisheries research group, consists of limestone well-pitted with solution cavities (Erb, 1963).

\section{Soils}

Three types of soil - red-yellow latosols, grumüsol and solodized solonetz - have been identified from the Jaffna Peninsula and the islands around it. Of these three types, the type Calcic red latosols are the main soil type present in the region (Panabokke, 1996). 


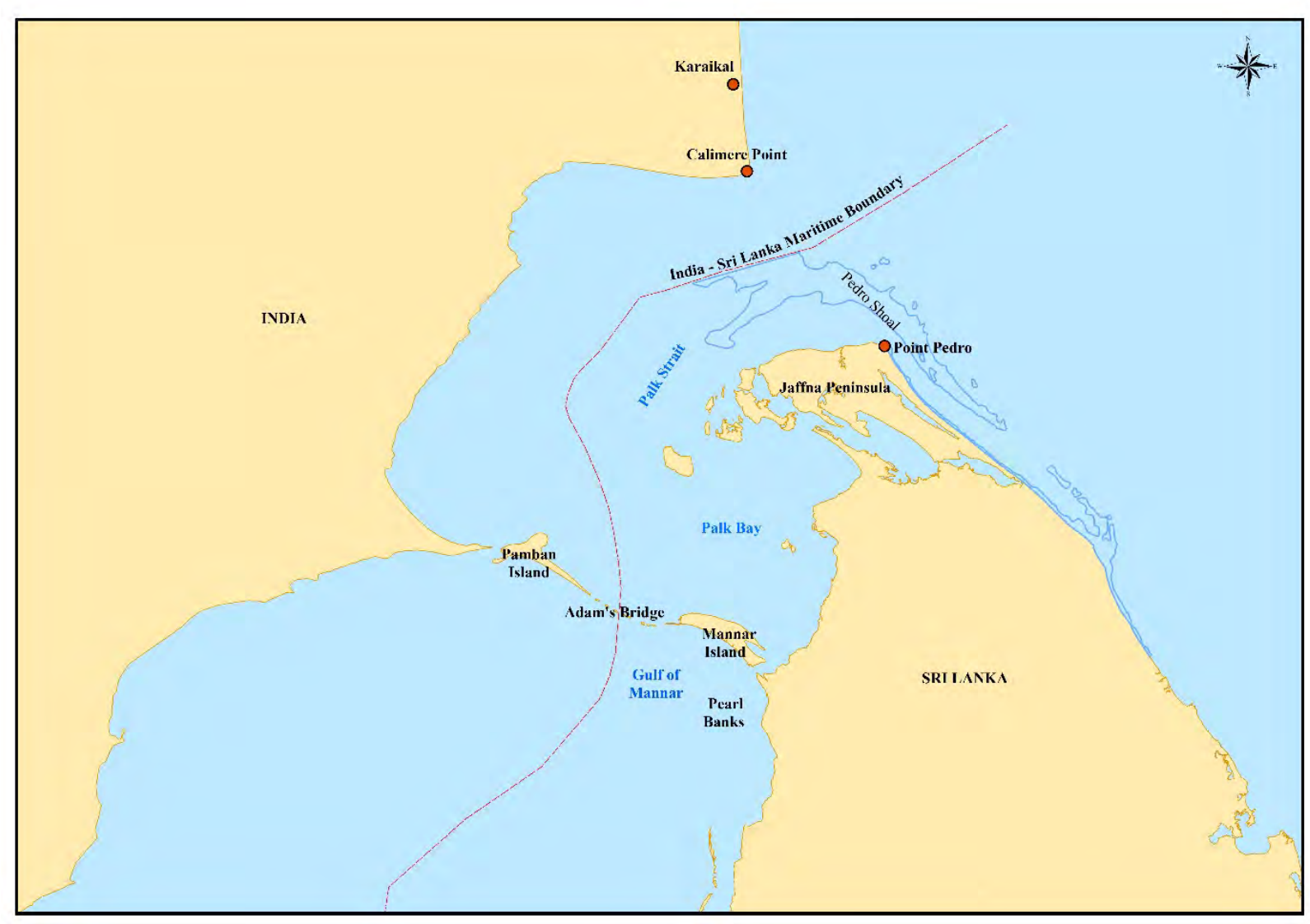

Figure 3. Adam's Bridge and its surrounds

(Source: Adapted from Wijeynanda, 2007)

Red-yellow latosols (subgroup: calcic red latosol): This type of soil is dominant in open shrub and grass-covered areas. These soil layers are formed from the parent material of the remnants of old alluvium and are mixed with limestone fragments (Miocene vacuolary limestone). Topographically, this soil type is found on a micro-mound, about 0.6-1.2 $\mathrm{m}$ above the flat limestone plain with numerous limestone outcrops (barrocal relief) varying between elevations of 6-9 m (Moorman and Panabokke, 1961). The calcic subgroup in the Jaffna Peninsula is by far one of the most intensively cultivated soils in the country. Extreme land pressure is compelling farmers to reclaim small plots of land from stony areas (Panabokke, 1996).

Grumüsol: This type of soil is dominant in areas covered with short grass savannahs, thorny scrubs and scattered trees. It was formed on the parent rock of ponded sub recent clayeyalluvium over decomposed quartzitic Archaean rock (Khondalite series). The topography is a flat, slightly digressional plain with distinct gilgai relief (Moorman \& Panabokke, 1961).

Solodized Solonetz: This type of soil is dominant in areas covered with short grass with many bare spots, some halomorphic species and scattered trees (Manilkara hexandra). Parent material is semi-recent marine clayey alluvium. Topographically, it occurs on flat tidal plains that are no more inundated by the sea and have slight but distinct gilgai relief with an elevation up to six metres (Moorman \& Panabokke, 1961). 


\section{Hydrology}

The geomorphologic and hydro-geological setting of two types of aquifers - shallow karstic ${ }^{3}$ and coastal sand - have been studied adequately and characterised, and their location and distribution patterns have also been delineated and mapped at different levels of intensity.

Shallow Karstic Aquifers of the Jaffna Peninsula: The whole Jaffna Peninsula is underlain by Miocene limestone formations, which are generally 100 to $150 \mathrm{~m}$ thick, distinctly bedded, welljointed and highly karstified. The shallow aquifers of the peninsula occur in the channels and cavities (karsts) of this Miocene limestone. All the shallow groundwater found within the karstic cavities originates from the infiltration of rainfall, and this shallow groundwater forms mounds or lenses floating over the saline water. These water mounds or lenses reach their peak during the monsoon rains of November-December. According to Balendran et al., (1968), around $50 \%$ of the annual re-charge of rainwater (between 10 to $20 \times 10^{7} \mathrm{~m}^{3}$ ) eventually drains out to sea and the remainder is used for agriculture and domestic purposes. Monitoring studies have confirmed a significant imbalance between the draw-off and re-charge rates, as reported by Balendran (1969).

Coastal Sand Aquifers: Three main types of coastal sand aquifers have been recognised and characterised in Sri Lanka, of which one is a shallow aquifer on coastal spits and bars and is found in the Kalpitiya Peninsula and the Mannar Island in the north-western region of Sri Lanka. These aquifers are re-charged mainly during the three to four months of rain in the wet maha season, and water in these aquifers is then collected in the form of a freshwater 'lens' floating above the denser saline water. The volume of fresh water in these aquifers usually expands during the rainy season and contracts during the dry season with fluctuating brackish and saline boundaries. Any over-extraction from these freshwater lenses results in the coning or entering of the underlying brackish water into fresh water (Panabokke \& Perera, 2005).

\section{Climate}

The northern area is in the arid zone of the island and receives less than $1,250 \mathrm{~mm}$ of sharply seasonal rainfall (MoMD\&E, 2016a) (Table 2).

Table 2. Air temperature and rainfall variations within the northern districts (Source: Northern Provincial Council, 2016)

\begin{tabular}{|c|c|c|}
\hline District & Air temperature $\left({ }^{\circ} \mathrm{C}\right)$ & Rainfall $(\mathrm{mm})$ \\
\hline Jaffna & $26.3-30.9$ & $1,811.8$ \\
\hline Kilinochchi & $25.0-30.0$ & $1,178-1,822$ \\
\hline Mannar & $28.0-33.0$ & 1,003 \\
\hline Mullaittivu & $23.0-39.3$ & $1,300-2,416$ \\
\hline
\end{tabular}

\footnotetext{
3 An area of irregular limestone in which erosion has produced fissures, sinkholes, underground streams, and caverns (The Free Dictionary, 2017).
} 


\section{Historical background}

The north-western and northern coastal belt directly faces the lowermost tip of the Indian subcontinent, which is only $32 \mathrm{~km}$ across the narrow Adam's Bridge. According to Swan (1983), the coastal belt of the northern Palk Bay is subdivided into seven sections, each with distinctive physical attributes. These sections can be identified as Point PedroThiruvadiniliyam, the Jaffna Islands, the lagoon country of Jaffna, the Pooneryn Peninsula, Palli kulam-Mantai, Mannar Island, and Adam's Bridge. These geographical distinctions are a direct cause of Sri Lanka's biological, cultural, ethnic and political diversity. During the historical period, Roman, Arabic and Chinese merchants, travellers, explorers, scholars, religious dignitaries, royalty and pirates sailed from west to east using this narrow strip.

The area along the coastal belt and the islands of Palk Bay can be grouped under four categories based on archaeological and cultural significance:

(a) Paleontological and bio-geographical;

(b) Prehistoric human migration (Palaeolithic, Mesolithic and Megalithic);

(c) Folklore and chronicles; and

(d) Ancient settlements, ports and colonial forts.

These sites are inter-connected with the oceanographic nature (geomorphology, current pattern) of the Gulf of Mannar and Palk Bay (Goonatilake, 2007b).

\section{Area of paleontological and bio-geographical significance}

During the Late Proterozoic (600 mya), the Gondwana supercontinent separated, resulting in India and Sri Lanka shifting into the Asian region (Dissanayake \& Chandrajith, 1999). During the Miocene period, the Tethys Sea that encroached the land surface between India and Sri Lanka converted the latter into an island for the first time (Senanayake, 1990). A Miocene limestone deposit underlines the whole of the Jaffna Peninsula and extends southwards along the north-western coast up to the Puttalam area as a narrow belt (Goonatilake, 2001). This deposit contains a varied assemblage of fossils representing foraminiferans, gastropods, echinoids, corals, calcified algae, and vertebrates (Cooray, 1984; Deraniyagala, 1958). During the 1960s, Deraniyagala described several fossil species from this deposit.

The Pleistocene has been identified as the period of radiation and speciation for Sri Lankan biota, while Holocene events also played a part in creating the present biogeographic patterns. This global phenomenon, termed the Holocene transgression, resulted in a sea level of approximately the same level as that can be seen today, around 35,000 YBP. However, between 35,000 YBP and the present, the sea level fell by about $130 \mathrm{~m}$ and rose again to the present level (Senanayake, 1990). The riverine floodplain in the North was created by two large rivers which joined together during the middle Pleistocene (Deraniyagala, 1958, Senanayake, 1990). They remained during the early and latter phases of the Holocene. One river was an extension of the Malwatu Oya (Aruvi Aru) while the other drained the watersheds of Kal Aru, Modaragam Aru, Kala Oya and Mi Oya. This large river created a series of riverine flats that existed for about 22,000 years. This land connection facilitated movement of fauna and flora, including humans, between Indian mainland and Sri Lanka during the Pleistocene 
to the early Holocene (Figure 4). This is supported by the fact that Pleistocene fossils of Sri Lanka (rhinoceroses, hippopotamuses, tigers, lions and gaur) are related to the Shivalik fossil fauna of India (Deraniyagala, 1958). According to Deraniyagala (1958), a flooded forest belonging to the Pleistocene period is located south of Karaitivu Island in the Gulf of Mannar, but it has not been excavated yet.

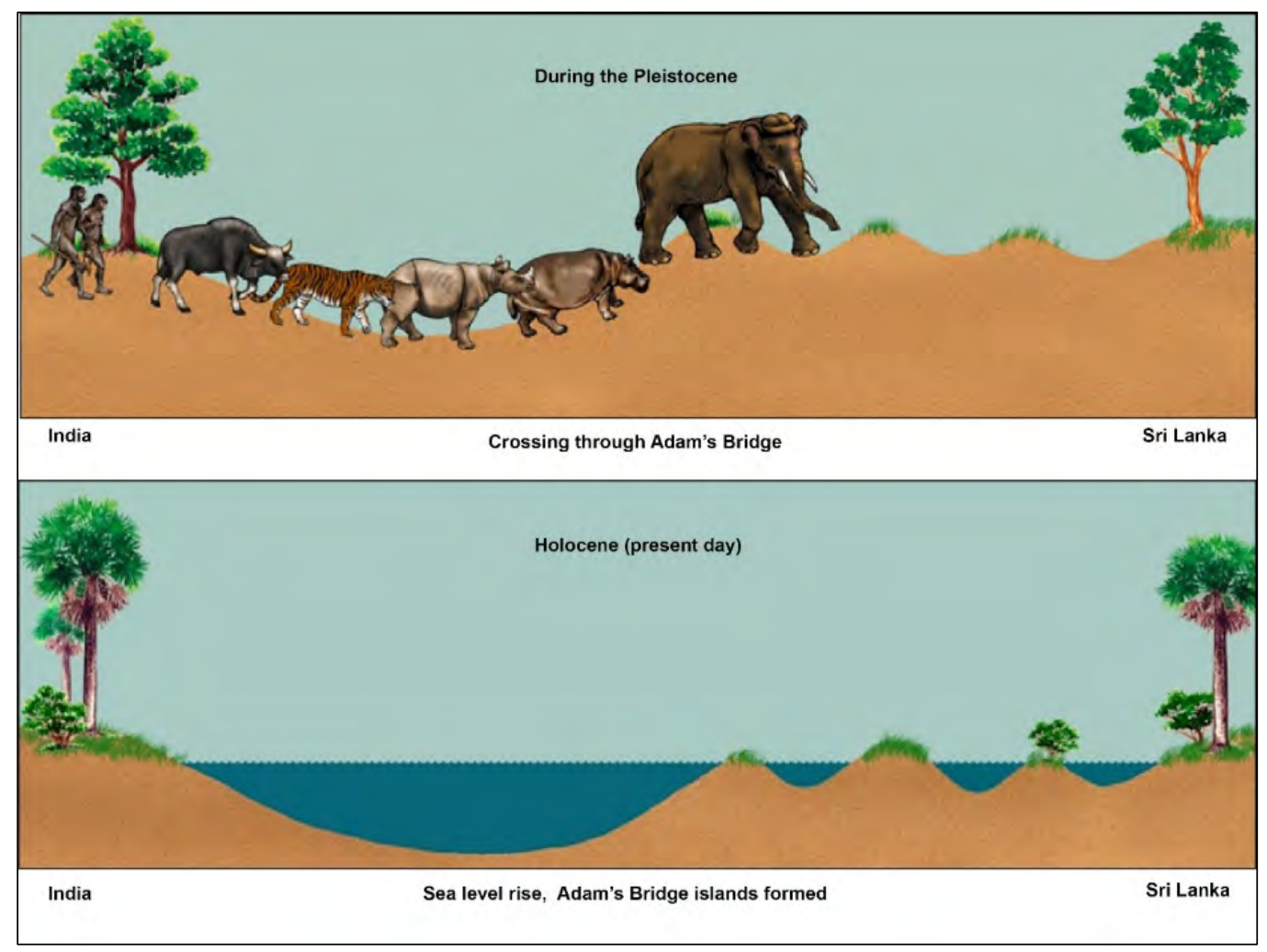

Figure 4. The migration of megafauna to Sri Lanka, during the Pleistocene period

(Illustration: Thusitha Premaratne)

\section{Area of prehistoric human migration (Palaeolithic, Mesolithic and Megalithic)}

During the Pleistocene and Holocene periods, humans migrated by crossing the land bridge and using water craft (boats and ships). A Palaeolithic tool discovered from Manikkai, close to Point Pedro in 1984, is believed to have belonged to the Palaeolithic man who was the earliest to come to the island. Upper Palaeolithic and Mesolithic human settlement sites were identified along the coastal belt, especially near the river mouths (Brohier, 1929; Carswell \& Prickett, 1984; Goonatilake, 2006). However, neither proper excavations nor exploration has taken place at any of these sites or in any of the islands in the Palk Bay. A Megalithic cemetery bordering Modaragam Aru and Kala Oya, a few kilometres from the coast, was excavated by Deraniyagala $(1957,1958)$, and Begley (1967). According to Begley's findings, the burial ground covered an area of about 1.2-1.6 km² and an estimated 8000 burials are found at this site. It also contained the remains of about 10,000-12,000 humans (Sitrampalam, 1990). 


\section{Area of folklore and legends}

The Indian name for Adam's Bridge is Rama Sethu and is a reference to the Indian legend Ramayanaya. The bridge is supposed to have been built for the Indian Prince Rama to cross from India to Sri Lanka to rescue his wife Sita from Ravana, the king of Sri Lanka (Goonatilake, 2007b). The name Adam's Bridge was given by a British mapmaker and referred to the legend which said that Adam (the first man in Christianity and Islam who was banished from Eden and fell onto Adam's Peak) crossed from Sri Lanka along this bridge to go back to the Middle East via India.

\section{Ancient ports}

According to the ancient chronicles Deepavansa, Mahawansa, and Rajawaliya, the Sri Lankan coastal belt of the Gulf of Mannar and Palk Bay goes back beyond the beginnings of Sri Lankan history to the legends and traditions associated with the original arrival of the northern Indian Prince Vijaya who founded the first civilised settlements on the island (Geiger, 1960). The exact location of the landing place - Tambapanni or Tammanna Nuwara - lies somewhere between the mouth of Moderagam Aru and Kudiremalai. The red soil of Kudiremalai lends credence to this belief, as the word Tambapanni is derived from the red soil (which stained the hands and feet of the travellers) and Kudiremalai has red soil (Figure 5).

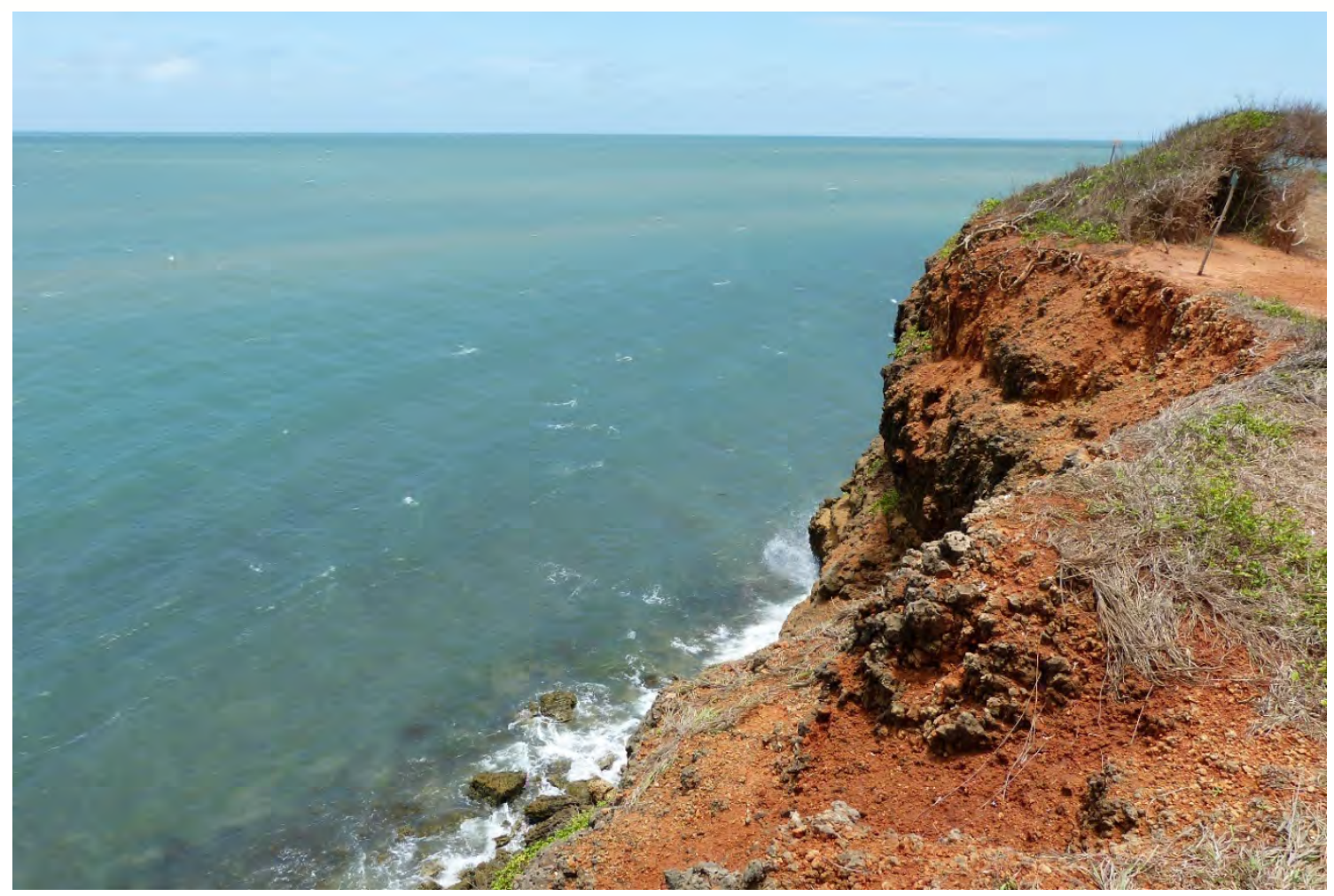

Figure 5. Kudiremalai Point

(C) Sriyanie Miththapala)

Also along the Mannar coastline, is Mantai (also called Manthai, and Mahatita, Maha tota, Matota, Maha tiththa in Sinhala), historically known as Manthottam/Manthoddam, which was an important port as far back as the $5^{\text {th }}$ century $\mathrm{BC}$, with traders from Greece, Rome, Arabia, Ethiopia, and Persia, as well as Japan and Burma, docking at this important port. 
An ancient marine silk route ran through the Palk Bay and the Gulf of Mannar. Mantai Port, which played an important role in the exchange of goods between east and west, served as a main port of Sri Lanka for over 1500 years (Bandaranyake,1990). Therefore, the ports along the coastal passage of this region were linked with countries such as Arabia, China, Ethiopia, Greece, India, Java, Persia, Phoenicia, and Rome. During the colonial period, the Portuguese and Dutch invaders built several forts along the coastal belt because of the economic and security importance of the region. Because of the importance of these sites, the British rulers also used and maintained some of these ports. At present, there is an urgent need for marine archaeological studies to document the ancient maritime trade routes, ships and fishing communities, in this marine and coastal region.

The available evidence belonging to the Megalithic (BRW), early historic (rouletted ware, thin grey ware, BRW) and Medieval period (grey stoneware heavy jars, Chinese colour ware, Sasanian and Islamic ware) indicates that Mantai Port operated at its best during the period 6 BC to 14 AD. The relationship between this evidence and Chinese, Greek, Persian, Roman, Syrian and South Indian evidence has also been confirmed (Prematilake, 2003).

Tirukesvaram Kovil, currently located about $450 \mathrm{~m}$ from the coastal belt, is believed to have been situated inside the ancient Mantai Fort. Several inscriptions found on the island also support the claim that the ancient kovil was situated inside Mantai Port (Goonatilake, 2007b).

Mantai port also played an important role in the history of Sri Lanka. The South Indian Pandyan King Vijaya, invaded Sri Lanka at the end of the $13^{\text {th }}$ Century $A D$, via this port, which remained a part of the Pandyan Empire for two decades.

Additionally, two inscriptions by King Kassapa $V$ indicate that four villages were donated to the two Buddhist monasteries located at Mantai. Parakramabahu I fought two naval battles here and built a fortress at a place called Pilavasu to retain his hold on this region (Goonatilake, 2007b).

The narrow channel between the island of Mannar and the mainland, and the Pamban Channel between the island of Rameswaram and the Indian mainland, may have allowed the passage of slightly large boats, but certainly not the ocean-going vessels used for long distance international trade. It is therefore evident that Mantai represented a terminus for westbound traffic. From this point, goods would either have been carried overland to the west, or trans-shipped through the Mannar Channel in smaller boats to large boats waiting out at sea.

The tides in the Gulf of Mannar and the tides in Palk Bay are very different: there is almost a twelve-hour difference in the tides, although they are close together. Because of this, there is a water depth differential on either side of Adam's Bridge, driving strong currents through the gaps between the islands. These currents change direction as the tide changes. This means that little boats would be carried through the channel in either direction simply by the tidal flow.

At the Mantai port, the surface mound is covered with open scrub and occasional trees, with a few Baobab trees (Adansoniya digitata) (Vandercone et al., 2004), a native of tropical Africa, which, by legend, was imported by Arab seafarers (Goonatilake, 2007b). 
Another important ancient port is Uratota (Kayts), which was mentioned in the Rajavaliya during the reign of King Panduwasudeva in the $5^{\text {th }}$ century BC. However, the first reliable evidence on the existence of Uratota, is the landing of the Vallabha expeditionary force at this port, also called Sukaratitta and Huratota, during the reign of Mahinda IV (956-972 AD).

In 1976, a hoard of Chinese porcelain and pottery was discovered on Kayts Island. It was clear from the location of the Chinese material in the heart of the dune, and the fact that it was in no way connected with traces of occupation, that the hoard was the result of a single deposit, probably as the result of a shipwreck or some other disaster. More than 6,000 shards found from the site were cleaned and sorted and it was possible to identify 443 vessels of more than 35 different types (Goonatilake, 2007b).

The ports of the Jaffna Peninsula were less commercially important in ancient times than Mantai, but they were used by South Indian invaders to make landings (Nicholas, 1963). Jambukola patuna port was used to bring the Sri Mahabo tree during the $3^{\text {rd }}$ century BC. This was identified as Sambilturai, near Kankesanturai (Goonatilake, 2007b).

A map showing these ancient ports is presented below, in Figure 6.

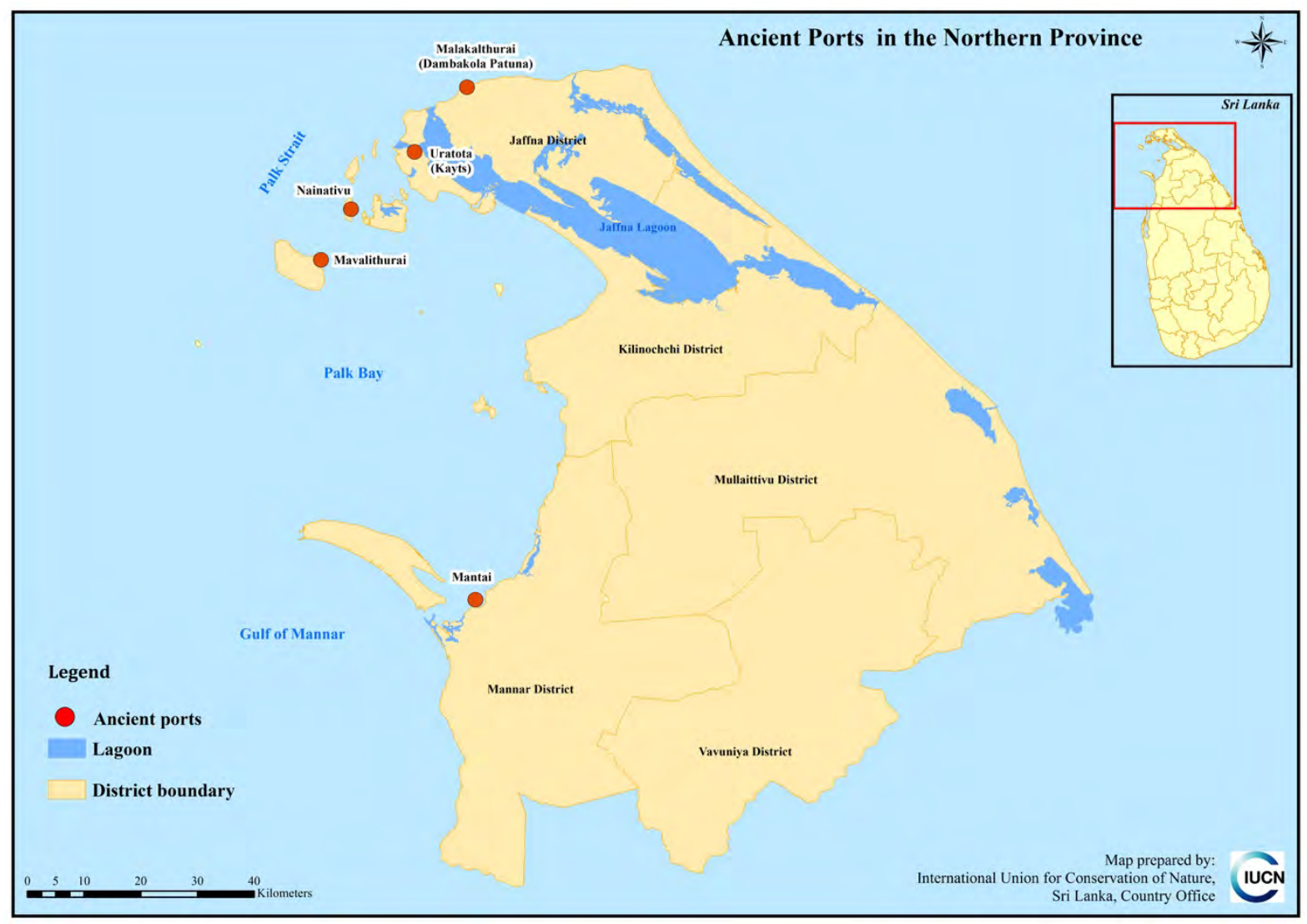

Figure 6. Ancient ports of northern Sri Lanka

(Source: Ponnampalam, 1987) 


\section{Areas recorded in ancient chronicles}

Ptolemy was the first foreigner to prepare a detailed map of Sri Lanka (then known as Taprobane) during the $2^{\text {nd }}$ century AD. However, he had not visited Sri Lanka and he collected his material from sailors and merchants. The ports, towns, marts, and capes important to sailors and merchants were included in his descriptions. Several place names which Roman and Greek merchants sailed to in the island could be identified along the Gulf of Mannar and the Palk Bay sea coast. These were Anarismoundou for Antarapara smudda (now called Kalpitiya Peninsula), Hipporos for Acha giri or Horse Mountain (now called Kudiremalai), Margon for Magana (now called as Pukkulam), the River Phasis for an ancient river that flowed through Pelivapi gama (now called as Malvatu Oya or Aravi Aru), Mouduuttou for Matota (now called Mantai), and Galiba for Kalmunai in Jaffna (meaning mountain people) (Weerasinghe, 1985).

The reefs of Musal tivu, Valai tivu, and others are a line of reefs spreading between Silavatturai and Vankalai and their extensions across the Gulf. On these reefs, there are pearl banks on which pearl oysters thrived in association with corals and sponges. Most of these banks lie 10-20 km offshore and in water depths of 10-20 m. These banks have attracted eastern and western merchants to the area since early historic times (Figure 7). Currently, however, these banks have been over-fished.

The archaeological or cultural importance of this area has not been explored or excavated yet (Goonatilake, 2007b).

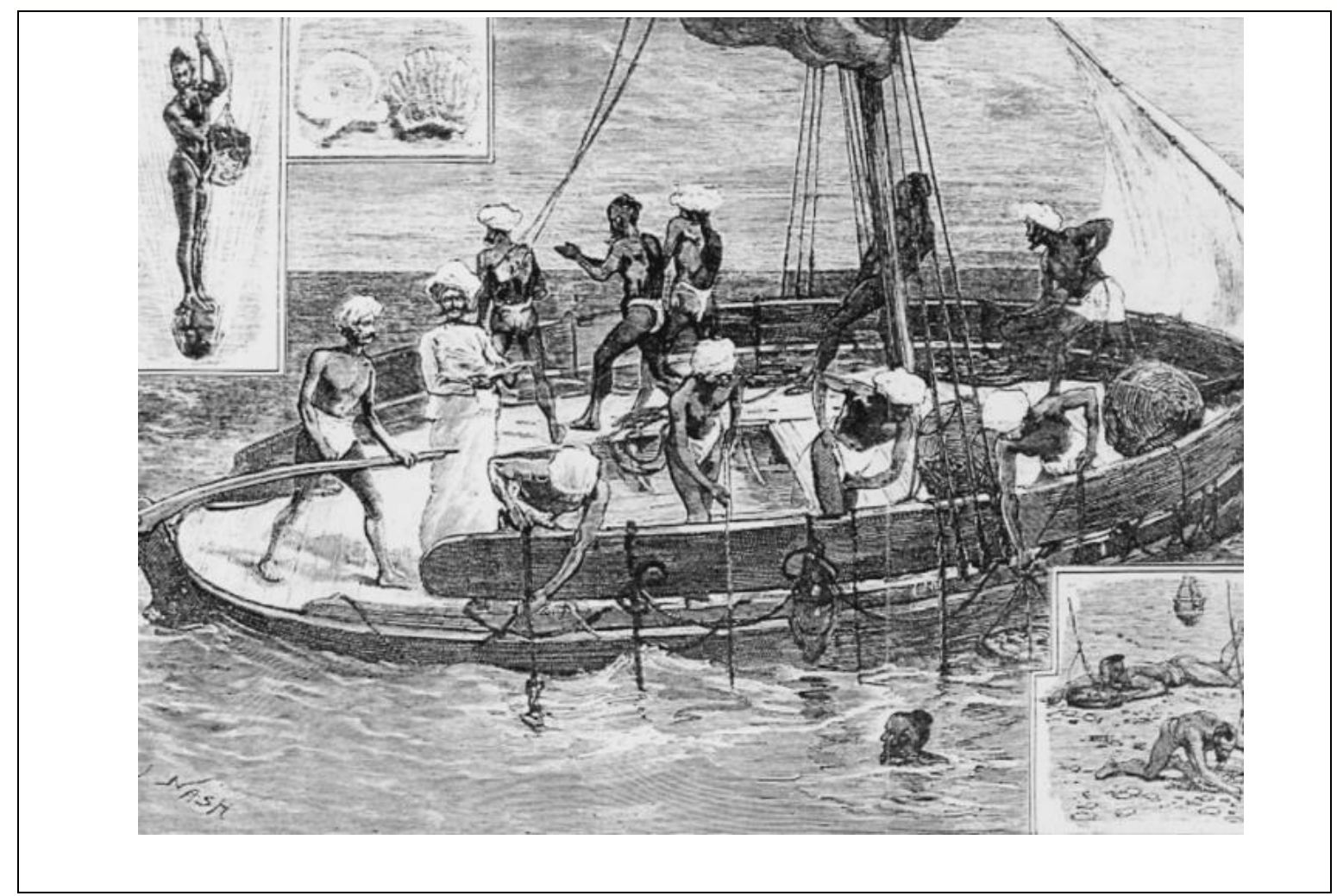

Figure 7. Pearl-fishery in Ceylon

(Source: The Graphic, October 22, 1887 http://anywater.ru/pubs/the-history-of-freediving/) 
Ancient chronicles such as Sihalavaththupakaranya and Rasavahinya mention a place named Ariyala at Nagadipa in the present Velanai (Kayts) Island. The story is that the person called Ariyalatissa offered an almsgiving to bhikkhus (monks) from Mandapadeepa (Mandaitivu) and Puvagudeepa (Pungudutivu) (Buddhatta, 2006).

Another ancient Buddhist site mentioned in the Nampotha as Karadivayina was later changed to Kaaraitheevu. The name change occurred in the late $19^{\text {th }}$ century after the construction of the Punnalai causeway but was accepted officially only in 1922. Dutch records refer to the island as Nieuw Amsterdam. However, its oldest name was Kaaradeepa, which was also referred to as Ahideepa, as stated in the Buddhist Akitti Jaathaka, which relates the story of the Buddhist recluse Akitti who came to Kaaradeepa. Akitti lived on a diet of Kaara leaves. Hence, the name may have arisen from kaara, a thorny shrub. The Pali name kaara was used even in South Indian inscriptions. Further, Tamil inscriptions (Udayendiram copper plates) refer to kaara trees (Webera tetrandra; Tamil: karai). Even at present, an ancient Buddhist site known as Vearppiddi (Veherapitiya), is found in Karaitivu Island. In addition, Megalithic burial sites are found at Chaththirantai (Chatrangana is an area for hoisting flags) in Karaitivu Island.

Legend holds that the Buddha visited Nagadeepa. The ancient reference seems to be to the whole of the Jaffna Peninsula, where a vihara and a city centre existed. This was an important territory of the Naga tribe in pre-Buddhist times. The capital of Nagadeepa was Nagapura, or Nakpur which later became known as Nallur (Dharmawardana, 2006). Thus, modern Nallur was the capital of the Nagas. They worshipped the Naka Deva, or Natha Deva. An inscription at Mihintale refers to this Naka Indra. The Naka Deva was adopted by Hindus, who built a temple named Naka-poshani, while Buddhists also adopted the Natha Deva as a Bodhisatva (Dharmawardana, 2006).

The island presently called Pungudutivu was referred to in Mahakam's Nampotha as Pongardiva which is also documented by Baldaeus (1658). This is an ancient name and possibly based on a type of tree known as Puvangu (Myristica horsfieldia, and Aglaia roxburghiana) (Dharmawardana, 2006).

The ancient Uratota, presently known as Kayts was, also referred as Uraturai and Urkavalthurai. It is an ancient, pre-Christian Buddhist site. It is referred to in the Nampotha as Tannidivayina. It was a major naval base under Parakramabahu I ( $12^{\text {th }}$ century AD). The military history of the Uratota is mentioned in the Nainativu inscription (written partly in Tamil) installed by King Parakramabahu. It is also mentioned in the thovila ritual Kohombakankariya. During the Portuguese period, it was known as Cais [meaning quay], which gave rise to its current English name. Baldaeus (1658) used the name 'Ourature' (Dharmawardana, 2006) for Kayts Island.

\section{Areas of historical colonial ruins and buildings (Portuguese and Dutch Forts and churches)}

\section{Forts}

There are several Portuguese and Dutch forts located beyond Arrippu in Mannar. Among those that still have remains are: 
- Jaffna Fort - originally built by the Portuguese as Nossa Senhora dos Milagres in 1560, and strengthened by the Dutch around 1680;

- Hammenhiel Fort - originally built by the Portuguese as Fortaleza do Cais dos Elefantes and later taken over by the Dutch in 1658. Hammenhiel means 'heel of ham' in Dutch, which the Dutch thought resembled Sri Lanka. It is situated between Karaitivu and Kayts (Figure 8);

- Fort Eyrie (Urundi Fort or Kayts Fort) — built by the Portuguese but taken over by the Dutch and then neglected;

- Pooneryn Fort - probably built originally by the Portuguese and later taken by the Dutch;

- Fort Beschutter - built by the Dutch near the village of Kovilvayal;

- Fort Elephant Pass - built by the Dutch on the northern shore of the lagoon on the Jaffna Peninsula;

- Mannar Fort - built by the Portuguese in 1560, taken over and rebuilt by the Dutch in 1686 (Fabry et al., 2006).

\section{Churches}

During colonial times, the Portuguese, Dutch and British spread Christianity throughout the region, so that churches are easily visible. These include:

- The Groote Kerk or Krurys or Dutch Church inside Jaffna Fort, only remains of walls are found now, built in 1730, destroyed during the civil war;

- St Mary's Cathedral, built in 1789 by the Dutch, found in Gurunagar;

- Vaddukoddai Portuguese Church, built originally by the Portuguese in the 1660 s, later modified by Dutch commander Laurens Pyls Anno in 1678. It then passed to the American Ceylon Mission and is now the seat of the Jaffna Diocese of the Church of South India;

- The ruins of a Portuguese Church at Atchuvely, (construction date unknown), but with typical Portuguese architecture; and

- St. Lucia's Church in Pallimunai, constructed using limestone (Fabry et al., 2006).

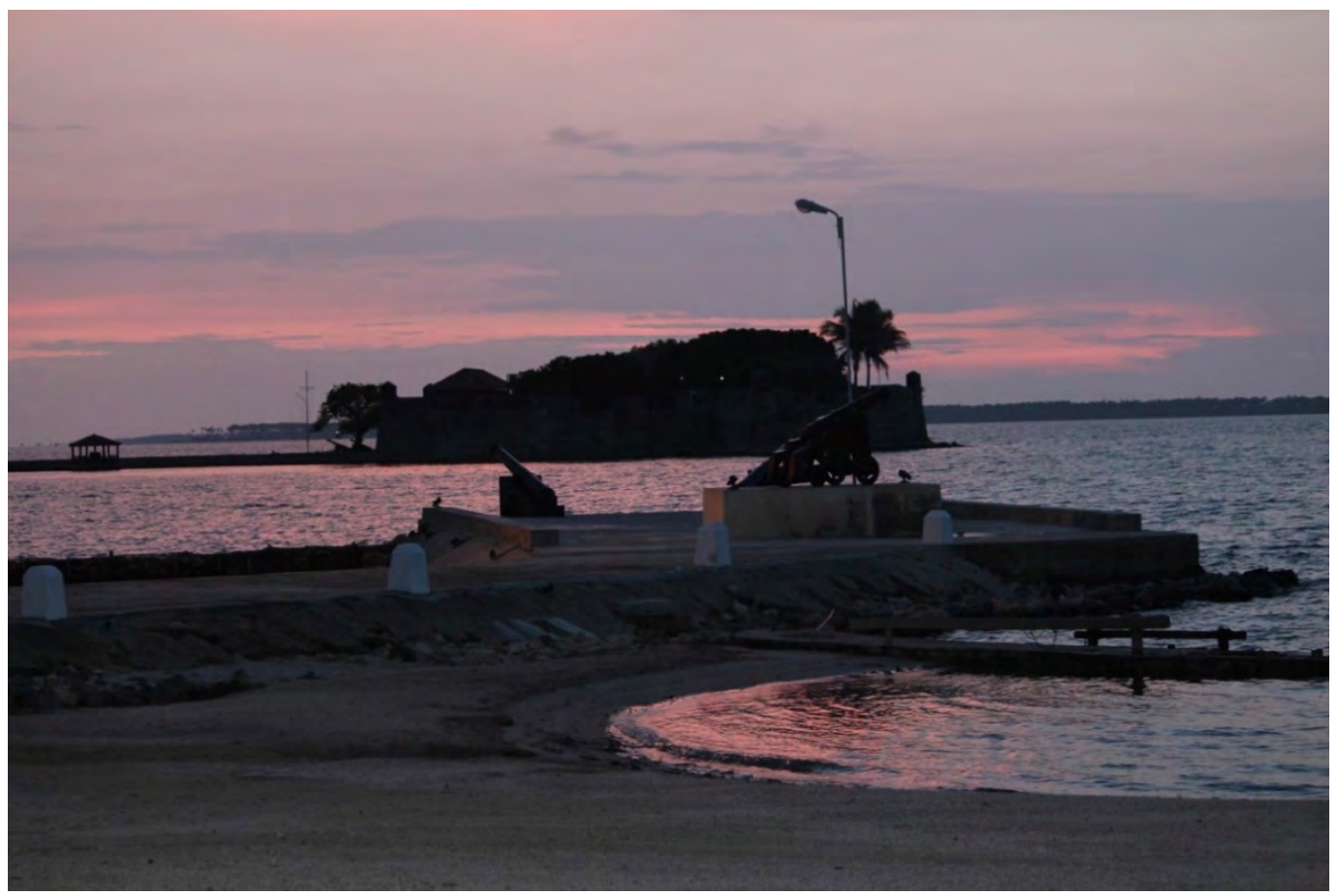

Figure 8. Sunset at Hammenhiel Fort, seen from Karaitivu (c) IUCN/Sampath de A. Goonatilake) 


\section{Chapter 2: Objectives of the study}

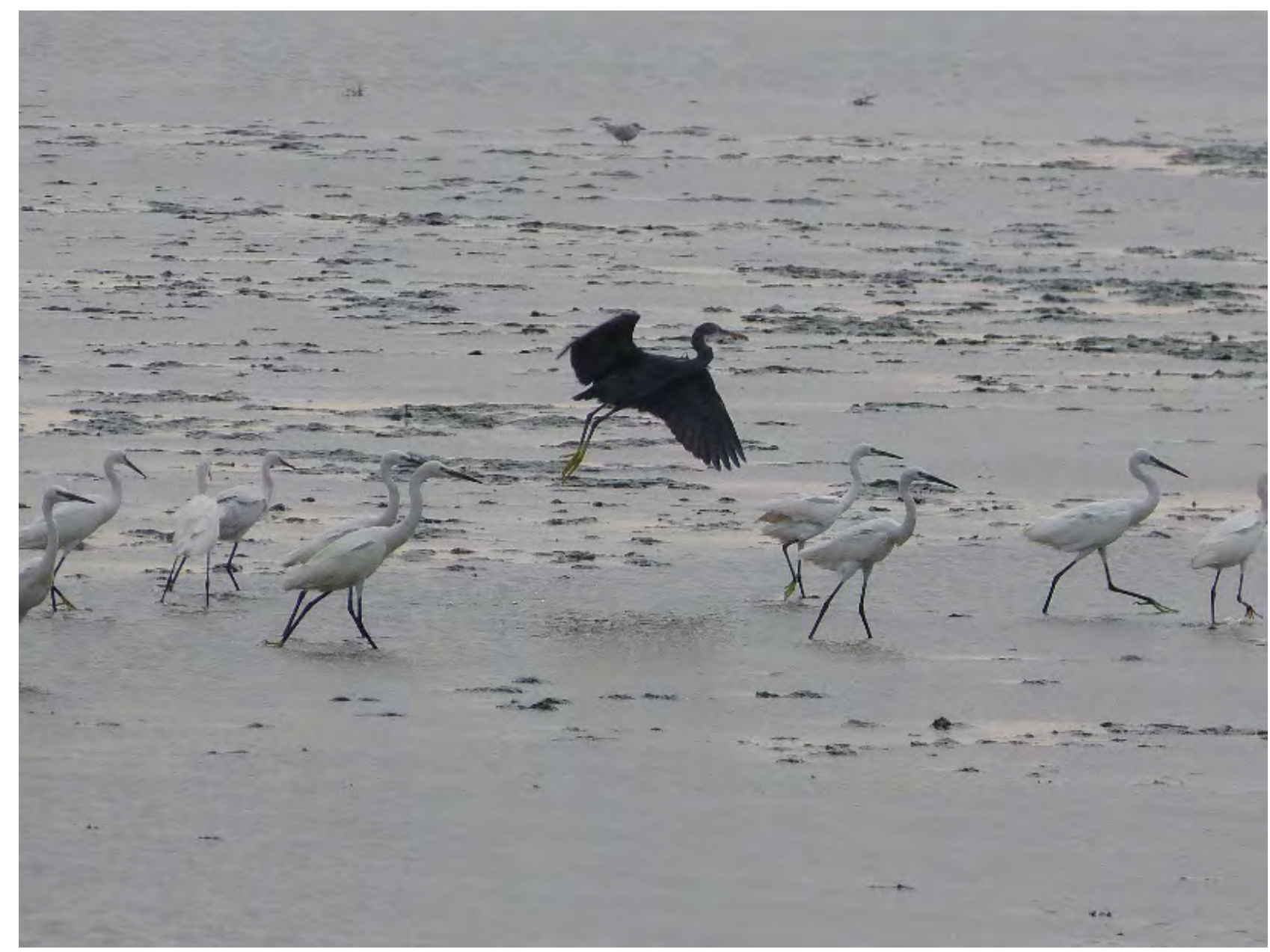

Western reef egret (Egretta gularis), Mannar Island $\odot$ Sriyanie Miththapala 


\section{Goal of the study}

The goal of this study was to assess the biodiversity of the coastal islands in the North, and the lagoon ecosystems found in the northern coastal area, to support the formulation of a strategic development planning framework that takes into consideration the need for environmental safeguards and conservation of biodiversity. In addition, this study aims to assess the resource base for the promotion of sustainable tourism.

\section{Specific objectives of the study}

The specific objectives of the study are to:

- document site-specific information on habitats, species; and the potential for sustainable tourism for the islands and lagoons in the northern coastal belt; and

- Identify threats to the biodiversity of the area, identify comprehensive studies that are essential to further understand the resource base, define potential carrying capacities for each island and

- provide-detailed recommendations to conserve the biodiversity of the area.

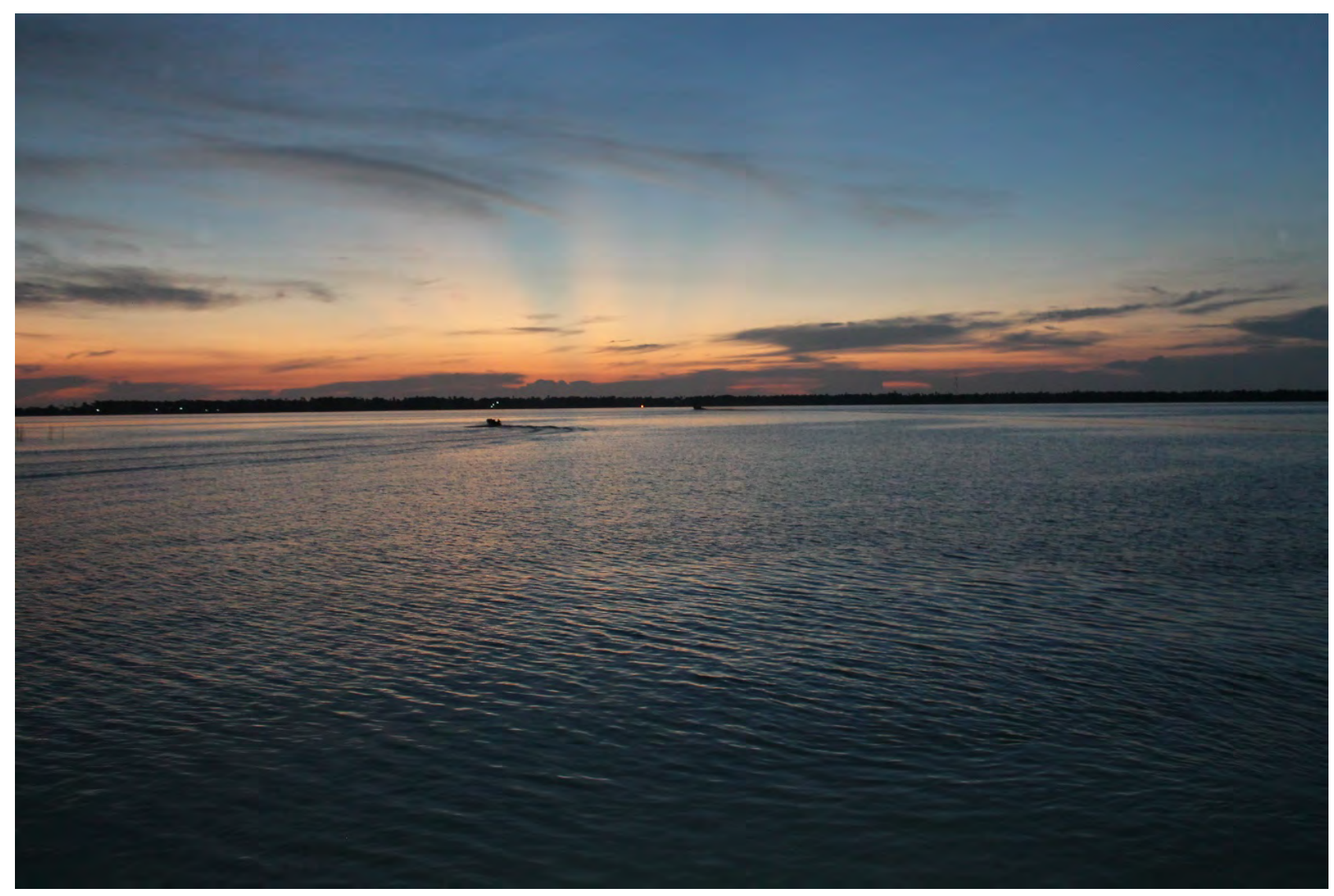

Figure 9. Sunset over Jaffna Lagoon

(C IUCN /Sampath de A. Goonatilake) 


\section{Chapter 3: Methodological approach}

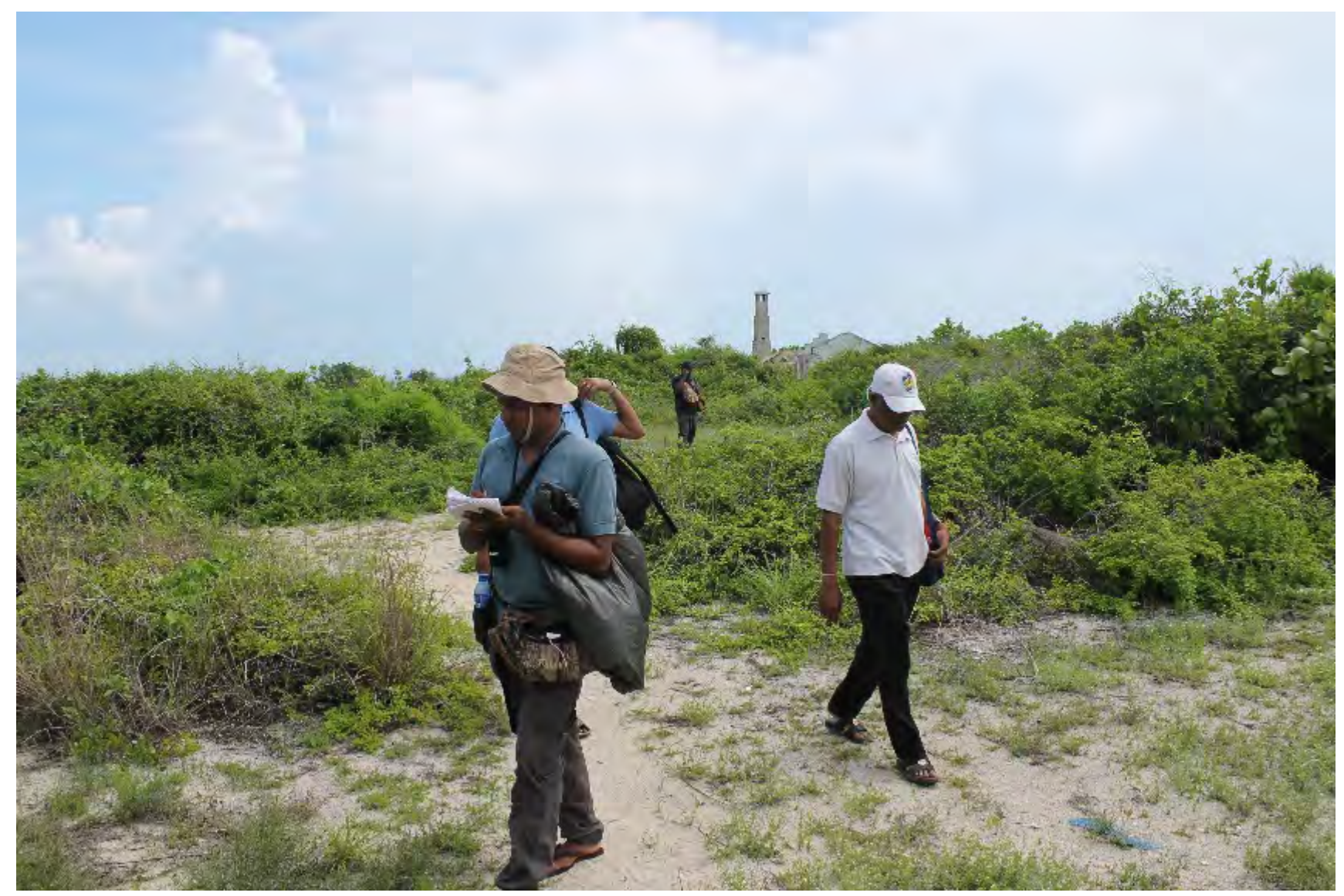

Field assessments, Kakaretivu ๑ IUCN/Sampath de A. Goonatilake 


\section{Methodology used for the terrestrial biodiversity survey}

Initially, a desk review of all published reports pertaining to fauna, flora, climate, geography etc. in the study area was carried out to document the available information, as well as to identify gaps in information that need to be addressed during the detailed field surveys. This review was followed by two field visits to collect information on identified data gaps. These field visits were carried out during the months of November 2015 and March 2016, by a group comprising officers from the UDA, SLTDA, CC\&CRMD, MEPA and IUCN.

During these field visits, the primary focus was to collect information on habitats and species observed in each habitat, document site-specific threats to biodiversity, and identify potential sustainable tourism attractions in each site surveyed, with respect to biodiversity, archaeology or any other significant cultural or social attribute.

Twenty-one islands, five coastal stretches and four lagoons were surveyed during these two field visits, through rapid assessments ${ }^{4}$ (Figure 10). This study used rapid biodiversity assessments to identify selected groups of flora and fauna present in the area.

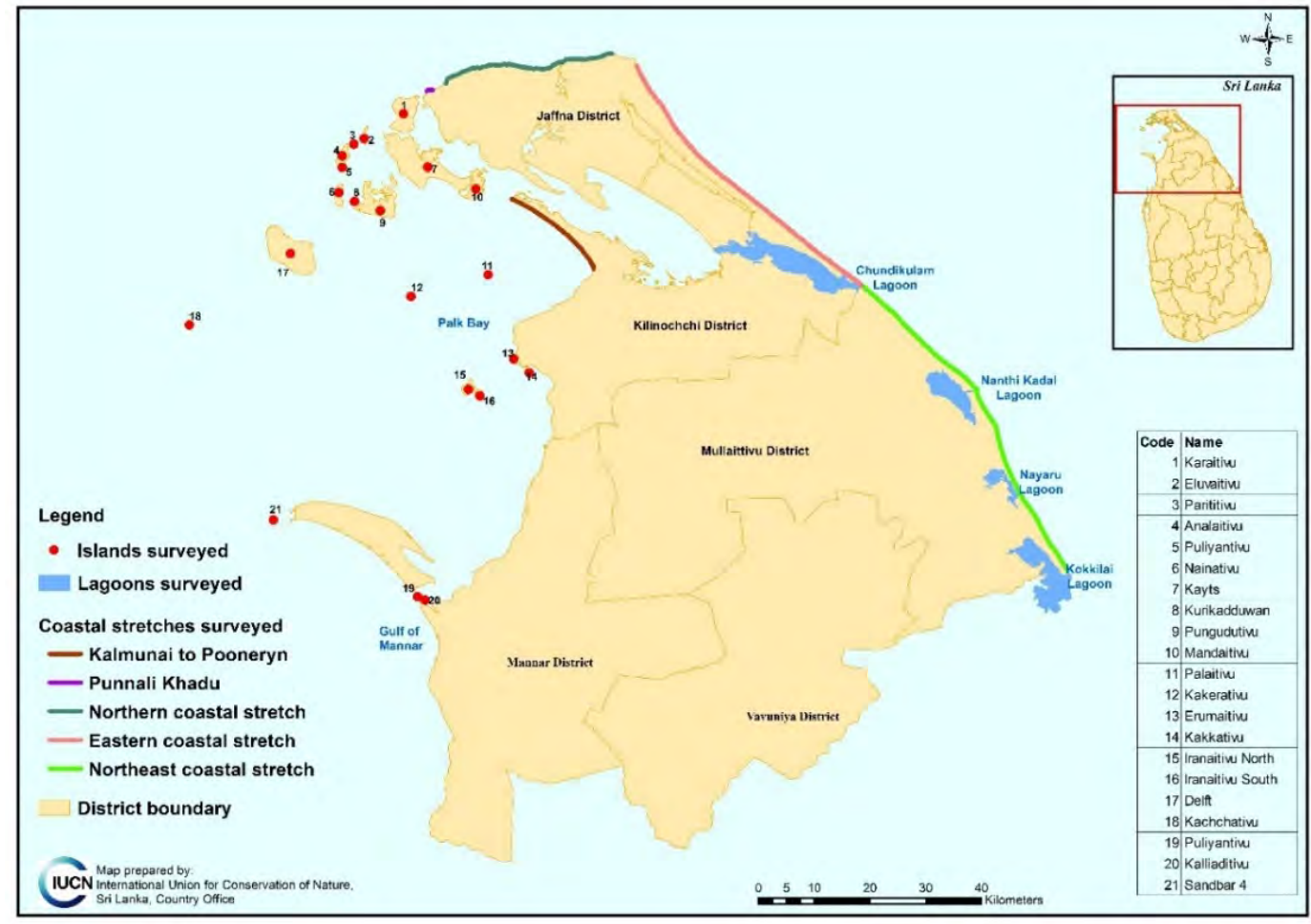

Figure 10. Islands, coastal stretches and lagoons in the Northern Province, sampled during this survey

\footnotetext{
${ }^{4}$ Standard field research takes years, but political leaders will not usually wait that long to make decisions affecting the most biologically important areas of Earth. [Rapid Assessment Programmes] RAP gathers relevant scientific information quickly enough to aid in protecting such places from irreversible damage that can occur on a very short time scale.' (Source: Murray Gell-Mann, Professor, Santa Fe Institute, and 1969 Nobel Prize recipient.)
} 


\section{Survey of flora}

A rapid line transect method was used to assess terrestrial floristic species richness in each island/inland coastal site. Forty-five line transects were carried out at one-kilometre intervals.

Because there were different vegetation types and land use patterns between one island/site and another, the length of transects varied and depended on the vegetation types and extent of land use patterns of each island. Apart from transect surveys; visual observations on all islands/sites were also used throughout to obtain inventories of floristic diversity. All known species observed during the survey were recorded and photographed. Specimens of unknown species were collected using standard herbarium techniques and herbarium sheets were prepared for later identification. Standard texts were used for nomenclature (Table 3).

\section{Survey of fauna}

A biodiversity assessment of terrestrial fauna was carried out on each island. Fauna were sampled within each island using the Visual Encounter Survey (VES) method. Vertebrate groups found within each site (amphibians, reptiles, birds and mammals), as well as selected invertebrate groups (scorpions, land molluscs/land snails, dragonflies and butterflies), were recorded as part of the faunal assessment. Aquatic assessments of freshwater fish and molluscs were not carried out because of time limitations. Each observed habitat and ecosystem type was sampled via a series of transects. Animal species observed opportunistically outside each transect were also recorded separately to ensure that the field data gathered was as comprehensive as possible.

Both direct and indirect observations (animal signs such as pellets, tracks, sounds and food remains) were used to document animals, especially mammals present within the study area. Bird identification was carried out directly, as well as indirectly by their calls. The identification and classification of faunal species were based on the most recently published field guides and taxonomic keys (Table 3) (Figure 12).

Table 3. Taxonomic guides and other publications used for species identification and nomenclature

\begin{tabular}{|c|c|c|}
\hline Subject & Taxon & Source \\
\hline \multirow{5}{*}{$\begin{array}{l}\text { Taxonomic } \\
\text { Identification }\end{array}$} & Flora & $\begin{array}{l}\text { Ashton et al., (1997); Dassanayake \& Fosberg (1980 - 1991); } \\
\text { Dassanayake et al., (1994 - 1995); Dassanayake \& Clayton } \\
\text { (1996 - 1999); Dassanayake, M. D., Clayton, W. D. and Shaffer- } \\
\text { Fehre, M. (2006); de Vlas \& de Vlas (2008). }\end{array}$ \\
\hline & Invasive species & MoMD\&E, (2016b) \\
\hline & Freshwater crabs & Bahir \& Yeo (2005) \\
\hline & Scorpions & Kovařík et al., (2016) \\
\hline & Land snails & Naggs \& Raheem (2000) \\
\hline
\end{tabular}




\begin{tabular}{|c|c|c|}
\hline Subject & Taxon & Source \\
\hline & Dragonflies & Bedjanic et al., (2007); Bedjanic et al., (2014) \\
\hline & Butterflies & $\begin{array}{l}\text { D' Abrera (1998); van der Poorten \& van der Poorten (2016); } \\
\text { Jayasinghe et al., (2015) }\end{array}$ \\
\hline & Freshwater fish & Goonatilake (2007a); De Silva, et al., (2015) \\
\hline & Amphibians & Manamendra-arachchi \& Pethiyagoda (2006) \\
\hline & Reptiles & Somaweera (2006); Somaweera \& Somaweera (2009) \\
\hline & Birds & Harrison (1999); Warakagoda, et al., (2012) \\
\hline & Mammals & Phillips (1935, 1981a, b,c); Kotagama \& Goonatilake (2013) \\
\hline Nomenclature & Flora/Fauna & Senaratna (2001); MoE (2012) \\
\hline Redlist Status & All & MoE (2012); IUCN (2017) \\
\hline
\end{tabular}

\section{Methodology used for the marine biodiversity survey}

A rapid coral reef survey was carried out in the coastal waters of Palk Bay and Palk Strait. The aim of the survey was to collect information on reef quality by identifying good coral reef sites that can be used for tourism related activities and to identify reefs that need protection. The survey was conducted around the islands of Iranaitivu, Erumaitivu, Kakkativu, Kakerativu, Palaitivu, Mandaitivu, Pungudutivu, Kachchativu and Delft and the fringing reefs from Kayts Island to Point Pedro on the northern coast of the Jaffna Peninsula ( Figure 11). The survey was conducted from $1^{\text {st }}$ to $8^{\text {th }}$ November 2015 and from $4^{\text {th }}$ to $10^{\text {th }}$ March 2016 . Underwater visual estimation methods, as specified in the Survey Manual for Tropical Marine Resources (English et al., 1997), were used to assess the quality of the reef habitats. The survey was carried out by snorkelling at several coral reef sites around islands and on the fringing reefs along the mainland coast. Inventories of species were limited to hard and soft corals, reef fish and large invertebrates such as molluscs, echinoderms and crustaceans. 


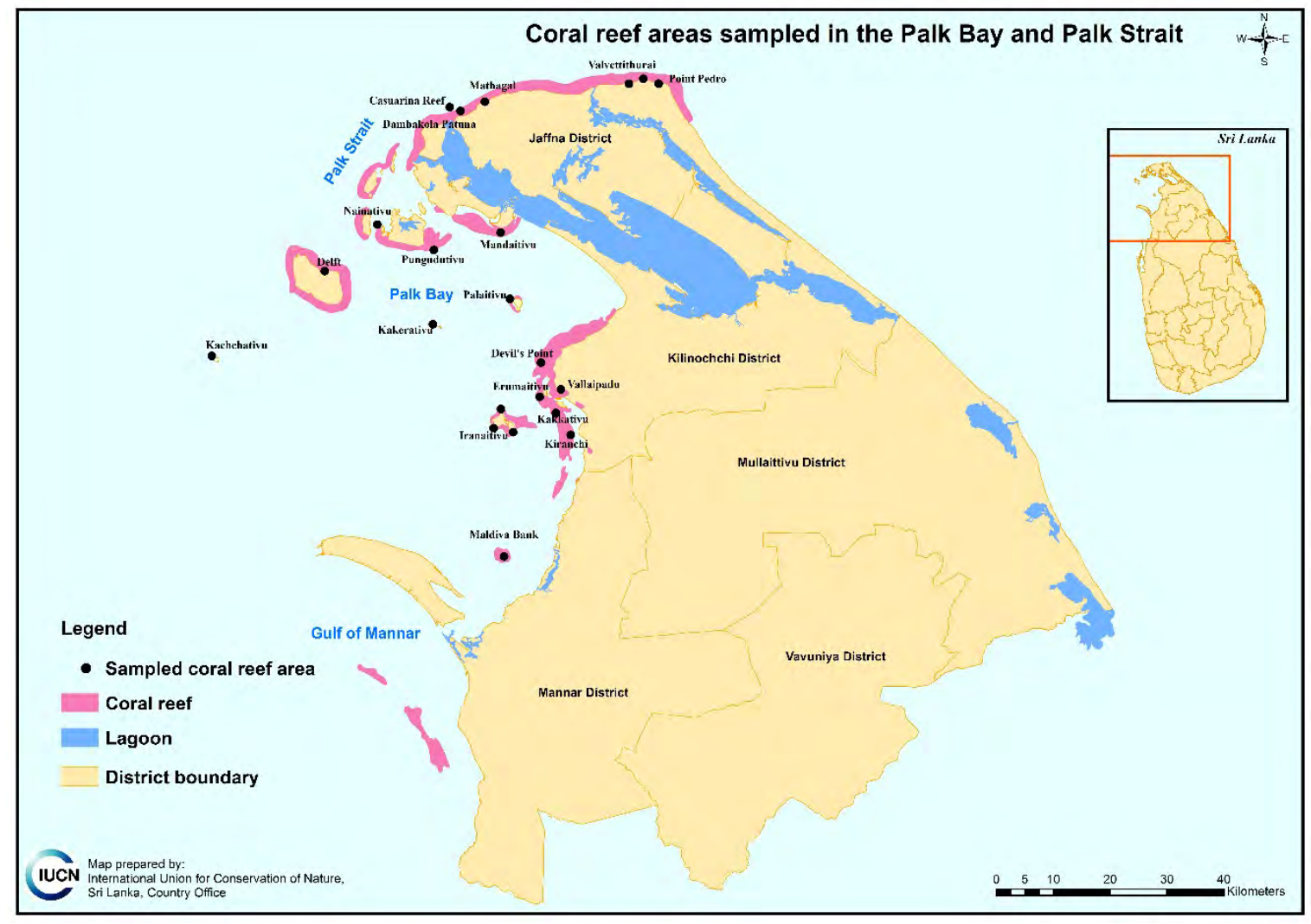

Figure 11. Coral reef areas sampled in Palk Bay and Palk Strait 

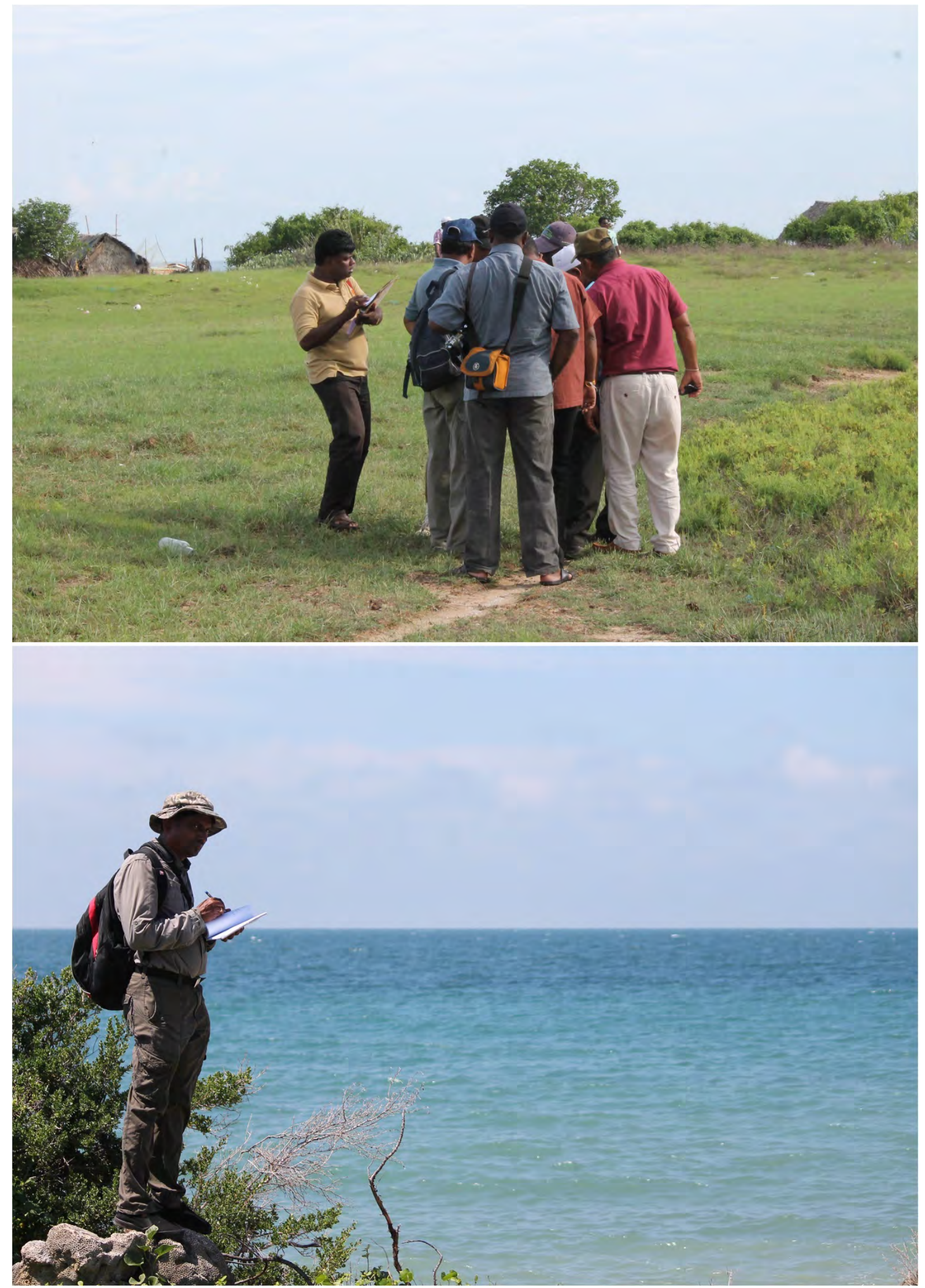

Figure 12. Top: examining the island map, Iranaitivu South; bottom: field assessment Kachchativu

(Top ๔ IUCN/Sampath de A Goonatilake; bottom: @ IUCN/Naalin Perera) 

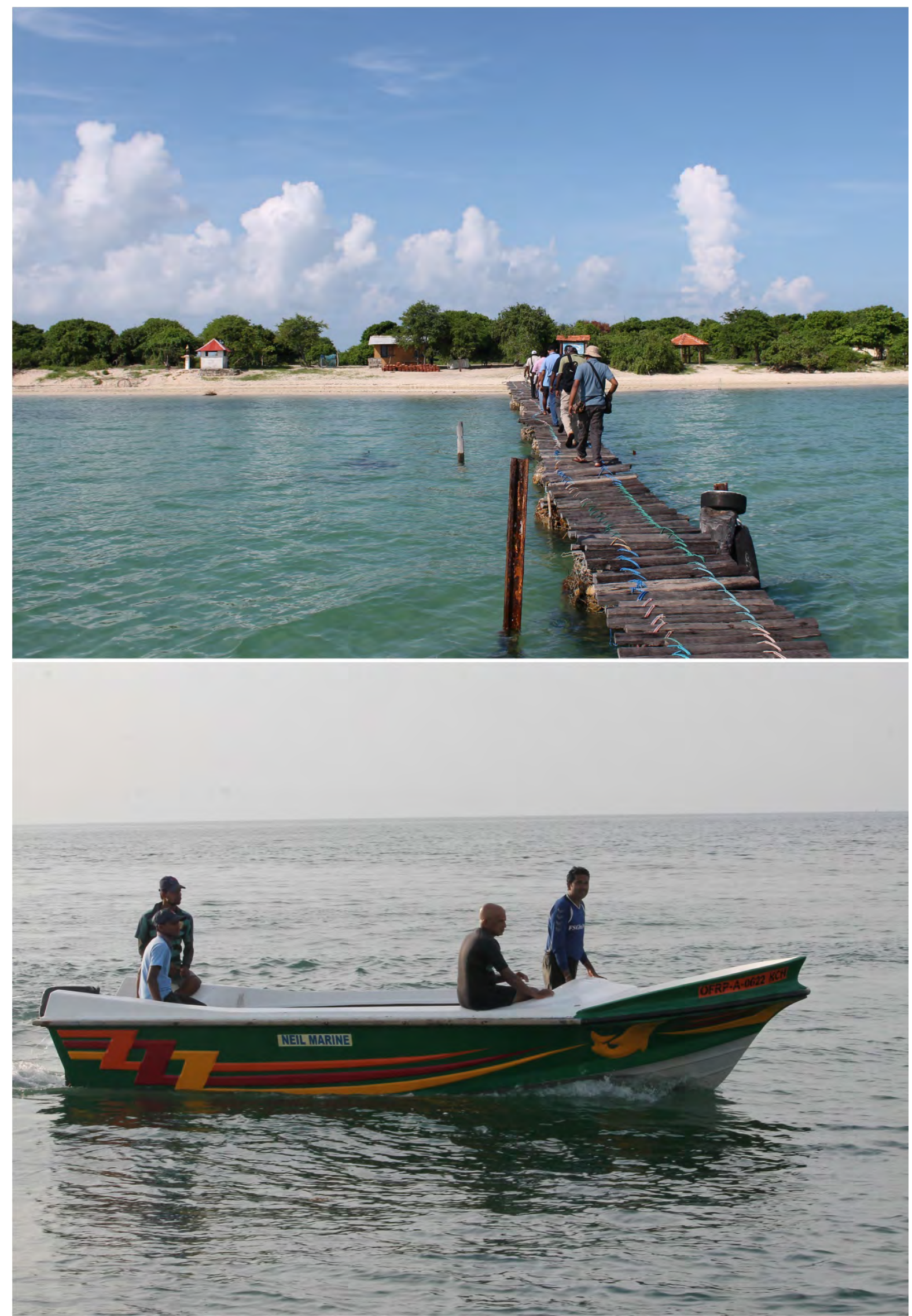

Figure 13. Top: the team disembarking at Palaitivu; bottom: returning from marine surveys

(C) IUCN/Sampath de A Goonatilake) 


\section{Chapter 4: Results of the study}

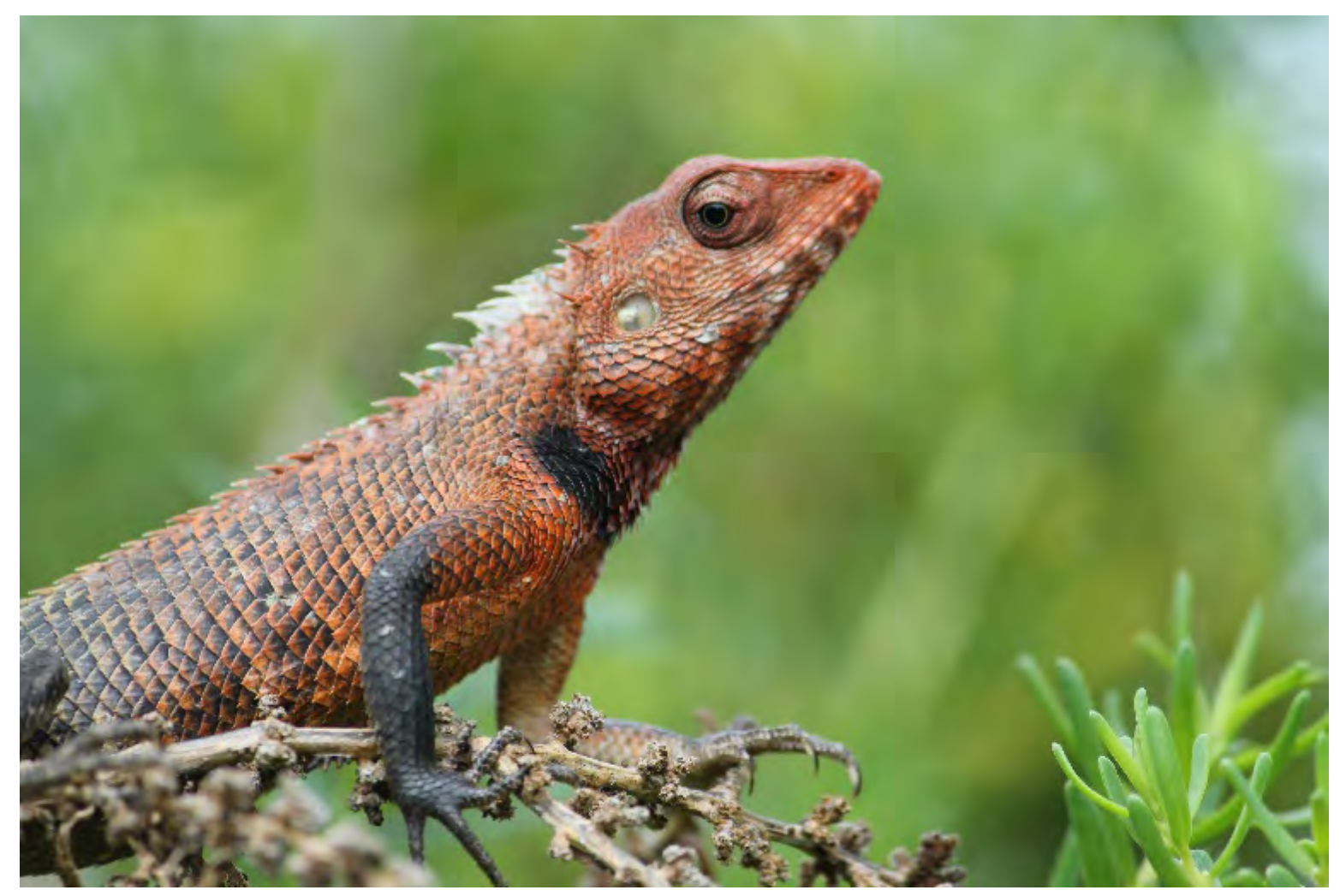

Common garden lizard (Calotes versicolor), Iranaitivu North (৫) IUCN/Sampath de A. Goonatilake 


\section{Ecosystem diversity in the study area}

\section{Terrestrial and coastal ecosystem diversity}

Based on field observations, terrestrial ecosystem diversity ${ }^{5}$ of the islands and the coastal zone of the northern area can be divided generally into three major categories, namely, natural, semi-natural and man-made ecosystems.

\section{Natural ecosystems}

The natural vegetation of this area and its distribution has been shaped by its semi-arid climate and coastal saline conditions. For example, natural coastal ecosystems - such as mangroves, salt marshes, sandy seashores and seashore scrublands - were distributed towards more saline and coastal/sandy conditions, while arid mixed evergreen forests were found more inland, in less saline conditions.

\section{Arid mixed evergreen forests (thorn scrubs)}

The main tree/shrub dominant vegetation in the islands was arid mixed evergreen forests, which were found mostly as isolated fragments surrounded by grasslands. These forests are also called thorn scrubs and this name is derived from the spiny characteristics of the stems of species found in these scrubs - such as Dichrostachys cinerea, Flueggea leucopyrus, Azima tetracantha, Toddalia asiatica, Carissa spinarum and Scutia myrtina. Thorn scrubs are characterised structurally by the presence of a few, scattered, short trees with low and spreading crowns in the uppermost stratum, consisting mainly of species such as Salvadora persica, Manilkara hexandra, Thespesia populnea and Ziziphus mauritiana.

As a continuous layer, shrubs are more abundantly spread than trees and are mainly composed of Senna auriculata, Dichrostachys cinerea, Flueggea leucopyrus, Carissa spinarum, Calotropis gigantea, Atalantia ceylanica, Gmelina asiatica, Diospyros vera, Ziziphus oenopila and Capparis spp.

The ground layer of thorn scrub ecosystems consists of a herbaceous plant community that is composed mainly of Tridax procumbens, Euphorbia rosea, Phyla nodiflora, Launaea sarmentosa, Leucas zeylanica, Boerhavia diffusa, and Hybanthus enneaspermus.

Many plant species in thorn scrubs show xerophytic characteristics.

Fauna found in this ecosystem include the Vulnerable land snail Cryptozona semirugata; dragonflies, such as the pruinosed bloodtail (Lathrecista asiatica) and the green skimmer (Orthetrum sabina); butterflies, such as the tailed jay (Graphium agamemnon) and small salmon Arab (Colotis amata); amphibians, such as the common bull frog (Kaloula taprobanica) and balloon frog (Uperodon systoma); reptiles, such as the star tortoise (Geochelone elegans) and common garden lizard (Calotes versicolor); birds, such as the grey francolin (Francolinus

\footnotetext{
${ }^{5}$ Ecosystem categories are as given in MoMD\&E (2016a)
} 
pondicerianus) and green bee-eater (Merops orientalis) and mammals, such as the grey langur (Semnopithecus priam) and the grey mongoose (Herpestes edwardsii).

See Figure 14 for a photograph of this ecosystem.

\section{Palmyra woodlands}

The palmyra palm (Borassus flabellifer) has long been an economically and culturally important tree species in the Jaffna Peninsula. Even though palmyra is associated generally with human settlements, it has spread naturally into natural habitats and dominates some scrublands, which are therefore, referred to as 'palmyra woodlands'. Field observations showed there were some modifications in the structure and composition of palmyra woodlands compared to natural thorn scrubs found in the area. Scattered scrub patches were distributed unevenly as the undergrowth of palmyra woodlands. A few trees and herbs are found among the scrub vegetation. Although palmyra is the dominant species, others - such as Phoenix pusilla, Flueggea leucopyrus, Morinda coreia, Azadirachta indica, Cissus quadrangularis, Dodonaea viscosa, Ziziphus oenopila, Jatropha glandulifera, Carissa spinarum, Ficus benghalensis, Dichrostachys cinerea, Canthium coromandelicum, Ehretia microphylla, Toddalia asiatica and Amorphophallus sylvaticus were found commonly among this vegetation type.

See Figure 14 for a photograph of this ecosystem.

Fauna found in palmyra woodlands include dragonflies, such as the blue pursuer (Potamarcha congener) and sociable glider (Tramea limbata); butterflies, such as the little orange tip (Colotis etrida) and African babul blue (Azanus jesous); reptiles, such as Devaka's fanthroated lizard (Sitana devakai) and saw-scaled viper (Echis carinatus); birds, such as the Asian palm swift (Cypsiurus balasiensis) and black drongo (Dicrurus macrocercus) and mammals such as the antelope rat (Tatera indica) and black-naped hare (Lepus nigricollis).

\section{Seashore scrublands}

Seashore scrublands occupy the interface between inland and coastal ecosystems of the islands. The structurally discontinuous vegetation of seashore scrublands is a mixture of some inland flora, some mangrove-associated flora, some sand dune flora and some plant species that are characteristic of seashore scrublands. Fleshy and thick stems or leaves that help the plants to store water and survive in harsh conditions are found in some of the shrub species of this ecosystem. Scaevola taccada, Pemphis acidula, Dichrostachys cinerea, Flueggea leucopyrus, Calotropis gigantea, Guettarda speciose and Thespesia populnea were the dominant species observed in the seashore scrubland ecosystems. Aloe vera and Opuntia dillenii were exotic herbs that were observed in this ecosystem.

See Figure 15 for a photograph of this ecosystem.

Fauna of this ecosystem includes butterflies, such as the tawny coster (Acraea violae) and common sailor (Neptis hylas); reptiles, such as the rat snake (Ptyas mucosa) and land monitor (Varanus bengalensis); birds, such as the ashy-crowned sparrow lark (Eremopterix grisea) 
and red-vented bulbul (Pycnonotus cafer); and mammals such as the brown and grey mongoose (Herpestes fuscus and $H$. edwardsii, respectively).

\section{Dead coral beaches}

At first, although dead coral beaches and seashore areas appear to be barren and without vegetation, they supported several species of plants - such as Spinifex littoreus, Ipomoea pes-capre, Launaea sarmentosa, Citrullus colocynthis and Bulbostylis barbata, which grow in isolated clumps. High temperatures during the day, incessant salt spray and lack of a fertile substrate make it impossible for other plant life to be sustained in these habitats. Beach sediment and organic debris are continually flushed by sea water into the spaces within these rocky habitats. This creates an ideal environment for some species of marine fauna. The rocky areas are also occupied by burrowing animals, such as crabs and worms. These animals hide among coralline rocks to avoid detection by predators and escape the strong wave action.

See Figure 15 for a photograph of this ecosystem.

Fauna found in this ecosystem include reptiles, such as Bibron's sand skink (Eutropis bibronii); birds such as the common sandpiper (Actitis hypoleucos), great crested tern (Sterna bergii), little egret (Egretta garzetta) and western reef egret (Egretta gularis); as well as several species of littoral zone molluscs and arthropods.

\section{Sand dune scrublands}

Sand dune scrublands are very dynamic coastal ecosystems, highly influenced by wind and tidal actions. The eastern coast of Jaffna Peninsula is an area of high winds and is home to fairly large extents of sand dunes.

Wind-blown accumulations of sand create dunes that maintain a unique structure and composition of flora and fauna that result in coastal sand dune scrublands. Sand dune scrublands cover these accumulated sands in dunes and increases their stability. Starting from eastern Point Pedro, discontinuous sand dunes extend along the coast up to Chundikulam. In addition, in the Pooneryn and Palk Bay areas, are found huge sand dunes. Calotropis gigantea, Borassus flabellifer, Bauhinia racemosa, Caesalpinia bonduc, Flueggea leucopyrus, Cissus quadrangularis and Aloe vera are common plants found on sand dunes. In addition to natural sand dune scrubs, a large extent of sand dunes associated with human settlements has been planted with Casuarina equisetifolia.

See Figure 15 for a photograph of this ecosystem.

Fauna of these scrublands include butterflies such as the small salmon Arab (Colotis amata) and common gull (Cepora nerissa); reptiles such as Devaka's fan-throated lizard (Sitana devakai) and land monitor (Varanus bengalensis); birds such as the common kestrel (Falco tinnunculus), paddyfield pipit (Anthus rufulus) and green bee-eater (Merops orientalis); and mammals such as the black-naped hare (Lepus nigricollis) and antelope rat (Tatera indica). 


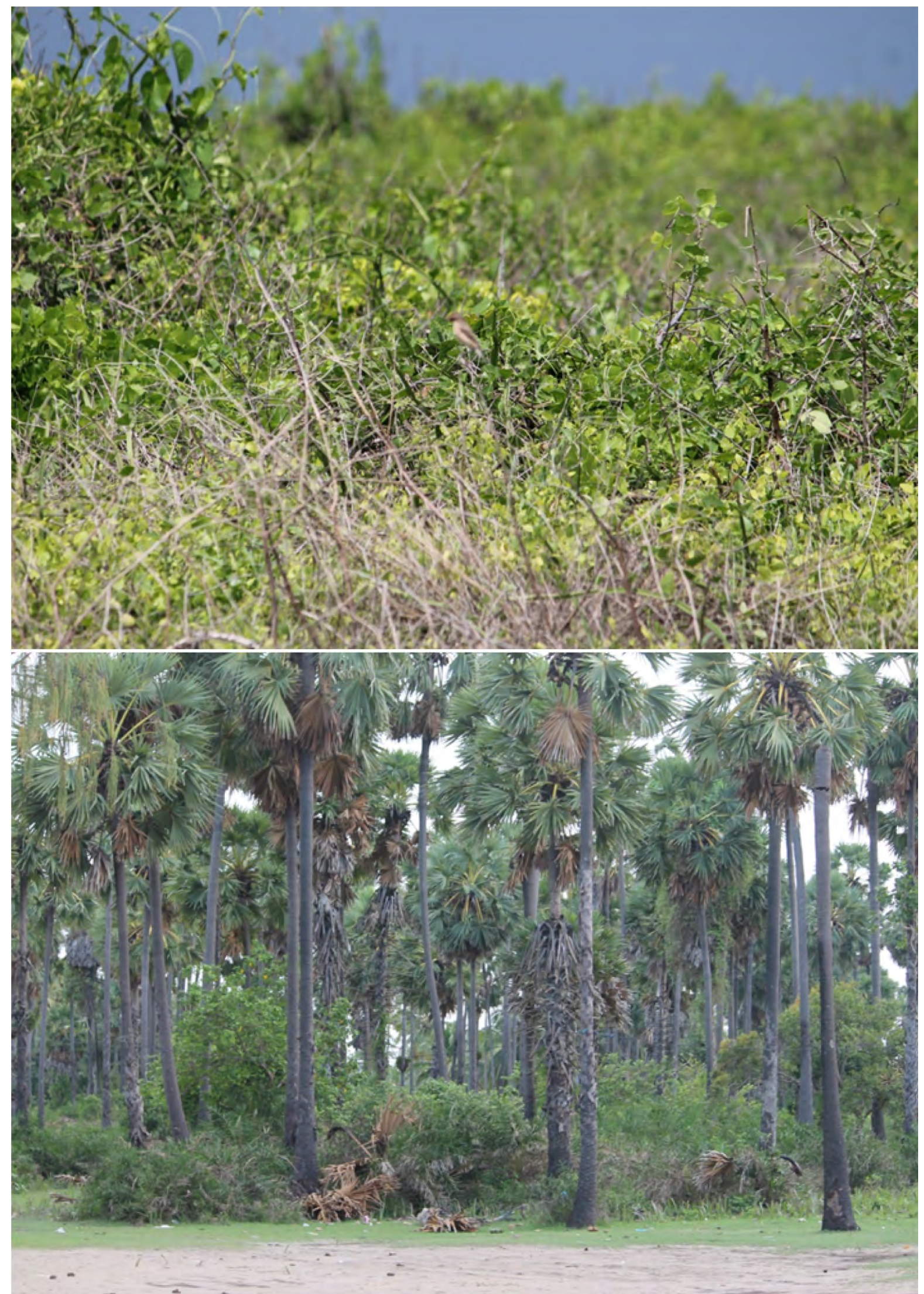

Figure 14. Top: arid mixed evergreen forests, Kakerativu Island; bottom: palmyra woodlands, Karainagar

(๔) IUCN /Sampath de A. Goonatilake) 

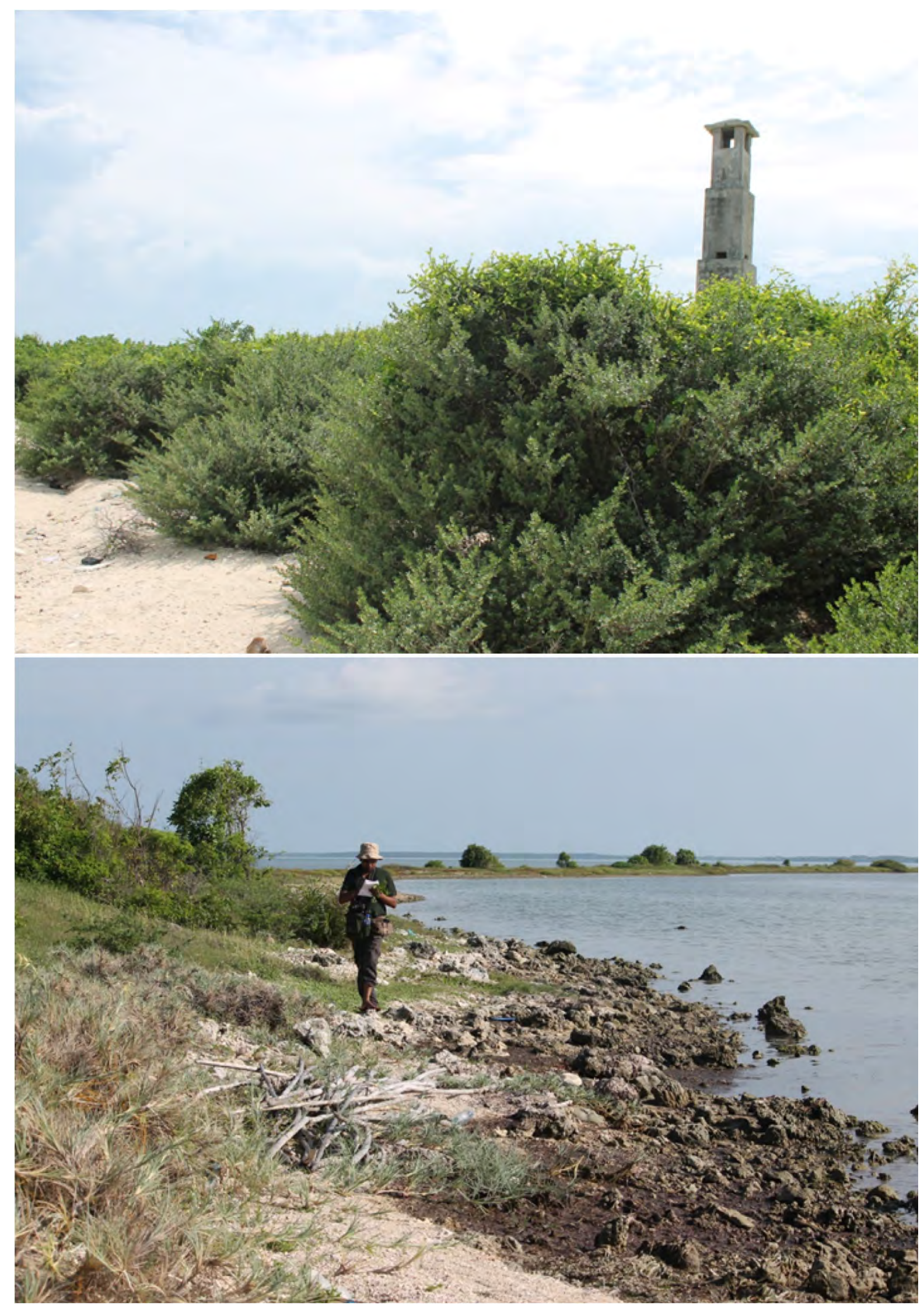

Figure 15. Top: beach front scrub, Kakerativu Island; bottom: coral rock and seashore vegetation, Parititivu Island

(๑ IUCN/ Sampath de A. Goonatilake) 


\section{Sandy seashores}

This vegetation type has a very simple structure and species composition. Only salt-tolerant herbaceous species (up to $30 \mathrm{~cm}$ in height), such as Citrullus colocynthis, Ipomoea pes-capre, Launaea sarmentosa, Spinifex littoreus, Catharanthus roseus, Sesuvium portulacastrum, Atriplex repens, Lablab purpureus and Pupalia lappacea were observed in this habitat. Often, pure populations of Spinifex littoreous provided shelter in the highly unstable seashore, exposed to heavy winds. These sandy areas attract a host of burrowing animals - such as bivalves, crabs and other marine invertebrates. These animals hide in the sand in order to escape from predators and strong waves.

Many avian species - such as the Kentish plover (Charadrius alexandrines), lesser sand plover (Charadrius mongolus), Eurasian curlew (Numenius arquata), lesser crested tern (Sterna bengalensis) - that prey on these invertebrate species can be seen feeding in this habitat type.

See Figure 16 for a photograph of this ecosystem.

\section{Mangroves and associates}

The Jaffna Lagoon opens into Palk Bay and there are mangroves on the shores of both the mainland and the islands of Palk Bay. As the dominant species of this ecosystem, Avicennia marina was widely distributed and was found associated frequently with salt marshes in the area. The height of the clumps of Avicennia marina rarely extended over one metre and thus, formed a stunted mangrove community. In addition to Avicennia marina, some true mangrove species such as Rhizophora mucronata, Bruguiera cylindrica, Ceriops tagal were found within mangrove ecosystems. Sonneratia alba was rarely observed near a few tidal flats in the islands. Apart from the salt marsh species associated with mangroves, some species considered to be mangrove associates - such as Thespesia populnea, Clerodendrum inerme, Premna obtusifolia, Pemphis acidula and Excoecaria agallocha were also observed among the mangrove habitats found along the seashore or islands. See Figure 17 for a photograph of this ecosystem.

Dragonflies, such as the marsh skimmer (Orthetrum luzonicum and orange-winged groundling (Brachythemis contaminata); butterflies such as the lemon emigrant (Catopsilia pomona) and leopard (Phalantha phalantha); reptiles such as the common garden lizard (Calotes versicolor) and dog-faced water snake (Cerberus rynchops); birds such as the white-throated kingfisher (Halcyon smyrnensis), white-bellied sea-eagle (Haliaeetus leucogaster) and house crow (Corvus splendens) and mammals such as the flying fox (Pteropus giganteus) and Sri Lanka toque monkey (Macaca sinica) are found in mangroves.

Mangrove ecosystems provide breeding and feeding grounds for several commercially important fin fish and shellfish. 


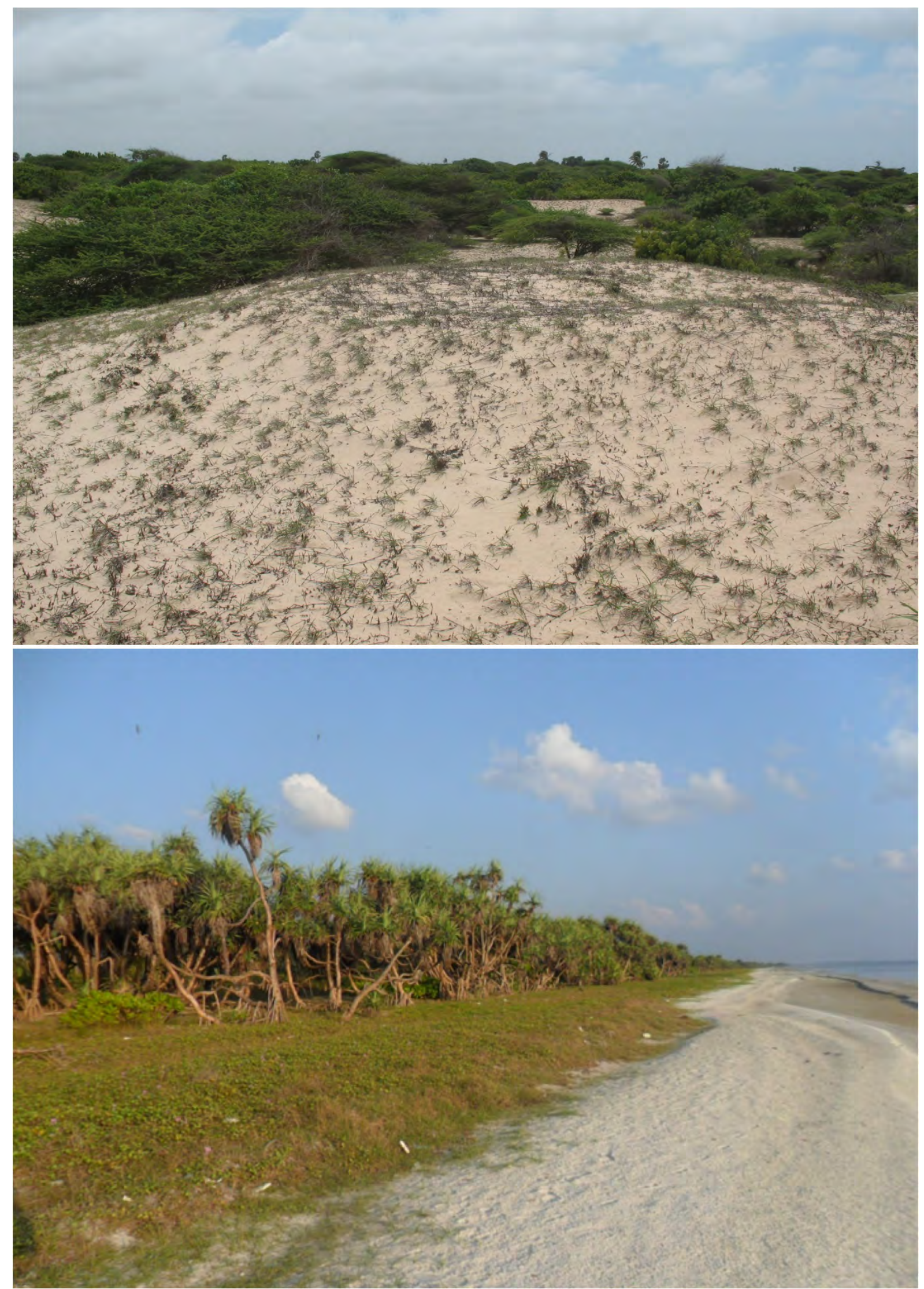

Figure 16. Top: sand dune scrub; bottom: sandy seashore vegetation (৫ IUCN/ Sampath de A. Goonatilake) 

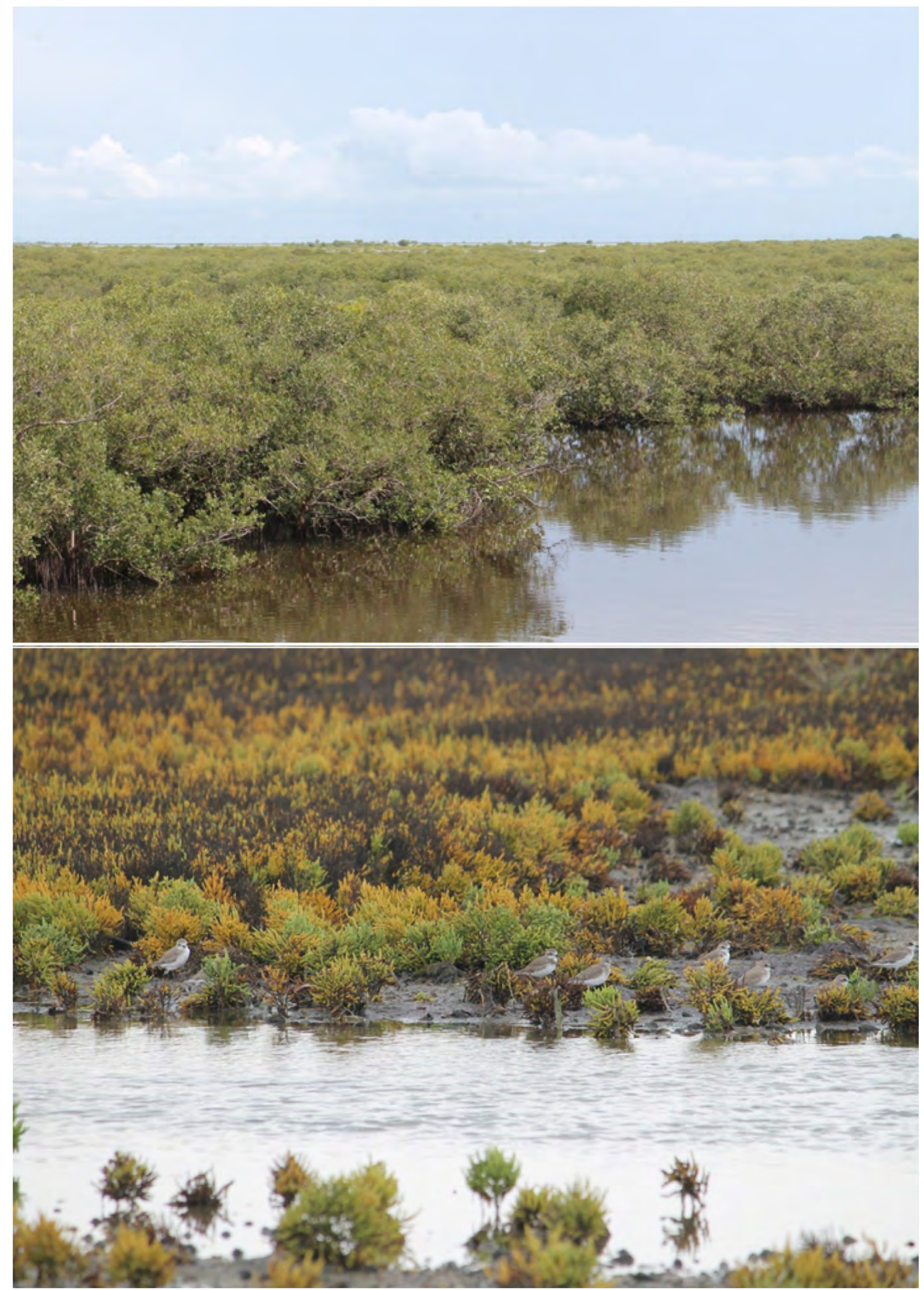

Figure 17. Top: mangroves and associates, Puliyantivu Island; bottom: salt marshes, Kayts Island

(๑ IUCN/ Sampath de A. Goonatilake) 

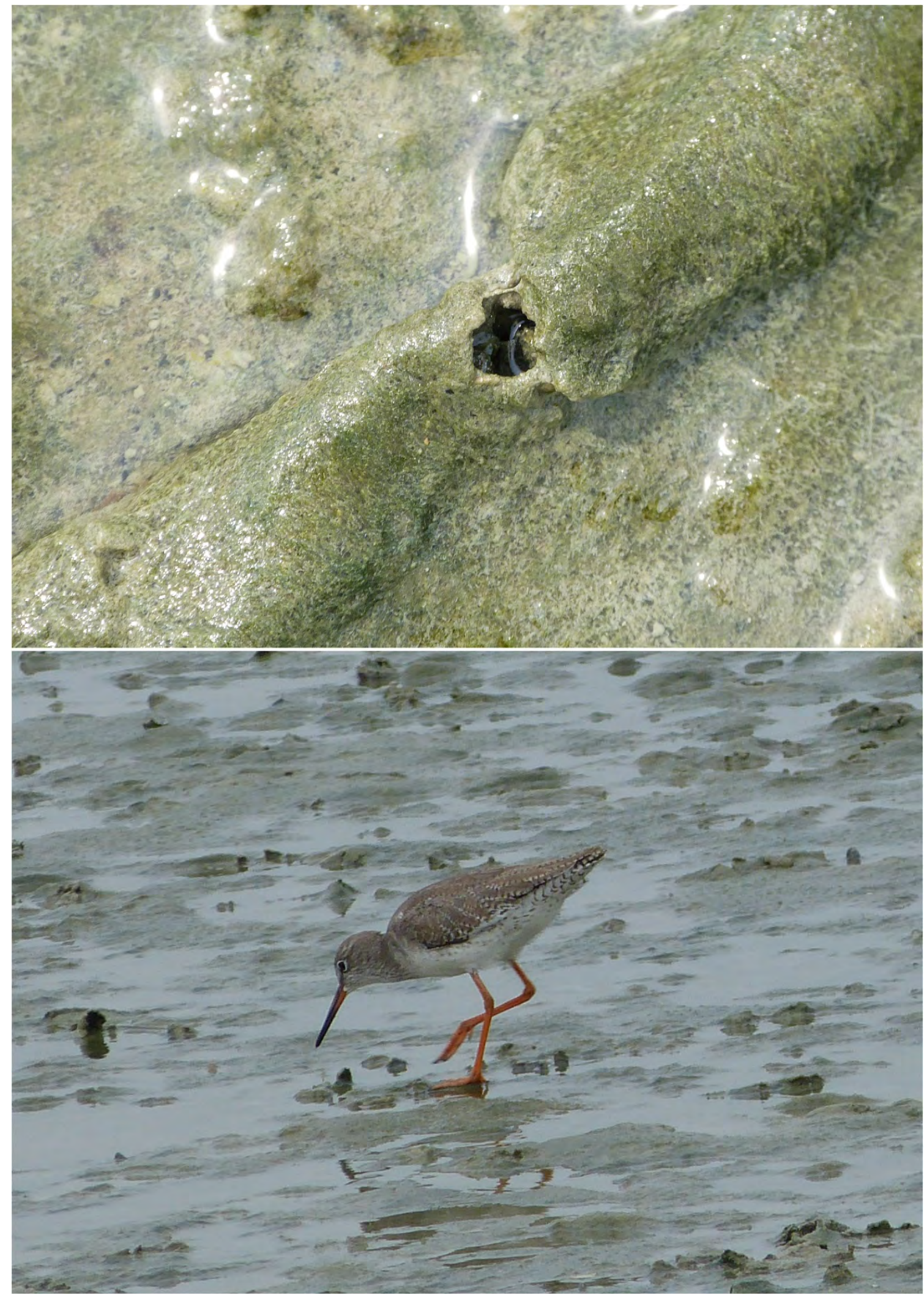

Figure 18. Top: mat of cyanobacteria in a tidal flat, Mannar Island; bottom; a common redshank (a common winter visitor) feeding on invertebrates on a submerged tidal flat, Mannar Island

(๑) Sriyanie Miththapala) 


\section{Salt marshes}

Salt marshes are coastal wetlands in the upper inter tidal zone, which are subjected to regular inundation by seawater because of tidal action. Several extensive salt marshes can be seen in the islands of Palk Bay and some of these were associated closely with clumps of Avicennia marina. Salt-tolerant herbaceous plants, belonging to the family Amaranthaceae, dominated salt marshes in the area. Suaeda maritima and Salicornia brachiata are the commonly occurring species in this ecosystem. Halosarcia indica was observed as few small isolated populations. Suaeda monoica was rarely observed in the area and it differed from other salt marsh species by its bushy habit. Salt marshes are found on higher ground than tidal flats.

See photograph of this ecosystem in Figure 17.

Found in salt marshes is a large number of macro and micro invertebrate species. Feeding on these invertebrates are birds such as the little egret (Egretta garzetta), black-winged stilt (Himantopus himantopus), common redshank (Tringa totanus) and green sandpiper (Tringa ochropus).

\section{Tidal flats}

Along coastlines, there is a range of coastal ecosystems: sand dunes; mangroves; salt marshes; tidal flats; lagoons and estuaries. Each of these ecosystems is interconnected and interdependent on others and forms a mixture of interconnected environments (Kallesőe et al., 2008). In the Jaffna Peninsula, mangroves, salt marshes and tidal flats form a mosaic of ecosystems. Some of these tidal flats are extensive (as in the Jaffna Lagoon and north of Mannar Island). Tidal flats are found on the shores of lagoons and estuaries in intertidal areas (areas that are flooded at high tide and exposed at low tides) (Smithsonian Institution, 2010). They are always exposed during low tide. Although tidal flats look barren, they are in fact, teeming with life (Miththapala, 2013a). Cyanobacteria are the autotrophs of tidal flats and often form a velvety mat - called 'lab-lab' - visible on the surface of tidal flats. These cyanobacteria provide the food base for a range of invertebrates - such as crustaceans, molluscs, flatworms and roundworms. Feeding on these invertebrates are birds such as the black-winged stilt (Himantopus himantopus), common redshank (Tringa totanus), eurasian spoonbill (Platalea leucorodia), great crested tern (Sterna bergii) and green sandpiper (Tringa ochropus).

See photograph in Figure 18.

\section{Lagoons and estuaries}

The coastline defined in this report has 10 lagoons, including the Jaffna Complex, which is the largest brackish water system in the island (Silva et al., 2013). Lagoons in Sri Lanka are of recent origin and came into existence during the Holocene Period $(10,000$ years BP) (NSAP, 2009).

Lagoons and estuaries, lying at the boundary between the ocean and land, house a unique mosaic of habitats from sea to land. Apart from lagoons and estuaries, there may be barrier islands, spits, beaches, sand dunes, salt marshes, seagrasses within lagoons and estuaries, as well as mangroves fringing their shores (de Wit, 2011 in litt. Miththapala, 2013b). This high ecosystem diversity within the immediate landscape of lagoons and estuaries, gives rise not 
only to high species diversity but also to the creation of ecotones - areas of transition between two habitats. Therefore, lagoons and estuaries - through the diverse habitats they house support a high level of biodiversity (de Wit, 2011; Kennish and Paerl, 2010 in litt. Miththapala, 2013b) and are often feeding grounds for many migratory birds - such as the greater flamingo (Phoenicopterus roseus) and black-headed gull (Larus ridibundus) — and breeding residents such the Indian and little cormorants (Phalacrocorax fuscicollis and P. niger), spot-billed pelican (Pelecanus philippensis) and Brahminy kite (Haliastur indus).

See Figure 19 for a photograph of this ecosystem.

One hundred species of fin fish, 28 species of molluscs, six species of crabs and seven species of prawns have been identified in catches from the Jaffna Lagoon (MFF, 2015a).

\section{Semi-natural ecosystems}

Most of the islands in Palk Bay had been influenced strongly by anthropogenic activities including the three-decade long civil war, settlements, and fisheries. As a result, many natural ecosystems have been degraded over a long period of time. Some of these degraded ecosystems have been regenerated by secondary growth of vegetation and therefore, are found as semi-natural ecosystems. These semi-natural ecosystems are extensively distributed in abandoned lands, influenced by human activities.

\section{Dry zone grasslands}

Two sub-types have been observed.

\section{Wet pasture lands}

Structurally, as well as functionally, wet pasture lands are more or less similar to dry pasture lands, with the exception of their species assemblage, which differs. Often, short plant species belonging to the sedge (Cyperaceae) family — such as Bulbostylis barbata, Cyperus arinarius, Cyperus bulbosa, Cyperus conglomaratus, Cyperus pygmaeus, Cyperus rotundus, Fimbristylis argentea and Fimbristylis dipsaceai - were observed commonly in wet pasture lands. Phyla nodiflora was the dominant plant species seen in the wet pasture lands of the islands. Other commonly occurring species in this habitat included Cressa criteca, Cynadon dactylon, Eragrostis maderaspatana, Peplidium maritimum, Evolvulus alsinoides, Sphaeranthus indicus, Sporobolus spicatus, Pedalium murex and Zoysia martella. Wet pasture lands favour lands that show a slight depression and therefore can hold water. These depressions can retain rainwater during the rainy season, during which they become shallow water bodies.

See a photograph of this ecosystem in Figure 20.

These grasslands provide feeding habitat for migratory bird species including the Pacific golden plover (Pluvialis fulva), black-tailed godwit (Limosa limosa), and the common snipe (Gallinago gallinago); as well as breeding residents such as the black-headed ibis (Threskiornis melanocephalus) and painted stork (Mycteria leucocephala). 

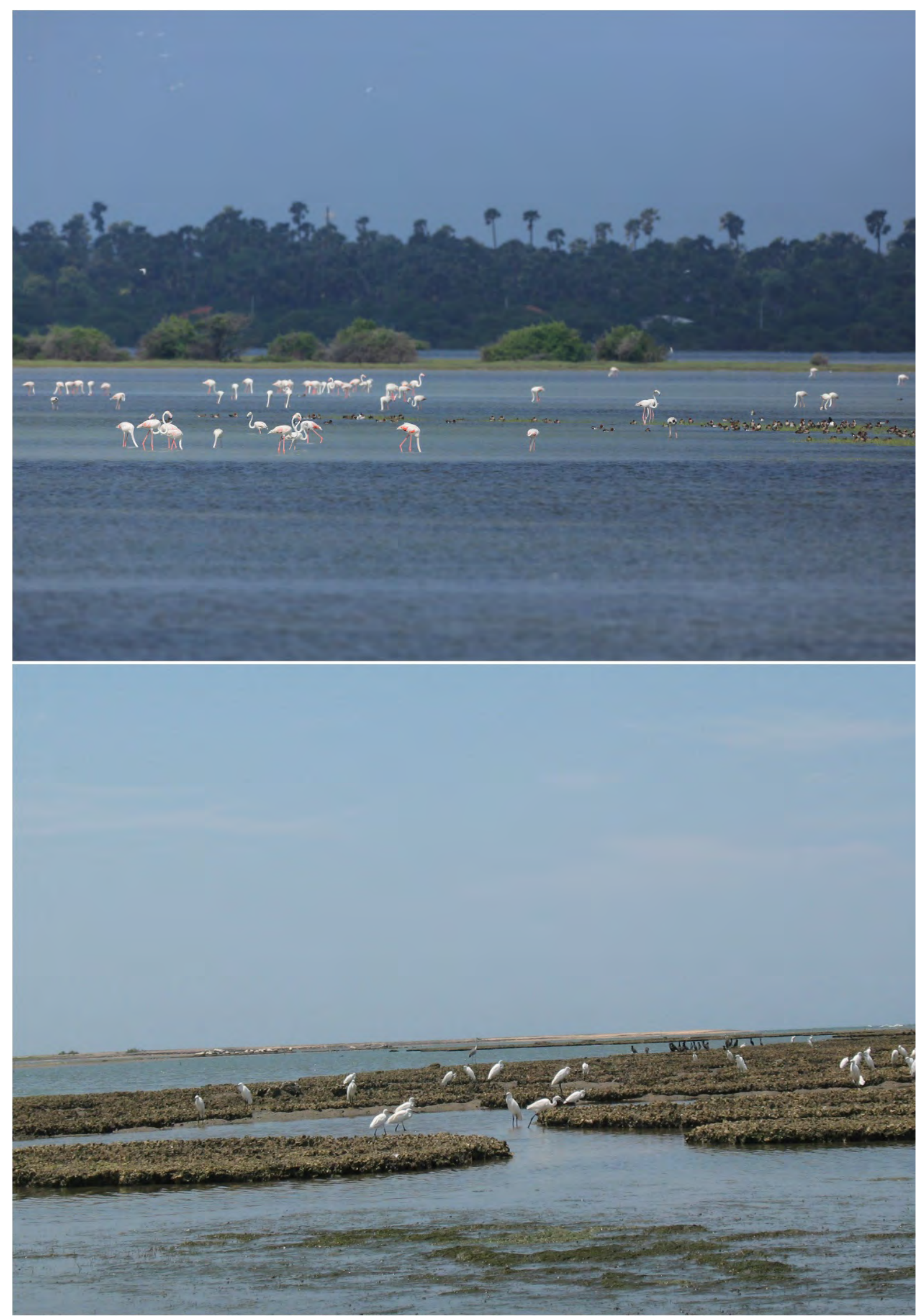

Figure 19. Top: greater flamingo and Eurasian wigeon (both migrants), Kayts Lagoon; bottom: egrets, cormorants, and a grey heron, Kokkilai Lagoon

(Top: @ Luxshmanan Nadaraja; bottom: @ IUCN/Kumudini Ekaratne) 


\section{Dry pasture lands}

Dry pasture lands were characterised by a dense growth of short grasses (up to $5 \mathrm{~cm}$ in height) forming a green carpet that spreads over large areas of the islands' landscapes. The structure and floristic composition of the grassland system is influenced considerably by grazing pressure, trampling, high salinity and drought. The dominant grass species observed in this habitat included Bulbostylis barbata, Cressa critica, Cyperus iria, Eragrostis maderaspatana, Fimbristylis argentea, Fimbristylis feruginea, Peplidium maritimum, Sporobolus tremulus and Zoysia martella. Species dominance and species composition appear to be determined by site-specific moisture levels. Dry pastures are indispensable, given the important role they play in sustaining the wild pony and cattle populations of the islands. As with other open vegetation types, dry pasturelands stabilise the soil, as they produce a mat-like vegetation cover, while the roots of these grasses hold the soil together, preventing erosion. These pasturelands also function as water efficient filters and trap surface run-off.

Birds such as the ashy-crowned sparrow lark (Eremopterix grisea), Oriental skylark (Alauda gulgula), paddyfield pipit (Anthus rufulus), yellow-wattled lapwing (Vanellus malabaricus) and great thick-knee (Esacus recurvirostris) can be found commonly in this ecosystem. See a photograph of this ecosystem in Figure 20.

\section{Man-made ecosystems}

Man-made ecosystems are human-influenced landscapes that are extensively spread across islands with human settlements. Although there were some agricultural ecosystems found on the islands, only home gardens were studied during this field survey.

\section{Home gardens}

Home gardens are found immediately around homesteads and are the result of long-term human manipulation. Home gardens were dominated by multi-purpose tree species that were arranged into different vertical levels. Well-developed, multi-storey home gardens were located on the islands with human settlements. While the palmyra palm was the dominant species in most home gardens, other tree crop species such as Cocos nucifera, Mangifera indica, Gliricidia sepium, Moringa oleifera, Musa x. paradisiaca and Sesbania grandiflora were also found. Also common was Azadarichta indica. There were also a few ornamental tree species such as Plumeria obtusa, Thespesia populnea and Hibiscus rosa-sinensis. These home gardens were protected by different types of live fences using native plants such as Commiphora berryi, Thespesia populnea as well as dead parts of palmyra plants such as leaves and rachis without the leaf blade. Apart from their aesthetically attractive nature, these fences perform the function of optimally protecting and demarcating the boundary. Dead plant parts were used in different fences surrounding home gardens. See a photograph of this ecosystem in Figure 21.

Among the fauna of home gardens are dragonflies, such as the blue percher (Diplacodes trivialis) and wandering glider (Pantala flavescens); butterflies, such as the lime butterfly (Papilio demoleus) and mottled emigrant (Catopsilia pyranthe); amphibians, such as the common house toad (Duttaphrynus melanostictus) and skipper frog (Euphlyctis cyanophlyctis); reptiles, such as the common garden lizard (Calotes versicolor) and common house-gecko (Hemidactylus frenatus); birds, such as the Oriental magpie robin (Copsychus saularis) and red-vented bulbul (Pycnonotus cafer) and mammals such as the common rat (Rattus rattus) and palm squirrel (Funambulus palmarum). 

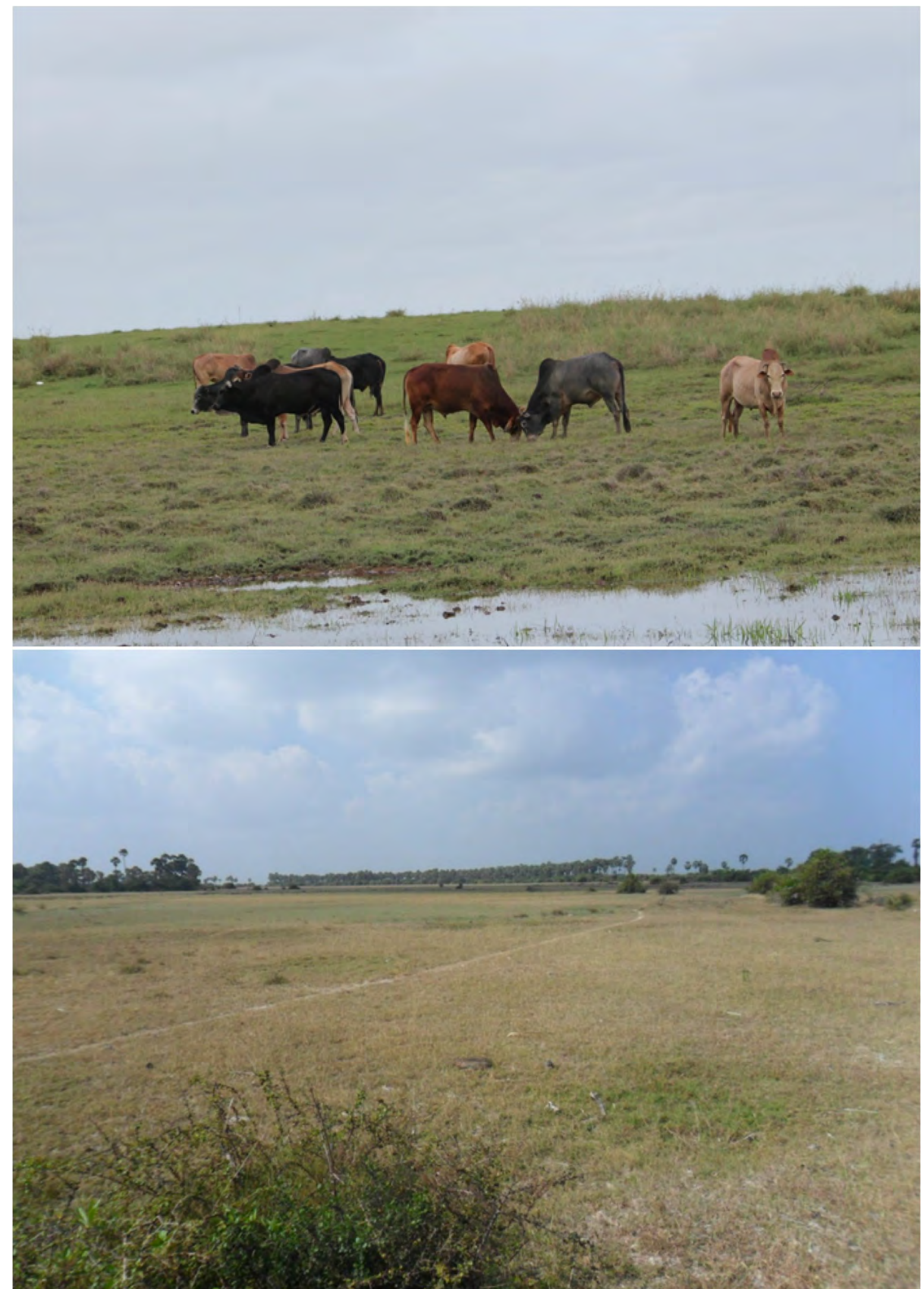

Figure 20. Top: wet pasture lands, Iranaitivu North Island; bottom: dry pasturelands, Punnalai Khadu

(top @/Sampath de A. Goonatilake; bottom @ IUCN/Naalin Perera) 


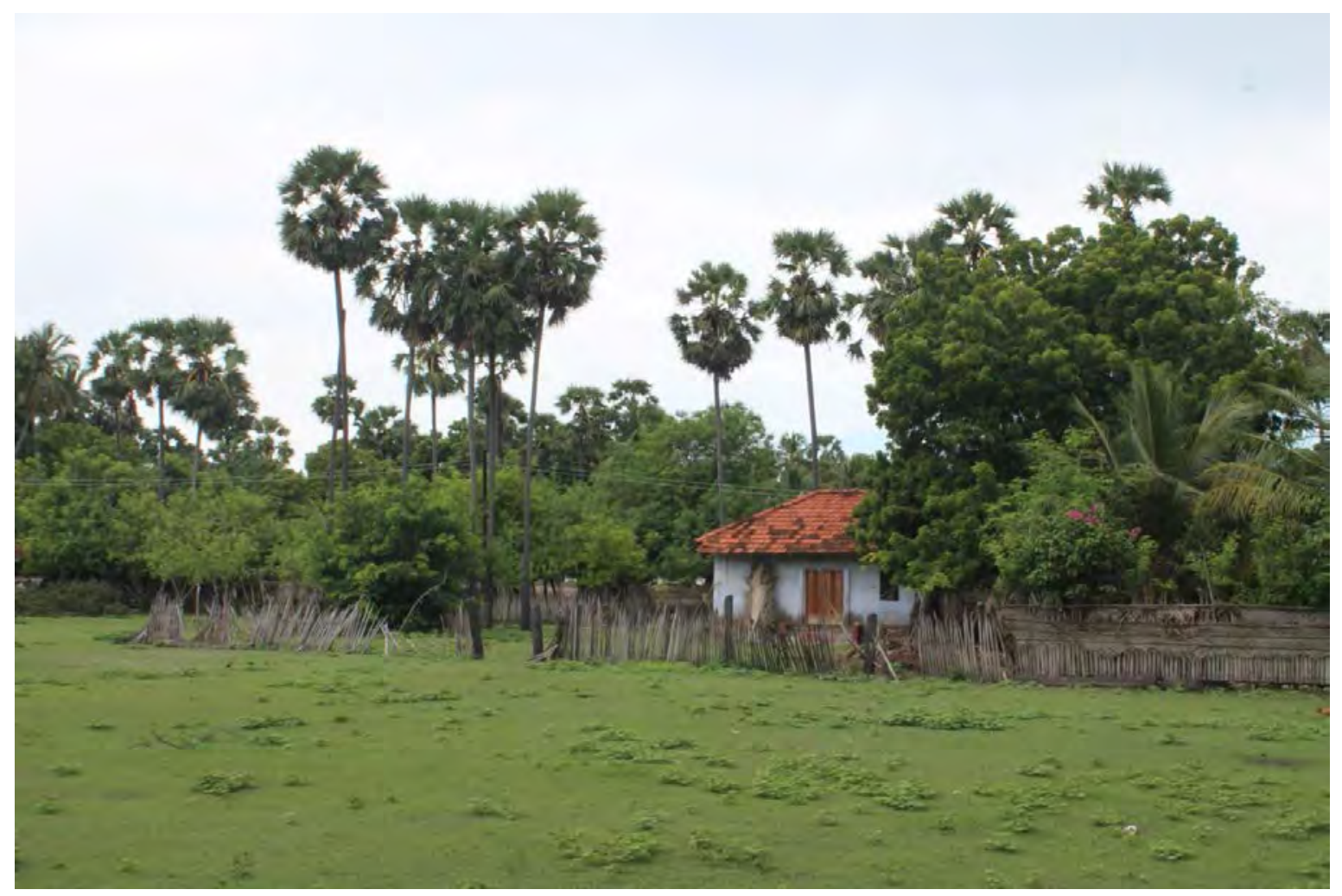

Figure 21. A home garden, Eluvaitivu Island (๑ IUCN/Sampath de A Goonatilake)

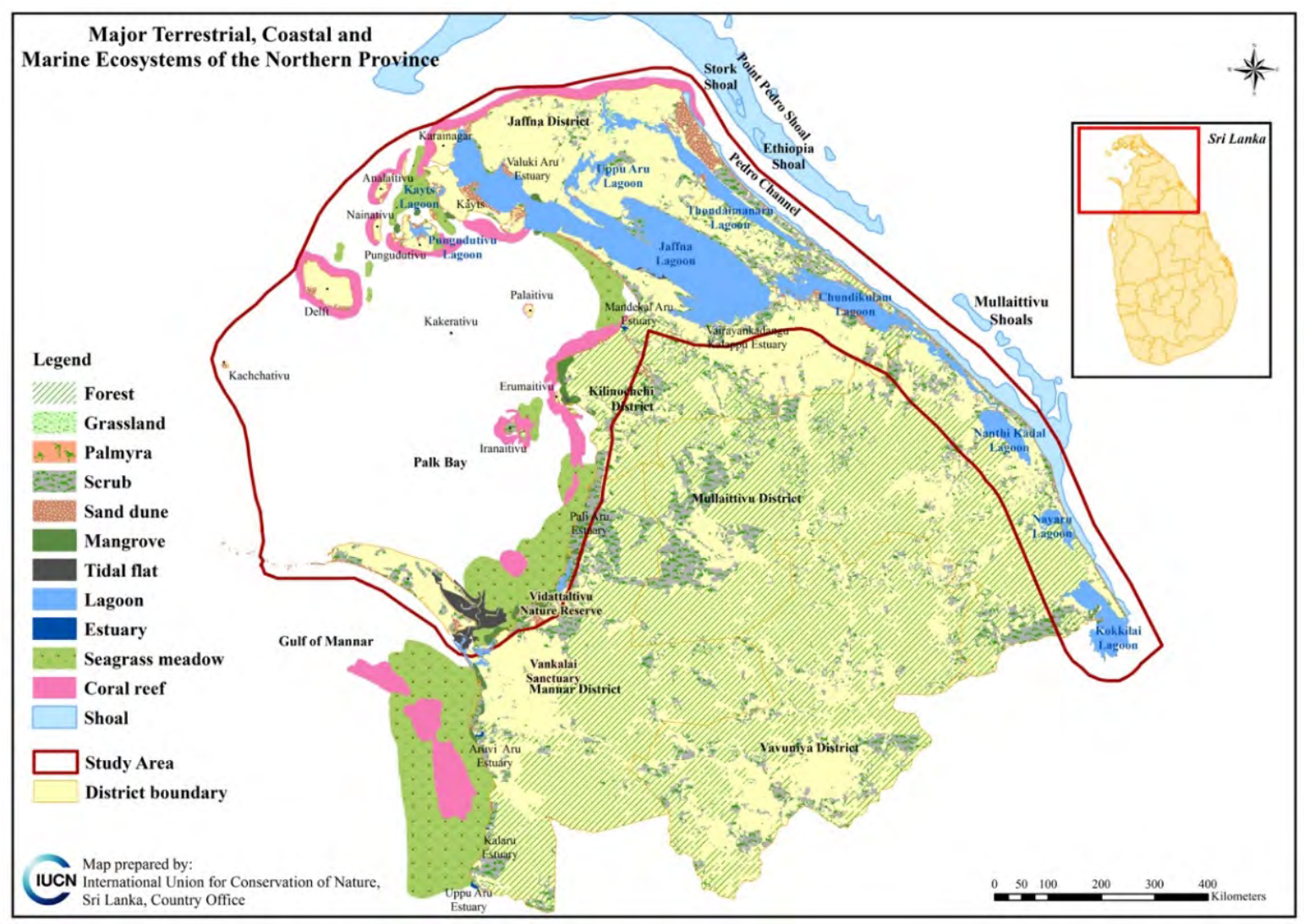

Figure 22. Map of terrestrial, marine and coastal ecosystems of the study area

Detailed maps of terrestrial, marine and coastal ecosystems are given in Annex 1. 


\section{Terrestrial species diversity}

\section{Floristic diversity of the islands}

A total of 342 different plant species which comprised 102 tree species, 53 shrub species, 59 climber species, 111 herbaceous species and three epiphytes, were recorded during the field survey (Table 4). Of these, seven species are endemic to Sri Lanka (Table 5), while 33 species are listed as Threatened (Table 6). This included two species Suriana maritima and Fimbristylis dipsacea listed as Critically Endangered (Possibly Extinct) (CR(PE)) and two species, Sesamum prostratum and Cyperus conglomerates listed as Critically Endangered (CR). Further, 28 species, listed as near threatened (NT) were also recorded.

A complete list of flora observed in this study is presented in Annex 2.

Table 4. Summary of flora recorded during the field survey

\begin{tabular}{|c|c|c|c|c|c|c|c|c|c|c|c|}
\hline \multirow[b]{2}{*}{ HABIT } & \multirow[b]{2}{*}{ TOTAL } & \multicolumn{4}{|c|}{ SPECIES STATUS } & \multicolumn{6}{|c|}{ CONSERVATION STATUS } \\
\hline & & Indigenous & Endemic & Exotic & IAS & $\begin{array}{l}\text { CR } \\
\text { (PE) }\end{array}$ & CR & EN & VU & NT & DD \\
\hline Trees & 104 & 57 & 4 & 42 & 2 & 0 & 0 & 5 & 3 & 7 & 0 \\
\hline Shrubs & 54 & 47 & 0 & 6 & 1 & 1 & 0 & 1 & 3 & 7 & 0 \\
\hline Herbs & 108 & 96 & 0 & 9 & 1 & 1 & 2 & 2 & 3 & 8 & 0 \\
\hline $\begin{array}{l}\text { Vines and } \\
\text { climbers }\end{array}$ & 65 & 55 & 3 & 3 & 1 & 0 & 0 & 4 & 7 & 4 & 0 \\
\hline Epiphytes & 2 & 2 & 0 & 0 & 0 & 0 & 0 & 0 & 1 & 0 & 0 \\
\hline $\begin{array}{l}\text { Total } \\
\text { number of } \\
\text { species }\end{array}$ & 342 & 237 & 7 & 60 & 05 & 02 & 02 & 12 & 17 & 26 & 0 \\
\hline
\end{tabular}

Table 5. Endemic flora recorded during field survey

\begin{tabular}{|l|l|l|l|}
\multicolumn{1}{|c|}{ Family } & \multicolumn{1}{c|}{ Species } & \multicolumn{1}{c|}{ Sinhala name } & \multicolumn{1}{c|}{ Tamil name } \\
\hline Asteraceae & Vernonia zeylanica & Papula, Wal-Pupula & Marlumutta \\
\hline Celastraceae & Cassine balae & Neraloo & Perun / Piyaree \\
\hline Celastraceae & Cassine glauca & Neralu & No name known \\
\hline Convolvulaceae & Argyreia populifolia & Girithilla & Sindu-kodi \\
\hline Fabaceae & Derris parviflora & Kala-wel & No name known \\
\hline Melastomataceae & Memecylon capitellatum & Dedi-Kaha & $\begin{array}{l}\text { Katti kaya / Venkali- } \\
\text { kaya }\end{array}$ \\
\hline Sapindaceae & Gleniea unijuga & Wal-Mora & No name known \\
\hline
\end{tabular}


Table 6. Threatened ${ }^{6}$ flora recorded during field survey

\begin{tabular}{|c|c|c|c|c|}
\hline Family & Species & Sinhala name & Tamil name & $\begin{array}{c}\text { Conservation } \\
\text { Status }\end{array}$ \\
\hline Cyperaceae & $\begin{array}{l}\text { Fimbristylis } \\
\text { dipsacea }\end{array}$ & No name known & $\begin{array}{l}\text { No name } \\
\text { known }\end{array}$ & $\mathrm{CR}(\mathrm{PE})$ \\
\hline Surianaceae & Suriana maritima & No name known & $\begin{array}{l}\text { No name } \\
\text { known }\end{array}$ & $\mathrm{CR}(\mathrm{PE})$ \\
\hline Cyperaceae & $\begin{array}{l}\text { Cyperus } \\
\text { conglomeratus }\end{array}$ & No name known & $\begin{array}{l}\text { No name } \\
\text { known }\end{array}$ & $\mathrm{CR}$ \\
\hline Pedaliaceae & $\begin{array}{l}\text { Sesamum } \\
\text { prostratum }\end{array}$ & No name known & $\begin{array}{l}\text { No name } \\
\text { known }\end{array}$ & $\mathrm{CR}$ \\
\hline Boraginaceae & Cordia subcordata & No name known & $\begin{array}{l}\text { No name } \\
\text { known }\end{array}$ & EN \\
\hline Boraginaceae & $\begin{array}{l}\text { Tournefortia } \\
\text { argentea }\end{array}$ & Karan & $\begin{array}{l}\text { No name } \\
\text { known }\end{array}$ & EN \\
\hline Capparaceae & Cadaba fruticosa & No name known & $\begin{array}{l}\text { No name } \\
\text { known }\end{array}$ & EN \\
\hline Celastraceae & Salacia oblonga & $\begin{array}{l}\text { Himbutu, Gal } \\
\text { Himbutu }\end{array}$ & $\begin{array}{l}\text { No name } \\
\text { known }\end{array}$ & EN \\
\hline Convolvulaceae & Ipomoea coptica & Karunkali & $\begin{array}{l}\text { No name } \\
\text { known }\end{array}$ & EN \\
\hline Ebenaceae & Diospyros ebenum & Kaluwara & $\begin{array}{l}\text { No name } \\
\text { known }\end{array}$ & EN \\
\hline Fabaceae & Crotalaria prostrata & & $\begin{array}{l}\text { No name } \\
\text { known }\end{array}$ & EN \\
\hline Fabaceae & Vigna marina & $\begin{array}{l}\text { Karal-li-me, Lee } \\
\text { ma }\end{array}$ & $\begin{array}{l}\text { Kodippayaru/ } \\
\text { Kodeppayam }\end{array}$ & EN \\
\hline Lythraceae & Sonneratia alba & Kirala & Kinnai & EN \\
\hline Menispermaceae & Cocculus hirsutus & Lunuketiya wel & $\begin{array}{l}\text { Kattukkodi/ } \\
\text { Sirungattukodi }\end{array}$ & EN \\
\hline Phrymaceae & $\begin{array}{l}\text { Peplidium } \\
\text { mariticum }\end{array}$ & No name known & $\begin{array}{l}\text { No name } \\
\text { known }\end{array}$ & EN \\
\hline Rhizophoraceae & Bruguiera cylindrica & Heen Mal Kadol & $\begin{array}{l}\text { No name } \\
\text { known }\end{array}$ & EN \\
\hline Amaryllidaceae & Crinum zeylanicum & No name known & $\begin{array}{l}\text { No name } \\
\text { known }\end{array}$ & VU \\
\hline Apocynaceae & Gymnema sylvestre & Masbedde & Shirukurinja & VU \\
\hline Apocynaceae & $\begin{array}{l}\text { Heterostemma } \\
\text { tanjorense }\end{array}$ & No name known & $\begin{array}{l}\text { No name } \\
\text { known }\end{array}$ & VU \\
\hline Celastraceae & Cassine glauca & No name known & $\begin{array}{l}\text { No name } \\
\text { known }\end{array}$ & VU \\
\hline Cucurbitaceae & Citrullus colocynthis & $\begin{array}{l}\text { Yak-komadu, } \\
\text { Thiththa labu }\end{array}$ & $\begin{array}{l}\text { Peykkomaddi/ } \\
\text { Peykkomakki }\end{array}$ & VU \\
\hline Fabaceae & $\begin{array}{l}\text { Dalbergia } \\
\text { candenatensis }\end{array}$ & No name known & $\begin{array}{l}\text { No name } \\
\text { known }\end{array}$ & VU \\
\hline Fabaceae & $\begin{array}{l}\text { Indigofera } \\
\text { oblongifolia }\end{array}$ & Nari Mun & $\begin{array}{l}\text { No name } \\
\text { known }\end{array}$ & VU \\
\hline Loranthaceae & $\begin{array}{l}\text { Taxillus } \\
\text { courtallensis }\end{array}$ & No name known & $\begin{array}{l}\text { No name } \\
\text { known }\end{array}$ & VU \\
\hline Menispermaceae & Pachygone ovata & No name known & $\begin{array}{l}\text { No name } \\
\text { known }\end{array}$ & VU \\
\hline
\end{tabular}

${ }^{6}$ According to IUCN Red List of Threatened Species, the categories Critically Endanaged (CR), Endangered (EN) and Vulnerable (VU) are considered Threatened species. 


\begin{tabular}{|c|c|c|c|c|}
\hline Family & Species & Sinhala name & Tamil name & $\begin{array}{c}\text { Conservation } \\
\text { Status }\end{array}$ \\
\hline Menispermaceae & Tinospora cordifolia & Rasa-Kinda & Chintil & VU \\
\hline Poaceae & $\begin{array}{l}\text { Aristida } \\
\text { adscensionis }\end{array}$ & $\begin{array}{l}\text { Boleela / Teli } \\
\text { tana }\end{array}$ & $\begin{array}{l}\text { No name } \\
\text { known }\end{array}$ & VU \\
\hline Poaceae & $\begin{array}{l}\text { Sporobolus } \\
\text { maderaspatanus }\end{array}$ & No name known & $\begin{array}{l}\text { No name } \\
\text { known }\end{array}$ & VU \\
\hline Rhamnaceae & Colubrina asiatica & $\begin{array}{l}\text { Mauirmanikkam, } \\
\text { Tel hiriya }\end{array}$ & Mayirmanikkam & Vu \\
\hline Rubiaceae & Guettarda speciosa & Nil-Pitcha & Panir & VU \\
\hline Rubiaceae & $\begin{array}{l}\text { Psilanthus } \\
\text { wightianus }\end{array}$ & No name known & $\begin{array}{l}\text { No name } \\
\text { known }\end{array}$ & VU \\
\hline Rutaceae & $\begin{array}{l}\text { Chloroxyclon } \\
\text { swietania }\end{array}$ & Burutha & $\begin{array}{l}\text { Moodudad- } \\
\text { marum / Muritai }\end{array}$ & Vu \\
\hline Sapotaceae & Manilkara hexandra & Palu & Palai & VU \\
\hline
\end{tabular}

\section{Notable species}

In the following section are descriptions of notable terrestrial flora recorded during the Jaffna island survey.

\section{Bay cedar (Suriana maritima)}

Bay cedar, Suriana maritima, is a rare, native, coastal shrub that is the only member of the Surianaceae family found in Sri Lanka ${ }^{7}$. Apart from its taxonomic significance, bay cedar is listed as a species that is Critically Endangered (Possibly Extinct) CR (PE) (MoE, 2012). According to the botanical history of Sri Lanka, this plant was first discovered in 1885 at Foul Point, and then subsequently in 1890 at Small Fox Island, Jaffna. This is the third time this species has been recorded after 125 years: Suriana maritima was recorded at Palaitivu Island and the Kavutharimunai coastal stretch, during this field survey in 2015 . Thus, it was an extremely significant finding. This plant was found in isolated islands, coral islets and atolls and is distributed in the Pacific and Indian Oceans. (See a photograph in Figure 23.)

\section{Octopus bush (Tournefortia argentea)}

Octopus bush, Tournefortia argentea belongs to the family Boraginaceae. It is a very rare plant that was found in Kachchativu Island, during this field survey. It is listed as an Endangered (EN) species (MoE, 2012). This plant is called 'octopus bush' because of the tentacle-like appearance of the inflorescence of the plant. The octopus bush can grow up to $5 \mathrm{~m}$ and is found rarely as a small tree with densely silk-pubescent leaves in the crowded near tips of branches. As this plant grows in sandy saline soils near coastlines, the silk-pubescent layer of the leaves helps it to survive the salt spray due to sea waves. According to the botanical history of Sri Lanka, Tournefortia argentea has not been recorded in the country since 1939. This native plant was recorded previously at Trincomalee and Tangalle before 1939. Therefore, this is the first record of Tounefortia argentea since 1939. It should be noted, however, that the octopus bush is common in the Indo-Pacific region. (See a photograph in Figure 24.)

\footnotetext{
7 Therefore, Suriana is a monotypic genus in Sri Lanka.
} 


\section{Sesamum prostratum}

Sesamum prostratum is a strong smelling, prostrate herb that grows on the sandy seashore. It bears reddish to pinkish-violet flowers from May to August, and possibly throughout the year. According to the botanical history of Sri Lanka, this species is remarkable because it has only been recorded in the Eastern Province around Panama. Therefore, the species has been listed as Critically Endangered (CR) (MoE, 2012). This is the first record outside Panama, where Sesamum prostratum was recorded on the sandy coast of Chundikulam. (See a photograph in Figure 24.)

\section{Sea trumpet (Cordia subcordata)}

This is another inhabitant of coastal areas and is commonly known as the sea trumpet because of its trumpet-shaped flower. The plant belongs to the family Boraginaceae. The height of the tree ranges between 3-10 m. The flowers are orange in colour and the petals are wrinkled. The fruits are dispersed by water, enabling the plant's distribution throughout the Indian Ocean and Pacific Islands. This plant is found in sunny, dry coastal areas. This is also a very rare species in the coastal areas of Sri Lanka and has been recorded only in a few localities, such as Foul Point, Norway Point, Aruwakalu and Karaitivu in the Ampara District. It is, therefore, listed as an Endangered (EN) species (MoE, 2012). Cordia subcordata was recorded in Palaitivu Island during this field survey. This was the first record of this plant in the Northern Province. (See a photograph in Figure 25.)

\section{Beach gardenia (Guettarda speciosa)}

Guettarda speciosa, a native shrub that belongs to the family Rubiaceae, is a common inhabitant of beachfront scrub ecosystems. The distribution of the species ranges from East Africa to Malaysia, Micronesia and the South Pacific. The species is listed as Vulnerable (VU) as the plant has been recorded previously only from a few locations (MoE, 2012). However, during this field survey, this species was recorded at Palaitivu, Kakerativu and Kachchativu islands. The fragrant flowers of this plant open after sunset. (See a photograph in Figure 25.)

\section{Palmyra (Borassus flabellifer)}

Palmyra is the most traditionally important and respected tree in the Jaffna Peninsula. Although Borassus flabellifer is a cultivated tree in Sri Lanka, it has naturally spread into other natural ecosystems in the Northern Province and North-western Provinces. All the parts of the palmyra tree are used extensively by local people. For example, the trunk is used for timber, leaves for thatching; the leaf-base fibre for making brushes; and split leaves for weaving mats and baskets. Inflorescences are used to make jaggery and toddy. The pulp of ripe fruits is used to make juice and sweets. Roots are boiled and eaten. The dried and powdered root is used to make the traditional seafood soup of the North — kool (See a photograph in Figure 26.)

\section{Baobab (Adansonia digitata)}

Baobab trees (Adansonia digitata) are trees native to the African continent, and are thought to have been brought to Sri Lanka by Arab traders around 700 AD. It is believed that these Arab traders, who brought camels, also brought baobab trees - whose leaves were used to feed these animals. These trees, also known as 'upside down trees' are so named because their sparse foliage and meagre crowns give the trees the appearance of bearing roots instead of branches. These trees are tall (up to $30 \mathrm{~m}$ ), and their swollen trunks are colossal. The oldest (reported to be over 700 years old) and the largest individual baobab tree in Sri Lanka, found 
at Pallimunai on Mannar Island, has an information board next to it that says its circumference is $19.5 \mathrm{~m}$. The baobabs of Sri Lanka are protected by gazette notification, under the Antiquities Ordinance of 1940 (Figure 26).

\section{Species in salt marshes}

The salt marshes of the islands comprise species such as Suaeda maritima, Suaeda monoica, Salicornia brachiata and Halosarcia indica, which belong to the family Amaranthaceae. Although Suaeda monoica occurs less in marshy habitats and is like a small bush, the other three species, are herbs, more frequently found in marshy areas. These species were seen in different compositions and structures from island to island. Suaeda maritima and Salicornia brachiata were more abundant than the other two species in the northern area. The edible young leaves of Suaeda maritima are used as a vegetable (Figure 27).

\section{Mangrove species}

During the field survey, five true mangrove species were recorded. Avicennia marina is the most commonly occurring mangrove species. Other species such as Bruguiera cylindrica, Ceriops tagal, Rhizophora mucronata and Sonneratia alba were rarely found and were unevenly distributed among marshy vegetation. Among those five species, Rhizophora mucronata and Sonneratia alba are listed as Endangered (EN) species (MoE, 2012). The branches and wood of some of these mangrove species are used for making boats, as brushpiles for fishing, as fuel-wood and also for medicinal purposes (Figure 27).

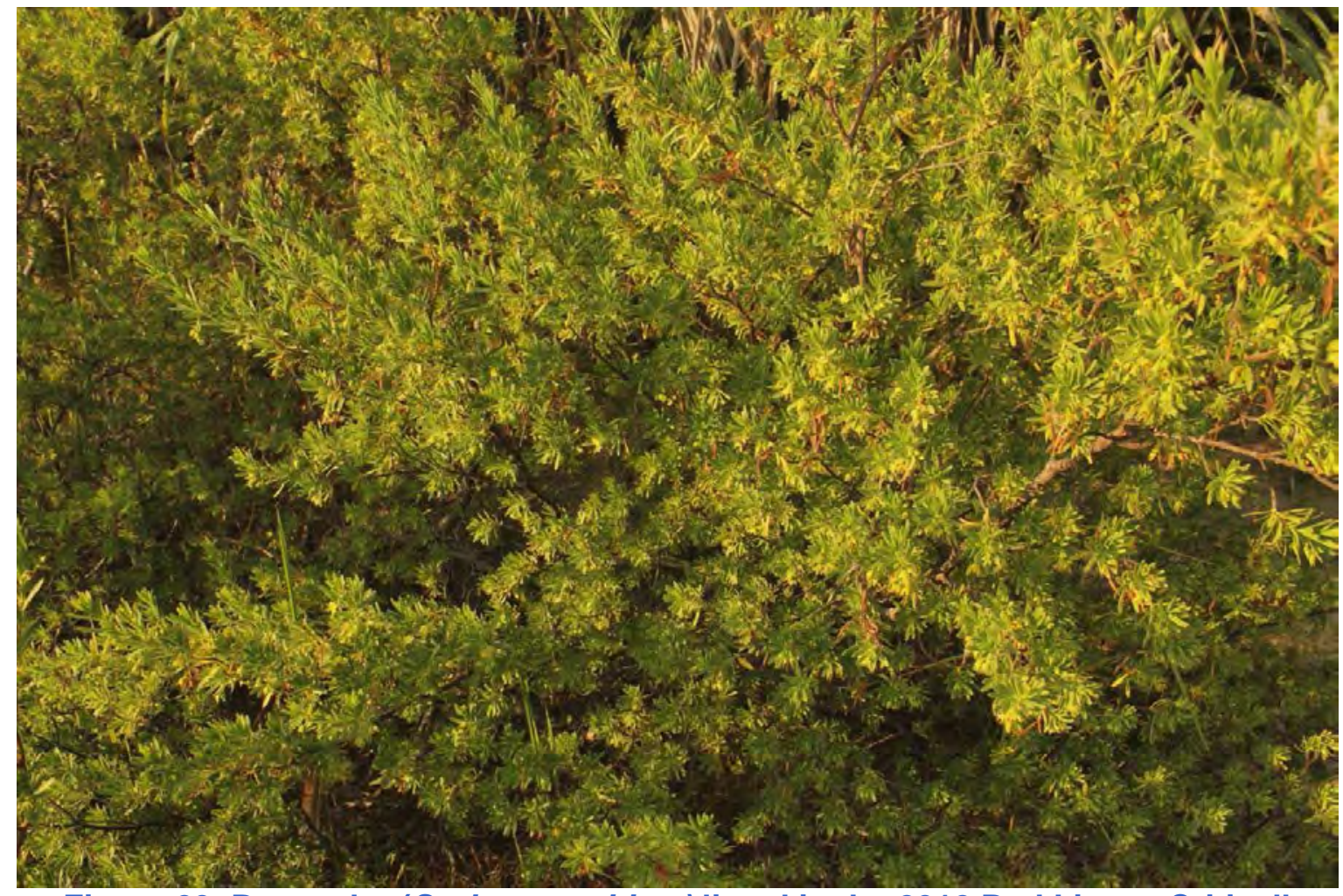

Figure 23. Bay cedar (Suriana maritima) listed in the 2012 Red List as Critically Endangered, Possibly Extinct

(৫ IUCN/Sampath de A. Goonatilake) 

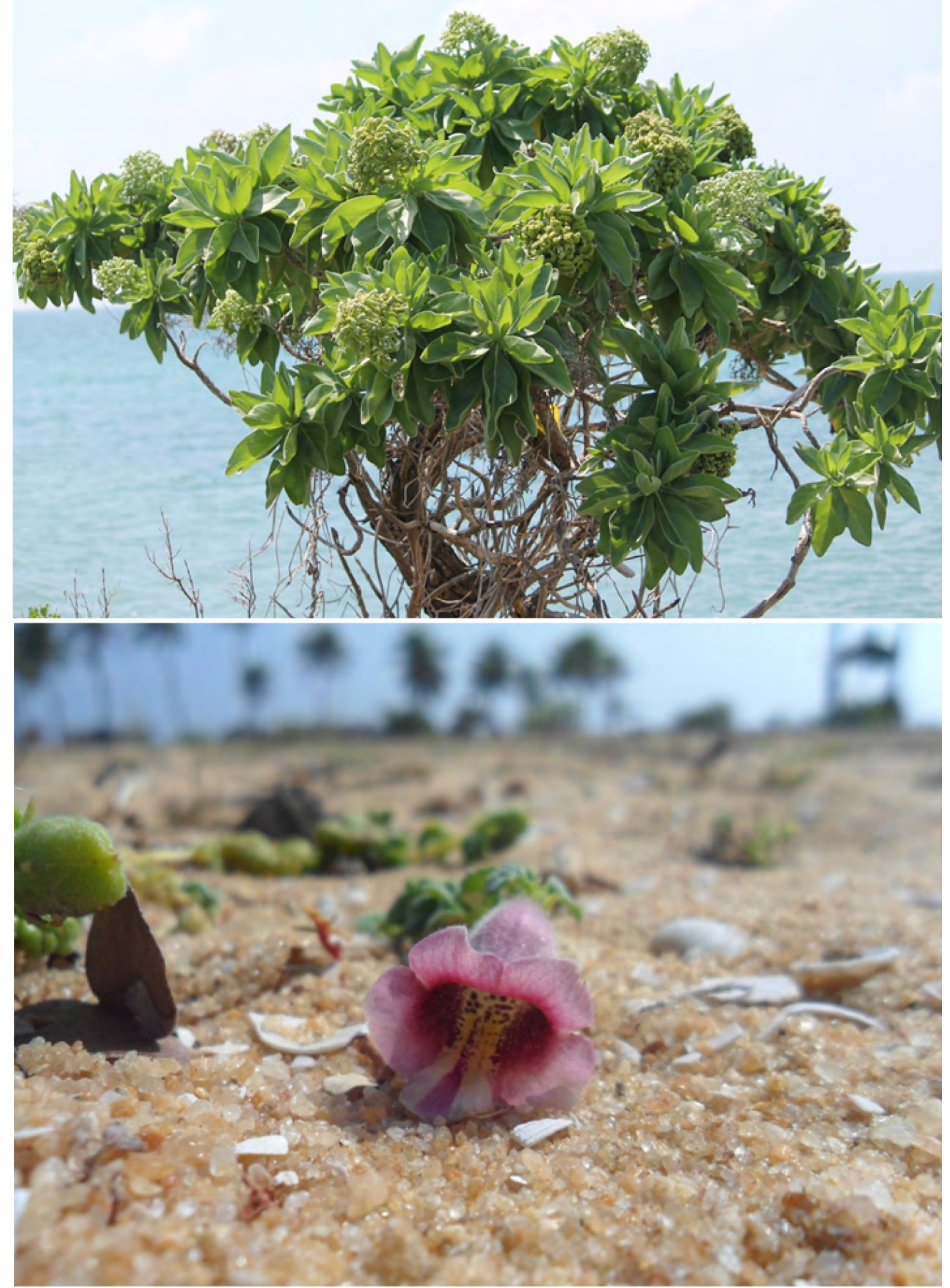

Figure 24.Top: octopus bush (Tournefortia argentea), an Endangered species; bottom: Sesamum prostratum listed as Critically Endangered

(৫) IUCN/Sampath de A. Goonatilake) 

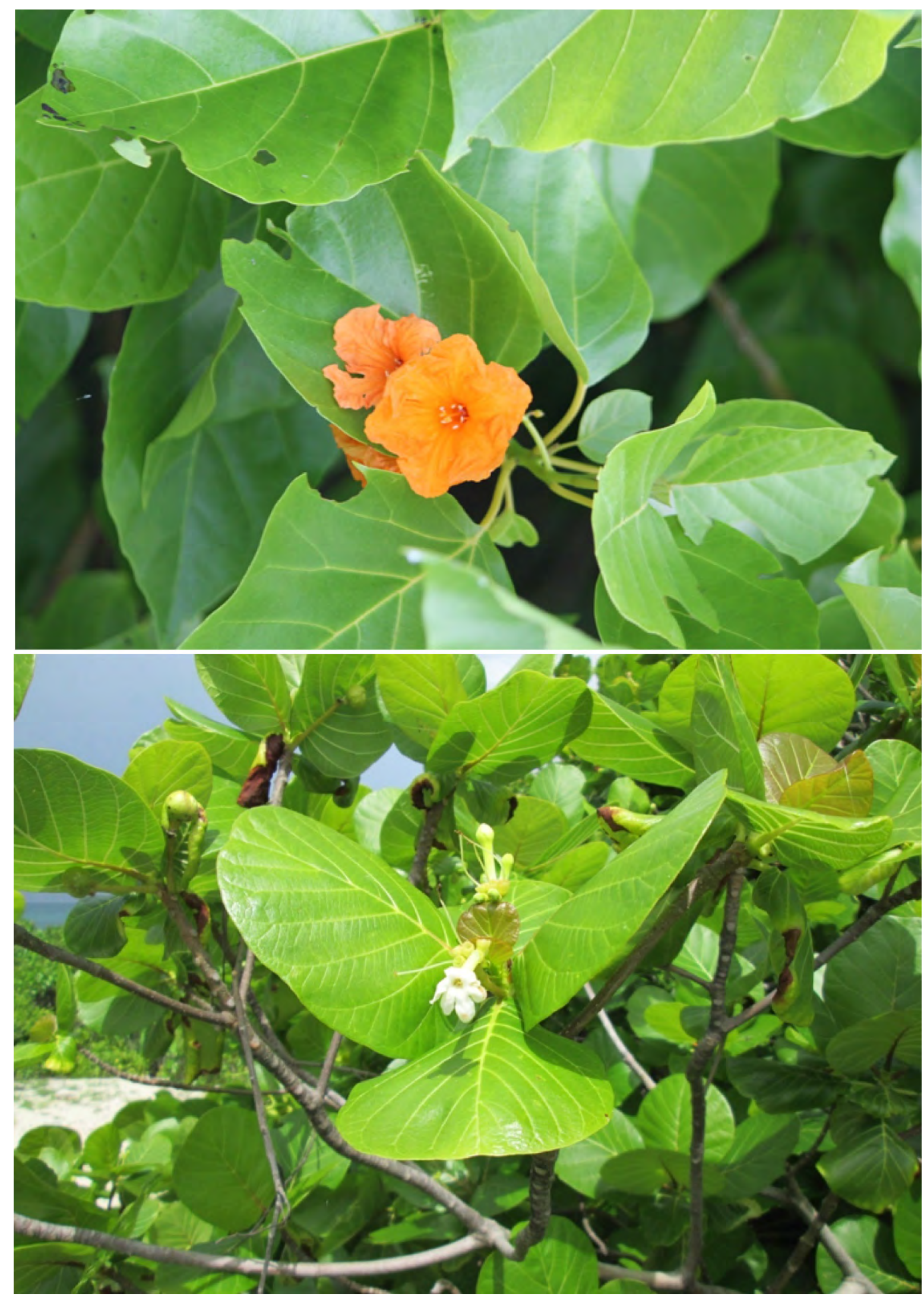

Figure 25. Top: sea trumpet (Cordia subcordata), an Endangered species; bottom: beach gardenia (Guettarda speciosa), listed as Vulnerable

(C IUCN/Sampath de A. Goonatilake) 

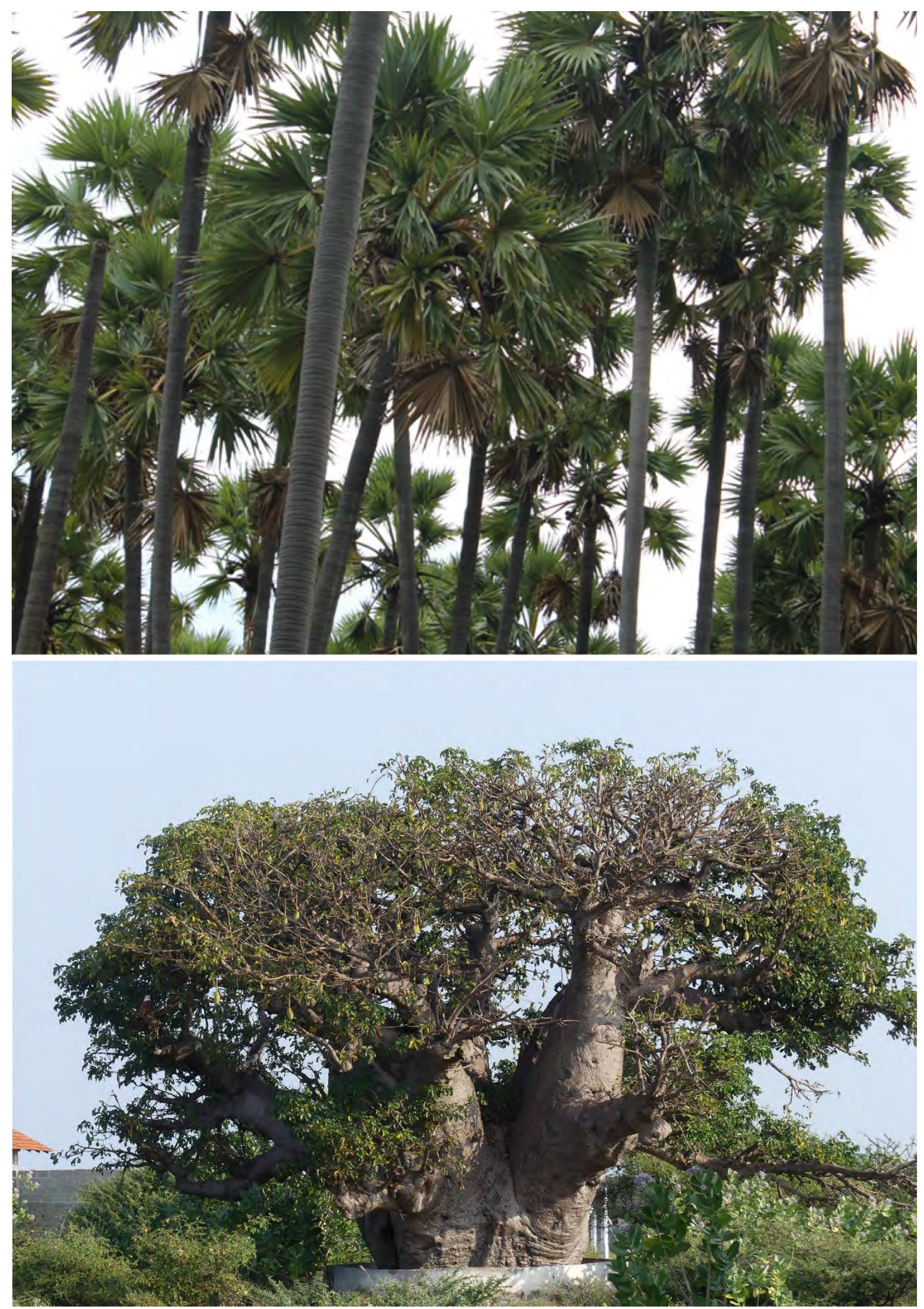

Figure 26. Top: the ubiquitous palmyra (Borassus flabellifer); bottom: baobab (Adansonia digitata), protected by the Antiquities Ordinance (৫) IUCN/Sampath de A. Goonatilake) 

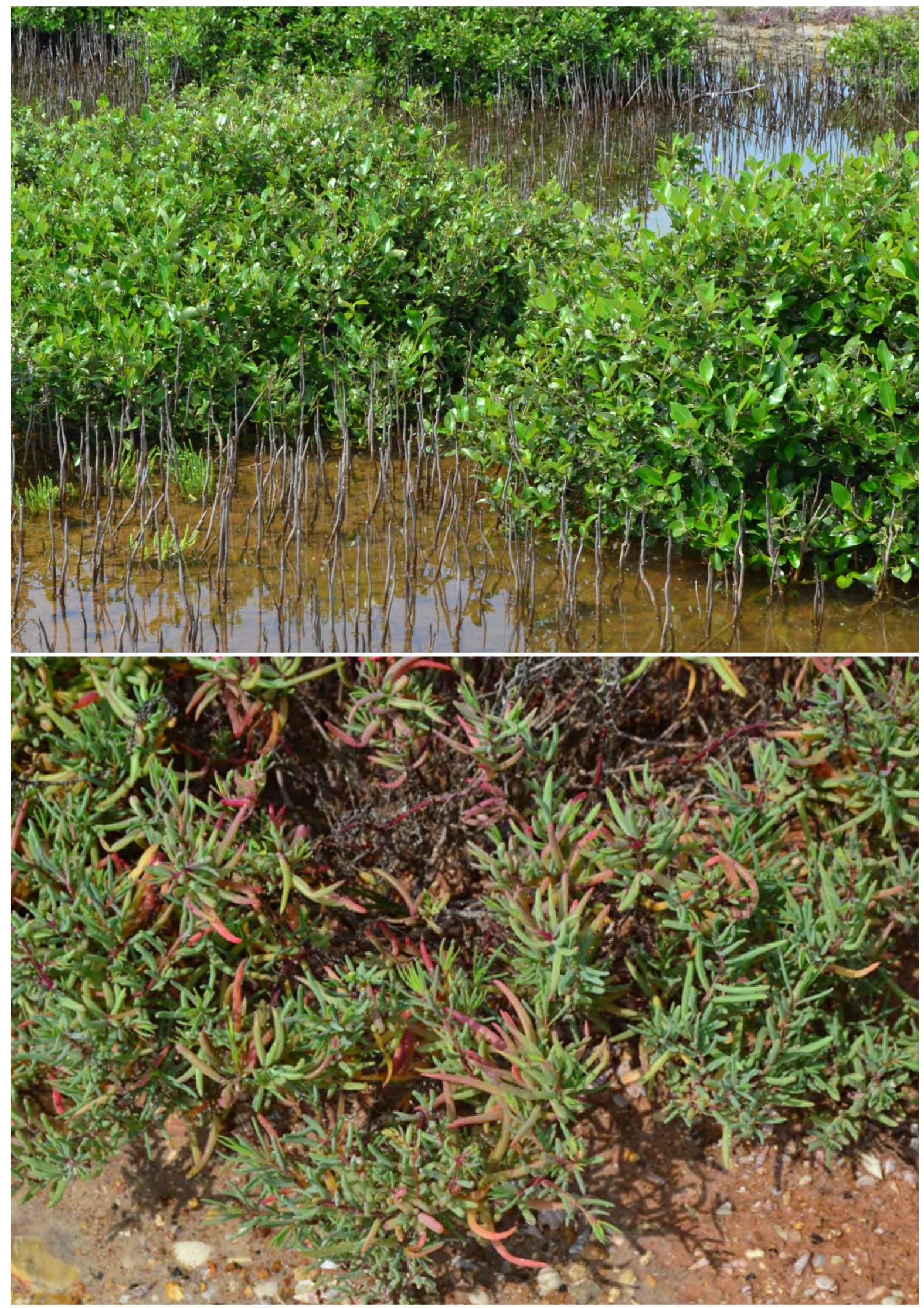

Figure 27. Top: Avicennia marina, the dominant mangrove species of the area, Mandaitivu; bottom: Suaeda maritima

(Top: ๑ Tharanga Wijewickrema; bottom: @ IUCN/Sampath de A. Goonatilake) 


\section{Faunal diversity of the islands}

In total, 347 species of fauna were recorded within the islands and the coastal areas surveyed (Table 7). This included nine endemic species: the lesser albatross (Appias galane); Devaka's fanthroat lizard (Sitana devakai); common lankaskink (Lankascincus fallax); flowery wolf snake (Lycodon osmanhilli), checkered keelback (Xenochrophis asperrimus), checkered keelback (Xenochrophis cf. piscator); Sri Lanka jungle fowl (Gallus lafayetii), Sri Lanka pompadour green-pigeon (Treron pompadora); and the Sri Lanka toque monkey (Macaca sinica). Of the 169 bird species recorded, 78 were migrants to Sri Lanka.

In addition, the faunal assemblage recorded included seven domestic species and two exotic species, Tilapia (Oreochromis mosambicus) and the feral domestic water buffalo (Bubalis bubalis), the latter listed as a potential Invasive Alien Species (IAS) in Sri Lanka (MoMD\&E, 2016b).

Table 7. Summary of fauna recorded during the field survey

\begin{tabular}{|l|c|c|c|c|c|}
\hline \multicolumn{1}{c|}{ GROUP } & TOTAL & \multicolumn{5}{|c|}{ SPECIES STATUS } \\
\hline Land snails & & Endemic & Migrant & Domestic & Exotic \\
\hline Scorpions & 2 & 0 & 0 & 0 & 0 \\
\hline Dragonflies & 3 & 0 & 0 & 0 & 0 \\
\hline Butterflies & 15 & 0 & 0 & 0 & 0 \\
\hline Fishes & 62 & 1 & 0 & 0 & 0 \\
\hline Amphibians & 1 & 0 & 0 & 0 & 1 \\
\hline Reptiles & 13 & 0 & 0 & 0 & 0 \\
\hline Birds & 48 & 5 & 0 & 0 & 0 \\
\hline Mammals & 169 & 2 & 78 & 0 & 0 \\
\hline
\end{tabular}

A complete list of fauna observed in this study is presented in Annex 3.

\section{Notable species}

Also encountered were 30 threatened fauna species (Table 8). Four species of the recorded fauna - the native land snail, Trachia vittata, bright babul blue (Azanus ubaldus); Indian courser (Cursorius coromandelicus) and Saunder's tern (Sterna saundersi) are listed as Critically Endangered (CR) (MoE, 2012).

A further five species - Sri Lankan chameleon (Chamaeleo zeylanicus), Bibron's sand skink (Eutropis bibronii), Oriental pratincole (Glareola maldivarum), fin whale (Balaenoptera physalus) and Asian elephant (Elephas maximus) are listed as Endangered (EN).

There are also 21 species listed as Vulnerable (VU), 13 species, Near Threatened (NT) and five Data Deficient (DD) species also recorded from the surveyed area (MoE, 2012). 
Table 8. Conservation status of the faunal species ${ }^{8}$ recorded in the study area

\begin{tabular}{|l|c|c|c|c|c|}
\hline \multicolumn{1}{c|}{ Animal Group } & \multicolumn{5}{c|}{ Conservation status of the recorded species } \\
\hline Land snails & CR & EN & VU & NT & DD \\
\hline Scorpions & 1 & 0 & 1 & 0 & 0 \\
\hline Dragonflies & 0 & 0 & 0 & 0 & 0 \\
\hline Butterflies & 0 & 0 & 1 & 4 & 0 \\
\hline Fishes & 1 & 0 & 5 & 4 & 0 \\
\hline Amphibians & 0 & 0 & 0 & 0 & 0 \\
\hline Reptiles & 0 & 0 & 1 & 0 & 0 \\
\hline Birds & 0 & 2 & 3 & 0 & 3 \\
\hline Mammals & 2 & 1 & 7 & 6 & 0 \\
\hline Total & 0 & 2 & 3 & 2 & 2 \\
\hline
\end{tabular}

\section{Bright babul blue (Azanus ubaldus)}

This is a Critically Endangered species found among scrublands in the northern and northwestern region (van der \& van der Poorten, 2016). This species is threatened by loss of habitats as a consequence of agriculture and settlements and over-grazing by livestock in the region (van der Poorten \& van der Poorten, 2016) (Figure 28).

\section{Large salmon Arab (Colotis fausta)}

This is a rare and seasonal species found only in the scrub forests of the north-western coast and in the Jaffna Peninsula and is listed as Vulnerable (van der \& van der Poorten, 2016) (Figure 28).

\section{Sri Lankan chameleon (Chamaeleo zeylanicus)}

This is the only chameleon found in Sri Lanka and is restricted to the arid zone in the northwest and in scattered areas of the dry zone, found burrowing under decaying leaves, near sand dunes. This species, like many other species in Sri Lanka is affected by habitat loss and degradation and is listed as Endangered (Figure 29).

\section{Bibron's sand skink (Eutropis bibronii)}

This species of skink is found in the arid and dry areas of the northern and eastern coast (Somaweera \& Somaweera 2009). This species too is affected by habitat loss and degradation and is listed as Endangered. (See a photograph in Figure 29.)

\section{Indian courser (Cursorius coromandelicus)}

This is a lapwing-like bird which is a rare breeding resident found in the coastal areas of the north and north-west (Kotagama \& Ratnavira, 2010). It is found along edges of lagoons and

\footnotetext{
8 Near Threatened (NT) and Data Deficient (DD) species are added to this table as NT species are becoming Threatened, and nothing is known about DD species, which means they could well be threatened.
} 
estuaries and in open areas of the coast. The loss and degradation of wetland habitats are major threats to this species. It is listed as Critically Endangered (MoE, 2012) (Figure 30).

\section{Siberian stonechat (Saxicola maurus)}

This is a rare vagrant observed in grasslands in various parts of the country (de Silva Wijeyeratne, 2017) (Figure 30).

\section{Saunder's tern (Sterna saundersi)}

This is a rare breeding resident found in the coasts of the dry zone and in estuaries, lagoons and reservoirs (Kotagama \& Ratnavira, 2010). The loss and degradation of wetland habitats are major threats to this species. It is listed as Critically Endangered (MoE, 2012). (There is, unfortunately, no photograph of this species.)

\section{Crab plover (Dromas ardeola)}

This is a rare breeding resident, restricted to tidal flats in the north-western and northern coasts (de Silva Wijeyeratne, 2017), listed as Critically Endangered (MoE, 2012) (Figure 31).

\section{Indian spot-billed duck (Anas poecilorhyncha)}

A rare breeding resident of the northern region (de Silva Wijeyeratne, 2017), listed as Critically Endangered (MoE, 2012) (Figure 31).

\section{Delft ponies (Equus caballus)}

Delft ponies are larger than regular ponies but are smaller than normal horses. The wild ponies are thought to be a legacy of the Portuguese and then the Dutch, and later the British, who used the island to breed horses. They now roam free and are wild, depending on nature for their food. However, during the dry months, they must compete with livestock for food and water. (See a photograph in Figure 32.)

\section{Feral donkeys (Equus asinus)}

Also found on some islands (Puliyantivu and Mannar for example) are feral donkeys, thought to have been brought to Sri Lanka by Arab traders. (See a photograph in Figure 32.) 

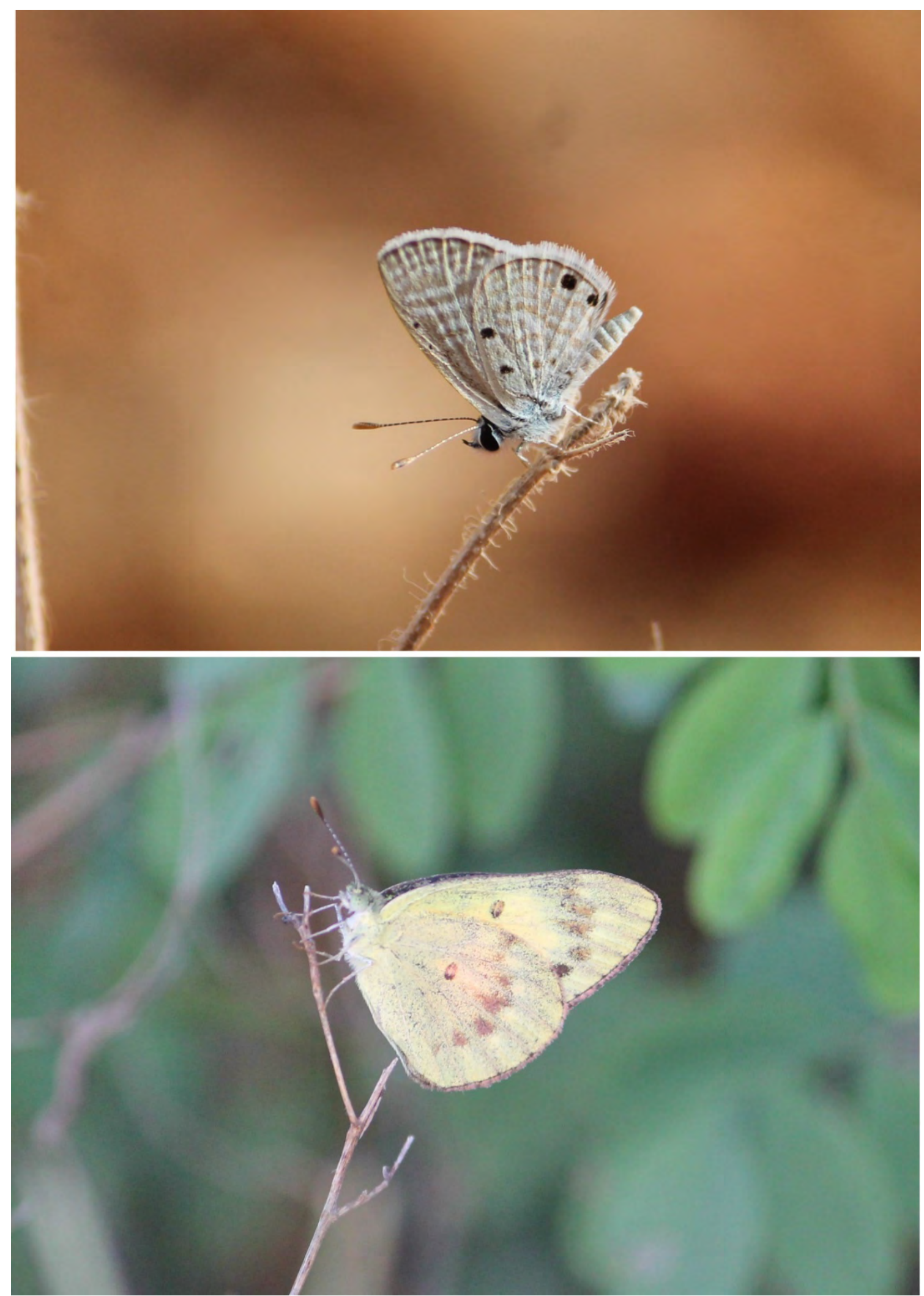

Figure 28. Top: bright babul blue (Azanus ubaldus), a Critically Endangered species, restricted to the north and north-west of the island; bottom: large salmon Arab (Colotis fausta), listed as Vulnerable (C IUCN/Sampath de A. Goonatilake) 


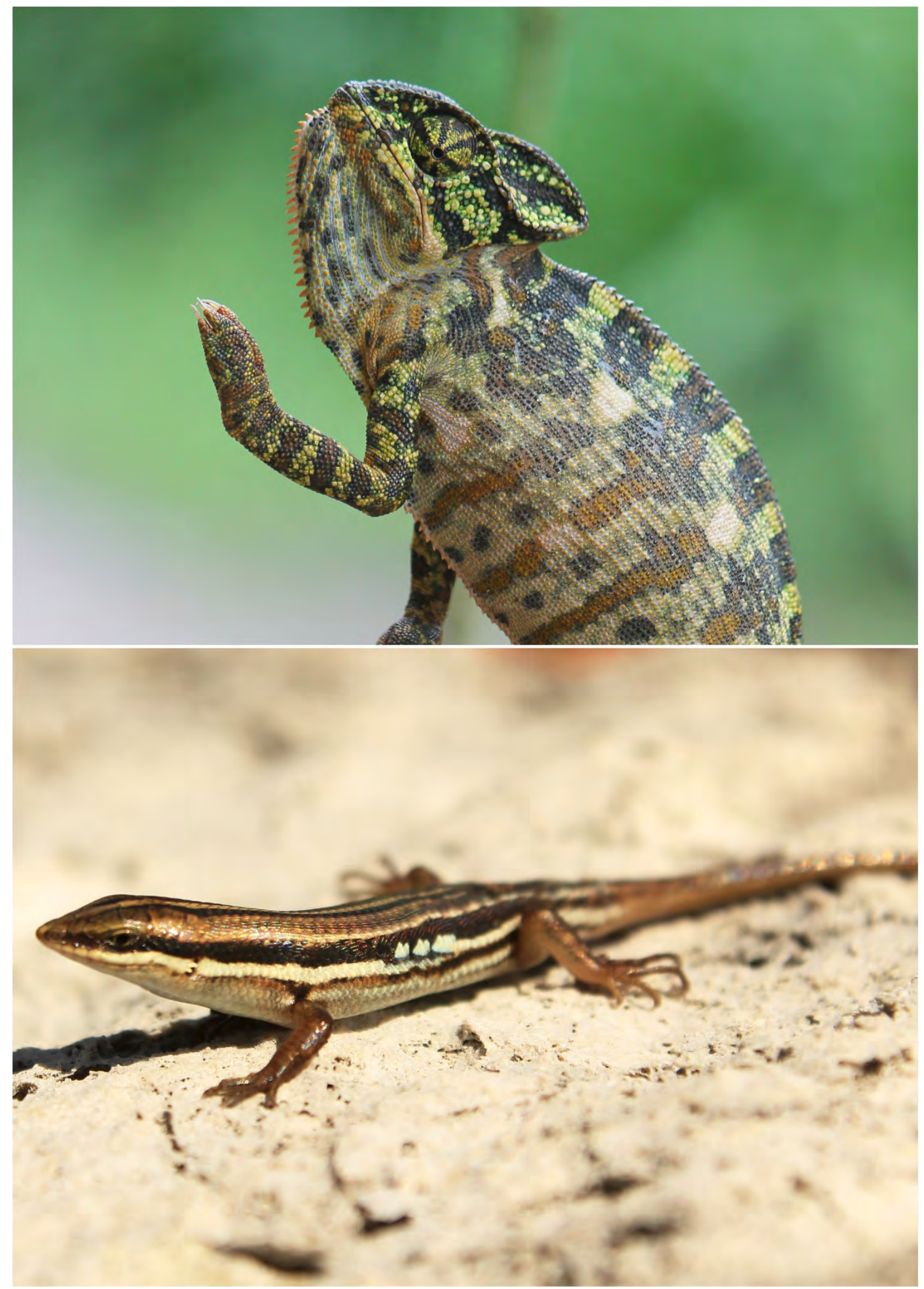

Figure 29. Top: Sri Lankan chameleon (Chamaeleo zeylanicus); bottom: Bibron's sand skink (Eutropis bibronii), both Endangered species (Top @ IUCN/Sampath de A. Goonatilake; bottom: @ IUCN/Naalin Perera) 

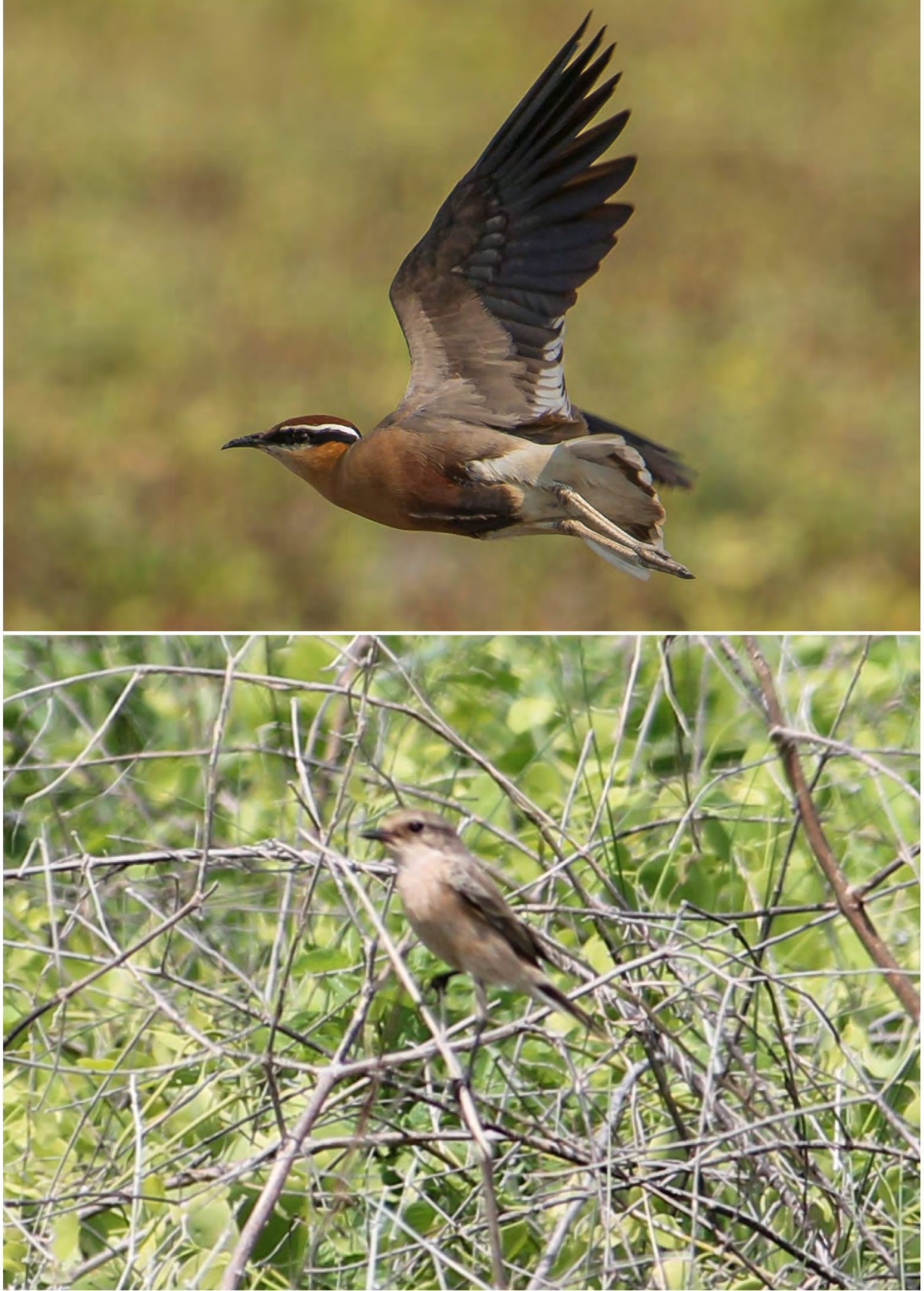

Figure 30. Top: Indian courser (Cursorius coromandelicus), a Critically Endangered species; bottom: Siberian stonechat (Saxicola maurus), a rare winter vagrant (Top: @) Milinda Wattegedara; bottom: @ IUCN/Sampath de A. Goonatilake) 

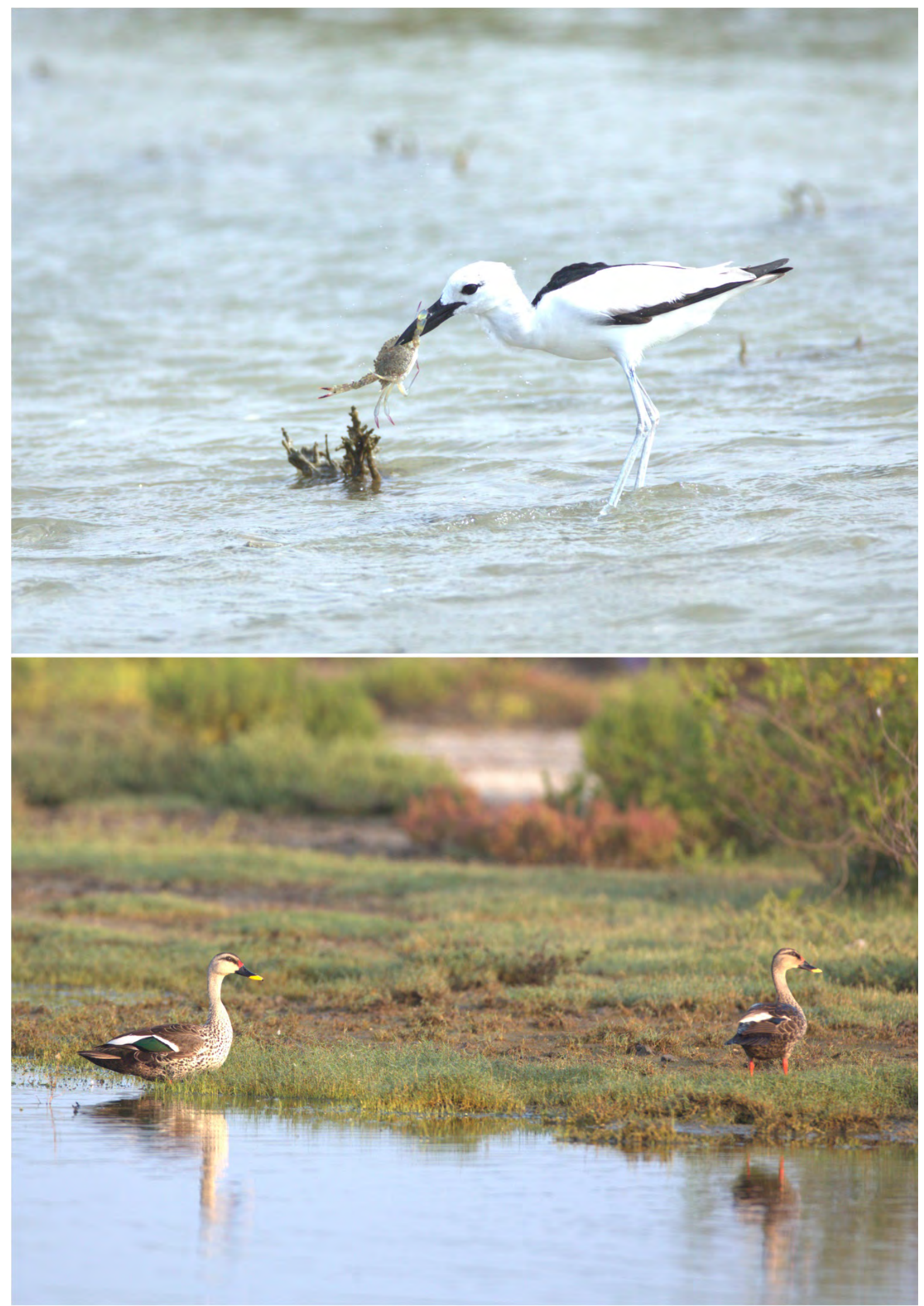

Figure 31. Top: crab-plover (Dromas ardeola); bottom: Indian spot-billed duck (Anas poecilorhyncha), both rare breeding residents of the northern region

(๑ Luxshmanan Nadaraja) 


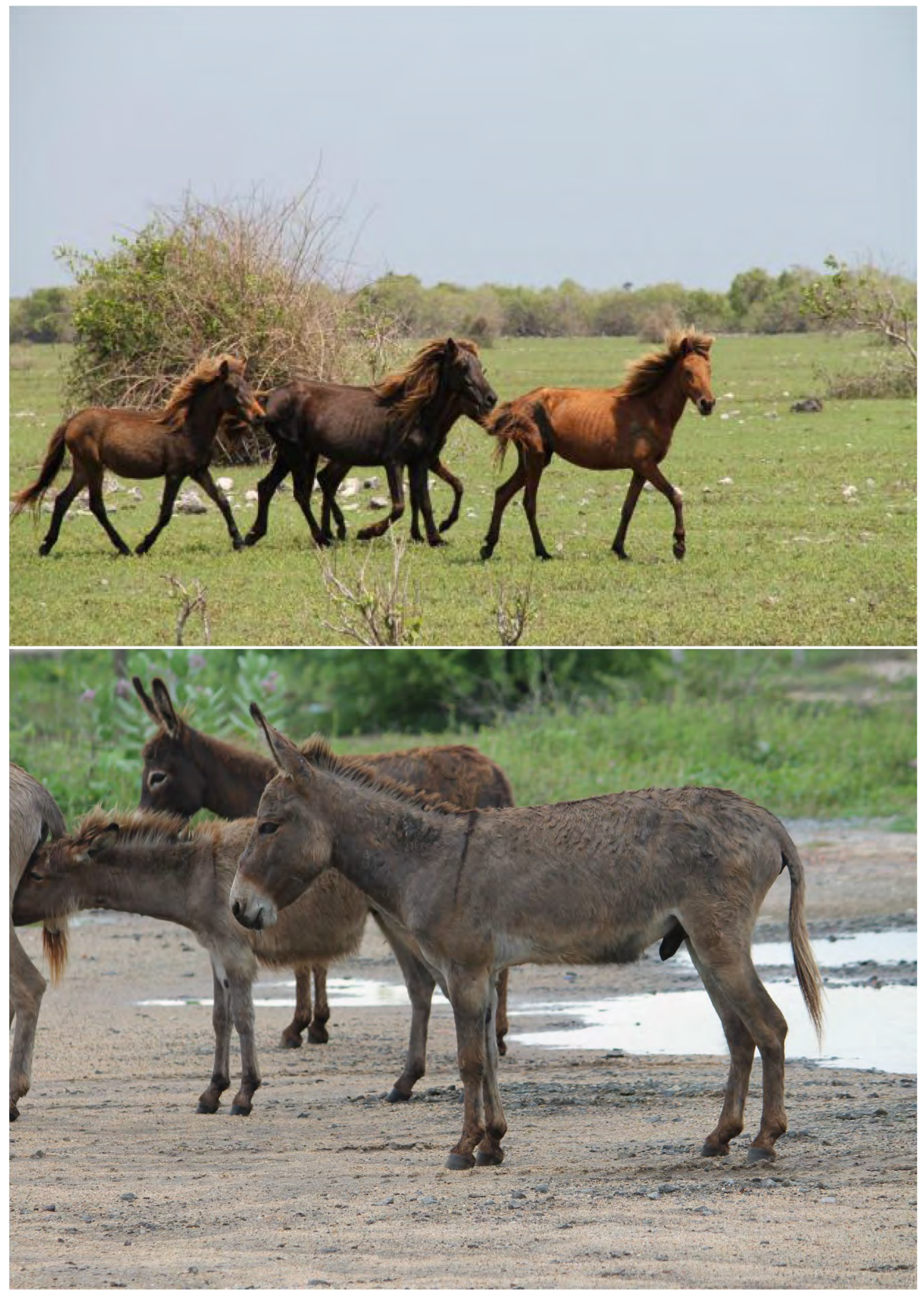

Figure 32. Top: Delft ponies (Equus caballus); bottom: feral donkeys (Equus asinus) (๔ IUCN/Sampath de A. Goonatilake) 


\section{Marine ecosystem diversity}

\section{Coral reefs}

Palk Bay and Palk Strait are shallow, with a maximum depth of about $20 \mathrm{~m}$. Sedimentation is high in the Palk Bay waters and as a result, water transparency is low. Both north-east and south-west monsoons have a profound influence on water transparency. During the peak periods of both monsoons, visibility is less than two metres. During the calm periods, water clarity increases up to about five metres. Therefore, environmental conditions for the growth of coral are relatively poor and coral reefs are restricted to shallow nearshore waters to about eight metres in depth. Fringing coral reefs are present in the Palk Bay and Palk Strait along the northern coast of the Jaffna Peninsula, around the islands and from Devil's Point to Kiranchi. They are about $300 \mathrm{~m}$ wide. The maximum depth along the seaward margin is about eight metres. The only offshore patch reef is the Maldiva Bank located in the south-eastern section of Palk Bay (Figure 22).

The fringing reefs have the typical zonation of fringing reefs with a narrow reef lagoon, a reef crest and a seaward reef slope. The reef lagoons were mainly filled with coral rubble, small living coral colonies of Favia, Favites, Echinopora, Leptoria, Porites and species of Acropora and Montipora. The reef lagoons also contain many species of algae including Sargassum and Turbinaria sp. (Figure 33). Reef lagoons were absent in areas where the fringing reef is part of the ancient coral reef that makes up the coastline. Such reefs can be seen on sections of several islands including Delft and Kakerativu. A clear reef zonation was not present along Erumaitivu and Kakkativu, as well as on the Maldiva Bank where the average depth was two metres throughout the width of the reef. Coral growth is poor along the coast from Point Pedro to Mullaittivu.

Fifty-seven (57) species of hard corals were recorded in the Palk Bay and Palk Strait. The main growth forms were branching, foliose, massive and tabulate (Figure 34 and Figure 35). Colonies of Porites, Goniastrea, Platygyra, Leptoria and Favia have formed large domes over one metre in diameter. Large colonies of Porites lutea and $P$. lobata exceed three to four metres in diameter; they are common, especially along the northern coast of the Jaffna Peninsula and on the fringing reef from Erumaitivu to Kakkativu. Dead coral and coral rubble areas were widespread on many islands including Delft, Mandaitivu, Pungudutivu, Palaitivu, Kakerativu, and Kachchativu, as well as on the reef tract from Kakkativu to Kiranchi (Figure 22).

Soft corals are common especially along the northern coast of the Jaffna Peninsula. Large colonies of leather corals (Sarcophyton spp., Sinularia spp.) over one metre in diameter were present (Figure 33).

Sea fans and gorgonians were very rare in the Palk Bay. Scattered small colonies were present in the Palk Strait. Overall, coral diversity was higher in the Valvettithurai and Point Pedro section of the Palk Strait than in the Palk Bay and the islands.

See Figure 36 for a photograph of a coral reef. 

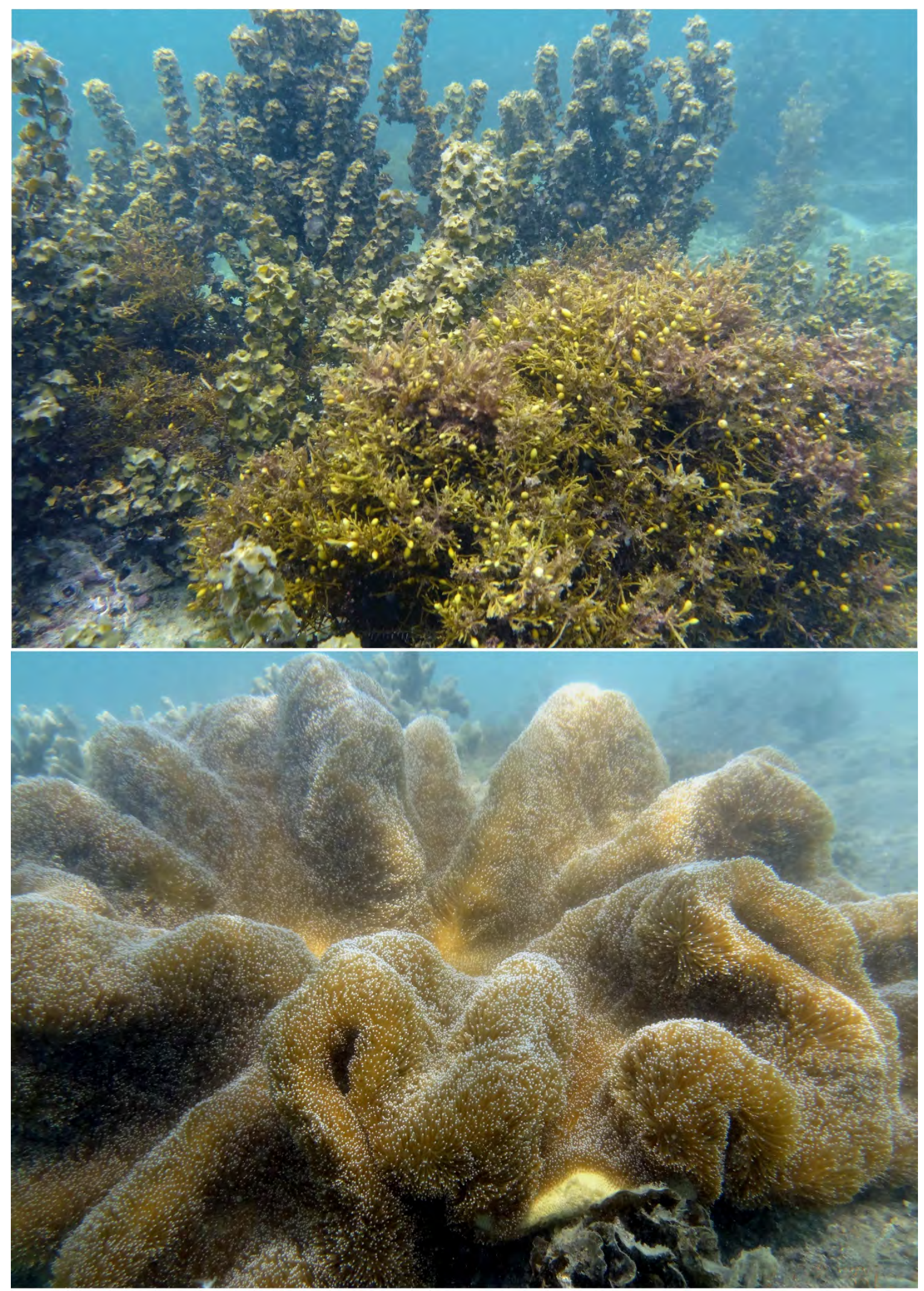

Figure 33. Top: algae species Sargassum and Turbinaria spp.; bottom: soft coral Sarcophyton spp.

(๑ IUCN/Arjan Rajasuriya) 

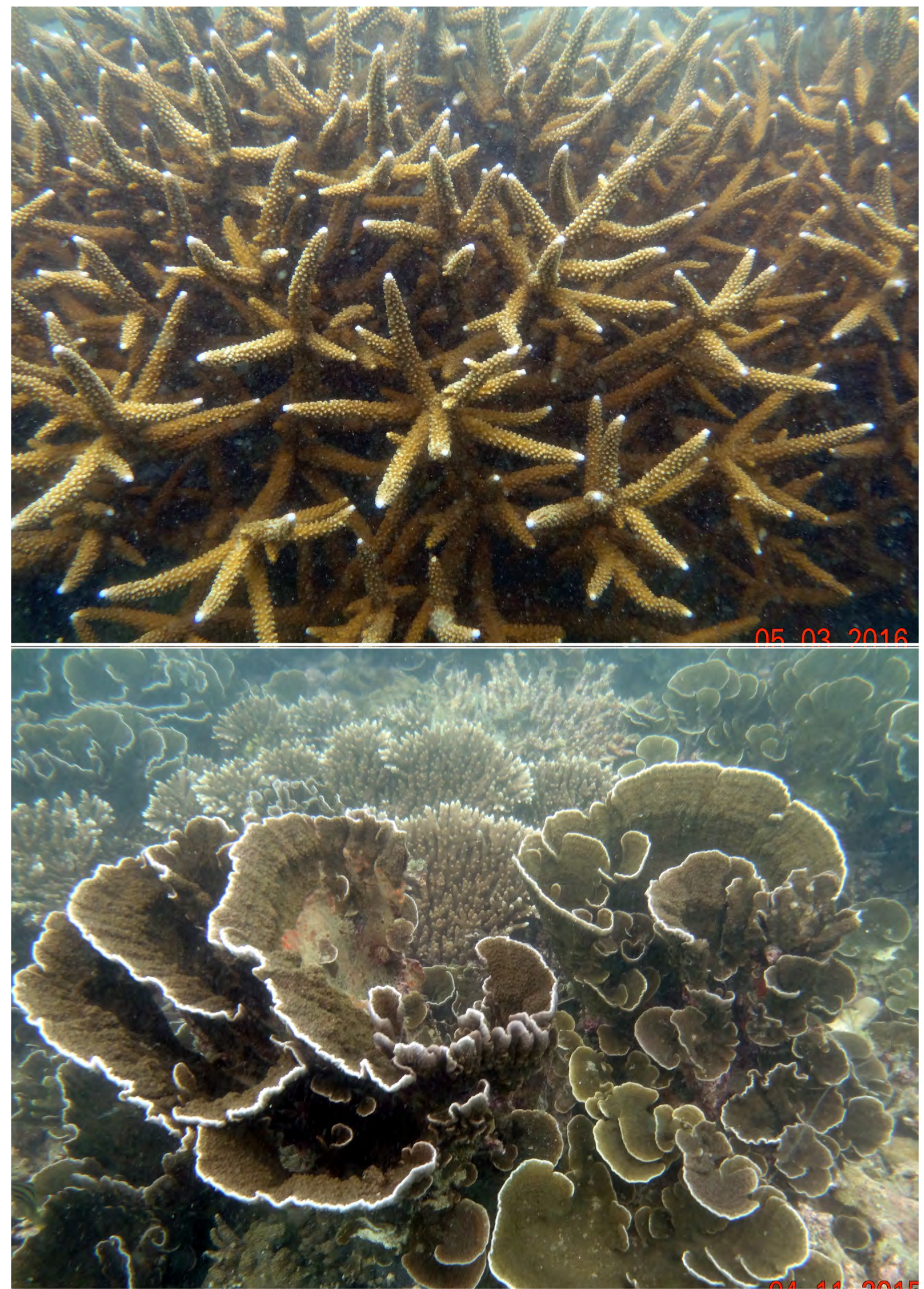

Figure 34. Top: branching coral (Acropora formosa), Kiranchi; bottom: foliose coral (Montipora aequituberculata), Palaitivu

(๑ IUCN/ Arjan Rajasuriya) 

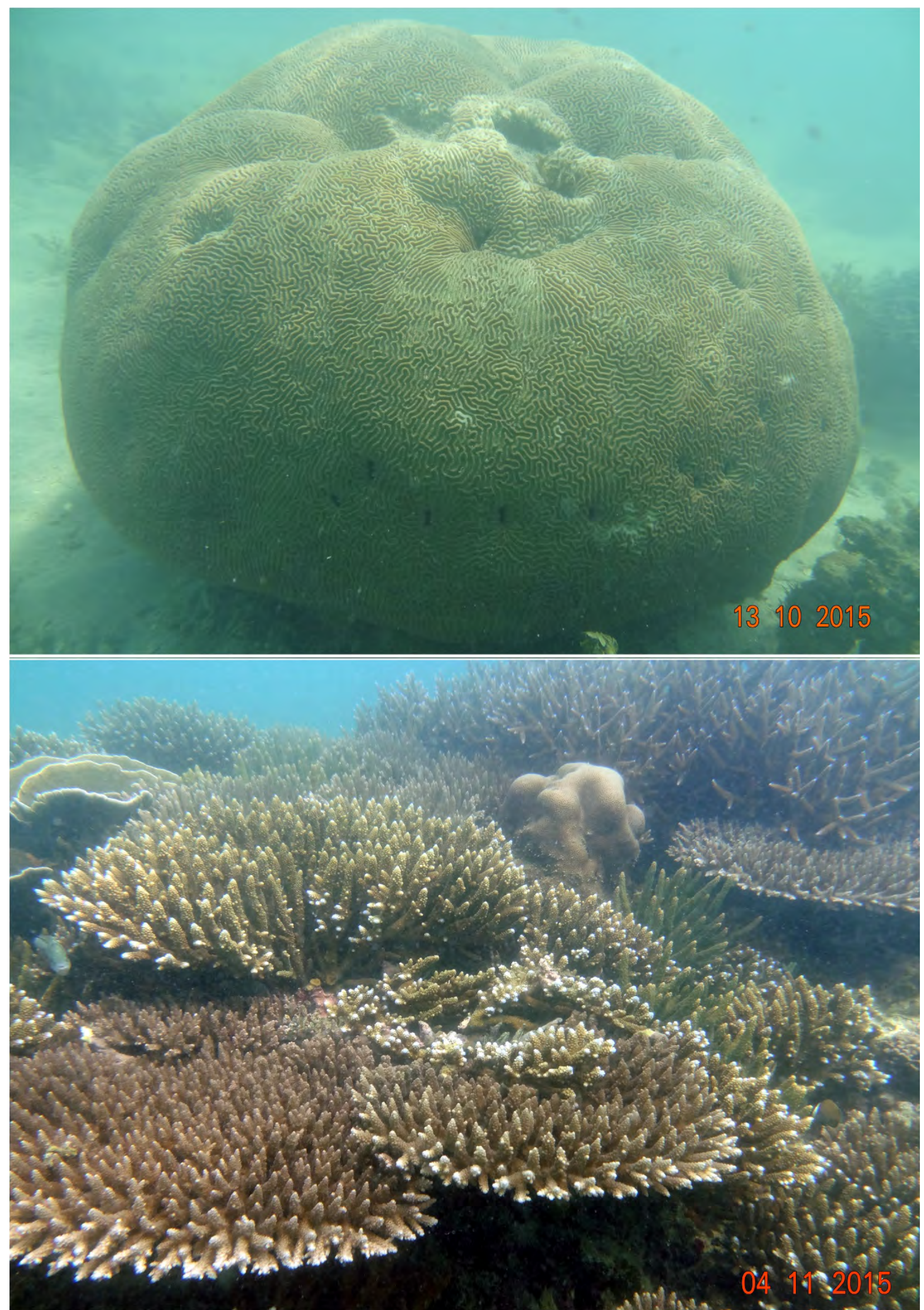

Figure 35. Top: massive coral (Platygyra sinensis), Iranaitivu; bottom: tabulate coral (Acropora latistella in the foreground and $A$. formosa in the background), Palaitivu (C IUCN/ Arjan Rajasuriya) 


\section{Seagrass meadows}

Seagrasses depend on light for photosynthesis and therefore, they generally grow only in clear, shallow waters. Many edible fish are found living in seagrass meadows, which provide feeding, breeding and nursery grounds for many commercially important fish, shellfish and marine invertebrates. These meadows also provide protection. Because of this, seagrasses are critical in sustaining coastal fisheries (Spalding et al., 2003).

The main seagrass meadows in the north are found in the Palk Bay from Mannar Island to Kiranchi along the coast and between the islands of the Jaffna Peninsula. These waters are generally full of sediment. However, seagrasses grow well because of the shallowness of the waters of the area. The maximum depth is about three metres. Eleven species of seagrass belonging to genera Cymodocea, Enhalus, Thallasia, Syringodium, Halodule, and Halophila have been recorded from the Palk Bay (Pradeep Kumara \& Udagedara, 2013).

See Figure 36 for a photograph of a seagrass meadow.

\section{Marine species diversity}

Two hundred and eighty species (280) were recorded under the major categories of corals, reef fish, sea cucumber, seagrasses and seaweeds. They include 86 species of hard corals, 11 species of seagrasses and 172 species of reef fish. Among them 25 species of hard corals and six species of reef fish are listed as Near Threatened (NT) in the IUCN Red List. Five species of hard corals, one species of seagrass and one species of reef fish are listed under the Vulnerable (VU) category (Table 9).

Table 9. Summary of marine species recorded during the field survey

\begin{tabular}{|l|c|c|c|c|c|c|c|c|}
\hline \multicolumn{1}{|c|}{ GROUP } & $\begin{array}{c}\text { Number of } \\
\text { Species }\end{array}$ & CR & EN & VU & NT & DD & LC & NE \\
\hline Corals & 86 & 0 & 0 & 5 & 25 & 1 & 38 & 17 \\
\hline Seagrasses & 11 & 0 & 0 & 1 & 0 & 0 & 10 & 0 \\
\hline Reef fish & 172 & 0 & 0 & 1 & 6 & 1 & 89 & 75 \\
\hline Sea cucumber & 6 & 1 & 0 & 0 & 0 & 1 & 3 & 1 \\
\hline Seaweeds & 5 & 0 & 0 & 0 & 0 & 0 & 0 & 5 \\
\hline Total & $\mathbf{2 8 0}$ & $\mathbf{1}$ & $\mathbf{0}$ & $\mathbf{7}$ & $\mathbf{3 1}$ & $\mathbf{3}$ & $\mathbf{1 4 0}$ & $\mathbf{9 8}$ \\
\hline
\end{tabular}

A complete list of corals observed in this study is presented in Annex 4.

There are many species of hard corals that are growing well in the Palk Bay and Palk Strait; most of the reef building corals belong to the families of Poritidae, Faviidae and Acroporidae. 


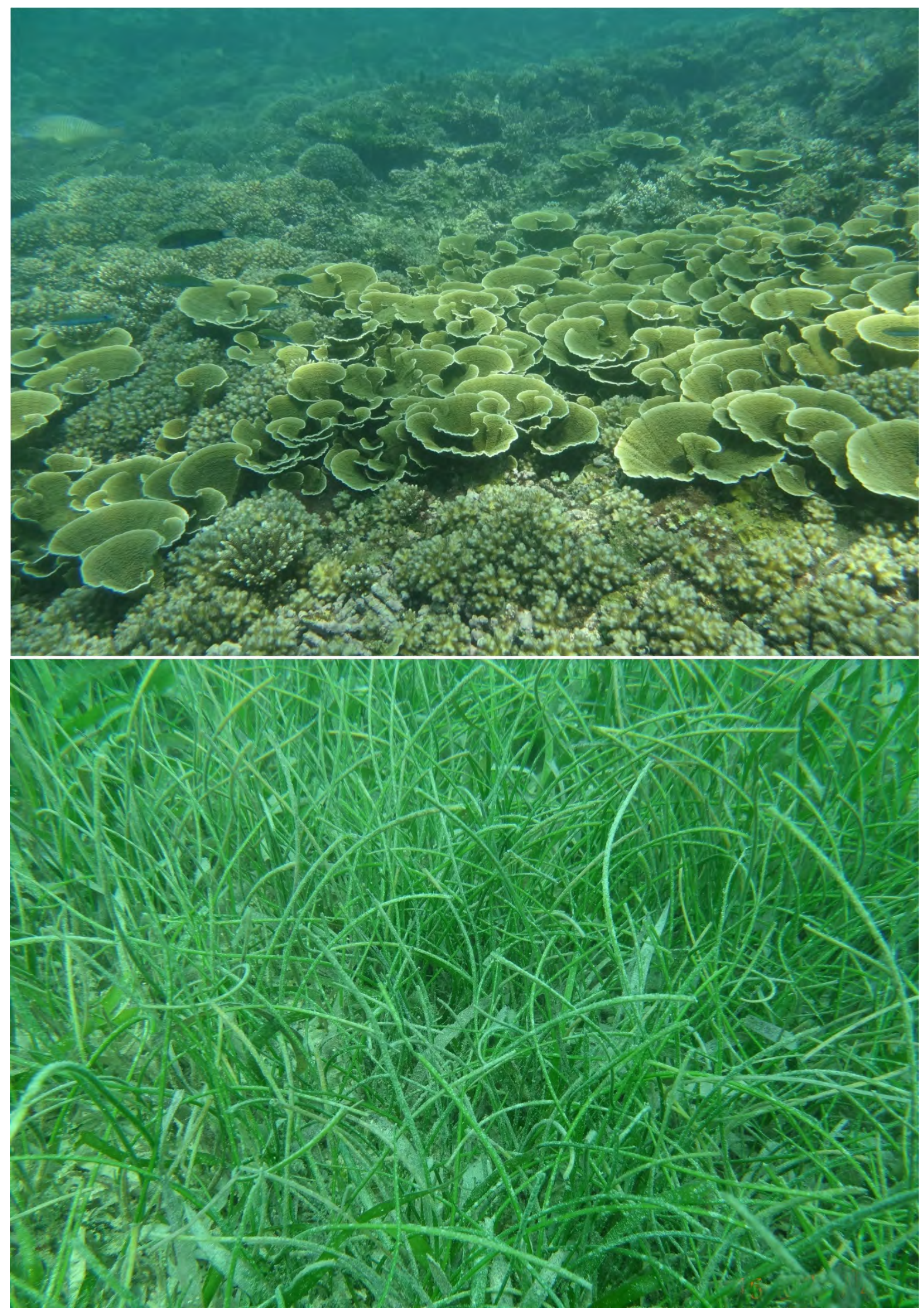

Figure 36. Top: coral reef, off Point Pedro; bottom: seagrass meadow, Vankalai, Gulf of Mannar

(৫ IUCN/ Arjan Rajasuriya) 


\section{Corals}

Montipora hispida was recorded in the Palk Bay and Palk Strait during the present survey (Figure 37). It was also recorded in 2014 and 2015 in the Gulf of Mannar (Rajasuriya, unpublished data). However, it has not been included in the checklist of stony corals previously recorded for Sri Lanka by Rajasuriya (2007). The previous records of stony corals for Sri Lanka included 208 species of hard corals. With the addition of Montipora hispida, the number stony corals species for Sri Lanka becomes 209, divided among 71 genera in 19 families.

\section{Reef fish}

One hundred and twenty-four (124) reef and reef associated fish from 44 families were recorded during the underwater surveys conducted in the Palk Bay and Palk Strait. The following list does not include species from fish landing sites and from the Gulf of Mannar. IUCN (2011) reported 48 different kinds of fish from the Gulf of Mannar and Palk Bay.

The range of some species - such as eight-banded butterflyfish (Chaetodon octofasciatus) and Bengal sergeant (Abudefduf bengalensis) - is restricted to the shallow coral habitats within the north-western and northern waters extending from Gulf of Mannar to Point Pedro (Figure 37). The yellowtail mullet (Sicamugil cascasia) has been recorded only from the fringing reefs along the northern shore of the Jaffna Peninsula. Trigger fish were not observed during these surveys although this is a common group in other reef areas in Sri Lanka. Wrasses were also scarce, and no cleaner wrasses were observed. The abundance of reef fish was generally low. Only three species of parrotfish (Scarus ghobban, S. niger and S. rubroviolaceus) and three species of groupers (Epinephelus longispinis, E. malabaricus and E. merra) have been recorded. The low abundance can be attributed to extensive use of passive fishing gear such as fish kraals (stake nets) which continuously trap all reef fish including small-sized species due to the small mesh size of the net.

Angelfish were rare. Only two species (Pomacanthus annularis and $P$. semicirculatus) of angelfish were recorded. Pygmy angelfish (Centrypyge spp) were not observed within the study area.

A list of reef fish observed in this study is presented in Annex 7.

\section{Selected invertebrates}

Twelve species of molluscs, seven species of crustacean and four species of echinoderms were observed during the marine surveys. A list of these species is presented in Annex 8 . Lagoon aquatic invertebrates were not surveyed.

\section{Dugong (Dugong dugon)}

Dugongs are marine mammals which graze on seagrasses, found in tropical and subtropical coastal areas in the Indo-Pacific region (Illangakoon, 2011). It is found on both sides of the Gulf of Mannar, Palk Bay and Palk Strait. Historically, dugongs were commonly found in the Gulf of Mannar, Palk Strait and the islands off the north and north-western coast (Illangakoon, 2011). Very little is known about this species in Sri Lanka, and it is believed that it is now 
confined to the shallow coastal waters in the Gulf of Mannar and Palk Bay where extensive seagrass meadows are found (Jones, 1967; Pilcher et. al., 2014).

This is a transboundary species and the population is shared by India and Sri Lanka. However, there are no estimates for the existing population.

These animals are listed as globally Vulnerable as they face many anthropogenic threats across their geographical range.

\section{Whales and dolphins}

This study did not survey marine mammals and the information included in this report is from other studies, cited in the following text. Strandings have been recorded of large whales along the coast of Gulf of Mannar and the Palk Strait: sperm whale (Physeter macrocephalus), blue whale (Balaenoptera musculus) and the Minke whale (Balaenoptera acutorostrata) Brydes whale (Balaenoptera edeni), and the humpback whale (Megaptera novaeangliae). The melonheaded whale (Peponocephla electra), and false killer whale (Pseudorca crassidens), dwarf sperm whale (Kogia sima) have also been recorded (De Silva, 1987; Broker and Ilangakoon, 2008) (Figure 38).

Smaller cetaceans such as the Indo-Pacific humpback dolphin and the Indo-Pacific finless porpoise inhabit the nearshore areas. De Silva (1987) also reports of an Indo-Pacific finless porpoise (Neophocaena phocaenoides) caught by Smithsonian Carangid Survey Team from the Wadge Bank in 1970 and listed this record for Sri Lanka. However, the Wadge bank belongs to India. More recently Nanayakkara et al. (2017) reported the Indo-Pacific finless porpoise from the Palk Bay.

Also recorded are bottlenose dolphins (Tursiops truncatus), Indo-Pacific humpback dolphin (Sousa chinensis) and spinner dolphins (Stenella longirostris) (Figure 38). More recent information indicates that the killer whale (Orcinus orca) is observed in the Gulf of Mannar off the Kalpitiya Peninsula (Nanayakkara pers. comm.).

\section{Table 10. Conservation status of whales and dolphins found in the northern waters} of Sri Lanka

\begin{tabular}{|c|c|c|c|c|}
\hline Scientific name & Common name & $\begin{array}{l}\text { Sinhala } \\
\text { name }\end{array}$ & Tamil name & $\begin{array}{c}\text { Conservation } \\
\text { status }\end{array}$ \\
\hline Balaenoptera musculus & Blue whale & Nil thalmasa & $\begin{array}{l}\text { Neela } \\
\text { thiminkalam }\end{array}$ & EN \\
\hline $\begin{array}{l}\text { Balaenoptera } \\
\text { acutorostrata }\end{array}$ & Minke whale & $\begin{array}{l}\text { Minki } \\
\text { thalmaha }\end{array}$ & $\begin{array}{l}\text { Minke } \\
\text { thimingilam }\end{array}$ & LC \\
\hline Balaenoptera brydei & Bryde's whale & $\begin{array}{l}\text { Brydige } \\
\text { thalmaha }\end{array}$ & $\begin{array}{l}\text { Broodes } \\
\text { thimingilam }\end{array}$ & DD \\
\hline $\begin{array}{l}\text { Megaptera } \\
\text { novaeangliae }\end{array}$ & $\begin{array}{l}\text { Hump-backed } \\
\text { whale }\end{array}$ & $\begin{array}{l}\text { Molli } \\
\text { thalmaha }\end{array}$ & $\begin{array}{l}\text { Koon } \\
\text { muthuku } \\
\text { thimingilam }\end{array}$ & LC \\
\hline Physter macrocephalus & Sperm whale & $\begin{array}{l}\text { Manda } \\
\text { thalmaha }\end{array}$ & $\begin{array}{l}\text { Vinthu } \\
\text { Thimingilam }\end{array}$ & VU \\
\hline Kogia sima & Dwarf sperm whale & $\begin{array}{l}\text { Mitimunda } \\
\text { thalmasa }\end{array}$ & $\begin{array}{l}\text { Kuttai kular } \\
\text { thimikalam }\end{array}$ & DD \\
\hline
\end{tabular}




\begin{tabular}{|c|c|c|c|c|}
\hline Scientific name & Common name & $\begin{array}{l}\text { Sinhala } \\
\text { name }\end{array}$ & Tamil name & $\begin{array}{c}\text { Conservation } \\
\text { status }\end{array}$ \\
\hline Peponocephala electra & $\begin{array}{l}\text { Melon-headed } \\
\text { whale }\end{array}$ & $\begin{array}{l}\text { Puhulolu } \\
\text { thalmaha }\end{array}$ & $\begin{array}{l}\text { Mulaam } \\
\text { palath thalai- } \\
\text { thiminkalam }\end{array}$ & LC \\
\hline Orcinus orca & Killer whale & & & \\
\hline Pseudorca crassidens & False killer whale & $\begin{array}{l}\text { Boru } \\
\text { minimaru } \\
\text { thalmaha }\end{array}$ & $\begin{array}{l}\text { Poli kolaith- } \\
\text { thiminkalam }\end{array}$ & DD \\
\hline $\begin{array}{l}\text { Neophocaena } \\
\text { phocaenoides }\end{array}$ & Finless porpoise & Not known & Not known & NE \\
\hline Sousa chinensis & $\begin{array}{l}\text { Indo-pacific hump- } \\
\text { back dolphin }\end{array}$ & Kabara mulla & $\begin{array}{l}\text { Koonmuthuhu } \\
\text { tholpin }\end{array}$ & NT \\
\hline Stenella longirostris & Spinner dolphin & Sannali mulla & $\begin{array}{l}\text { Neel munchi } \\
\text { sulal ongil }\end{array}$ & DD \\
\hline Tursiops truncatus & $\begin{array}{l}\text { Bottle-nosed } \\
\text { dolphin }\end{array}$ & $\begin{array}{l}\text { Digasubu } \\
\text { mulla }\end{array}$ & $\begin{array}{l}\text { Kuppi } \\
\text { mukkinai } \\
\text { oonjia }\end{array}$ & LC \\
\hline
\end{tabular}




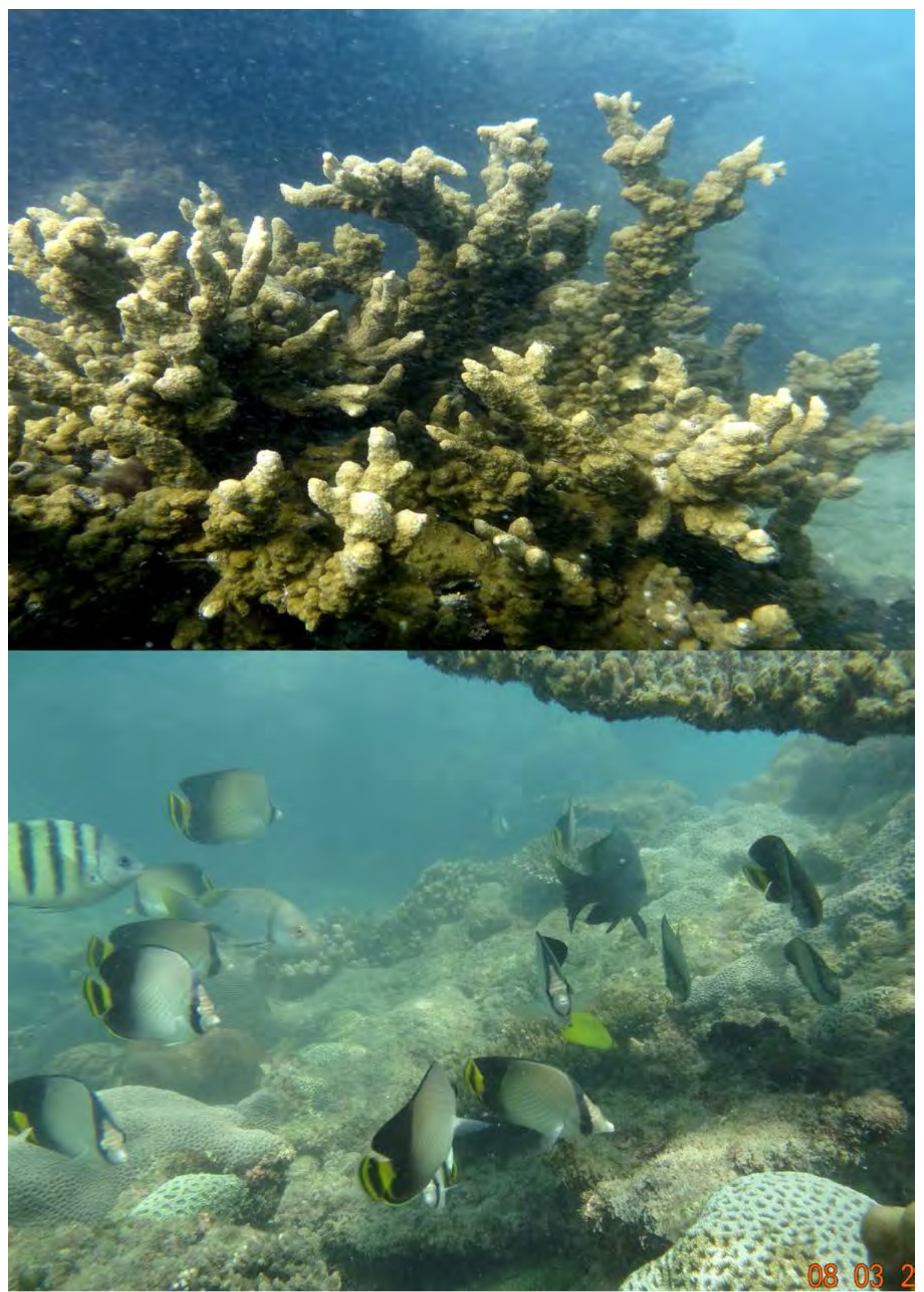

Figure 37. Top: Montipora hispida, Arippu; bottom: from left to right: Indo-Pacific sergent (Abudefduf vaiginensis), Indian vagabond butterflyfish (Chaetodon decussatus), blubberlip snapper (Lutjanus rivulatus), Andaman butterflyfish (Chaetodon andamanensis), Point Pedro

(C) IUCN/ Arjan Rajasuriya) 


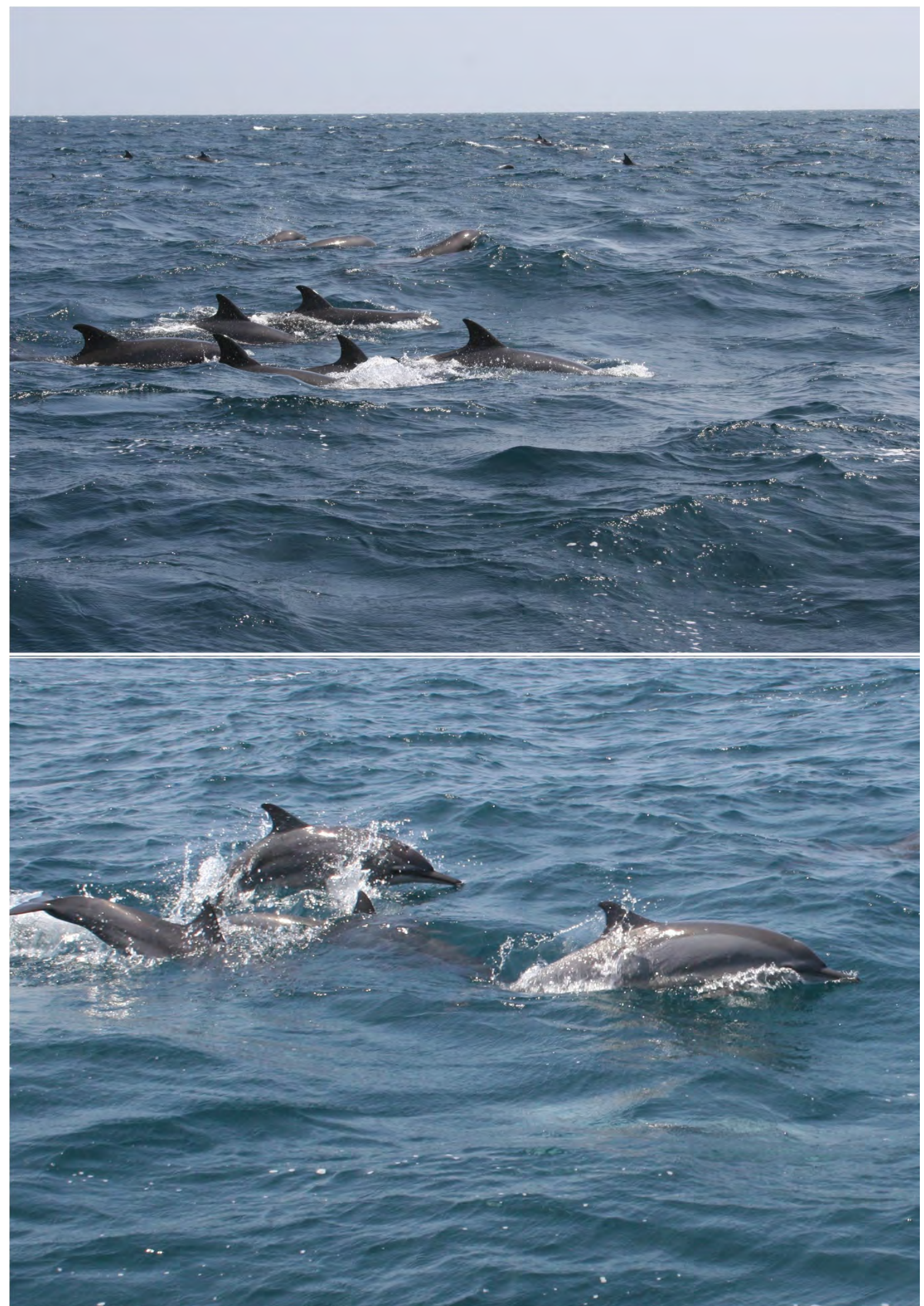

Figure 38. Top: melon-headed whale (Peponocephala electra); bottom: spinner dolphins (Stenella longirostris)

(C Anouk Illangakoon) 


\section{Chapter 5: Threats to natural resources and biodiversity in the study area}

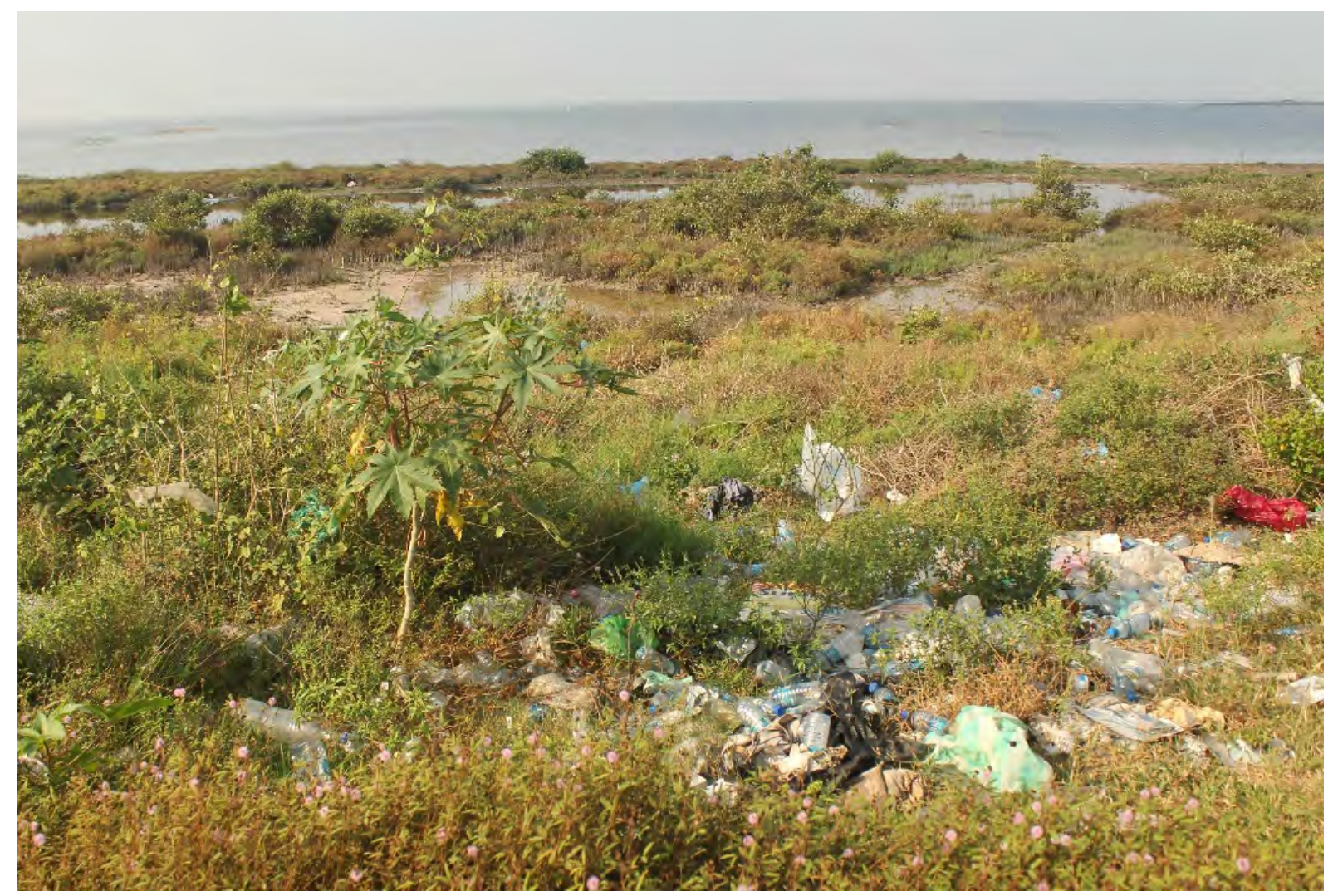

Solid waste pollution beside the Jaffna-Punnalai-Point Pedro Road (৫ IUCN/Naalin Perera) 
Many potential threats to the natural resources and biodiversity of the areas have been observed in the study area. These are described below.

\section{Habitat destruction and degradation}

\section{Clear felling areas and destroying habitats}

Habitat destruction results in the loss or reduction of life-sustaining ecosystem services.

For example, mangroves, which are adapted uniquely to the regular movement of tides are, therefore, also able to withstand stronger forces of waves and wind energy that occur with extreme weather events. They, therefore, provide physical protection from coastal storms and cyclones. In addition, mangrove roots and organic matter in the mud function to trap sediment, and act as sponges to absorb flood waters (UNEP-WCMC, 2006). In addition, many aquatic animals use mangroves as permanent or temporary habitats, but they also serve as hatcheries and nurseries for many commercially important finfish and shellfish.

A road has been built on the island of Chirutivu, destroying the lush mangrove vegetation there (MFF, 2015b) while in Vidattaltivu Lagoon, mangroves are being cut down for use in brush piles to aggregate fish and squid, by people who come from Pallimunai on Mannar Island. Mangrove wood is also being extracted in Thondaimanaru.

In Sarasalai and Nagarkovil, mangroves have been cleared for coconut cultivation, even though the latter was declared as a Nature Reserve under the Department of Wildlife Conservation in 2016 (Gnaneswaran, 2015).

Sand dunes also provide protection against flooding from storm surges. Intact sand dunes were the most effective barrier against tsunami waves that affected the coastal zone of Sri Lanka in 2004 (Bambaradeniya et al., 2006). The sediment in sand dunes protects the land behind them from storm erosion and potential sea level rise. Yet, sand is being extracted heavily from the large sand dune in Manatkadu, and the Pooneryn Peninsula resulting in the lowering of the sand dune.

In Puliyantivu, Jaffna, most of the natural terrestrial habitats were destroyed during the civil war but are now being used for cultivation instead of letting the vegetation revert naturally.

The damage inflicted on these ecosystems results in the degradation of the ecosystem services such as those mentioned above.

\section{Changing the physical configuration of lagoons and estuaries}

Because lagoons and estuaries are ecotones (see Chapter 4), they often have a larger number of species and larger population densities than species in rivers or inland water bodies in the sea. Therefore, they support a high level of biodiversity (de Wit, 2011; Kennish and Pearl, 2010 both in litt. Miththapala, 2013b), many species of which are important, such as edible shellfish and finfish. Lagoons and estuaries are, therefore, extremely important in the 
sustenance of coastal fisheries. The relatively calm habitats of lagoons allow for the practice of traditional and artisanal fisheries (Bjork et al., 2008 in litt. Miththapala, 2013b). They also function as buffer zones, protecting coastal communities from the full force of weather-related events - such as storm surges, floods and cyclones - by damping wave action, dissipating river discharge and temporarily storing water.

After the cessation of the civil war and the commencement of development activities, negative impacts on lagoon have already been observed, such as, for example, improper construction of roads, across lagoons blocking the through-flow of water (Gnaneswaran, 2015), resulting in different salinities in the partitioned sections of the lagoons. Changing salinities affect species composition, promoting salt-tolerant species in areas of high salinity and freshwater species in areas of low salinity. (See Box 2.)

Such partitioning has occurred in many places on the Peninsula: the reconstruction of the Jaffna-Pannai road has blocked the free flow of water in the northern part of the Jaffna Lagoon (MFF, 2015a). Another road constructed for Mandaitivu village divided a rich mangrove ecosystem, with consequences for species within this wetland (Gnaneswaran, 2015). Barrages built across the mouth of the Thondaimanaru Lagoon in the 1950s and the Arialai bridge, across part of the Jaffna Lagoon, restricting the natural ebb and flow of the tides (MFF, 2015b). In Thondaimanaru Lagoon, before the barrage was installed, the average annual fish catch in this lagoon was 150 tonnes; after the barrage was established the fish catch decreased drastically to 35 tonnes per year. In the space of a decade, 32 of the 47 identified fish species found in this lagoon disappeared (Piratheepa et al., 2016).

In addition, cross-roads have been built across other parts of the Thondaimanaru Lagoon, as well as in Kayts and Uppu Aru Lagoons, have caused the degradation of mangroves in these areas, as the free flow of water has been blocked (Gnaneswaran, 2015).

\section{Box 2. Changing the ebb and flow of tides in a lagoon destroys it}

One of the major impacts on lagoons and estuaries is the development of structures that change the physical configuration of a lagoon or estuary (Samarakoon \& Samarawickrama, 2012). A normal flushing regimen in a lagoon or estuary involves freshwater inflow from rivers or surface runoff and the natural ebb and flow of tides. When structures impede this flow of water or isolate parts of the water body there are serious impacts, one of which is the exacerbation of flooding inland when the natural ebb of the tide, which could drain excess water from lagoons and estuaries, is obstructed (Samarakoon \& Samarawickrama, 2012).

Changes to the flushing regimen also changes the salinity regimen. Species in lagoons and estuaries are adapted to daily changes in salinity. When this is disrupted, there often are changes in species composition, affecting fisheries, which, in turn, affects livelihoods.

The alteration of lagoons has a negative impact on nature-based tourism because of the loss of biodiversity, especially bird life. 

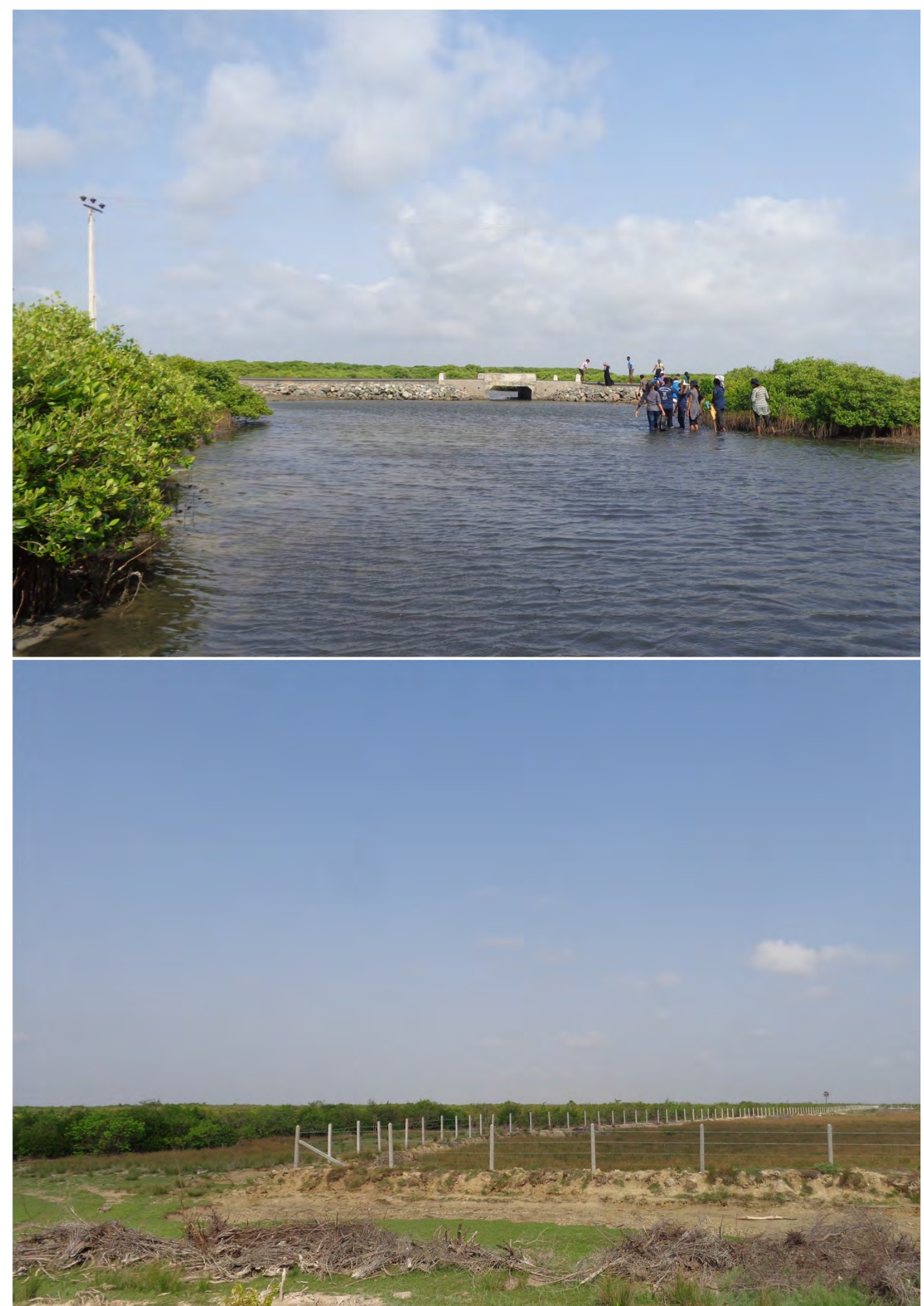

Figure 39. Top: road built across a mangrove ecosystem, Mandaitivu; bottom: mangroves clear cut for coconut cultivation, Sarasalai

(๔ Raji Gnaneswaran) 


\section{Destructive fishing}

\section{Blast fishing}

Blast fishing uses dynamite to stun and kill fish so that they may be collected easily. Explosives are also used to stun schools of fish offshore during purse seine fishing operations.

Blast fishing is widespread both in the Palk Bay and Gulf of Mannar.

During the coral reef survey in the Mandaitivu Island, the sound of a blast was heard underwater.

Coral reefs are extremely productive ecosystems and provide humans with many services. For example, it is estimated that nearly 500 million people depend - directly and indirectly on coral reefs for their livelihoods, food and other resources (Wilkinson, 2004). Like other coastal habitats, coral reefs protect the shoreline from extreme weather events.

\section{Destructive fishing gear}

Fishing is a major economic activity in the area and many different types of fishing gear are used.

Many types of fishing gear have the potential to be destructive depending on how and where they are used. For example, some fishing gear- such as drag nets; trammel nets; push nets and pull nets - damage and destroy ecosystems such as seagrasses, and are extremely detrimental to demersal and benthic organisms, as well as other species that are found in these ecosystems, because they drag against the bottom substrate.

Various fishing gear are being used in the Gulf of Mannar, Palk Bay and Palk Strait. These are described in Table 11.

Table 11. Types of potentially destructive fishing gear

\section{Type of gear used}

Push and pull nets

Trammel nets

Use of nets on coral reefs

Shark/skate gill nets

Purse seine

\section{Used where}

Used on seagrass meadows, damages seagrass. Between islands in the Jaffna Peninsula.

This is widespread as it is underwater and cannot be seen. It gills, entangles everything its wake, irrespective of sizes, so it is very damaging,

Bottom set nets are used freely on reefs to catch spiny lobsters and reef fish throughout the study area. According to the Fisheries and Aquatic Resources Act (1996 as amended by 2016) one should not lay nets on hard substrates such as reefs.

These are especially designed to catch skates, rays and sharks. These nets have a large mesh size from about $22-45 \mathrm{~cm}$. These are death traps for dugongs and large fish.

These nets are used widely throughout the Gulf of Mannar and the northern waters. Currently, saw fishes are threatened with extinction in Sri Lanka because of these nets.

This type is not allowed in coastal waters because it interferes with artisanal fishers. 
It is widely used throughout the study area, but mostly in the Gulf of Mannar. Here, the use of this net, coupled with the use of scuba, has nearly wiped out most aggregating shoals of trevallies (Scientific name: Caranx; Sinhala: Paraw; Tamil: Parai) and barracuda (Scientific name: Sphyraenal; Sinhala: Jeelawa; Tamil: Seela). Sometimes, this type of net is coupled with dynamite when shoals are large. Dynamite is used to control or kill fish in the net so that the net can be hauled in.

This is presently banned but the ban is not enforced. (Regulation was gazetted

Spear fishing in 2017).

Used mainly in the Gulf of Mannar in the study area. This type of fishing is also a major problem throughout the west, south and east coasts of Sri Lanka.

This passive fishing gear causes immense damage to the reef fish population and also traps sea turtles. As these are permanently fixed on seagrass beds and coral reefs, they trap reef fish continuously. In the Palk Bay, there is a

Fish kraals serious decline of reef fish, even in areas where the coral is good such as in Erumaitivu and Kakkativu islands in line with Iranaitivu, Guf of Mannar, Palk Bay and Palk Strait (not along the northern coast of the Jaffna Peninsula) (Figure 40 and Figure 41).

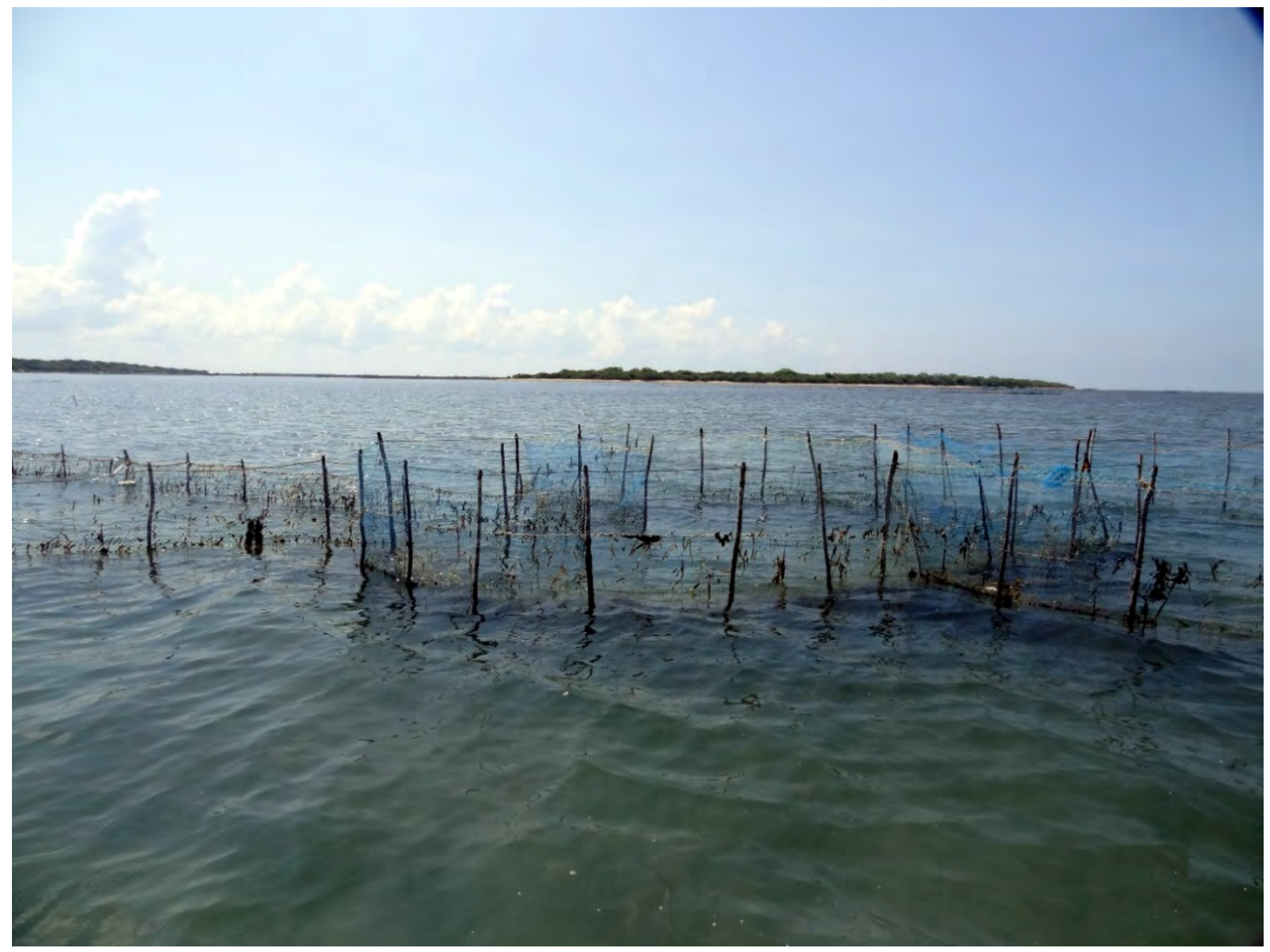

Figure 40. Stake net (fish kraal) at Iranaitivu (@IUCN/Arjan Rajasuriya) 


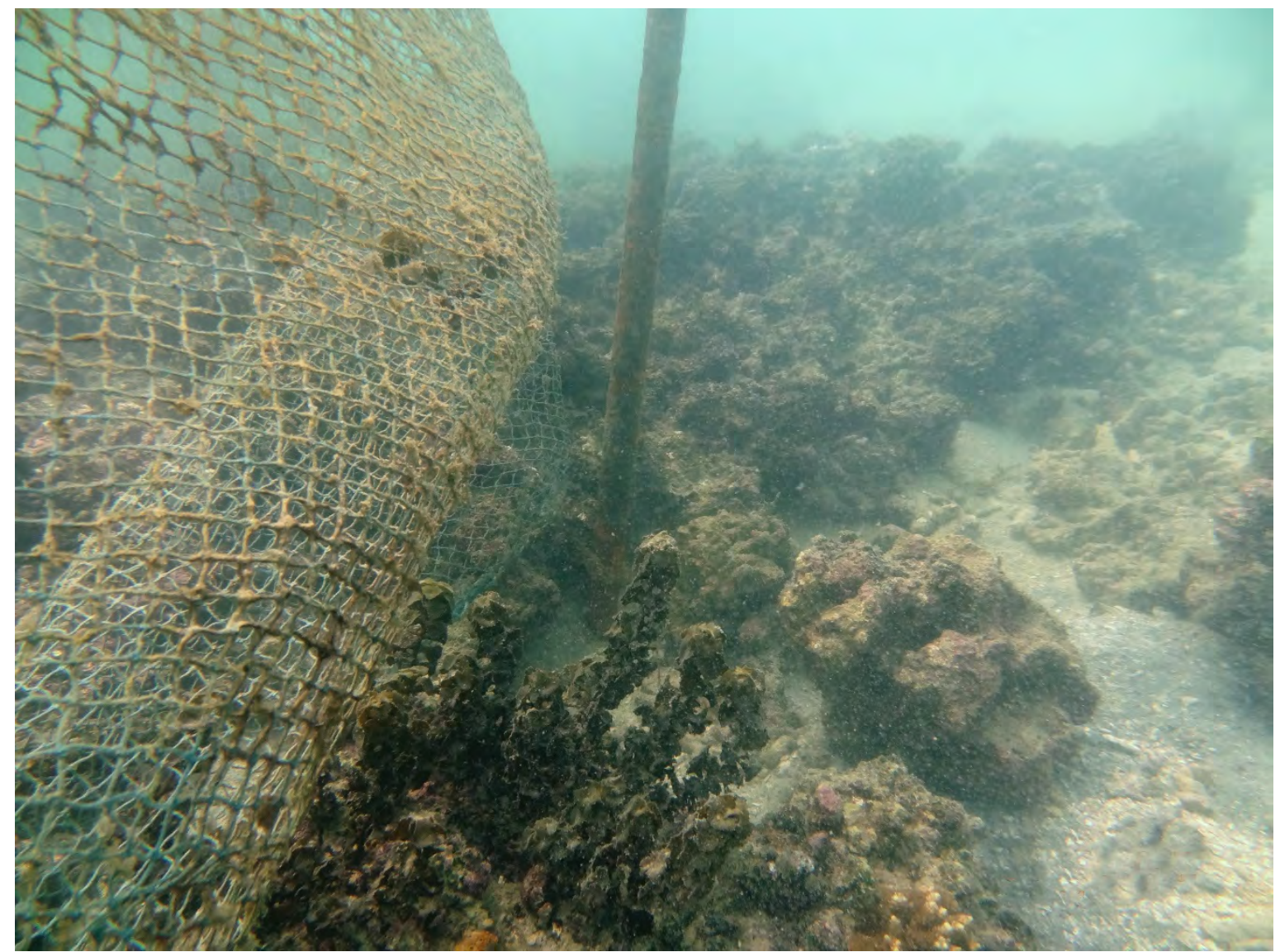

Figure 41. Stake net (fish kraal) fixed on reefs using metal pipes (This shows how reefs and seagrass meadows can be damaged. (c) IUCN/ Arjan Rajasuriya)

Scuba diving also has detrimental impacts of natural resources and biodiversity. (See Box 3.)

\section{Box 3. The detrimental impacts of scuba diving}

Scuba diving is used to catch sea cucumber and chanks mainly in the Gulf of Mannar. Scuba diving was not encountered in the Palk Bay, although it may be used occasionally to collect sea cucumber. The use of scuba for resource harvesting is highly detrimental to the resource as it allows the diver to stay longer underwater, harvesting more of the target species. In addition, scuba diving allows access to many different types of resources such as chank, sea cucumber, lobster, and ornamental fish. If not properly monitored, there is a danger that a diver with a license for only one type of resource may end up illegally harvesting other resources types too.

Combined with nets that are legally permitted scuba diving contributes to overharvesting of demersal fish resources (Figure 42). 


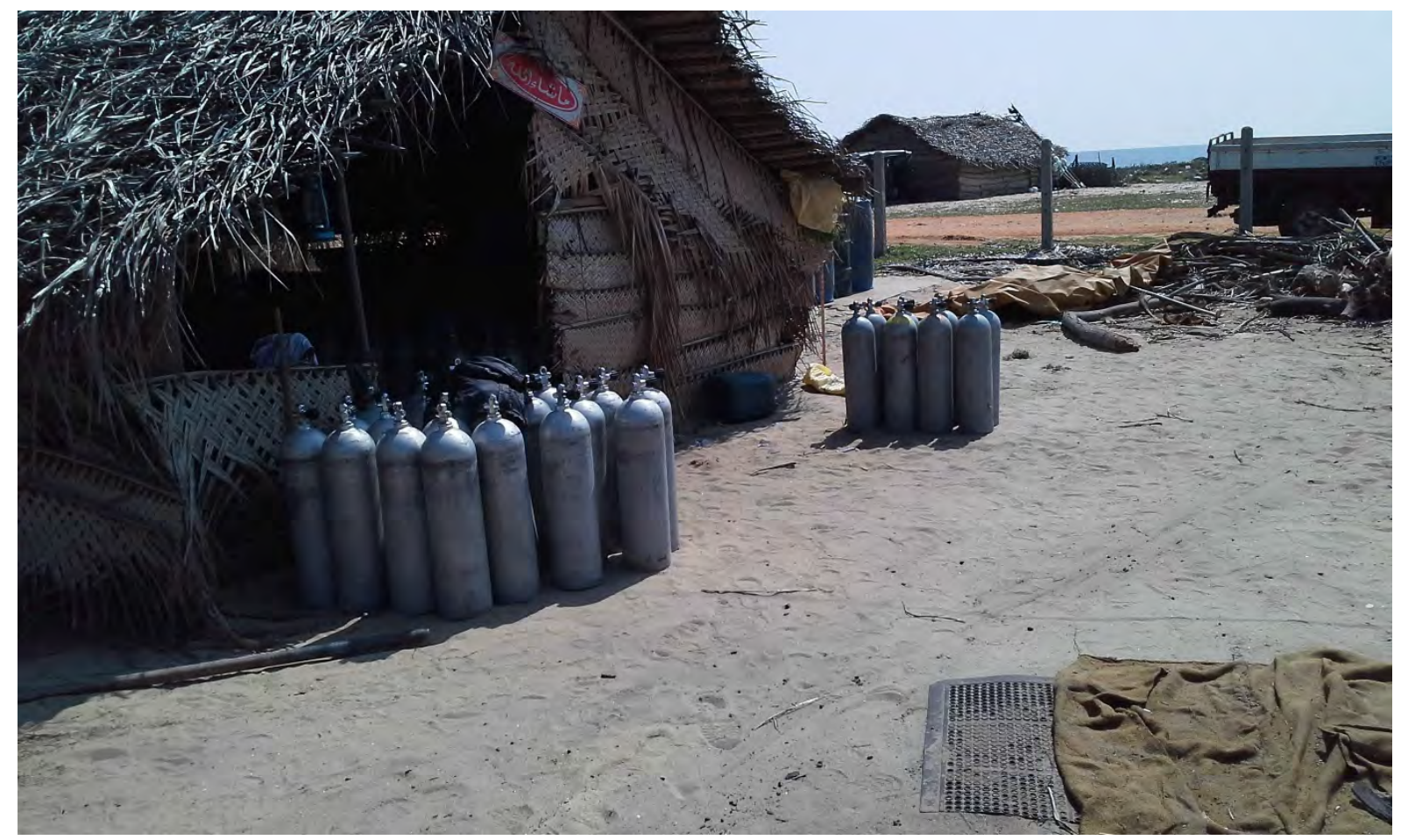

Figure 42. Scuba diving equipment used for chank and sea cucumber harvesting (C IUCN/ Arjan Rajasuriya)

\section{Shrimp fishery}

Shrimp fishery in Sri Lanka dates back 200 years (Long et al., 2010). It is reported that one of the first records of commercial fishing in 1926 was from Pedro Bank, and that there were offshore trawling grounds in Pedro Bank and the Gulf of Mannar (Long et al., 2010). The mud banks of Palk Bay and off the coast of Mullaittivu are among Sri Lanka's main shrimp concentration areas.

It has been reported that a fleet of about 2,500 South Indian bottom trawlers are fully or seasonally dependent on Sri Lankan waters to secure a profitable shrimp catch (Madanayaka, 2015). This is calculated to be 1557.7 tonnes of shrimp annually foregone for Sri Lankan fishermen (Madanayaka, 2015), estimated at a cost of over 750 million USD annually (Hettiarachchi, 2007, in litt. Madanayaka, 2015). These encroachments create severe threats to security, exploitation of fisheries resources and irrecoverable loss to ecosystems such as seagrasses and coral reefs and has been labelled a non-traditional security threat to the country (Madanayaka, 2015).

The impact of damaging coral reefs has been described in the section on blast fishing. The destruction of seagrass meadows also affects coastal fisheries because, they, like mangroves, are nursery areas for many finfish and shellfish (Heck et al., 2003, in litt. Miththapala 2008a).

\section{Boat propellers}

Boat propellers cause damage to seagrass meadows in shallow areas where boats are constantly moving. This occurs in the Gulf of Mannar, Palk Bay and the seagrass meadows among the islands near the Jaffna Peninsula (Figure 43). 


\section{Galvanised iron pipes offshore as kraals}

Instead of using wooden stakes, fishermen now use galvanised iron pipes offshore to set up permanent stake nets (fish kraals) fixed on coral reefs and seagrass meadows that damage such ecosystems. (See Figure 41.)

When turtles are caught in different types of nets, they are often put into the pens made by stake nets (discussed in the section above) and left until it is time to sell (when someone places an order). This provides access to fresh meat. This occurs mainly in the Gulf of Mannar on the southern side of Mannar Island where turtles heading north encounter various fishing gear.

Olive Ridley turtles (Lepidochelys olivacea) are considered the most abundant of the marine turtle species, and the largest nesting site for this species is the coast of Orissa in India (WWF, 2017). Their migratory route to Orissa is via the Palk Strait and thus, they are often netted and caught. This occurs even though this species is listed as Endangered in the National Red List (MoE, 2012) and is also protected by law through the Fauna and Flora Protection Ordinance of 1939 as amended in 2009.

\section{Overexploitation of natural resources}

Overexploitation affects provisioning services, mostly that of food. In coastal areas, this is often related to fisheries, so in addition to a decrease in food species because of overexploitation (resource depletion), there is also loss of livelihoods. Overexploitation also alters species composition and results in the alteration of entire ecosystems.

Much of the overexploitation observed in the study is centred on fisheries, given its importance in the areas.

\section{Use of small-meshed nets}

Sangili nets and nylon monofilament nets are small-meshed, and catch not only target species, but juveniles as well. Thus, these nets have significant negative impacts on various species. Hence, their use is prohibited (Figure 43).

Use of such illegal fishing gear is common in the northern region. For example, fishermen in Araliththurai and Punnalai along the Jaffna Lagoon were found to be using small-sized mesh nets (MFF, 2015a).

Apart from the waste stemming from by-catch (see section below) many air breathing species such as marine reptiles (for example, marine turtles) and mammals (for example, dugongs and dolphins) are accidentally netted by such illegal nets and drown (Figure 44). 


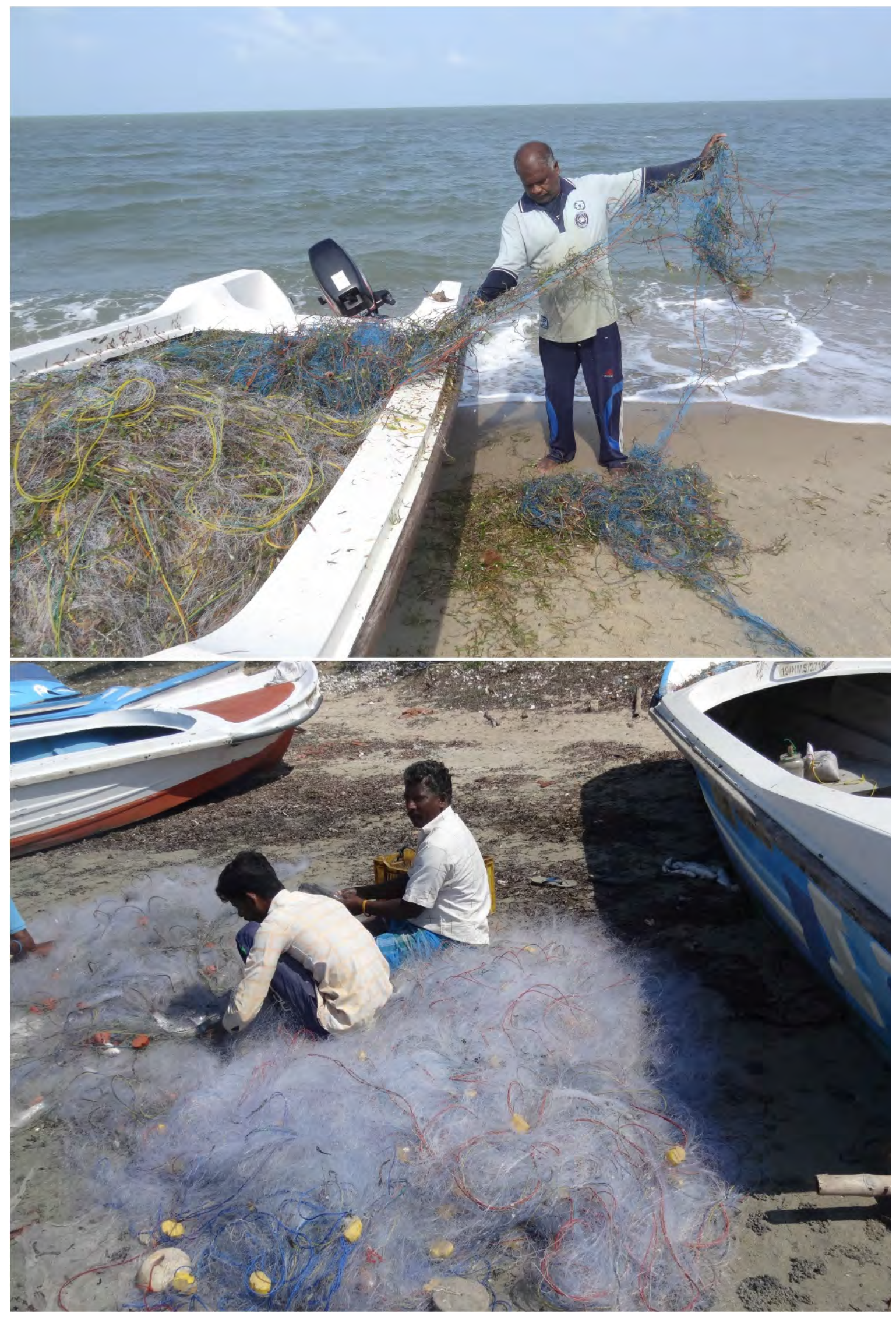

Figure 43. Top: fisherman with a boat showing how propellers have damaged seagrasses, Mannar.

bottom: fishermen using banned mono-filament nets, Vallaipadu

(Top: note the shredded leaves on the sand $\odot$ IUCN/ Arjan Rajasuriya) 


\section{Use of kraals}

Kraals contribute to overexploitation of fish as all the reef fish end up inside the nets. As a result, the reefs are devoid of large reef fish. Reef fish are one of the main attractions for tourists and their absence make the reefs barren and unattractive to visitors. Kraals were observed in Iranaitivu.

\section{Overexploitation through waste of by-catch}

Another form of overexploitation is waste from by-catch. Beach seine, bottom-set nets, bottom trawling, non-selective fishing gear in general, generates by-catch. Many fishers target specific species, such as shrimps and those which are not target species - such as jacks (Carangidae), goatfish (Mullidae), emperors (Lethrinidae) and ponyfish (Leiognathidae) — are accidentally caught in the net. Often, they are juveniles and are too small to be commercially important. Therefore, they are discarded, often while the species are still alive, instead of releasing them back into the sea or lagoon (Figure 44).

By-catch also includes many bottom dwelling organisms such as molluscs. Large mounds of discarded molluscs can be observed in many fishing villages in the North (See Figure 44.)

This results in a significant waste of resources and an unnecessary depletion of marine species diversity and is also detrimental to commercial fisheries. (See Figure 43.)

Large piles of shells of the molluscs, including the branched murex, have also been observed, discarded. (See Figure 43 and section below.)

\section{Targeted over-harvesting}

\section{Indian chanks}

Indian chanks (Turbinella pyrum), found in the area, are valued ornamentals for the export industry (Long et al. 2010). Chank fishery is not new and has been going on since the early 1800s. It was reported that 1,669,745 chanks were exported in 1937 and 1,592,120 in 1939 (Deraniyagala, 1938 and 1940, in litt. Long et al., 2010). Sacred chanks are used as religious objects and to make bangles and baubles (De Bruin et. al., 1994, in litt. Long et al., 010). (See Figure 44.)

Chanks that have left-handed whorls are rare (1:1000s) and have considerable value as lucky charms. These are known as sacred chanks and are called valampuriya in Sinhala and valampuri in Tamil and have an extremely high market value (Long et al., 2010).

Long et al. (2010) report that because chank collectors incorrectly believe that every chank egg case contains an immature left-handed chank, they collect every egg case and every chank they find, resulting in the diminishing of chank populations.

Chanks are collected in Silavatturai and Arrippu. See a photograph in Figure 46.

\section{Other molluscs}

The operculum from the branched murex (Chicoreus ramosus) is known to be extracted from live individuals and the molluscs are thrown back in the sea. (See Figure 43.) Fishermen 
believe that the operculum grows back. Although technically, the operculum can grow, the mollusc is highly vulnerable without the operculum and is devoured by predators. In addition, the damaged flesh may not be capable of regenerating the operculum and therefore this form of fishing is highly destructive.

Another highly damaging method is to use bottomset nets to entangle the molluscs, such as Chicoreus ramosus and Cassis cornuta, the latter which is a protected species under the FFPO. As these are large molluscs, they have flesh that can be dried and sold, and the fresh meat can also be marketed locally or exported. The meat is extracted by smashing the shell with a hammer and the shells are then discarded. (Figure 45). This occurs mainly in the Gulf of Mannar, Silavatturai, Arrippu and Vankalai and on Mannar Island itself.

\section{Sea cucumbers}

Sea cucumbers (Holothurians) are collected from sandy bottoms and seagrass meadows, processed (graded, cleaned, eviscerated, boiled; stored in salt; boiled again and dried) prior to export. The entire catch is exported as bêche de mer, considered a culinary delicacy. (See Figure 45.)

They are collected easily as they can be hand-picked. Records from the Kalpitiya Peninsula indicate that fishermen selectively collect high-valued species, and the populations of these species are decreasing (Long et al., 2010).

Sea cucumbers are picked up by skin divers in the coastal and offshore areas of the Jaffna Lagoon. In Guru Nagar, fishermen fish off trawlers for sea cucumbers. After the war, there has been uncontrolled overexploitation. A study examining the abundance of sea cucumbers in Jaffna Lagoon, found that between 1980 and 1981, there were 20-160 individuals of highvalue Holothuria nobilis (English: black teat fish; Sinhala: polanga attaya; Tamil: kal attai) per square metre. However, a study a few years back revealed that only 10 locations in the Jaffna Lagoon had any sea cucumbers at all (MFF, 2014).

Nationally, the sea cucumber fishery is considered unsustainable.

\section{Poaching of species}

\section{Dugongs}

There is active hunting of the legally protected dugong and there are many records of dugongs being killed (by harpooning) in the recent past, as dugong meat is considered a delicacy. (See Figure 45.)

The dugong is also faced with multiple threats from fishing activities, especially the use of gillnets, bottom-set nets, trawling and blast fishing. 
Madu del ${ }^{9}$ (Tamil name: Thirikkawala) - large mesh-sized gill nets placed closed to the sea floor in coastal areas, used specially for demersal skates and rays - trap dugongs as well, who then drown. This type of net is widely used throughout the Gulf of Mannar, Palk Bay and Palk Strait.

Destruction and damage to seagrass meadows are also serious indirect threats to this rare marine mammal.

In Sri Lanka, the conservation status of dugongs has not yet been evaluated nationally but they are listed as Vulnerable in the global list.

Poaching of bird species such as ibis and open bills was reported by communities in Kokkilai Lagoon and occasionally on the north-east coast.

${ }^{9}$ Sawfish populations in Sri Lanka have also been depleted seriously as consequence of madu del. 


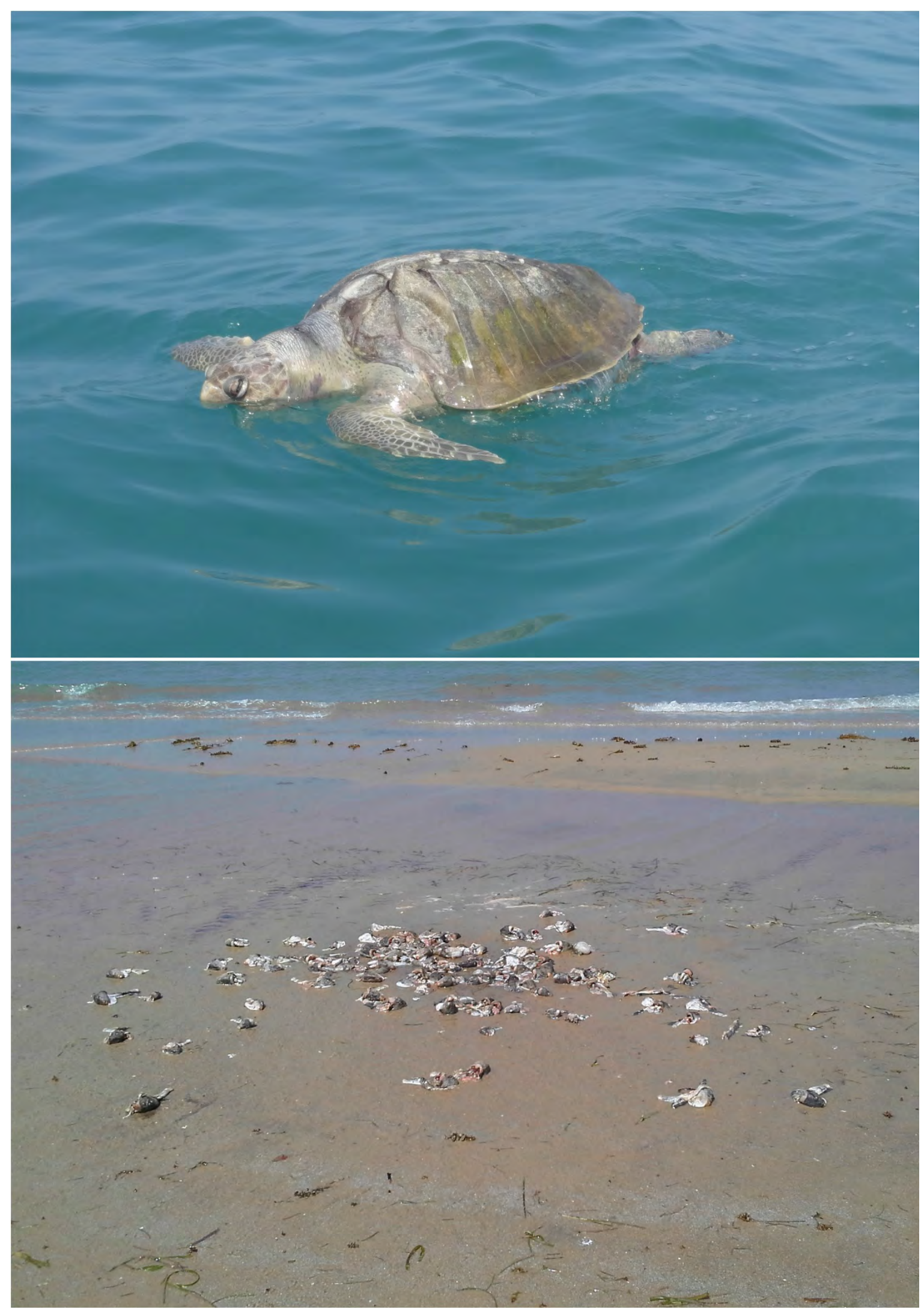

Figure 44. Top: a dead marine turtle, Casuarina Beach, Karainagar; bottom: discarded by-catch

(C IUCN/ Arjan Rajasuriya) 

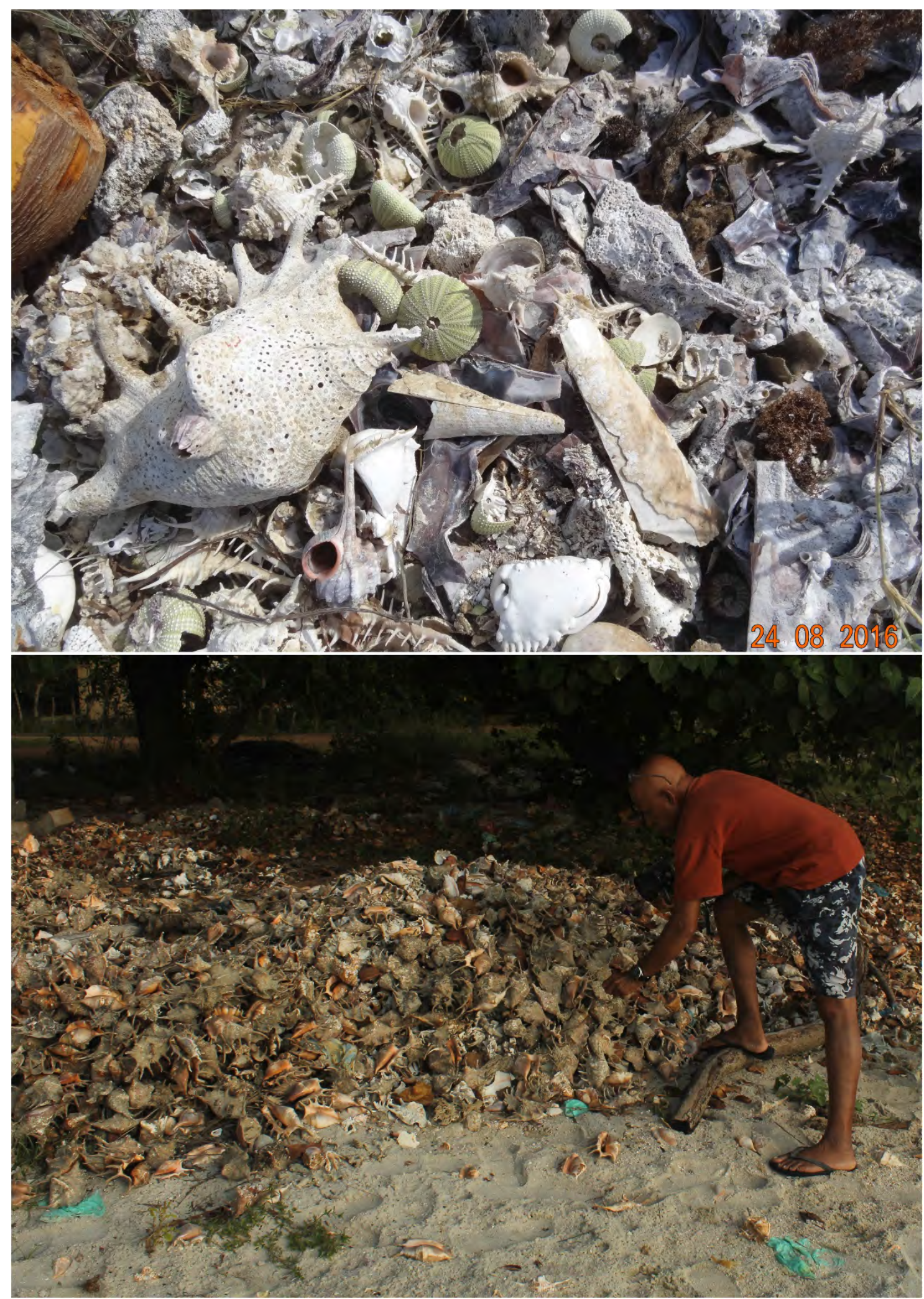

Figure 45. Top: discarded by-catch, including spider conchs, sea urchins and Murex shells; bottom: a huge pile of discarded molluscs

(Top: @ IUCN /Arjan Rajasuriya; Bottom: @ IUCN /Naalin Perera) 


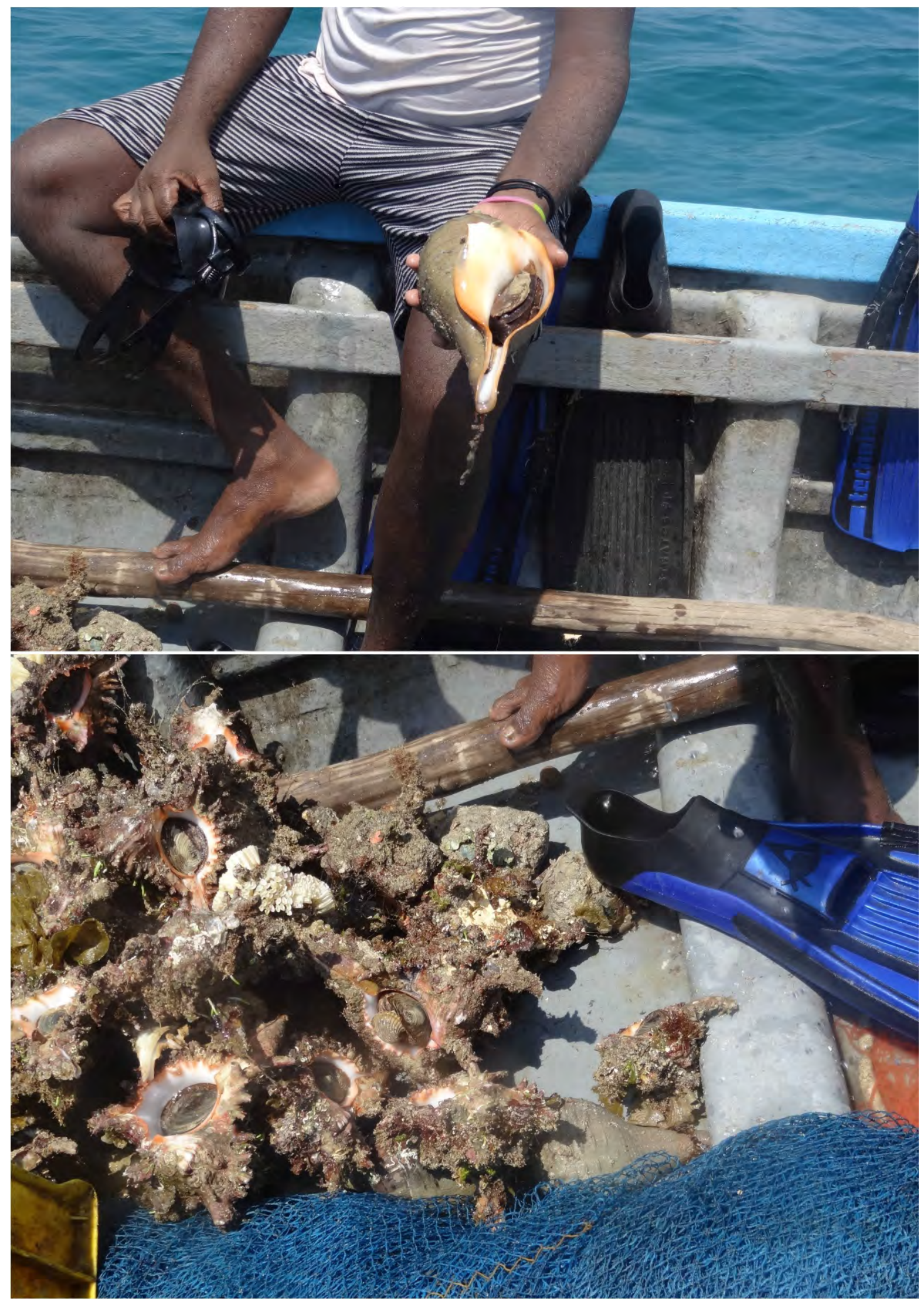

Figure 46. Top: a skin diver holding a sacred chank he has picked up, Vankalai, Mannar; bottom: harvested branched Murex

(๑ IUCN/ Arjan Rajasuriya) 


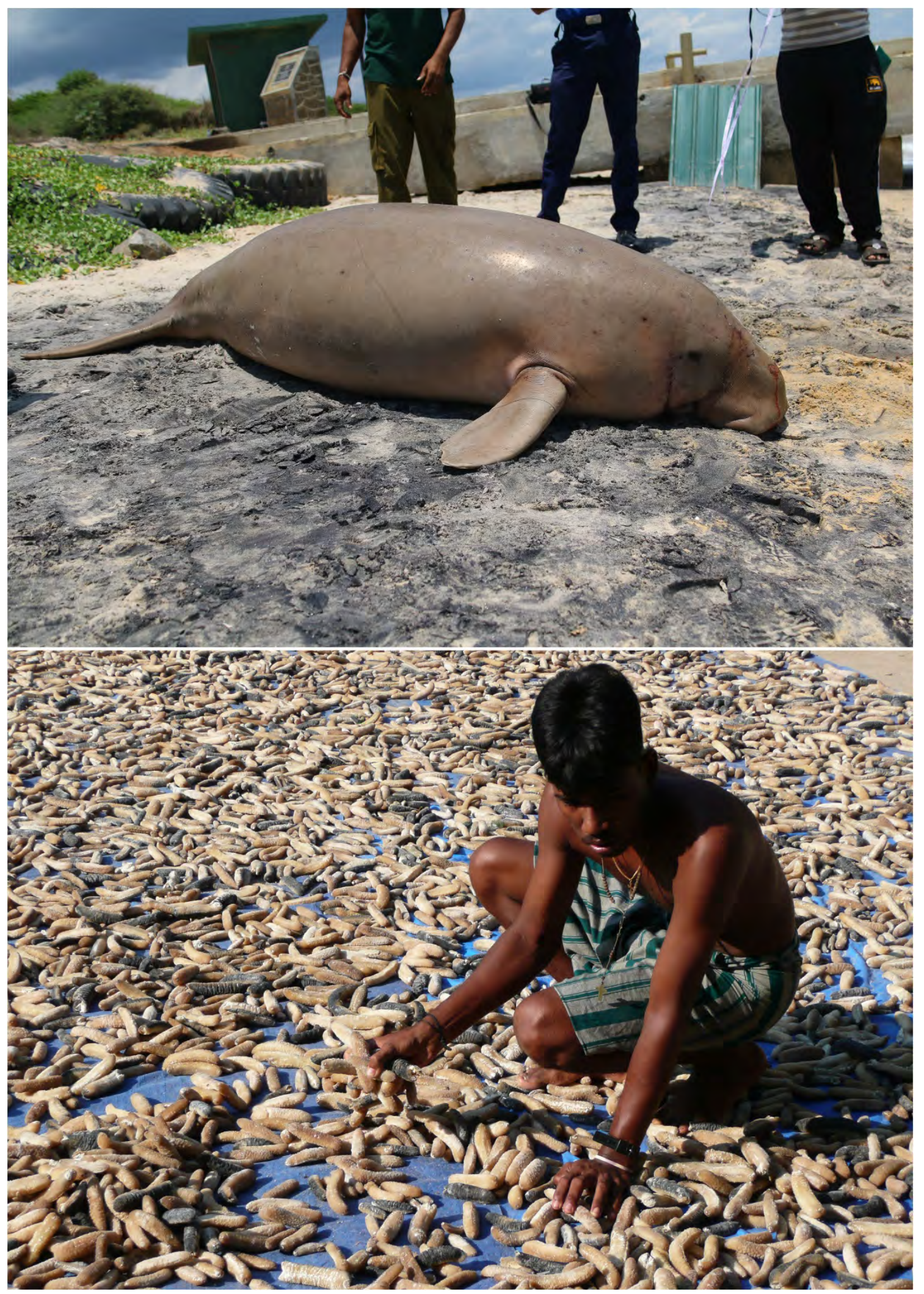

Figure 47. Top: killed dugong, caught off Battalangudu, photographed in Mollikulam; bottom: drying sea cucumbers, Pallimunai, Mannar

(Top: @ Sajith Subashana, Ocean Resources Conservation Association (ORCA); bottom: @ Terney Pradeep Kumara) 


\section{Pollution}

Pollution, in any form, degrades ecosystems and, often, affects species. Solid waste pollution is not only unsightly and detrimental to human health but is also damaging to ecosystems and species. Water pollution, from point and non-point sources, is a serious issue for most coastal ecosystems such as lagoons, and estuaries, as well as marine ecosystems, such as coral reefs and seagrass meadows (Joseph, 2004). Excessive use of agro-chemicals inland, is the cause of much of this pollution (Imbulana et al. 2006). In the southern areas of Sri Lanka, such pollution has been reported in many coastal areas as well as in inland water bodies (Imbulana et al., 2006).

\section{Solid waste pollution}

Solid waste pollution is an increasing threat to the biodiversity of the islands. Waste is dumped by roadsides, or on undeveloped or open land. Unplanned and ad hoc waste management also contributes to solid waste pollution.

In addition, this solid waste is often washed to the ocean and carried away by littoral drift, polluting coastal waters.

Apart from being aesthetically unpleasing, solid waste pollution has serious impacts on terrestrial biodiversity.

Firstly, ecosystems such as seagrasses are affected by solid waste pollution as seagrasses are smothered and unable to photosynthesise. This was observed in the Gulf of Mannar (Pradeep Kumara \& Udagedara, 2013).

Secondly, species - such as the iconic Delft ponies and dugongs, and other marine mammals - can die from eating plastic, as their bowels become impacted (that is, obstructed).

The CBD studied the impacts of marine debris on marine species and found that over half of these were entanglements or ingestion (CBD \& STAP, 2012). Their reports states that 'all known species of sea turtles, about half of all species of marine mammals, and one-fifth of all species of sea birds were affected by entanglement or ingestion of marine debris . . . that $15 \%$ of these species were on the IUCN Red List ${ }^{\mathrm{TM}}$ and . . . 80\% of these impacts were due to plastic' (CBD \& STAP, 2012).

Thirdly, hazardous chemical residues in dumped solid waste can leach into the soil and affect plant growth. Studies in other countries have shown decreased plant diversity in sites in which the soil is contaminated with heavy metals (Ali et al., 2014).

Solid waste has been observed in many places in the study area. During marine surveys, solid waste was observed in Valvettithurai, Point Pedro and Manatkadu and the Gulf of Mannar. 
Solid waste is being dumped in the coastal stretches from Pooneryn to Sangupiddy and Valvettithurai to Point Pedro, Mullaittivu, and Pudumathalan beach.

Waste is also being dumped on the banks of Thondaimanaru Lagoon, the banks of the Jaffna Lagoon near Vaddukkoddai, Arialai in Kayts and Mannar Island.

In Iranaitivu South, the beach was covered with waste originating elsewhere in the Palk Strait.

See photographs of solid waste pollution in Figure 48.

\section{Water and marine pollution}

Pollution in the coastal areas of Sri Lanka is high, given that there is a higher concentration of people living along the coast, as well as other development activities such as tourism and industries (CZMP, 2006, in litt. BOBLME, 2013). Faecal pollution, nutrients such as nitrogen and phosphorus, organic (non-toxic and toxic) and heavy metal pollution, oil pollution and thermal pollution and thermal pollution are all types of pollution that can affect coastal areas (CZMP, 2006, in litt. BOBLME, 2013).

A recent study of the Jaffna Lagoon shows that in the areas of Navanthurai, Pannai, Guru Nagar, Columbuthurai and Pasaiyur, there are increased phosphate levels and a high occurrence of Escherichia coli, indicating pollution from agrochemicals and dumping of sewage into the lagoon (MFF, 2015a).

Seagrasses are very sensitive to changes in the quality of water, particularly eutrophication resulting from nutrient loading (from fertilisers, animal and domestic waste) and sediments that settle and block sunlight and prevent photosynthesis. When polluted, seagrass meadows deteriorate quickly and die (Bjork et al., 2008, in litt. Miththapala, 2008a).

As with other marine mammals, whales and dolphins face a multitude of anthropogenic threats such as noise pollution in the sea - from ships, sonar and other human activities - which appear to disrupt whale and dolphin communication. In addition, these animals often swim in polluted - sometimes toxic - waters, and often accumulate these toxins into their bodies. Another major threat to cetaceans is accidental entrapment in fishing nets (WWF, 2017). 


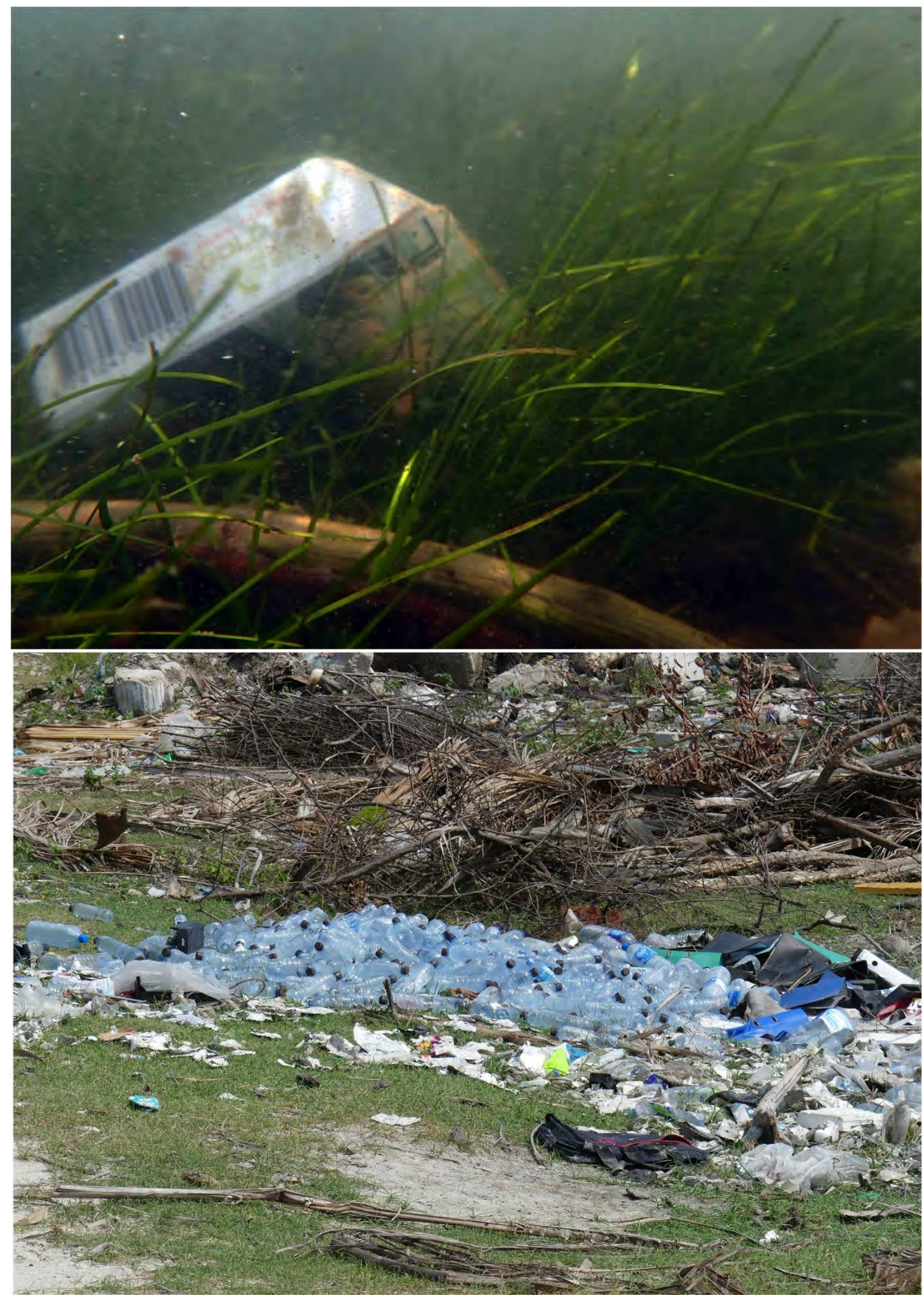

Figure 48. Top: solid waste pollution in seagrass meadows in the Gulf of Mannar; bottom: solid waste near Kora kulam, Mannar Island, where rare winter visitors are found

(Top: @ Susantha Udagedera: Bottom: @ Sriyanie Miththapala) 


\section{Invasive alien species}

Five species of invasive alien flora were observed in various locations as shown in Table 12.

Table 12. List of invasive alien flora found in the study area

\begin{tabular}{|c|c|c|c|c|c|c|c|}
\hline Family & $\begin{array}{c}\text { Scientific } \\
\text { name }\end{array}$ & $\begin{array}{c}\text { Common } \\
\text { name }\end{array}$ & $\begin{array}{c}\text { Sinhala } \\
\text { name }\end{array}$ & $\begin{array}{l}\text { Tamil } \\
\text { name }\end{array}$ & $\begin{array}{l}\text { Listed in } \\
\text { national } \\
\text { priorityl } \\
\text { potential } \\
\text { IAS list }^{10}\end{array}$ & $\begin{array}{c}\text { Listed in } \\
\text { Global } \\
\text { invasive } \\
\text { species } \\
\text { database } \\
11\end{array}$ & $\begin{array}{l}\text { Location } \\
\text { found }\end{array}$ \\
\hline Fabaceae & $\begin{array}{l}\text { Prosopis } \\
\text { juliflora }\end{array}$ & Mesquite & $\begin{array}{l}\text { Katu- } \\
\text { siyam- } \\
\text { bala/ } \\
\text { Kalapu } \\
\text { andara }\end{array}$ & $\begin{array}{l}\text { Valikka- } \\
\text { than }\end{array}$ & Priority IAS & Yes & Kayts \\
\hline Verbenaceae & $\begin{array}{l}\text { Lantana } \\
\text { camara }\end{array}$ & Lantana & $\begin{array}{l}\text { Gandap- } \\
\text { ana }\end{array}$ & $\begin{array}{l}\text { Arisima- } \\
\text { lar }\end{array}$ & Priority IAS & $\begin{array}{l}\text { Yes, and } \\
\text { also listed } \\
\text { in the } 100 \\
\text { worst IAS } \\
\text { of the } \\
\text { world }\end{array}$ & $\begin{array}{l}\text { Akkarai beach, } \\
\text { Delft, Karaitivu, } \\
\text { Kavutharimunai, } \\
\text { Kayts, } \\
\text { Mandaitivu, } \\
\text { Nanthi Kadal, } \\
\text { Valvettithurai }\end{array}$ \\
\hline Cactaceae & $\begin{array}{l}\text { Opuntia } \\
\text { dillenii }\end{array}$ & $\begin{array}{l}\text { Prickly } \\
\text { pear }\end{array}$ & $\begin{array}{l}\text { Katu- } \\
\text { pathok }\end{array}$ & Kalli & Priority IAS & $\begin{array}{l}\text { Yes, and } \\
\text { also listed } \\
\text { in the } 100 \\
\text { worst IAS } \\
\text { of the } \\
\text { world }\end{array}$ & $\begin{array}{l}\text { Analaitivu, } \\
\text { Chundikulam, } \\
\text { Delft, Eluvaitivu, } \\
\text { Erumaitivu, } \\
\text { Iranaitivu North, } \\
\text { Iranaitivu South, } \\
\text { Kakkativu, } \\
\text { Kalliaditivu, } \\
\text { Kayts, } \\
\text { Nainativu, } \\
\text { Nanthi Kadal, } \\
\text { Nayaru, } \\
\text { Palaitivu, and } \\
\text { Valvettithurai }\end{array}$ \\
\hline Asteraceae & $\begin{array}{l}\text { Mikania } \\
\text { cordata }\end{array}$ & $\begin{array}{l}\text { Mile-a- } \\
\text { minute }\end{array}$ & $\begin{array}{l}\text { Gam } \\
\text { palu, Ke- } \\
\text { hel palu }\end{array}$ & $\begin{array}{l}\text { Tuni- } \\
\text { kodi }\end{array}$ & $\begin{array}{l}\text { No, but is a } \\
\text { species of } \\
\text { concern see } \\
\text { next column }\end{array}$ & $\begin{array}{l}\text { Yes, and } \\
\text { also listed } \\
\text { in the } 100 \\
\text { worst IAS } \\
\text { of the } \\
\text { world }\end{array}$ & Nanthi Kadal \\
\hline Fabaceae & $\begin{array}{l}\text { Leucaena } \\
\text { leucoceph } \\
\text { ala }\end{array}$ & $\begin{array}{l}\text { Wild } \\
\text { tamarind/ } \\
\text { Ipil-Ipil }\end{array}$ & Ipil-Ipil & $\begin{array}{l}\text { Nat- } \\
\text { tucavund } \\
\text { al }\end{array}$ & Priority IAS & $\begin{array}{l}\text { Yes, and } \\
\text { also listed } \\
\text { in the } 100 \\
\text { worst IAS } \\
\text { of the } \\
\text { world }\end{array}$ & $\begin{array}{l}\text { Delft, Kakkativu, } \\
\text { Pungudutivu, } \\
\text { Valvettithurai }\end{array}$ \\
\hline
\end{tabular}

10 MoMD\&E, 2016b.

11 Lowe et al., 2004., GISD, 2005 
Tilapia (Oreochromis mosambicus), although used a common food fish to stock inland water bodies in Sri Lanka, is a known IAS in tropical countries and is listed as one of the 100 worst IAS of the world (Athauda, 2010). It is a superior competitor, a generalist in terms of environmental tolerance, an opportunistic omnivore that feeds on a wide range of faunal and flora species, breeds rapidly, and causes turbidity in water bodies as it digs up the substrate (Athauda, 2010). Tilapia was observed on Mandaitivu Island.

Feral dogs (Canis familiaris) are listed as potential IAS on the national list (MoMD\&E, 2016b). Feral dog populations were found on Iranaitivu North and South, Kakkativu, Karainagar, Kayts, Mandaitivu, Nainativu and in Mannar Island. Feral dogs are known to prey on wild species such as wild reptiles, birds and small mammals (Marambe et al., 2011) - and, therefore, are listed as potential IAS on the national list (MoMD\&E, 2016b). Therefore, they may negatively affect the local biodiversity of the islands. For example, feral dogs are found in Sand Bar IV, Adam's Bridge. If they spread to Sand Bar III, they can eat the eggs of breeding resident seabirds such as sooty tern (Onychoprion fuscatus), bridled tern (O. anaethetus), little tern (Sternula albifrons), common tern (S. hirundo) and greater crested tern (Thalasseus bergii), as well as the eggs of the rarer brown noddy (Anous stolidus), Saunders's tern ( $S$. saundersi), and roseate tern (Sterna dougallii) which nest there (Seneviratne et al.,2015) (Figure 50).

Feral cats, also on the list of potential IAS species (MoMD\&E, 2016ba), were found in Karainagar. Again, cats are very efficient predators and pose a serious threat to native wildlife (Marambe et al., 2011).

Several migrant birds, who breed in Sri Lanka as well as rare breeding residents are found on Mannar Island - for example, the gull-billed tern (Sterna nilotica), roseate tern (Sterna dougallii), bridled tern (Sterna anaethetus), Saunders's tern (Sterna saundersi), Caspian tern (Charadrius asiaticus) and the little tern (Sterna albifrons). The brown noddy (Anous stolidus), a rare migrant, was observed in Vidattaltivu. Many of these lay their eggs on the ground, and therefore, are highly vulnerable to predation by feral dogs. Figure 49 shows feral dogs in Sand Bar IV. If they spread to Sand Bar III, they can eat the eggs of rare breeding residents.

\section{Climate change}

Climate change is an overarching anthropogenic driver of ecosystem change that has synergistic effects on all other drivers of change (MoMD\&E, 2016a). The impacts of climate change on coastal areas and ecosystems of Sri Lanka will be significant and will include sea level rise, salt water intrusion, changes in rainfall patterns and temperature, increasing ocean acidity and changes in the frequency and severity of extreme weather events (MoMD\&E, 2016a).

\section{Sea level rise}

Figure 51 shows the impacts of sea level rise on the coastline and islands of the Northern Province. Figure 51 shows that several areas - such as Periya Kalapu and Vankalai Lagoon, Palaitivu, Parititivu, part of the Chundikulam Lagoon and a part of coastline could be inundated by 2025. 
Accompanying sea level rise and coastal inundation is saltwater intrusion. This will alter the salinity regimen in coastal ecosystems such as mangroves, salt marshes, tidal flats, lagoons and estuaries, which will, in turn, change species composition in these ecosystems, favouring more salt-tolerant species. Given that several of these ecosystems have within them, commercially important fin and shell fish, such changes will have profound negative consequences, as the freshwater from the land will not flow freely into the sea and pools of brackish and fresh water will remain as ideal grounds for the breeding of mosquitoes.

\section{El Niño}

Another major impact of climate change is the worsening of the effects of El Niño and La Niña episodes. See Box 4 for a description.

\section{Box 4. What is El Niño?}

El Niño is Spanish for 'the little boy', referring to the Christ child, because this event is noticed usually around Christmas time. It is a fluctuation of the ocean-atmosphere system in the tropical Pacific Ocean that is important for the world's climate. In normal, non-El Niño conditions, trade winds (prevailing tropical winds) blow towards the west across the tropical Pacific, piling up warm surface water in the west Pacific, so that the sea surface is about $0.5 \mathrm{~m}$ higher in height and $8^{\circ} \mathrm{C}$ warmer at Indonesia than at Ecuador. The waters off South America are cool because of an upwelling from the deep (called the Humboldt current) and are nutrient-rich, with high marine primary productivity which supports fisheries.

During El Niño, the air pressure over the Indian Ocean, Indonesia, and Australia rises, but drops over Tahiti and the rest of the central and eastern Pacific Ocean. The trade winds in the South Pacific weaken. Warm air rises near Peru causing rain in its deserts, while warm water spreads from the West Pacific and Indian Ocean to the East Pacific Ocean. When it spreads, it takes the rain with it, causing rainfall in normally dry areas and drought in normally wet areas. El Niño also results in less upwelling of the Humboldt current, less nutrients, warmer sea surface temperatures $\left(+0.5^{\circ} \mathrm{C}\right)$ and decreased marine primary production along the west coast of South America.

La Niña means 'the little girl' in Spanish, meant to reflect that its effects are the opposite to that of El Niño. Here, the result is a lowering of sea surface temperatures by about $0.5^{\circ} \mathrm{C}$. It usually follows an El Niño event.

Together El Niño and La Niña are known as the El Niño-Southern Oscillation (ENSO) cycle. Thus, ENSO is an irregular, periodic variation of the winds and sea surface temperatures, where, together, El Niño is the warming phase and La Niña is the cooling phase.

(Source: NOAA, 2008 in litt. Miththapala 2008, extracted directly) 

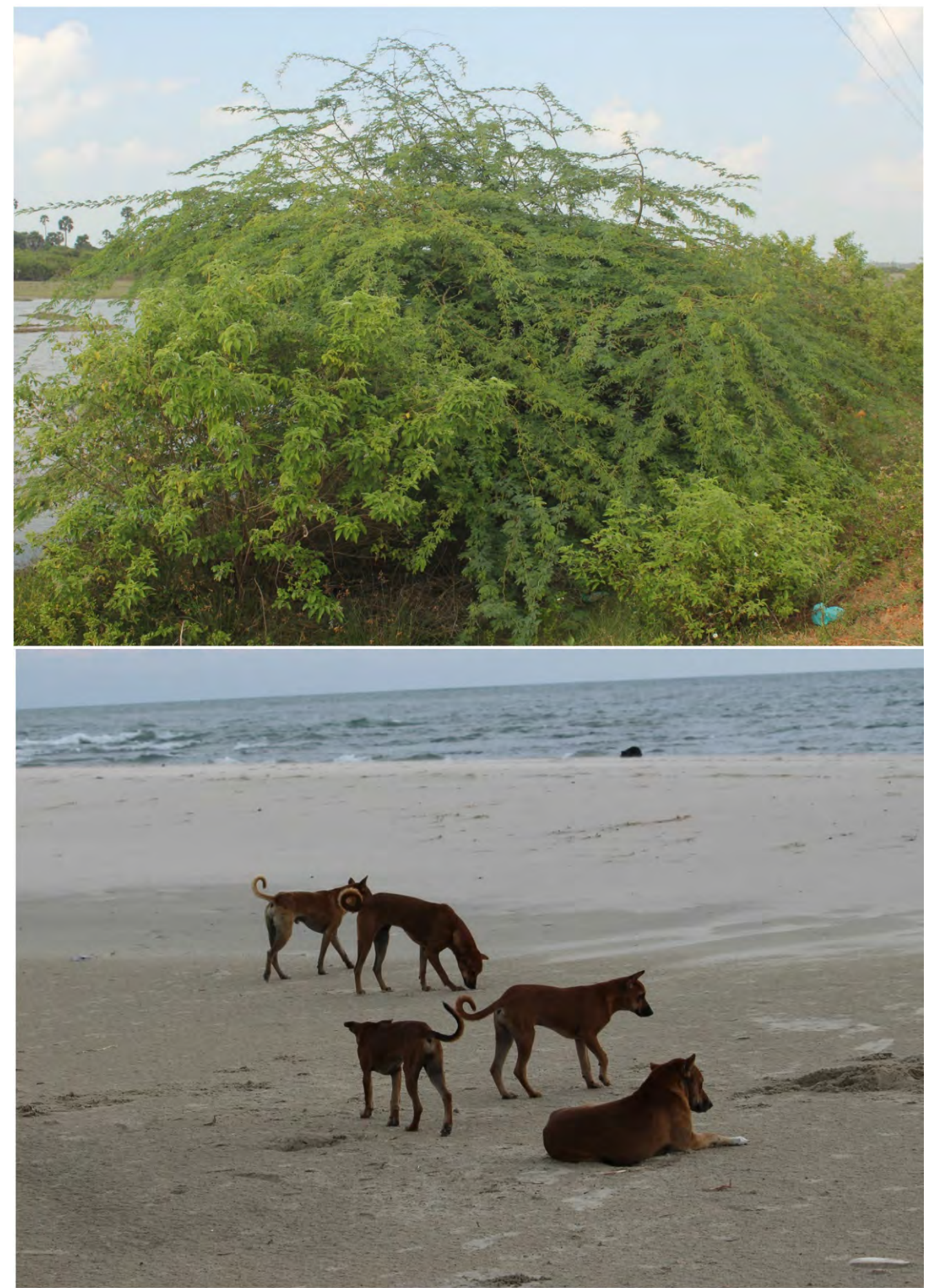

Figure 49. Top: mesquite (Prosopis juliflora) growing in Vankalai Sanctuary; bottom: feral dogs (Canis familiaris), Sand Bar IV

(Top: ๑ IUCN/Naalin Perera; Bottom: @ IUCN/Sampath de A. Goonatilake) 

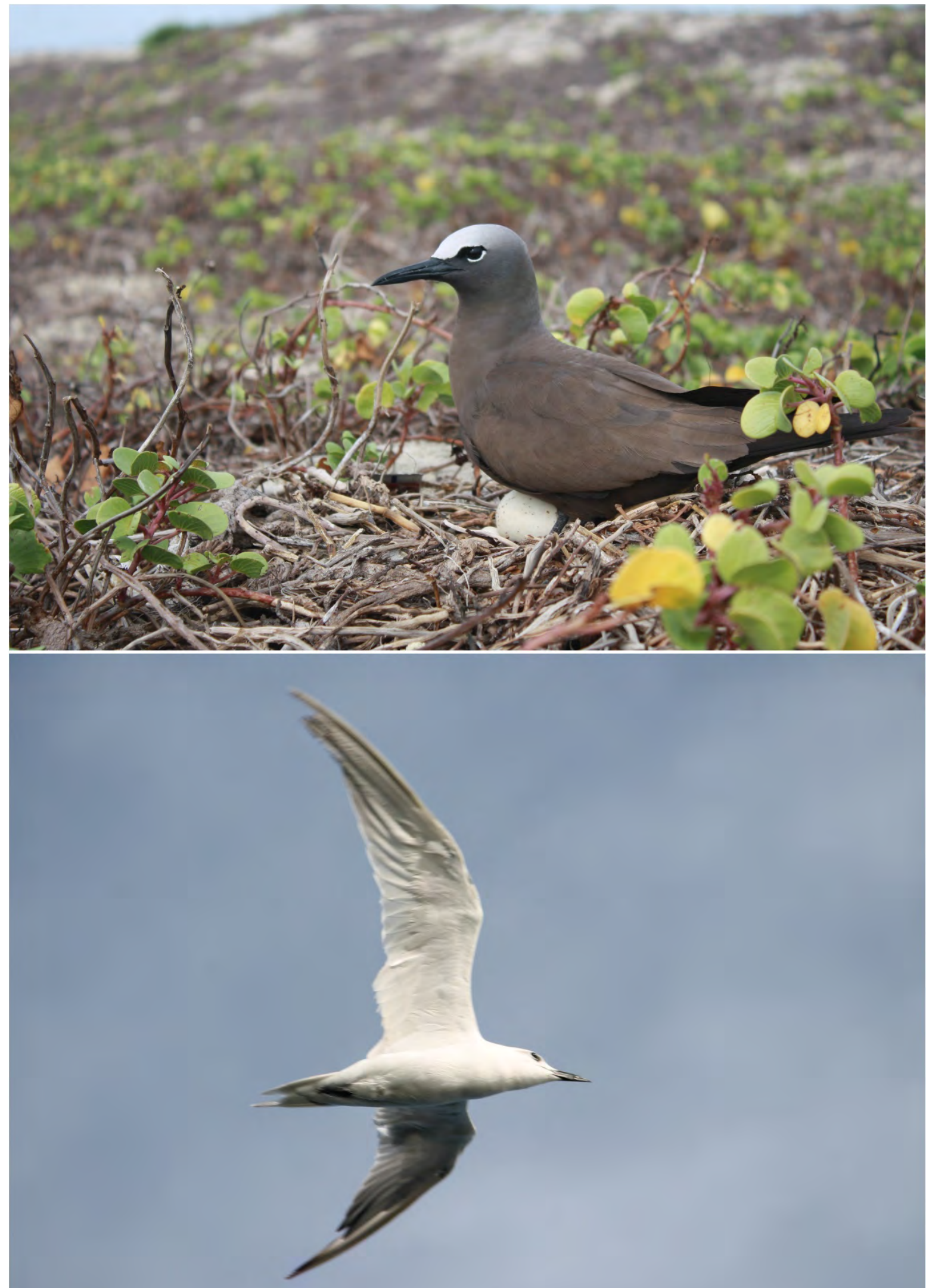

Figure 50. Top: a nesting brown noddy (Anous stolidus) on Sand Bar Island III; bottom: gull-billed tern (Sterna nilotica) in Iranaitivu, both rare breeding residents (Top: @ Sampath Seneviratne; bottom @ IUCN/ Sampath de A. Goonatillake) 


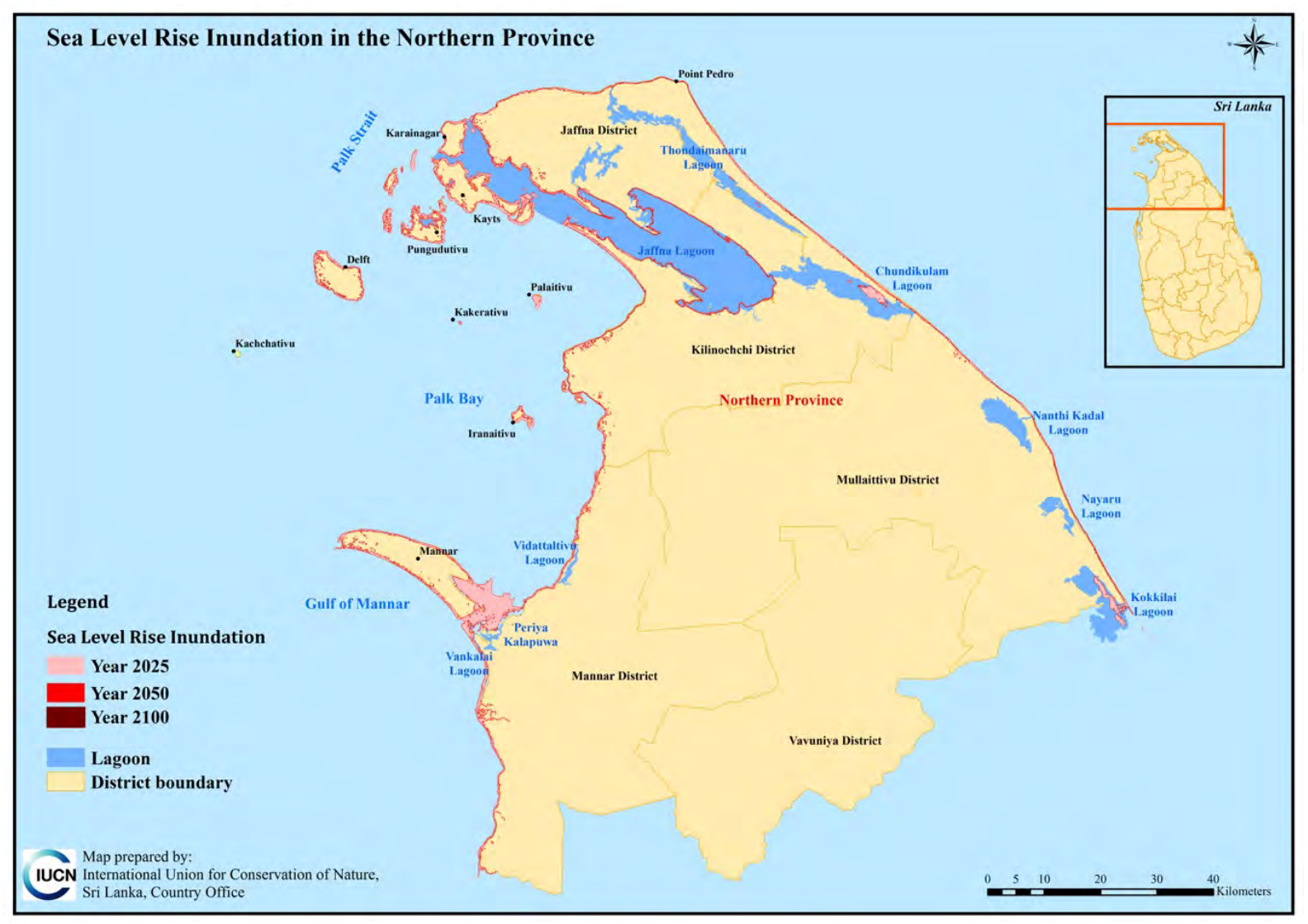

Figure 51. Predicted sea level rise in northern Sri Lanka

(Source: DMC, 2012. IPCC 2007 temperature predictions for the B2 scenario and elevation data from the Improved Advanced Space borne Thermal Emission and Reflection Radiometer (ASTER) were processed in a GIS system using 1984 WGS datum to estimate the sea level rise in 2025, 2050 and 2100 years. Respective coastal inundations were estimated using the Bruun rule using estimated sea level rise.)

\section{Coral bleaching}

Reef-building corals (hermatypic corals) obtain their food from one-celled organisms called zooxanthellae. Zooxanthellae are single-celled organisms that use sunlight for photosynthesis and transfer $95 \%$ of the food they produce to coral polyps. Both coral and the zooxanthellae benefit from this association (a mutualistic association). Because of this association with zooxanthellae that need sunlight to produce food, hermatypic corals are dependent on sunlight and only grow in clear shallow waters less than $60 \mathrm{~m}$ deep, which have a temperature range between $25^{\circ}$ and $30^{\circ} \mathrm{C}$.

Because reef building coral species can live only within a small temperature range, even a tiny change in temperature causes seriously detrimental effects, as exemplified by the widescale coral bleaching of 1998 and 2015-2016, because of an El Niño event. When hermatypic corals are stressed - such as with an increase in temperature - the critical balance that maintains their mutualistic relationship with zooxanthellae is lost. The coral may lose some or most of their zooxanthellae, a major source of nutrition and colour. In this condition, corals are referred to as 'bleached.' In some species, even their life cycles are disrupted.

Bleached coral reefs were observed in Mandaitivu. 
Coral reef ecosystems are important in fisheries, providing about a quarter of the total fisheries catch as providing food for about one billion people in Asia alone (Moore and Best, 2001). They are also a source for medicines. Already, extracts from coral reef organisms are being used in treatments for diseases like cancer and HIV (WWF, 2017). In Sri Lanka, beaches and nature were considered the most 'outstanding attractions' for tourists (SLTDA, 2017a). Coral reefs form natural physical barriers that protect shorelines from the impacts of extreme weather event, the eroding forces of the sea. It is estimated that more than $150,000 \mathrm{~km}$ of shoreline in 100 countries and territories receive some physical protection from reefs (Burke et al., 2011). When corals are bleached, these services are foregone.

\section{Loss of carbon sequestration}

Carbon sequestration is the process by which plant life removes carbon dioxide $\left(\mathrm{CO}_{2}\right)$ from the atmosphere and stores it as biomass. Plants and oceans are, therefore, called carbon sinks. Coastal ecosystems — such as mangroves, seagrasses and tidal flats - are carbon sinks. (See Box 5 for a description.)

\section{Box 5. The importance of coastal ecosystems in carbon sequestration}

- Perera et al. (2012, in litt. MoMd\&E, 2016b) estimated that mangroves in the estuaries of Kala Oya, Malwatu Oya and the Batticaloa Lagoon have carbon stocks of 204, 165 and 150 t/ha respectively.

- There are no studies of carbon sequestration in seagrass meadows in Sri Lanka, but globally, it has been estimated that seagrass ecosystems could store as much as 4.2-8.4 19.9 petagrammes of organic carbon (Fourqurean et al., 2012). At the present rate of loss of seagrasses, the destruction of these ecosystems could release up to 299 teragrammes of carbon per year (Fourqurean et al., 2012).

- A striking difference among carbon sequestration in coastal, marine and terrestrial ecosystems is the capacity in coastal ecosystems to store, for a very long period of time, carbon in their sediments. It has been estimated that the amount of carbon sequestered in the sediments of many coastal ecosystems is as much as 50 times higher than the carbon stored in land sinks (Pidgeon, undated).

When coastal ecosystems are destroyed (See Chapter 5), this supporting ecosystem service provided by these ecosystems is lost.

\section{Other impacts of climate change}

The impacts of climate change on other ecosystems is summarised in Table 13.

Table 13. Impact of climate change on ecosystems

(Source: MoMD\&E, 2016a, extracted from Miththapala, 2008a, 2008b, 2008c, 2008d, 2013a and 2013b)

\begin{tabular}{l|l|l}
\hline $\begin{array}{c}\text { Effect of climate } \\
\text { change }\end{array}$ & Ecosystem & \multicolumn{1}{c}{ Impact on ecosystem } \\
\hline $\begin{array}{l}\text { Ocean } \\
\text { acidification }\end{array}$ & $\begin{array}{l}\text { There could be profound changes in marine food webs, affecting } \\
\text { food security - such as slowing down of calcification critical for } \\
\text { coral reefs }\end{array}$ & $\begin{array}{l}\text { coral growth, coral bleaching; ocean acidity is corrosive to marine } \\
\text { shelled organisms. }\end{array}$
\end{tabular}




\begin{tabular}{|c|c|c|}
\hline $\begin{array}{l}\text { Effect of climate } \\
\text { change }\end{array}$ & Ecosystem & Impact on ecosystem \\
\hline & & This will worsen the impact of other effects such as temperature. \\
\hline $\begin{array}{l}\text { Changes in } \\
\text { ocean wave } \\
\text { currents }\end{array}$ & $\begin{array}{l}\text { Open ocean, } \\
\text { coral reefs, } \\
\text { seagrasses } \\
\text { beaches, } \\
\text { mangroves, } \\
\text { tidal flats }\end{array}$ & $\begin{array}{l}\text { There can be profound changes in marine food webs, affecting } \\
\text { food security; hypoxic zones form; there is nutrient mixing } \\
\text { including upwelling of nutrients from deep waters. } \\
\text { Beaches, tidal flats and mangroves will also be affected, as } \\
\text { erosion and accretion patterns will change due to shifts in the } \\
\text { transport of sand and sediment on the ocean floor, particularly in } \\
\text { nearshore areas. This means current models predicting the } \\
\text { movement of sand and erosion/accretion may no longer be valid. }\end{array}$ \\
\hline $\begin{array}{l}\text { Changes in } \\
\text { rainfall patterns }\end{array}$ & $\begin{array}{l}\text { Mangroves, } \\
\text { terrestrial } \\
\text { forests, } \\
\text { grasslands, } \\
\text { villus, } \\
\text { lagoons, } \\
\text { estuaries, } \\
\text { rivers and } \\
\text { streams }\end{array}$ & $\begin{array}{l}\text { Causes changes in species composition in mangroves, terrestrial } \\
\text { forests, grasslands; land degradation due to erosion; results in } \\
\text { increasing landslides; affects soil formation and soil quality; } \\
\text { causes changes in the soil-water environment. } \\
\text { Changes in rainfall will affect inflow (either an increase or } \\
\text { decrease) into floodplains, villus, lagoons, estuaries, rivers and } \\
\text { streams, changing their natural hydrological patterns. }\end{array}$ \\
\hline $\begin{array}{l}\text { Changes in } \\
\text { temperature on } \\
\text { land }\end{array}$ & $\begin{array}{l}\text { Terrestrial } \\
\text { ecosystems } \\
\text { will be } \\
\text { affected. }\end{array}$ & $\begin{array}{l}\text { Changes in species composition because of changes in } \\
\text { photosynthesis and other biological reactions; decrease in } \\
\text { species populations due to disruption of life cycles and change in } \\
\text { behavioural patterns; heat waves and related impacts; fires; } \\
\text { changes in oxygen balance. } \\
\text { Evaporation will increase in aquatic systems such as rivers, } \\
\text { reservoirs, lagoons and estuaries. In coastal brackish-water } \\
\text { systems, salinity could increase. } \\
\text { Changes in wave currents, drying up of waterways, steams, } \\
\text { changes to biodiversity and established food webs. Economic } \\
\text { impacts can be serious, as people's livelihoods may change. }\end{array}$ \\
\hline $\begin{array}{l}\text { Changes in } \\
\text { ocean } \\
\text { temperature }\end{array}$ & $\begin{array}{l}\text { Coral reefs } \\
\text { (El Niño } \\
\text { events) } \\
\text { Open ocean } \\
\text { Seagrasses }\end{array}$ & $\begin{array}{l}\text { Coral bleaching, damaging whole ecosystems including } \\
\text { seagrasses, } \\
\text { Changes in ocean oxygen levels, wave currents, nutrient cycling } \\
\text { Ocean stratification resulting in phytoplankton booms and } \\
\text { reduction in productivity. } \\
\text { Higher water temperatures will affect directly growth, reproduction } \\
\text { and general metabolism of seagrasses (Short and Neckles, 1999; } \\
\text { Bjork et al., } 2008 \text { both in litt. Miththapala 2008a). }\end{array}$ \\
\hline $\begin{array}{l}\text { Increase in } \\
\text { extreme weather } \\
\text { events (such as } \\
\text { tropical cyclones, } \\
\text { droughts, flash } \\
\text { floods, } \\
\text { landslides, forest } \\
\text { fires, and heat } \\
\text { waves) }\end{array}$ & $\begin{array}{l}\text { All } \\
\text { ecosystems }\end{array}$ & $\begin{array}{l}\text { Physical damage and increased erosion in coastal ecosystems; } \\
\text { salinity increase in coastal ecosystems and paddy fields; habitat } \\
\text { loss and decrease in species populations. }\end{array}$ \\
\hline
\end{tabular}




\section{Chapter 6. Recommendations for the sustainable management of natural resources and the conservation of biodiversity of the study area}

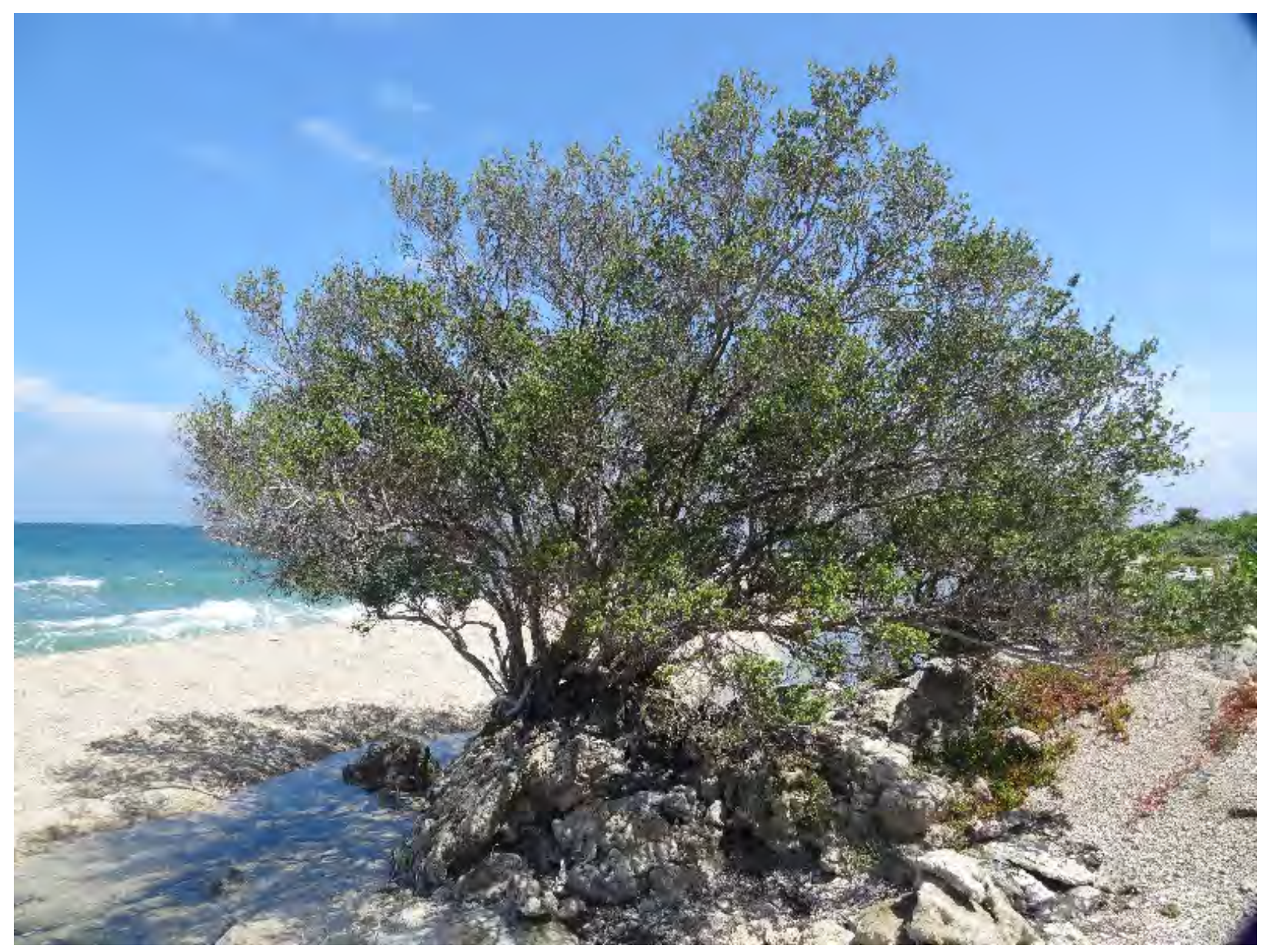

Kachchatiivu Island @ IUCN/Arjan Rajasuriya 
Current development activities in the northern regions are often being carried without the inclusion of environmental safeguards that protect ecosystems and the services they provide to humans. It is essential that development is made sustainable through the inclusion of such safeguards, in a planned and integrated manner, and that it uses multi-sectoral collaboration.

\section{Recommendation 1: conserve natural ecosystems}

Based on this study, it is strongly recommended that certain areas be set aside as conservation areas. These are shown in the figure below and presented in detail in Annex 1.

The coastal islands of the northern region - except for a few large islands such as Delft have not been studied previously. The conservation areas proposed in this study are based on additional information gathered during the study, and the conservation value of the area. The justification for these additional conservation areas are presented in Table 14.

However, the second recommendation in this report (see below) is that further detailed studies should be undertaken so that exact boundaries can be demarcated based on their conservation value, as well as impact on local livelihoods on such a declaration and ownership of the land. This will ensure that declaration will have minimum social impacts.

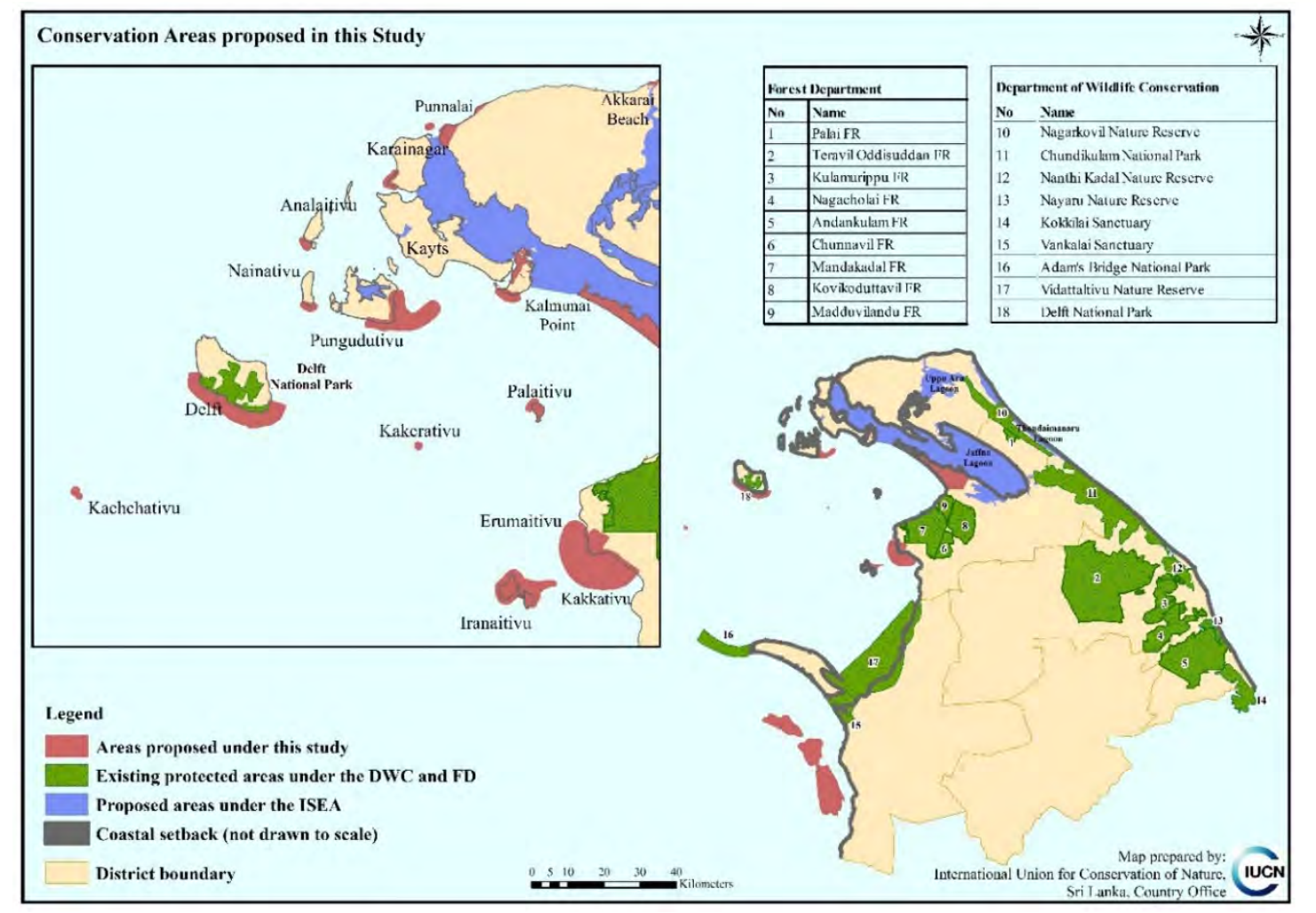

Figure 52. Map of existing conservation areas, areas proposed under the ISEA and areas proposed under this study 
Table 14. Areas proposed in this study as conservation areas, justification for their conservation and ranked priorities for action

(1=very high priority; $2=$ high priority; 3 =medium priority; 4=low priority)

\begin{tabular}{|c|c|c|c|c|c|}
\hline Island & Terrestrial & $\begin{array}{l}\text { Coastal } \\
\text { and } \\
\text { Marine }\end{array}$ & Area & Justification & Rank \\
\hline Analaitivu & & $\sqrt{ }$ & $\begin{array}{l}\text { Small fringing } \\
\text { coral reef along } \\
\text { the western and } \\
\text { south-western } \\
\text { sides }\end{array}$ & $\begin{array}{l}\text { Small reef area with } \\
\text { massive corals, mainly } \\
\text { species belonging to } \\
\text { the genera Porites, } \\
\text { Goniastrea, Favia and } \\
\text { Favites (marine } \\
\text { diversity is high). } \\
\text { Provisioning } \\
\text { (important for fisheries } \\
\text { productivity) and } \\
\text { protective services to } \\
\text { the island. }\end{array}$ & 3 \\
\hline $\begin{array}{l}\text { Erumaitivu } \\
\text { and } \\
\text { Kakkativu } \\
\text { Islands }\end{array}$ & & $\sqrt{ }$ & $\begin{array}{l}\text { Coral reef along } \\
\text { the western side } \\
\text { of the islands of } \\
\text { Erumaitivu and } \\
\text { Kakkativu. } \\
\text { Seagrass on the } \\
\text { eastern side of the } \\
\text { islands between } \\
\text { the mainland and } \\
\text { islands. }\end{array}$ & $\begin{array}{l}\text { Erumaitivu has the } \\
\text { best coral reef in the } \\
\text { Palk Bay. Provisioning } \\
\text { (fisheries productivity } \\
\text { from coral reefs and } \\
\text { seagrasses) and } \\
\text { protective services, as } \\
\text { well as aesthetic } \\
\text { appeal. }\end{array}$ & 1 \\
\hline $\begin{array}{l}\text { Iranaitivu } \\
\text { North and } \\
\text { Iranaitivu } \\
\text { South } \\
\text { Islands }\end{array}$ & & $\sqrt{ }$ & $\begin{array}{l}\text { Area north, west, } \\
\text { and north-west of } \\
\text { the island. } \\
\text { Seagrasses on the } \\
\text { western side of } \\
\text { the island }\end{array}$ & $\begin{array}{l}\text { Coral reefs and } \\
\text { seagrass meadows. } \\
\text { Provisioning } \\
\text { (important for fisheries } \\
\text { productivity) and } \\
\text { protective services to } \\
\text { the islands, as well as } \\
\text { aesthetic appeal. }\end{array}$ & 1 \\
\hline Kachchativu & & $\sqrt{ }$ & $\begin{array}{l}\text { Coral reefs on the } \\
\text { northern side. } \\
\text { Other reef habitats } \\
\text { are in poor } \\
\text { condition }\end{array}$ & $\begin{array}{l}\text { Coral reefs and whole } \\
\text { island, because of } \\
\text { threatened flora } \\
\text { present. But there is a } \\
\text { need to zone the } \\
\text { island for different } \\
\text { activities (for example, } \\
\text { for visitation by } \\
\text { pilgrims). Provisioning } \\
\text { and protective } \\
\text { services to the island } \\
\text { as well as aesthetic } \\
\text { appeal }\end{array}$ & 1 \\
\hline Kakerativu & & $\sqrt{ }$ & $\begin{array}{l}\text { Coral reefs to the } \\
\text { north and north- } \\
\text { west of the island }\end{array}$ & $\begin{array}{l}\text { Along with Erumaitivu } \\
\text { for its coral reef. See a } \\
\text { under Erumaitivu. }\end{array}$ & 2 \\
\hline Karaitivu & & $\sqrt{ }$ & $\begin{array}{l}\text { Coral reefs to the } \\
\text { south-west of the } \\
\text { island }\end{array}$ & $\begin{array}{l}\text { A fringing reef with } \\
\text { large coral domes, } \\
\text { high marine diversity. } \\
\text { Provisioning } \\
\text { (important for fisheries }\end{array}$ & 2 \\
\hline
\end{tabular}




\begin{tabular}{|c|c|c|c|c|c|}
\hline Island & Terrestrial & $\begin{array}{l}\text { Coastal } \\
\text { and } \\
\text { Marine }\end{array}$ & Area & Justification & Rank \\
\hline & & & & $\begin{array}{l}\text { productivity) and } \\
\text { protective services to } \\
\text { the island as well as } \\
\text { aesthetic appeal. }\end{array}$ & \\
\hline Mandaitivu & $\sqrt{ }$ & $\sqrt{ }$ & $\begin{array}{l}\text { Much of the } \\
\text { coastline } \\
\text { containing rich } \\
\text { mangroves and } \\
\text { salt marshes and } \\
\text { a small marine } \\
\text { area with coral } \\
\text { reef in the south } \\
\text { and south-west of } \\
\text { the island }\end{array}$ & $\begin{array}{l}\text { It is already an } \\
\text { Important Bird Area } \\
\text { along with Kayts. } \\
\text { Important for migratory } \\
\text { birds. Important for } \\
\text { fisheries productivity } \\
\text { and marine } \\
\text { biodiversity. }\end{array}$ & 1 \\
\hline Nainativu & & $\sqrt{ }$ & $\begin{array}{l}\text { Fringing coral } \\
\text { reefs around the } \\
\text { island with the } \\
\text { best coral area in } \\
\text { the south of the } \\
\text { island }\end{array}$ & $\begin{array}{l}\text { Presence of a fringing } \\
\text { reef. Provisioning } \\
\text { (important for fisheries } \\
\text { productivity) and } \\
\text { protective services to } \\
\text { the island as well as } \\
\text { aesthetic appeal. }\end{array}$ & 3 \\
\hline Neduntivu & & $\sqrt{ }$ & $\begin{array}{l}\text { Fringing coral reef } \\
\text { around the island, } \\
\text { The marine area } \\
\text { adjacent to the } \\
\text { National Park is } \\
\text { included in the } \\
\text { MPA }\end{array}$ & $\begin{array}{l}\text { For prevention of } \\
\text { erosion of the } \\
\text { coastline. Important } \\
\text { for fisheries } \\
\text { productivity and } \\
\text { marine biodiversity }\end{array}$ & 2 \\
\hline Palaitivu & $\sqrt{ }$ & $\sqrt{ }$ & $\begin{array}{l}\text { The entire island, } \\
\text { as well as a small } \\
\text { north-western part } \\
\text { of the marine area }\end{array}$ & $\begin{array}{l}\text { High ecosystem and } \\
\text { species diversity, this } \\
\text { island also has } \\
\text { aesthetic and scenic } \\
\text { value }\end{array}$ & 1 \\
\hline $\begin{array}{l}\text { Ponneryn } \\
\text { Peninsula }\end{array}$ & $\sqrt{ }$ & & $\begin{array}{l}\text { Much of the } \\
\text { peninsula which } \\
\text { has sand dunes } \\
\text { and other sand } \\
\text { dune related } \\
\text { ecosystems }\end{array}$ & $\begin{array}{l}\text { Large sand dunes, } \\
\text { only area with mature } \\
\text { Pandanus along the } \\
\text { western coast. Unique } \\
\text { ecosystem with dune } \\
\text { forests, protection for } \\
\text { the Jaffna Lagoon }\end{array}$ & 1 \\
\hline $\begin{array}{l}\text { Punnalai } \\
\text { Khadu }\end{array}$ & $\sqrt{ }$ & & $\begin{array}{l}\text { The headland and } \\
\text { a small strip }\end{array}$ & $\begin{array}{l}\text { Salt marshes, } \\
\text { important for water } \\
\text { birds }\end{array}$ & 2 \\
\hline
\end{tabular}

It should be noted that although the historical custodians of the island's biodiversity have been the Department of Wildlife Conservation (DWC) and Forest Department (FD), the Central Environmental Authority (CEA), Coast Conservation and Coastal Resource Management Department (CC\&CRMD) and the Department of Fisheries and Aquatic Resources (DFAR) also have areas where sustainable management of the use of natural resources is practised (MoMD\&E, 2016a). A diagram showing these different managed areas is presented in Figure 53. 


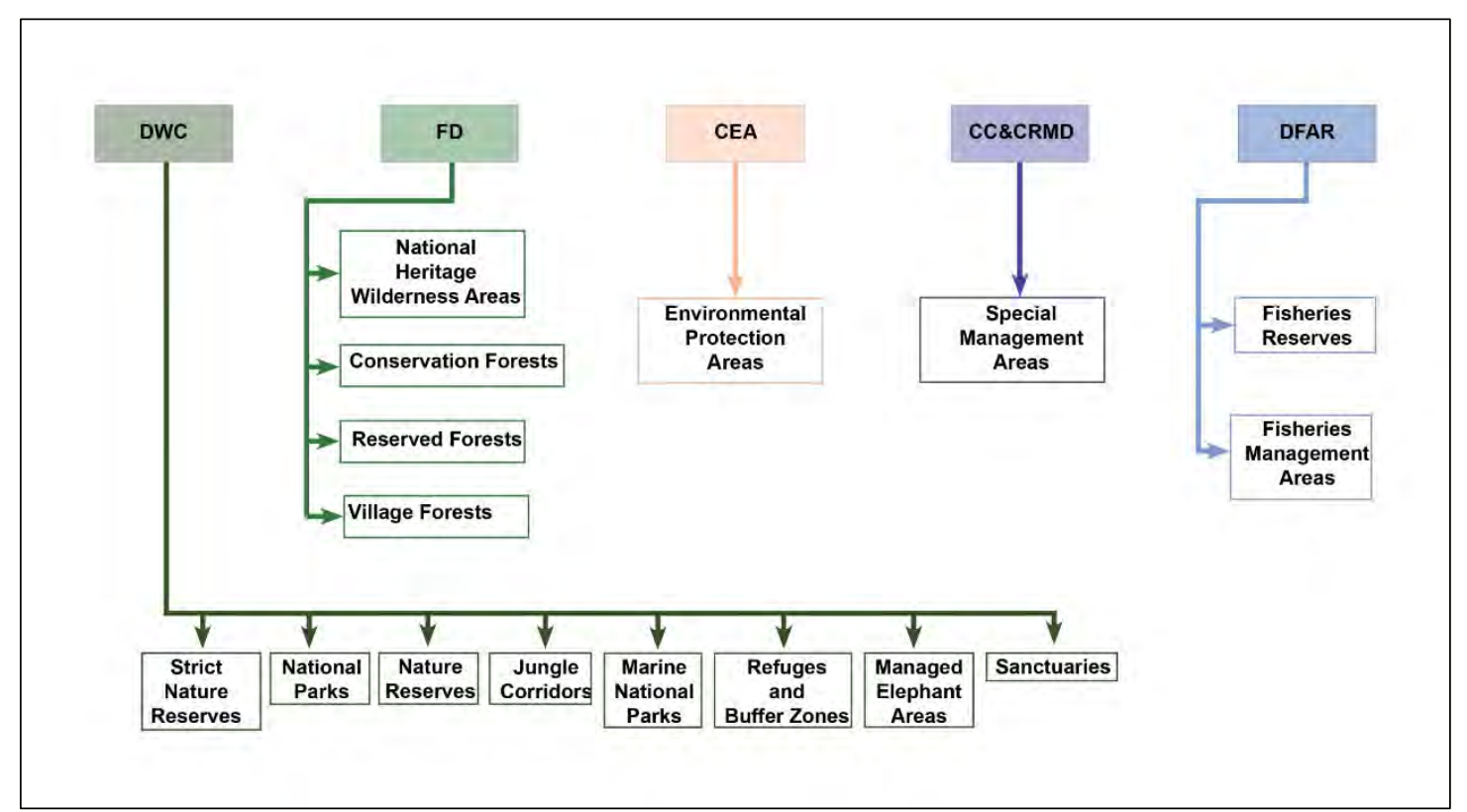

Figure 53. Diagram showing the different organisations and the different categories of areas managed for the conservation of natural resources

Each of these areas has a different level of protection, and activities which are prohibited within. (See Table 14.)

Table 15.Types of areas managed for conservation and brief details

(Source: MoMD\&E, 2016a, Blackhall Publishing, 2014)

\begin{tabular}{|c|c|c|c|}
\hline $\begin{array}{l}\text { Type of } \\
\text { managed area } \\
\text { (number in } \\
\text { parentheses) }\end{array}$ & $\begin{array}{l}\text { Level of } \\
\text { protection } \\
\text { afforded }\end{array}$ & Permitted activities & $\begin{array}{c}\text { Land } \\
\text { ownership }\end{array}$ \\
\hline \multicolumn{4}{|c|}{ Under the jurisdiction of the DWC } \\
\hline $\begin{array}{l}\text { Strict Nature } \\
\text { Reserve (SNR) }\end{array}$ & $\begin{array}{l}\text { Highest } \\
\text { possible }\end{array}$ & $\begin{array}{l}\text { Entry and development activities are } \\
\text { prohibited. Construction within one-mile radius } \\
\text { of a SNR needs permission from the } \\
\text { Department of Wildlife Conservation. }\end{array}$ & State land \\
\hline Nature Reserve & High & $\begin{array}{l}\text { No person shall enter or remain within any } \\
\text { nature reserve except under the authority and } \\
\text { in accordance with the condition of a permit } \\
\text { issued by the prescribed officer on payment of } \\
\text { the prescribed fee. Entry and development } \\
\text { activities are prohibited. Construction within } \\
\text { one-mile radius of a national reserve needs } \\
\text { permission from the Department of Wildlife } \\
\text { Conservation. However, traditional practices } \\
\text { situated within the limits of any national reserve } \\
\text { or state land in any sanctuary, if being } \\
\text { practised before the declaration of such } \\
\text { protected area, are permitted to continue. }\end{array}$ & State land \\
\hline National Park & $\begin{array}{l}\text { High, entry } \\
\text { only by } \\
\text { permit and }\end{array}$ & $\begin{array}{l}\text { Entry is only by permit and fee as well as under } \\
\text { regulated conditions for the specific purpose of } \\
\text { viewing wildlife. Development activities are }\end{array}$ & State land \\
\hline
\end{tabular}




\begin{tabular}{|c|c|c|c|}
\hline $\begin{array}{c}\text { Type of } \\
\text { managed area } \\
\text { (number in } \\
\text { parentheses) }\end{array}$ & $\begin{array}{l}\text { Level of } \\
\text { protection } \\
\text { afforded }\end{array}$ & Permitted activities & $\begin{array}{l}\text { Land } \\
\text { ownership }\end{array}$ \\
\hline & $\begin{array}{l}\text { designated } \\
\text { area for } \\
\text { disembarking }\end{array}$ & $\begin{array}{l}\text { prohibited here. Construction within one-mile } \\
\text { radius of a national park needs permission } \\
\text { from the Department of Wildlife Conservation } \\
\text { However, traditional practices situated within } \\
\text { the limits of any national reserve or state land } \\
\text { in any sanctuary, if being practised before the } \\
\text { declaration of such protected area, are } \\
\text { permitted to continue. }\end{array}$ & \\
\hline Jungle corridor & High & $\begin{array}{l}\text { Development activities are prohibited here. } \\
\text { Construction within one-mile radius of a jungle } \\
\text { corridor needs permission from the Department } \\
\text { of Wildlife Conservation. However, traditional } \\
\text { practices situated within the limits of any } \\
\text { national reserve or state land in any sanctuary, } \\
\text { if being practised before the declaration of } \\
\text { such protected area, are permitted to continue. }\end{array}$ & State land \\
\hline $\begin{array}{l}\text { Marine National } \\
\text { Park }\end{array}$ & High & $\begin{array}{l}\text { Entry is only by permit and under regulated } \\
\text { conditions for the specific purpose of viewing } \\
\text { wildlife. Development activities are prohibited } \\
\text { here. Construction within one-mile radius of a } \\
\text { national park needs permission from the } \\
\text { Department of Wildlife Conservation. However, } \\
\text { traditional practices situated within the limits of } \\
\text { any national reserve or state land in any } \\
\text { sanctuary, if being practised before the } \\
\text { declaration of such protected area, are } \\
\text { permitted to continue. }\end{array}$ & State-owned \\
\hline $\begin{array}{l}\text { Refuges and } \\
\text { Buffer zones (not } \\
\text { yet declared) }\end{array}$ & High & $\begin{array}{l}\text { Development activities are prohibited here. } \\
\text { Construction within one-mile radius of a nature } \\
\text { reserve needs permission from the Department } \\
\text { of Wildlife Conservation. However, traditional } \\
\text { practices situated within the limits of any } \\
\text { national reserve or state land in any sanctuary, } \\
\text { if being practised before the declaration of } \\
\text { such protected area, are permitted to continue. }\end{array}$ & State land \\
\hline $\begin{array}{l}\text { Managed } \\
\text { Elephant Areas }\end{array}$ & Low & $\begin{array}{l}\text { Managed Elephant Reserves are declared to } \\
\text { ensure that both humans and elephants can } \\
\text { live in harmony and not in conflict with each } \\
\text { other. They are meant to strike a balance } \\
\text { between different needs, rather than acquiring } \\
\text { such lands to resettle people and declare } \\
\text { national reserves. }\end{array}$ & $\begin{array}{l}\text { Both state } \\
\text { and private } \\
\text { land }\end{array}$ \\
\hline Sanctuaries & Lowest & $\begin{array}{l}\text { Hunting, trapping animals, collecting of eggs of } \\
\text { wild birds and reptiles, disturbing any nest of } \\
\text { any bird, and firing a gun in any sanctuary is } \\
\text { prohibited. On state land in of the sanctuary, to } \\
\text { carry, or possess a gun, or a cartridge or other }\end{array}$ & $\begin{array}{l}\text { Both state } \\
\text { and private } \\
\text { land }\end{array}$ \\
\hline
\end{tabular}




\begin{tabular}{|c|c|c|c|}
\hline $\begin{array}{l}\text { Type of } \\
\text { managed area } \\
\text { (number in } \\
\text { parentheses) }\end{array}$ & $\begin{array}{l}\text { Level of } \\
\text { protection } \\
\text { afforded }\end{array}$ & Permitted activities & $\begin{array}{l}\text { Land } \\
\text { ownership }\end{array}$ \\
\hline & & $\begin{array}{l}\text { explosive of any description is prohibited } \\
\text { except by permission of the DWC. On state } \\
\text { land within a sanctuary, it is also against the } \\
\text { law to destroy plants, clear areas for cultivation } \\
\text { or mining, create fires, construct infrastructure } \\
\text { or roads, dispose of or discharge waste or fill } \\
\text { land. }\end{array}$ & \\
\hline \multicolumn{4}{|c|}{ Under the jurisdiction of the FD } \\
\hline $\begin{array}{l}\text { Conservation } \\
\text { Forests }\end{array}$ & High & $\begin{array}{l}\text { No entry except under the authority of a permit } \\
\text { issued by the Conservator General for } \\
\text { scientific or observation purposes. Extractive } \\
\text { use of any kind is prohibited; so is firing a gun, } \\
\text { possessing or using a trap, weapon, tool, } \\
\text { explosives or poisonous substances; kindling, } \\
\text { keeping or carrying any fire or causing the } \\
\text { kindling of any fire or allows any fire to keep } \\
\text { burning or to spread; clearing or breaking up } \\
\text { soil or digging any land for cultivation or for any } \\
\text { other purpose or cultivating any such cleared } \\
\text { land or erecting a hut or doing any other } \\
\text { activity on it; and construction. }\end{array}$ & State land \\
\hline $\begin{array}{l}\text { Reserved } \\
\text { Forests (Forest } \\
\text { Reserves) }\end{array}$ & $\begin{array}{l}\text { High but less } \\
\text { than the } \\
\text { above }\end{array}$ & $\begin{array}{l}\text { As above, but certain activities may be } \\
\text { permitted with the approval of the CGF }\end{array}$ & State land \\
\hline Village Forests & Low & $\begin{array}{l}\text { Areas that are used for different uses by a } \\
\text { community or several communities and certain } \\
\text { kinds of extractive practices can be carried out } \\
\text { inside such areas. There is a certain degree of } \\
\text { protection in these forests as some activities } \\
\text { are regulated. } \\
\text { However, polluting of water, setting fires, } \\
\text { injuring, cutting or felling any protected } \\
\text { (reserved) trees and clearing is still prohibited. }\end{array}$ & State land \\
\hline \multicolumn{4}{|c|}{ Under the jurisdiction of the CEA } \\
\hline $\begin{array}{l}\text { Environmental } \\
\text { Protection Areas }\end{array}$ & High & $\begin{array}{l}\text { An important feature of this Act is that there } \\
\text { can be regulations to prohibit, restrict, regulate } \\
\text { and approve certain types of activities within } \\
\text { such areas and these are implemented through } \\
\text { these regulations. }\end{array}$ & $\begin{array}{l}\text { Both state } \\
\text { and private } \\
\text { land }\end{array}$ \\
\hline \multicolumn{4}{|c|}{ Under the jurisdiction of the CC\&CRMD } \\
\hline SMA & Low & $\begin{array}{l}\text { Restricted to the coastal zone. Management } \\
\text { and planning are carried out with the } \\
\text { assistance of communities }\end{array}$ & $\begin{array}{l}\text { Both state } \\
\text { and private } \\
\text { land }\end{array}$ \\
\hline
\end{tabular}




\begin{tabular}{|c|c|c|c|}
\hline $\begin{array}{l}\text { Type of } \\
\text { managed area } \\
\text { (number in } \\
\text { parentheses) }\end{array}$ & $\begin{array}{l}\text { Level of } \\
\text { protection } \\
\text { afforded }\end{array}$ & Permitted activities & $\begin{array}{c}\text { Land } \\
\text { ownership }\end{array}$ \\
\hline \multicolumn{4}{|c|}{ Under the jurisdiction of the DFAR } \\
\hline $\begin{array}{l}\text { Fisheries } \\
\text { Reserves }\end{array}$ & Medium & $\begin{array}{l}\text { To ensure sustainable management of a } \\
\text { particular area. Any development activity within } \\
\text { a fishery reserve requires the permission and } \\
\text { approval of the Department of Fisheries and } \\
\text { Aquatic Resources. Fishing, mining, collecting } \\
\text { or processing of coral or other aquatic } \\
\text { resources, dredging or extracting sand or } \\
\text { gravel; discharging or depositing waste or any } \\
\text { other polluting matter or in any other way } \\
\text { disturbing, interfering with or destroying, fish or } \\
\text { other aquatic resources or their natural } \\
\text { breeding grounds or habitat within such } \\
\text { reserve is prohibited without a permit by the } \\
\text { Director of Fisheries and Aquatic Resources. } \\
\text { Similarly, construction or erection of any } \\
\text { building or other structure on or over any land } \\
\text { or waters within such reserve is also prohibited } \\
\text { without a permit from the director. }\end{array}$ & State \\
\hline FMA & Low & $\begin{array}{l}\text { Protects a particular resource or the resources } \\
\text { that are found in a particular area by restricting } \\
\text { and controlling the activities that are allowed in } \\
\text { such an area. }\end{array}$ & State \\
\hline
\end{tabular}




\section{Recommendation 2: carry out further detailed studies of the biodiversity of the region}

The previous recommendation presented areas for conservation. However, further in-depth, detailed studies of the biodiversity of the region, are essential. In particular, studies of Iranaitivu North, Iranaitivu South, Eluvaitivu, Kachchativu, Karaitivu, Kayts, Mandaitivu, Delft, Palaitivu, Erumaitivu and Kakeraitivu are required to identify under which category and at which level, protection is afforded to those areas.

Inter alia, these studies should focus on species - such as threatened species and migratory species identified during this study - assessing species richness, abundance as well as other Essential Biodiversity Variables (EBV) (see Box 6) such as species interactions, behaviour, taxonomic diversity, phenology, extending over several seasons to capture seasonal variation.

\section{Box 6. Essential Biodiversity Variables (EBV)}

Essential Biodiversity Variables (EBV) are 'defined as the derived measurements required to study, report, and manage biodiversity change, focusing on status and trend in elements of biodiversity should play the role of brokers between monitoring initiatives and decision makers. They provide the first level of abstraction between low-level primary observations and high-level indicators of biodiversity' (GEO BON, 2018). EBVs are the basic building blocks that allow for higher level (regional, national, global) assessments through predictive modelling.

Studies should also focus on ecosystems, assessing parameters not only such as net primary productivity, habitat structure, but also measuring ecosystem services such as harvested wild goods; cultivated goods; global climate regulation (estimating carbon sequestration, estimate greenhouse gas emissions); assessing flood protection services; estimating water quantity provision for domestic and industrial purposes; measure water quality services; and assessing nature-based recreation (estimating annual number of visits made for tourism and recreation purposes; estimating annual total income from tourism and recreation; estimating annual tourism income from nature-based activities) (Peh et al., 2017). From such ecosystem service studies, meaningful ecosystem valuation can be carried out.

Yet other studies should be carried out to quantify and prioritise threats discussed in Chapter 5 ; so that remedial measures can be formulated.

From such studies, integrated management plans for the above-mentioned areas targeting the protection of threatened species, preventing the degradation of ecosystems, and identifying the players and their roles can be formulated.

In addition, it is strongly recommended that similar detailed studies are also carried out for the lagoons of the northern area, in particular Jaffna, Thondaimanaru, Nanthi Kadal, Nayaru and Kokkilai Lagoons, which are surrounded by heavy human settlements and anthropogenic change. In particular, the salinity regimens of these lagoons must be studied in depth, over 
time, as there have been many hydrological alterations made in these lagoons. Current fish diversity, fish harvest (type and quantity of fish harvested) are also needed for comparison with earlier available data. Many of the northern lagoons serve as feeding grounds for migratory species and also are extremely important to fisheries-related livelihoods.

Also largely ignored is the archaeological wealth in the study area. Detailed studies are also needed in this area. (See Box 7.)

\section{Box 7. The need for marine archaeological expeditions}

The northern region has immense archaeological and cultural significance since the prehistoric period. The ancient marine Silk Route also runs through this narrow sea passage that was used by ancient Chinese, Arabic, Persian, Greek and Roman traders. Marine archaeological expeditions are lacking in this region and therefore, only a few artefacts have been recovered in this region. Therefore, future detailed explorations are also needed to understand the ancient maritime trade in this area and to preserve the archaeological sites in the area.

\section{Recommendation 3: shift to an inter-sectoral approach to management}

One of the major institutional flaws in Sri Lanka is that there is a multitude of policies and laws, as well as numerous organisations, each with their own mandates and agendas, working in the same area, with little or no reference to each other. This is exemplified in the coastal zone, where the Coast Conservation and Coastal Resources Management Department has primary jurisdiction over all coastal areas in Sri Lanka; the Department of Wildlife Conservation manages marine and coastal protected areas, while the Forest Department has jurisdiction over mangroves, which are also found in coastal areas (Joseph, 2004; IUCN, 2011a). Fisheries resources in lagoons come under the aegis of the Department of Fisheries and Aquatic Resources. Added to the mix of organisations are, inter alia, local and provincial governments, the Sri Lanka Tourism Development Authority ${ }^{12}$ and the Urban Development Authority. Each of these institutions often works largely in isolation of the others. The users of the coastal zone - communities, developers and others are rarely included in management.

There is also a lack of knowledge about and mainstreaming of the links between ecosystem well-being and human well-being (MoMD\&E, 2016a).

Therefore, it is essential that an integrated, inter-sectoral approach is used for planning. MultiStakeholder Platforms (MSPs), that include government officials from relevant organisations - such as the CEA, DWC, FD, CC\&CRMD, DFAR, Department of Land Use Planning, UDA, SLTDA - to ensure a holistic approach, the private sector - such as hoteliers and other service providers - as well as communities, safeguard their rights - have been proven to be effective in many areas of the island. These MSPs are convened under the Chairmanship of the District Secretary (the highest-ranking government officer in the area) (Miththapala, 2011a). Such MSPs are recommended for the study area too.

It is heartening to note that recent amendments to some legislation (for example, Fisheries

12 Coastal tourism accounts for $70 \%$ percent of the total tourism infrastructure in the country and a significant portion of the national economy (BOBLME, 2013). 
and Coast Conservation Acts, Forest Conservation Ordinance) provide a legal basis for intersectoral (inter-agency) collaboration to promote resources management and environment conservation. It is hoped that these new amendments will provide the impetus for better integration of management.

\section{Recommendation 4: manage solid waste and other forms of pollution}

Solid waste management has become a serious national issue in the recent past, after the tragic events at Meethotamulla. An effective solution is yet to be implemented nationally. It is recommended that a solid waste management programme is established to ensure that the generation of waste is a) minimised, b) collected effectively (separated into reusable, recyclable, non-degradable and biodegradable waste) as well as in time, by municipal/local government authorities; and d) disposed of responsibly. (For garbage segregation to work, a finely tuned and smoothly operating collection system is also essential.)

To this end, recycling facilities, identified land fill areas, and repeated training for local government authorities, communities, businesses, and all stakeholders will be essential. Such a programme is needed urgently, particularly if activities such as tourism are being promoted.

Sewage, agrochemicals from agriculture and aquaculture, sedimentation, industrial effluents, and heavy metals all cause water pollution in other parts of the island (BOBLME, 2013).

Even though Sri Lanka ranks highest in Asia in relation to good sanitation, this national figure masks geographical discrepancies, as the urban poor, coastal and fishing communities, and estate/plantation workers still lag in sanitation (UNICEF, 2017). Data specific to the northern region are still hard to come by.

Irresponsible disposal of fish waste and by-catch in fisheries harbours and fish landing sites can cause high pollution throughout the coast. This, in turn, can cause high Chemical Oxygen Demand (COD) ${ }^{13}$ levels in associated coastal waters (CZMP, 2006 in litt. BOBLME, 2013).

Studies carried out to assess water quality along the south-western, southern and eastern coastlines have shown that there is eutrophication, high faecal contamination, industrial effluents and sedimentation in many areas (BOBLME, 2013). A small study of the Jaffna Lagoon (see Chapter 5) revealed that the lagoon, at various points, was polluted with faecal matter and agrochemicals.

Similar studies of the northern coastline, as well as the lagoons of the study area, are urgently needed before development activities increase and with them, water pollution.

Knowledge of and enforcement of laws and regulations related to water pollution (primarily

\footnotetext{
13 Higher COD levels mean a greater amount of oxidizable organic material in the sample, and therefore, COD assesses organic pollution.
} 
the National Environmental Act No. 47 of 1980, its amendments of 1998, 2000 and 2005 and regulations) is also essential (CEA, 2013).

As above, creating awareness about these laws is of paramount importance.

Air and noise pollution standards must also be maintained as stated in the regulations under the National Environmental Act (CEA, 2013).

\section{Recommendation 5: minimise overexploitation}

The main issues of overexploitation are associated with fisheries. Firstly, it should be noted that fishing was restricted severely during the three decade-long war. The release of this restriction, post-war, without regulation, can lead to over-fishing in coastal waters as seen in other parts of the island. Secondly, observations from this study, showed that the use of destructive and often illegal fishing gear and targeted over-harvesting of species is rife in the study area.

Thus, there is an urgent need to introduce fisheries management to reduce overexploitation of resources and the use of illegal and destructive fishing gear.

In collaboration with the Department of Fisheries and Aquatic Resources and the Department of Wildlife Conservation, it is essential that, as for other threats, concerted programmes to create awareness are conducted about which gear is permissible, which species have controls placed on fishery, and which species cannot be harvested, targeting fishermen, the Sri Lankan Navy, and hoteliers.

Enforcement of the FFPO and the FARA will also be essential.

\section{Recommendation 6: control invasive alien species (IAS)}

Five species of invasive alien flora and one potential invasive alien fauna species were observed in the study area. The Convention on Biological Diversity (CBD) defines IAS as: '. .. species whose introduction and/or spread outside their natural past or present distribution threatens biological diversity.' (CBD, undated). 
Invasive alien species have several intrinsic characteristics:

a) they have a history of invasiveness outside their natural range;

b) they have a wide distribution in different habitats;

c) they are generalists;

d) they grow and mature fast but can live long;

e) they reproduce efficiently and have effective means of dispersing;

f) they can endure harsh conditions and have many adaptations to overcome environmental hardships; and

g) they are superior competitors and can cause the extinction of native species.

Their impacts on natural ecosystems are very detrimental as they

a) alter ecosystems;

b) destroy and deplete native species;

c) can cause severe damage in agricultural lands;

d) can transmit diseases and can cause illness and/or death;

f) can facilitate the spread of forest fires;

g) can cause pollution of water bodies; and

h) are costly to control and eradicate, once they have been established (Wittenberg \& Cock, 2001).

A good example of the impacts of IAS can be seen in the Hawaiian archipelago, isolated in the middle of the Pacific Ocean. This archipelago has many endemic and native species. Of the 140 species of indigenous birds, half are now extinct because rats, wild boar, goats and mongooses introduced either deliberately, or accidentally to these islands devastated the native flora and fauna of Hawaii (IUCN \& MASL, 2014).

Given the damage that IAS can wreak on natural system (see Box 8) it is in important that attempts are made to control or eradicate the species listed in Chapter 5. Particular attention should be given to feral cats and dogs which feed on native species. The presence on feral dogs on Sand Bar IV of Adam's Bridge is an imminent threat to the rare breeding residents who nest (on the ground) in Sand Bar III.

To this end, a plan for the management of these species should be developed and should include a) training for the personnel of the divisional secretariats and local government authorities who will be involved directly in identifying these IAS species; b) detailed methodology for management (deciding whether eradication or control is practical); c) monitoring to prevent re-infestation and d) early detection of eradicated species should they re-establish ${ }^{14}$.

It is recommended that a university or research organisation be co-opted for assistance in this endeavour.

\footnotetext{
14 It is strongly recommended that even though Tilapia is not listed as an IAS in Sri Lanka, given its biology and known invasiveness in Sri Lanka, it is eradicated from Mandaitivu as the coastal waters of the island have been proposed as a protected area.
} 


\section{Recommendation 7: mitigate and adapt to climate change}

\section{Mitigation}

Climate change mitigation refers to efforts to reduce or prevent emission of greenhouse gases.

Through an integrated approach, stringent energy conservation measures, improving energy supplies, optimising equipment to work at $100 \%$ efficiency and the use of renewable energy - such as solar power - should be promoted actively. In addition, there should be stringent adherence to air quality parameters required by the CEA for vehicle emissions and ambient air quality parameters (CEA, 2013).

Alternative modes of transport - such as bullock carts and electrical golf carts - should be considered for tourism activities on islands, so that certain islands can remain emission free. For example, it is recommended that Iranaitivu North, Iranaitivu South, Eluvaitivu, Kachchativu, Karaitivu, Delft, Paraitivu and Analaitivu are developed as emission free islands.

Often overlooked in Sri Lanka as a means of reducing emissions, is the protection of forests and coastal ecosystems (See Chapter 5 ). The role of such ecosystems in climate change mitigation must be highlighted (Box 9).

\section{Box 9. The role of ecosystems in climate change mitigation}

- Green plants, through the process of photosynthesis, absorb atmospheric carbon and release oxygen as a by-product. Because of this, forests serve as carbon sinks to absorb large quantities of carbon dioxide. It is reported that in the past few decades, the forests of the world have absorbed as much as 30\% every year (2 petagrams of carbon per year) of the world's carbon emissions (Pan et al., 2011).

- Coastal ecosystems such as mangroves, seagrass meadows and tidal marshes are estimated to sequester carbon dioxide at a significantly higher rate than rain forests. Of this 'blue carbon' stored, $50-99 \%$ is located in the soils below ground, up to six metres deep (Blue Carbon Initiative, 2017). The dramatic difference between carbon absorption in coastal marine and terrestrial ecosystems is the capacity in coastal ecosystems for long-term carbon sequestration in their sediment.

Protection of such ecosystems has been recommended in the first section of this chapter as because of their biodiversity and ecosystems. The above reveals a second reason for the conservation of terrestrial, coastal and marine systems.

\section{Adaptation}

Climate change mitigation, however, alone will not be enough. Even if greenhouse gas emissions are reduced drastically, the current effects of climate change will be felt for several decades more. Therefore, a second strategy for dealing with climate change - adaptation also becomes essential (Miththapala, 2008e). 'Adaptation refers to adjustments in ecological, social, or economic systems in response to actual or expected climatic stimuli and their effects or impacts' (UNFCCC, 2018). Simply stated, adaptation is accepting that climate change will occur, and preparing for it. At a local level, the single most important response to climate change is adaptation. 
Ecosystem-based adaptation (EbA) uses 'biodiversity and ecosystem services into an overall adaptation strategy to help people to adapt to the adverse effects of climate change' (Lo, 2016). While not yet mainstreamed into development agendas, case studies have proven that EbA a) provides protection from extreme elements; b) contributes to climate change mitigation by restoration of natural habitats and c) provides innovative agricultural solutions to adapt to climate change (Lo, 2016). The above reveals a third reason for the conservation of terrestrial, coastal and marine systems.

EbA activities - such as restoring degraded ecosystems; managing invasive alien species that degrade land; agricultural management (using climate-resilient species, crop rotation and diversification); promoting water and soil conservation measures (such as rain water harvesting, drip irrigation and management of livestock grazing respectively); planting a tree when felling one is inevitable - as well as other such EbA activities should be routinised in development and livelihoods-related projects.

\section{Recommendation 8: ensure adherence to environmental laws}

Embedded in the constitution of Sri Lanka is the protection of the country's natural wealth and the services it provides humans, and this is buttressed by several ordinances, acts, regulations and policies (MoMD\&E, 2016a). There are many laws related to management of natural resources, but these can be culled to 24 key laws that have bearing on the drivers of ecosystem change (See Annex 9 for details). These laws have been enacted to 'regulate human behaviour so that ecosystems and species, and thereby the services provided by them, are conserved. This, in turn, ensures the protection of livelihoods. Failing to uphold these laws and regulations leads to many far reaching and damaging impacts, including increased vulnerability to extreme weather events, decreased agricultural production, and diminishing natural resources, including fish stocks. Laws also ensure that our natural capital is managed sustainably and equitably' (IUCN, 2006).

Weak enforcement of environment-related laws in rampant Sri Lanka, for a number of reasons. Prime among these is a lack of knowledge about these laws. There is also a lack of integrated planning (addressed in a previous section); a multiplicity of agencies and several ministries; weak or lack of communication among these agencies and ministries; lack of capacity and lack of mainstreaming of 'key concepts such as the relationships among biodiversity and development, ecosystem services and human well-being into medium and long-term planning (MoMD\&E, 2016).

Thus, there is a need to more rigorous enforcement of environment-related laws and targeted creation of awareness about environment-related laws (such what can/cannot be done; where it can/cannot be done) is urgently needed for a wide range of sectors-such as tourism, development, fisheries, aquaculture, provincial and municipal councils, and developmental agencies to reduce ad hoc development that damages ecosystems and their services. 


\section{Recommendation 9: carry out extensive awareness programmes about the area's natural wealth}

The National Biodiversity Strategic Action Plan 2016-2022 (MoMD\&E, 2016) states that 'In post-conflict Sri Lanka, there has been a strong and urgent thrust for infrastructure development, with less focus on the conservation of natural capital. In this current climate the paradigm of biodiversity conservation as we know it must change. Conservation can no longer be relegated to the mandated custodians of biodiversity such as the Department of Wildlife Conservation, the Forest Department and the Central Environmental Authority but must be the responsibility of every single citizen of Sri Lanka. It is, therefore, imperative that all stakeholders be made aware of the actions proposed in the [plan], so that a larger group of stakeholders may assist in/support these conservation actions.'

As important as the previous recommendations, is the creation of awareness among the gamut of stakeholders such as government agencies, local government politicians, district secretaries, divisional secretaries, grama niladharis, the armed forces and police, nongovernmental organisations, the private sector, school children, media personnel, the general public and targeted communities such as fishing communities.

Such creation of awareness should focus on

- 'Creat[ing] a clear understanding about the need for biodiversity conservation and the links between ecosystem well-being and human well-being among all stakeholders' (MoMD\&E, 2016). This is crucial, as people need to understand the immediate and long-term benefits that ecosystems provide (i.e. what is the benefit for themselves from for example, conserving mangroves);

- 'Mainstream[ing] biodiversity conservation as a multi-sector, value-added, and benefit-sharing effort to on-going development efforts' (MoMD\&E, 2016); and

- As noted in the previous recommendation, increase the knowledge about environmental laws.

Such creation of awareness will foster and augment inter-sectoral cooperation and ensure a 'buy in' from communities and the general public that will, in turn, promote participation in conservation activities.

\section{Recommendation 10: ensure responsible tourism}

Many of these northern islands are ideal for nature-based tourism (See Annex 1). However, tourism can place heavy, additional stresses on an environment already seriously overused and overstretched, as daily, it consumes immense quantities of resources (for example, energy for lighting, cooling rooms and cooking; water for laundry and filling swimming pools); generates excessive waste and pollution; destroys natural habitats during construction; forces local people to compete for essential resources with tourists and hotels; and contributes hugely to global warming through air travel (Miththapala, 2011b). 
Since the civil war in Sri Lanka ended, there has been a robust growth in the number of foreign tourists. In 2016, there were 2,050,832 arrivals showing an increase of 14\% from 2015 (SLTDA, 2016). In 2016, tourism ranked third as a foreign exchange earner (SLTDA, 2016). Nature-based tourism is important in Sri Lanka and many of these visitors visit national parks and in 2016, 1,967,138 local and foreign tourists visited national parks (SLTDA, 2016). However, nature tourism can damage the very environment that tourists are coming to see, if tourism is unregulated and tourist behaviour becomes irresponsible (Box 10).

\section{Box 10. The impact of unregulated tourism}

Yala is a good example of such damage, as visitation increased from 43,368 visitors in 2008 to 658,277 visitors in 2016 , well beyond the carry capacity of the park (which has not changed), resulting in severe overcrowding (MoMD\&E, 2016a). This can be observed in the photographs of traffic jams of jeeps lined up at the entrance or surrounding a leopard - that are circulated commonly in social and regular media.

Accompanying this overcrowding is irresponsible behaviour - such as speeding - which has resulted in the death of leopards and jungle cats (MoMD\&E, 2016a).

\section{Prevent over-visitation and overexploitation}

Over-visitation is a form of overuse. In Annex 1, clear recommendations are given for the carrying capacity of each island recommended for nature-based tourism. These recommendations should be followed strictly.

Often coupled with over-visitation is irresponsible behaviour, which disrupts natural animal behaviour or contributes to overexploitation. Such behaviour includes the

- use of lures (taped bird calls) to entice birds into the open;

- the purchase of species protected by law (shells, trinkets made of tortoise shell);

- the consumption of protected species (turtle or dolphin meat, lobsters during season); and

- disruption of the nesting behaviour of species.

Many of these activities occur because of the lack of awareness about responsible behaviour and species which are protected by law or threatened with extinction. Local government officers, district level officers, communities, hoteliers, tour guides, developers, law enforcement officers and all stakeholders should be provided with good conservation education.

To this end, it is recommended that a capacity building/communication plan be developed with different messages and training as needed for each target group, as well as targeted communication materials (such as clear signboards), so that all stakeholders are aware of, inter alia, what can and cannot be done and where, what use is permissible and not.

Secondly, it is essential that existing laws related to the environment are enforced properly (see above) and that all law enforcement officers are made aware of them. 


\section{Prevent habitat destruction}

Off-roading can cause damage to terrestrial ecosystems.

Irresponsible snorkelling, diving, jet-skiing and boating can cause direct physical damage to coral reefs and seagrass meadows. For example, when visitors walk on reefs, they cause physical damage to the reef structure, stirring up sediment. Boats can drop anchors directly onto reefs while the propellers of jet skis and boats can damage and destroy seagrass meadows.

Tourism infrastructure, if built without integrated planning and consideration for environmental laws, can cause habitat destruction. For example,

- forests and wetlands are clear-felled, and sand dunes levelled to build infrastructure;

- seagrasses are destroyed to build jetties, piers and erosion defence structures;

- lagoon and estuarine hydrology are negatively affected when infrastructure is built across the mouths of such water bodies.

As Kalliaditivu and Puliyantivu Islands are located inside the Vankalai Sanctuary, permanent infrastructure should be avoided.

As with the above section, it will be essential to create awareness about the impacts of habitat destruction, and also ensure that relevant laws are enforced strictly (for example, the constraints on built infrastructure in relation to protected areas, according to the FFPO).

\section{Prevent pollution}

When hotels or related infrastructure are constructed, it is essential that there are, in place, adequate and approved measures for sewage management, solid waste management and wastewater and water pollution management.

A study by the Greening Sri Lanka Hotels project, under the aegis of the European Commission Switch Asia Program, sampled 276 hotels (61 large $=\geq 50$ rooms; medium and small $=<50$ rooms) in Sri Lanka and revealed that while $92 \%$ of the large hotels had sewage treatment plants (STP), only $17 \%$ of the medium and small hotels had STPs (Switch Asia, Greening Sri Lanka Hotels Project, 2013, in litt. BOBLME, 2013).

The CZMP of 2016 noted that ' $[\mathrm{In}$ ] many coastal resorts where there are clusters of restaurants and guest houses, and other major tourist centers. The near shore waters receive untreated sewage, sullage in the form of kitchen and laundry wastewater, and solid waste including plastics. This causes pollution problems, as apparent in most major tourist centres along the south, southwest and east coasts. Tourism expansion in Hikkaduwa, Beruwala, Unawatuna and Arugam Bay areas has led to water quality degradation as well as visual pollution of beaches and near shore waters. . It is clearly evident that the qualities of the near shore coastal waters in the vicinity of tourism centers have been significantly degraded due to discharge of effluents.' 
It is, therefore, imperative that any tourism infrastructure that is built is carried out in conformity to CEA regulation standards and SLTDA (2017b) development standards.

Tourists, particularly local tourists, should be advised against irresponsible littering in areas where there are nature trails in protected areas, or if they are snorkelling near coral reefs or seagrasses. To this end, clear signage and awareness are essential.

\section{Prevent the spread of IAS}

Ensure that the spread of invasive alien species is not increased. Building equipment is known to be a pathway through which IAS spread.

In addition, when tourism infrastructure is constructed, it should be ensured that the landscaping of gardens that often follows, uses species native to the area, thus minimising the risk of introducing IAS.

On the sandbar islands declared as the Adam's Bridge National Park, it is crucial that tourism is regulated by the Department of Wildlife Conservation. Access to the islands must be controlled strictly, especially for those islands used by birds for breeding. If access is not controlled, the bird breeding colonies could be destroyed due to the introduction of predatory species like feral dogs.

\section{Use green building practices during construction}

'Green building, also known as green construction or sustainable building, is the practice of creating structures and using processes that are environmentally responsible and resourceefficient throughout a building's life-cycle: from siting to design, construction, operation, maintenance, renovation, and deconstruction' (Environment and Ecology, 2017). The aim of green building is:

- Siting and structure design efficiency: the objective is to minimise the total environmental impact associated with all life-cycle stages of the building project;

- Energy efficiency: this includes maximising use of natural light and ventilation and use of alternative energy - such as solar power for heating water and for lighting.

- Water efficiency: this includes recycling grey water for flushing toilets; using waterconserving fixtures such as low-flush toilets and low-flow shower heads; ensuring thorough maintenance that spots and fixes leaks immediately.

- Materials efficiency: this includes obtaining wood from plantation forests; reusing materials from demolished buildings, sourcing and using local material.

- Indoor environmental quality enhancement: this includes the use of environmentally friendly cleaning agents; refraining from use of chemical air fresheners; and ensuring that anything containing volatile organic chemicals (VOC) are not used.

- Operations and maintenance optimisation: these include ensuring that a framework for ensuring environmental management is established during construction and maintained through training and internal audits (Miththapala, 2011b). 
- Waste reduction: this includes ensuring that sewage and grey water are treated before release into the environment; ensuring reducing, reusing and recycling waste at all stages of building so that the amount going into landfill is minimised (All of the above adapted from Environment and Ecology, 2017).

\section{Ensure mitigation and adaptation to climate change}

Many of the principles of green building address climate change mitigation and adaptation.

Other measures are operational measures that include ensuring all vehicles are serviced on a regular schedule to ensure optimum performance and minimum emissions; buying locally to avoid food miles ${ }^{15}$; making efforts to plant trees ${ }^{16}$ on the premises with native plants of the region, when felling of trees in unavoidable and using landscaping as a means to cool the premises (Miththapala, 2011b).

It should be ultimately ensured that any tourism project that is commenced is climate-proofed.

\section{Conclusion}

The northern coastal stretch from Mannar to Kokkilai has been untouched by development for over three decades, retaining some pristine ecosystems, a collection of range-restricted species and has several feeding areas for migrating birds.

These ecosystems also provide the residents of these coastal areas with life-sustaining ecosystem services.

It is imperative, therefore, that future development is planned in an integrated manner, ensuring that sensitive ecosystems and species of concern (such range-restricted, rare and threatened species and rare migrants and breeding residents) are conserved and ecosystem services so needed by humans are retained through minimising overall damage to ecosystems.

Sustainable, nature-based tourism, if planned and implemented will be an appropriate development strategy for the area, for the improvement of livelihoods. However, it cannot be over-emphasised that incorporating stringent environmental safeguards is essential.

\footnotetext{
${ }^{15}$ Food miles are the distance food travels from where it is grown to where it is ultimately purchased or consumed

${ }^{16}$ Each tree planted in the humid tropics absorbs $22 \mathrm{~kg}$ of carbon dioxide every year.
} 

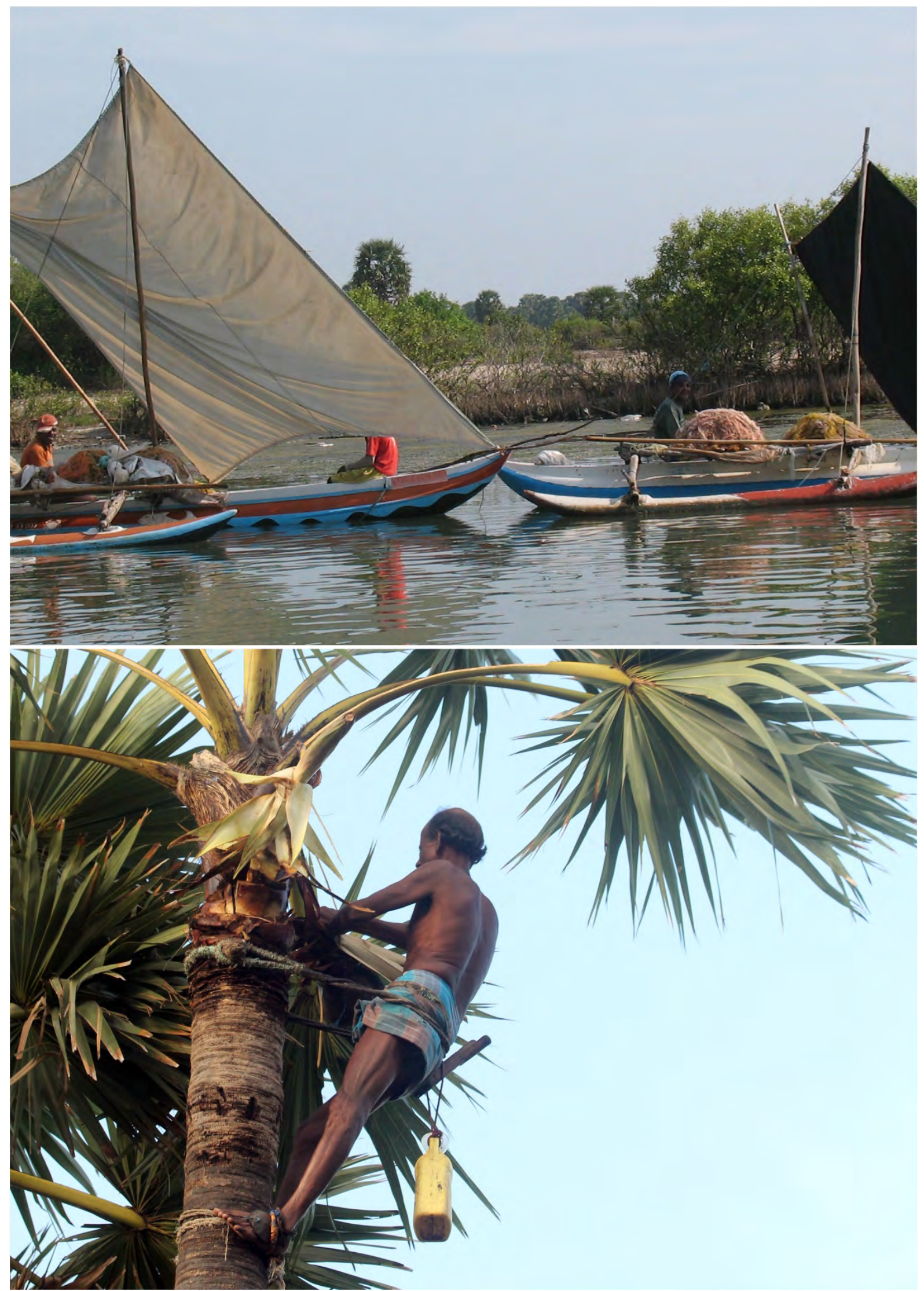

Figure 54. Top: fishermen, Kokkilai Lagoon; bottom: toddy tapping, Delft (Top: @ IUCN/Kumudini Ekaratne; bottom: @ IUCN/Naalin Perera) 


\section{References}

Abhayagunawardena, V. (2015). 'Will conservation boom in the north?' The Sunday Times (Sri Lanka). Accessed 29 March 2015.

Abhirami, S. and Shivashanthini, K. (2008). 'Diversity of the Snakes from Jaffna Peninsula, Sri Lanka.' Pakistan Journal of Biological Sciences 11(16): 1969-1978. https://doi.org/10.3923/pjbs.2008.1969.1978

Ali, S.M., Pervaiz, A., Afzal, B., Hamid, N. and Yasmin, A. (2014). 'Open dumping of municipal solid waste and its hazardous impacts on soil and vegetation diversity at waste dumping sites of Islamabad city.' Journal of King Saud University - Science 26: 59-65. https://doi.org/10.1016/j.jksus.2013.08.003

Antiquities Ordinance (No. 9 of 1940). An Ordinance to Provide for the Better Preservation of the Antiquities of Sri Lanka, and of Sites and Buildings of the Historical or Archaeological Importance in Sri Lanka. As amended 2 of 1955, 22 of 1955, 24 of 1998, and 12 of 2005.

Ariyawansa, M.A. (2007). 'Hydrography'. In: R. Silva, P.A. Ariyaratne, B.J.P. Mendis, S.D. Bandaranayake, M.M. Karunanayake, L.C. Rajapaksa, D. Wjeyesekera, D. S. Epitawatte, T. Jayasingam, A.T.P.I. Abeykoon, S.M.W. Fernando, K. Thavalingam, U.S.B. Panamaldeniya, K. Dayananda and R.M.K. Ratnayake (eds.) The National Atlas of Sri Lanka, pp. 50-51. Colombo, Sri Lanka: Government Press.

Asela, M.D.C., Peiris, T.N., Kasige, A. and Weerakoon, D.K. (2014). 'Butterfly Diversity in the Jaffna Peninsula and the Surrounding Islets.' WILDLANKA 2: 65-76.

Ashton, M.A., Gunatilleke, S., de Zoysa, N., Dassanayake, M.D., Gunatilleke, N. and Wijesundara. S. (1997). A field guide to the common trees and shrubs of Sri Lanka. Colombo, Sri Lanka: Wildlife Heritage Trust Publications. 432 pp.

Athauda, S. (2010). 'Is tilapia becoming an invasive fish in Sri Lanka.' In: B. Marambe, P. Silva, S. Wijesundara, and N. Atapattu (eds.) Invasive Alien Species in Sri Lanka Strengthening Capacity to Control Their Introduction and Spread, pp 127-130. Sri Lanka: Biodiversity Secretariat, Ministry of Environment.

Atputhanathan, M. and Chitravadivelu, K. (1969). 'Fish population of the Thondaimannar Lagoon its distribution and economic potential.' Hydro-biological survey, Research Council and Northern Province Science Teacher's Association of Sri Lanka 9: 1-81.

Bahir, M.M. and Yeo, D.C.J. (2005). 'A revision of the genus Oziotelphusa Müller, 1887 (Crustacea: Decapoda: Parathelphusidae), with descriptions of eight new species.' In: D.C.J. Yeo, P.K.L. Ng and R. Pethiyagoda (eds.) Contributions to Biodiversity Exploration and Research in Sri Lanka, pp 77-120. The Raffles Bulletin of Zoology, Supplement No. 12. 
Baldaeus, P. (1658). A Description of the East-India Coasts of Malabar and Coromandel and also of the Isle of Ceylon with their Adjacent Kingdoms \& Provinces (translated from the HighDutch printed at Amsterdam. London: Printed for A. and J. Churchill. 350 pp.

Balendran, V.S., Sirimanne, C.H.L. and Arumugam, S. (1968). Groundwater in Jaffna. Colombo, Sri Lanka: Water Resources Board. 35 pp.

Balendran, V.S. (1969). Salt Water Fresh water Interface Studies in the Jaffna Peninsula, Report III. Colombo, Sri Lanka: Geological Survey Department. 36 pp.

Balasubramaniam, A., Krishnarajah, P. and Santiapillai, C. (2003). Diversity of Amphibian Fauna of Jaffna Peninsula: A Preliminary Study. International Workshop on Environmental Management in North-East Sri Lanka. 13-17 pp.

Bambaradeniya, C.N.B., Perera, M.S.J. and Samarawickrama, V.A.M.P.K. (2006). 'A rapid assessment of post-tsunami environmental dynamics in relation to coastal zone rehabilitation and development activities in Hambantota District of southern Sri Lanka'. IUCN Sri Lanka Occasional Paper No. 10. Colombo, Sri Lanka: IUCN. 27 pp. http://purna.Ik/iucnsl/shared/biblio_view.php?bibid=3533\&tab=opac

Bandaranayake, S. (1990). 'Introductory note: Sri Lanka and the Silk Road on the sea.' In: S. Bandaranayake and R. Silva (eds.) Sri Lanka and the Silk Road of the Sea, $2^{\text {nd }}$ Edition, pp. 920. Colombo, Sri Lanka: Sri Lanka Institute of International Relations, Central Cultural Fund, Sri Lanka National Commission for UNESCO.

Bassett, R.H. (1997). Romantic Ceylon: Its History, Legend, and Story. Asian Education Service. $323 \mathrm{pp}$.

Bedjanic, M., Conniff, K., van der Poorten, N.E. and Šalamun, A. (2014). Dragonfly Fauna of Sri Lanka: Distribution and Biology, with Threat Status of its Endemics. Sofia, Bulgaria: Pensoft Publishers. $321 \mathrm{pp}$.

Bedjanic, M., Conniff, K. and Wijeyeratne, G. de S. (2007). A photographic Guide to the Dragonflies of Sri Lanka. Colombo, Sri Lanka: Jetwing Eco Holidays. 248 pp.

Begley, V. (1967). Archaeological expedition of North Ceylon. Expedition 9 (4): 23.

Birdlife International (2017a). Sri $\quad$ Lanka. [Website] http://datazone.birdlife.org/site/results?cty=197 Accessed 7 September, 2017.

Birdlife International (2017a). Global IBA Criteria. [Website] http://datazone.birdlife.org/site/ibacritglob_Accessed 7 September, 2017.

Blackhall Publishing (2014). Laws of Sri Lanka. [Online edition] http://www.blackhallpublishing.com/index.php/revised-laws/sri-lanka/laws-of-sri-lankaprint.html Accessed 12 August, 2017. 
Blue Carbon Initiative (2017). Why are coastal and marine ecosystems important for climate change mitigation? http://thebluecarboninitiative.org/blue-carbon/ Accessed 7 January, 2018.

BOBLME (2013). Country report on pollution - Sri Lanka. BOBLME-2011-Ecology-14. [Online report] http://www.boblme.org/document Repository/BOBLME-2011-Ecology-14.pdf. Accessed 12 August, 2017.

Brohier, R.L. (1929). Notes on an ancient habitation near Kudiremalai. Journal of the Royal Asiatic Society (Ceylon Branch) 82: 388-397.

Broker, K.C.A. and Illangakoon, A. (2008). 'Occurrence and Conservation needs of cetaceans in and around the Bar Reef Marine Sanctuary, Sri Lanka.' Oryx 42 (2): 286-291. https://doi.org/10.1017/S0030605308006728

Buddhatta, P. (2006). Seehalavattuve Sinhala anuvadaya, Itha parani Sinhala bana katha. (Sinhala text). Deraniyagala: Buddhist Cultural Centre. 175 pp.

Burke, L., Reytar, K., Spalding, M. and Perry, A. (2011). Reefs at Risk Revisited. Washington, D.C.: World Resources Institute (WRI), The Nature Conservancy, WorldFish Center, International Coral Reef Action Network, UNEP World Conservation Monitoring Centre and Global Coral Reef Monitoring Network. 114 pp.

Calder, J. (2009). Worldislandinfo.com. [Online list]

http://www.worldislandinfo.com/LARGESTV1.html . Accessed 28 March, 2016.

Carswell, J. and Prickett, M. (1984). 'Mantai 1980, a preliminary investigation.' Ancient Ceylon 5: 7-80.

Convention on Biological Diversity (CBD) (undated). What are Invasive Alien Species? [Website] https://www.cbd.int/invasive/WhatarelAS.shtml Accessed 28 August, 2017.

CBD and the Scientific and Technical Advisory Panel (STAP) - GEF (2012). Impacts of Marine Debris on Biodiversity: Current Status and Potential Solutions. Technical Series 67. Montreal, Canada: $61 \mathrm{pp}$.

Central Environmental Authority (CEA) (2013). Acts \& Regulations. [Website] http://www.cea.lk/web/en/acts-regulations Accessed August 28, 2017.

Ceylon Bird Club (2010). A million shorebirds at Vidattaltivu. [online report]. http://www.ceylonbirdclub.org/articles-2010-02.php Accessed Sept 7, 2017.

Coast Conservation Act (Coast Conservation and Coastal Resource Management Act) No. 57 of 1981, as amended by 64 of 1988, 49 of 2011.

Coastal Zone Management Plan (CZMP) (2018) Sri Lanka Coastal Zone and Coastal Resource Management Plan - 2018. Gazette Extraordinary No. 2072/58, 2018.05.25. http://coastal.gov.Ik/images/pdf/acts/czcrmp_2018_gazette_2072_58_e.pdf Accessed 20 October, 2020. 
Chitravadivelu, K. (1994). 'Aspects of fishery and species composition of edible crabs in the Jaffna lagoon.' Journal of National Science Country Sri Lanka 22(1): 43-55. https://doi.org/10.4038/jnsfsr.v22i1.7109

Cooray, P.G. (1984). An introduction to the geology of Sri Lanka (Ceylon). Colombo, Sri Lanka: National Museums of Sri Lanka. 340 pp.

D'Abrera, B. (1998). The butterflies of Ceylon. Colombo, Sri Lanka: Wildlife Heritage Trust. 224 pp.

Dassanayake, M.D. and Fosberg, F.R. (eds.) (1980). A Revised Handbook to the Flora of Ceylon, Vol. I. New Delhi: Amerind Publishing. vii +508 pp.

Dassanayake, M.D. and Fosberg, F.R. (eds.) (1981-1991). A Revised Handbook to the Flora of Ceylon, Vols. II-VII New Delhi: Oxford \& IBH Publishing. Volume iii: vii + 499 pp; Volume iv: vii + 532 pp; Volume V: vii + 476 pp; Volume vi: vii + 424 pp; Volume vii: vii +439 pp.

Dassanayake, M.D., Fosberg, F.R. and Clayton, W.D. (eds.) (1994-1995). A Revised Handbook to the Flora of Ceylon, Vols. VIII-IX. New Delhi: Oxford \& IBH Publishing. Vol. VIII: v +458 pp; Vol. IX: v + 482 pp.

Dassanayake, M.D. and Clayton, W.D. (eds.) (1996 - 2000). A Revised Handbook to the Flora of Ceylon, Vols. X-XIV. New Delhi: Oxford \& IBH Publishing. Vol. X: v + 426 pp; Vol. XI: v + 420; Vol. XII: v + 390 pp; Vol. XIII: v + 284; Vol. XIV: v + 307 pp.

Dassanayake, M.D., Clayton, W.D. and Shaffer-Fehre, M. (eds.) (2006). A Revised Handbook to the Flora of Ceylon, Vols. XV Part A \& Part B. USA: Science Publishers, USA. Vol. XV Part A: v + 310 pp; Part B: v+ 616 pp.

Deraniyagala, P.E.P. (1957). Report of the Archaeological Survey of Ceylon for 1956. Part IV Education, Science and Art (G). Colombo, Sri Lanka: Government publication Bureau. 12 pp.

Deraniyagala, P.E.P. (1958). The Pleistocene of Ceylon. Colombo, Sri Lanka: Colombo National Museum, Ceylon Government Press. 164 pp.

De Silva, M., Hapuarachchi, N. and Jayaratne, T. (2015). Sri Lankan Freshwater Fishes. Galle: Wildlife Conservation Society. 391 pp.

De Silva, P.H.D.H (1987). 'Cetaceans Whales Dolphins and Porpoises Recorded off Sri Lanka India from the Arabian Sea and Gulf, Gulf of Aden and from the Red Sea.' The Journal of the Bombay Natural History Society 84: 505-525.

De Silva Wijeyeratne, G. (2017). A photographic guide to the Birds of Sri Lanka. Colombo, Sri Lanka: Vijitha Yapa Publishers. 296 pp.

de Vlas, J. and de Vlas-de Jong, J. (2008). Illustrated Field Guide to the Flowers of Sri Lanka. Netherlands: de Vlas, J. 304 pp. 
Dharmawardana, C. (2006). Some ancient Buddhists sites in the Jaffna Peninsula and their probable ancient names. [Online interactive map] http://dhweb.org/place.names/maps/jaff1Bu.html Accessed 31 August, 2017.

Dissanayake, C.B. and Chandrajith, R. (1999). 'Sri Lanka-Madagascar Gondwana Linkage: Evidence for a Pan-African Mineral Belt.' Journal of Geology 107: 223-235. https://doi.org/10.1086/314342

Ekanayake, S.P. and Fernando, R.H.S.S. (2015), Preliminary documentation of biodiversity of Chundikulam wildlife sanctuary, Northern Province, Sri Lanka (Final project report submitted to the Biodiversity Secretariat, Ministry of Environment, Colombo), Center for Applied Biodiversity Research and Education (CABRE), 209/3, Allen Avenue, Dehiwala,Sri Lanka. 24 pp. Unpublished report.

Ellepola, G and Ranawana, K.B. (2016). 'Survey on fishery in Nayaru Lagoon, Mullaitivu, Sri Lanka.' In: Proceedings of the National Aquatic Resources Research and Development Agency (NARA), scientific sessions, pp. 9-11.

English, S., Wilkinson, C. and Baker, V. (1997). Survey Manual for Tropical Marine Resources $2^{\text {nd }}$ ed. ASEAN-Australia Marine Science Project: Living Coastal Resources, Townsville, Australia: Australian Institute of Marine Science, PMB No. 3 4810, 390 pp.

Erb, D.K. (1963). The Geomorphology of Ceylon: A Study of Tropical Terrain Based on Aerial Photographs. PhD thesis. McGill University. 431 pp.

Environment and Ecology (2017). Green Building. [Website] http://environmentecology.com/environment-and-architecture/80-green-building.html Accessed 24 August, 2017.

Fabry, P. Fabry-Bewly, L., Fabry, A. and Fabry, E. (2006). The Essential Guide for Jaffna and its region. Negombo, Sri Lanka: Viator Publications. 157 pp.

Fauna and Flora Protection Ordinance No. 2 of 1937 (as amended by 31 of 1942, 12 of 1944, 12 of 1945, 38 of 1949, 44 of 1964,1 of 1970,49 of 1993, 12 of 2005, 22 of 2009).

Fisheries and Aquatic Resources Act No. 2 of 1996 (as amended by 2 of 1996, 4 of 2000, 4 of 2004, 22 of 2006, 35 of 2013, 2 of 2015, 2 of 2016).

Forest Ordinance (Forest Conservation Ordinance) No. 16 of 1907 (as amended 16 of 1907,11 of 1912, 24 of 1918, 23 of 1931, 16 of 1935, 30 of 1945, 8 of 1947, 34 of 1951, 49 of 1954, 13 of 1966, 56 of 1979, 13 of 1982, 84 of 1988, 23 of 1995, and 65 of 2009).

Fourqurean, J.W., Duarte, C.M., Kennedy, H., Marbà, N., Holmer, M., Mateo, M.A., Apostolaki, E.T., Kendrick, A., Krause-Jensen, D., McGlathery, K.J., and Serrano, O. (2012). 'Seagrass ecosystems as a globally significant carbon stock.' Nature Geoscience 5:505-509. https://doi.org/10.1038/ngeo1477 
Geiger, W. (1960). The Mahawamsa. Colombo. Ceylon Government Information Department. $189 \mathrm{pp}$.

GEO BON (2018). Essential Biodiversity Variables.German Centre for Integrative Biodiversity Research (iDiv) Halle-Jena-Leipzig. https://geobon.org/ebvs/what-are-ebvs/ Accessed June 24, 2018.

Global Invasive Species Database (GISD) (2005). [Online database] http://issg.org/database/welcome/feedback.asp Accessed 24 August, 2017.

Gnanam, A (2017). Discover Mannar, Sri Lanka. Mannar, Sri Lanka: The Palymyrah House. $156 \mathrm{pp}$.

Gnaneswaran, R. (2015). Status of Mangrove Ecosystems in Jaffna Peninsula. Conference paper, read at the $2^{\text {nd }}$ International Scientist forum for mangrove conservation and management, June 26-28 2017, Pambala, Chillaw, Sri Lanka.

Goonatilake, W.L.D.P.T.S. de A. (2001). 'Miocene vertebrates of Sri Lanka described by P.E.P. Deraniyagala.' Loris 22 (6):12-18.

Goonatilake, W.L.D.P.T.S. de A. (2006). Archaeologically important sites in Wilpattu National Park: present status and new findings. National Archaeological Symposium 2006: papers submitted to the symposium 1: 57-80.

Goonatilake, S. de A. (2007a). Freshwater Fishes of Sri Lanka. (Sinhala text). Battaramulla: Biodiversity Secretariat, Ministry of Environment and Natural Resources. 134 pp.

Goonatilake, W.L.D.P.T.S. de A. (2007b). 'Historical and archaeological sites of Gulf of Mannar and Palk Bay, coastal Maritime zone of Sri Lanka.' In Sri Lanka Advisory Group on SSCP Ministry of Foreign Affairs (eds). Views of Sri Lanka on Sethusamudram ship channel project, pp. 111-117. Colombo, Sri Lanka: Vijitha Yapa Publishers.

Harrison, J. (1999). A field guide to the Birds of Sri Lanka. New York, USA: Oxford University Press Inc. 219 pp.

http://anywater.ru/pubs/the-history-of-freediving [Online image] Accessed 31 August, 2017.

Ilangakoon, A.D. (2011). 'Survival prospects and conservation needs of the dugong in Sri Lanka.' In: Arai, N. (ed.) Proceedings of the $6^{\text {th }}$ International Symposium on SEASTAR2000 and Asian Biologging Science, 23-25 February 2010, pp 49-53. Thailand: Phuket.

Illangakoon, A.D. (2012). 'Exploring anthropogenic activities that threaten endangered blue whales (Balaenoptera musculus) off Sri Lanka.' Journal of Marine Animals and Their Ecology 5 (1): 3-7.

Imbulana, K.A.U.S., Wijesekara, N.T.S. and Neupane, B.R. (eds.) (2006). Sri Lanka National Water Development Report. Sri Lanka, Paris and New Delhi: MAI\&MD, UN-WWAP, UNESCO and University of Moratuwa. $221 \mathrm{pp}$. 
International Union for Conservation of Nature (IUCN) (2006). After the Tsunami: Knowing about Environmental Policies and Legislation Information Paper No. 9 Series on Best Practice Guidelines (Sri Lanka). http://www.iucn.org/about/union/secretariat/offices/asia/regional_ activities/elg/mcp/coastal/our_work/best_practice_guidelines/ Accessed 20 June, 2011.

IUCN Sri Lanka (2010). Rapid Biodiversity Survey of Mannar Biosphere, Sri Lanka. IUCN Sri Lanka (unpublished document). 68 pp.

IUCN Sri Lanka (2011a). An Environmental and Fisheries Profile of the Puttalam Lagoon System. Regional Fisheries Livelihoods Programme for South and Southeast Asia (GCP/RAS/237/SPA) Field Project Document 2011/LKA/CM/05. xvii+237 pp.

IUCN Sri Lanka (2011b). Biodiversity and Socio-economic Information of selected areas of Sri Lankan side of the Gulf of Mannar: Report submitted by IUCN Sri Lanka Country Office to BOBLME Project Component 2.4 Collaborative Critical Habitat Management: Gulf of Mannar. Colombo, Sri Lanka: IUCN Sri Lanka Country Office. vii + 194 pp.

IUCN (2017). The IUCN Red List of Threatened Species. Version 2017-1. [Online database] http://www.iucnredlist.org. Accessed 24 August, 2017.

IUCN Sri Lanka and CEA (2006). National Wetland Directory of Sri Lanka. Colombo, Sri Lanka: IUCN and CEA. https://portals.iucn.org/library/node/9087

IUCN Sri Lanka and Mahaweli Authority of Sri Lanka (2014). Guidelines for dealing with Invasive Alien Species in the Moragahakanda Agricultural Development Project and the Kalu Ganga Reservoir and Agricultural Extension Project. 16 pp. (Unpublished document.)

Jayasinghe, H.D., Rajapakshe, S.S., and de Alwis, C. (2015). A Pocket Guide to the Butterflies of Sri Lanka. Colombo, Sri Lanka: Butterfly Conservation Society of Sri Lanka. (second edition). $184 \mathrm{pp}$.

Jones, S. (1967). The dugong Dugong dugon (Muller) its present status in the seas round India with observations on its behavior in captivity. International Zoo Yearbook, Zoological Society of London. 7: 215-220. https://doi.org/10.1111/j.1748-1090.1967.tb00398.x

Joseph, L. (2004). National report of Sri Lanka on the formulation of a transboundary diagnostic analysis and strategic action plan for the Bay of Bengal Large Marine Ecosystem Programme.[Online Unpublished Report] http://www.boblme.org/documentRepository/Nat_Sri_Lanka.pdf. Accessed 30 April, 2016.

Kallesöe, M.F., Bambaradeniya, C.N.B., Iftikhar, U.A., Ranasinghe, T., and Miththapala, S. (2008). Linking Coastal Ecosystems: and Human Well-Being: Learning from Conceptual Frameworks and Empirical Results. Colombo, Sri Lanka: Ecosystems and Livelihoods Group, Asia, IUCN. viii + 49 pp. https://portals.iucn.org/library/node/9236

Karunarathna, D.M.S.S., Nawaratne, M.A.J.S. and Amarasinghe, A.A.T. (2009). 'A review of the distribution and conservation status of Chamaeleo zeylanicus Laurenti, 1768 (Reptilia: 
Chamaeleonidae) in North-Western Sri Lanka.' Taprobanica 1(2): 115-122. https://doi.org/10.4038/tapro.v1i2.2765

Katupotha, K.N.J. (2016). 'Mangroves in Lagoon Ecosystems: A Neglected Habitat iln Sri Lanka.' Wildlanka 4(3): 079-105.

Kehelpannala, K.V.W. (2007). Geology. In: R. Silva, P.A. Ariyaratne, B.J.P. Mendis, S.D. Bandaranayake, M.M. Karunanayake, L.C. Rajapaksa, D. Wjeyesekera, D. S. Epitawatte, T. Jayasingam, A.T.P.I. Abeykoon, S.M.W. Fernando, K. Thavalingam, U.S.B. Panamaldeniya, K. Dayananda and R.M.K. Ratnayake (eds.) The National Atlas of Sri Lanka pp 20-23. Colombo, Sri Lanka: Government Press. 170 pp.

Kotagama, S. and Goonatilake, S. de A. (2013). Pictorial Pocket Guide to the Mammals of Sri Lanka: Revised \& Expanded. Colombo 3, Sri Lanka: Field Ornithology Group. 153 pp.

Kotagama, S.W. and Ratnavira, G. (2010). An illustrated guide to the birds of Sri Lanka. Colombo, Sri Lanka: Field Ornithology Group. xviii + 357 pp.

Kotagama, S. W., Pinto, L. and Samarakoon, J. L. (1998). 'Country report, Sri Lanka.' In: D. A. Scott, (compiler), A Directory of Asian Wetlands, Ramsar Site information services, Biodiversity Ecological Networks, Wetlands International, Netherlands.

Kovařík, F., Lowe, G., Ranawana, K.B., Hoferek, D., Jayarathne V. A.S., Plíšková, J. and Št'áhlavský, F. (2016). 'Scorpions of Sri Lanka (Scorpiones: Buthidae, Chaerilidae, Scorpionidae) with description of four new species of the genera Charmus Karsch, 1879 and Reddyanus Vachon, 1972, stat. n. Euscorpius.' Scorpiology 220: 1-133. https://doi.org/10.18590/euscorpius.2016.vol2016.iss220.1

Krishanthan, G., Thiruchchelvan, N. and Mikunthan, G. (2015). 'Pedestal Study for Diversity of Fishes, Crabs and Shrimps in Kokkilai Lagoon of Sri Lanka.' Advances in Biological Research 9 (1): 49-52. https://doi.org/10.5829

KRI (Kusaka Research Institute) (2004). Islands in Sri Lanka. http://www.jpp.co.jp/lanka/geo/geote/geo05e.htm Accessed 24 June, 2018.

Lo, V. (2016). Synthesis report on experiences with ecosystem-based approaches to climate change adaptation and disaster risk reduction. Technical Series No.85. Montreal, Canada: Secretariat of the Convention on Biological Diversity. 106 pp.

Long, B.G., Amarasiri, C., Rajasurya, A., Dissanayaka, D.C.T., Liyanage, K.U.S.P., Jayasinghe, R.P.P.K., Athukoorala, A.A.S.H., Karunathilaka, K.M.B., Fernando, H.S.G., and Fernando, T.D. (2010). Near shore Fisheries Status Atlas, North West, South and East Coast Aquarium Fish, Chank, Lobster, Shrimp and Sea Cucumber Fisheries of Sri 196 Lanka, Volume 1. Colombo 15, Sri Lanka: National Aquatic Resource Research and Development Agency, Crow Island, Mattakkuliya, GCP/SRL/054/CAN, 213+x pp.

Lowe, S., Browne, M., Boudjelas, S. and de Poorter, M. (2004). 100 of the World's Worst Invasive Alien Species: a selection from the Global Invasive Species Database. Auckland, 
New Zealand: ISSG. 12pp [Online report] . http://www.iucngisd.org/gisd/pdf/100English.pdf Accessed 30 April, 2016.

Madanayaka, S.A. (2015). 'Illegal fishing issue as a non-traditional security threat to Sri Lanka (with reference to India).' In: Proceedings of the $8^{\text {th }}$ International Research Conference, Kotalawela Defence Univeristy, pp. 72-78.

Madduma Bandara, C.M. (2007). 'Relief and drainage.' In: R. Silva, P.A. Ariyaratne, B.J.P. Mendis, S.D. Bandaranayake, M.M. Karunanayake, L.C. Rajapaksa, D. Wjeyesekera, D. S. Epitawatte, T. Jayasingam, A.T.P.I. Abeykoon, S.M.W. Fernando, K. Thavalingam, U.S.B. Panamaldeniya, K. Dayananda and R.M.K. Ratnayake (eds.) The National Atlas of Sri Lanka pp 36-41. Colombo: Government Press. 170 pp.

Manamendra-arachchi, K. and Pethiyagoda, R. (2006). Sri Lankave Ubayajeeveen. Colombo, Sri Lanka: Wildlife Heritage Trust (Pvt) Limited. 400 pp.

Marambe, B., Silva, P., Ranwala, S., Gunawardena, J., Weerakoon, D., Wijesundara, S., Manawadu, L., Atapattu, N. and Kurukulasuriya, M. (2011). 'Invasive alien fauna in Sri Lanka: National list, impacts and regulatory framework.' In: Veitch, C.R., Clout, M.N. and Towns, D.R. (eds.) (2011). Island invasives: eradication and management, pp. 445-450. Gland, Switzerland: IUCN. https://portals.iucn.org/library/node/10038.

Mangroves for the Future (MFF) (2015a). Developing a Socio-ecological Profile of the Jaffna Lagoon, Final report. Unpublished report submitted to MFF. $10 \mathrm{pp}$. Also [Website] https://www.mangrovesforthefuture.org/grants/small-grant-facilities/sri-lanka/phase-2-sgfprojects-Ik/cycle-4-sgf-projects-Ik/developing-socio-ecological-profile-of-the-jaffna-lagoon/ Accessed 24 August, 2017.

MFF (2015b). Baseline analysis of Development opportunities to Thondamanaru lagoon, Final report. Unpublished report submitted to MFF. 18 pp. Also [Website] https://www.mangrovesforthefuture.org/grants/small-grant-facilities/sri-lanka/phase-2-sgfprojects-Ik/cycle-4-sgf-projects-Ik/baseline-analysis-of-development-opportunities-forthondaimanaru-lagoon/ Accessed 24 August, 2017.

MFF and IUCN (2018). Biodiversity status report on Kokkilai Lagoon. Colombo: IUCN and MFF. 64 pp. Unpublished report.

Millennium Ecosystem Assessment (MEA) (2005). Ecosystems and Well-being Synthesis report. Washington D.C., USA: Island Press. v+86 pp.

Miththapala, S. (2008a). Seagrasses and sand dunes. Coastal Ecosystems Series: Volume 3. Colombo, Sri Lanka: Ecosystems and Livelihoods Group Asia, IUCN. iii + 36 pp. https://portals.iucn.org/library/node/9231

Miththapala, S. (2008b). Incorporating Environmental Safeguards into Disaster Risk Management. Volume 1. Reference Material. Colombo, Sri Lanka: Ecosystems and Livelihoods Group, Asia, IUCN. viii + 130 pp. https://portals.iucn.org/library/node/9326 
Miththapala, S. (2008c). Coral reefs. Coastal Ecosystems Series: Volume 1. Colombo, Sri Lanka: Ecosystems and Livelihoods Group Asia, IUCN. iii $+36 \mathrm{pp}$. https://portals.iucn.org/library/node/9178

Miththapala, S. (2008d). Mangroves. Coastal Ecosystems: Volume 2. Colombo, Sri Lanka: Ecosystems and Livelihoods Group Asia, IUCN. iii +29 pp. https://portals.iucn.org/library/node/9146

Miththapala, S. (2008e). Incorporating environmental safeguards into disaster risk management. Volume 2: The Disaster Management Cycle. Colombo, Sri Lanka: Ecosystems and Livelihoods Group, Asia, IUCN. viii+43 pp. https://portals.iucn.org/library/node/9327

Miththapala, S. (2011a). Improving Natural Resource Governance for the rural poor in Sri Lanka: lessons learned. Consultancy report for IUCN, Sri Lanka Country Office. Unpublished document. $43 \mathrm{pp}$.

Miththapala, Sriyanie (2011b). Good practice guidelines on environmental management for Sri Lankan hoteliers. Colombo: SWITCH Asia Greening Sri Lanka Hotels Project, C C Solutions. $x i+120$ pp.

Miththapala, Sriyanie (2012). The Gulf of Mannar and its surroundings: A resource book for teachers in the Mannar District. Colombo: IUCN Sri Lanka Office. $\mathrm{x}+64 \mathrm{pp}$. https://portals.iucn.org/library/node/10420

Miththapala, Sriyanie. (2013a). Tidal flats. Coastal Ecosystems Series Volume 5. Colombo, Sri Lanka: IUCN. iii+ 48pp. https://portals.iucn.org/library/node/44946

Miththapala, Sriyanie (2013b). Lagoons and Estuaries. Coastal Ecosystems Series (Vol 4). vi + 73 pp. IUCN Sri Lanka Country Office, Colombo. https://portals.iucn.org/library/node/44945

MoMD\&E (2016a). National Biodiversity Strategic Action Plan 2016-2022. Colombo, Sri Lanka: Biodiversity Secretariat, Ministry of Mahaweli Development and Environment. xxi +284 pp.

MoMD\&E (2016b). National List of priority and potential IAS of Sri Lanka. Unpublished document.

MoE (2012). The National Red List 2012 of Sri Lanka; Conservation Status of the Fauna and Flora. Colombo, Sri Lanka: Ministry of Environment. vii+479 pp.

Moore, F. and Best, B. (2001). 'Coral reef crisis: Causes and consequences.' In: Global Trade and Consumer Choices: Coral Reefs in Crisis. Papers presented at a Symposium held at the 2001 Annual Meeting of the American Association for the Advancement of Science, 19 February 2001, San Francisco, CA.

Moorman, F.R. and Panabokke, C.R. (1961). Soils of Ceylon. Ceylon: Government Press, 66 pp. 
MSDW (Ministry of Sustainable Development and Wildlife) (2015). Performance Report (01.01.2015 to 31.12.2015). Colombo: Ministry of Sustainable Development and Wildlife. 86 pp.

Naggs, F. and Raheem, D. (2000). Land snail diversity in Sri Lanka. London: The Natural History Museum. 214 pp.

Nanayakkara, R.P, Jefferson, T.A. and Abayarattne, S (2017). 'First records of the Indo-Pacfiic Finless Porpoise Neophocaena phocaenoides (G. Cuvfier, 1829) (Cettariodacttyla: Phocoenidae) from Sri Lanka.' Journal of Threatened Taxa 9(12): 11081-11084. http://dofi.org/10.11609/jott.1811.9.12.11081-11084.

National Aquatic Resource Research and Development Agency (NARA) (2017). Mapping and spatial interpretation of sensitive coastal and marine ecosystems covering the coastal area from Arrippu to Point Pedro of North Province in Sri Lanka. Unpublished report. 26 pp.

National Environmental Act No. 47 of 1980, as amended by 56 of 1988, and 53 of 2000.

Nicholas, C.W. (1963). 'Historical topography of ancient and Medieval Ceylon.' Journal of the Royal Asiatic Society (Ceylon Branch) 6: 1-232.

NSAP (Sri Lanka National Strategy and Action Plan) (2009). Sri Lanka National Strategy and Action Plan. Colombo: Mangroves for the Future Programme, IUCN Sri Lanka Country Office. xxxii $+219 \mathrm{pp}$.

Packiyanathan, R. and Wijesundara, C. (2014). Preliminary Observations on Migratory Birds on the Island of Mandaitivu, Jaffna, Sri Lanka. Proceedings of The Peradeniya Univ. International Research Sessions, Sri Lanka, 18: 30.

Pan, Y., Birdsey, R.A., Fang, J., Houghton, R., Kauppi, P.E., Kurz, W.A., Phillips, O.L., Shvidenko, A., Lewis, S. L., Canadell, J.G., Ciais, P., Jackson, R.B., Pacala, S.W., McGuire, A.D., Piao, S., Rautiainen, A., Sitch, S., and Hayes, D. (2011). 'A Large and Persistent Carbon Sink in the World's Forests.' Science 19 (333) Issue 6045: 988-993. https://doi.org/10.1126/science.1201609

Panabokke, C.R. (1996). Soils and Agro-Ecological Environments of Sri Lanka. Colombo: Natural Resources Energy \& Science Authority. 220 pp.

Panabokke, C.R. and Perera, A.P.G.R.L. (2005). Groundwater Resources of Sri Lanka. Colombo: Water Resources Board. 20 pp.

Peh, K.S.H., Balmford, A.P., Bradbury, R.B., Brown, C., Butchart, S.H.M., Hughes, F.M.R., MacDonald, M.A, Stattersfield, A.J., Thomas, D.H.L., Trevelyan, R.J., Walpole, M., and Merriman, J.C. (2017). Toolkit for Ecosystem Service Site-based Assessment (TESSA). Version 2.0 Cambridge, UK: University of Cambridge, Anglia Ruskin University, Birdlife International, Tropical Biology Association, RSPB, UNEP, and WCMC. 194 pp. 
Perera, K.A.R.S., Amarasinghe, M.D., and Sumanadasa, W. (2012). 'Contribution of plant species to carbon sequestration function of mangrove ecosystems in Sri Lanka (Abstract only).' Pp 137 in (eds.) Dahdouh-Guebas, F., Satyanarayana, B., 2012. Proceedings of the International Conference 'Meeting on Mangrove ecology, functioning and ManagementMMM3'. xxxix + 192 pp. Galle, Sri Lanka, 2-6 July 2012. VLIZ Special Publication 57.

Pilcher, N.J., Williams, J., Hopkins, G., Hess, D. and Jaouen, L. (2014). CMS-UNEP Questionnaire Survey: Assessment of Dugong distribution and Interaction with small-scale fisheries. Abu Dhabi, United Arab Emirates: CMS-UNEP. 86 pp.

Phillips, W.W.A. (1935). Manual of the Mammals of Ceylon. Ceylon Journal of Science, London: Dulau and Company. $371 \mathrm{pp}$.

Phillips, W.W.A. (1981). Manual of the Mammals of Sri Lanka. Part I. Colombo: Wildlife and Nature Protection Society of Sri Lanka. xxix+116 pp.

Phillips, W.W.A. (1981). Manual of the Mammals of Sri Lanka. Part II. Colombo: Wildlife and Nature Protection Society of Sri Lanka. ix+267 pp.

Phillips, W.W.A. (1981). Manual of the Mammals of Sri Lanka. Part III. Colombo: Wildlife and Nature Protection Society of Sri Lanka. xxxiii+389 pp.

Pidgeon, E. (undated). Sequestration of Carbon Along Our Coasts: Important Sinks and Sources. $14 \mathrm{pp}$. [Online presentation] https://www.cbd.int/cooperation/pavilion/cancunpresentations/2010-12-1-Pidgeon-en.pdf Accessed 24 August, 2017.

Piratheepa, S., Rajendramani, G. and Eswaramohan, T. (2016). 'Changes in Fish and Shellfish in Thondamanaru Lagoon, Jaffna, Sri Lanka.' International Journal of Environmental, Chemical, Ecological, Geological and Geophysical Engineering 10 (6): 669-673.

Ponnampalam, R. (1987). Early settlements in Jaffna: an archaeological survey. Madras Thillimalar Ragupathy. 226 pp.

Pradeep Kumara, T. and Udagedara, S. (2013). The status of seagrasses in the Gulf of Mannar. Unpublished data. Also [Website] https://www.mangrovesforthefuture.org/grants/small-grant-facilities/sri-lanka/phase-2-sgfprojects-Ik/cycle-2-sgf-projects-Ik/evaluation-of-the-present-status-of-seagrass-ecosystemsalong-the-west-coast-stretching-from-kalpitiya-to-thaleimannar/ Accessed 24 August, 2017.

Prematilake, P.L. (2003). 'Chinese Ceramics discovered in Sri Lanka.' In: S. Bandaranayake and R. Silva (eds.) Sri Lanka and the Silk Road of the Sea, pp.225-236. Colombo: Sri Lanka Institutes of International Relations, Central Cultural Fund, Sri Lanka National Commission for UNESCO.

Rajasuriya, A. (2007). 'Coral reefs in the Palk Strait and Palk Bay in 2005.' Journal of the National Aquatic Resources Research Development Agency 38: 77-86. 
Rajasuriya, A. (2015). Report on the Rapid Reef Survey in the Palk Bay; Maldiva Bank, Iranativu and Erumativu. Study conducted for the Community Aid Foundation Sri Lanka. Funded by the GEF Small Grants Programme through UNDP. (unpublished report).

Samarakoon, J. and Samarawickrama, S. (2012). An Appraisal of Challenges in the SustainableManagement of the Micro-tidal Barrier-built Estuaries and Lagoons in Sri Lanka. Colombo, Sri Lanka: IUCN Sri Lanka Country Office. xxii+171pp. https://portals.iucn.org/library/node/10198

Santiapillai, C. and Wijeyamohan, S. (2004). 'Return of the croc to Jaffna.' The Sunday Times (Sri Lanka). 1 February 2004.

Senaratna, L. K. (2001). A checklist of the flowering plants of Sri Lanka. Colombo: National Science Foundation of Sri Lanka. ix+ 451 pp.

Senanayake, F.R. (1990). 'The evolution of the major landscape categories in Sri Lanka and distribution patterns of some selected taxa: ecological Implications,' in W. Erdelen, C. Preu, N. Ishwaran and C.M. Madduma Bandara (eds.), pp. 201-220 Proceedings of International and Interdisciplinary Symposium, 'Ecology and landscape management in Sri Lanka', 12-26 March 1990. Weikersheim, Germany: Verlag Josef Margraf.

Seneviratne, Sampath S., Weeratunga, Vimukthi, Jayaratne, Thilak and Weerakoon, Devaka (2015). 'Brown Noddy Anous stolidus: first breeding record in Sri Lanka.' BirdingASIA 23: 6365.

Silva, E.I.L., Katupotha, J., Amarasinghe, O., Manthrithilake, H., Ariyaratna, R. (2013). Lagoons of Sri Lanka: from the origins to the present. Colombo, Sri Lanka: International Water Management Institute (IWMI). 122 pp. https://doi.org/10.5337/2013.215.

Sirivardana, U. and Hettige, U. (2010). 'A million shorebirds at Vidattaltivu.' Ceylon Bird Cub Notes. http://www.ceylonbirdclub.org/articles-2010-02.php Accessed 28 January, 2018.

Sitrampalam, S.K. (1990). 'The Urn Burial site of Pompatippu of Śrī Lanka - A study.' Ancient Ceylon 2: 263-297.

Smithsonian Institution (2010). Tidal Flat Habitats. [Online fact sheet] http://www.sms.si.edu/irlspec/Tidal_Flats.htm Accessed 24 August, 2017.

Somaweera, R. (2006). Sri Lankave Sarpayan. Colombo, Sri Lanka: Wildlife Heritage Trust (Private) Company Limited. 297 pp.

Somaweera, R. and Somaweera, N. (2009). Lizards of Sri Lanka, A colour guide with Field Keys. Frankfurt, Germany: Andreas S. Brahm. 303 pp.

Spalding, M., Taylor, M., Ravilious. C., Short, F. and Green, E. (2003). 'The distribution and status of seagrasses.' In E.P. Green and F.T. Short. World Atlas of Seagrasses, pp 5-26. Berkely, CA: UNEP-WCMC, University of California press. xii+298 pp. 
Sri Lanka Advisory Group on SSCP (2007). Views of Sri Lanka. Report of the Expert Advisory Group of Sri Lanka on Sethusamudram Ship Channel Project. Colombo, Sri Lanka: Ministry of Foreign Affairs. 234 pp.

Sri Lanka Tourist Development Authority (2017a). Survey of departing foreign tourists from Sri Lanka 2017 https://sItda.gov.Ik/storage/common_media/b3038228cba16e0d8ede849c71605d5b.pdf Accessed 20 October, 2020.

Sri Lanka Tourism Development Authority (SLTDA) (2017b). Development Standards. [Online standards] http://www.sltda.Ik/development_guidelines Accessed 24 August, 2017.

Sri Lanka Tourism Development Authority (SLTDA) (2016). Annual Statistical Report 2016. Colombo: Research \& International Relations Division, Sri Lanka Tourism Development Authority. 70 pp.

Statistical Information, Northern Provincial Council (2016). Statistical Information, Northern Province. Chundikuli, Jaffna: Office of the Deputy Chief Secretary, Planning, Northern Province. 223 pp.

Swan, B. (1983). An Introduction to the Coastal Geomorphology of Sri Lanka. Colombo: National Museum of Sri Lanka. 182 pp.

TEEB (2017). Ecosystem services. [Website] http://www.teebweb.org/resources/ecosystemservices Accessed 12 June, 2017.

The Free Dictionary (2017). Definition of karst. [Online dictionary] www.thefreedictionary.com/karstic Accessed 28 August, 2017.

Vandercone, R., Sajithran, T.M., Wijeyamohan, S. and Santiapillai, C. (2004). 'The status of the baobab (Adansonia digitata L.) in Mannar Island, Sri Lanka.' Current Science 87(12): 1709-1713.

Van der Poorten, G. and van der Poorten, N. (2016). The Butterfly Fauna of Sri Lanka. Canada: Lepodon Books. 418 pp.

Veronika, K., Akilan K., Murugananthan A., and Eswaramohan, T. (2013). 'Diversity and Identification Key to the Species of Scorpions (Scorpiones: Arachnida) from Jaffna Peninsula, Sri Lanka.' Journal of Entomology and Zoology Studies 1(5): 70-77.

Wadia, D.N. (1945). 'The three superposed peneplains of Ceylan - their physiography and geological structure.' Records of Department of Minerology, Professional Paper No. 1, Colombo, Ceylon.

Warakagoda, D., Inskipp, C., Inskipp, T. and Grimmett, R. (2012). Birds of Sri Lanka. London: Helm Guides. 224 pp. 
Wayland, E.J. and Davies, A.M. (1923). 'The Miocene of Ceylan.' Quarterly Journal of Geological Society LXXIX (4): 577-602. https://doi.org/10.1144/GSL.JGS.1923.079.01-04.26

Weerasinghe, P. (1985). Ptolemy and Nagadeepa. Sri Lanka Cultural Publications. 73pp.

Wijeynanda, N.P. (2007). 'Law of the sea and non-living marine resources. In: R. Silva, P.A. Ariyaratne, B.J.P. Mendis, S.D. Bandaranayake, M.M. Karunanayake, L.C. Rajapaksa, D. Wjeyesekera, D. S. Epitawatte, T. Jayasingam, A.T.P.I. Abeykoon, S.M.W. Fernando, K. Thavalingam, U.S.B. Panamaldeniya, K. Dayananda and R.M.K. Ratnayake (eds.) The National Atlas of Sri Lanka, pp. 46. Colombo, Sri Lanka: Government Pres

Wijesena, U. (2015). Bird watching in Chundikkulam / Jaffna - North Sri Lanka. Forest Bird Blogspot. https://udithawijesena.blogspot.com/2015/02/bird-watching-in-chundikkulamjaffna.html Accessed 23 June, 2018.

Wilkinson, C. (2004). Status of Coral Reefs of the World, 2004 (Volume 1) Townsville, Australia: Australian Institute of Marine Science. xiv + 301 pp.

Wittenberg, R. and Cock, M.J.W. (eds.) (2001). Invasive Alien Species: A Toolkit of Best Prevention and Management Practices. Wallingford, Oxon, UK CAB International, xvii +228 pp. https://doi.org/10.1079/9780851995694.0000

World Wide Fund For Nature (2017). Threats to whales and dolphins. http://wwf.panda.org/knowledge_hub/endangered_species/cetaceans/threats/ Accessed 23 June, 2018.

UNEP-WCMC (2006). In the Front Line: Shoreline Protection and Other Ecosystem Services from Mangroves and Coral Reefs. Cambridge, UK: UNEP-WCMC. 33 pp.

UNICEF (2017). Water, Sanitation and Hygiene [Online report] https://www.unicef.org/srilanka/WASH.pdf Accessed 28 August, 2017.

UNFCCC (2018). Adaptation Adaptation \& the UNFCCC Process. [Online report] http://unfccc.int/focus/adaptation/items/6999.php Jan 2018. 


\section{Annex 1. Profiles of the islands surveyed}

(in alphabetical order)

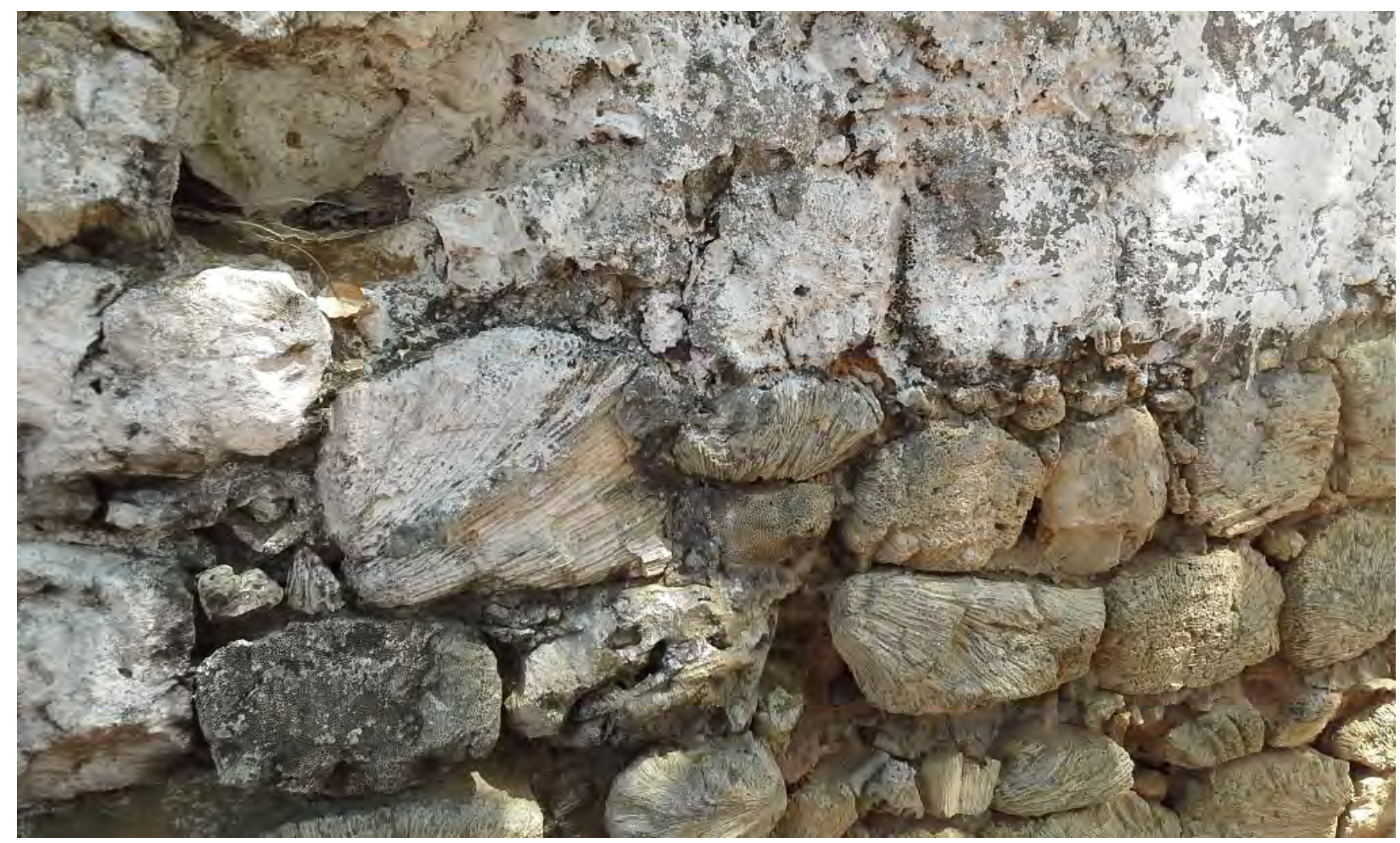

Coral wall, Delft Island $\odot$ IUCN/Arjan Rajasuriya 


\section{Analaitivu Island (Sinhala: Annaladoova; Dutch: Rotterdam)}

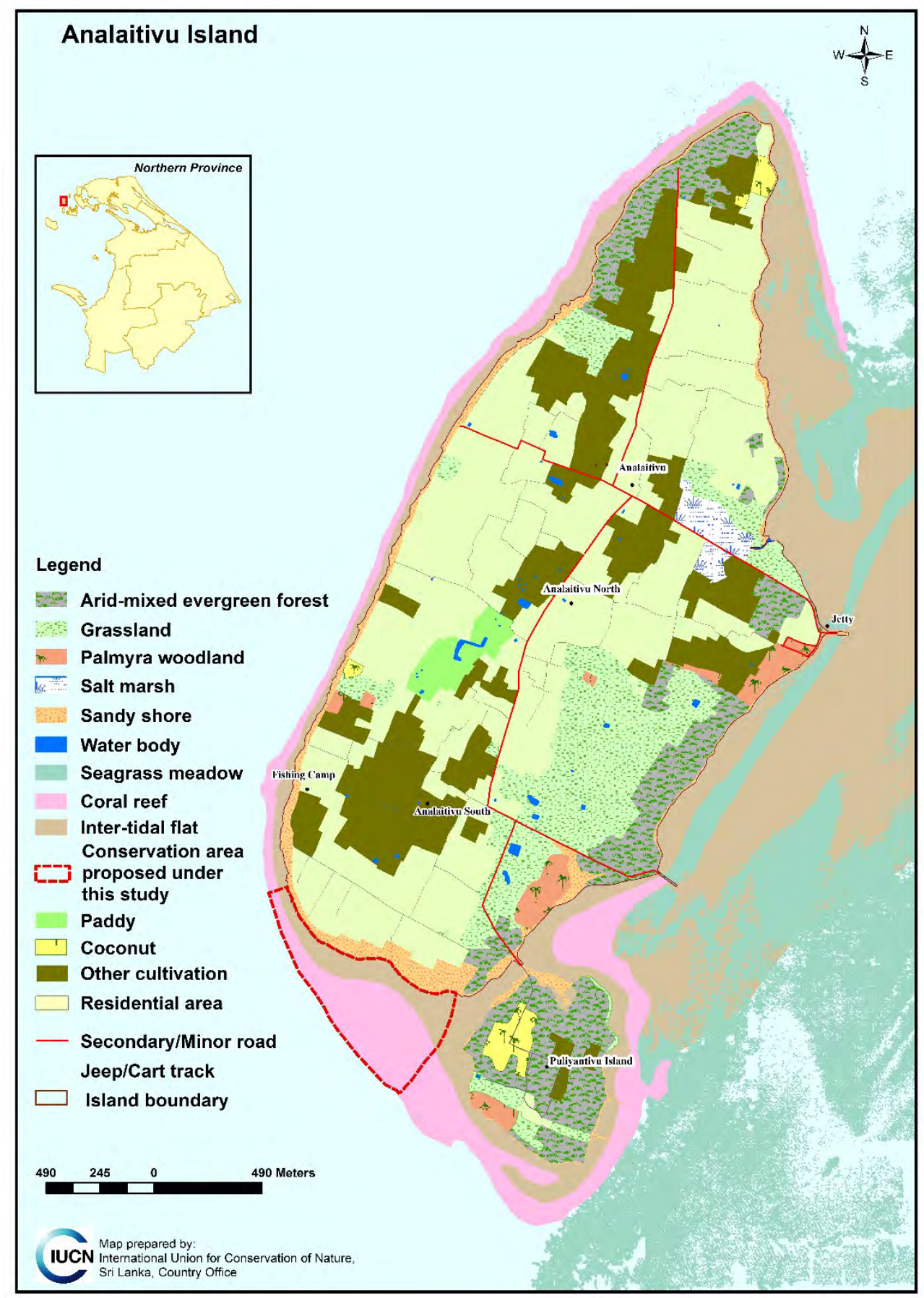

Figure 55. Map of Analaitivu Island, showing ecosystems, land use and proposed conservation area 


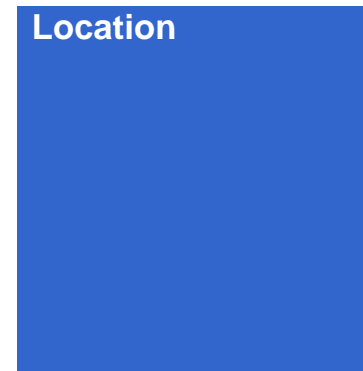

\section{Ecosystems}

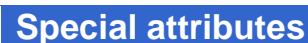

The island has an extent of about $4.8 \mathrm{~km}^{2}$ and belongs to the islands' North (Kayts) Divisional Secretariat in the Jaffna District. It is highly populated, and the current population is around 1,773. Analaitivu Island was called 'Donna Clara' by the Portuguese and 'Rotterdam' by the Dutch. It was also called 'Kotedhasi'. The first kovil in the island was named 'Elumangei Nachchimarei'. During the Dutch period, a church named 'Mādā' was built for the Catholic community, which is the only church that is present in the island (Bassett, 1997) (Figure 55).

\section{Terrestrial ecosystems}

The ecosystems found on the island include arid mixed evergreen forests, seashore scrubland, dead coral beaches, sandy seashore, home gardens and cultivated lands. Seashore scrublands are dominated by hopbush (Dodonaea viscosa). A total of 71 plant and 42 animal species, respectively, were recorded from the island. The palmyra tree (Borassus flabellifer) was the most notable terrestrial plant recorded on the island and is found in different ecosystems from home gardens to arid mixed evergreen forests. The endemic plant species Cassine balae, was also found in the arid mixed evergreen forests. The faunal assemblage comprised a land snail, two dragonfly, ten butterfly, four reptiles, 23 birds and two mammal species, respectively.

Marine ecosystems: Analaitivu ${ }^{17}$ has a fringing reef along the western side of the island and seagrasses on the eastern side. The reef is a narrow belt about $50 \mathrm{~m}$ in width. There is a narrow back reef area about one metre in depth. The reef crest consists of dead coral and rubble overgrown by seaweeds (Caulerpa, Halimeda, Turbinaria and Sargassum). The upper margin of the seaward reef slope had tabulate Acropora spp. dominated by Acropora hyacinthus. Colonies were relatively small, with a maximum diameter was about one metre. The reef slope contained massive corals, mainly species belonging to the genera Porites, Goniastrea, Favia and Favites. Soft corals (Sarcophyton and Sinularia) were common (Rajasuriya, 2007).

The diversity and abundance of reef fish were relatively low. Surgeonfish (Acanthuridae) and damselfish (Pomacentridae) were common.

Small clumps of seagrasses were present in the narrow back reef. Extensive seagrass meadows were present on the eastern side of the island. Cymodocea and Enhalus were common.

\section{Notable terrestrial fauna}

Notable species of terrestrial fauna found on the island include one endemic species - the Lesser albatross (Appias galane); one nationally Critically Endangered species, a land snail (Trachia vittata); and four nationally Vulnerable species - pPlain orange tip (Colotis aurora), the saw-scaled viper (Echis carinatus), little ringed plover (Charadrius dubius) and Kentish plover (Charadrius alexandrinus).

\section{Notable marine fauna}

17 This island was not visited during the present survey for marine assessment. Data are extracted from Rajasuriya, 2007. 

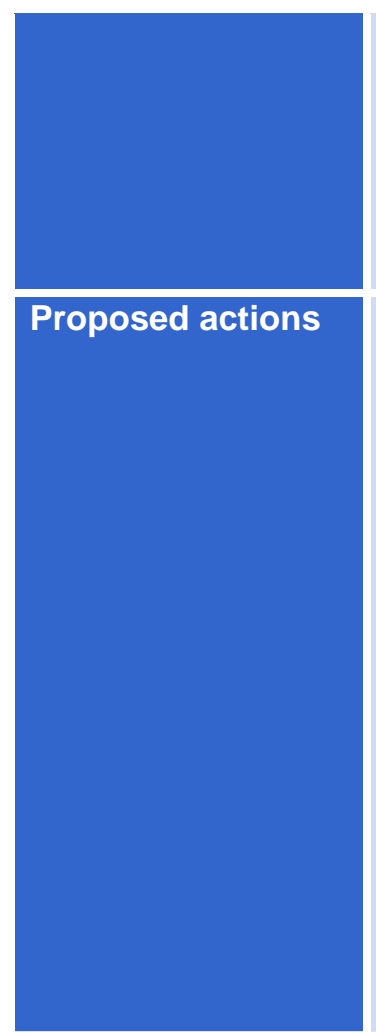

Proposed

improvements

Carrying capacity

for tourism

activities
Notable species include the Bengal sergeant (Abudefduf bengalensis) that occurs only in the northern areas of Sri Lanka from the northern Gulf of Mannar to the north-east coast. Among the dominant species of hard corals Acropora hyacinthus (NT), Favites halicora (NT), Favites chinensis (NT), Favia matthai (NT), Porites lobata (NT) and Turbinaria peltata (VU) are listed under the Red List of Threatened Species (MoE, 2012).

A small marine area in the south of the island is proposed as a conservation area (Figure 55). The type and degree of protection must be decided upon after detailed studies, as recommended in Chapter 6.

Palmyra woodlands and scenic views on the northern end of Analaitivu Island present opportunities for nature-based tourism. Coral reefs and seagrass meadows nearby can be an added attraction, as activities such as snorkelling and wind surfing can be promoted.

Analaitivu Island has a rich cultural diversity, as well as many archaeological monuments (for example, a survey beacon) and therefore, there is opportunity to promote cultural tourism as well.

The presence of human settlements and a road network provide opportunities to develop home stays. Tourism activities will promote further livelihood opportunities for the inhabitants.

Currently, the island does not have any infrastructure facilities. Tourism specific infrastructure - such as nature trails, a boat deck, snorkelling areas will also have to be developed, while ensuring that environmental safeguards are included. (See Chapter 6.)

Up to 25 visitors can be accommodated in the island at a given time. 


\section{Eluvaitivu Island (Sinhala: Eluvadoova)}

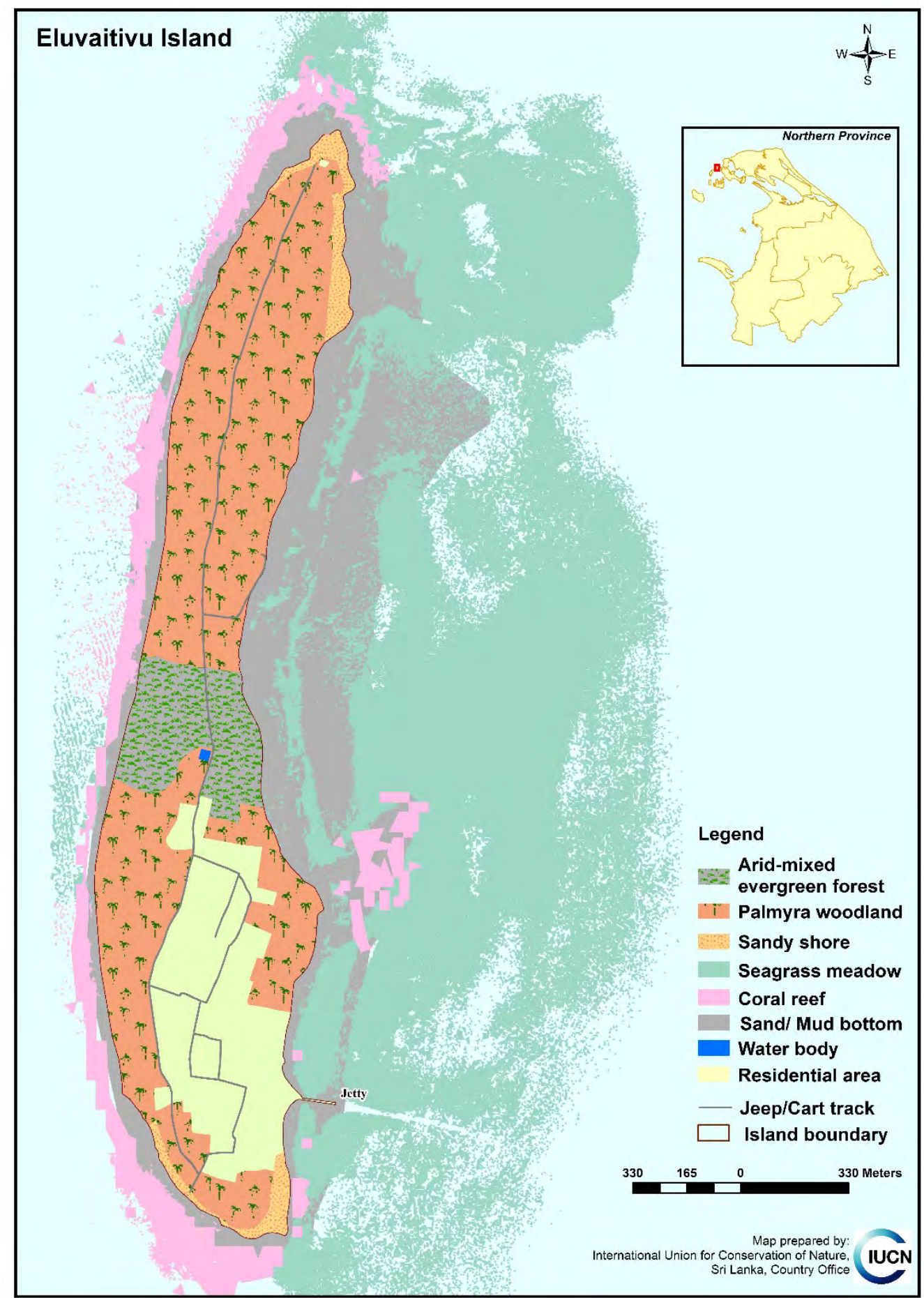

Figure 56. Map of Eluvaitivu Island, showing ecosystems and land use 


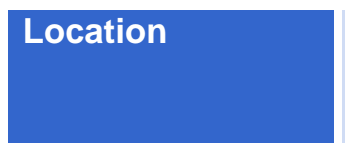

\section{Ecosystems}

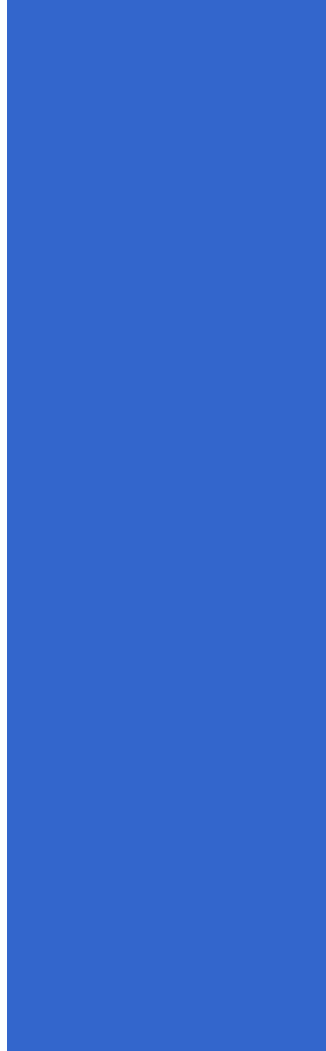

Special attributes

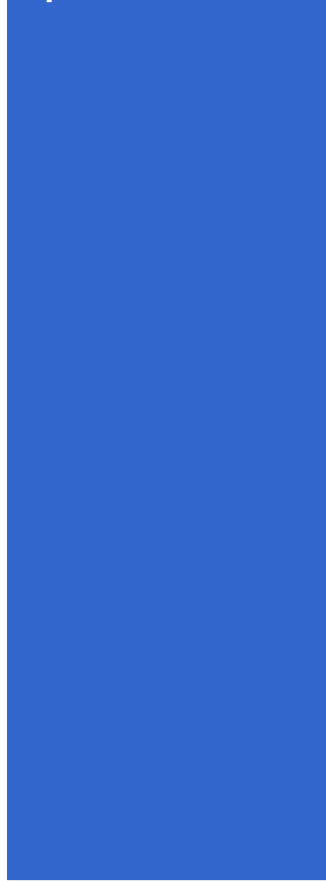

The island has an extent of about $1.4 \mathrm{k} \mathrm{m}^{2}$ and is located in the Islands North (Kayts) Divisional Secretariat of the Jaffna District. The island has a human population of 663 (Figure 56).

\section{Terrestrial ecosystems}

Palmyra woodlands, sandy seashores and home gardens are the ecosystems found on the island. A total of 47 plant species and 50 animal species were recorded from the island. The faunal assemblage observed on the island comprised one land snail, four dragonfly, eight butterfly, two amphibian, six reptile, 26 birds and three mammal species, respectively.

\section{Marine Ecosystems}

Eluvaitivu ${ }^{18}$ has coral reefs and seagrass meadows. A narrow fringing reef about $50 \mathrm{~m}$ in width was present along the length of the western coast of Eluvaitivu Island. The depth at the seaward margin of the reef is about seven metres. A narrow strip of water with the back reef is present. The reef crest is like Analaitivu reef. It contains dead corals and coral rubble covered by seaweeds (Caulerpa, Halimeda, Turbinaria and Sargassum). Small clumps of seagrasses were found in the back-reef area. There are extensive seagrasses on the eastern side of the island.

A total of 23 species of hard corals have been recorded (Rajasuriya, 2007). The main coral genera were Acropora, Goniastrea, Favia, Favites, Platygyra and Porites. Tabulate Acropora species dominated the reef at Eluvaitivu. Reef fish diversity was low, only 19 species have been recorded including four species of butterflyfish (Chaetodon auriga, C. collare, C. decussatus and C. octofasciatus). Middle and lower seaward reef slopes had Turbinaria and Sargassum seaweeds (Rajasuriya, 2007).

Inhabitants of this island are either Catholics or Hindus. There are three churches (St. Thomas church being the main one) and five kovils, (Murugan kovil also known as Muruga Murthi kovil being the main, and the others, Arulmagu Nnayanavira pathira, Sdhayi vaaivraver, Nnayana vaaivraver and Naresinha vaaivraver). These churches and kovils can be used as cultural attractions of the island.

\section{Notable terrestrial species}

The notable species of terrestrial flora recorded on the island include Commiphora berryi used as live fences around home gardens and palmyra (Borassus flabellifer), which is the most abundant plant species on the island, found in palmyra woodlands located (in the northern part of the island), on roadsides and in home gardens.

Notable species of terrestrial fauna recorded on the island include two species that are listed as Nationally Vulnerable - the land snail Cryptozona semirugata and the saw-scaled viper (Echis carinatus); and two species that are listed as Nationally Near Threatened - the marsh skimmer (Orthetrum luzonicum) and the great crested tern (Strena bergii).

\section{Notable marine species}

\footnotetext{
${ }^{18}$ This island was not visited during the present survey for marine assessment. Data are extracted from Rajasuriya,
} 2007. 

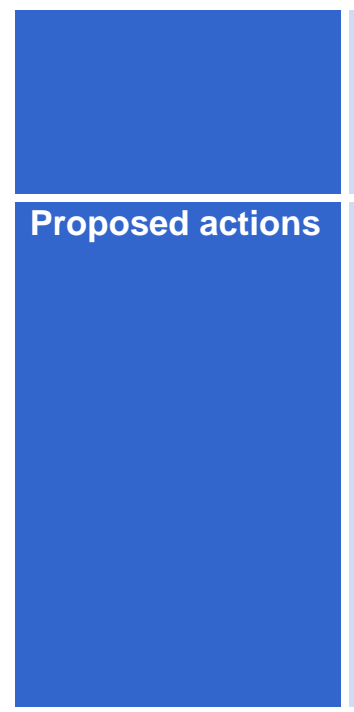

Proposed

improvements

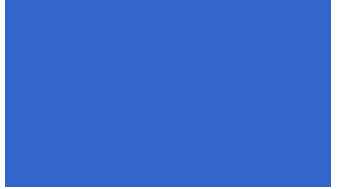

Carrying capacity

for tourism

activities
Notable species include the Bengal sergeant (Abudefduf bengalensis). Among the dominant hard corals Acropora hyacinthus (NT), Favia matthai (NT), Favites halicora (NT), Porites lobata (NT) and Diploastrea heliopora (NT) are listed in the Red List of Threatened Species (MoE, 2012).

Currently, there are visitor facilities available in the Eluvaitivu Island. However, there is a potential to develop nature-based and cultural tourism on the island. The presence of a palmyra woodland provides an opportunity to showcase the palmyra palm, including activities such as toddy-tapping and making handicrafts.

Coral reefs, seagrass beds and shallow seas around the island provide opportunities to develop activities such as snorkelling and wind surfing.

Because the island is inhabited, it will be possible to develop a home stay programme on the island.

If tourism development is to take place in the island, basic infrastructure must be improved. Tourism specific infrastructure - such as nature trails, a boat deck, snorkelling areas, home stays, restaurants will also have to be developed, while ensuring that environmental safeguards are included. (See Chapter 6.)

At any given time, up to 25 visitors can be accommodated on the island because of its small size. 


\section{Erumaitivu Island (Sinhala: Mahisadoova)}

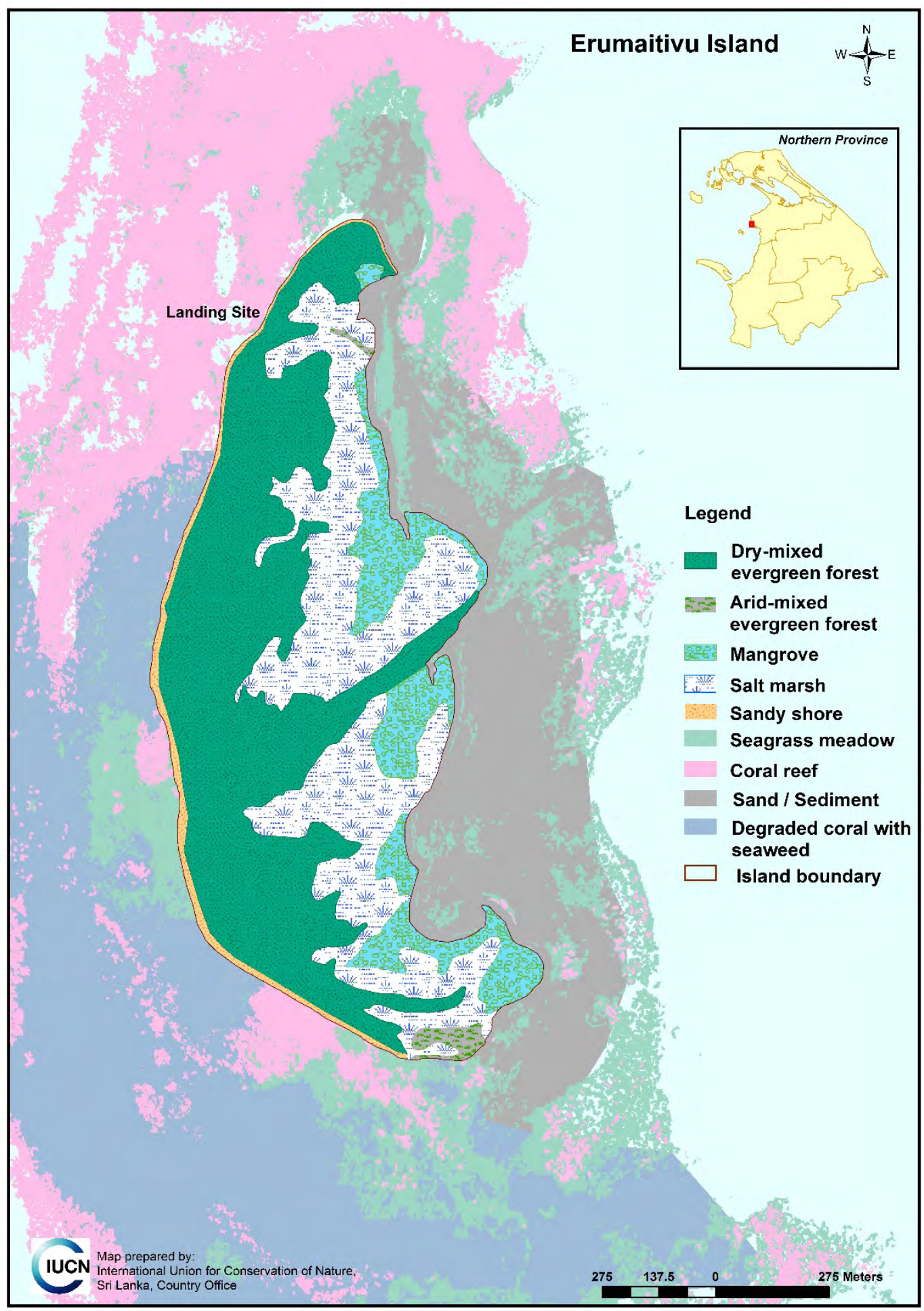

Figure 57. Map of Erumaitivu Island, showing ecosystems and land use 


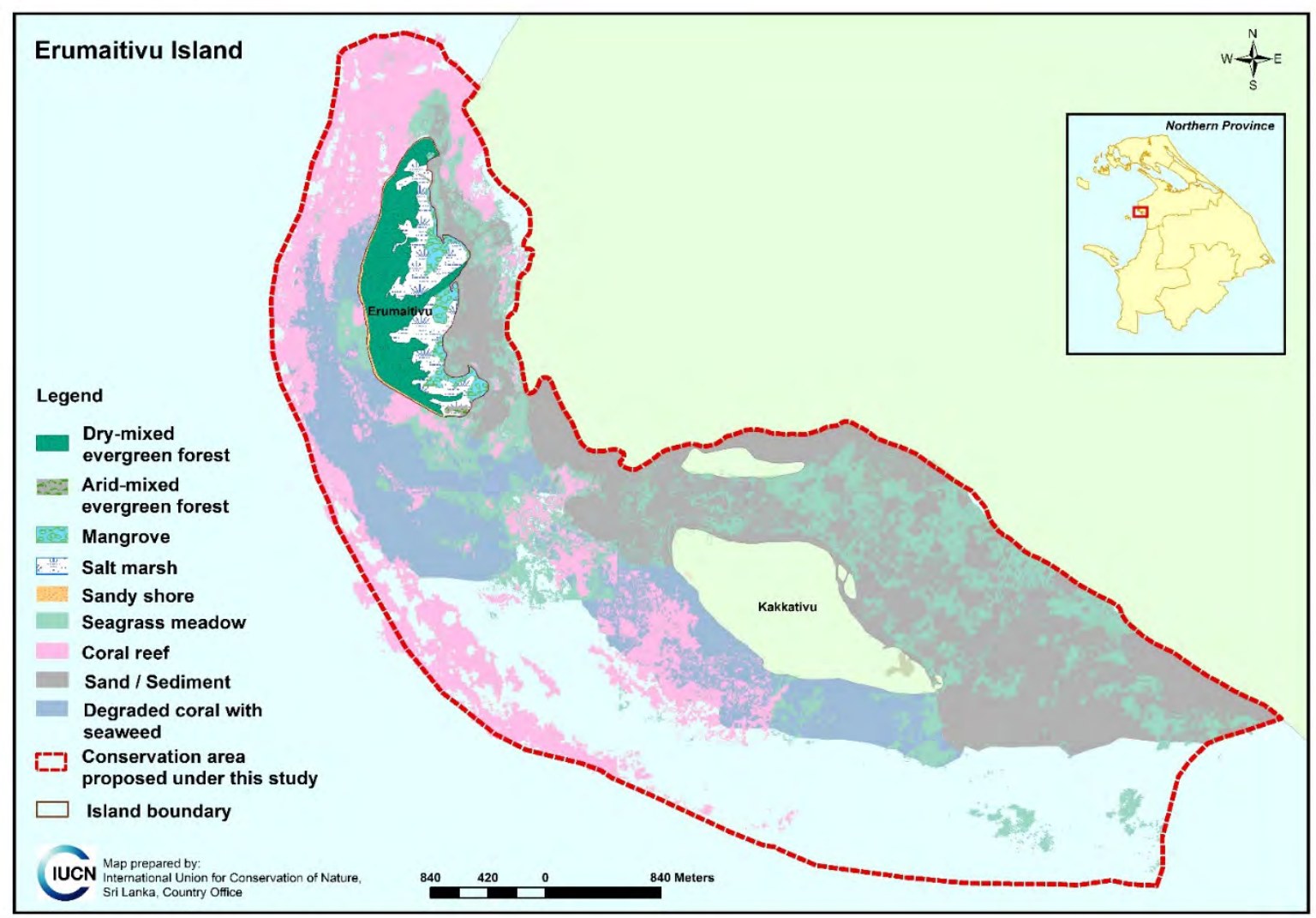

Figure 58. Map showing the proposed conservation area encompassing Erumaitivu and Kakativu Islands 


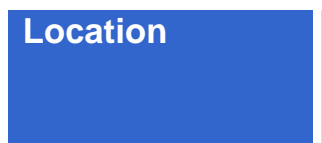

\section{Ecosystems}

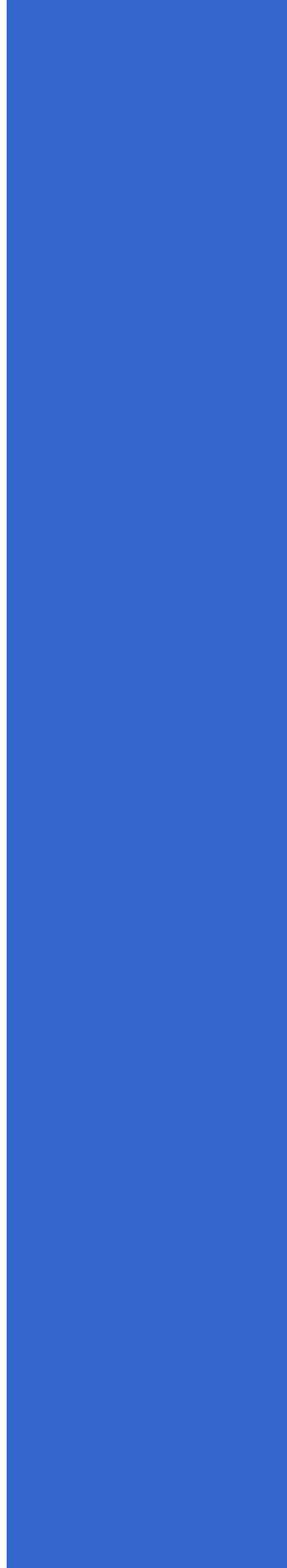

Special

attributes
This island has an extent of about $1 \mathrm{~km}^{2}$ and is located in the Poonakary Divisional Secretariat of the Kilinochchi District. The island is uninhabited even though it is close to the mainland (Figure 57).

\section{Terrestrial ecosystems}

Arid mixed evergreen forests, seashore scrublands, mangroves, salt marshes are the main ecosystems of this island. In addition, seagrass meadows and coral reefs are found in the immediate surroundings of the Erumaitivu Island. Arid mixed evergreen forests are dominated by helicopter trees (Gyrocarpus americanus) and mustard trees (Salvadora persical). A total of 35 species of flora and 84 species of fauna was recorded from this island. The faunal assemblage was represented by one species of dragonfly, 14 butterflies, four reptiles, 61 birds and six mammals.

\section{Marine ecosystems}

Corals and seagrasses are found in the shallow coastal waters from Pooneryn Peninsula to Vellankulam. Erumaitivu is located approximately in the centre of this coastal stretch. Mangroves are found in small patches on Erumaitivu on the eastern side and along the coast of the mainland.

Erumaitivu has the best coral reef in the Palk Bay. The width of the fringing reef varies from about $600 \mathrm{~m}$ to $1.5 \mathrm{~km}$. The seaward margin of the reef is at depth of about $7 \mathrm{~m}$. There were extensive patches of seagrass and sand in the backreef area at varying depths from one to two metres.

There were patches of live corals containing Echinopora lamellosa, Montipora aequituberculata, M. digitata, Acropora formosa, Porites spp., and Favia spp. Corals on the seaward reef included Echinopora lamellosa, branching and tabulate Acropora spp., Montipora aequituberculata, M. digitata, M. hispida, M. foliosa and massive corals including Platygyra daedalea, P. lamellina, Leptoria phrygia, Symphyllia radians, Porites lobata, P. Lutea, Favites halicora, Favia speciosa, F. pallida and $F$. matthai. The width of the reef was about $100 \mathrm{~m}$ on the west of Erumaitivu. The reef was dominated by tabulate and branching Acropora species on the north-western side of the island. Other common species belonged to the genera Porites, Favia, Favites, Platygyra and Porites.

The common genera of seagrasses were Cymodocea, Enhalus, Halodule and Thallasia.

The reef fish population was extremely low. Large reef fish such as groupers, snappers and parrotfish were not observed.

Notable species of terrestrial fauna recorded on the island include the endemic pompadour green pigeon (Treron pompadora), Critically Endangered bright babul blue (Azanus ubaldus), Endangered Asian elephant (Elephas maximus), Vulnerable saw-scaled viper (Echis carinatus), little ringed plover (Charadrius duius), and Kentish plover (Charadius alexandrinus). Another two species that are listed as Near Threatened - the grey francolin (Francolinus pondicerianus) and barking deer (Muntiacus muntjak) - were also recorded on the island. The sightings of wild elephants were particularly significant. They reach the island by crossing the narrow sea passage between the mainland and the island. 


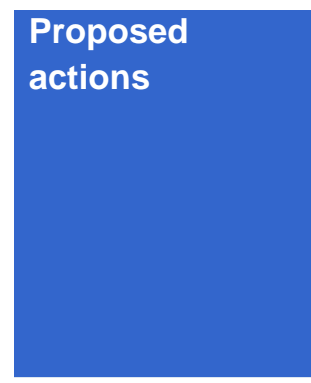

Proposed

improvements

Carrying

capacity for

tourism

activities
A conservation area encompassing the coastal waters around this island and Kakkativu is proposed (Figure 58). The type and degree of protection must be decided upon after detailed studies, as recommended in Chapter 6.

The island has a high potential to be developed as a nature-tourism destination because there is high ecosystem and species diversity and is close to the mainland. Nature tourism activities such as nature trails and bird watching can be developed easily on the island.

A detailed biodiversity study must be conducted to document the natural resource base. It is also recommended that a zonation plan is developed for all the ecosystems and the island, including the coral and seagrass meadows in the surrounding areas declared as a protected area as shown in Figure 58, to ensure long-term viability of the rich biodiversity found on this island.

At a given time, the island can support up to 50 visitors. Construction of permanent structures in the island is not recommended. 


\section{Iranaitivu North Island (Sinhala: Erandoowa; Dutch: Enkhuizen)}

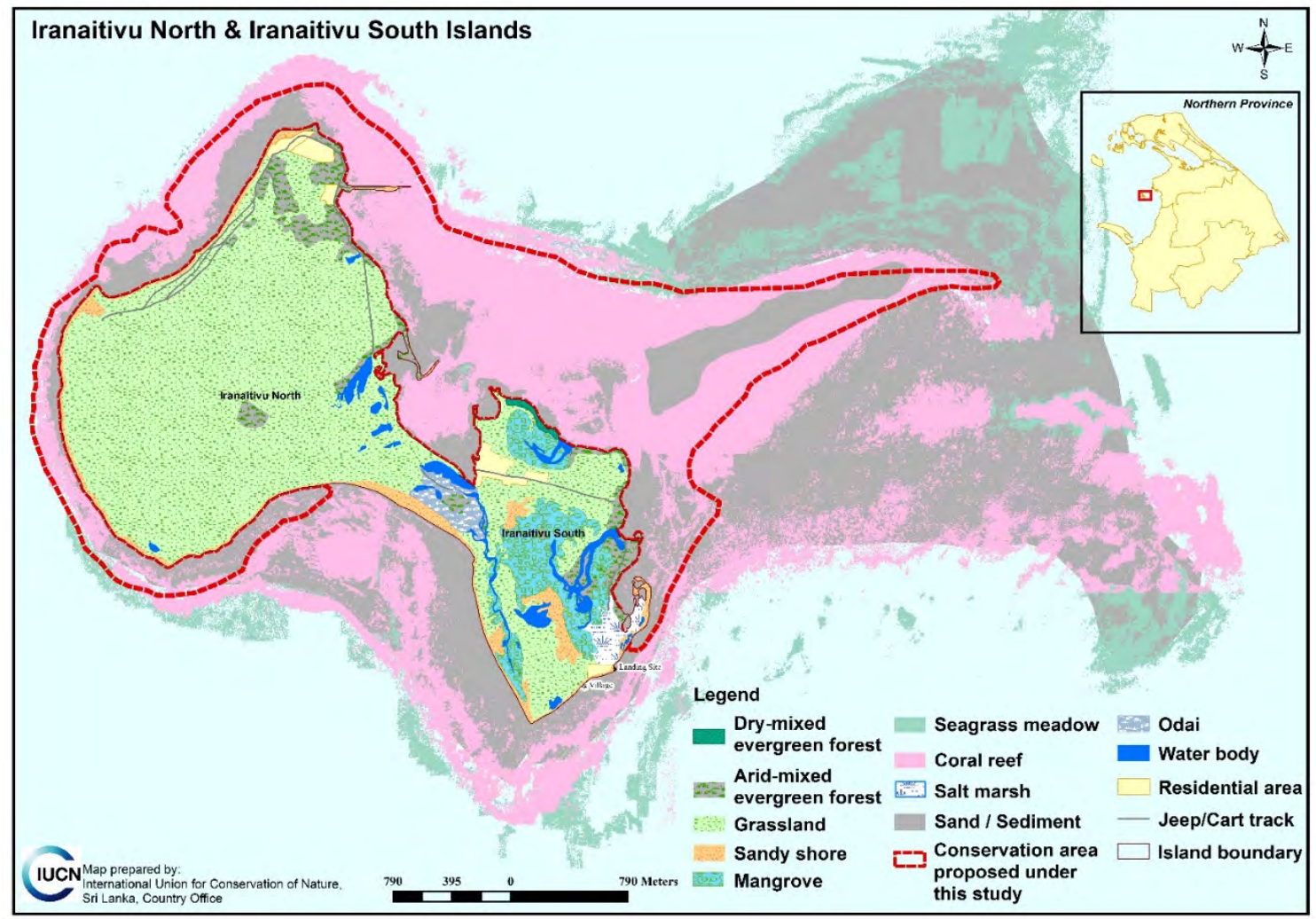

Figure 59. Map of the Iranaitivu North and Iranaitivu South islands, ecosystems, land use and proposed conservation area 

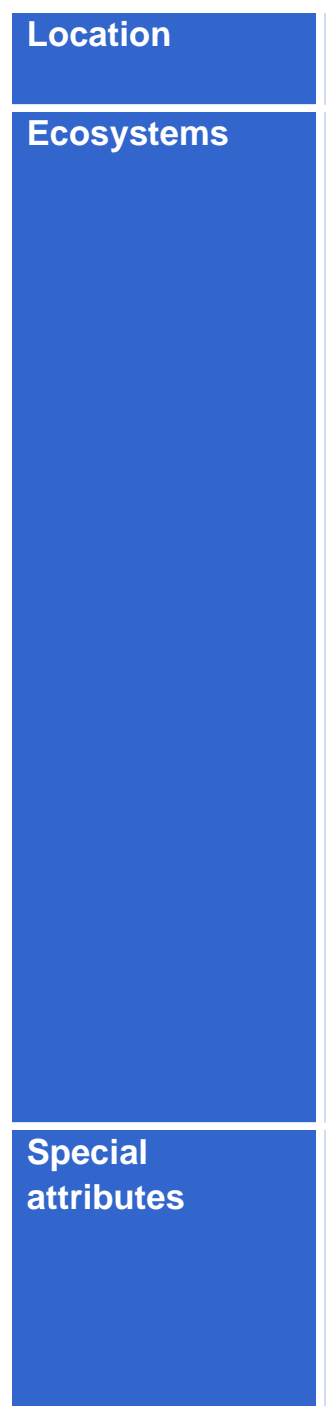

Proposed

actions

Proposed

improvements
This island has an extent of $4.22 \mathrm{~km}^{2}$ and is located in the Poonakary Divisional Secretariat of the Kilinochchi District (Figure 59).

\section{Terrestrial ecosystems}

Grasslands are the main type of natural ecosystem in the island. In addition, a small patch of scrubland, salt marshes are also found. A total of 49 floral and 47 faunal species were recorded from this island. Fauna species are represented by one land snail, two dragonflies, eight butterflies, three reptiles, 31 bird species and two mammal species.

\section{Marine ecosystems}

Although there are two islands Iranaitivu North and South, they should be considered as a single island for describing the marine area. Coral reefs and seagrass meadows are the main underwater ecosystems. The main coral areas were in the southern and western sides of the island. The fringing reef has a reef lagoon, which is about $300 \mathrm{~m}$ at its widest point in the northern areas of Iranaitivu North Island. The average width of the reef is about $150 \mathrm{~m}$ and the seaward margin is at a depth of about eight metres. The following species of corals were recorded on the fringing reef; Acropora cytherea, A. formosa, A. valenciennesi, Porites lutea, Porites lobata, Goniastrea pectinata, Favia speciosa, Montastrea valenciennesi, Goniastrea retiformis, G. edwardsi, Echinopora lamellosa, Montipora hispida, Montipora foliosa, $M$. aequituberculata, Turbinaria mesenterina, Echinopora lamellose and Leptoria phrygia. Most corals were in poor condition. There was much dead coral covered by Turbinaria seaweed and other algae.

Four faunal species - the land snail Cryptozona semirugata, saw-scaled viper (Echis crinatius), little ringed plover (Charadius dubius), and Kentish plover (Charadius alexandrinus) - listed as Vulnerable and two species - little branded swift (Pelopidas agna) and great crested tern (Sterna bergii) — listed as Near Threatened, were recorded on the island. In addition, there is a herd of feral cattle roaming freely.

A marine area shown in Figure 59 is recommended as a conservation area. The type and degree of protection must be decided upon after detailed studies, as recommended in Chapter 6.

Iranaitivu North has an aesthetic appeal because of its expanse of grasslands. The feral cattle found here can be used to transport tourists within the island via bullock carts. The island's surrounding shallow sea and sandy beaches can support activities such as sunbathing, kite surfing and wind surfing.

The areas of salt marshes on island are frequented by wading birds, thus providing opportunities for bird watching. The island also offers opportunities for cultural tourism, connected with religious and fishing activities. There is also the potential for snorkelling and research-based tourism on the island, because of coral reefs and seagrass meadows in the surrounding sea.

A nature trail covering different habitats can be established and used for nature interpretation. It is recommended that the areas recommended in Annex 5 within this island are protected. Providing lodging facilities for visitors will also be critically important. These will have to be developed ensuring that environmental safeguards are included. (See Chapter 6.) 
The island cannot support more than 50 tourists at a given time.

capacity for

tourism

activities 


\section{Iranaitivu South Island (Sinhala: Uoona Duwa; Dutch: Hoorn)}

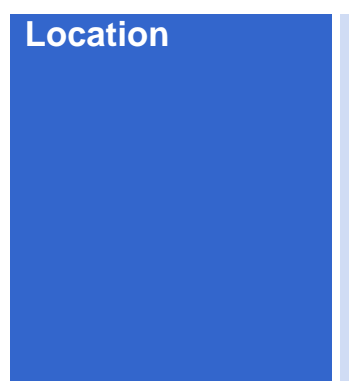

Ecosystems

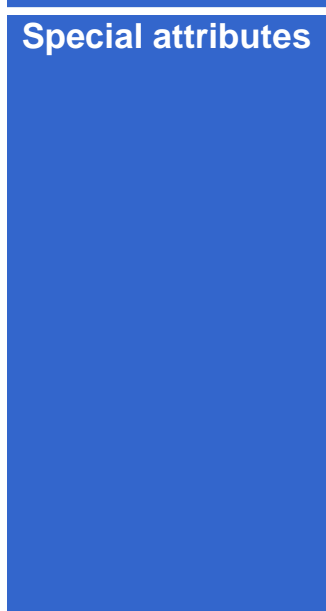

Proposed actions

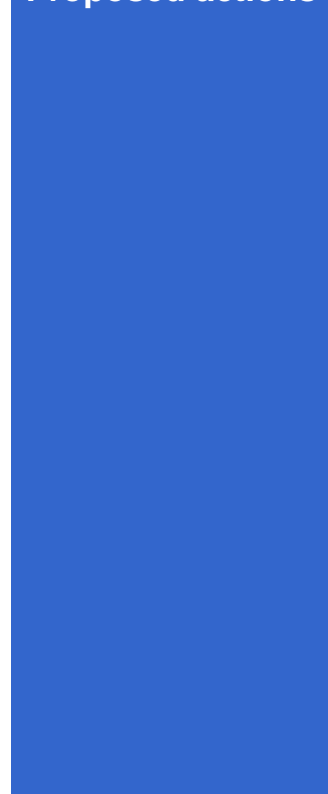

Iranaitivu South Island has an extent of $1.71 \mathrm{~km}^{2}$ and belongs to the Poonakary Divisional Secretariat in the Kilinochchi District. There are no permanent inhabitants on the island. As in the case of Iranaitivu North, this island was inhabited by people in the past and remnants of their old houses can still be seen in the north-western end of the island. A small fishing village and a landing site are found in the south-eastern end of the island, used by fishermen during the fishing season. The Sri Lanka navy operates a small camp near the fishing village (Figure 59).

The main ecosystems found on the island include grasslands, Avicennia marina-dominant mangroves, salt marshes are also found. Altogether, 22 floral species and 40 faunal species were recorded during the survey. The faunal assemblage observed on the island comprised one land snail, two dragonflies, six butterflies, two reptiles, 27 birds and two mammals.

\section{Terrestrial ecosystems}

The attraction of this island is the large mangrove patch found in the centre of the island. Mangrove flora include two species - Bruguiera cylindrica and Sonneratia alba - both listed as Endangered. Further, three Vulnerable species - the land snail (Cryptozona semirugata), large salmon Arab (Colotis fausta) and saw-scaled viper (Echis carinatus) —and two Near Threatened species faunal species - little branded swift (Pelopidas agna) and the great crested tern (Sterna bergii) — were also recorded on the island.

\section{Marine ecosystems}

The marine area of both Iranaitivu North and South should be considered as a marine area. The eastern side of Iranaitivu South had a long shallow patch of sand containing patches of seagrass and coral rubble.

A marine area shown in Figure 59 is recommended as a conservation area. The type and degree of protection must be decided upon after detailed studies, as recommended in Chapter 6 .

Iranaitivu South also has a population of feral cattle (Bos indicus) and these animals can be used to transport tourists within the island via bullock carts. The occurrence of saw-scaled viper Echis carinatus, which is one of the five fatally poisonous snakes in Sri Lanka, is a feature to attract scientists. The presence of threatened species on the island can also promote nature tourism and attract researchers.

The attractive scenery of grasslands, salt marshes, marshes and mangroves, with wading migratory birds present opportunities for bird watching. Sandy beaches, shallow waters and the hot sun can support activities, such as sunbathing, wind surfing and kite surfing. The seagrass meadows and coral reefs in the vicinity provide opportunities for snorkelling.

At present, landowners have abandoned the island but with nature-tourism development, there can be livelihood opportunities. 
Proposed

improvements

Carrying capacity

for tourism

activities
A detailed biodiversity survey of the island should be conducted, and areas proposed in Annex 5 should be declared as a protected area. Nature trails within the mangroves and salt marshes should be also be developed.

The site can support up to 25 day visitors at a given time. Lodging facilities are not recommended 


\section{Islands at Adam's Bridge}

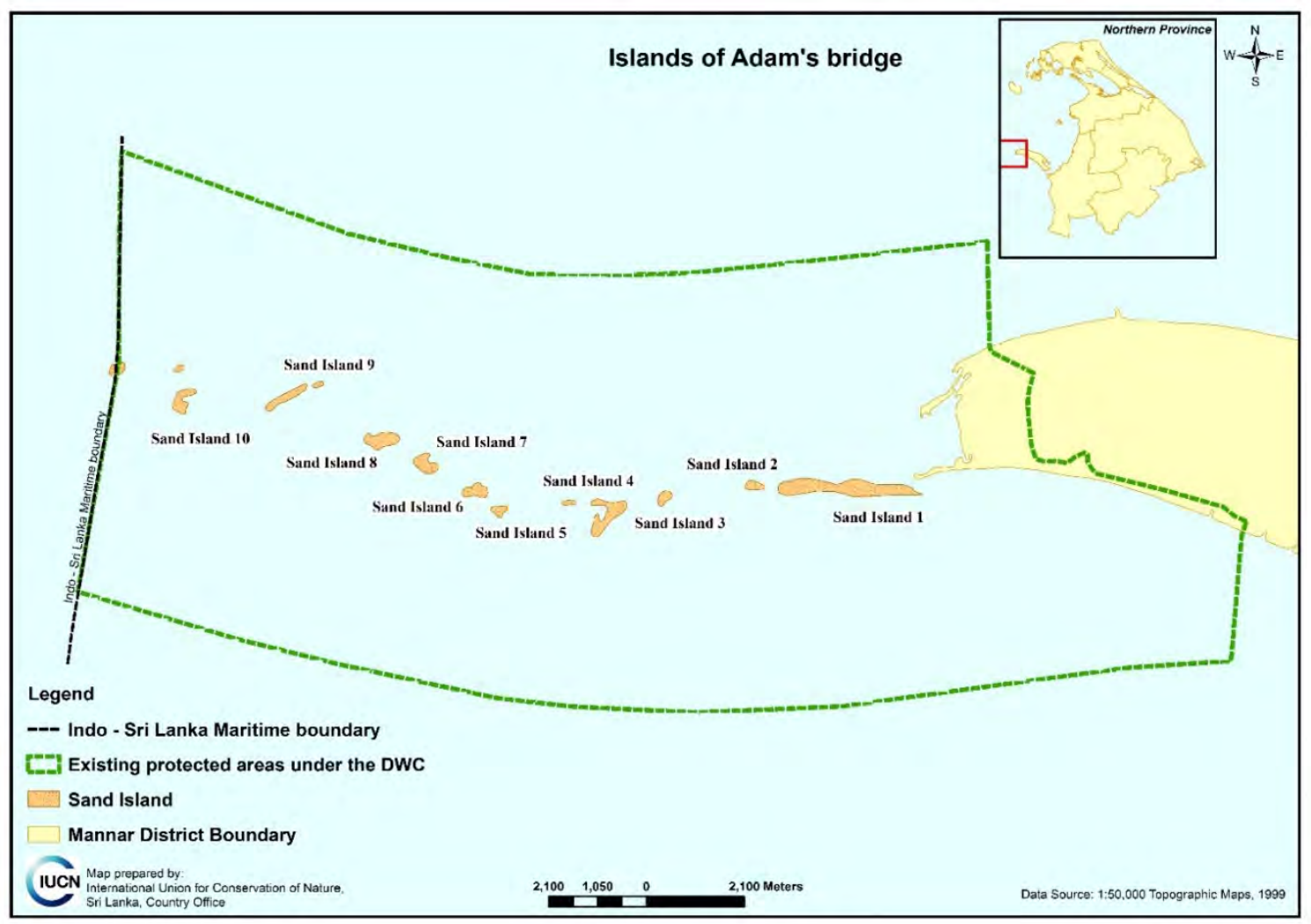

Figure 60. Map of the Adam's Bridge Islands showing existing protected area boundary 


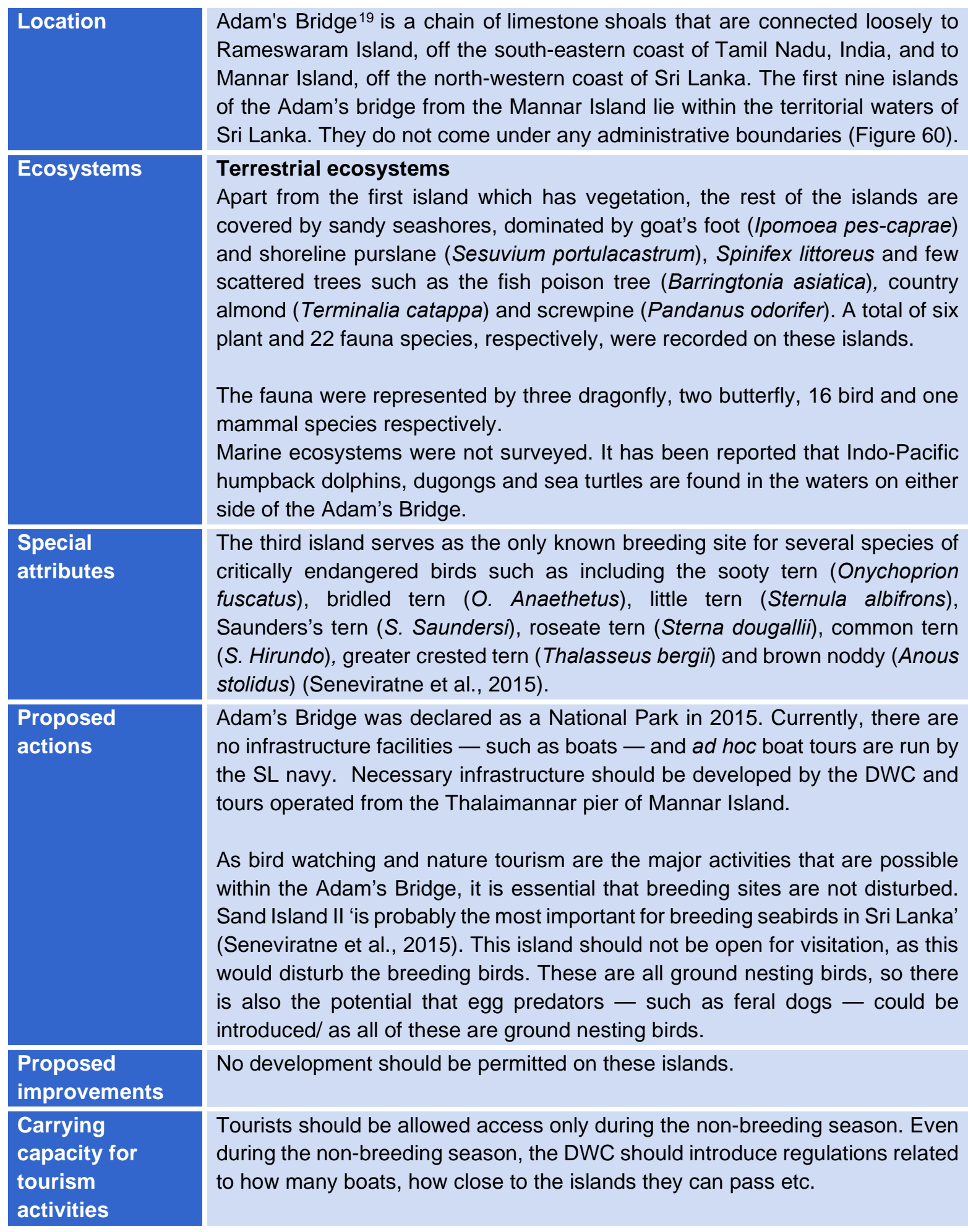

19 Only Sand bar IV was surveyed from terrestrial systems and species. 


\section{Kachchativu Island (Pali: Kachchatheetha; Sinhala: Kachchadoova)}

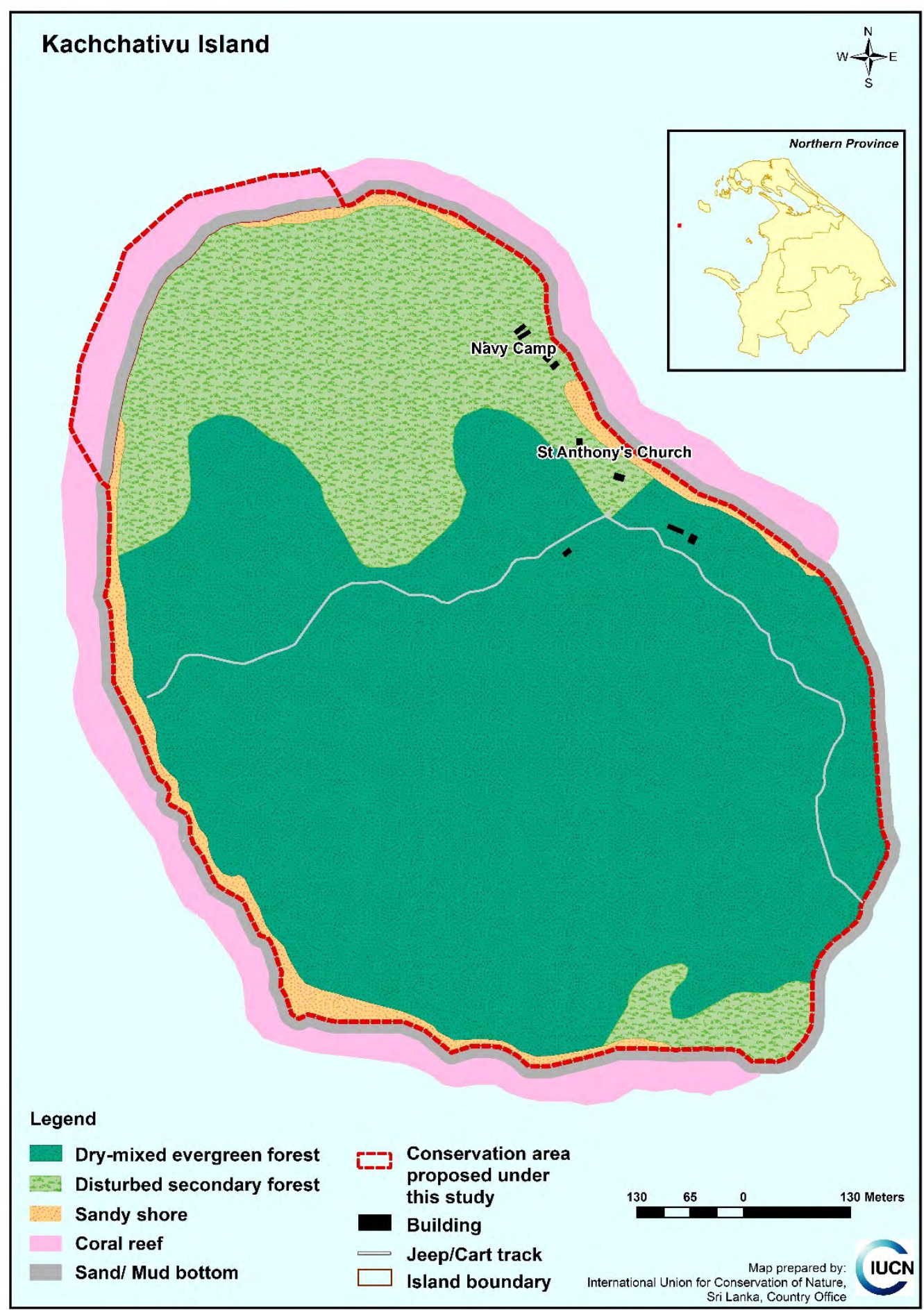

Figure 61. Map of Kachchativu Island, ecosystems, land use and proposed conservation area 

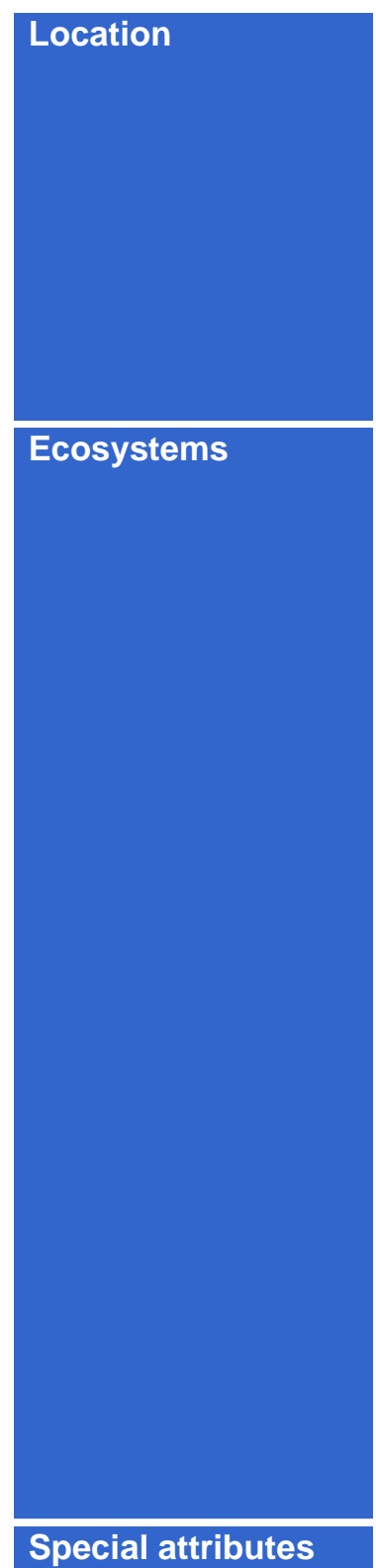

Proposed actions
The island has an extent of about $0.68 \mathrm{~km}^{2}$ and belongs to the Neduntivu (Delft) Divisional Secretariat of the Jaffna District (Figure 61). The only building located in the island is an old church (St. Anthony's Church) (Figure 62), which dates to the Dutch period. According to the Sirima-Shastri agreement signed on the $24^{\text {th }}$ June 1974 , construction of permanent buildings or permanent human inhabitations is not allowed in the island. Annually, this church hosts a festival to St Anthony, the patron saint of fishermen. Participation for the 2018 festival was estimated to be about 1,920 devotees from Tamil Nadu and over 4,000 locals from various parts of the island.

\section{Terrestrial ecosystems}

Dry mixed evergreen forests, arid mixed evergreen forests, sandy seashores and small extents of seashore scrublands are observed on the island. Manilkara hexandra and helicopter tree (Gyrocarpus americanus) are the most abundant plants observed in arid mixed evergreen forests; while beach naupaka/half flower (Scaevola taccada), Pemphis acidula and Premna obtusifolia are the dominant plant species observed in seashore scrublands. The sandy seashores were covered with goat's foot (Ipomoea pes-caprae) and shoreline purslane (Sesuvium portulacastrum). A total of 50 plant and 34 fauna species, respectively, were recorded on the island. The faunal assemblage comprised one land snail, two dragonfly, 12 butterfly, three reptile, 14 bird and two mammal species, respectively.

\section{Marine ecosystems}

A small coral area is found on the northern end of the island. The reef quality is poor with low coral cover and few species of fish. The main coral species were Acropora hyacinthus, A. cytherea, Montipora aequituberculata, Pocillopora damicornis and Favia sp. Three species of marine bivalves divided among 3 families and about 20 species of marine gastropods divided among 20 families were identified from specimens collected on the beach. Movement of sand underwater is relatively high and therefore reef development is poor around the island.

Erosion was also high especially along the southern shore.

The cctopus bush (Tournefortia argentea) recorded near the western coast of the island is a very rare plant in Sri Lanka even though it is a common species in the Indo-Pacific region. It is listed as nationally Endangered and has not been recorded in the country since 1939.

Several notable species of terrestrial fauna were also recorded on the island. These include Bibron's sand skink (Eutropis bibronii) listed as a nationally Endangered species; Cryptozona semirugata and Ferguson's toad (Duttuphrynus scaber) listed as a nationally Vulnerable species; and great crested tern (Sterna bergii) listed as a nationally Near Threatened species.

A small marine area in the northern part of the island is recommended as a conservation area (Figure 61). The type and degree of protection must be decided upon after detailed studies, as recommended in Chapter 6.

The presence of several interesting flora and fauna on Kachchativu Island presents opportunities to promote nature-based tourism. The island's 
cultural and religious events/festivals provide value-addition for tourism development.

Coral reefs, sandy beaches and shallow seas around the island can be used snorkelling and wind surfing.

\section{Proposed}

improvements

Carrying capacity
During the festival season, human actions should be managed. Regulations should be issued to prevent solid and other pollution during the festival season as well as preventing the wanton cutting of trees. (See Chapter on Recommendations for more details.) The island should be zoned so that certain areas are protected from people entering those areas.

Carrying capacity for this island cannot be discussed as it had been the longterm home of an annual festival to St. Anthony. It is the management of human behaviour that needs attention as noted in the row above.

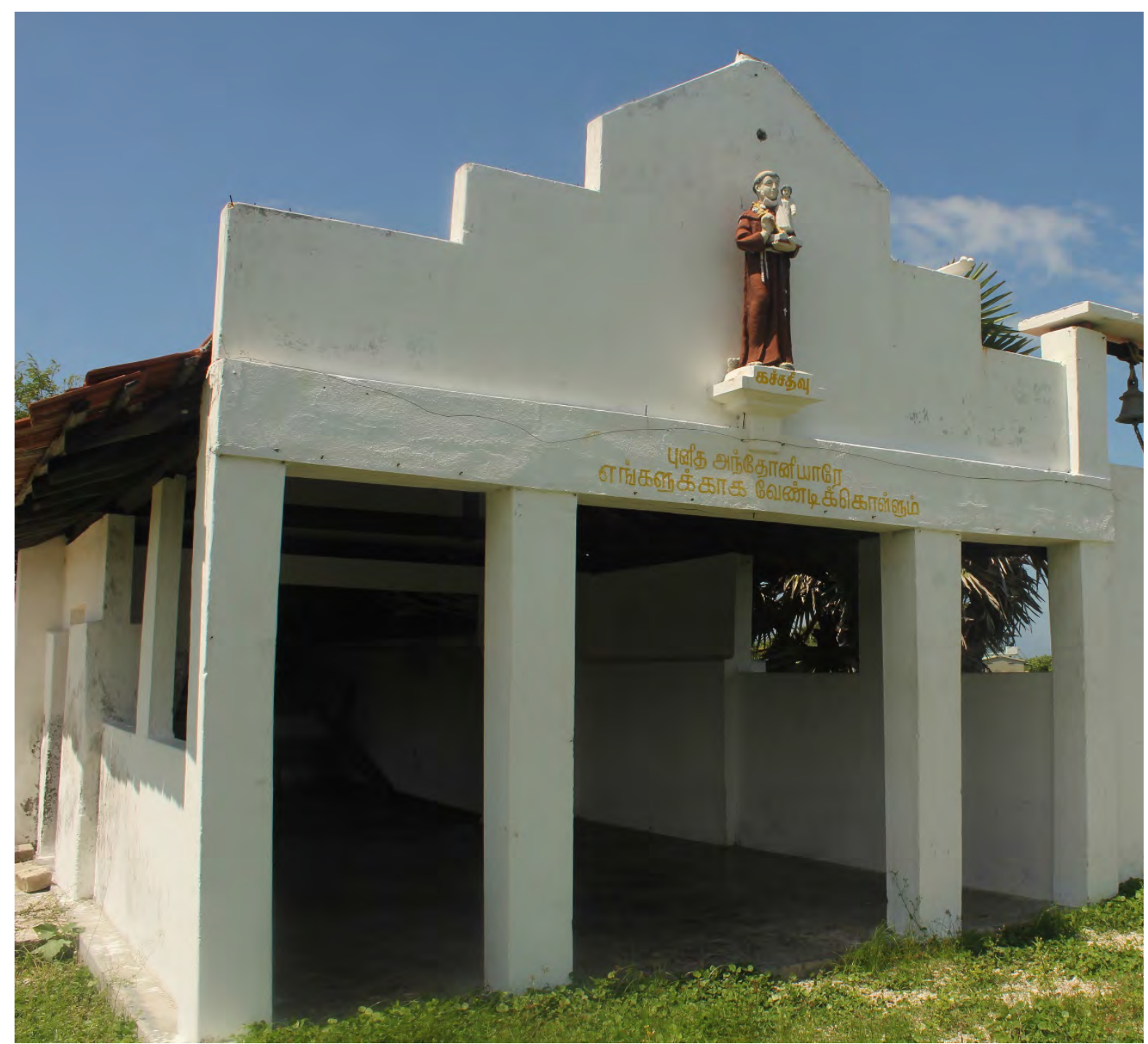

Figure 62. Kachchativu Church, where an annual festival is held, with pilgrims from both India and Sri Lanka

(๔ IUCN/Naalin Perera) 


\section{Kakerativu Island (Sinhala: Sakkaradoova; Dutch: Calienye)}

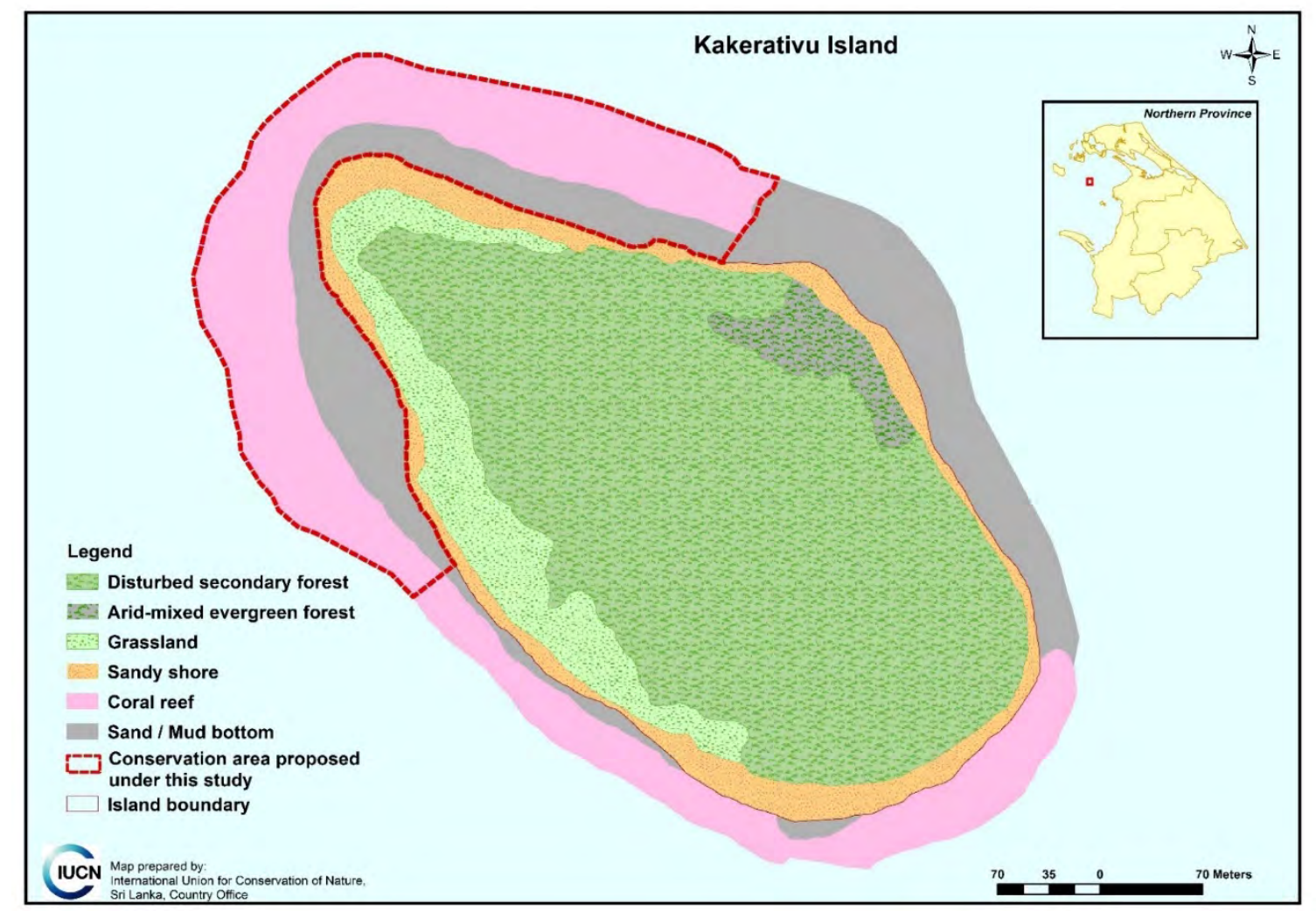

Figure 63. Map of Kakerativu Island, showing ecosystems, land use and proposed conservation area 


\begin{tabular}{|c|c|}
\hline Location & $\begin{array}{l}\text { This island is about } 0.14 \mathrm{~km}^{2} \text { and belongs to the Neduntivu (Delft) Divisional } \\
\text { Secretariat in the Jaffna District (Figure 63). }\end{array}$ \\
\hline Ecosystems & $\begin{array}{l}\text { Terrestrial ecosystems } \\
\text { Sandy seashores and seashore scrublands are found on the island. A total of } 32 \\
\text { plant and } 31 \text { fauna species, respectively, were observed on the island. The fauna } \\
\text { observed in the island comprised one dragonfly, two land snail, five butterfly, one } \\
\text { reptile, } 20 \text { bird and two mammal species, respectively. } \\
\text { Marine ecosystems } \\
\text { Coral patches occur around the island. A small coral area was investigated on } \\
\text { the north-western corner of the island. The common living corals were Acropora } \\
\text { hyacinthus, Montipora digitata, M. aequituberculata, Goniastrea retiformis, } \\
\text { Platygyra daedalea, Favia matthaii, Favites halicora and Porites spp. } \\
\text { Damselfish (Pomacentridae) were common but no other large reef fish were } \\
\text { observed in the investigated area. }\end{array}$ \\
\hline & $\begin{array}{l}\text { Guettarda speciosa is the only notable plant species found in the seashore } \\
\text { scrubland of the island. } \\
\text { The nationally Critically Endangered snail, Trachia vittata; as well as the } \\
\text { nationally Vulnerable land snail Cryptozona semirugata and little-ringed plover } \\
\text { (Charadrius dubius); the Near Threatened dark blue tiger (Tirumala septentrionis) } \\
\text { and the great-crested tern (Sterna bergii) were recorded in the island. }\end{array}$ \\
\hline & $\begin{array}{l}\text { A marine area in the north-western part of the island is recommended as a } \\
\text { conservation area (Figure } 63 \text { ). The type and degree of protection must be decided } \\
\text { upon after detailed studies, as recommended in Chapter } 6 \text {. } \\
\text { Sandy seashores, coral reefs and seagrass meadows provide opportunities to } \\
\text { promote beach-based activities and snorkelling. As there are notable species on } \\
\text { this island, nature-based tourism could also be promoted. In addition, the island } \\
\text { has a survey beacon, which is an archaeological monument that could also be } \\
\text { used as an attraction. }\end{array}$ \\
\hline $\begin{array}{l}\text { Proposed } \\
\text { improvements }\end{array}$ & $\begin{array}{l}\text { Tourism specific infrastructure facilities will have to be constructed if the island is } \\
\text { to be promoted as a major tourism destination. This will include identification of } \\
\text { tourism zones, specific tourism attractions and further development of these with } \\
\text { proper interpretation, establishing a visitor centre to create awareness among } \\
\text { visitors about the type of attractions available in and around the island, } \\
\text { establishing nature trails, bird watching facilities, boating decks, snorkelling } \\
\text { facilities. All these will have to be carried out ensuring the integration of } \\
\text { environmental safeguards as listed in Chapter } 6 \text {. }\end{array}$ \\
\hline $\begin{array}{l}\text { Carrying } \\
\text { capacity for } \\
\text { tourism } \\
\text { activities }\end{array}$ & Up to 25 visitors can be accommodated in the island at a given time. \\
\hline
\end{tabular}




\section{Kakkativu Island (Sinhala: Kaakadoova)}

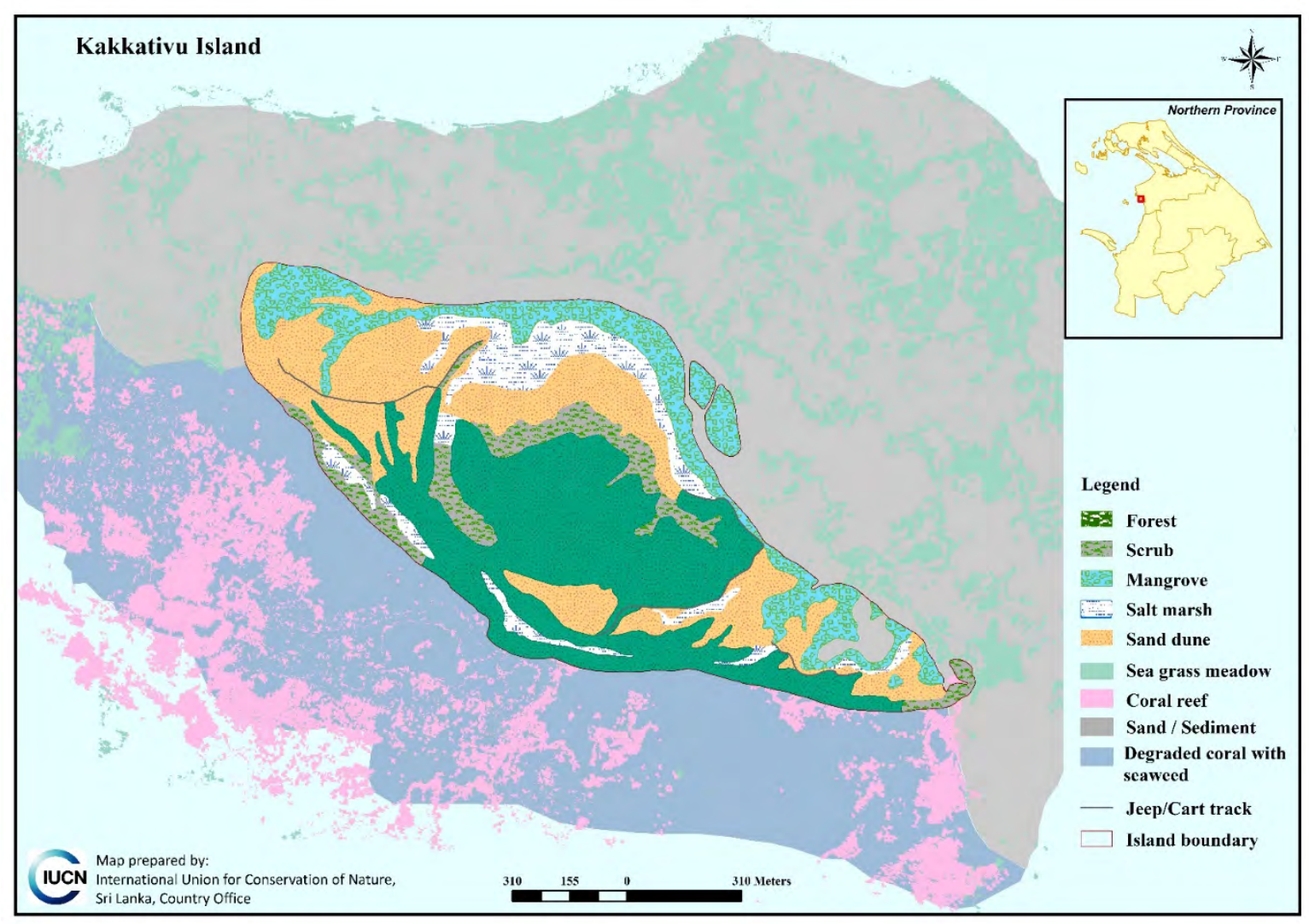

Figure 64. Map of Kakkativu Island, showing ecosystems and other land use 


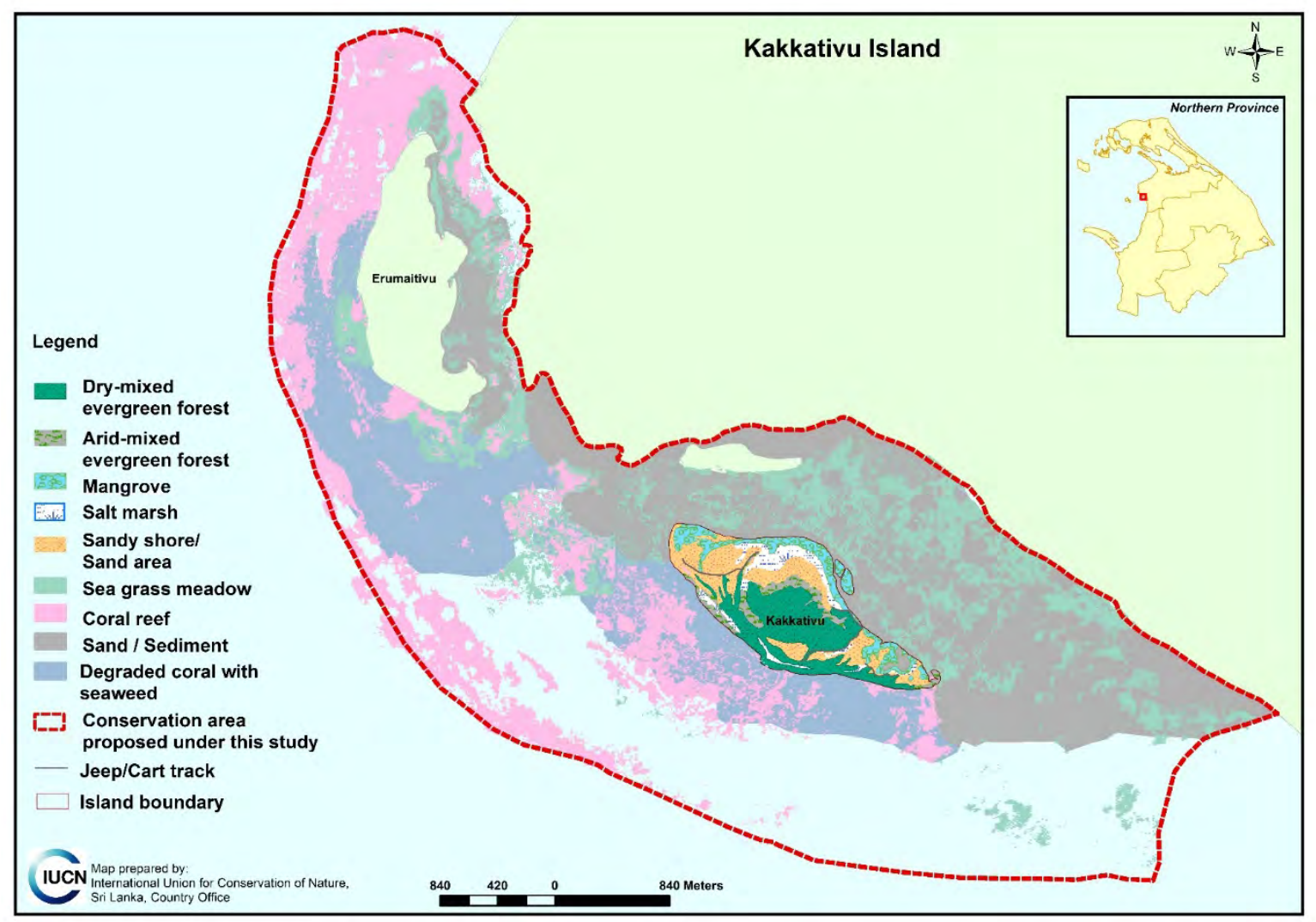

Figure 65. Map showing the proposed conservation area encompassing Erumaitivu and Kakativu Islands 


\begin{tabular}{|c|c|}
\hline Location & $\begin{array}{l}\text { he island is about } 1.1 \mathrm{~km}^{2} \text { and belongs to the Poonakary Divisional Secretariat } \\
\text { the Kilinochchi District (Figure 64). }\end{array}$ \\
\hline Ecosystems & $\begin{array}{l}\text { Terrestrial ecosystems } \\
\text { Arid mixed evergreen forests, mangroves, seashore scrublands, grasslands, and } \\
\text { salt marshes are found on this island. A total of } 48 \text { plant and } 29 \text { fauna species } \\
\text { were recorded on the island. The faunal assemblage comprised four dragonfly, } \\
12 \text { butterfly, } 12 \text { bird and one mammal species, respectively. } \\
\text { Marine ecosystems } \\
\text { Corals in good condition were present on the western and southern sides of the } \\
\text { island. This section of the coral reef is the southern section of the coral reef of } \\
\text { Erumaitivu. Unlike the reef at Erumaitivu, this section is dominated by large } \\
\text { domes of Favia speciosa, Favia matthaii, Favites halicora, Porites lutea and other } \\
\text { Porites species. There were small patches of branching Acropora spp including } \\
\text { A. Formosa, Montipora digitata, M. foliosa and M. aequituberculata. The southern } \\
\text { section of the reef was in relatively poor condition with patches of dead coral. } \\
\text { Fish were scarce in this section of the reef. The most abundant species was the } \\
\text { Indian damselfish (Pomacentrus indicus). }\end{array}$ \\
\hline & $\begin{array}{l}\text { Colubrina asiatica and Manilkara hexandra are the notable plant species } \\
\text { observed on the island. } \\
\text { Elephant (Elephas maximus) (EN); little ringed plover (Charadrius dubius) (VU) } \\
\text { and plain orange tip (Colotis aurora (VU), barking deer (Muntiacus muntjak) (NT), } \\
\text { great crested tern (Sterna bergii) (NT), dark blue tiger (Tirumala septentrionis) } \\
\text { (NT) were observed on the island. }\end{array}$ \\
\hline & $\begin{array}{l}\text { A conservation area encompassing the coastal waters around this island and } \\
\text { Erumaitivu is proposed (Figure 58). The type and degree of protection must be } \\
\text { decided upon after detailed studies, as recommended in Chapter } 6 \text {. } \\
\text { The high ecosystem and species diversity provide opportunities to develop } \\
\text { nature-based tourism activities. }\end{array}$ \\
\hline $\begin{array}{l}\text { Proposed } \\
\text { improvements }\end{array}$ & $\begin{array}{l}\text { Tourism specific infrastructure facilities will have to be improved if the island is to } \\
\text { be promoted as a major tourism destination. This will include identification of } \\
\text { tourism zones, specific tourism attractions and further develop of these with } \\
\text { proper interpretation, establishing a visitor centre to create awareness among } \\
\text { visitors about the type of attractions available in and around the island, } \\
\text { establishing nature trails, bird watching facilities. All these will have to be carried } \\
\text { out ensuring the integration of environmental safeguards. }\end{array}$ \\
\hline & Up to 50 visitors can be accommodated in the island at a given time. \\
\hline
\end{tabular}




\section{Kalliaditivu Island (Sinhala: Galadi Doova)}

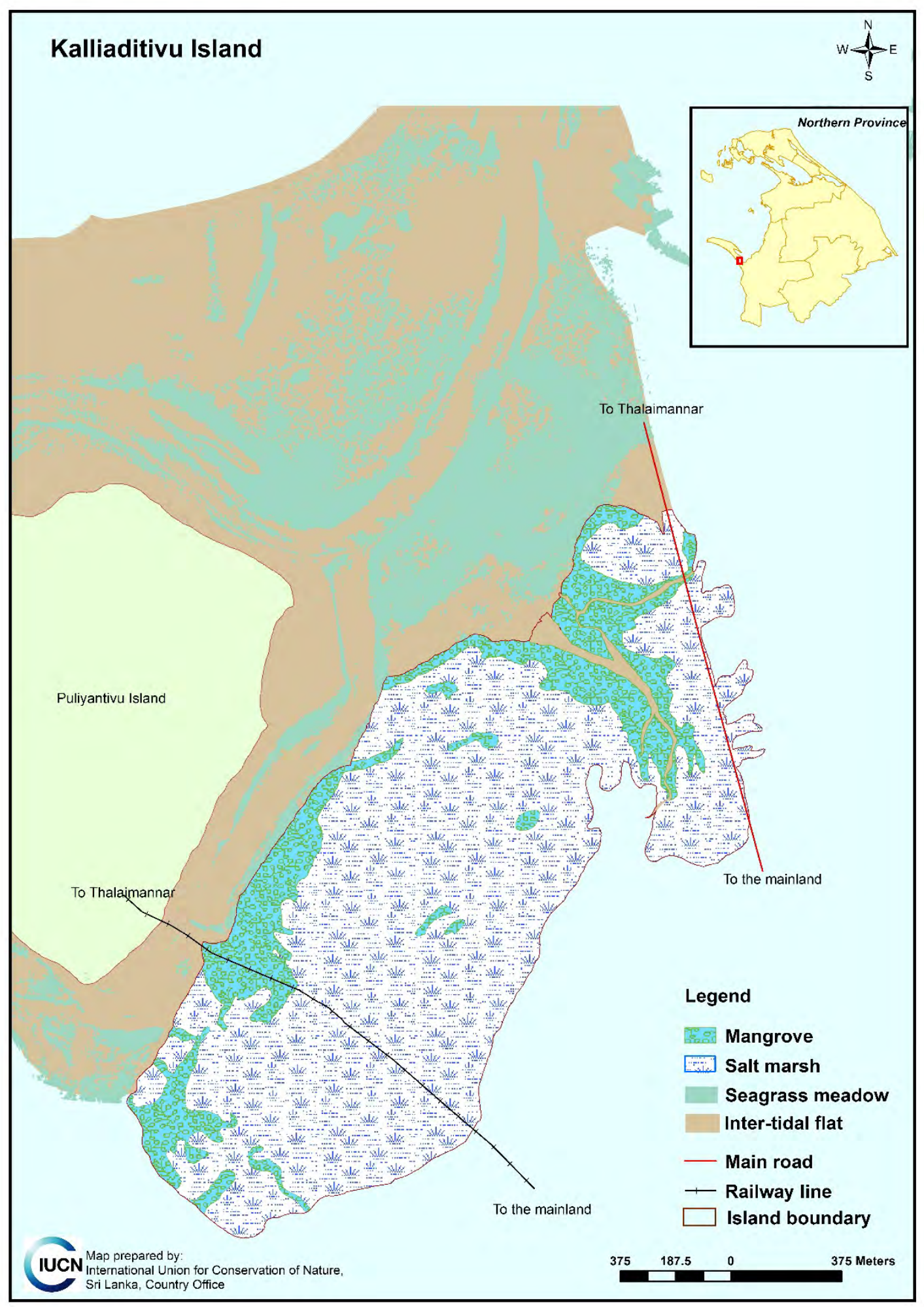

Figure 66. Map of the Kalliaditivu Island, showing ecosystems and other land use

(Note that the entire island is within a DWC protected area, please refer to Figure 52) 

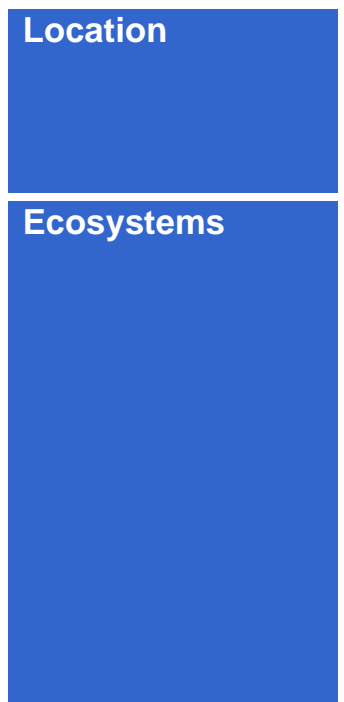

Special attributes

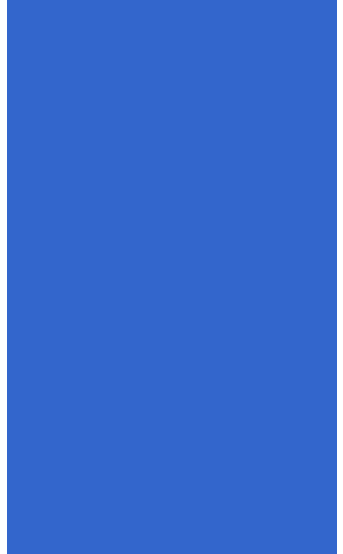

Proposed actions

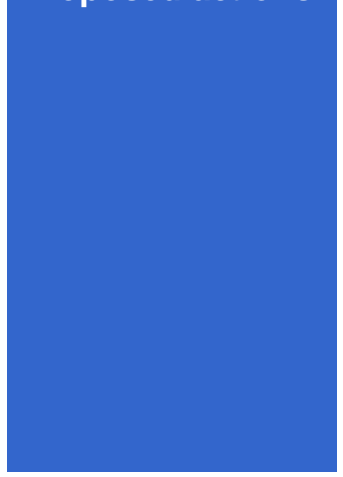

Proposed

improvements

arrying capacity

for tourism

activities
Kalliaditivu Island extends over $1.71 \mathrm{~km}^{2}$ and belongs to the Mantai Divisional Secretariat in the Mannar District. The island is not inhabited by people. The only land access is via the railway line, although the island can also be reached by boat (Figure 66).

Terrestrial ecosystems Mangroves and salt marshes are the dominant ecosystems observed on the island. Around the island re tidal flats. Kalliaditivu has a high level of biodiversity compared to other areas because of these ecosystems and its location within the Vankalai Bird Sanctuary. A total of 14 flora species recorded from the site. The dominant plants are Suaeda maritima, Salicornia brachiata and Avicennia marina, and Rhizophora mucronata. Further, 120 terrestrial faunal species represented by five species of dragonflies, four butterflies, 20 reptiles, 81 birds and ten mammals were recorded in the island.

Marine ecosystems were not surveyed.

Among the notable terrestrial species recorded in the island includes three species of endemic snakes - the flowery wolf snake (Lycodon osmanhilli), checkered keelback (Xenochropis asperrimus and Xenochrophis cf. piscator). Another five species found on the island - the wart snake (Acrochordus granulates), greater painted snipe (Rostratula benghalensis), Kentish plover (Charadrius alexandrines), small pratinocole (Glareola lacteal) and the Indian pipistrel (Pipistrellus coromandra) — are listed as nationally Vulnerable (VU). Further, three species listed as nationally Near Threatened - the paddy field parasol (Neurothemis intermedia), Eurasian collared dove (Streptopelia decaocto) and black-crowned night heron (Nycticorax nycticorax). Two species listed as nationally Data deficient (DD) - the rainbow mud snake (Enhydris enhydris) and Bombay gulf sea snake (Hydrophis mammilaris) were also recorded in the island.

The islands and its surrounds were declared in 2016 under the Fauna and Flora Protection act as a nature reserve that extends up to and includes Vidattaltivu Lagoon.

However, facilities - such as boats - have not yet been provided by the DWC and the area is still under the control of the SL navy.

Bird watching is the best nature-based tourism activity that can be carried out in the island. Boat rides among the mangrove and salt marsh ecosystems, surrounded by the shallow sea could also be promoted, but these will have to be managed by the DWC.

Kalliaditivu is located within the Vankalai Bird Sanctuary, and therefore, establishing nature trails, including raised walkways and canopy walks is possible on the island. Further, the island is used as a feeding ground by many migratory birds and therefore, hides and towers can be established to facilitate bird watching.

Non-motorised boats are recommended.

The site can support up to 100 bird watchers during the migratory season. Only day trips should be permitted. 


\section{Karaitivu Island (Sinhala: Karaduva)}

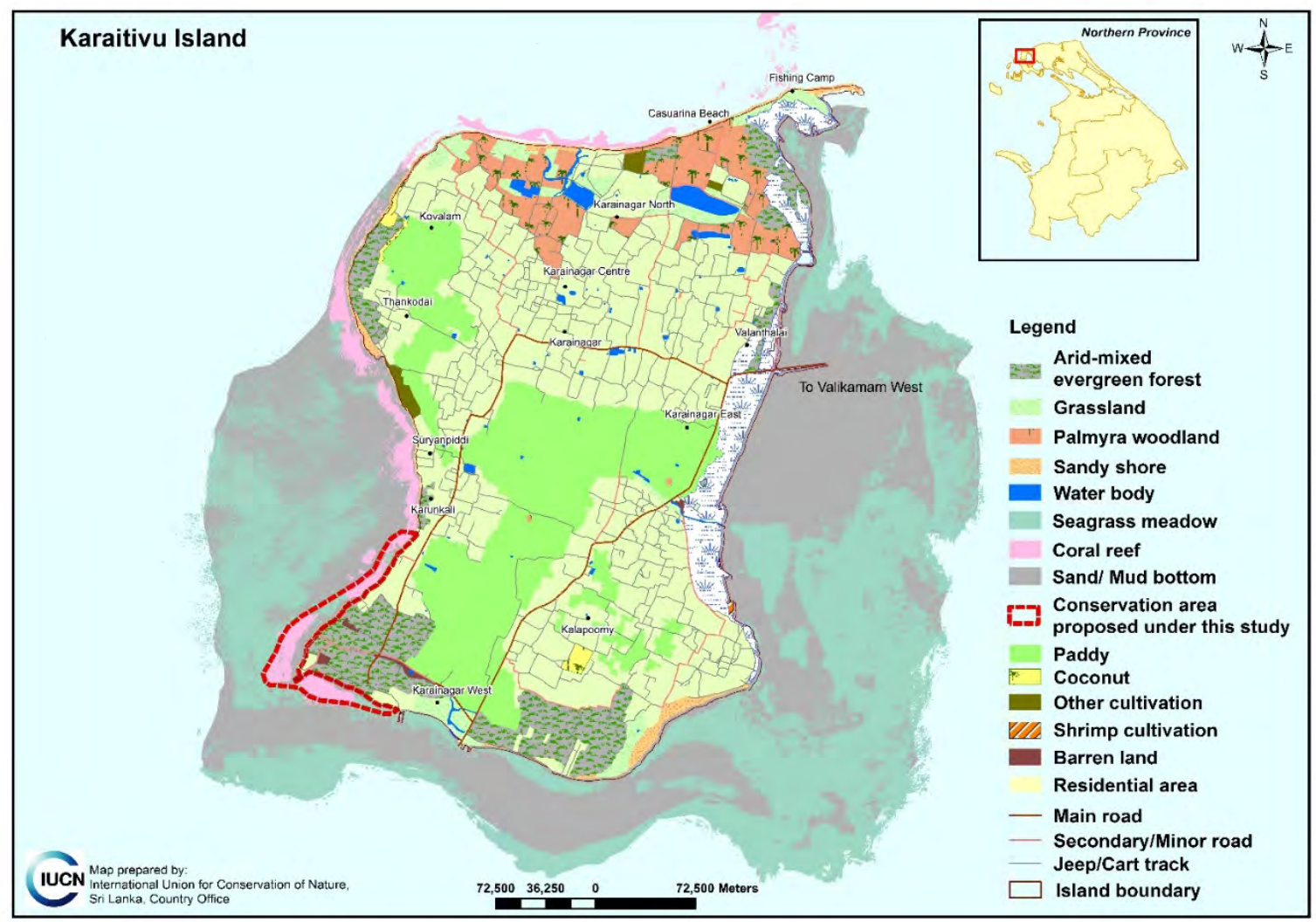

Figure 67. Map of the Karaitivu Island, showing ecosystems, land use and proposed conservation area 


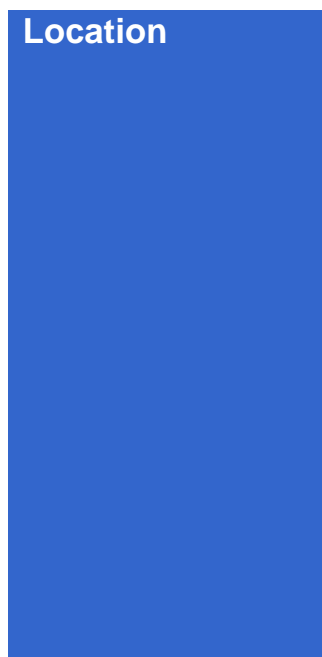

Ecosystems

\section{Special}

attributes
Karaitivu Island has an extent of about $22.95 \mathrm{~km}^{2}$ and belongs to the Karainagar Divisional Secretariat of the Jaffna District, with a resident population of 10,596 (Figure 67). It is an ancient site mentioned in the Nampotha by the name of 'Karadivayina'. It was known even in Tamil as 'Kaaraitheevu'. The name change occurred with the construction of the Punnalai causeway in the late 19th Century, and officially in 1922. Dutch records refer to the island by the name 'Nieuw Amsterdam'. However, its oldest name is 'Kaaradeepa'. The island is also referred to as 'Ahideepa' in the Buddhist Akitti Jaathaka, which relates the story of the Buddhist recluse Akitti who came to Kaaradeepa (Dharmawardana, 2006).

The name Karainagar is thought to be derived from karai, from the Tamil name for Canthium coromandelicum (Sinhala: kara). It is said that during famines, monks used to survive on the fruits of this plant.

\section{Terrestrial ecosystems}

This is a highly developed island with patches of palmyra woodland found in the north and north-east, and scrublands in the south and south-west. In the north there is a stretch of beach planted with Casuarina trees called Casuarina Beach. A total of 64 plant species and 65 faunal species were recorded from the island. The faunal species are represented by two species of dragonfly, one land snail, three scorpion, 16 butterfly, one reptile, 39 bird and three mammal species.

\section{Marine ecosystems}

A fringing reef like the fringing reef of Analaitivu is present along the western and northern coast side of the island. In addition, an offshore coral patch is present approximately $1 \mathrm{~km}$ north-east of Casuarina Beach. The dominant species of hard corals include tabulate and branching Acropora spp., Goniastrea retiformis, G. pectinata, Platygyra daedalea, Echinopora lamellosa and Porites spp. The average depth on the shoreward side was about $2 \mathrm{~m}$. The northern (seaward reef slope consisted of large coral domes belonging to the families of Faviidae (Favia, Favites, Goniastrea, Platygyra, and Leptoria) and Poritidae (Porites lutea and P. lobata).

Snappers (Lutjanidae), damselfish (Pomacentridae) and butterfly fish (Chaetodontidae) were present.

Casuarina beach is a popular bathing spot.

Cassine balae, an endemic species found near the beach is the only notable plant species observed in the island.

Notable faunal species observed in the island include the endemic Sri Lanka toque monkey (Macaca sinica), Trachia vittata, a land snail listed as a Nationally Critically Endangered species, large salmon Arab (Colotis fausta), little ringed plover (Charadrius dubius) and Kentish plover (Charadrius alexandrines) listed as Nationally Vulnerable species and the dark blue tiger (Tirumala septentrionis) and grey francolin (Francolinus pondicerianus) listed as nationally Near Threatened species.

Access to Fort Hammenheil is through this island. 
It is also a Special Management Area (SMA) under the CCZRMP (2016).

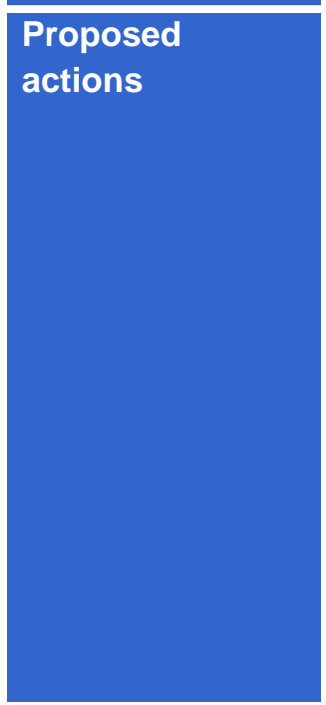

Proposed

improvements

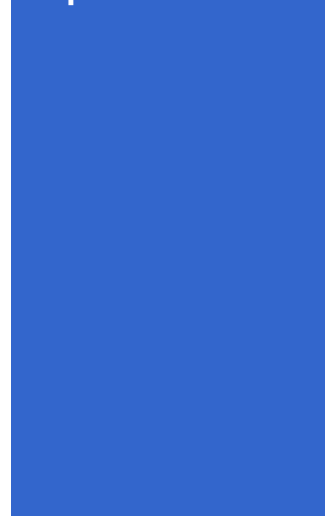

Carrying

capacity for

tourism

activities
A small marine area in the south-west of the island is proposed as a conservation area (Figure 67). The type and degree of protection must be decided upon after detailed studies, as recommended in Chapter 6.

Karaitivu holds cultural and archaeological monuments (such as Fort Hammenheil), thereby presenting opportunities for cultural tourism.

Its broad beaches and shallow seas are good for sun bathing, snorkelling and boat rides.

As the island serves as a feeding ground for migratory birds, bird watching could also be promoted.

Additionally, human settlements and road networks are present in the island that can help tourism development in the island.

Tourism specific infrastructure facilities will have to be improved if the island is to be promoted as a major tourism destination. This will include identification of tourism zones, specific tourism attractions and further develop of these with proper interpretation, establishing a visitor centre to create awareness among visitors about the type of attractions available in and around the island, establishing nature trails, bird watching facilities, boating decks and snorkelling facilities. All these will have to be carried out ensuring the integration of environmental safeguards. (See Chapter 6.)

It is also essential that a solid waste management programme is established immediately for the waste generated by tourists (both local and foreign) who come to Casuarina Beach and to see the Fort. Mooring points for boats carrying tourists should be established on the offshore.

Over-crowding should be prevented. Mass scale-tourism should not be conducted here. 


\section{Kayts or Velanai Island (Sinhala: Uruthota or Bellana; Dutch: Leiden)}

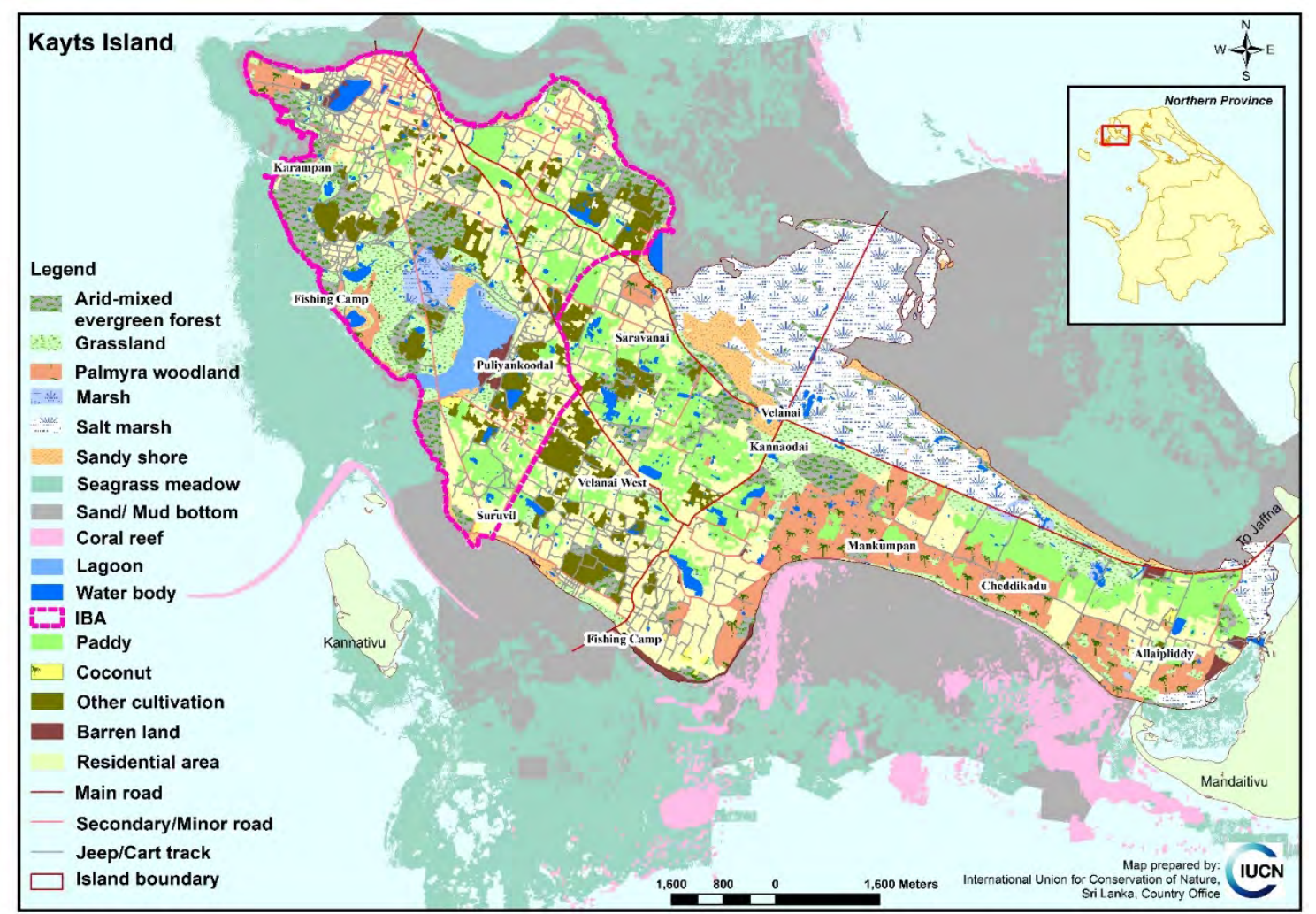

Figure 68. Map of Kayts Island, showing ecosystems, other land use and important bird area (IBA) 


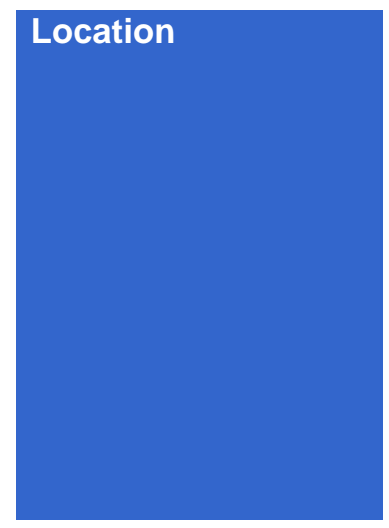

Ecosystems

Special attributes

Proposed actions

Proposed

improvements
Kayts extends over about $64 \mathrm{~km}^{2}$ and belongs to the Divisional Secretariats Atuvan (north island Kayts) and Velanai Islands South (Velanai) in the Jaffna District. It is a highly populated island with a population of 16,865 people (Figure 68). The island has a rich history. Kayts was known as 'Leiden' by the Dutch and 'Urkavaththurai' by Tamil citizens. It was also known as 'Urathota' and 'Tannidivayina' in the 'Nainathivu' inscriptions by Parakramabahu I ( $12^{\text {th }}$ century AD) and in the 'Nampotha'. In addition, it is mentioned in the 'Thovila' ritual as 'Kohombakankariya'. The name 'Kayts' first came to use as the island looked like a kite. The historian Baldaeus (1658) used the name 'Ourature' when referring to Kayts (Dharmawardana, 2006).

\section{Terrestrial ecosystems:}

Seashore scrublands, salt marshes, palmyra woodlands, home gardens, sandy seashores and wet pastures are the main ecosystems recorded on the island. A total of 68 floral species was recorded from the island. Among the floral species, palmyra (Borassus flabellifer) is one of the dominant plants found in the island that forms palmyra woodlands, on roadsides and in home gardens. In addition, 74 species of terrestrial fauna were recorded, represented by three dragonfly species, 25 butterflies, four reptiles, 40 birds and two mammals.

\section{Marine ecosystems were not surveyed.}

Kayts, along with Mandaitivu, is an Important Bird and Biodiversity Area $\left(\right.$ IBA) ${ }^{20}$ (Birdlife International, 2017a) (Figure 71). Large populations of lesser sandplover (Charadrius mongolus) and marsh sandpiper (Tringa stagnatilis) have been observed here (Birdlife International, 2017a). It is also a haven for migratory ducks and other shorebirds, as well as greater flamingos (Phoenicopterus roseus). About 25,000 ducks - including northern pintail (Anas acuta), garganey (Spatula querquedula), Eurasian wigeon (Anas penelope) - were reported one year near the Jaffna-Kayts causeway; over a 1,000 including the common teal (Anas crecca) and the northern shoveller (Anas clypeata) in Uppu Kuli and over 1,000 black-tailed godwits (Limosa limosa) in Mudali kuli (Kotagama et al., 2009).

Among the fauna species observed, four - the plain orange tip (Colotis aurora), saw-scaled viper (Echis carinatus), little-ringed plover (Charadrius dubius), and Kentish plover (Charadrius alexandrinus) - are listed as nationally Vulnerable, while another four species - the light-tipped demon (Indothemis carnatica), dark blue tiger (Tirumala septentrionis), grey francolin (Francolinus pondicerianus) and great crested tern (Sterga bergii) - are listed as nationally Near Threatened (NT). The presence of many bird species makes this island an ideal place for bird watching.

At present, a few sites of the island are used for local tourism. However, there is a high potential to develop the island as a nature or cultural tourism destination.

As Kayts has mangroves, nature trails - such as raised walkways and canopy walks - can be established in this island. The presence of salt marshes at Ariyalai and wading migratory birds provide opportunities to

20 Based on IBA criterion A4 which is that it is known to have predicatable congregations $\geq 1 \%$ of the global population of a species (Birdlife International, 2017b). 

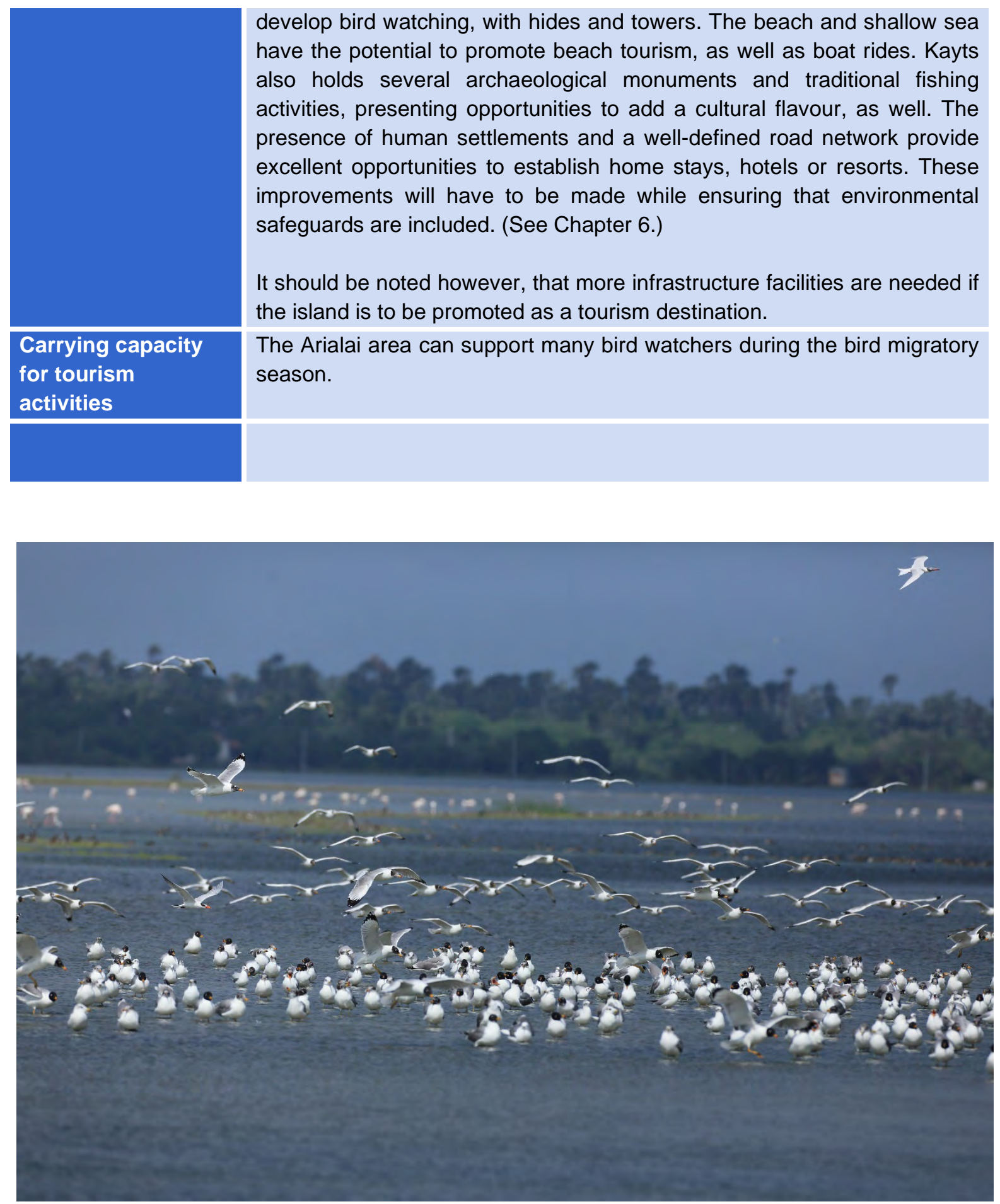

Figure 69. Migrant black-headed gulls (Chroicocephalus ridibundus) in Kayts 


\section{Kurikadduwan Island (Sinhala: Kiralakatuvana)}

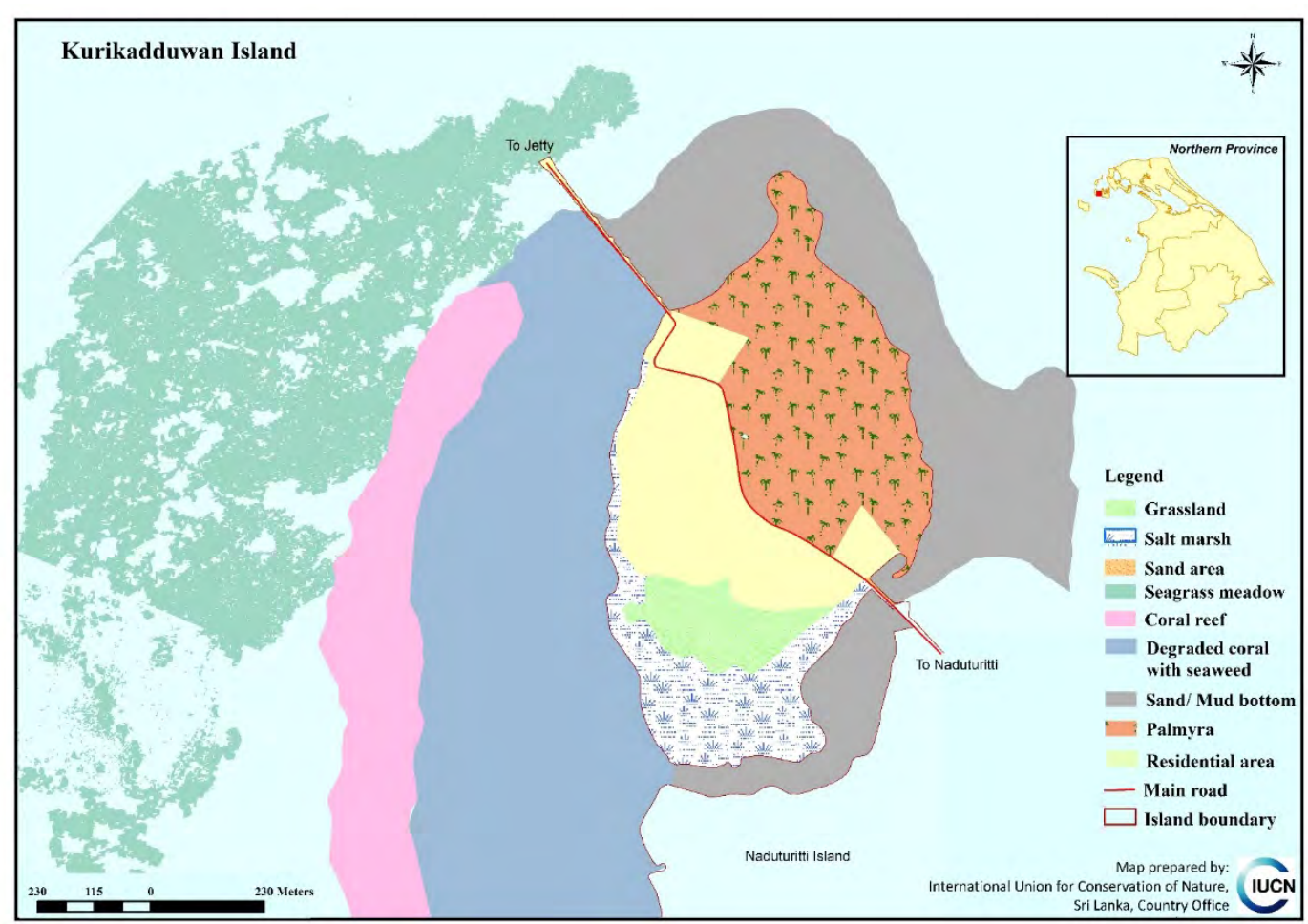

Figure 70. Map of Kurikadduwan Island, showing ecosystems and land use 


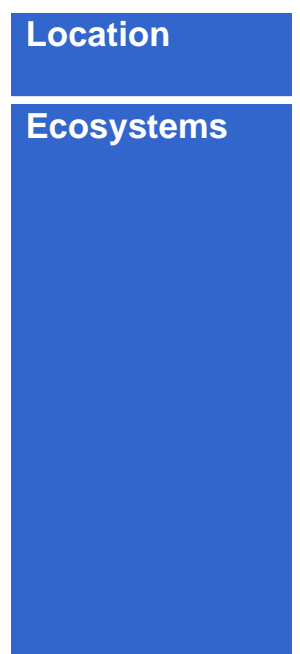

Special

attributes

Proposed

actions

Proposed

improvements

Carrying

capacity for

tourism

activities
The island has an extent of about $0.38 \mathrm{~km}^{2}$ and belongs to the Islands South (Velanai) Divisional Secretariat of the Jaffna District (Figure 70).

\section{Terrestrial ecosystems}

This a populated island, with strands of palmyra and some salt marshes in the south. A total of eight plant and six fauna species, respectively, were recorded from the island. All six species of fauna were birds recorded on the Kurikadduwan causeway.

There were notable species such as the nationally Vulnerable little ringed plover (Charadrius dubius) and salt marsh species such as Salicornia brachiata and Suaeda maritima observed along the causeway.

Marine ecosystems were not surveyed in this assessment but a study by NARA (2017) mapped seagrass meadows and coral reefs to the west of the island.

This island provides the link to Delft and Nainativu.

This island should be developed to support tourism to Delft.

Home stays, small guest houses and restaurants should be developed in accordance to the recommendations provided in Chapter 6 .

Over-crowding should be prevented. 


\section{Mandaitivu Island (Sinhala: Mandadoova)}

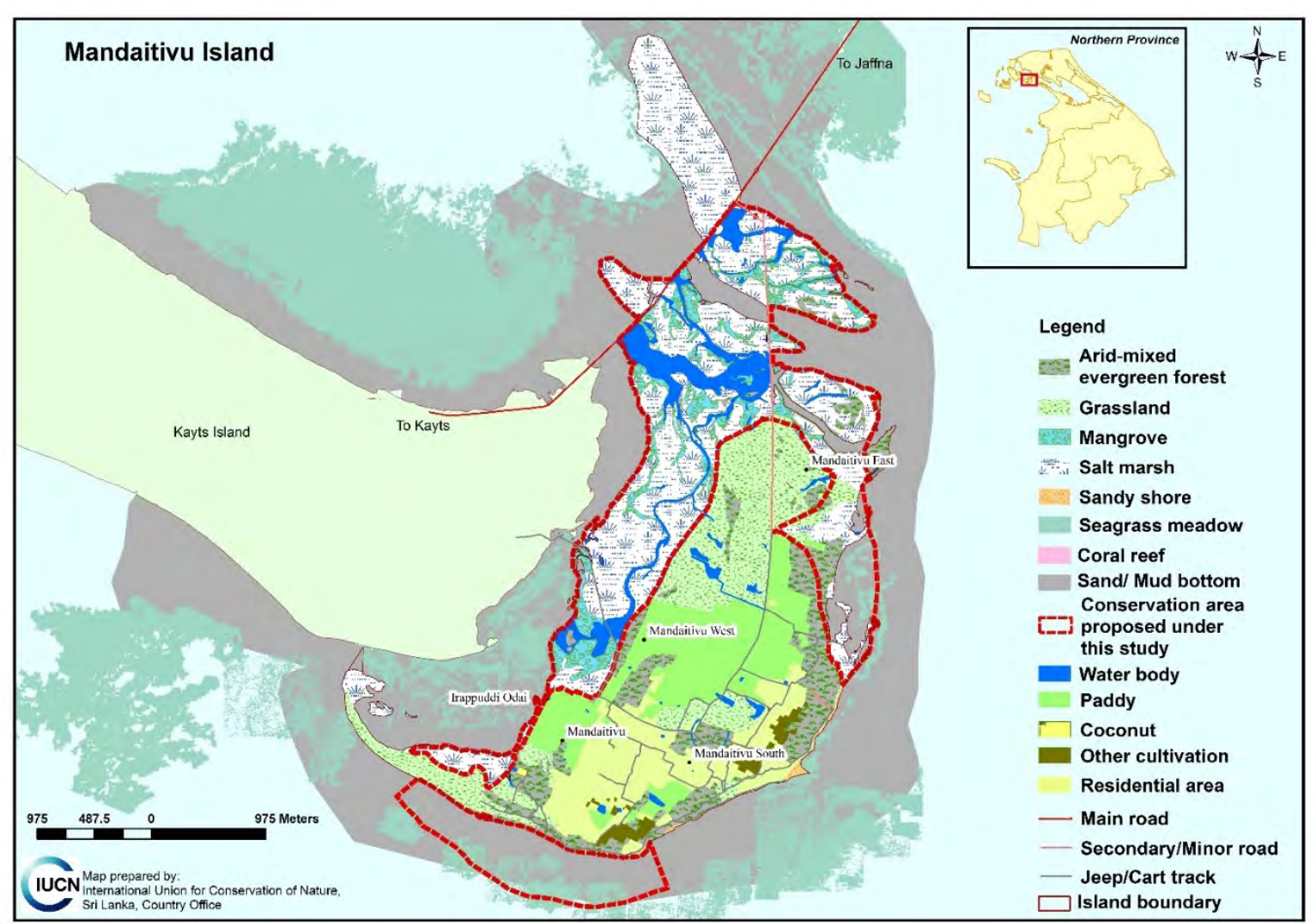

Figure 71. Map of Mandaitivu Island, showing ecosystems, land use and proposed conservation areas 


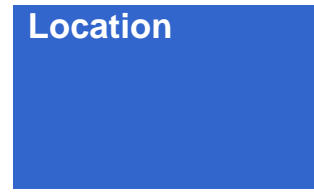

Ecosystems

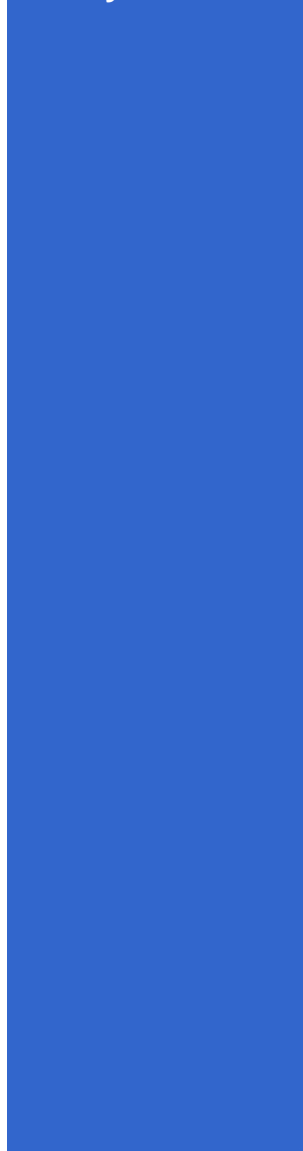

Special

attributes

Proposed

actions
This island extends over $7.56 \mathrm{~km}^{2}$ and belongs to the Islands South (Velanai) Divisional Secretariat in the Jaffna District. Mandaitivu is another highly populated island in the Jaffna Peninsula, with a human population of 1616 (Figure 71).

\section{Terrestrial ecosystems}

A broad spread of mangrove swamps is found on the island and are associated with salt marshes. Seashore scrublands, sandy seashores, home gardens and abandoned paddy fields are the other major land use types that can be seen on the island. A total of 52 floral species was recorded in the island. The notable species of terrestrial flora recorded here include Suaeda maritima and Salicornia brachiate, found in salt marshes and Commiphora berryi and palmyra (Borassus flabellifer) associated with the home gardens and roadsides. A total of 61 species of terrestrial fauna were recorded represented by two species of land snails, two scorpions, two dragonflies, 28 butterflies, one exotic freshwater fish, two reptiles, 22 birds and two mammals.

\section{Marine ecosystems}

Mandaitivu had a fringing reef along the southern and western coasts. There were numerous small coral patches dominated by species belonging to the families of Acroporidae, Faviidae and Poritidae. The common species were Acropora formosa, A. anthocercis, A. hyacinthus, A. cytherea, A. digitifera, A. aspera, $A$. aculeus and $A$. humilis. Other common species were Porites lutea, P. lobata, P. rus, Montipora digitata, M. foliosa, M. aequituberculata, M. verrucosa, Platygyra daedalea, Favia pallida, F. Speciosa, F. Matthaii, Favites chinensis, F, abdita, Diploastrea heliopora and Leptoria phrygia. Corals were in good condition.

Reef fish abundance was low; there were mainly rabbit fish (Siganidae), damselfish (Pomacentridae), wrasses (Labridae) and mullets (Mugilidae) were present.

Mandaitivu, along with Kayts is Important Bird and Biodiversity Area (IBA) (Birdlife International, 2017a). (See section on Kayts for more details of species.) It is also a Special Management Area (SMA) under the CCZRMP (2016).

Notable terrestrial fauna recorded from the island include two endemic species - the lesser albatross (Appias galane) and Devaka's fanthroat lizard (Sitana devakai). Among the recorded species are Trachia vittata and the bright babul blue (Azanus ubaldus) which are listed as nationally Critically Endangered. Four other species - Cryptozona semirugata and the large salmon Arab (Colotis fausta), Devaka's fanthroat lizard (Sitana devakai) and the Indian pipistrel (Pipistrellus coromandra) — are listed as nationally Vulnerable.

Much of the coastline containing natural ecosystems and a small marine area in the south of the island are proposed as a conservation area (Figure 71). The type and degree of protection must be decided upon after detailed studies, as recommended in Chapter 6 .

At present, there is no tourist infrastructure on the island. Mandaitivu Island is endowed with rich mangrove and salt marsh ecosystems, within which nature trails could be established. The mangroves, salt marshes, shallow sea and paddy fields of the island serve as feeding grounds for wading birds, most of 


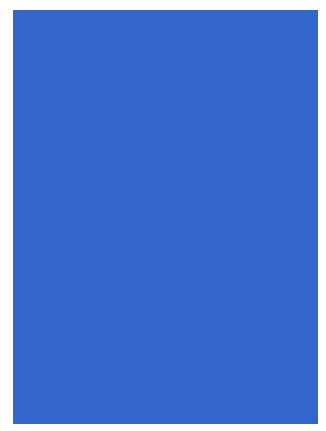

Proposed

improvements

Carrying

capacity for

tourism

activities which are migratory, thus presenting an opportunity for bird watching. The beaches and shallow seas allow for boat rides and sunbathing. Coral reefs found here, with a high diversity of Acropora spp., can be accessed easily and therefore, presents opportunities for snorkelling.

Also, Mandaitivu's cultural diversity, including traditional fishing activities and archaeological monuments, could promote cultural tourism. The presence of human settlements, a well-developed road network and other infrastructure presents opportunities to develop home stays and resorts.

Development of home stays hotels, resorts, nature trails, and bird watching towers and hides. Mooring points for boat anchoring must be established. All these will have to be carried out while ensuring that environmental safeguards are included. (See Chapter 6.)

The northern sector of the island can support many bird watchers during the bird migratory season. 


\section{Mannar Island (Sinhala: Mannaram Doopatha, Tamil: Mannār)}

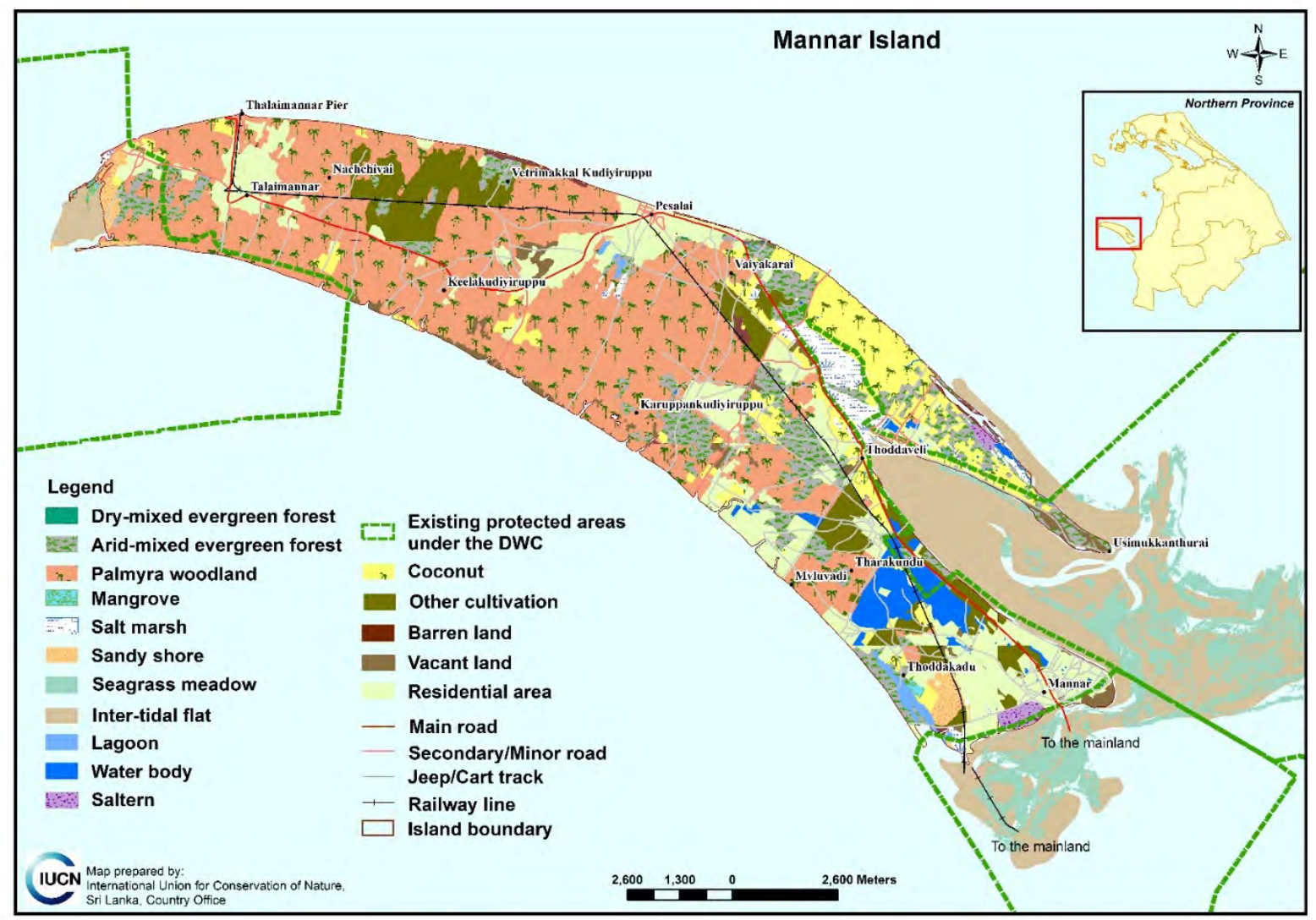

Figure 72. Map of Mannar Island, showing ecosystems and other land use (Note that DWC protected area boundaries extend beyond the extent of this map) 

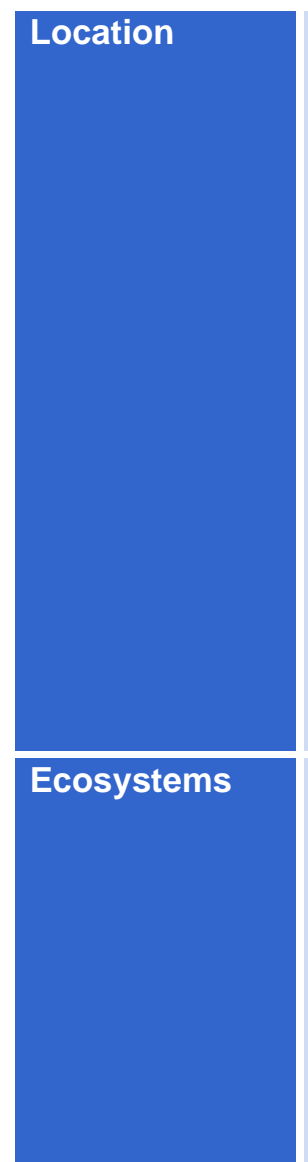

Special

attributes
This island extends about $126.46 \mathrm{~km}^{2}$ and belongs to the Mannar Town Divisional Secretariat in the Mannar District (Figure 72). The population of the island is 4,528. The name is derived from the term Mann-aru, which is a river that is supposed to have separated the island from the mainland (Gnanam, 2017).

Mannar Island falls within the arid zone of Sri Lanka where the annual rainfall, is sharply seasonal, and less than $1000 \mathrm{~mm}$. The area experiences heavy rains from October to December, during north-east monsoon.

Mantai, on the mainland, in the Mannar District, was a major trading port in ancient times (See Chapter 1). From 5-13 AD, Mannar was part of the Rajarata Kingdom and later became part of the Jaffna Kingdom (Gnanam, 2017). In the mid-16 ${ }^{\text {th }}$ century, the Portuguese conquered the Jaffna Kingdom, and with it, Mannar Island. Subsequently, the Dutch gained control, and finally, the British. Remnants of the forts and churches that these colonists built were described in Chapter 1.

\section{Terrestrial ecosystems ${ }^{21:}$}

Mannar is a populated island. There are patches of scrubland and extensive palmyra woodlands, as well as coconut plantations and home gardens. Also found around the island are tidal flats and small patches of salt marshes (where) as well as sand dunes near the tip of the island and in Nadukuda.

\section{Marine ecosystems}

The sea around Mannar Island supports seagrass meadows. Seagrass meadows are seen in Adam's Bridge, Thalaimannar and Pallimunai.

The presence of baobab trees (Adansonia digitata), native to Africa, is a unique feature of the Mannar Island. These trees were introduced to the island by Arab sailors to feed camels.

In addition, the island supports a rich biodiversity including number of threatened and endemic species.

Mannar Island is visited/inhabited by many water birds, including annual migrants travelling on the Central Asian Flyway, which use this area as an entry point to Sri Lanka, a major wintering site, as well as a staging point before they exit Sri Lanka. More than $30 \%$ of the birds recorded in Sri Lanka (more than 150 species) have been recorded on the island.

The island is inhabited by some of the rarest species of birds recorded in Sri Lanka such as spot-billed Duck (Anas poecilorhyncha), black drongo (Dicrurus macrocercus), long-tailed Shrike (Lanius schach), Eurasian collared-dove (Streptopelia decaoto), grey francolin (Francolinus pondicerianus), black kite (Milvus migrans), crab-plover (Dromas ardeola), great black-headed gull (Larus ichthyaetus), Eurasian wigeon (Anas penelope) and the black-tailed godwit (Limosa limosa).

Also found in the waters around Mannar island are Endangered dugongs and marine turtles. Recently discovered in the waters off the tip of Mannar island is

21 Although Mannar was not assessed during this study, data are available from IUCN, 2001b and Miththapala, 2012. 


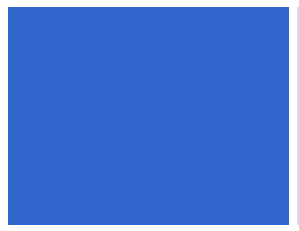

Proposed

actions

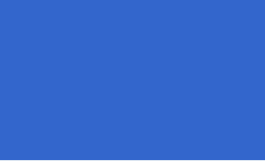

Proposed

improvements

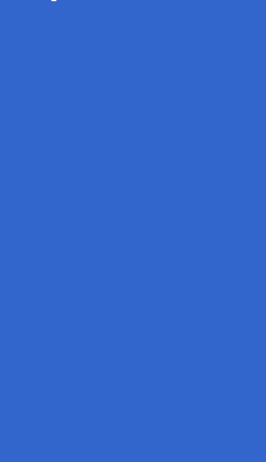

Carrying

capacity for

tourism

activities
Indo-Pacific finless porpoise (Neophocaena phocaenofides), a globally Vulnerable species (Nanayakkara et al., 2017).

Also in Mannar are several historical sites such as the Dutch Fort, Doric House and the oldest Baobab tree (Figure 73).

Mannar Island has a rich cultural diversity, as well as archaeological past. The island attracts many visitors whose focus is bird watching.

The presence of human settlements and a road network provides an opportunity to develop home stays. Further, there are many small guest houses that have been established during the last few years.

Tourism specific infrastructure facilities will have to be improved if the island is to be promoted as a major tourism destination. This will include identification of tourism zones, specific tourism attractions and further development of these with proper interpretation, establishing a visitor centre to create awareness among visitors about the type of attractions available in and around Mannar Island, establishing nature trails, bird watching facilities, boating decks, snorkelling facilities. All these will have to be carried out ensuring the integration of environmental safeguards.

Current trends of bird watching during the migratory season, indicate at increase in visitors without the establishment of environmental safeguards is becoming detrimental (Figure 48).

A maximum of 500 visitors can be accommodated in the island at a given time for bird watching. Victors for bird watching should be restricted. 

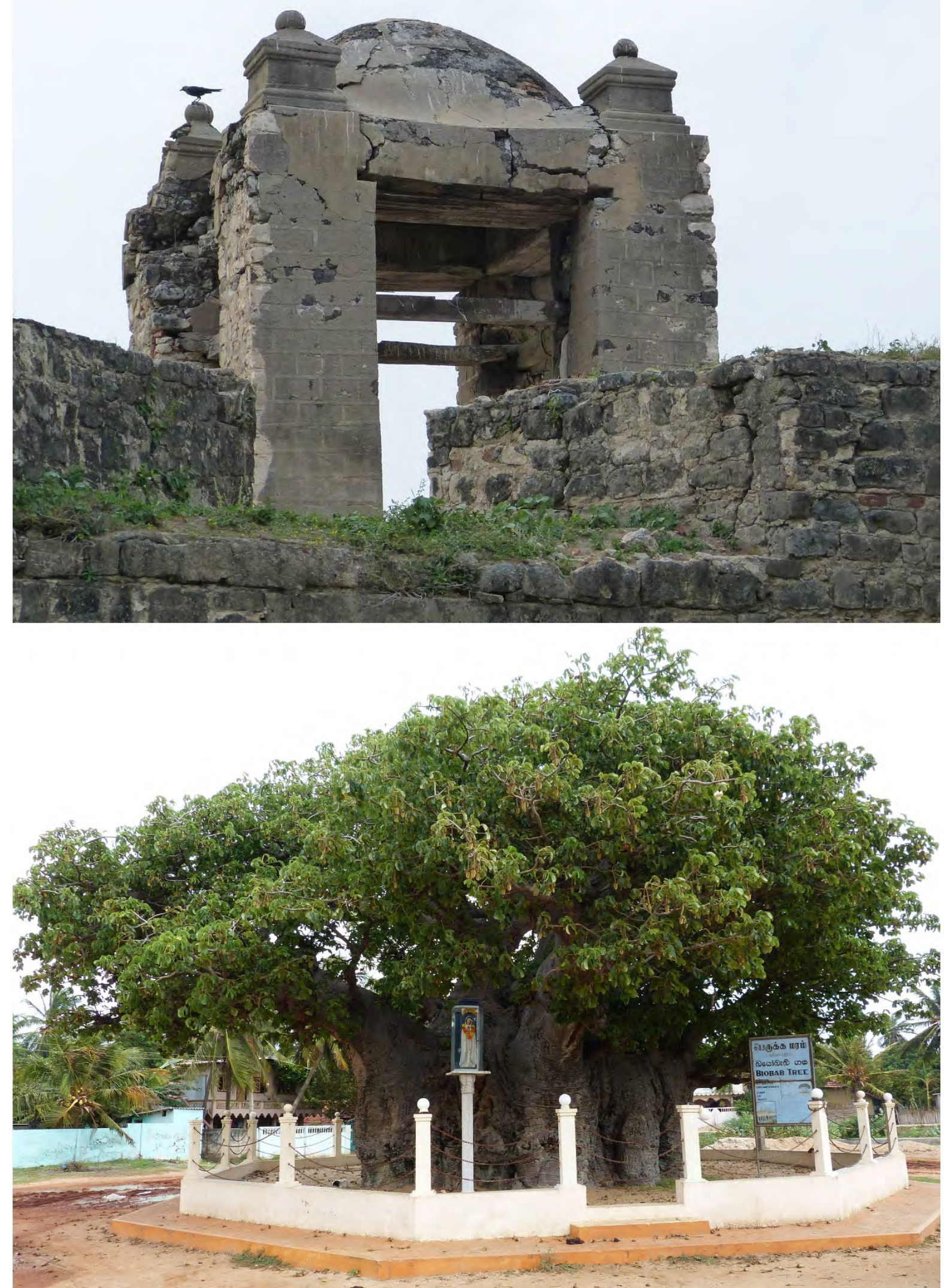

Figure 73. Top: Dutch Fort, Mannar Island; Bottom, the oldest (reported to be over 700 years old) and the largest individual baobab (Adansonia digitata) tree in Sri Lanka, found at Pallimunai, Mannar Island

(C) Sriyanie Miththapala) 


\section{Nainativu Island (Sinhala: Nagadeepa; Dutch: Haarlem)}

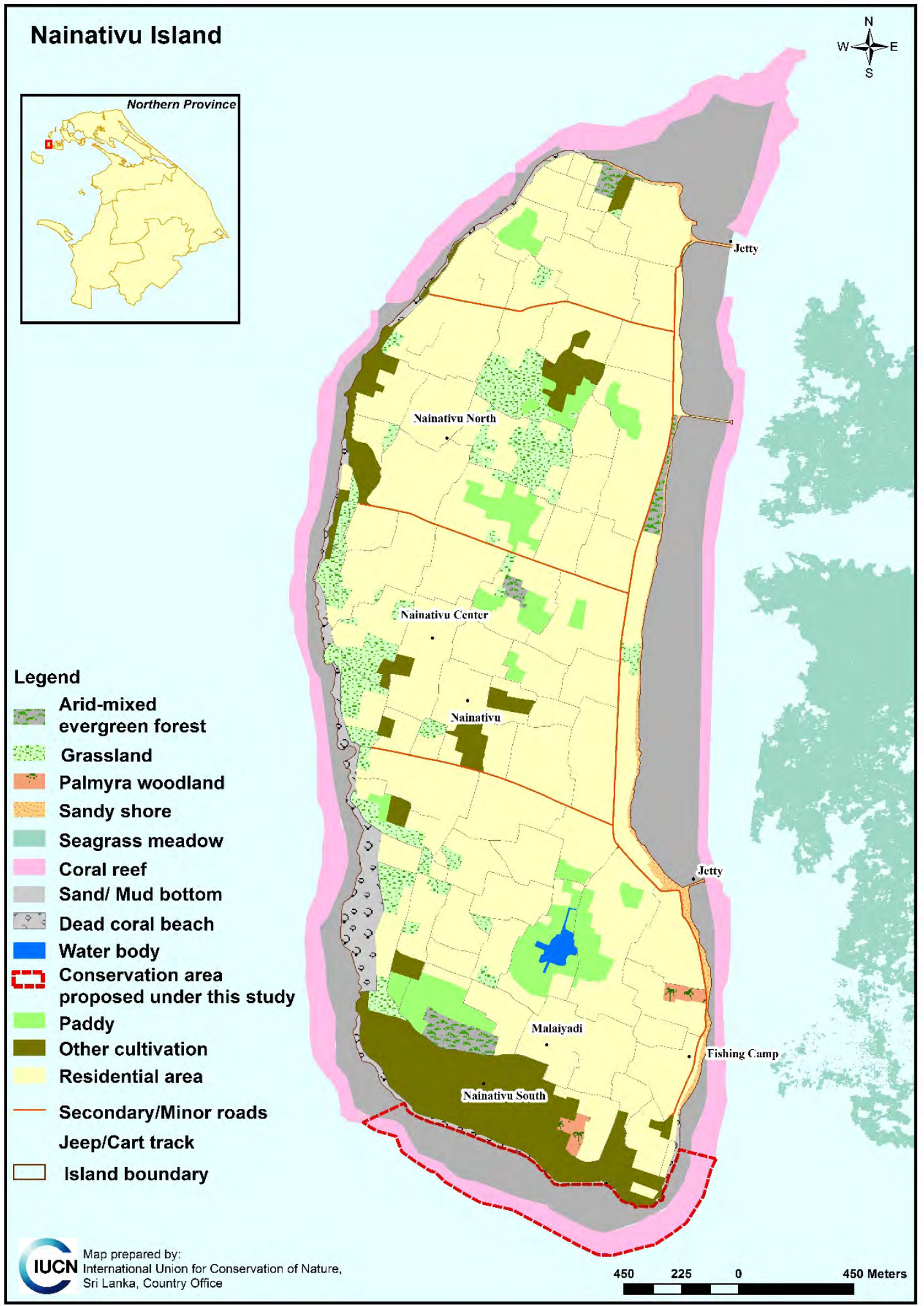

Figure 74. Map of Nainativu Island, showing ecosystems, land use and proposed conservation area 


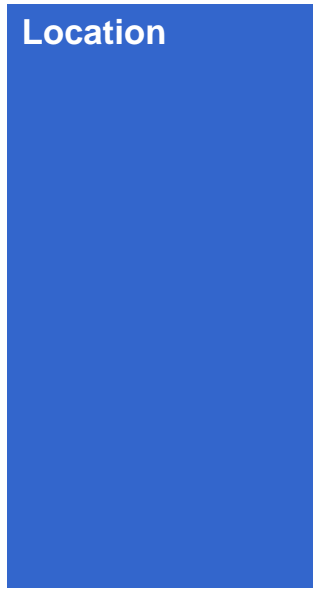

Ecosystems

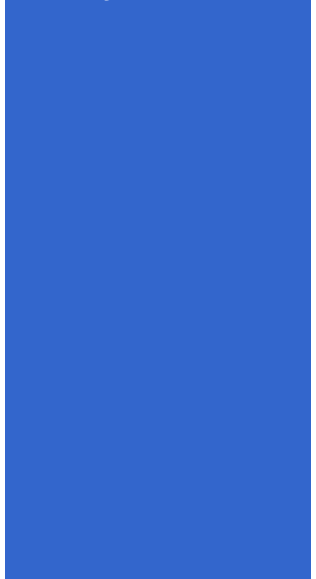

Special

attributes

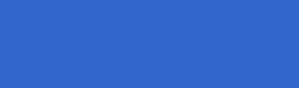

Proposed

actions

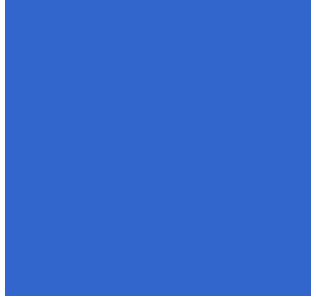

Proposed

improvements

Carrying

capacity for

tourism

activities
The island extends over about $4.82 \mathrm{~km}^{2}$ and belongs to the Islands South (Velanai) Divisional Secretariat in Jaffna district (Figure 75). The Dutch called Nainativu 'Haarlem' and the island is also known by several other names such as Nagadheepa, Naga Dhivayine, Nagthivu, Naga Nainarthivu, Nainarthivu and Maninagethivu. The name Nagadeepa means 'Yapa Patuna', which comes from the term 'Jaffna Peninsula'. Its recorded that second visit of Lord Buddha was to Nagadeepa in 518 B.C (Geiger, 1912). The island has two important cultural buildings, the Nagadeepa Buddhist temple and the Naga pusheni amman Hindu kovil. The Hindu kovil was built for the Goddess Uma, is one of the 64 kovils built around the world for this Goddess and is the $48^{\text {th }}$ kovil out of the 64 . The Goddess Uma has been known by 108 different names in different eras (Bassett, 1997).

\section{Terrestrial ecosystems}

Seashore scrublands, dead coral beaches, pasture lands (dry), palmyra woodlands, agro-plantations (mixed culture and home gardens) are found on the island. A total of 42 plant and 22 animal species, respectively, were recorded from the island. The palmyra tree (Borassus flabellifer) was the most abundant tree found all over the island. The animal assemblage comprised four butterfly, one dragonfly, 14 bird and three mammal species, respectively.

\section{Marine ecosystems}

Although this island was not assessed for marine diversity, a report from NARA (2017) shows that Nainativu has a fringing reef around the island. The width of the reef varies from $100-250 \mathrm{~m}$. The reef is well developed in the south and in the north. To the east of the island are seagrasses.

This island has a rich historical background, which can be the main attraction for tourism development in the island. The biodiversity of the island does not offer a unique opportunity for tourism development but can be used for value addition. It is a Special Management Area (SMA) under the CCZRMP (2016).

A small marine area in the south of the island is proposed as a conservation area (Figure 55). The type and degree of protection must be decided upon after detailed studies, as recommended in Chapter 6 .

The island has a rich cultural diversity and is already visited by Buddhist pilgrims. The presence of human settlements and a road network provides opportunities to develop home stays. Tourism activities will promote further livelihood opportunities for the inhabitants.

Tourism specific infrastructure as well as general infrastructure will also have to be developed, while ensuring that environmental safeguards are included. (See Chapter 6.)

At any given time, more than 500 visitors should not be accommodated on the island, although this restriction may be difficult to enforce. 


\section{Neduntivu Island (Sinhala: Maedundoova; Dutch: Delft)}

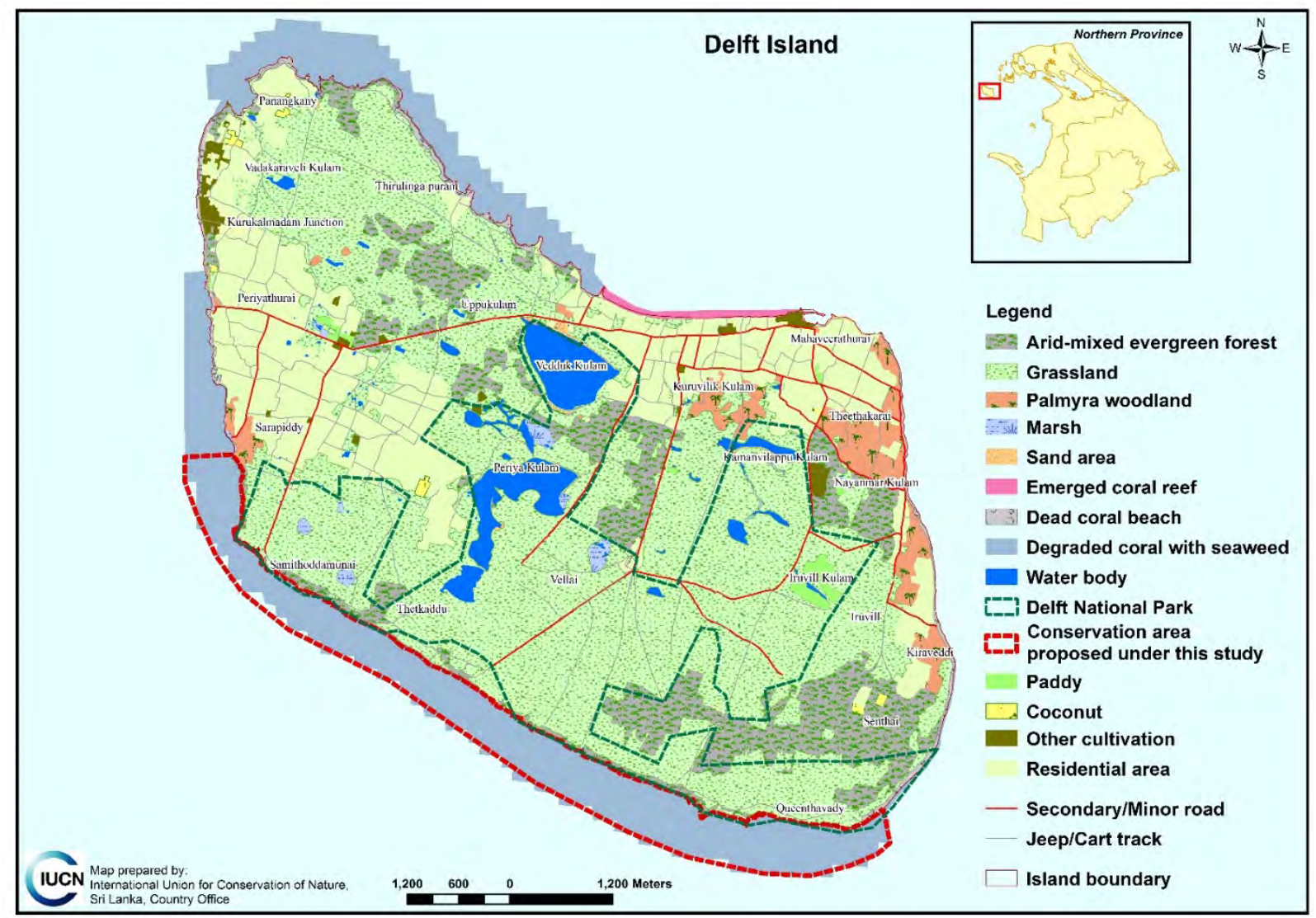

Figure 75. Map of Neduntivu Island, showing ecosystems, land use and proposed conservation area 


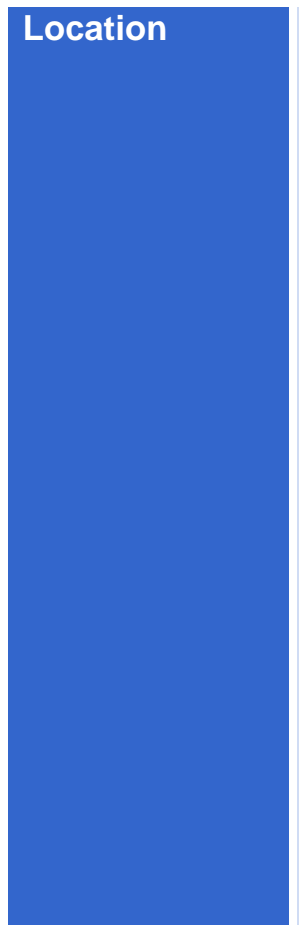

Ecosystems

Special

attributes

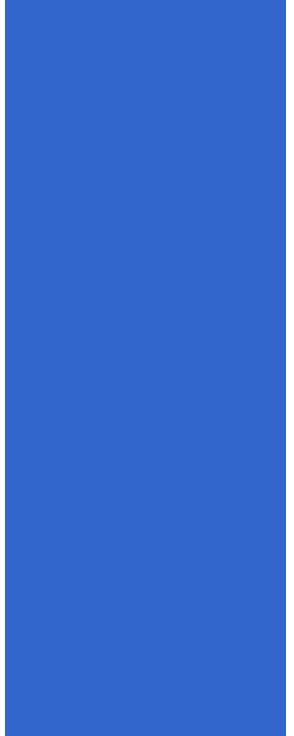

Proposed

actions
This island has an extent of about $47.17 \mathrm{~km}^{2}$ and belongs to the Neduntivu (Delft) Divisional Secretariat of the Jaffna District (Figure 75). The population of the island is 4,528. The island was referred to by Baldaeus (1658) as Nindundiva, and Nedointivo by the Dutch according to VOC records. The name 'Delft' was given by the Dutch Governor Rijckloff van Goens (of the VOC 1678-1681). The Sinhalese names Maedundoova and Diveldoova have been given to the fishermen who inhabited the island. The Sinhala name is believed to have derived from the word maedun or maedha, indicating that the island is located more or less midway between the island of Rameshwaram and Jaffna Peninsula. The Tamil name may have also come from the same roots, and indeed, it may have derived from the Tamil word națuttitțam, which also means 'middle location'.

During the Portuguese period, the name 'cow island' was used for the island. Ruins of an old Portuguese fort still exist in the island. A herd of wild ponies (approximately 600 ponies), first introduced during the Portuguese period, also survives in the island to date. Mr. D. T. Devendra, during a visit to Nedundoova in the 1940s, discovered a mound, which on closer examination turned out to be a Dageba. Other ancient ruins have also been discovered from the island. Remnants of a Chola Hindu temple (12- X 3 metres) belonging to the $11^{\text {th }}$ century have also been found in the Island (Dharmawardana, 2006).

\section{Terrestrial ecosystems}

Arid mixed evergreen forests, wet pastureland, dry pastureland, palmyra woodlands, home gardens, dead coral rock and sandy seashores were observed on the island. A total of 191 plant and 102 animal species, respectively, were recorded in the island. The faunal assemblage is represented by eight dragonfly, 17 butterfly, one amphibian, one reptile, 64 bird, and 11 mammal species respectively.

Marine ecosystems were not surveyed during this present study.

Notable plant species found on the island include the Critically Endangered, Possibly Extinct Fimbristylis dipsacea; the Critically Endangered Cyperus conglomerates; the Endangered Cadaba fruticosa, Ipomoea coptica, Cocculus hirsutus, and Peplidium mariticum. The baobab tree (Adansonia digitata) is also present found on the island.

Notable faunal species observed in the island include the Critically Endangered Indian courser (Cursorius coromandelicus), the Vulnerable Burmeister's glider (Tramea basilaris), plain orange tip (Colotis aurora), joker (Byblia ilithyia), ILittleringed and Kentish plovers (Charadrius dubius and C. alexandrines, respectively) and the silverbill (Lonchura malabarica). Near Threatened species include the pruinosed bloodtail (Lathrecista asiatica), marsh skimmer (Orthetrum luzonicum), paddyfield parasol (Neurothemis intermedia), Eurasian collared dove (Streptopelia decaocto) and the black-crowned night heron (Nycticorax nycticorax).

Further, the famous Delft ponies (Equus caballus), which roam freely around the island are a notable feature of the island's faunal assemblage.

Part of the island is now a national park under the jurisdiction of the DWC. The marine area adjoining the national park is proposed as a conservation area (Figure 75). The type and degree of protection must be decided upon after detailed studies, as recommended in Chapter 6. 


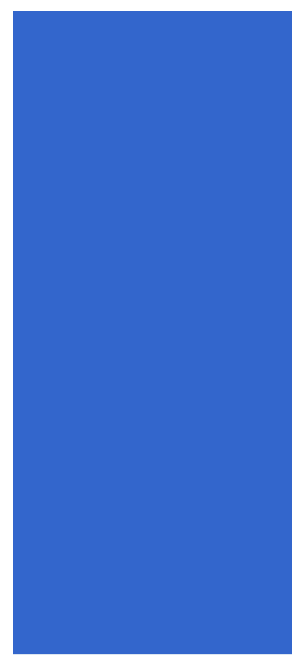

Proposed

improvements

Carrying

capacity for

tourism

activities
It is also a Special Management Area (SMA) under the CCZRMP (2016).

The high habitat diversity, the Delft ponies in Delft National Park, presents tourism opportunities to established nature trails and hides for bird watching.

Archaeological monuments, including ruins belonging to the Anuradhapura and colonial period (for example, the survey beacon) can be used to promote cultural tourism.

Tourists could also have the opportunity use the beaches of the island, as well as dive in the dead coral habitat around the island. The shallow seas could also promote troll fishing, angling and water skiing (within designated areas). Meanwhile the coral reefs could promote snorkelling.

As the island is partly populated and home stays as well as guest houses could also be developed. Tourism activities will promote further livelihood opportunities in Delft, although, these activities will have to be developed with strict environmental safeguards (Chapter 6).

Visitors to the national park should be restricted to a maximum of $40-50$ people in the morning and the same number in the afternoon. 


\section{Palaitivu Island (Sinhala: Paludoova; Dutch: Galue)}

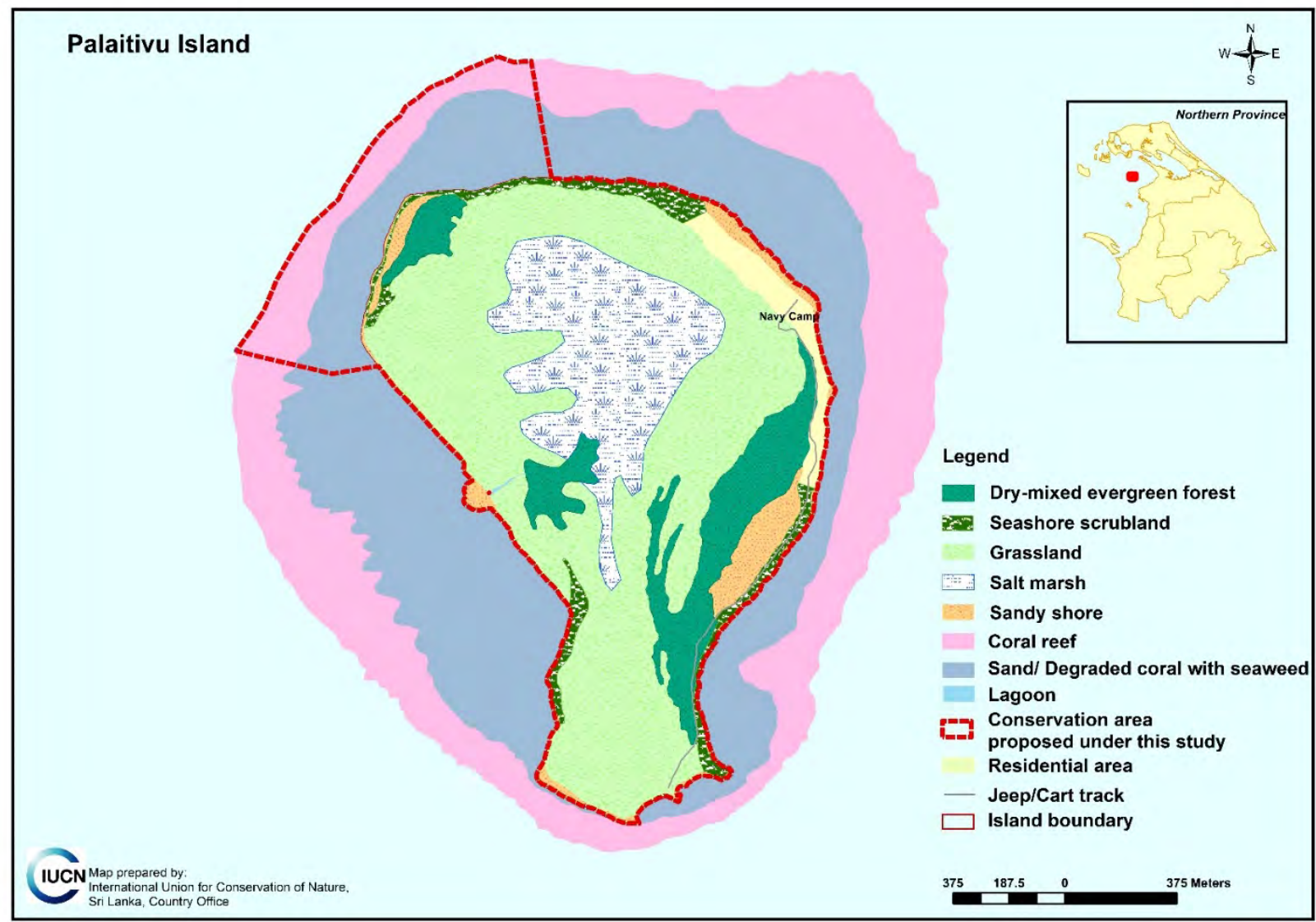

Figure 76. Map of Palaitivu Island, showing ecosystems, land use and proposed conservation area 


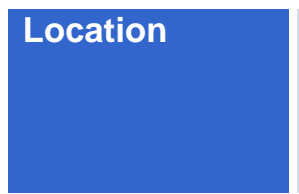

Ecosystems

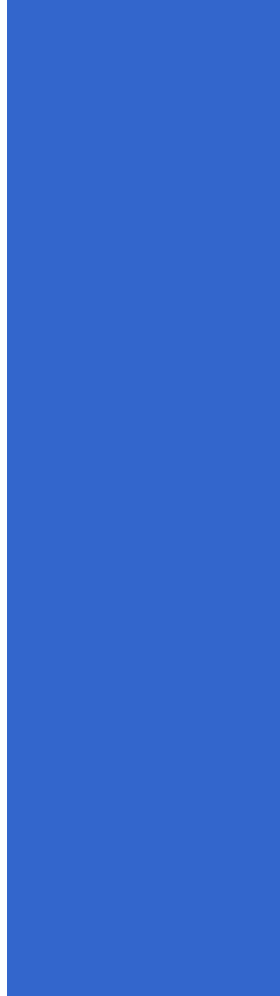

Special

attributes

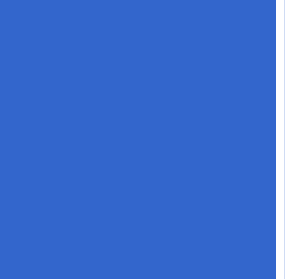

Proposed

actions

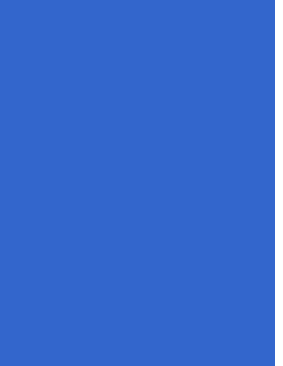

Proposed

improvements

Carrying

capacity for

tourism

activities
The island is about $1.81 \mathrm{~km}^{2}$ in extent and belongs to the Poonakary Divisional Secretariat of the Kilinochchi District (Figure 76). In 1895, a Christian church was built with a statue of St. Anthony, who was considered the protector of fishermen. Palaitivu Island was named 'Galue' by the Dutch.

\section{Terrestrial ecosystems}

Dry-mixed evergreen forests dominated by Manilkara hexandra is an ecosystem found on the island. In addition, grasslands intermingled with salt marshes, seashore scrublands and sandy seashores are also found on the island. A total of 53 plant and 42 animal species, respectively, were recorded from the island. Fauna were represented by three dragonfly, ten butterfly, six reptiles and 23 bird species, respectively.

\section{Marine ecosystems}

A well-developed fringing reef is present around the island. The outer reef on the western side has a well-developed spur and groove structure. Reef condition was better on the north-western side of the island. A relatively extensive reef lagoon, which was about $500 \mathrm{~m}$ in width, was present on the western side of the island. The reef lagoon has very few live corals; seaweeds (Sargassum and Turbinaria) were abundant. There are small colonies of Porites spp in the reef lagoon. The reef slope is also degraded. The depth on the seaward margin was about seven metres. The coral reef in the north-western corner had the most amount of live corals with large domes of Porites lutea and $P$. lobata. Other common species of hard corals were Acropora hyacinthus, Acropora formosa, Symphyllia radians, Platygyra daedalea, Leptoria phrygia, Favities chinensis and Favia speciosa.

Reef fish abundance was low; mainly damselfish (Pomacentridae) and wrasses (Labridae) were present.

Notable terrestrial plant species recorded on the island include the sea trumpet (Cordia subcordata) and bay cedar (Suriana maritima), which are very rare species. In addition, Guettarda speciosa was also observed near the coast.

Notable fauna include the nationally Vulnerable include plain orange tip (Colotis aurora), saw-scaled viper (Echis carinatus), little-ringed and Kentish plovers (Charadrius dubius and C. alexandrinus respectively) and the Near Threatened marsh skimmer (Orthetrum luzonicum).

The entire island, as well as a small north-western part of the marine area is proposed as a conservation area. The type and degree of protection must be decided upon after detailed studies, as recommended in Chapter 6 . In addition to the high ecosystem and species diversity, this island also has aesthetic and scenic value. Thus, tourism activities such as nature trails, bird watching, snorkelling and camping could be promoted on the island. The presence of an archaeological monument and a survey beacon can also be used as tourist attractions. The shallow seas and sandy beaches present around the island are opportunities for beach-based activities. All these will have to be promoted while ensuring environmental safeguards (Chapter 6).

Fresh water will be needed. Accommodation can be provided in Analaitivu for day trips.

Up to 20 day visitors only. 


\section{Parititivu Island (Sinhala: Paludoova)}

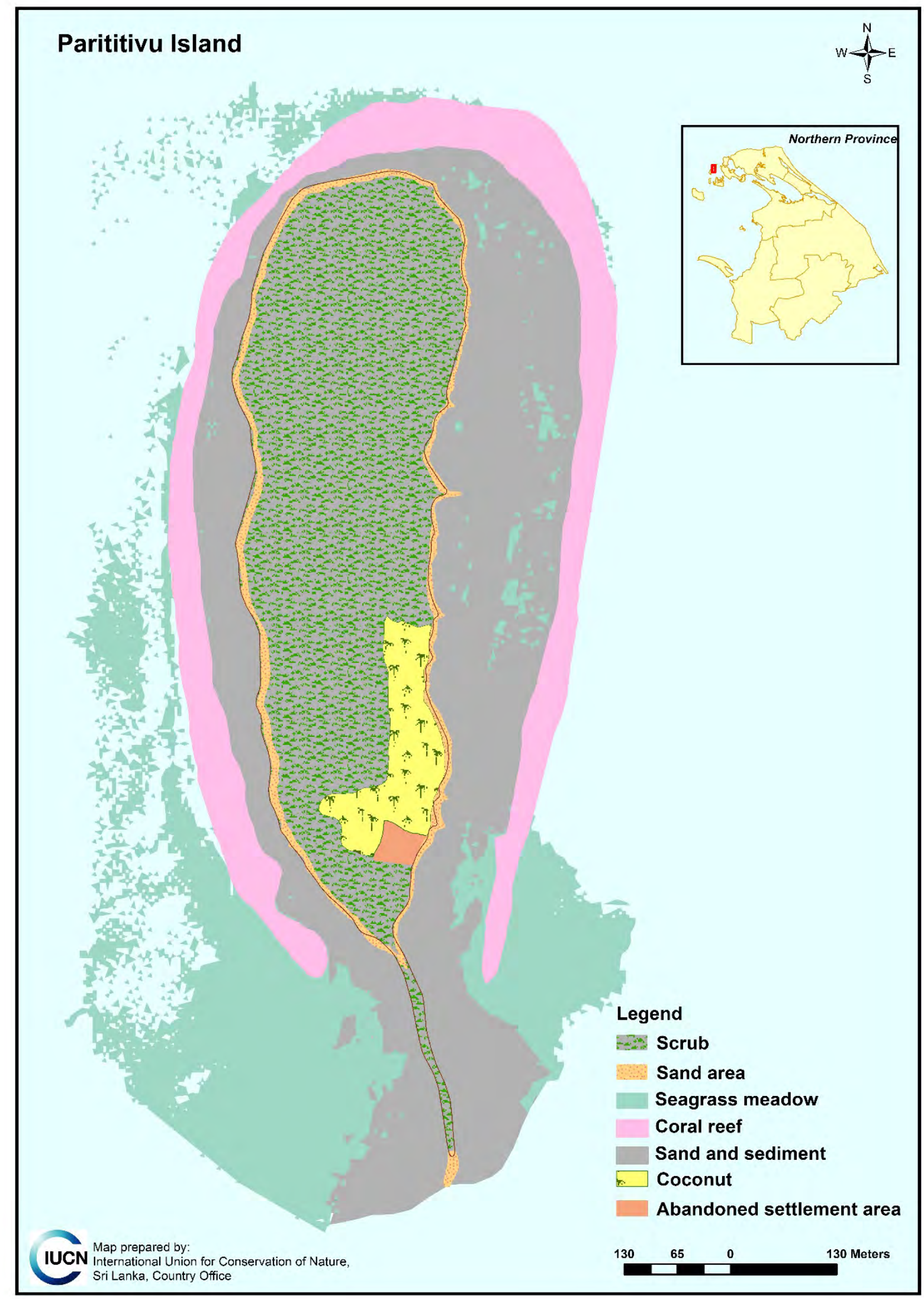

Figure 77. Map of Parititivu Island, showing ecosystems and land use 

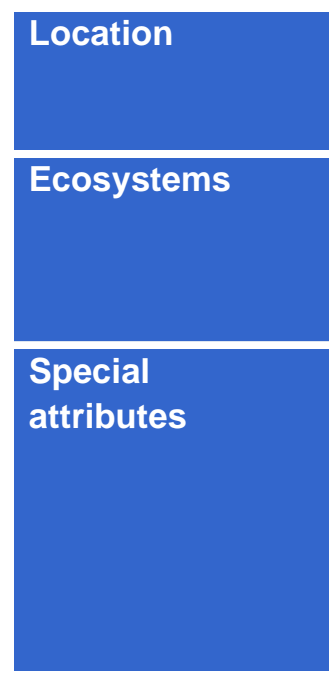

Proposed

actions

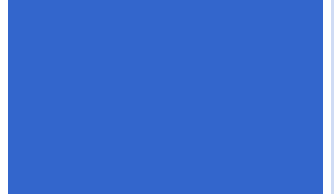

Proposed

improvements

Carrying

capacity for

tourism

activities
This island has an extent of about $0.4 \mathrm{~km}^{2}$ and belongs to the Islands North (Kayts) Divisional Secretariat in the Jaffna District (Figure 77). The island is not inhabited.

Seashore scrublands and palmyra woodland were seen across the island. A total of 50 plant species and 33 animal species were recorded on the island. The fauna recorded were represented by one land snail, one dragonfly, six butterfly, one reptile and 23 bird species, respectively.

\section{Terrestrial ecosystems}

Notable species of terrestrial fauna recorded on the island include two species - the landsnail Cryptozona semirugata and Kentish plover (Charadrius alexandrinus) listed as nationally Vulnerable; and one species - the dark blue tiger (Tirumala septentrionis) — listed as nationally Near Threatened.

Marine ecosystems were not surveyed.

Parititivu's scrub forest presents opportunities for establishing nature trails and camping sites (which can be operated from Analaitivu).

The seagrass meadows around the island can be used for snorkelling. Because it is isolated, it provides an ideal site for strictly controlled and managed, naturebased tourism development.

Currently, the island does not have any infrastructure facilities tourism specific infrastructure - such as nature trails, a boat deck, snorkelling areas will also have to be developed, while ensuring that environmental safeguards are included. (See Chapter 6.)

At any given time, less than 25 visitors can be accommodated on this island. 


\section{Puliyantivu Island (Sinhala: Kotidoova) (Jaffna)}

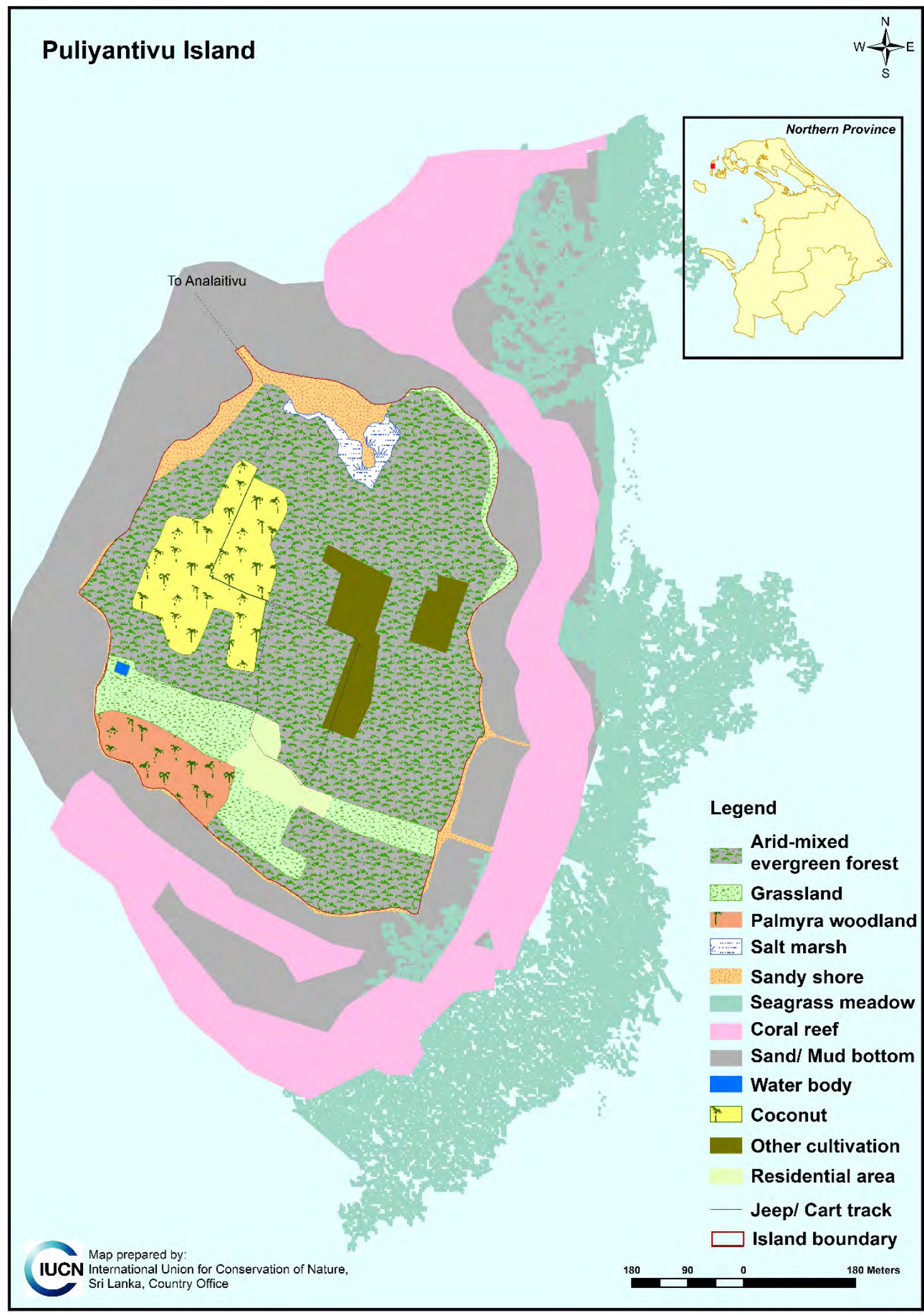

Figure 78. Map of Puliyantivu Island (Jaffna), showing ecosystems and land use 


\begin{tabular}{|c|c|}
\hline Location & $\begin{array}{l}\text { The island has an extent around } 0.44 \mathrm{~km}^{2} \text { and belongs to the islands' North } \\
\text { (Kayts) Divisional Secretariat of the Jaffna District (Figure } 78 \text { ). The island was } \\
\text { referred to as 'Juliyene' in the past. There is a historical kovil situated in the island } \\
\text { that was known as 'Nage thambiranye', which was later changed to } \\
\text { 'Kanegeshvern Shiven' kovil. }\end{array}$ \\
\hline Ecosystems & $\begin{array}{l}\text { Terrestrial ecosystems } \\
\text { Arid mixed evergreen forests and sandy seashores were observed in the island. } \\
\text { A total of } 27 \text { plant and } 20 \text { animal species were recorded from the island. The } \\
\text { faunal species recorded were represented by three butterfly and } 17 \text { bird species, } \\
\text { respectively. } \\
\text { Marine ecosystems were not surveyed. }\end{array}$ \\
\hline $\begin{array}{l}\text { Special } \\
\text { attributes }\end{array}$ & No notable terrestrial faunal species were recorded on this island. \\
\hline $\begin{array}{l}\text { Proposed } \\
\text { actions }\end{array}$ & $\begin{array}{l}\text { Nature trails can be established within the arid mixed evergreen forests/ The } \\
\text { shallow seas and seagrass meadows around the island are suitable for } \\
\text { snorkelling, while the sandy beach can also be used for tourism activities. }\end{array}$ \\
\hline $\begin{array}{l}\text { Proposed } \\
\text { improvements }\end{array}$ & $\begin{array}{l}\text { Camping sites (which could be operated from Analaitivu Island) and resorts could } \\
\text { also be developed, while ensuring that environmental safeguards are integrated. } \\
\text { (See Chapter } 6 \text {.) }\end{array}$ \\
\hline $\begin{array}{l}\text { Carrying } \\
\text { capacity for } \\
\text { tourism } \\
\text { activities }\end{array}$ & A maximum of $20-25$ per day \\
\hline
\end{tabular}




\section{Puliyantivu Island (Sinhala: Kotidoova) (Mannar)}

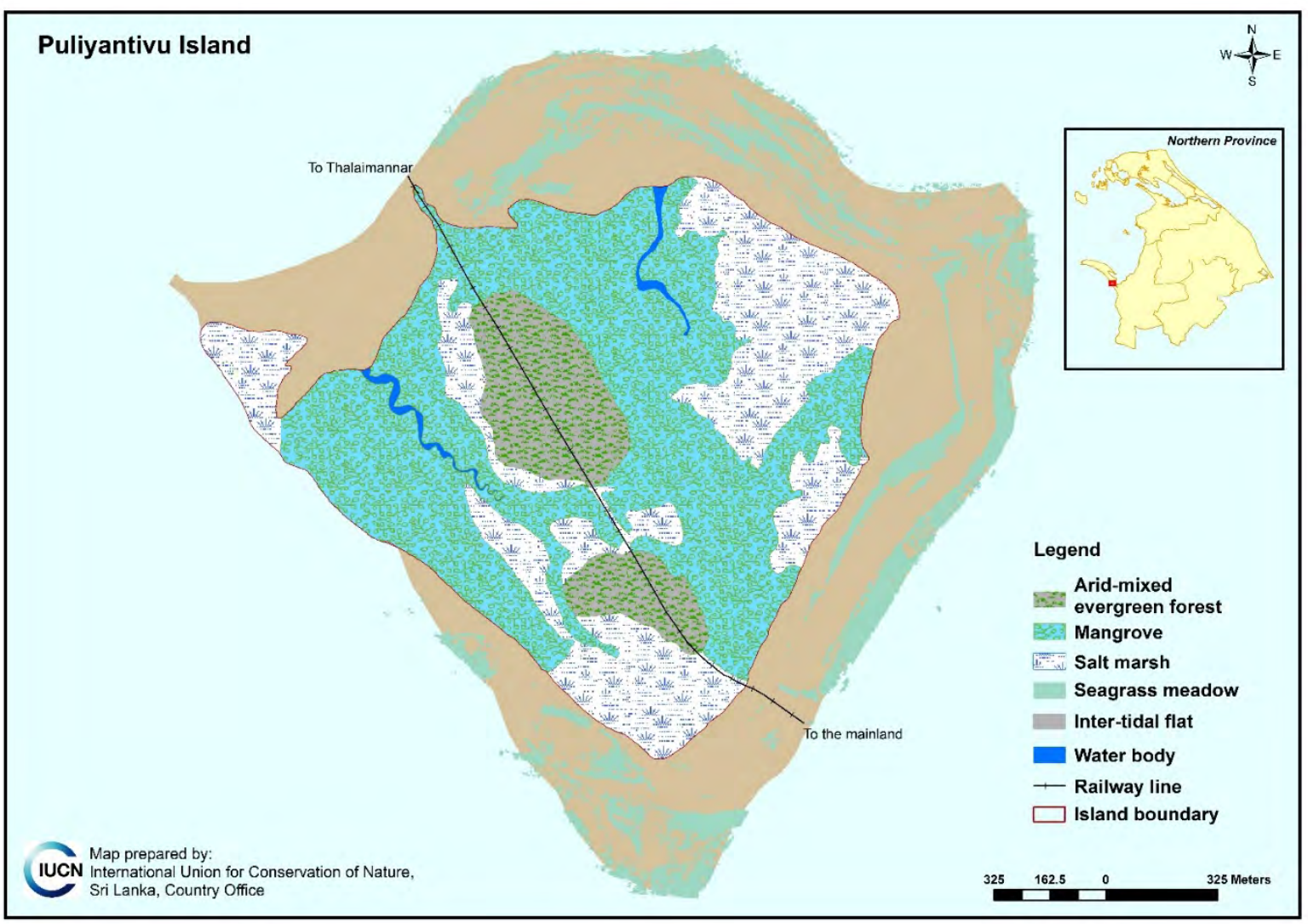

Figure 79. Map of Puliyantivu Island (Mannar), showing ecosystems and land use (Note that the DWC protected area completely encircles this island and extends well beyond it) 
Location

Ecosystems

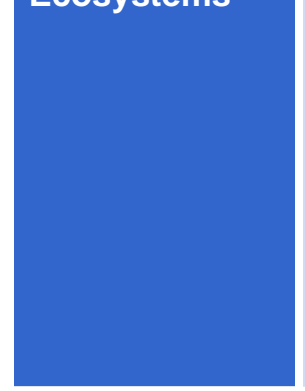

Special

attributes

Proposed

actions

Proposed

improvements

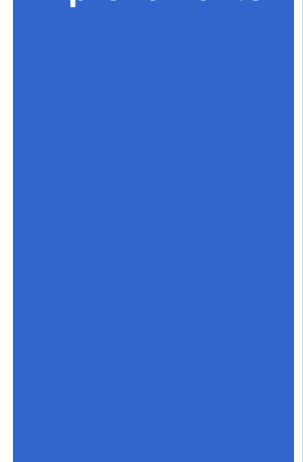

Carrying

capacity for

tourism

activities
The island has an extent of about $0.9 \mathrm{~km}^{2}$ and belongs to the Mantai Divisional Secretariat in the Mannar District (Figure 79).

\section{Terrestrial ecosystems}

Mangroves, salt marshes and arid mixed evergreen forests are found on the island. A total of 27 plant and 112 animal species were recorded in the island. The faunal assemblage of the island comprised two dragonfly, ten butterfly, one amphibian, 26 reptile, 65 bird and eight mammal species, respectively. This high diversity of bird species is likely because this island is closes to Vanakalai Bird Sanctuary.

Marine ecosystems were not surveyed.

Notable terrestrial floral species recorded on the island include Suaeda maritima and Suaeda monoica, observed in salt marshes. Notable terrestrial faunal species observed in the island include three endemic species - common lankaskink (Lankascincus fallax), checkered keelback (Xenochrophis asperrimus) and checkered keelback (Xenochrophis cf. piscator); one listed as nationally Endangered species - the oriental pratincole (Glareola maldivarum); two listed as nationally Vulnerable species - the Kentish plover (Charadrius alexandrinus) and small pratincole (Glareola lactea); and two listed as nationally Near Threatened - the drongo cuckoo (Surniculus lugubris) and Eurasian collared dove (Streptopelia decaocto); and one listed as Data Deficient collared sea snake (Hydrophis stricticollis).

As Puliyantivu is located within the Vankalai Bird Sanctuary, it provides opportunities for nature trails and bird watching.

Bird watching hides and towers could be especially promoted in this area, as it is a feeding ground for migratory birds. Pulliyantiivu is located within the Vankalai Bird Sanctuary, and therefore, establishing nature trails, including raised walkways and canopy walks is possible on the island. Further, the island is used as a feeding ground by a large number of migratory birds and therefore, hides and towers can be established to facilitate bird watching.

Its unique mangrove and salt marsh ecosystems surrounded by shallow seas could also be used for tourism product development in the island. Boat rides among the mangrove and salt marsh ecosystems, surrounded by the shallow sea could also be promoted, while ensuring that environmental safeguards are integrated. (See Chapter 6.)

A maximum of 50 persons per day. Non-motorised boats should be used. 


\section{Pungudutivu Island (Sinhala: Punguthdeepa; Dutch: Middleberg)}

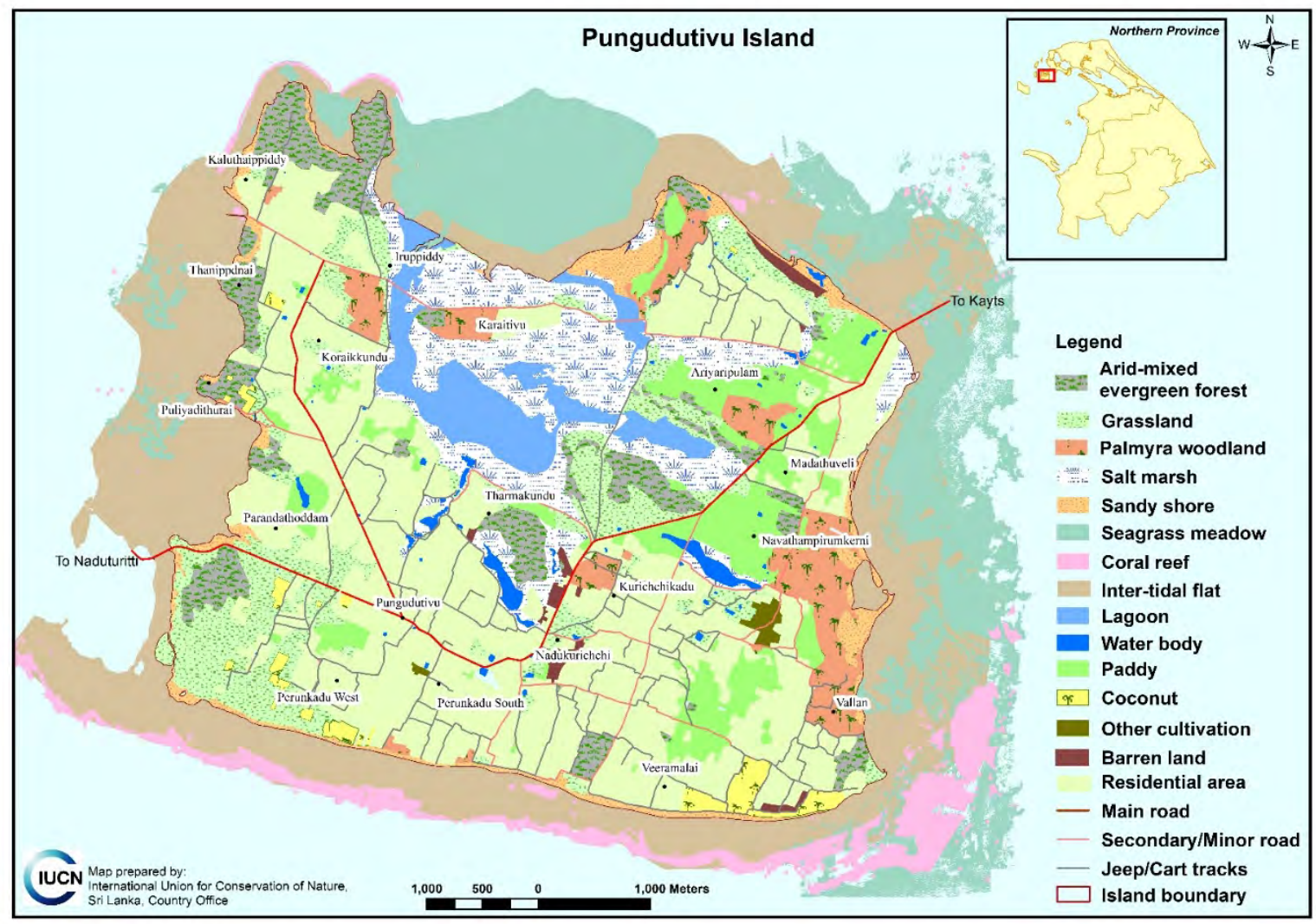

Figure 80. Map of Pungudutivu Island, showing ecosystems and land use 


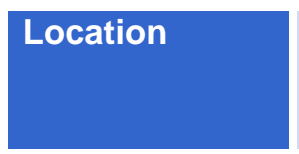

Ecosystems

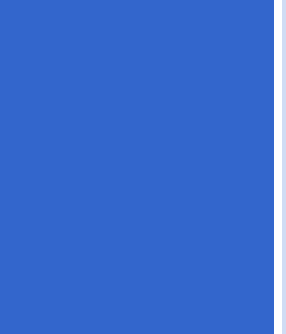

\section{Marine ecosystems}

Pungudutivu reef is located on the southern and south-eastern side of the island. It also extends about $4 \mathrm{~km}$ to the east towards Mandaitivu from the south-eastern corner of Pungudutivu. The outer reef slope was about 200 meters wide on the western side of the island and the maximum depth at the outer edge was about seven meters. The reef on the south-eastern side was about $4 \mathrm{~km}$ in width. However, much of it was in an extensive reef flat with numerous small coral colonies of Goniastrea, Porites and Montipora. Acropora hyacinthus and $A$. formosa patches were present.

A series of spur and groove reef sections were present on the outer reef slope which consisted of Acropora rubble. The reef crest, inner reef lagoon and outer reef flats contained Goniastrea colonies. Goniastrea retiformis and Goniastrea edwardsi colonies about one metre across were observed. The spur and groove reef sections of Acropora rubble may be due to a previous coral bleaching event. There were large Porites lutea and $P$. lobata domes along the seaward edge of the outer reef slope. Some domes were about three metres in diameter and about two metres in height. Thirty-six species of hard corals were recorded for the Pungudutivu reef (Rajasuriya, 2007). Live hard coral cover was 53.12\% while coral rubble amounted to $46.87 \%$ in 2005 (Rajasuriya, 2007). Soft corals were rare at this site. The middle reef slope had patches of Turbinaria and Sargassum seaweeds growing on coral rubble and limestone substrate.

Extensive seagrass areas were found off the north-eastern and northern coasts of the island.

Rajasuriya (2007), recorded thirty two species of reef fish including four species of butterflyfish [Threadfin butterflyfish (Chaetodon Auriga); Redtail butterflyfish ( $C$. collare); Indian vagabond butterflyfish (C. decussatus); and Eight band butterflyfish (C. octofasciatus)]; rabbit fish [Streaked spinefoot (Siganus javus); White-spotted spinefoot ( $S$. canaliculatus), Golden-lined spinefoot ( $S$. lineatus); parrotfish [Ember parrotfish (Scarus rubroviolaceus); Blue-barred parrotfish ( $S$. ghobban); sweetlips [Minstrel sweetlips (Plectorhinchus schotaf)]; and surgeonfish [Yellowfin surgeonfish (Acanthurus xanthopterus) Black-spot surgeonfish $(A$. bariene). However, reef fish were scarce during the present survey; large reef fish were absent. Cadaba fruticose, three nationally Vulnerable species - Indigofera oblongifolia, plain orange tip (Colotis aurora) and the little-ringed plover (Charadrius dubius) 


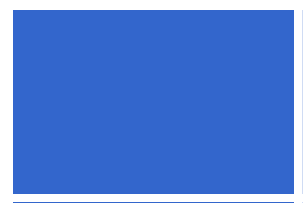

Proposed

actions

Proposed

improvements

Carrying

capacity for

tourism

activities as well as the endemic species, Vernonia zeylanica recorded in arid mixed evergreen forests. The palmyra tree (Borassus flabellifer) is the most commonly seen plant in the island. The tidal flat also contained mangrove species such as Avicennia marina and Salicornia brachiata.

Bird watching during the migratory season can be promoted.

Hides, nature trails, home stays, guest houses and small restaurants should be established but with environmental safeguards integrated. (See Chapter 6.)

Twenty to thirty at a time (morning/afternoon) for bird watching. 


\section{Annex 2. Profiles of coastal stretches surveyed}

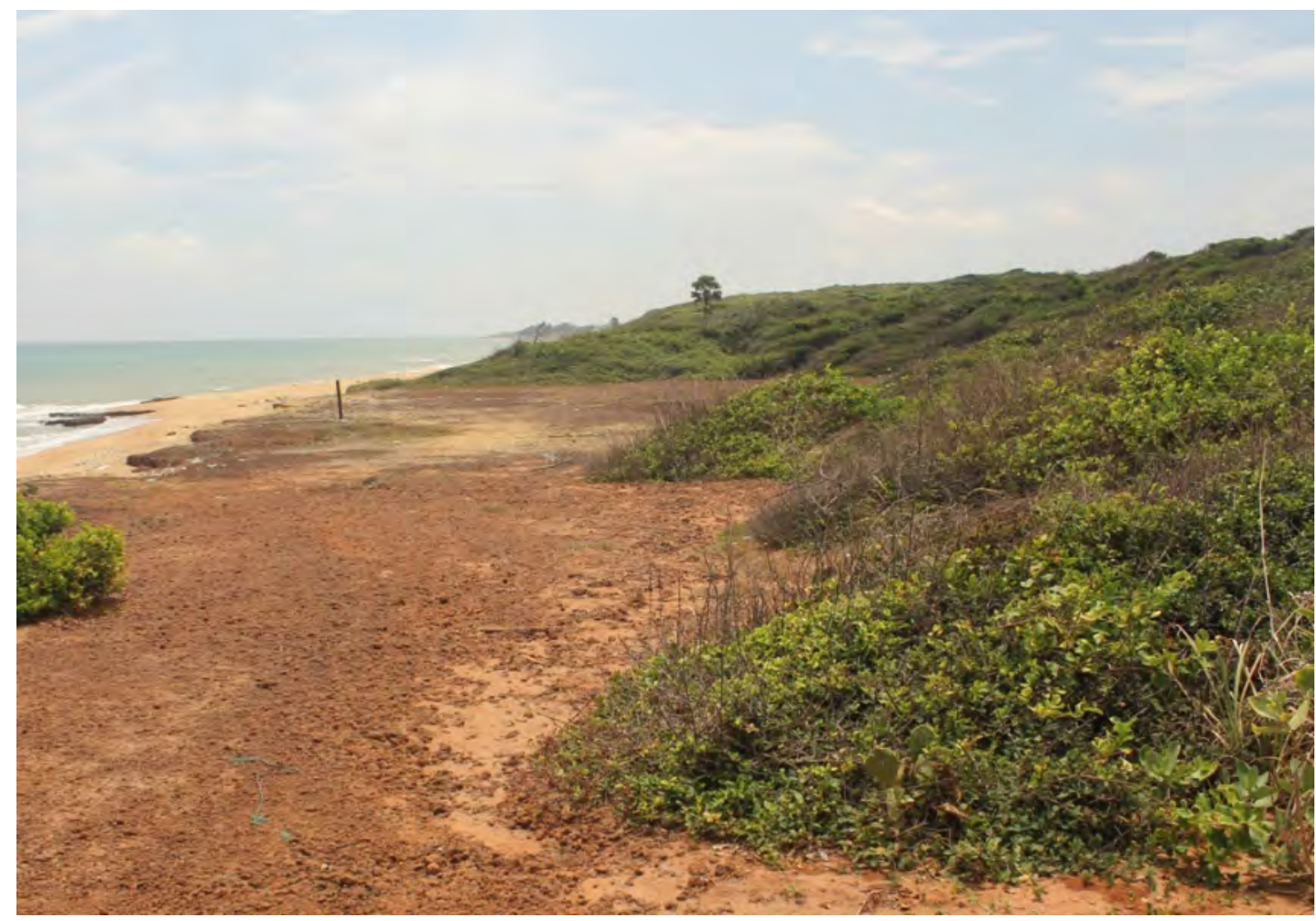

Beach front view of dry-mixed evergreen forest, Mullaittivu $\odot$ IUCN/Naalin Perera 


\section{Kalmunai to Pooneryn}

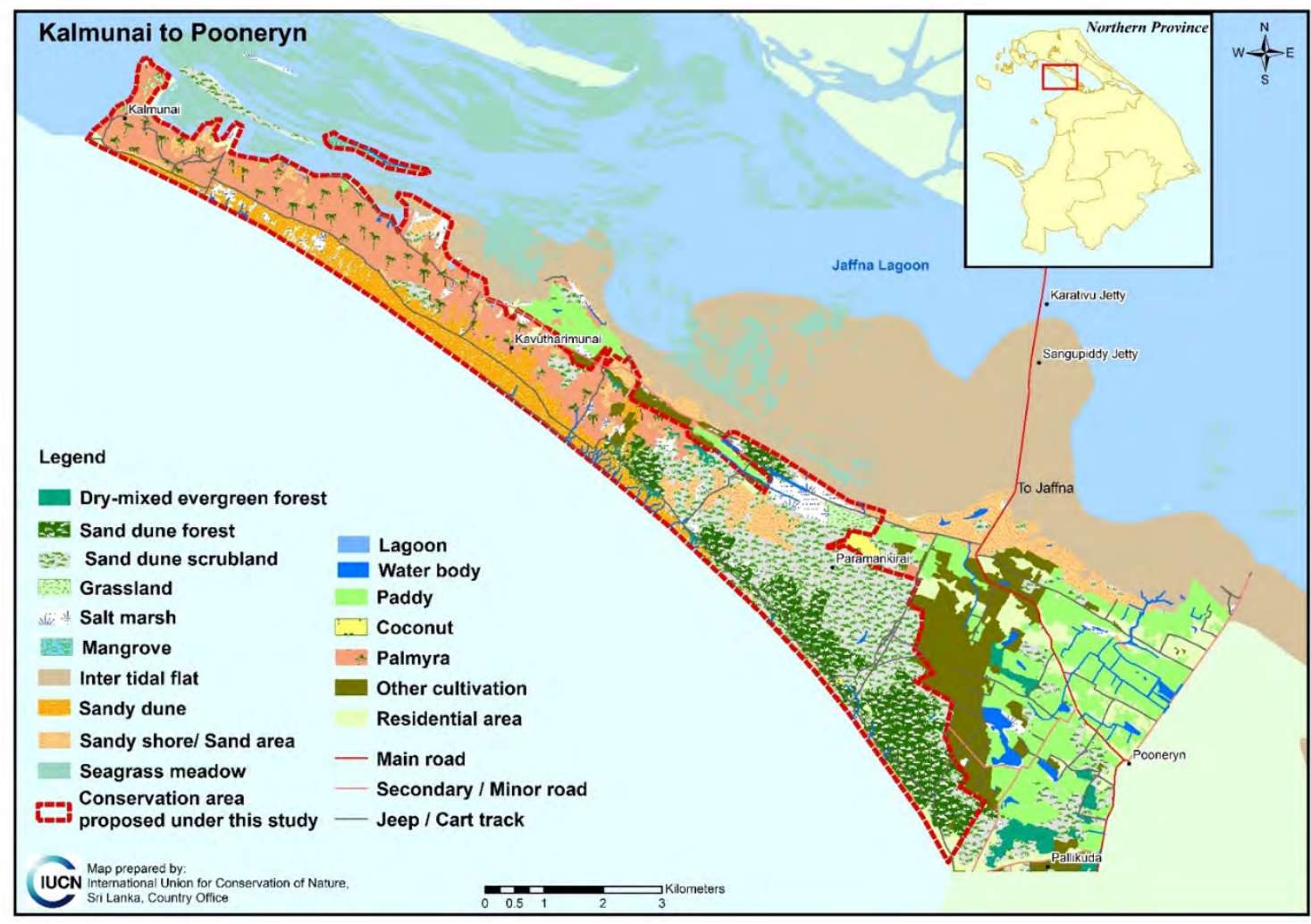

Figure 81. Map of the coastal stretch from Kalmunai to Pooneryn, showing ecosystems and land use 


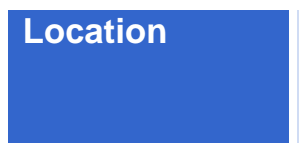

\section{Ecosystems}

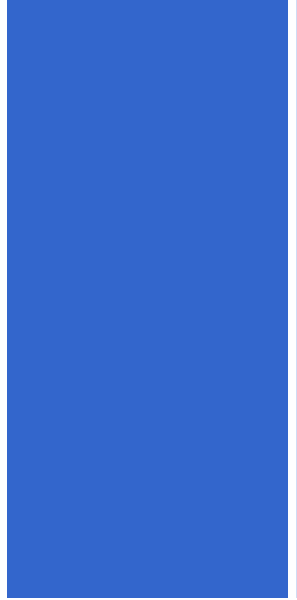

\section{Special}

attributes

Proposed

actions

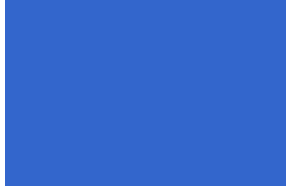

Proposed

improvements

Carrying

capacity for

tourism

activities

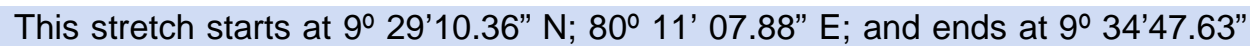
$\mathrm{N} ; 80^{\circ} 05^{\prime} 11.39^{\prime \prime} \mathrm{E}$ and lies in the Poonakary divisional secretariat division in the Kilinochchi District (Figure 81).

\section{Terrestrial ecosystems}

Patches of sand dune forests, sand dunes and seashore scrubland, tidal flats, palmyra woodlands, paddy lands and human habitation are found in this Peninsula.

Species found here include black-naped hare (Lepus nigricollis), jungle fowl (Gallus lafayettii), rose-ringed parakeet (Psittacula krameri), Brahminy kite (Haliastur indus), palm swift (Cypsiurus parvus), star tortoise (Geochelone elegans), sand lizard (Sitana devakai), common Pierrot (Castalius rosimon), and common jezebel (Delias eucharis).

Marine ecosystems were not surveyed, but other data (NARA, 2017) show seagrasses almost surrounding the Peninsula and extensive inter-tidal flats on the northern border of the Peninsula.

Waders such as sandpipers, plovers, curlews, whimbrels and scrubland birds such as pitpits, skylarks and partridges are seen along this stretch.

Much of the peninsula is proposed as a conservation area to protect the sand dunes and associated ecosystems (Figure 81). The type and degree of protection must be decided upon after detailed studies, as recommended in Chapter 6.

Bird watching can be promoted during the migratory season, as well as camping and cycling.

Bird hides, and nature trails can be established as day trips arranged from Jaffna.

A maximum of 250 people per day. 


\section{Punnalai Khadu}

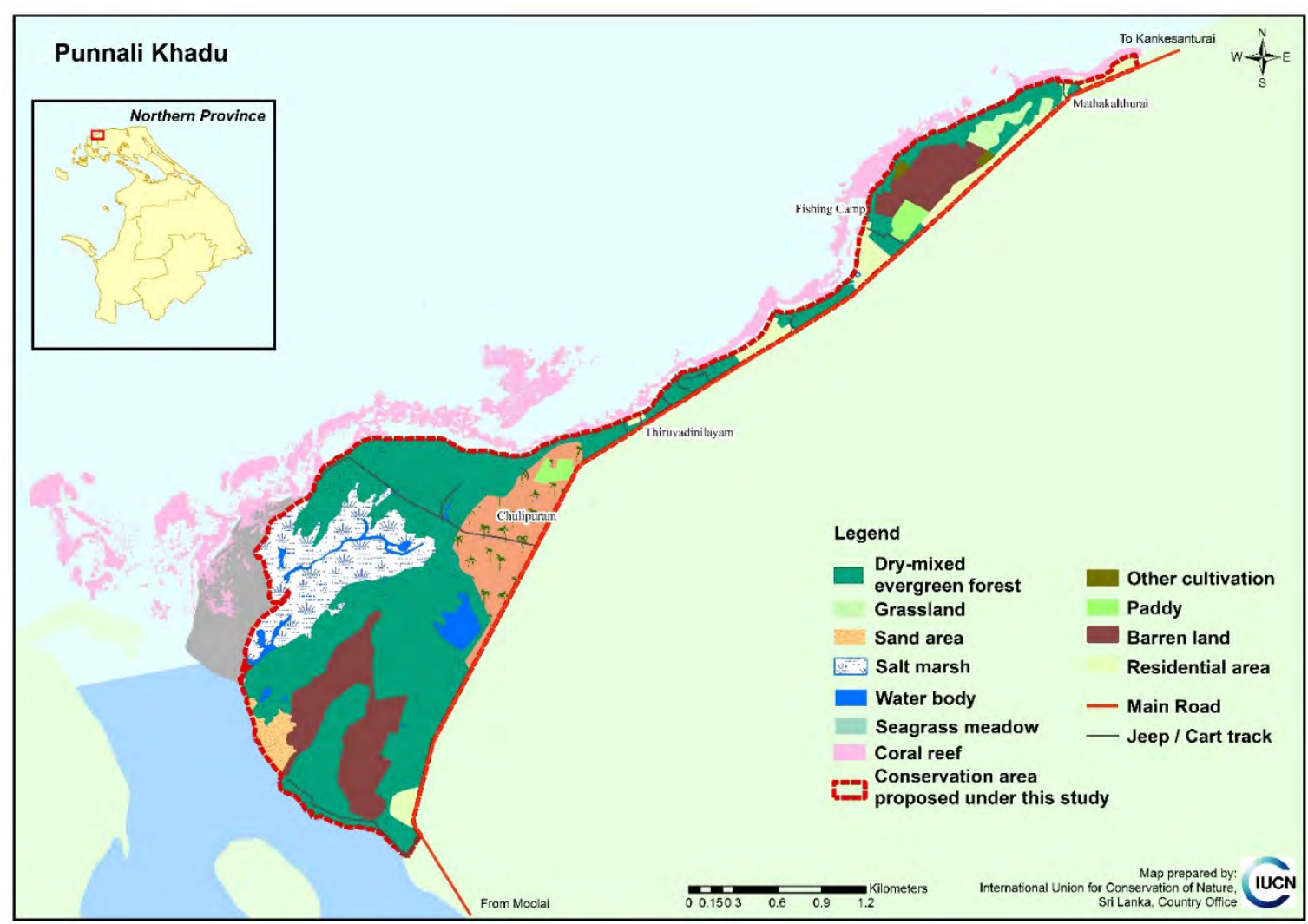

Figure 82. Map of the coastal stretch at Punnalai Khadu, showing ecosystems and land use 


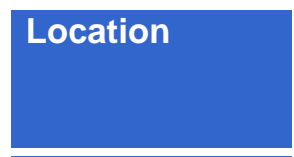

Ecosystems

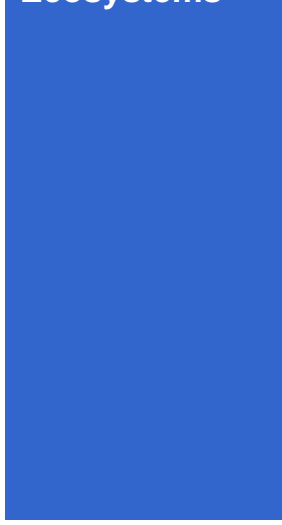

Special

attributes

Proposed

actions

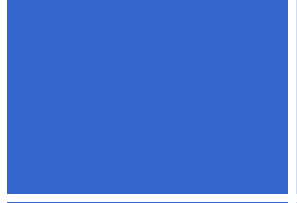

Proposed

improvements

Carrying

capacity for

tourism

activities
This stretch starts at $9^{\circ} 46^{\prime} 30.10^{\prime \prime} \mathrm{N}$; 79 54' 39.09" E and ends at End $9^{\circ} 46^{\prime}$ $31.28 " \mathrm{~N}$; $79^{\circ} 55^{\prime} 18.45^{\prime \prime} \mathrm{E}$ and is in the Valikamam West (Chankanai) divisional secretariat division in the Jaffna District (Figure 82).

\section{Terrestrial ecosystems}

Terrestrial ecosystems observed in this stretch include dry-mixed evergreen forests, palmyra woodlands, sandy shores, dry grasslands, ponds, salt marshes associated with tidal flats, and sandy seashores. The first two ecosystems mentioned are spread extensively over this coastal stretch. Home gardens were also found.

A total of 48 plant and 37 animal species, respectively, were recorded in this coastal stretch. The fauna species were represented by 15 butterfly, two reptile and 18 bird species, respectively.

Marine ecosystems were not surveyed.

This stretch has a sandy beach, fish landing sites, and small patches of salt marshes.

The headland and a narrow strip are proposed as a conservation area (Figure 82). The type and degree of protection must be decided upon after detailed studies, as recommended in Chapter 6.

Birdwatching can be promoted for scrubland birds and some waders in the small patch of salt marshes.

Nature trails, camping sites can be established, ensuring that environmental safeguards are also established (Chapter 6).

Twenty to forty persons per day. 


\section{Northern coastal stretch of the Jaffna Peninsula (from Thiruvadinilayam - Dambakolapatuna to Point Pedro)}

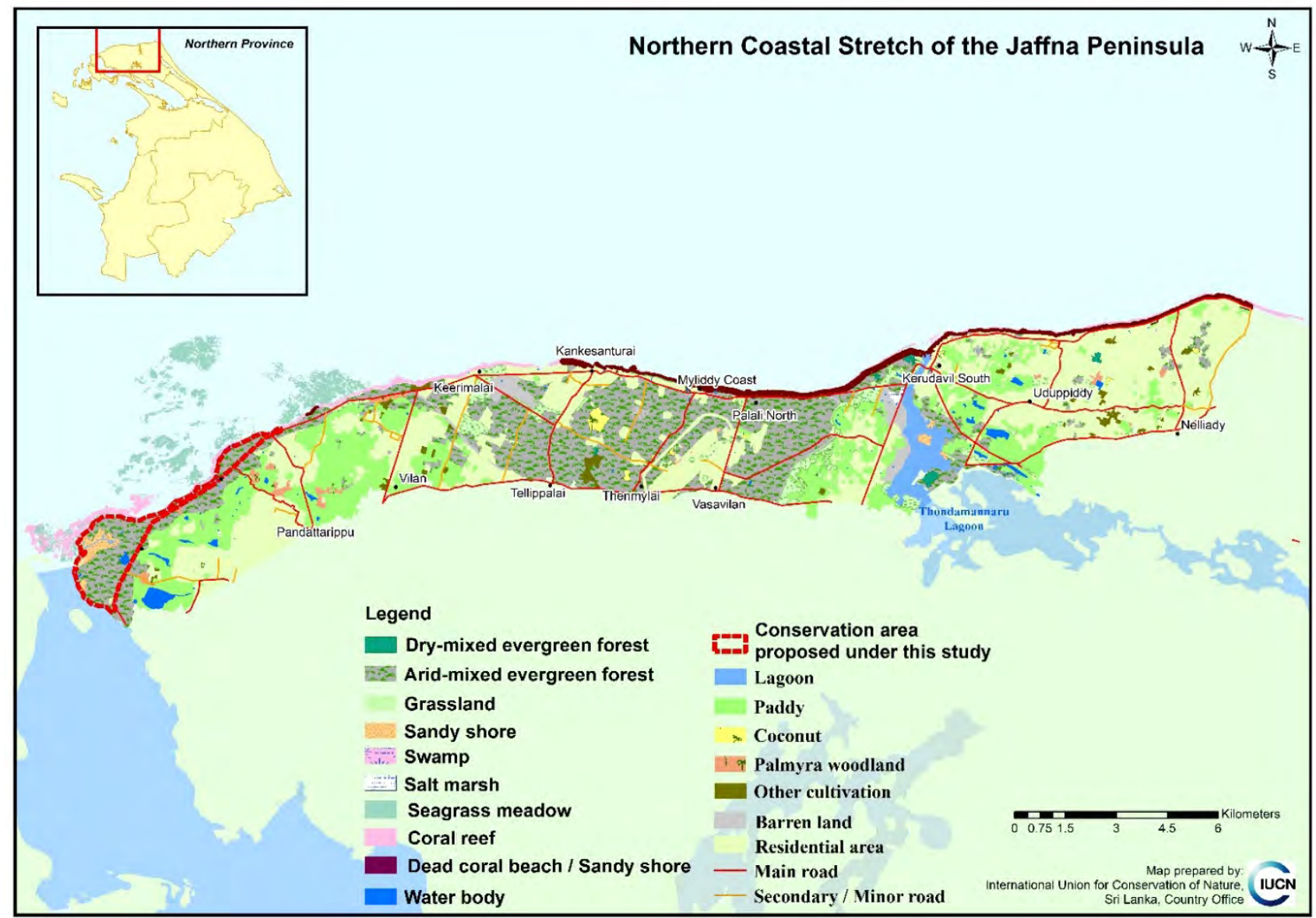

Figure 83. Map of the northern coastal stretch of the Jaffna Peninsula (from Thiruvadinilayam-Dambakolapatuna to Point Pedro), showing ecosystems and land use 


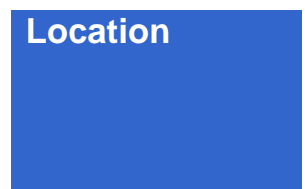

Ecosystems

\section{Special}

attributes
This stretch starts at $9^{\circ} 47^{\prime} 11.16^{\prime \prime} \mathrm{N} ; 79^{\circ} 56^{\prime} 35.30^{\prime \prime} \mathrm{E}$ and ends at $9^{\circ} 50^{\prime} 10.48^{\prime \prime}$ $\mathrm{N} ; 0^{\circ} 12^{\prime} 44.13^{\prime \prime} \mathrm{E}$ and includes parts of the divisional secretariat divisions of Vadamaradchi North (Point Pedro), Valikamam East (Kopay), Valikamam North (Tellippalai) and Valikamam South-West (Sandilipay) (Figure 83).

\section{Terrestrial ecosystems}

The coastal zone of the northern border of Jaffna Peninsula consists of limestone. It is noteworthy that the inter-tidal zone of this stretch comprises rubble and dead coral beaches, while the sub-tidal area is covered with rubble, and both dead and live corals. Terrestrial ecosystems observed along this stretch included dead coral beaches, sandy shores, small inland lagoons, home gardens (coastal) and built up areas. The Jaffna-Kankesanturai-Point Pedro main road lies along the coastal stretch of this area. The diversity of terrestrial flora and fauna observed along this stretch was low, as the area has built infrastructure.

\section{Marine ecosystems}

This coastal stretch has a continuous fringing coral reef from Dambakolapatuna to Point Pedro. The reef varies in width from about $50 \mathrm{~m}$ to $150 \mathrm{~m}$. A narrow $(10 \mathrm{~m})$ reef lagoon is present in several locations. The reef crest is exposed even at high tide and it is topped by dead coral pieces swept up by wave action. The reef crest is breached in several locations by fishermen to use as channels to bring in boats into the reef lagoon which is used as an anchorage. The water quality in the reef lagoon is generally poor where boats are anchored. There is much pollution in these areas due to discarded fish offal and pollution from the boats including oil.

The seaward side of the reef crest has good coral cover. The coral reef is dominated by massive corals, mainly belonging to the families of Poritidae, Faviidae and Mussidae. The dominant species were Favites halicora, F. chinensis, Favia matthaii, F. speciosa, F. pallida, Diploastrea heliopora, Platygyra lamellina, P. daedalea, Leptoria phrygia, Goniastrea retiformis, G. edwardsi, Porites lutea and Porites lobata. Species of Acropora and Montipora were common but was limited to small colonies. Large soft corals of the genus Sarcophyton and Sinularia were common in the sector of the nearshore area.

Many species of reef fish were observed in this area. Species diversity of reef fish, as well as corals, was higher than in the Palk Bay and the western part of the Palk Strait. Reef fish included surgeonfish (Acanthuridae), butterflyfish (Chaetodontidae), damselfish (Pomacentridae), wrasses (Labridae), snappers (Lutjanidae), sweetlips and grunts (Haemulidae), mullets (Mugilidae), rabbitfish (Siganidae) and parrotfish (Scaridae).

Notable plant species recorded on this coastal stretch included one nationally Endangered species, Cadaba fruticosa and three nationally Vulnerable species - Crinum zeylanicum, Cassine glauca and Indigofera oblongifolia. Cassine glauca is also endemic to Sri Lanka.

Notable fauna recorded along this coastal stretch included two nationally Vulnerable butterfly species - the plain orange tip (Colotis aurora) and large salmon Arab (Colotis fausta) - and two nationally Near Threatened species little orange tip (Colotis etrida) and Eurasian collared dove (Streptopelia decaocto). 

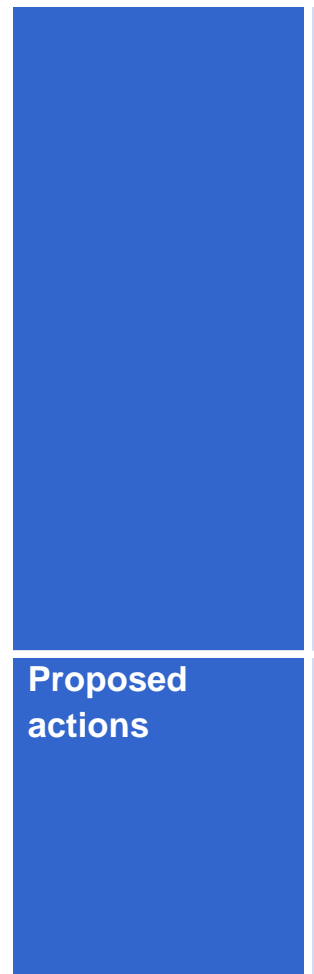

Proposed

improvements

Carrying
capacity for
tourism
activities

The diversity of corals and well as fish is higher here than in Palk Bay. Notable reef fish include the yellowtail mullet (Sicamugil cascasia ${ }^{22}$ )

The Dambakolapatuna, used as a port in historical times, is reported to be the place where Sangamiththa Theri landed with the Bo sapling; and where King Devanampiyathissa welcomed her. In commemoration of this event, the king built the Dambakolapatuna Viharaya (Jambokola Viharaya) (Figure 84). Keerimalai (Figure 84), also found in this coastal stretch, consists of two ponds that have been built next to the sea. Although the ponds are right next to the sea, their water is not saline but from an underground freshwater spring. Within the premises is Naguleswaram temple. Keerimalai literally translates to 'Mongoose Mound'. Legend has it a sage with a face like a mongoose bathed in these ponds and his face was turned into a human face. To this day, these ponds are believed to have curative properties.

The proposed conservation area in Punnalai Khadu has been discussed in the previous table. It should be noted that under the CCZRMP (2016) the coastal area from Kankesanthurai and Keeramalai been declared a Special Management Area (SMA).

Snorkelling and cultural tourism to Dambakolapatuna and Keerimalai can be promoted. Sport fishing (rod fishing) can also be promoted.

Home stays, guest houses, access road, safe bathing and snorkelling points all developed with the integration of environmental safeguard (Chapter 6).

A maximum of 1,000 per day

22 This species is primarily a freshwater fish which occurs naturally in Pakistan, India and Bangladesh. Found naturally in Indus, Brahmaputra, Ganges, Jamuna and Patna rivers and introduced into the Cauvery River system. This is a migratory species which has not been recorded in other parts of Sri Lanka. According to Bruin et al. (1994), this species lives in coastal and marine environments, mainly adults are over mud banks and some over coral reefs, whiles juveniles are found in estuaries. There are two distinct spawning seasons; April to May and September to October, during which these fish are found in large aggregations. They are caught in castnets, beach seines and bottom setnets and sometimes fishermen use dynamite to catch them, but do not indicate locations. 

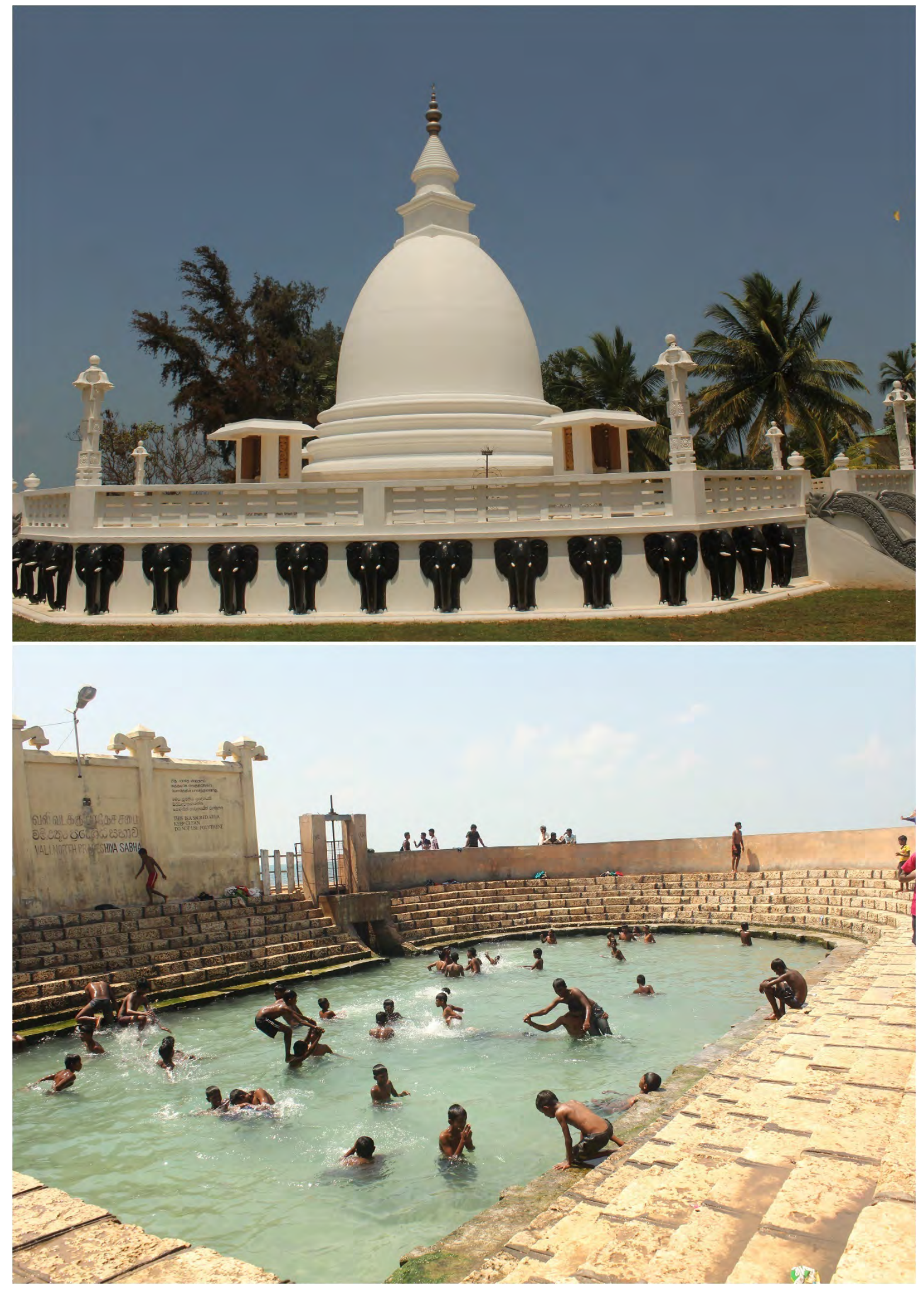

Figure 84. Top: Dambakolapatuna Viharaya and bottom: Keerimalai tank, both found in the northern coastal stretch of the Jaffna Peninsula

(৫) IUCN/Naalin Perera) 


\section{Eastern coastal stretch of the Jaffna Peninsula (Manatkadu to Chundikulam)}

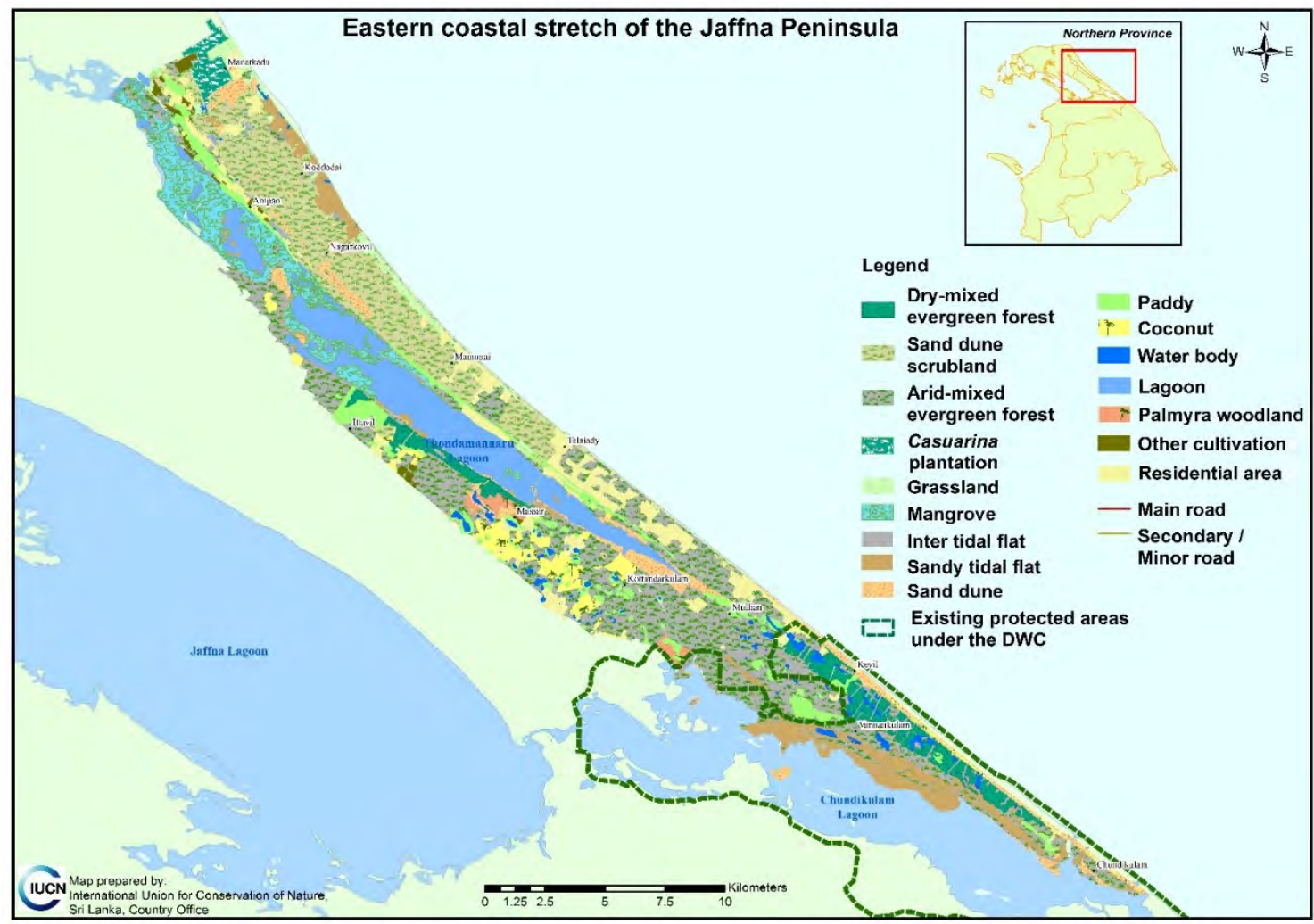

Figure 85. Map of the eastern coastal stretch of Manatkadu to Chundikulam, showing ecosystems, land use and existing protected areas 


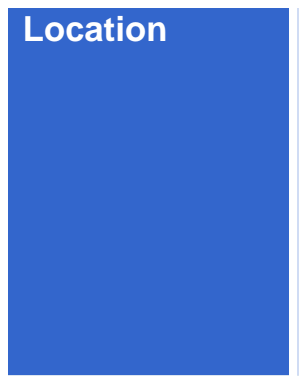

Ecosystems

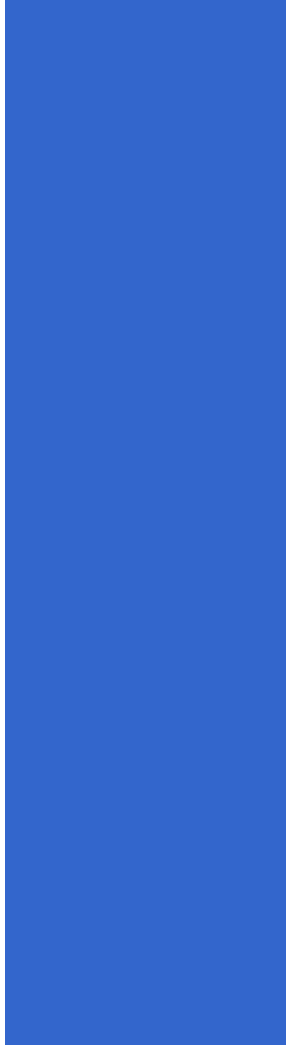

Special

attributes

Proposed

actions

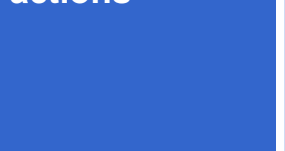

Proposed

improvements

Carrying

capacity for

tourism

activities
This coastal stretch starts at $9^{\circ} 48^{\prime} 57.17^{\prime \prime} \mathrm{N}$; $80^{\circ} 15^{\prime} 19.76^{\prime \prime} \mathrm{E}$ and ends at $9^{\circ} 28^{\prime}$ $47.89^{\prime \prime} \mathrm{N} ; 80^{\circ} 3530.01 \mathrm{E}$. It lies within the Vadamaradchi East (Maruthnkerny) divisional secretariat division of the Jaffna District (Figure 85).

The name Manatkadu means sand bush and is a reference to the vegetative growth on sand dunes found in this area. Manalkadu translates to sand-bush, referring to Sri Lanka's longest chain of sand dunes that are partly overgrown by thicket.

Ecosystems observed along this stretch included large patches of dry mixed evergreen forests mixed Palmyra, sand-dunes scrublands, sand dunes and sand dune forests, forest monoculture plantations (Casuarina), sandy shores and mangroves. The northern part of the area, known as Manatkadu, has extensive sand dunes - likely the longest stretch in Sri Lanka. Sand dunes narrow towards the south and finally turn into sandy beaches, with home gardens planted mostly with coconut. Within Thondaimanaru Lagoon are patches of mangroves.

Found within this coastal stretch are two lagoons - Thondaimanaru and Chundikulam. Thondaimanaru Lagoon is located east of Jaffna Lagoon and separates Thenmaradchchi to the west of it from the Vadamaradchchi region to its east (Piratheepa et al., 2016). It is $74.5 \mathrm{~km}^{2}$ in extent (Silva et al., 2013). It is a brackish water lagoon that extends south-east along the eastern side of the Peninsula for $45 \mathrm{~km}$ (Kotagama et al., 2009). It is also shallow - just two metres deep - and, during the dry season, much of the south-eastern section dries out (Kotagama et al., 2009). In 1953, in an attempt to provide fresh water to the Jaffna Peninsula, the Irrigation Department built a barrage close to the mouth of the lagoon. The intent was that by preventing the ebb and flow of the tides, a freshwater lake would be created (Piratheepa et al., 2016). On the edges of this lagoon are mangroves, salt marshes, tidal flats and submerged seagrass meadows (MFF, 2015b), as well as arid mixed evergreen forests, grasslands and beaches. There is a small area of urbanised land on the boundary of this lagoon. Because there is no opening to the sea (see below), this lagoon exists predominantly as a fresh water/ brackish water lake.

\section{Chundikulam is now a national park.}

The park will be developed by the DWC, with bungalows and other infrastructure. Bird watching should be promoted in this park with hides and boat rides. For the rest of the area, home stays, beach walks, camping, recreational finishing, bird watching, boat rides can be promoted but with environmental safeguards proposed in Chapter 6.

Prime among the essential needs for this area is training for jeep drivers within the park, and integration of environmental safeguards discussed in Chapter 6 .

This is a large stretch and could accommodate more than 500 people per day. 


\section{North-east coast (between Chundikulam to Kokkiliai Lagoon)}

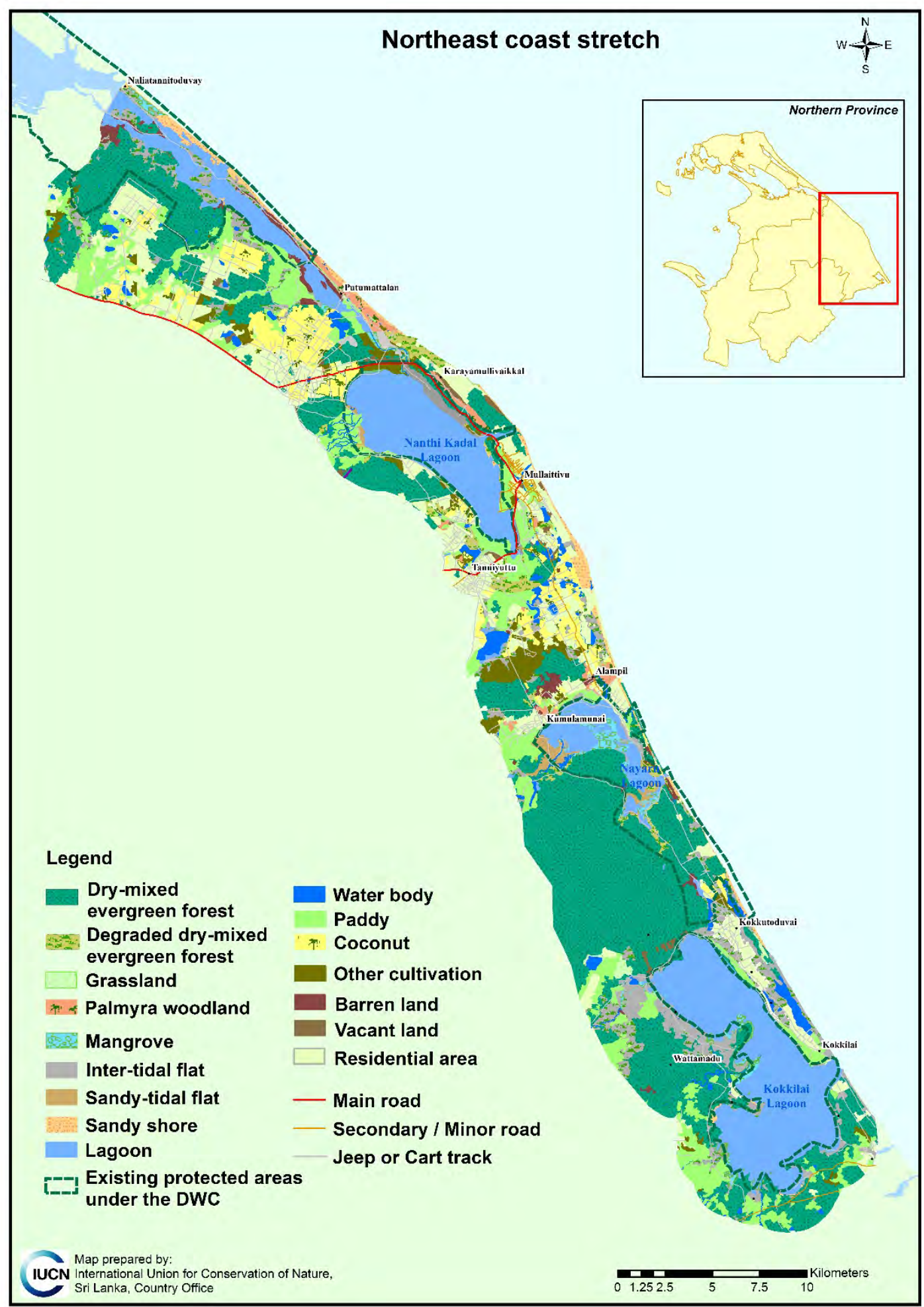

Figure 86. Map of the north-east coast (between Chundikulam to Kokkiliai Lagoon), showing ecosystems and land use 


\begin{tabular}{|c|c|}
\hline Location & $\begin{array}{l}\text { This coastal stretch starts at } 9^{\circ} 28^{\prime} 34.74 " \mathrm{~N} ; 80^{\circ} 3543.95 \mathrm{E} \text { and ends at } 8^{\circ} 59^{\prime} \\
16.40^{\prime \prime} \mathrm{N} ; 80^{\circ} 3543.95 \mathrm{E} \text {. This } 60 \mathrm{~km} \text { coastal stretch is in the Maritimepattu } \\
\text { divisional secretariat division of the Mullaitivu District (Figure } 86 \text { ). }\end{array}$ \\
\hline Ecosystems & $\begin{array}{l}\text { There are dry-mixed evergreen forests, sandy shores, gravelly shores, lagoons, } \\
\text { mangroves, tidal flats, dry grasslands, coconut plantations, home gardens and } \\
\text { towns in this coastal stretch. Nayaru, Nanthi Kadal and Kokkiliai are large lagoons } \\
\text { found along this stretch. The stretch of dry-mixed evergreen forests between } \\
\text { Mullaittivu and Kokkiliai is only one of its kind found along the north-east coast. } \\
\text { Apart from the brackish water lagoons, found along this stretch, there are also } \\
\text { are several freshwater wetland systems - such as, for example, Alampil Kulam. } \\
\text { Many aquatic bids including ducks, cormorants, egrets, herons can be found in } \\
\text { these wetlands. }\end{array}$ \\
\hline $\begin{array}{l}\text { Special } \\
\text { attributes }\end{array}$ & $\begin{array}{l}\text { The lagoons along this stretch are home to many plant and animal species, for } \\
\text { example } 330 \text { plant, } 28 \text { fish, } 24 \text { butterfly, nine dragonfly, four amphibian, four } \\
\text { reptile, } 132 \text { bird and } 21 \text { mammal species, respectively, have been recorded from } \\
\text { Kokkiliai Lagoon. For more details, please refer to the next annex. }\end{array}$ \\
\hline $\begin{array}{l}\text { Proposed } \\
\text { actions }\end{array}$ & Boat rides, bird watching, camping and wildlife bungalows. \\
\hline $\begin{array}{l}\text { Proposed } \\
\text { improvements }\end{array}$ & $\begin{array}{l}\text { Given that all these lagoons are now declared as protected areas under the DWC, } \\
\text { it is expected that improvements will be made by the DWC commensurate with } \\
\text { the level of protection afforded. }\end{array}$ \\
\hline $\begin{array}{l}\text { Carrying } \\
\text { capacity for } \\
\text { tourism } \\
\text { activities }\end{array}$ & A hundred visitors per day. \\
\hline
\end{tabular}




\section{Annex 3. Profiles of lagoons}

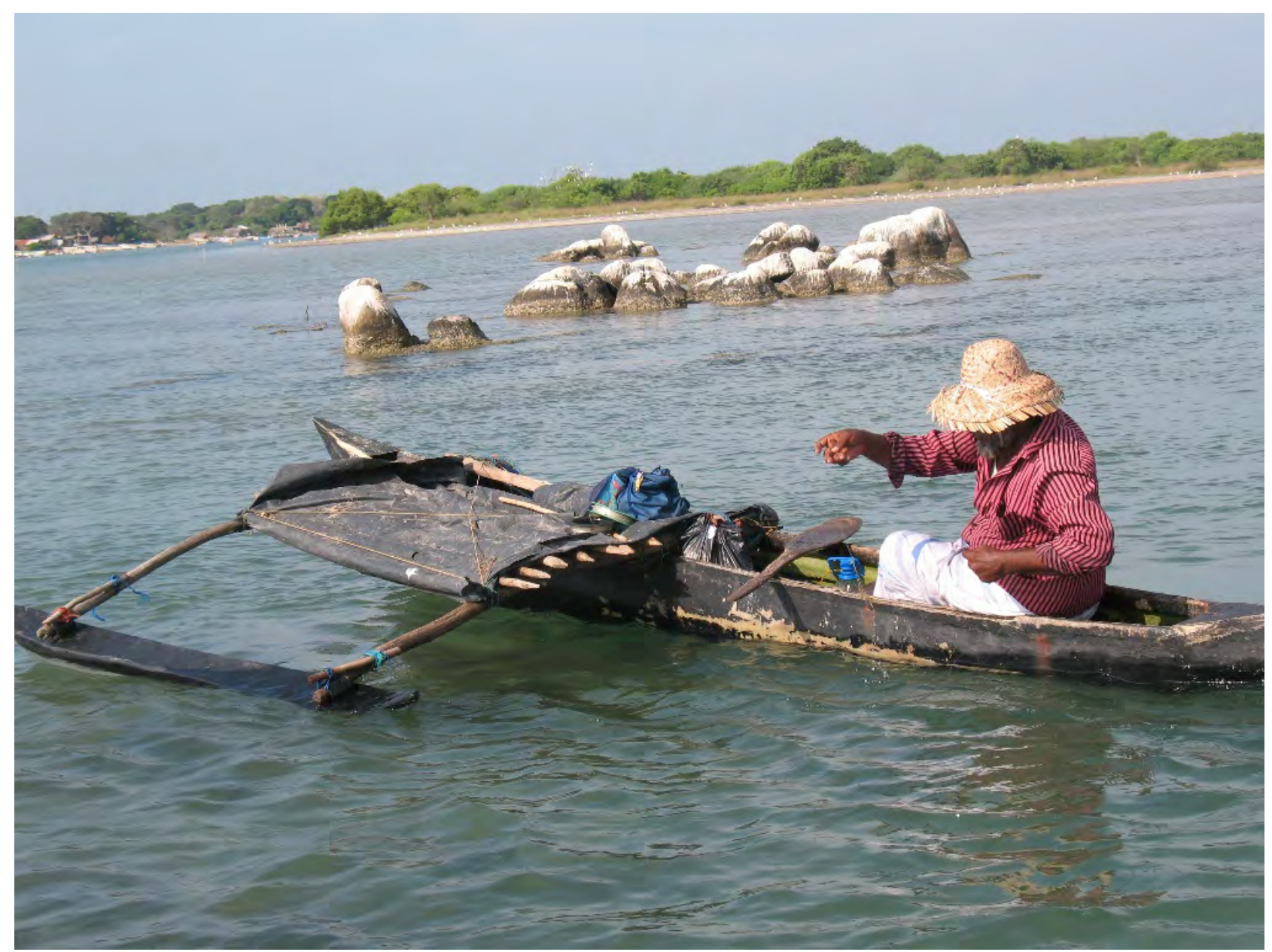

Fisherman, Kokkilai Lagoon $\odot$ IUCN/Kumudini Ekaratne 


\section{Introduction}

Coastal lagoons are shallow water bodies separated from the ocean by a barrier, connected at least intermittently to the ocean by one or more restricted inlets and usually oriented parallel to the shoreline and often length exceeds the width (Kennish and Paerl, 2010 in litt. Miththapala 2013b). Because lagoons are relatively shallow (a few metres in depth) and sometimes have limited water flow (Kjerfve, 1994, in litt Miththapala, 2013b), they are highly susceptible to changes in precipitation, evaporation and wind which results in rapid changes in salinity and temperature (Kennish and Paerl, 2010). Discharges from rivers and tidal inflow from the sea are essential for these ecosystems and they are, therefore, vulnerable to changes in these flows (Samarakoon and Samarawickrama, 2012).

Most of the lagoons of Sri Lanka originated in the mid-Holocene period, about 10,000 years BP (Silva et al., 2013; NSAP, 2009). During this period, the sea level rose, forming barrier and developing spits, eventually, enclosing a body of water between the land and sea. Depending on the coastal stretch, littoral drift, river inputs and sediments transported with these inputs and the tides maintained the developed barrier (Silva et al., 2013).

'Lagoons and estuaries, lying at the boundary between the ocean and land, house a unique mosaic of ecosystems from sea to land. Apart from lagoons and estuaries, there may be barrier islands, spits, beaches, sand dunes, salt marshes, seagrasses within lagoons and estuaries, as well as mangroves fringing their shores (de Wit, 2011). This high ecosystem diversity within the immediate landscape of lagoons and estuaries, gives rise not only to high species diversity but also to the creation of ecotones - areas of transition between two habitats.' (Miththapala, 2013b). Therefore, lagoons - through the diverse ecosystems they house - support a high level of biodiversity (de Wit, 2011; Kennish and Paerl, 2010 in litt Miththapala, 2013b).

Lagoons are extremely important in the sustenance of coastal fisheries. Many edible shell fish and fish are found in lagoons, estuaries and their associated habitats such as mangroves and seagrasses. The relatively calm habitats of lagoons allow for the practice of traditional and artisanal fisheries (Bjork et al., 2008 in litt Miththapala 2013b). They also provide a suite of other ecosystem services, such as nutrient cycling, flood protection and carbon sequestration.

'Lagoons and estuaries are water-dominated ecosystems formed at the interface between the land and the sea. Hence, the attributes of water determine the life or death of estuaries and lagoons ... '(Samarakoon and Samarawickrama, 2012). Lagoons are threatened by many anthropogenic activities both inland and on the coast (Kennish and Paerl, 2010 in litt Miththapala 2013b).

Hydrological changes to lagoons - changes in the natural inflow from rivers and ebb and flow of the tides - have profound impacts on the salinity regimen of lagoons (Kennish, 2002 in litt. 2013b) as does changes in water quality (pollution) (Kennish and Paerl, 2010 in litt Miththapala 2013b). Gnaneswaran (2015) details the concerns for the lagoons of the Northern Peninsula, and hydrological alterations appear to be rampant. 
This study focussed only on four lagoons in the Northern Province - Chundikulam, Nanthi Kadal, Nayaru and Kokkilai - and this annex provides brief profiles of these lagoons. Information for Vidattaltivu is also provided from other IUCN data.

However, it should be noted that a detailed study about their ecosystems and species diversity (capturing seasonal variation) including the terrestrial systems that surround these lagoons, as well as the marine environment adjacent to these lagoons is necessary to fully understand their biodiversity, current status and drivers of ecosystem change, in order to develop strategies to conserve them.

It is strongly recommended that

Table 16. Names of the five lagoons detailed in this report their extents.

\begin{tabular}{|c|c|}
\hline Name of Lagoon & Area (ha) \\
\hline Vidattaltivu & 386 \\
\hline Chundikulam & 5,398 \\
\hline Nanthi Kadal & 3,339 \\
\hline Nayaru & 1,150 \\
\hline Kokkilai & 5,474 \\
\hline
\end{tabular}

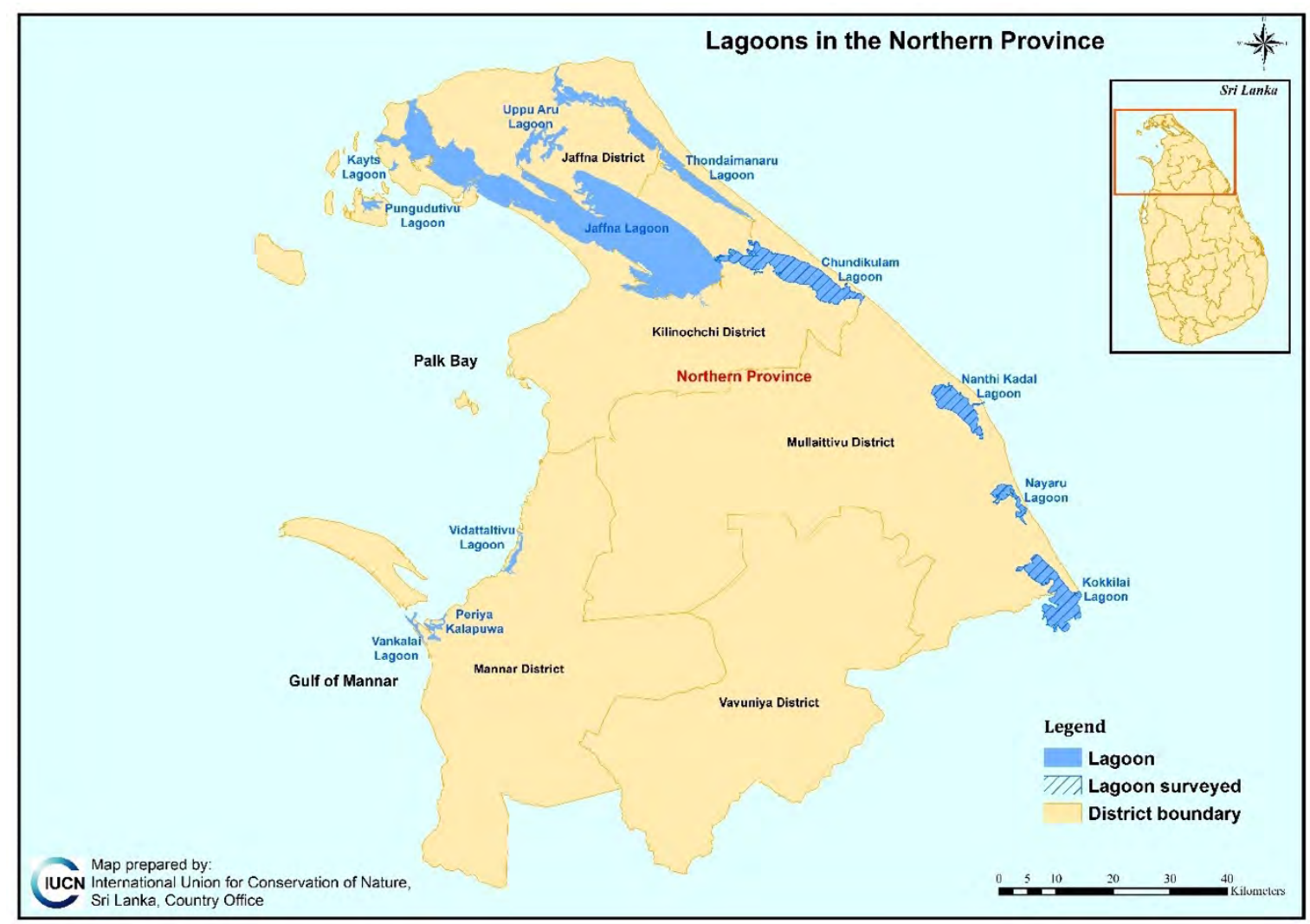

Figure 87. Map of the lagoons of the northern coastline 
Although Jaffna and Thondaimanaru lagoons were not studied under this assessment, their importance is discussed using secondary data/information. Given the thrust of development in the north and the rapid destruction of mangroves, construction of causeways, roads and culverts across parts of these lagoon (Gnaneswran, 2015), detailed studies, not only of the ecosystems and species of these lagoons, but also of the salinity levels is critically important, as ongoing development changes will, indubitably, have profound impacts on these lagoon systems.

Table 17. Ecological and livelihoods value of two major lagoons in the Jaffna Peninsula

\begin{tabular}{|c|c|c|c|}
\hline $\begin{array}{l}\text { Location and lagoon } \\
\text { characteristics }\end{array}$ & $\begin{array}{l}\text { Ecosystems and } \\
\text { species }\end{array}$ & Ecological value & Fisheries value \\
\hline \multicolumn{4}{|l|}{ Jaffna Lagoon } \\
\hline $\begin{array}{l}\text { Jaffna Lagoon, the } \\
\text { largest lagoon in Sri } \\
\text { Lanka, is a shallow (< } 4 \\
\text { m in depth) with a water } \\
\text { body extending over } 441 \\
\text { km² (Silva et al., 2013). It }_{\text {straddles the Jaffna and }} \\
\text { Kilinochchi Districts } \\
\text { [surrounded by } \\
\text { Thenmaradchi } \\
\text { (Chavakachcheri) of } \\
\text { Jaffna, and } \\
\text { Pachchilaipalli and } \\
\text { Kandavalai DSDs]. } \\
\text { This lagoon has multiple } \\
\text { entrances: in the north- } \\
\text { west, it opens between } \\
\text { Karaitivu and Punnalai to } \\
\text { Palk Bay; in the north, to } \\
\text { Uppu Aru Lagoon; in the } \\
\text { west between Kayts and } \\
\text { Karaitivu, in the south- } \\
\text { west between Mandaitivu } \\
\text { and Kalmunai and in the } \\
\text { south-east it connects } \\
\text { with Chundikulam } \\
\text { Lagoon } \\
\text { (Chitravadivelu,1994; } \\
\text { Silva et al., 2013). } \\
\text { Draining into this large } \\
\text { water body are } \\
\text { Kalawalappu Aru and } \\
\text { Akkarayan Aru (Silva et } \\
\text { al., 2013). The amount of } \\
\text { freshwater reaching the } \\
\text { lagoon is not sufficient for } \\
\text { proper mixing of the }\end{array}$ & $\begin{array}{l}\text { The lagoon boundary } \\
\text { comprises many } \\
\text { human use-dominated } \\
\text { areas, such as highly } \\
\text { urbanised areas, } \\
\text { paddy fields, coconut } \\
\text { plantations, palmyra } \\
\text { plantations and shrimp } \\
\text { cultivation. } \\
\text { However, there are } \\
\text { also extensive tidal } \\
\text { flats. At low tide it is } \\
\text { reported that 2,000 ha } \\
\text { of tidal flats are } \\
\text { exposed (Kotagama et } \\
\text { al. 2009). The lagoon } \\
\text { also has salt marshes, } \\
\text { seagrass meadows, } \\
\text { mangroves, some arid } \\
\text { mixed evergreen } \\
\text { forests, and } \\
\text { grasslands (CEA and } \\
\text { IUCN, 2006; MFF, } \\
2015 a \text { ). } \\
\text { One hundred species } \\
\text { of fin fish, } 28 \text { species } \\
\text { of molluscs, six } \\
\text { species of crabs and } \\
\text { seven species of } \\
\text { shrimps were } \\
\text { identified in the } \\
\text { catches from the } \\
\text { Lagoon (MFF, } 2015 a \text { ). } \\
\text { Seventy-seven } \\
\text { species of birds }\end{array}$ & $\begin{array}{l}\text { Jaffna Lagoon has } \\
\text { been identified as an } \\
\text { IBA based on the } \\
\text { criteria that it is a) } \\
\text { known or thought } \\
\text { regularly to hold } \\
\text { significant numbers } \\
\text { of a globally } \\
\text { threatened species; } \\
\text { and b) known or } \\
\text { thought to hold } \\
\text { congregations of } \geq 1 \% \\
\text { of the global } \\
\text { population of one or } \\
\text { more species on a } \\
\text { predictable basis } \\
\text { (Birdlife International, } \\
\text { 2017). Large } \\
\text { populations of Spot- } \\
\text { billed pelicans } \\
\text { (Pelecanus } \\
\text { philippensis) } \\
\text { congregate here. As } \\
\text { many as } 5,000 \\
\text { greater flamingos } \\
\text { (Phoenicopterus } \\
\text { roseus) have been } \\
\text { recorded here, as } \\
\text { well as large } \\
\text { populations of black- } \\
\text { tailed godwits } \\
\text { (Limosa limosa); little } \\
\text { stints (Calidris } \\
\text { minuta); curlew } \\
\text { sandpipers (C. } \\
\text { ferruginea); Eurasian } \\
\text { wigeon (Anas } \\
\text { penelope); northern }\end{array}$ & $\begin{array}{l}\text { Jaffna Lagoon is } \\
\text { also very significant } \\
\text { for fisheries. Total } \\
\text { annual fish } \\
\text { landings in Jaffna } \\
\text { Lagoon, are the } \\
\text { highest for the } \\
\text { island (5,754,990 } \\
\mathrm{kg} \text { ) and second, for } \\
\text { shrimp catches } \\
\text { (2,629,400 kg) } \\
\text { (Silva et al., 2013). }\end{array}$ \\
\hline
\end{tabular}




\begin{tabular}{|c|c|c|c|}
\hline $\begin{array}{l}\text { Location and lagoon } \\
\text { characteristics }\end{array}$ & $\begin{array}{l}\text { Ecosystems and } \\
\text { species }\end{array}$ & Ecological value & Fisheries value \\
\hline $\begin{array}{l}\text { saline water brought in by } \\
\text { the tides, so seasonally, } \\
\text { this lagoon becomes } \\
\text { hypersaline. }\end{array}$ & $\begin{array}{l}\text { (Wijesena, 2015), } 13 \\
\text { species of amphibians } \\
\text { (Balasubramaniam, et. } \\
\text { al., 2003) and } 18 \\
\text { species of snakes } \\
\text { (Abhirami and } \\
\text { Shivashanthini, 2008) } \\
\text { and three species of } \\
\text { crabs Neptunus } \\
\text { pellagicius, Charydbis } \\
\text { annulata and Scylla } \\
\text { serrata have been } \\
\text { also been recorded } \\
\text { (Chitravadivelu, 1994). }\end{array}$ & $\begin{array}{l}\text { pintails (Anas acuta) } \\
\text { and garganeys } \\
\text { (Spatula } \\
\text { querquedula) } \\
\text { (Kotagama et al., } \\
\text { 2009). } \\
\text { Jaffna Lagoon is also } \\
\text { very significant for } \\
\text { fisheries. Total } \\
\text { annual fish landings } \\
\text { in Jaffna Lagoon, are } \\
\text { the highest for the } \\
\text { island (5,754,990 kg) } \\
\text { and second, for } \\
\text { shrimp catches } \\
\text { (2,629,400 kg) (Silva } \\
\text { et al., 2013). } \\
\text { It should be noted that } \\
\text { under the CCZRMP } \\
\text { (2016) the lagoon is } \\
\text { near the town has } \\
\text { been declared a } \\
\text { Special Management } \\
\text { Area (SMA) }\end{array}$ & \\
\hline \multicolumn{4}{|l|}{ Thondaimanaru Lagoon } \\
\hline $\begin{array}{l}\text { Thondaimanaru Lagoon } \\
\text { is located east of Jaffna } \\
\text { Lagoon and separates } \\
\text { Thenmaradchchi to the } \\
\text { west of it from the } \\
\text { Vadamaradchchi region } \\
\text { to its east (Piratheepa et } \\
\text { al., 2016). It is } 74.5 \mathrm{~km}^{2} \\
\text { in extent (Silva et al., } \\
\text { 2013). It is a brackish } \\
\text { water lagoon that } \\
\text { extends south-east along } \\
\text { the eastern side of the } \\
\text { peninsula for } 45 \mathrm{~km} \\
\text { (Kotagama et al., 2009). } \\
\text { It is also shallow - just } \\
\text { two metres deep - and, } \\
\text { during the dry season, } \\
\text { much of the south- } \\
\text { eastern section dries out } \\
\text { (Kotagama et al., 2009). }\end{array}$ & $\begin{array}{l}\text { On the edges of this } \\
\text { lagoon are } \\
\text { mangroves, salt } \\
\text { marshes, tidal flats } \\
\text { and submerged } \\
\text { seagrass meadows } \\
\text { (MFF, 2015b), as well } \\
\text { as arid mixed } \\
\text { evergreen forests, } \\
\text { grasslands and } \\
\text { beaches. There is a } \\
\text { small area of } \\
\text { urbanised land on the } \\
\text { boundary of this } \\
\text { lagoon. Because there } \\
\text { is no opening to the } \\
\text { sea (see below), this } \\
\text { lagoon exists } \\
\text { predominantly as a } \\
\text { fresh water/ brackish } \\
\text { water lake. }\end{array}$ & $\begin{array}{l}\text { In } 1953 \text {, in an attempt } \\
\text { to provide fresh water } \\
\text { to the Jaffna } \\
\text { Peninsula, the } \\
\text { Irrigation Department } \\
\text { built a barrage close } \\
\text { to the mouth of the } \\
\text { lagoon. The intent } \\
\text { was that by } \\
\text { preventing the ebb } \\
\text { and flow of the tides, } \\
\text { a freshwater lake } \\
\text { would be created } \\
\text { (Piratheepa et al., } \\
2016) \text {. Before the } \\
\text { barrage was } \\
\text { constructed, the } \\
\text { annual fish catch was } \\
152,407 \mathrm{~kg} \text {; after the } \\
\text { barrage was built, the } \\
\text { fish catch dropped to } \\
35,561 \mathrm{~kg} \text { per annum }\end{array}$ & $\begin{array}{l}\text { The productivity of } \\
\text { this lagoon (fish } \\
\text { production per } \\
\mathrm{km} 2 \text { ) is the lowest } \\
\text { in the island ( } 429 \\
\mathrm{~kg} / \mathrm{km} 2) \text { (Silva et } \\
\text { al., 2013). } \\
\text { This lagoon is a } \\
\text { good example of } \\
\text { what the } \\
\text { consequences are } \\
\text { of meddling with } \\
\text { the natural } \\
\text { hydrology of } \\
\text { lagoons. }\end{array}$ \\
\hline
\end{tabular}


(Piratheepa et al., 2016).

A decade after the establishment of the barrage, there were 47 species of fish in the lagoon, but by the late 1970s, there were only 15 species (Atputhanathan \& Chitravadivelu, 1968, in litt. Piratheepa et al., 2016). Currently, there are only 11 (Piratheepa et al., 2016). Thirty-eight species of molluscs were also found (MFF, 2015b).

This lagoon is home to 13 species of migratory birds, including four species of sand piper, two species of plover and two species of ducks (MFF, 2015b).

Under the CCZRMP (2016) the Manatkadu dunes in the area have been declared as Special Management Area. 


\section{Chundikulam Lagoon}

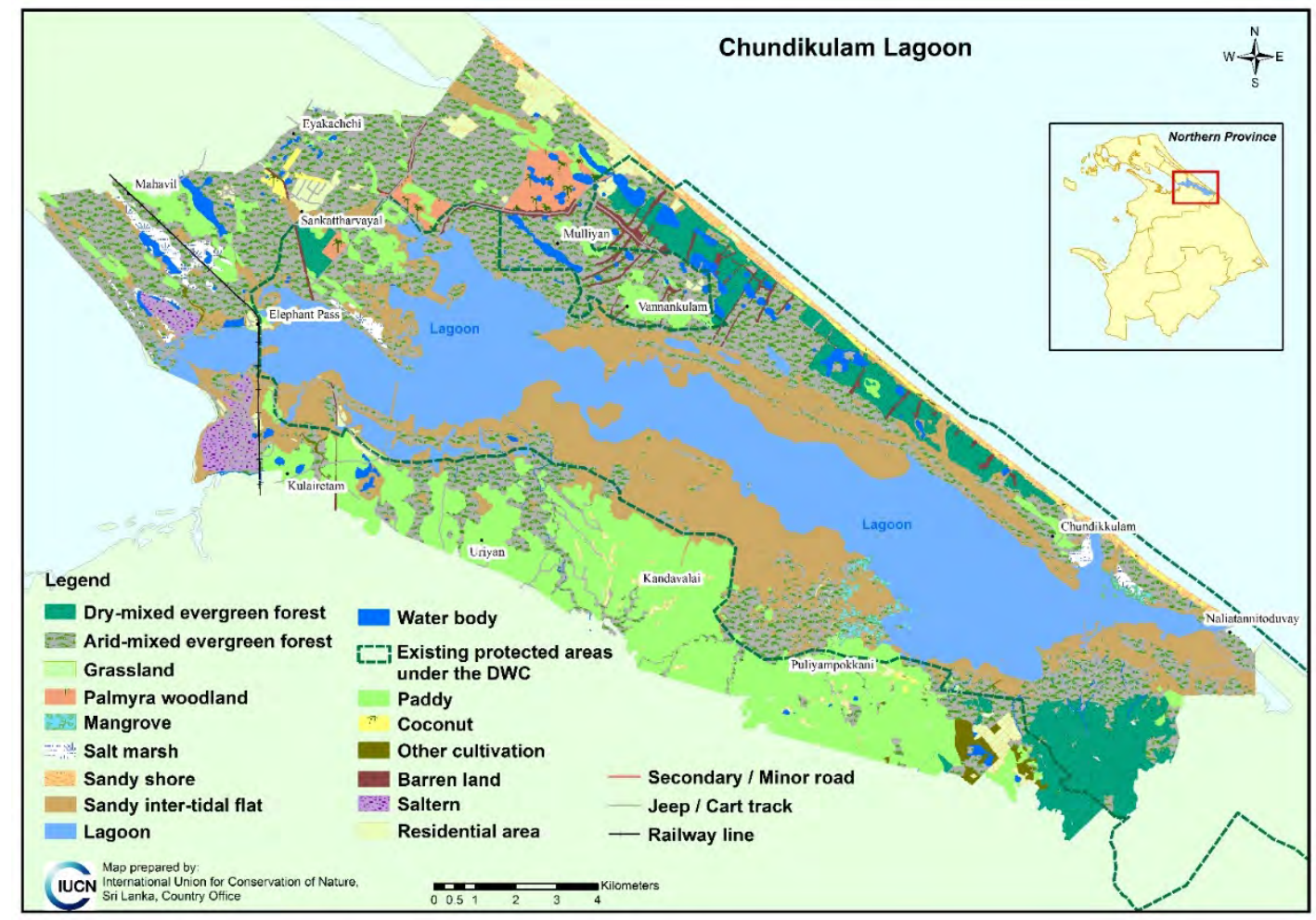

Figure 88. Map of Chundikulam Lagoon its surrounds, showing ecosystems, land use and existing protected areas 
Data are augmented by information from Ekanayake \& Fernando, 2015.

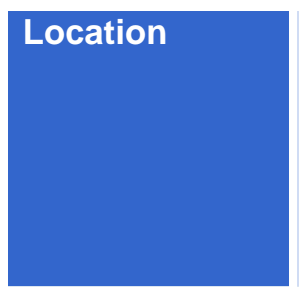

Ecosystems

Special

attributes

Chundikulam Lagoon lies south-east of Jaffna Lagoon and straddles the districts of Jaffna and Kilinochchi (divisional secretariat divisions of Vadamaradchi East (Maruthnkerny) in Jaffna, and Pachchilaipalli and Kandavalai DSD of Kilinochchi), extending over $72.28 \mathrm{~km}^{2}$ (Silva et al., 2013) (Figure 88). The brackish water lagoon is fed by number of small rivers from the south including Kanakarayan aru, Nethli aru and Theravil aru.

Around Chundikulam Lagoon are wide sandy tidal flat, arid mixed evergreen forests, patches of dry-mixed evergreen forest and palmyra woodlands. On the eastern coastal shore are sand dunes, sandy shores and sand dune forests ${ }^{23}$. Sand dune forests comprised Syzygium cumini, Flueggea leucopyrus, Cissus quadrangularis, Croton bonplandianus and Ecbolium ligustrinum. At the mouth of the lagoon are salt marshes. A total of 68 species of plants were observed in the Chundikulam area.

Fringing the lagoon are mangroves and within are seagrass meadows (Kotagama et al., 2009). Also found in the western side are salterns.

Sixty-three species of land and water birds were observed in one day in Chundikulam National Park. These birds included 30 winter visitors such as Eurasian wigeons (Anas penelope), northern shovelers (A. clypeata), northern pintails ( $A$. acuta); garganey ( $A$. querquedula), black-tailed godwits (Limosa limosa) Pacific golden plovers (Pluvialis fulva), common ringed plovers (Charadrius hiaticula), Kentish plovers (C. alexandrines), and lesser sand plovers (C. mongolus), as well as range restricted breeding residents such Saunder's tern (Sterna saundersi) and grey francolin (Francolinus pondicerianus) (Wijesena, 2015). It is also reported that leopards, sloth bear and spotted deer as well as both species of crocodiles (Crocodylus palustris and C. porosus) are found in this park (Abhayagunawardena, 2015; Santiapillai and Wijeyamohan, 2004).

The Elephant Pass causeway blocked the free-flow of water from Jaffna Lagoon, and this lagoon is therefore less saline than Jaffna Lagoon (Silva yet al., 2013) and large areas are reported to dry out during the dry season (Kotagama et al. 2009).

Chundikulam was declared as a bird sanctuary in 1938. In 2015, its conservation status was elevated to a National Park (Figure 88).

A healthy population of Sesamum prostratum, listed as a Critically Endangered species, a crop wild relative of gingelly (Sesamum indicum) was observed across the sandy area between beach and sand dunes. This was the first discovery of the species outside the Panama area. In addition, several species of plants listed as nationally Endangered - such as Salacia oblonga, ebony (Diospyros ebenum), Crotalaria prostrata and beach pea (Vigna marina) were also observed. Several species of endemic plants such as Vernonia zeylanica, Derris parviflora and Memecylon capitellatum were also recorded on the sand dune. Palmyra was the dominant plant observed in many areas (Ekanayake and Fernando, 2015).

Its range of wetland habitats are home to a variety of water birds (which is why it was originally declared a bird sanctuary), including migrants such as the Eurasian

${ }^{23}$ These details are not seen in the current map because of the scale. 


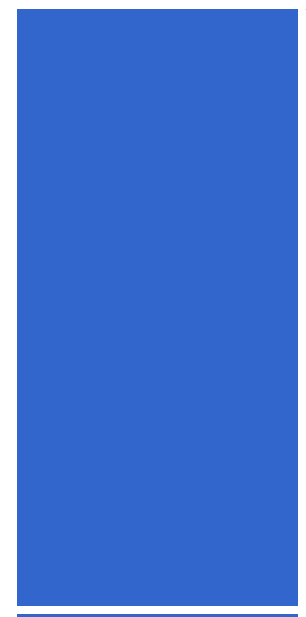

Proposed

actions

Proposed

improvements

Carrying

capacity for

tourism

activities wigeon (Anas Penelope), northern shoveller ( $A$. clypeata), northern pintail (Anas acuta), garganey (A. querquedula), common teal (Anas crecca), Pacific golden plover (Pluvialis fulva), common ringed, Kentish, lesser sand and Caspian plovers (Charadrius hiaticula; C. alexandrines; C. mongolus, and C. asiaticus, respectively), bar-tailed and black-tailed godwits (Limosa lapponica and Limosa limosa), whimbrel (Numenius phaeopus), Eurasian curlew (Numenius arquata), common redshank (Tringa tetanus) and common greenshank (Tringa nebularia).

Leopards, sloth bears as well as both mugger and saltwater crocodiles have been seen within the park.

The shrimp catch in Chundukkulam Lagoon 600,000 kg per annum (Silva, et al., 2013).

The DWC will develop the area as a national park with appropriate infrastructure.

Prime among the essential needs for this area is training for jeep drivers within the park, and integration of environmental safeguards discussed in Chapter 6.

The DWC will have to decide this but it is strongly recommended that the number of boats is regulated strictly to prevent overcrowding. 


\section{Kokkilai Lagoon}

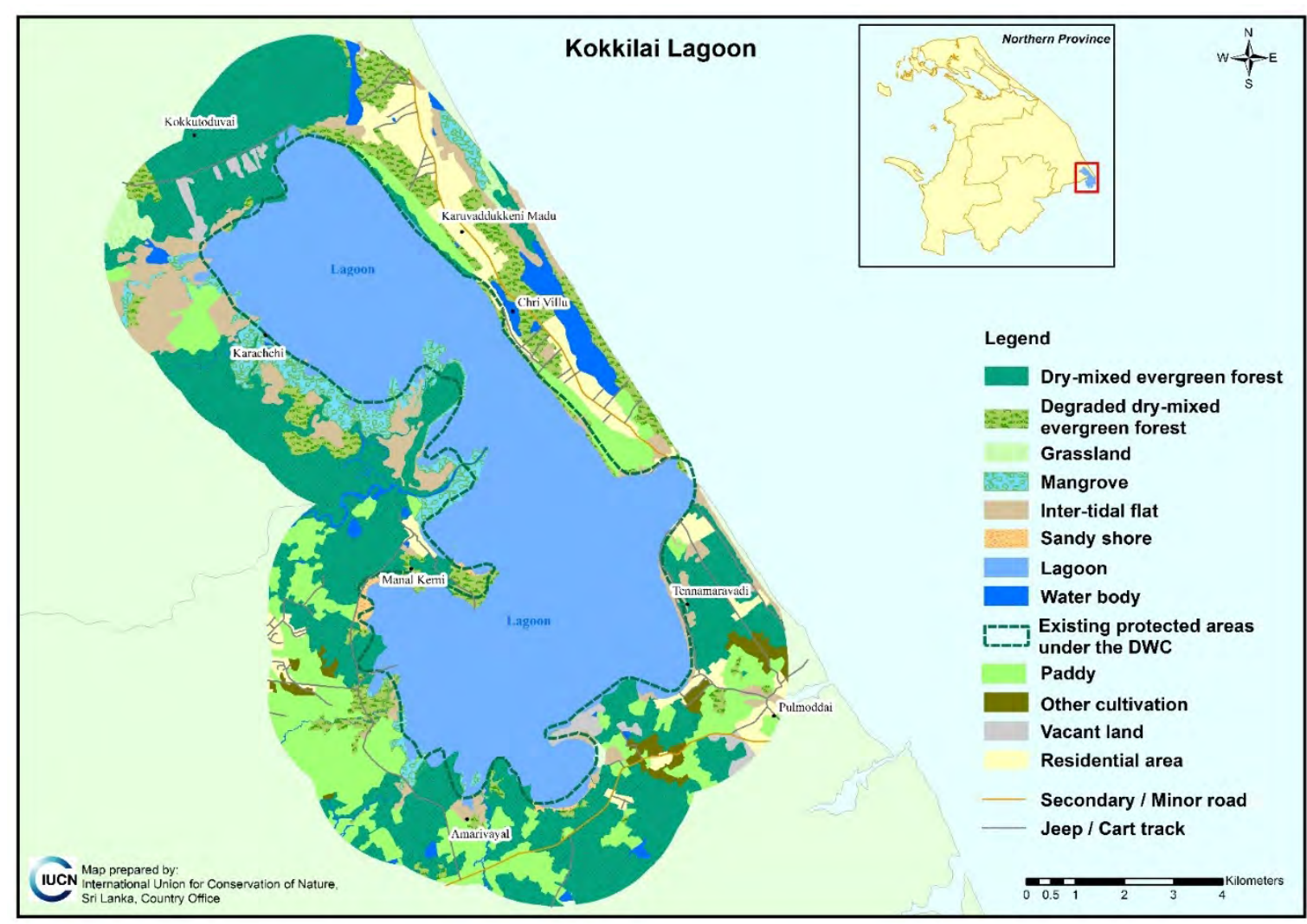

Figure 89. Map of Kokkilai Lagoon its surrounds, showing ecosystems and land use 
The data for this lagoon are augmented by IUCN/MFF, 2018.

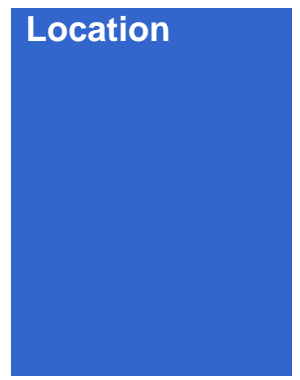

Ecosystems

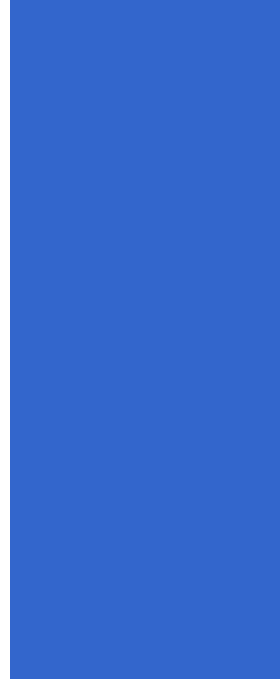

Special

attributes

Kokkilai, a large estuarine lagoon, has an extent of $29.95 \mathrm{~km}^{2}$ (Silva et al., 2013) and is located in the Mullaittivu (Maritimepattu DSD) and Trincomalee (Kuchchaveli DSD) districts in the north-eastern Sri Lanka (Figure 89). This is a very shallow lagoon (1-2 $\mathrm{m}$ in depth) which receives a number of inflows from rivers such as Ma Oya, Mee Oya, Churiyan Aru and Chavar Aru. It is linked to the sea by a narrow channel that is often blocked by a sand bar. When this bar is not breached in some years, it is detrimental to shrimp fishery, as recruitment of adults from the marine waters is essential for its maintenance.

One shore of this lagoon has human-dominated land use - such as paddy fields, other cultivation and densely populated human settlement. The land is used for shrimp fishing, paddy cultivation and some shifting cultivation. However, there are also dry-mixed evergreen forests, degraded dry mixed arid-mixed evergreen forests, mangroves, salt marshes and other marshes, extensive seagrass meadows within the lagoon, as well as inter-tidal flats, particularly along the western and southern shores.

A total of 329 plants species belonging to 87 plant families were recorded in from the ecosystems around the lagoon. Of these, 11 plants are endemic, and 25 species are Threatened (Critically Endangered: 1, Endangered: 7 and Vulnerable: 17).

A total of $\mathbf{2 8 3}$ vertebrate faunal species and $\mathbf{5 8}$ of invertebrates (Odonates and Lepidopterans) were recorded. Of these, 18 are endemic and 10 species are Threatened (Critically Endangered: 1; Endangered: 3 and Vulnerable: 6).

Declared as a wildlife sanctuary in 1952, for its birdlife and as a nature reserve in 2015, the lagoon is known to be an important feeding ground for migratory water birds, including the lesser sand plover (Charadrius mongolus), Kentish plover (Charadrius alexandrinus), marsh sandpiper (Tringa stagnatilis), common redshank (Tringa tetanus), spotted redshank (Tringa erythropus) and little stint (Calidris minuta) were common migrant waders observed in the lagoon area. Also observed were uncommon waders such Temminck's stint (Calidris temminckii), curlew sandpiper (Calidris ferruginea) and Terek sandpiper (Xenus cinereus).

Five endemic bird species, Sri Lanka junglefowl (Gallus lafayetii), Sri Lanka grey hornbill (Ocyceros gingalensis), Sri Lanka green pigeon (Treron pompadora), Sri Lanka woodshrike (Tephrodornis pondicerianus) and Sri Lanka brown-capped babbler (Pellorneum fuscocapillum) were observed in the surrounds of the lagoon. In addition, seven Nationally Threatened species: great crested tern (Sterna bergii), oriental honey-buzzard (Pernis ptilorhynchus), black-wing kite (Elanus caeruleus), grey-headed fish-eagle (Ichthyophaga ichthyaetus), great cormorant (Phalacrocorax carbo), black-crowned night heron (Nycticorax nycticorax) and woolly-necked stork (Ciconia episcopus) are also present.

The grey slender loris (Loris lydekkerianus), a Nationally Threatened primate was observed residing in short trees and bushes by the lagoon.

Among the reptiles were the endemic, black-spotted kangaroo lizard (Otocryptis nigristigma), and the sand lizard (Sitana devakai). 


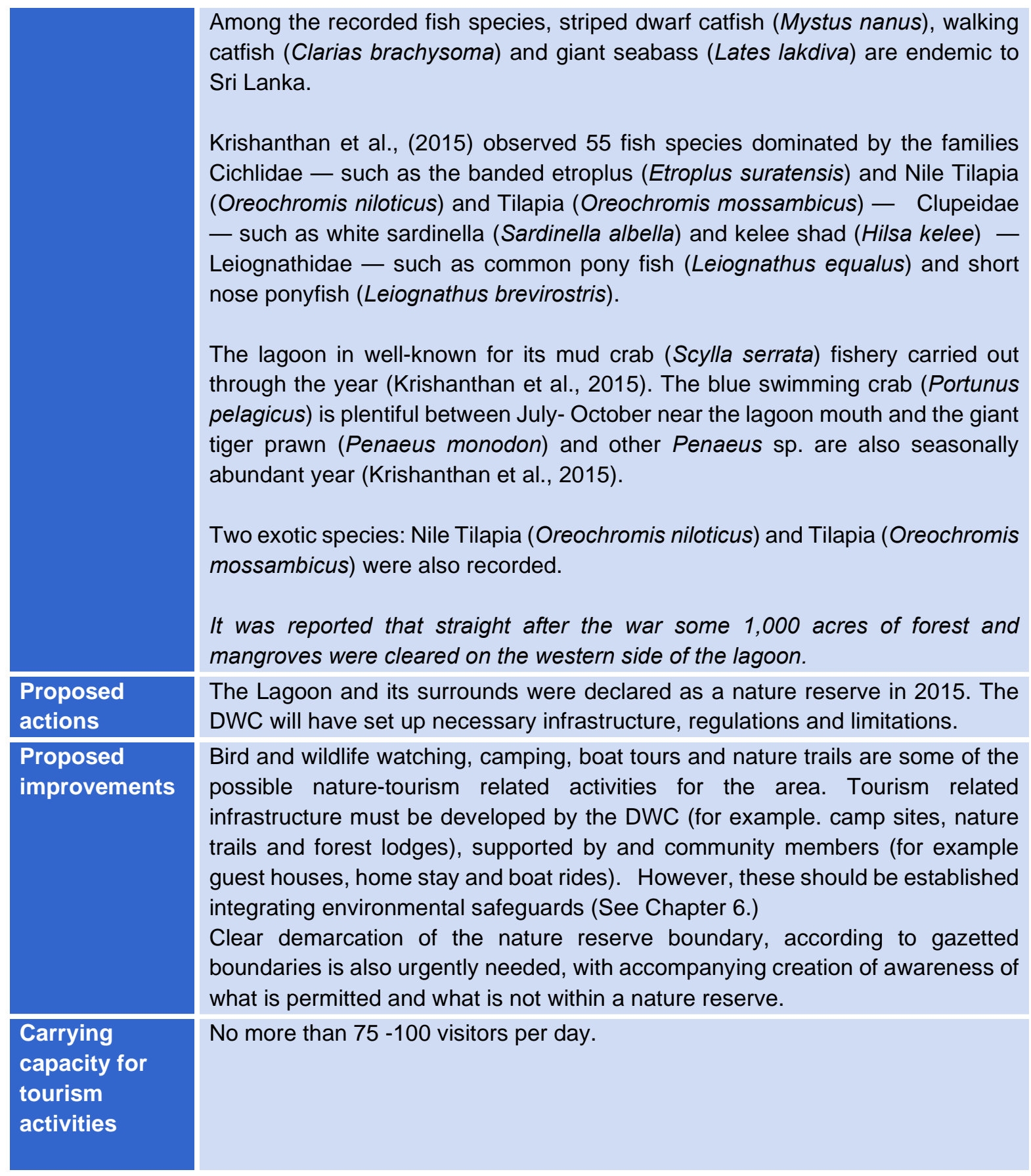




\section{Nanthi Kadal Lagoon}

The data obtained for Nathhi Kadal lagoon were insufficient to provide meaningful recommendations. However, it should be noted that under the CCZRMP (2016) this lagoon has been declared a Special Management Area (SMA)

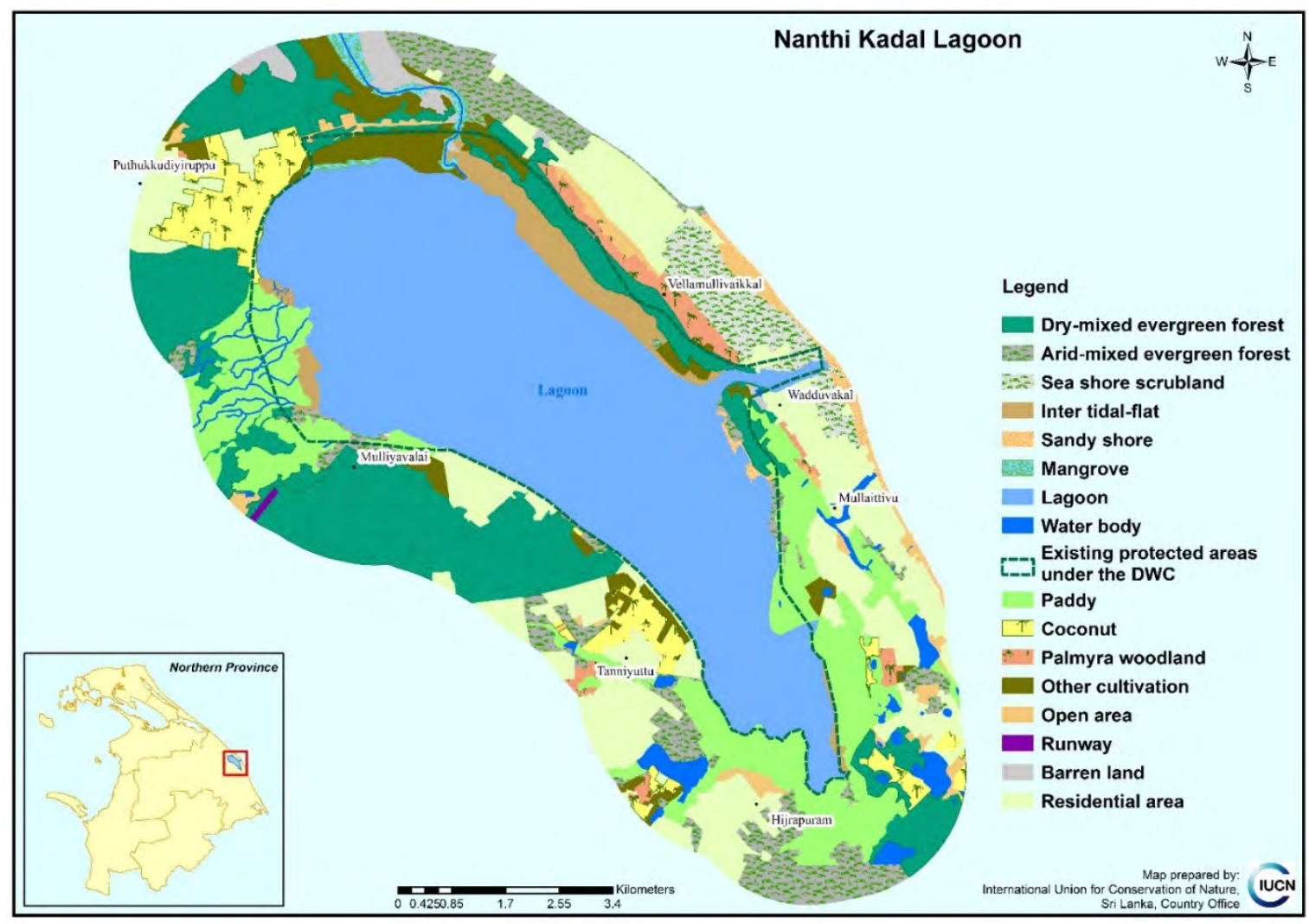

Figure 90. Map of Nanthi Kadal Lagoon its surrounds, showing ecosystems and land use 


\section{Nayaru Lagoon}

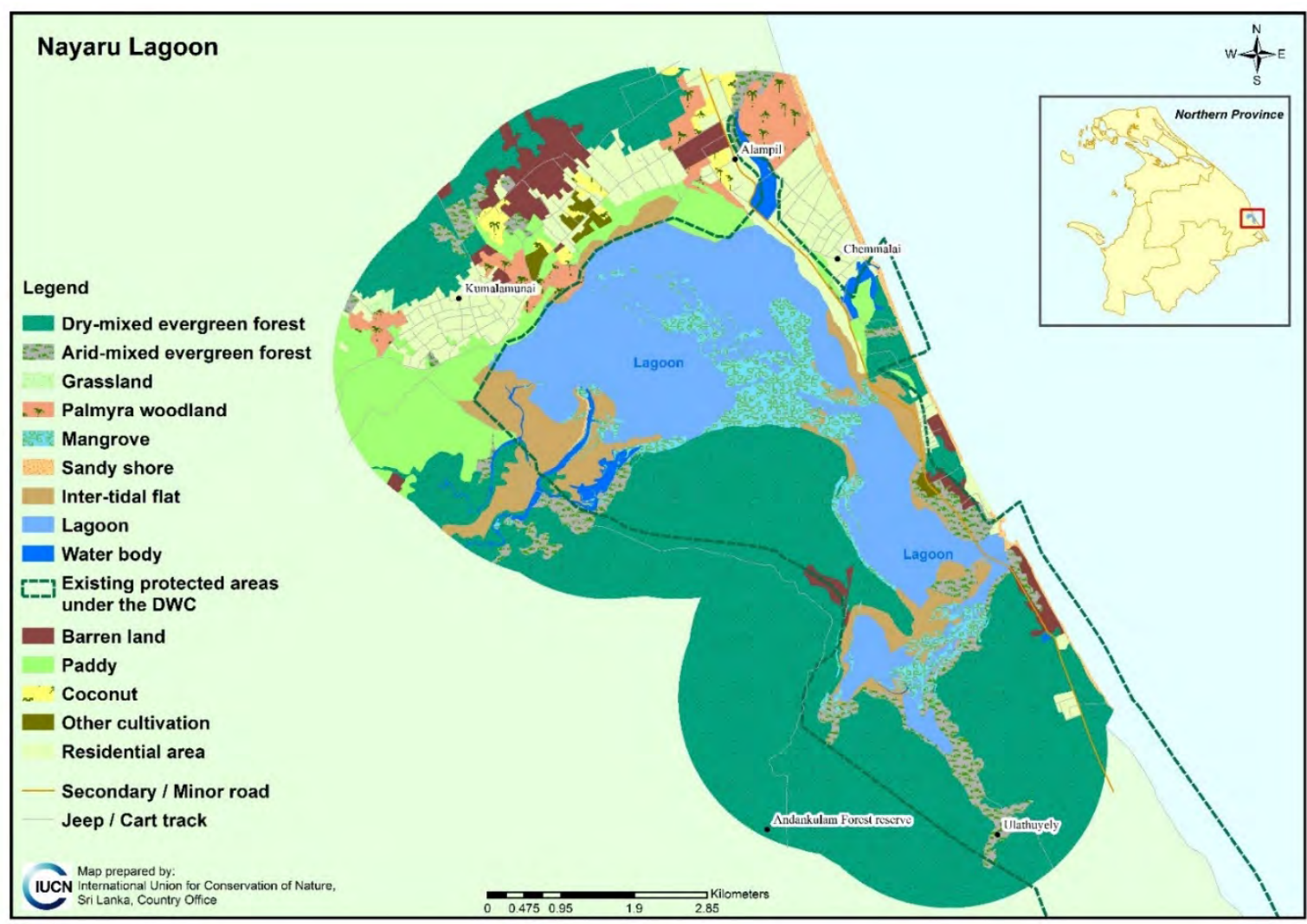

Figure 91. Map of Nayaru Lagoon its surrounds, showing ecosystems and other land use 
The data for this lagoon are extracted from Ellepola and Ranawana (2016), Ranawana person. comm., Silva et al., 2013, Un-Habitat, undated.

\begin{tabular}{ll}
\hline Location & $\begin{array}{l}\text { The Nayaru Lagoon is found in the Mullaitivu District and is approximately } 17.60 \\
\mathrm{~km}^{2} \text { in extent and is fed by Nay Aru and Palidai Aru. The lagoon is open to the } \\
\text { sea on the east (Figure 91). The Mullativu-Kokilai road runs parallel to the eastern } \\
\text { border of the lagoon. }\end{array}$ \\
\hline Ecosystems & $\begin{array}{l}\text { The southern and eastern shores have good mangrove cover. } \\
\text { Special } \\
\text { attributes } \\
\text { mucronata, Aegiceras corniculatum, Avicennia officinalis and Heritiera } \\
\text { littoralis were found in the lagoon surrounds. }\end{array}$ \\
The lagoon is important for fisheries. The mud crab (Scylaa serrata) and the \\
Indian prawn (Fenneropenaeus indicus) are popular shellfish harvested from the \\
lagoon. Fifty two percent of the lagoon harvest comprises flathead grey mullet \\
(Mugil cephalus) and other species harvested are milkfish (Chanos chanos), \\
barramundi (Lates calcarifer), bronze catfish (Arius bilineatus) and fourfinger \\
threadfin (Eleuthronema tetradactylum). The estimated annual yield is 9.237 kg \\
ha-1 year-1, which is lower than other similar coastal lagoons.
\end{tabular}




\section{Vidattaltivu Lagoon}

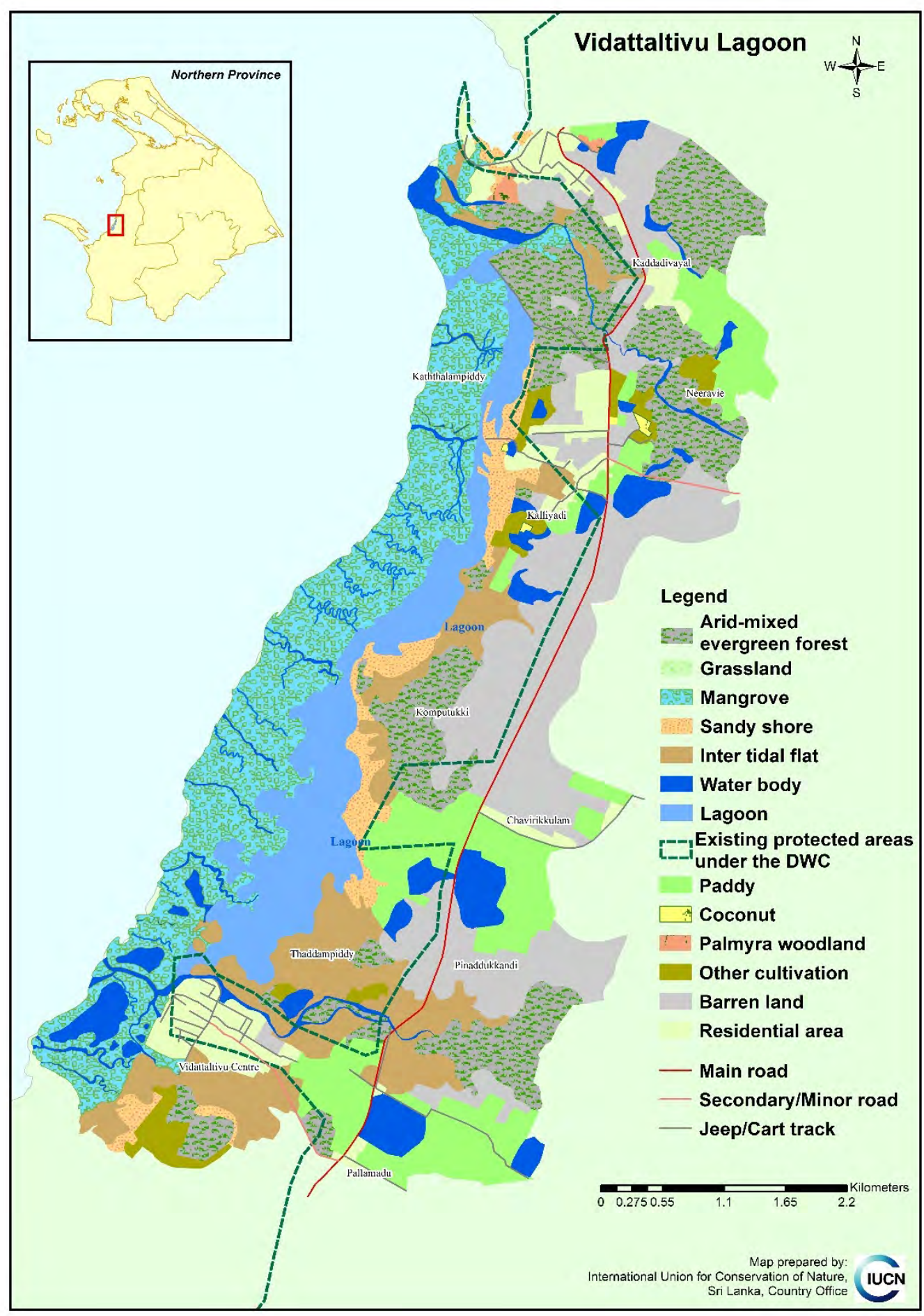

Figure 92. Map of Vidattaltivu Lagoon and its surrounds, showing ecosystems, land use and existing protected area.

(Note that the Vidattaltivu Nature Reserve extends beyond the limits of this map) 


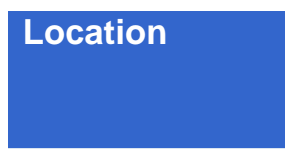

Ecosystems

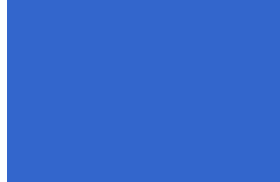

Special

attributes

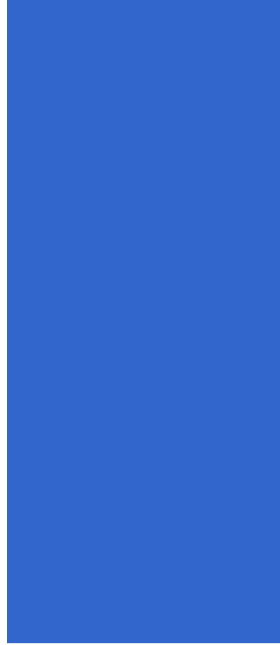

Proposed

actions

Proposed

improvements

Carrying

capacity for

tourism

activities
The shallow, brackish water lagoon extends over $16 \mathrm{~km}^{2}$ ha (Silva et al., 2013) and is located in the Mantai West divisional secretariat division of the Mannar District (Figure 92).

Dense and luxuriant mangroves are found along the one edge of this lagoon and there are also arid mixed evergreen forests, paddy fields and water bodies. The extent of human settlement is low and only a few roads pass close to the lagoon edge. As can be seen in the map above, several freshwater streams join with the lagoon at various places.

In 2016, it was declared a Natural Reserve under the jurisdiction of the Department of Wildlife Conservation.

A rare species of mangrove - small-leaved mangrove (Pemphis acidula) has been recorded in this area (Katupotha, 2016). One hundred and twenty-eight faunal species have been recorded from the area, of which 106 are bird species, but there is very little information about other species (IUCN, 2011b).

This Lagoon is a haven for migrating water birds. In its 2010 water bird census, the Ceylon Bird Club noted $1,100,000$ to $1,200,000$ birds in this lagoon (Sirivardana and Hettige, 2010). These identified birds included the curlew sandpiper (Calidris ferruginea), little stint (Calidris minuta), lesser sand plover (Charadrius mongolus), common redshank (Tringa tetanus), marsh sandpiper (Tringa stagnatilis) and grey plover (Pluvialis squatarola), all winter visitors.

The Lagoon and its surrounds are now under the jurisdiction of the DWC. However, the Lagoon in under threat of being taken over for aquaculture activities.

Currently, the Lagoon and its surrounds are still being protected by the SL navy. The DWC needs to set up necessary infrastructure, ensuring the integration of environment safeguards as well as capacity building for tour guides and boat drivers, for example.

This will be set by the DWC. 
Annex 4. List of Flora Found in the Study Area

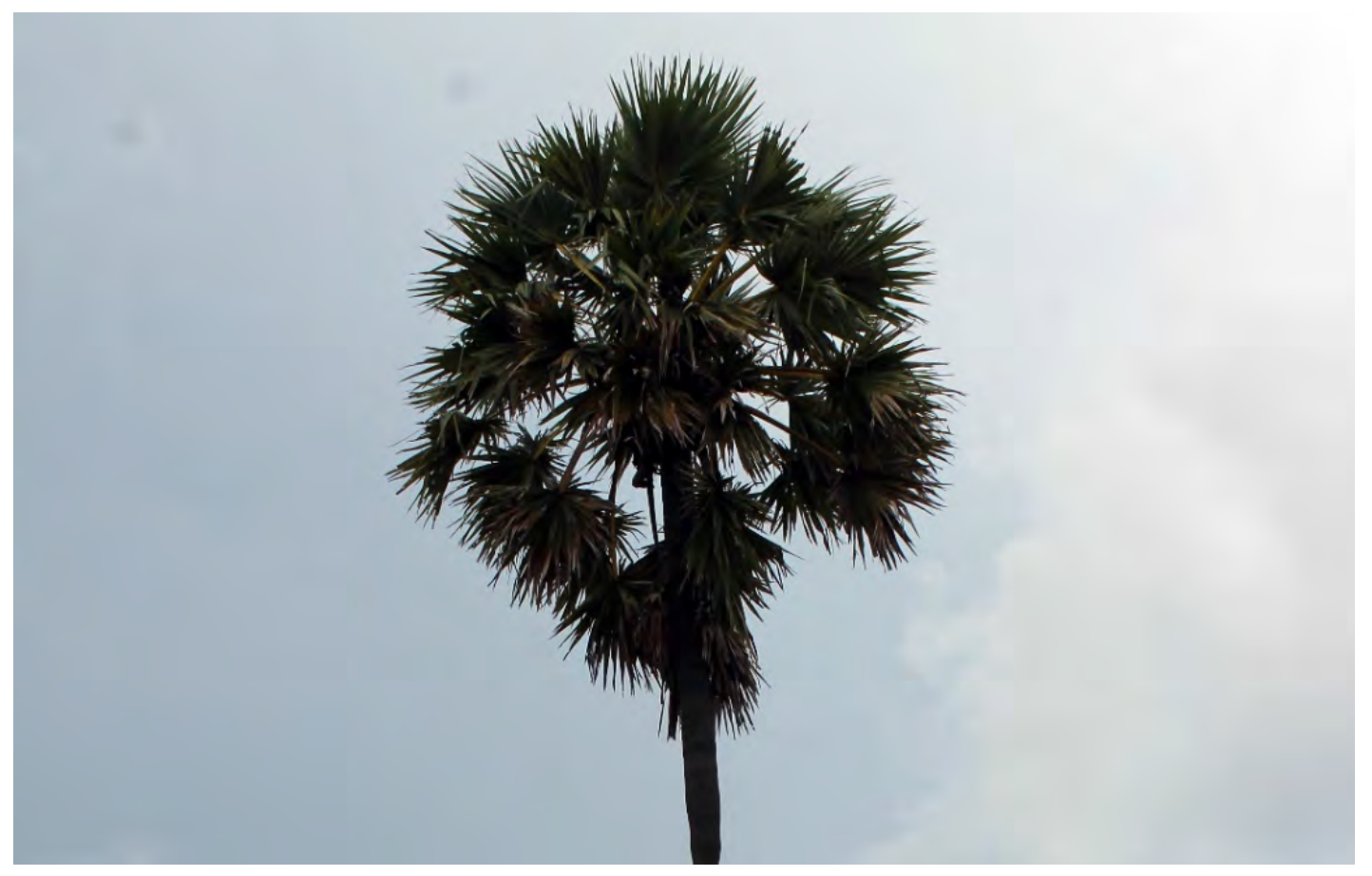



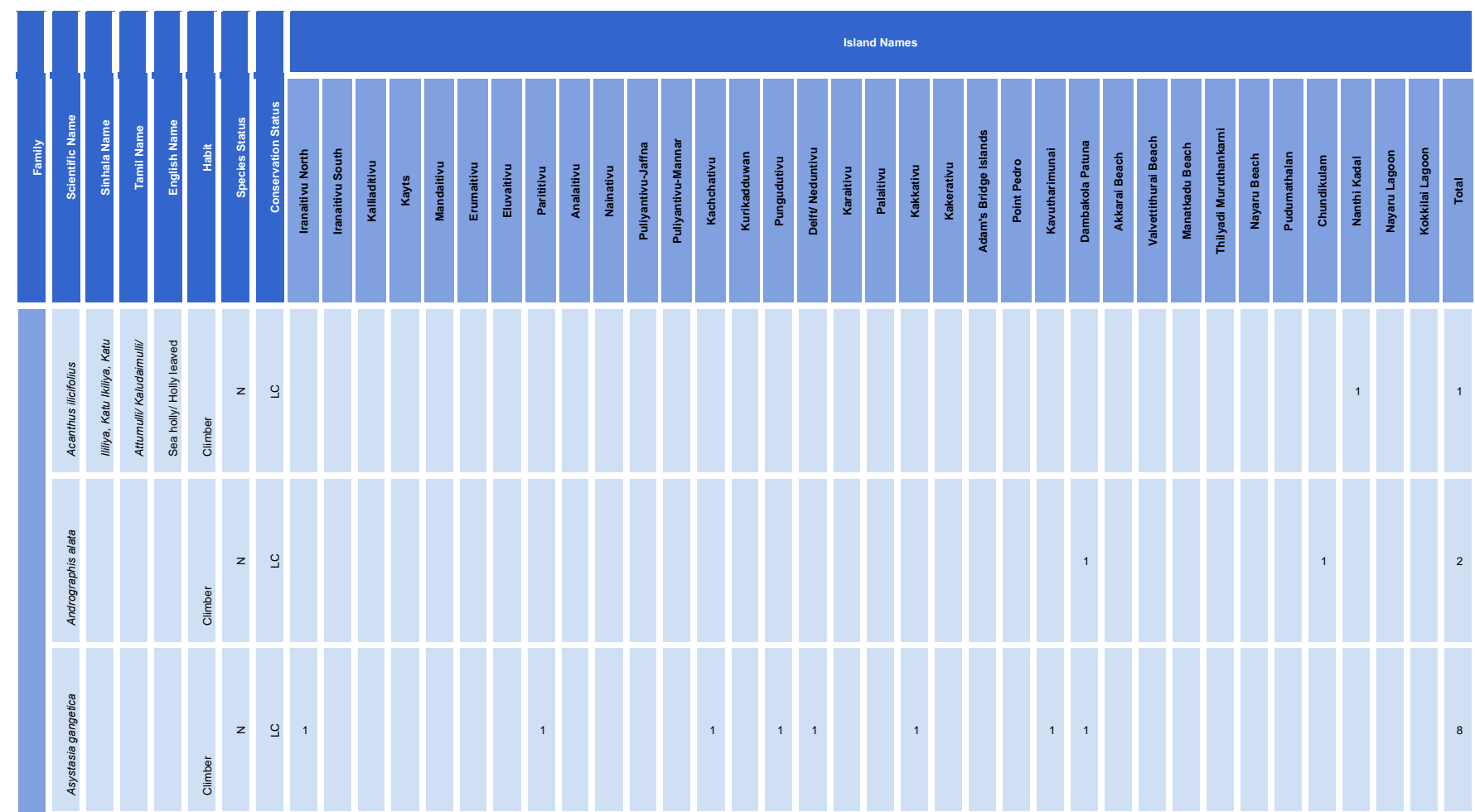

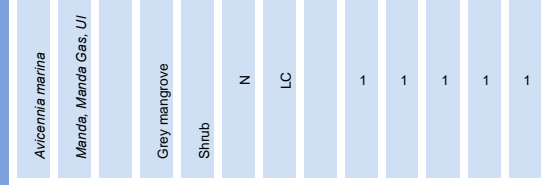

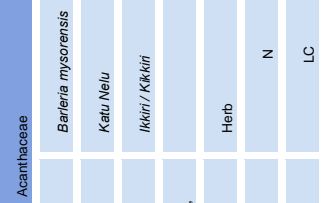

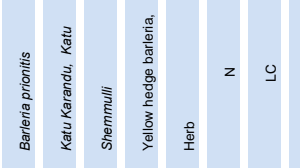

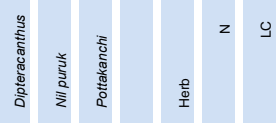

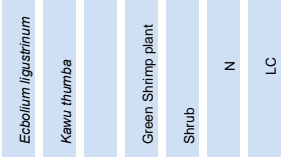

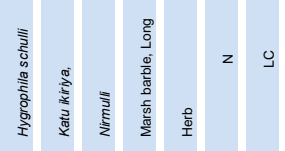

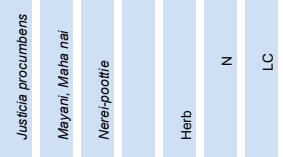



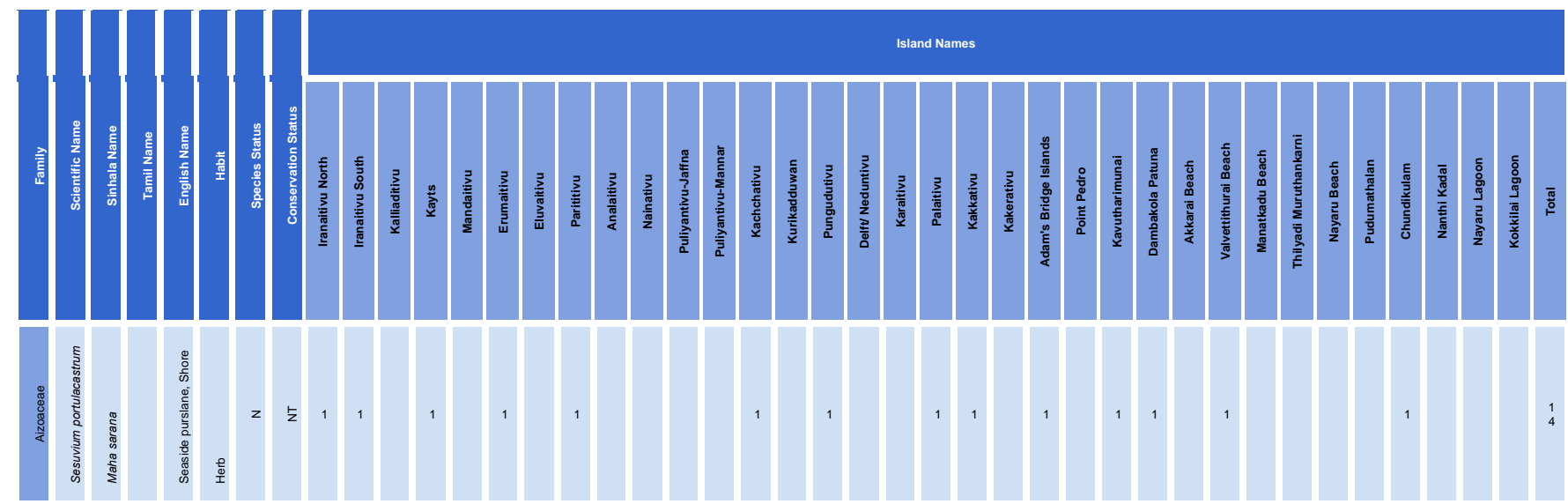

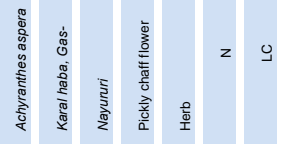

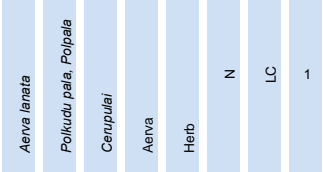

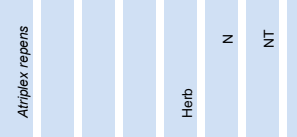

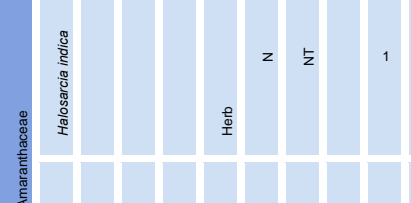

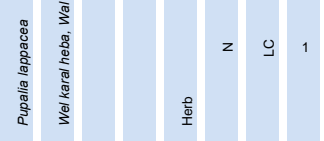

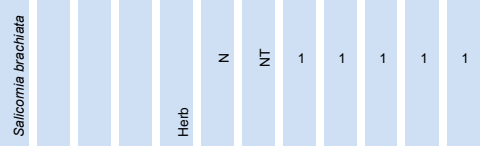

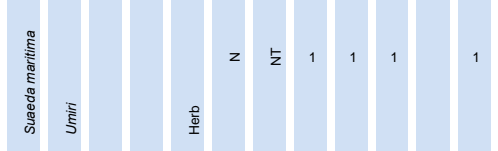

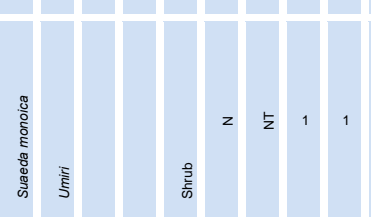



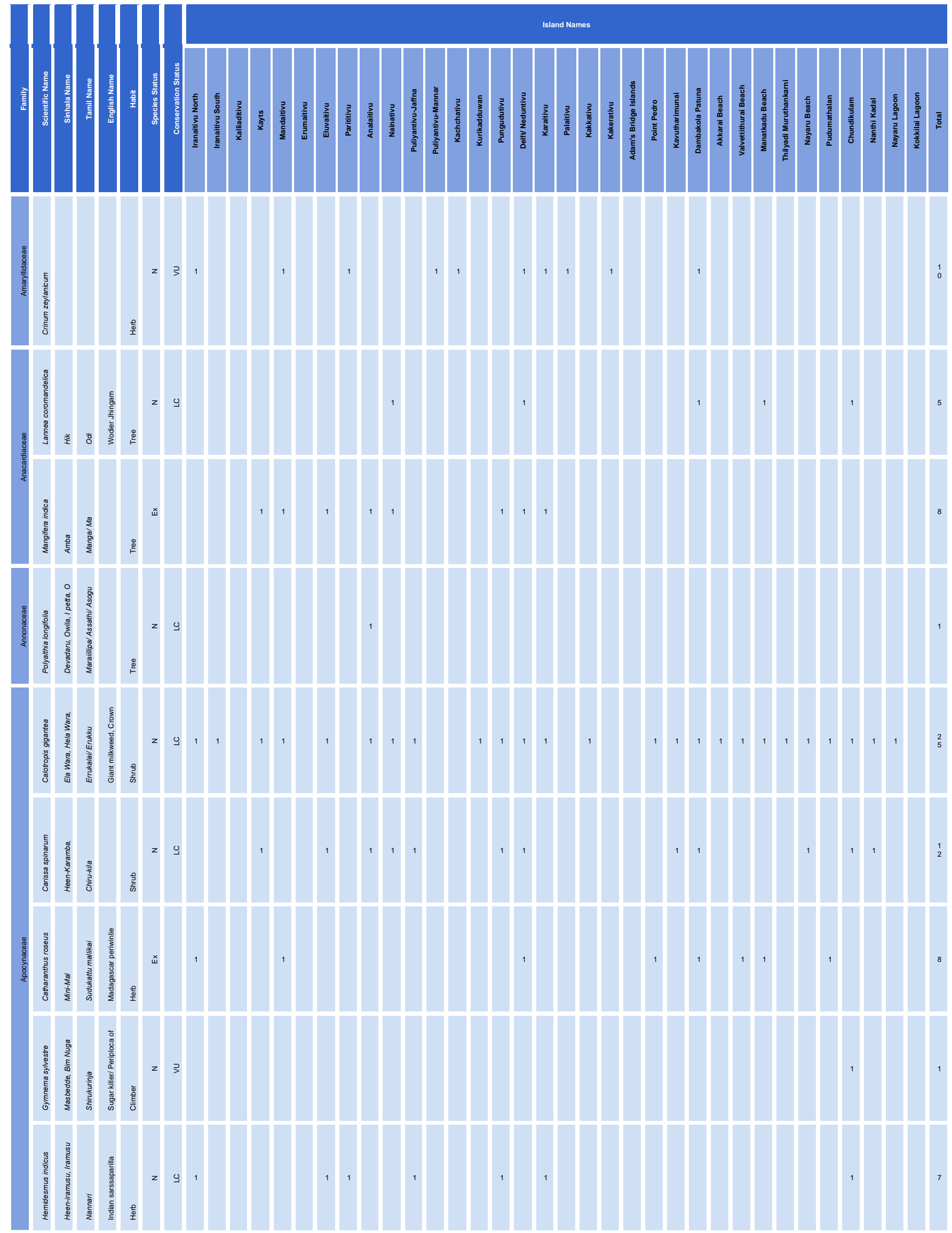

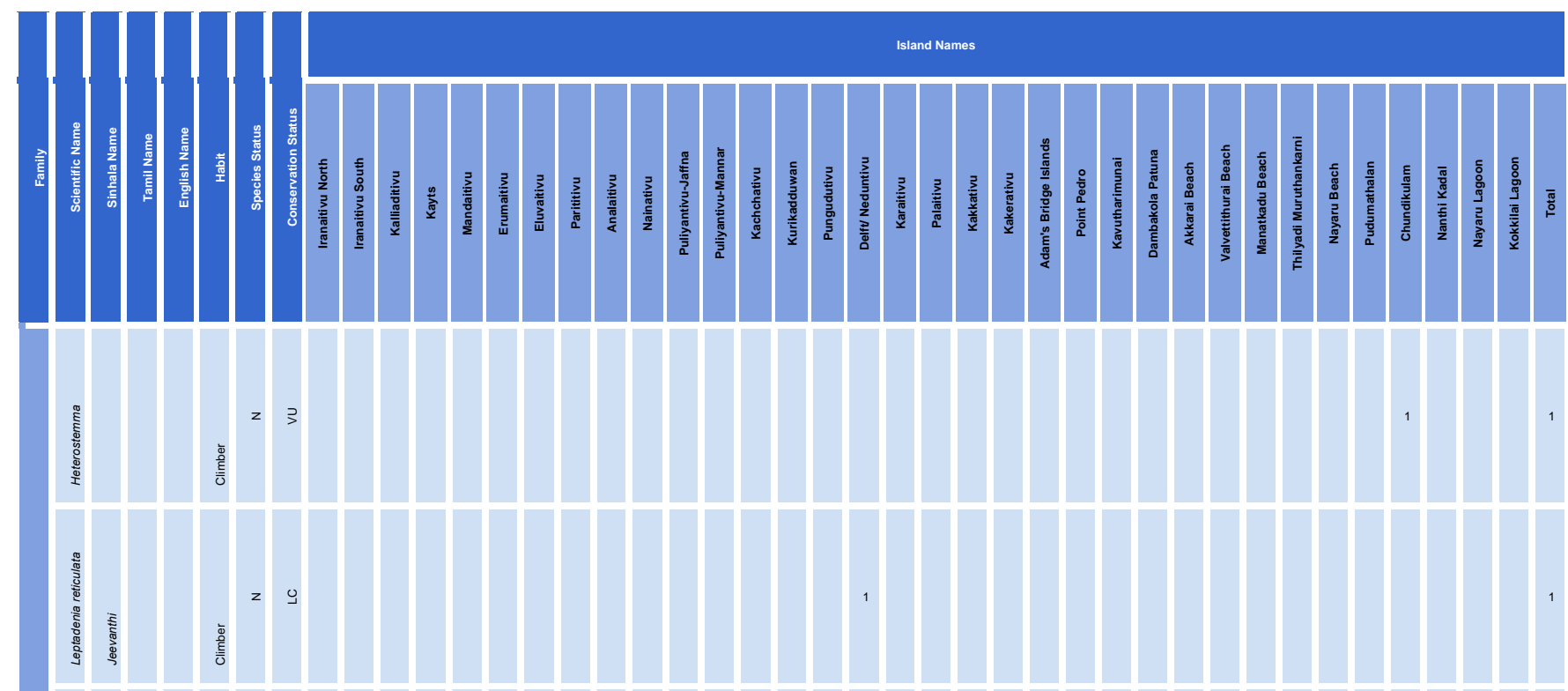

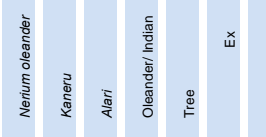

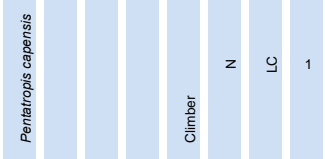

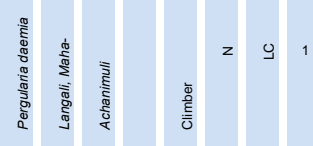

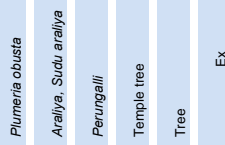

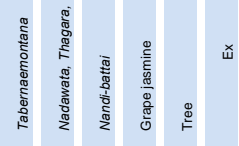

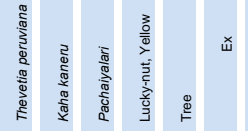

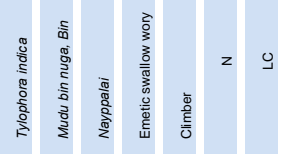

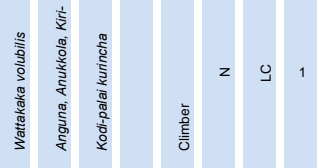




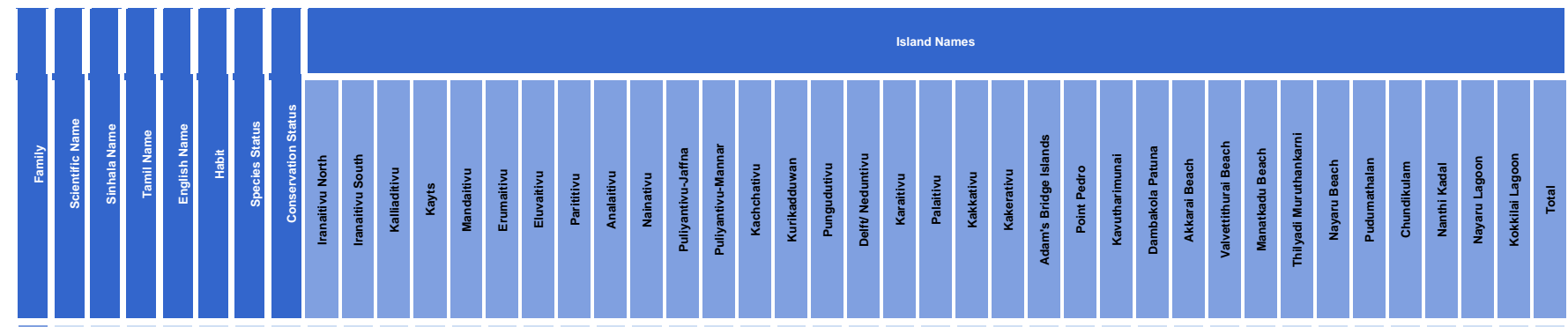

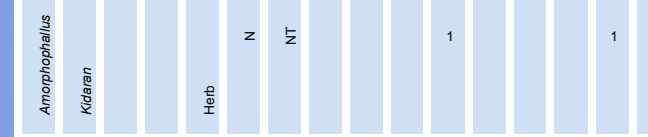

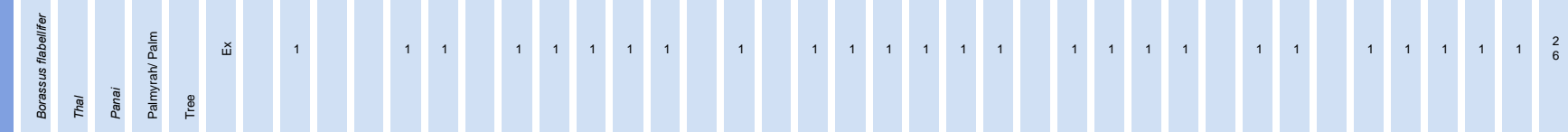

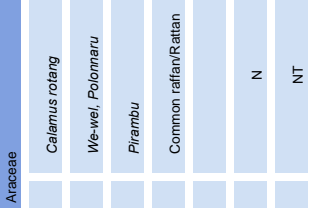

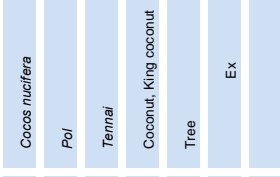

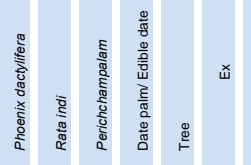

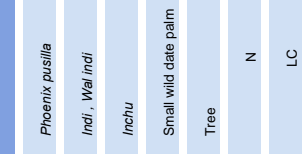
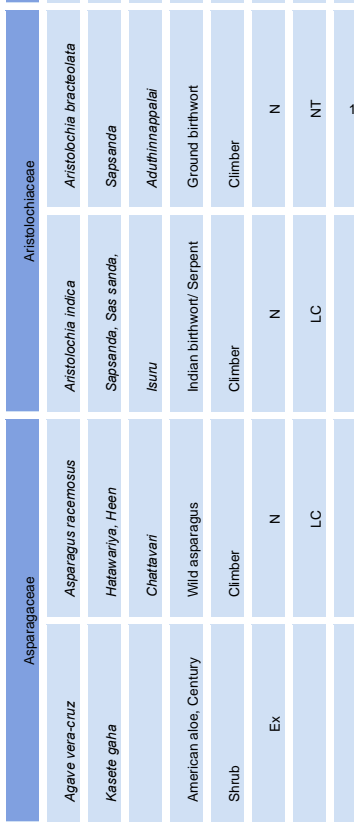

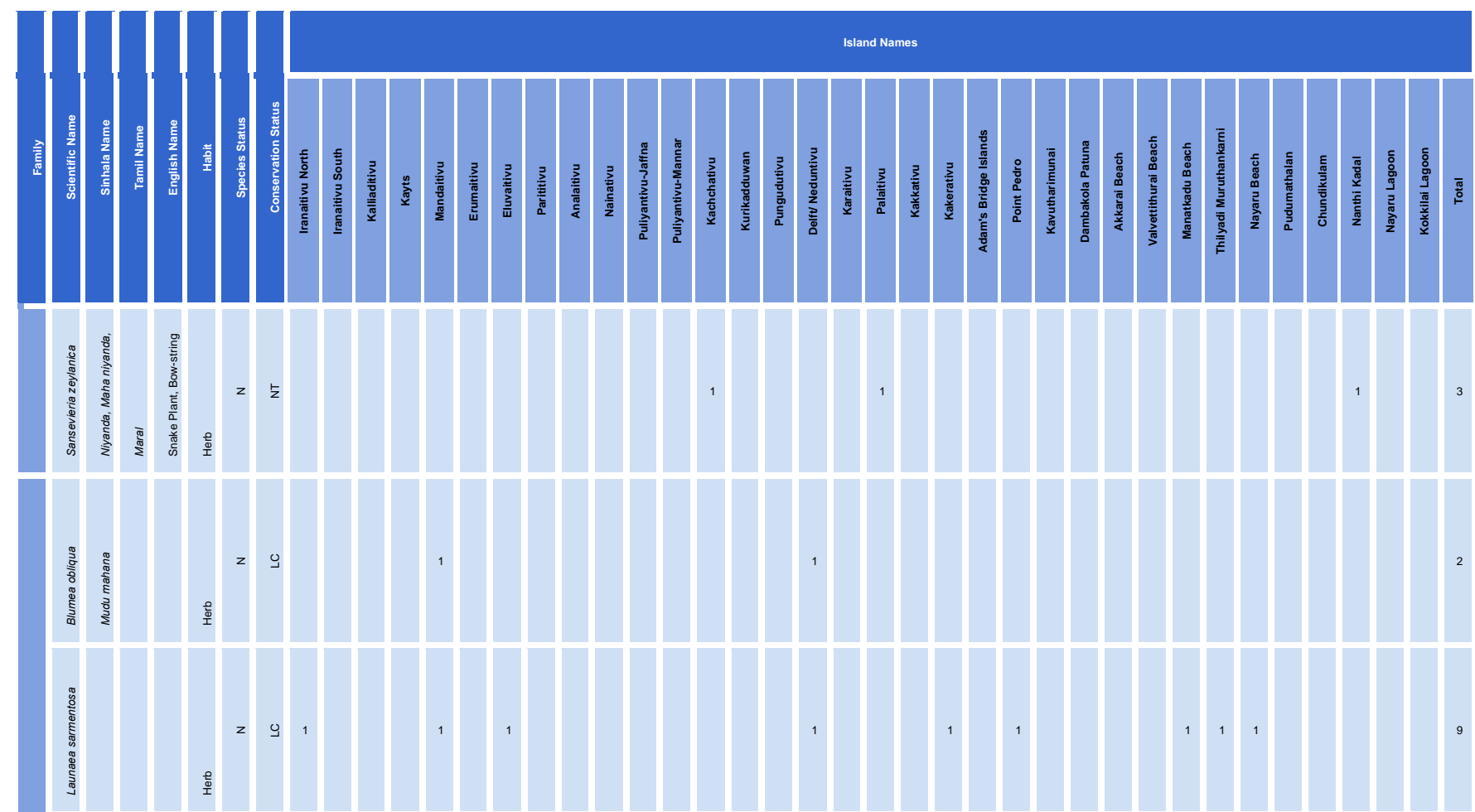

$$
\text { IIII. }
$$$$
\text { IIII, }
$$$$
\text { III. . }
$$$$
\text { (II) }
$$ 

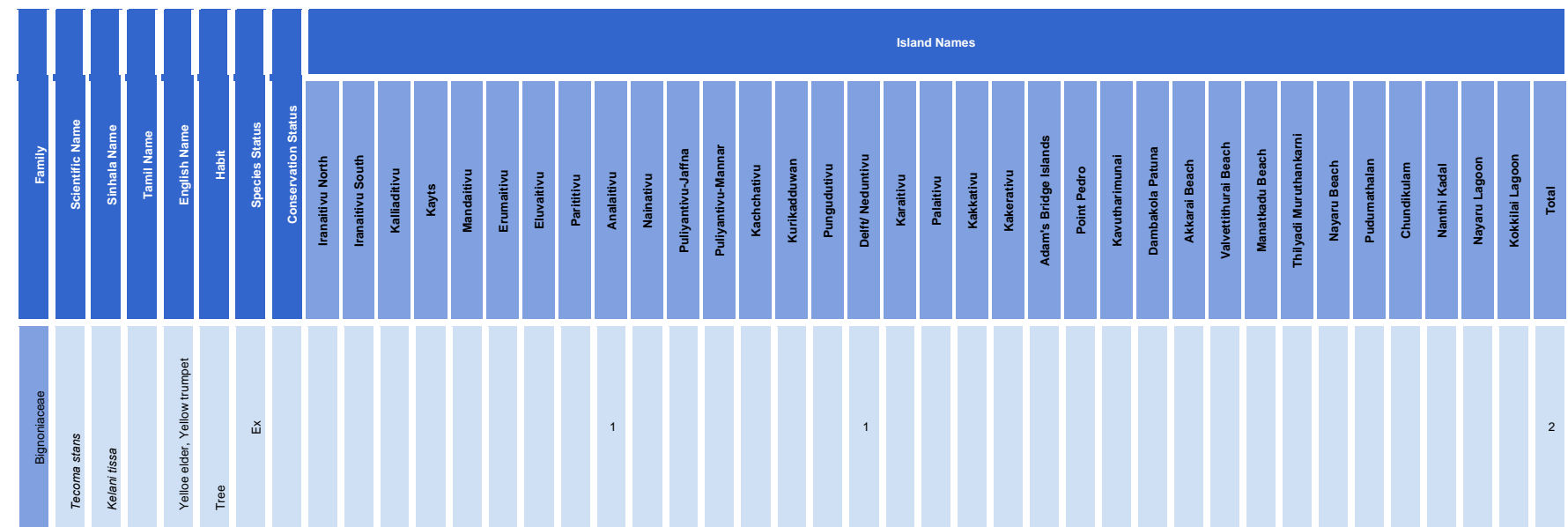

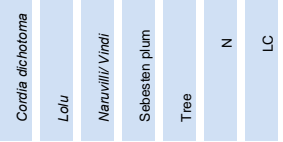

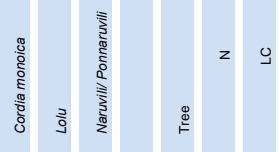

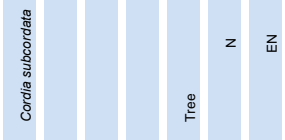

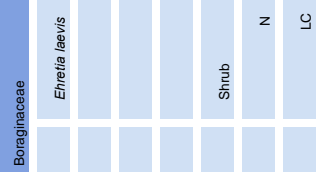

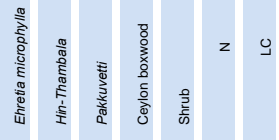

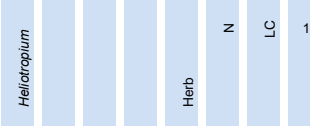

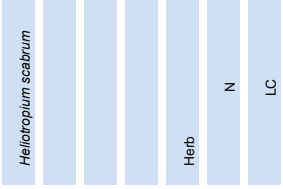

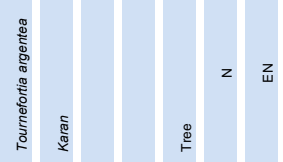




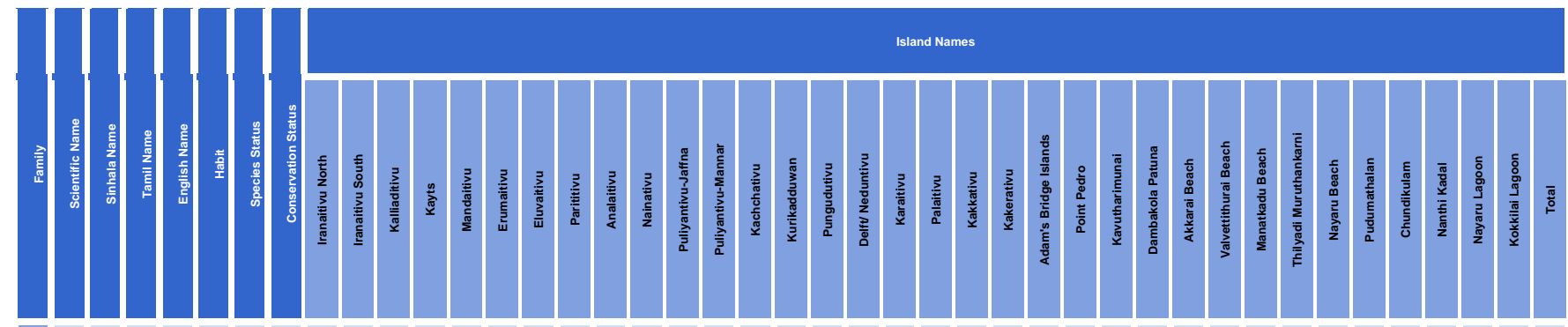

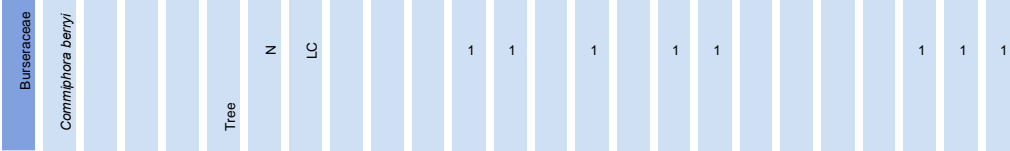

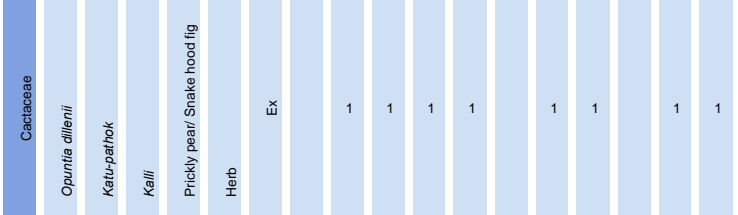

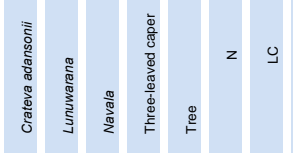

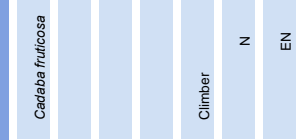

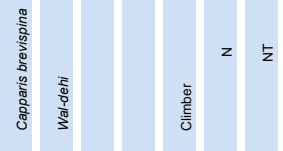

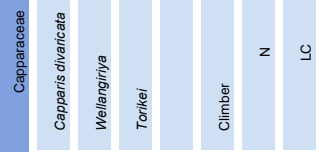

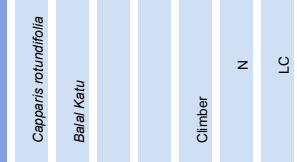

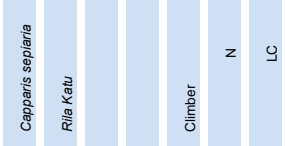

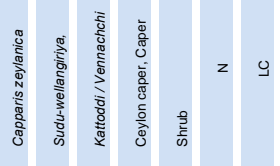




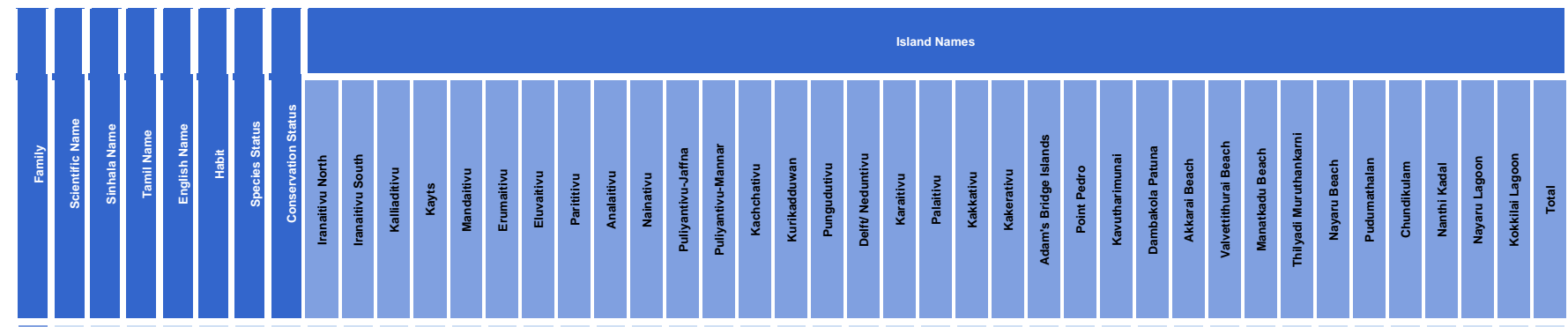

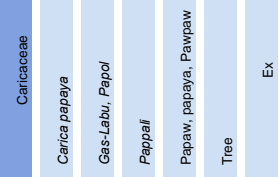

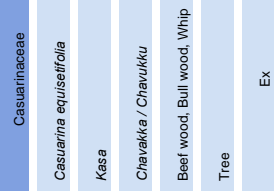

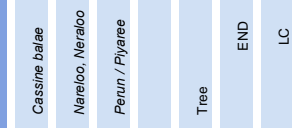

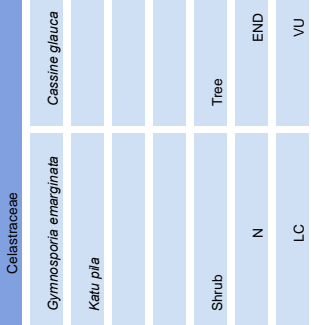

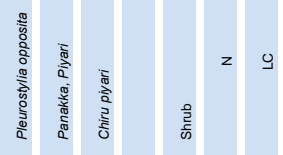

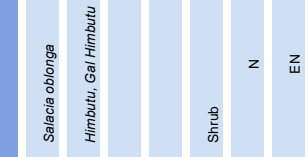

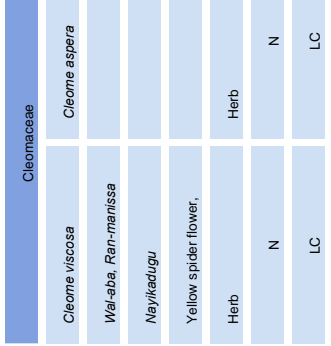



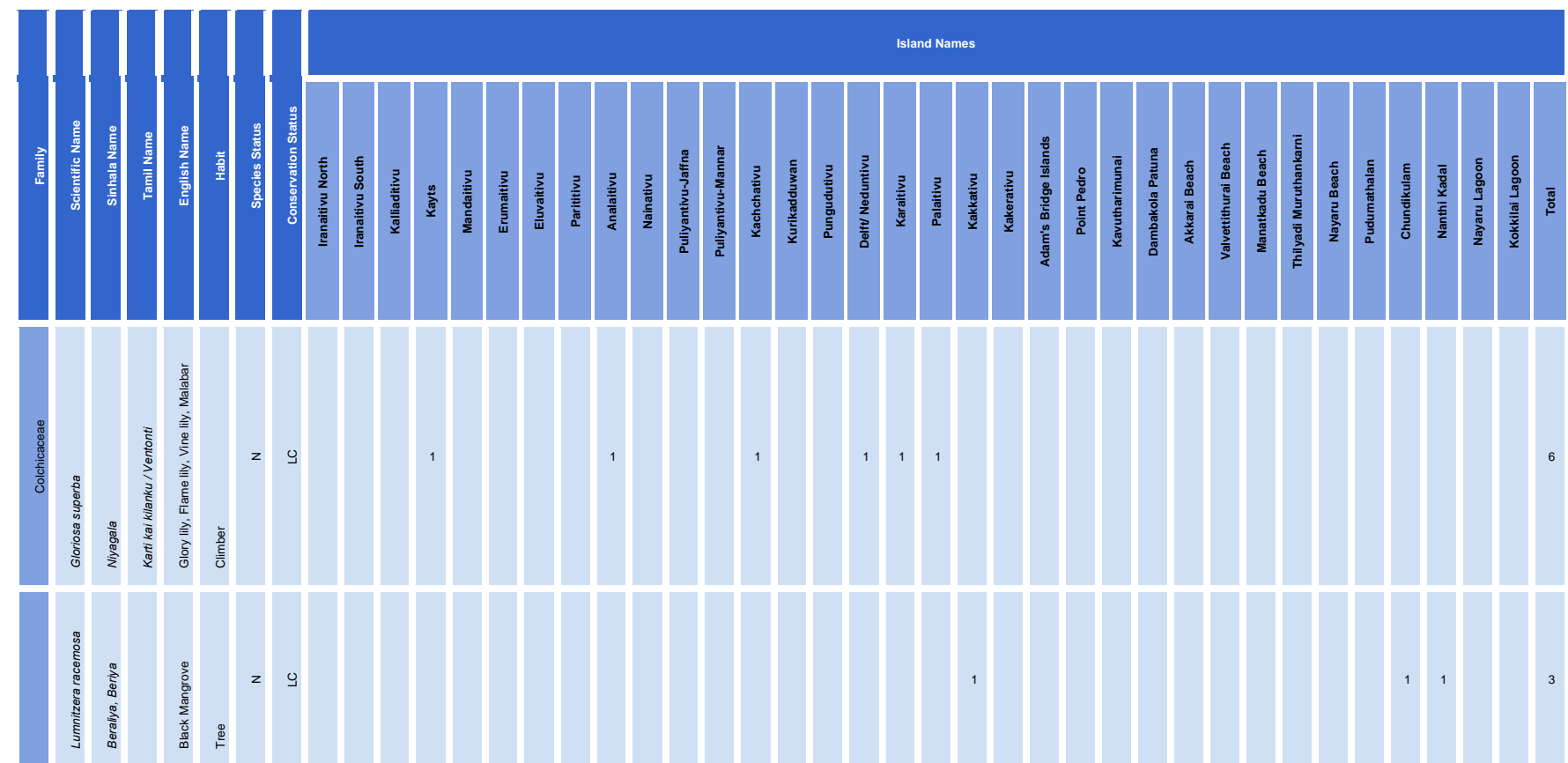

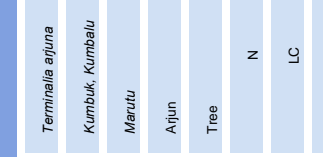

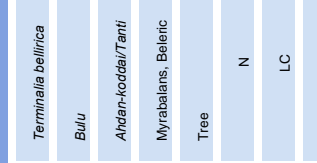

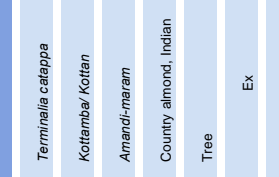

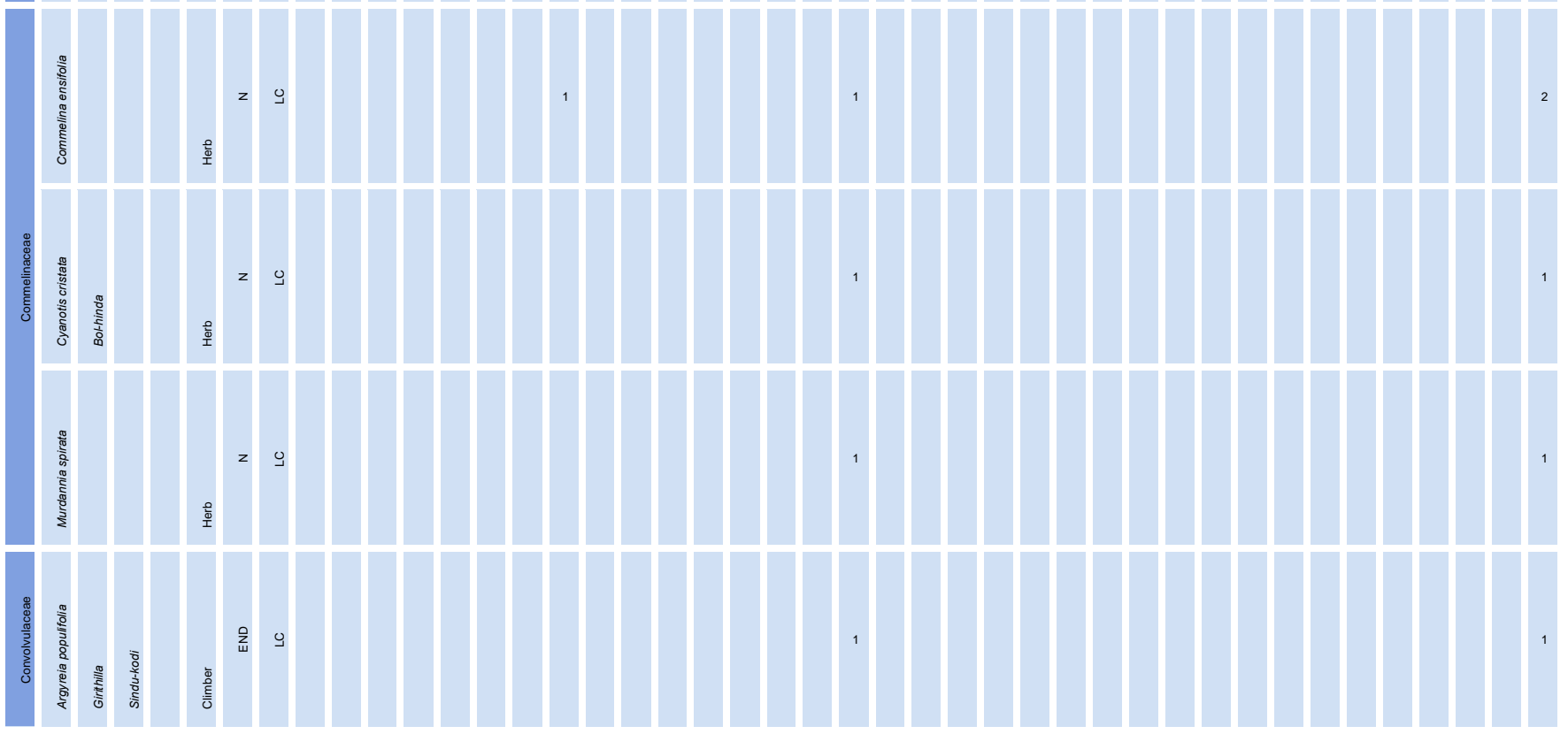



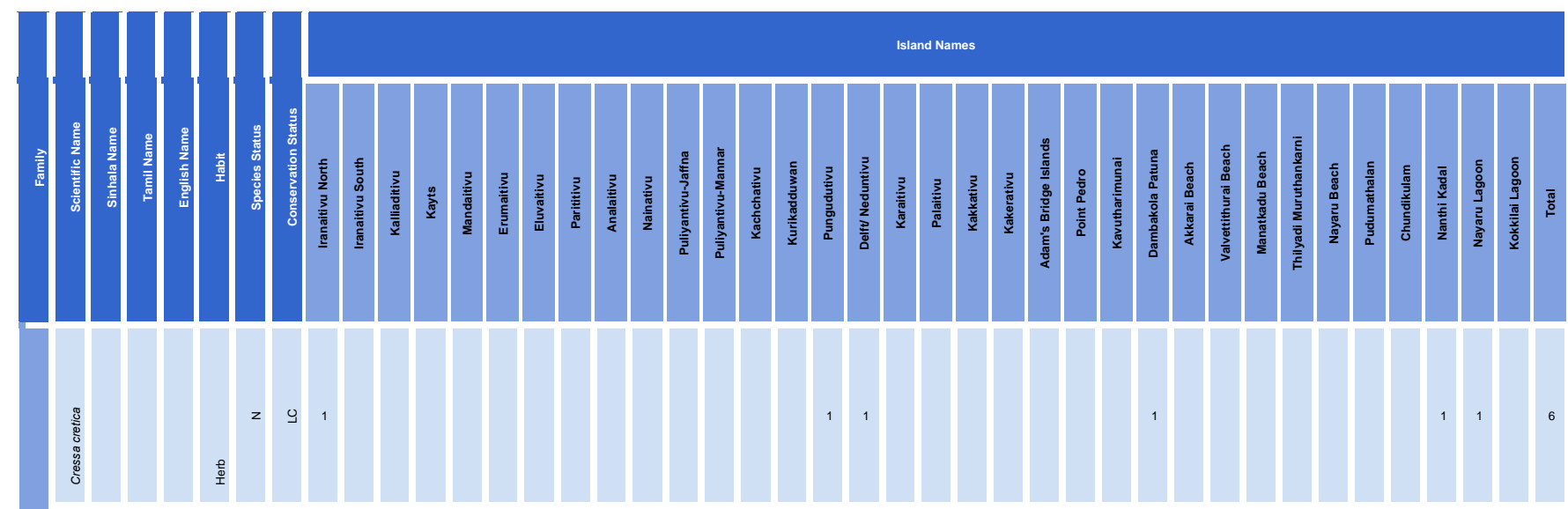

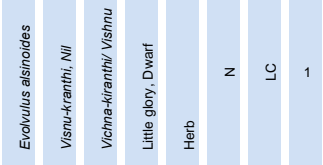

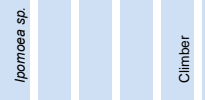

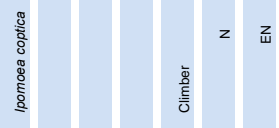

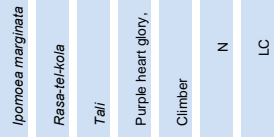

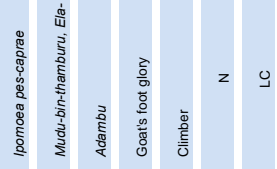

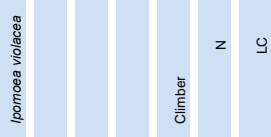

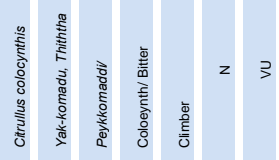

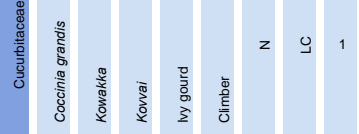

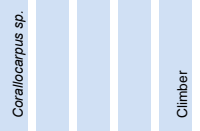



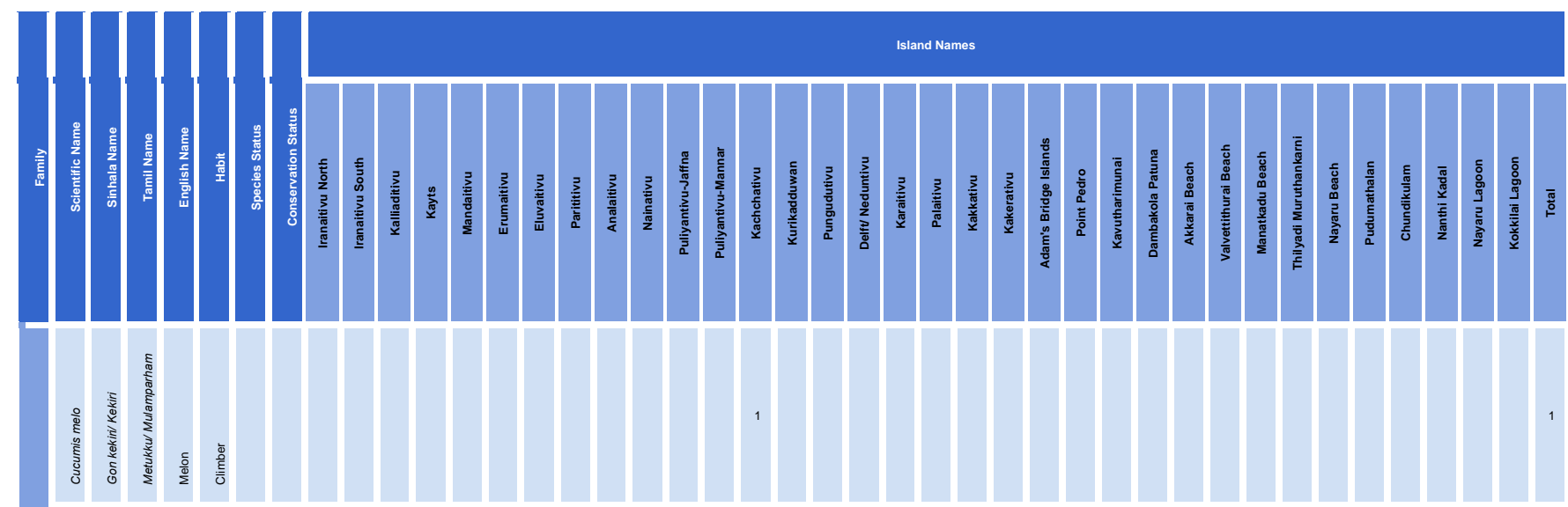

II I."

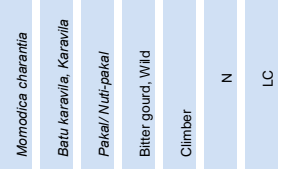

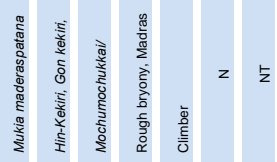

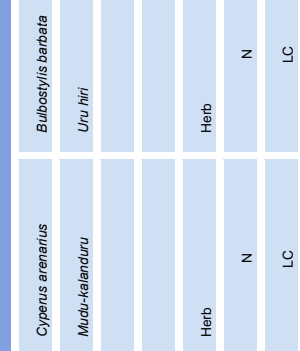

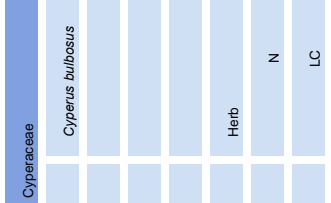
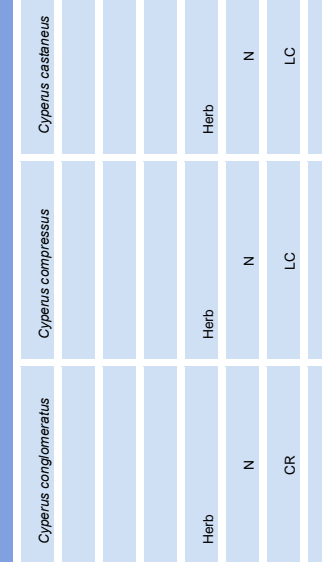


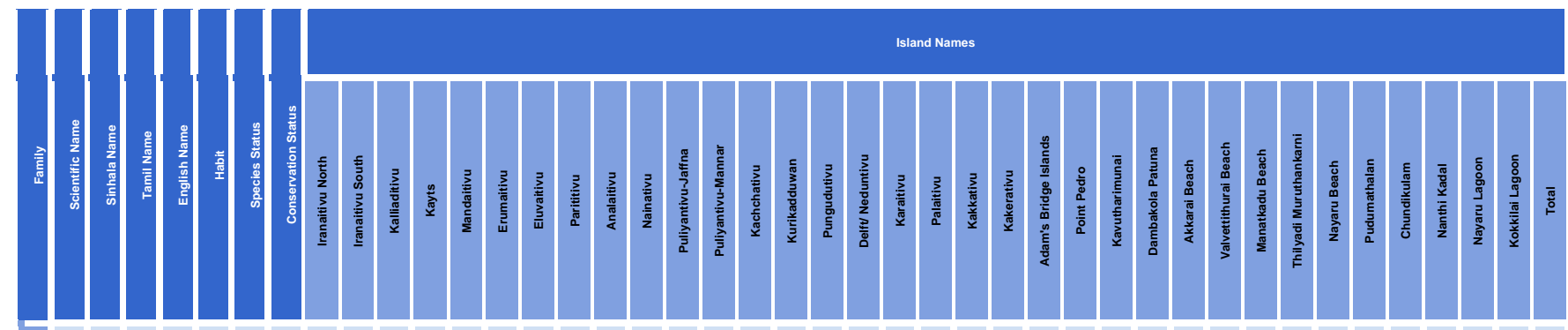

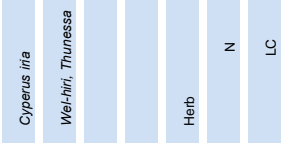

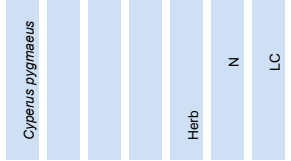

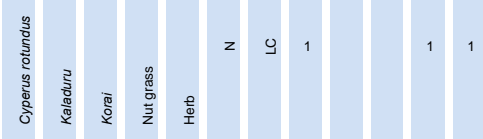
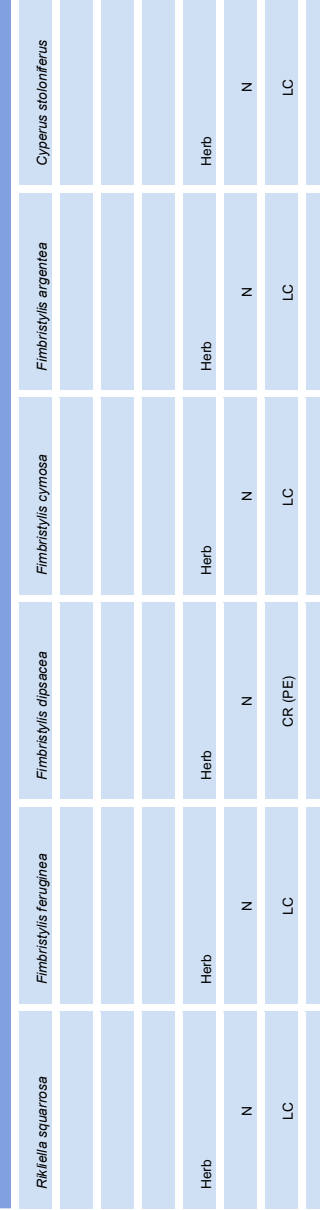


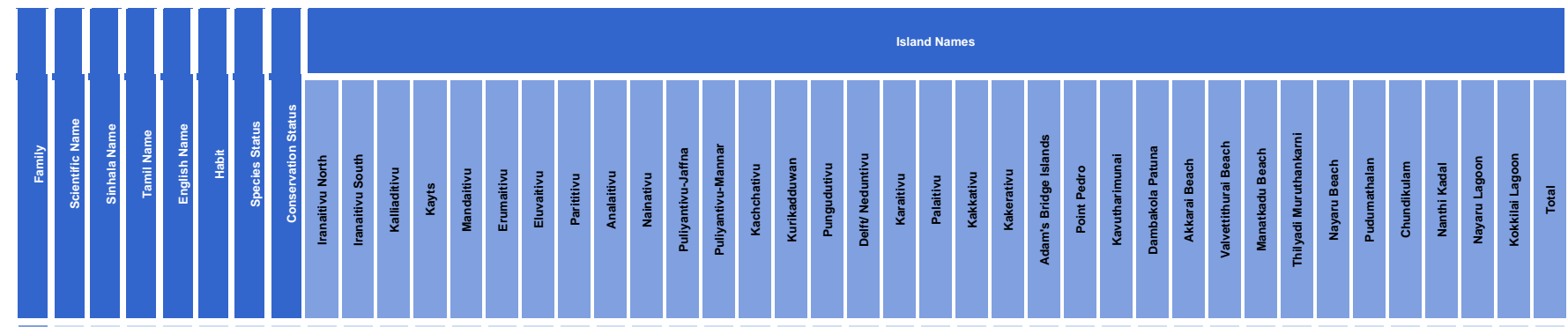

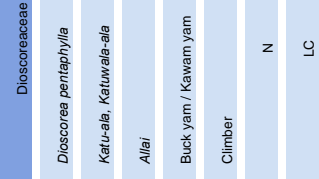

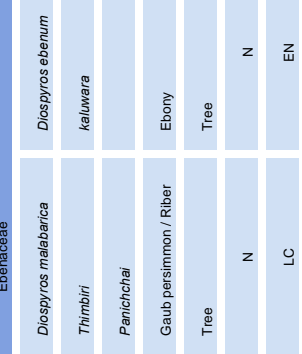

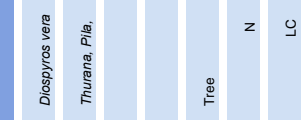

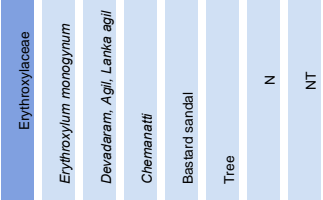

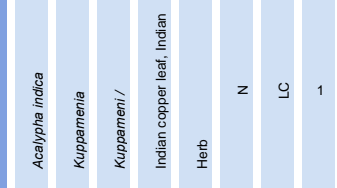

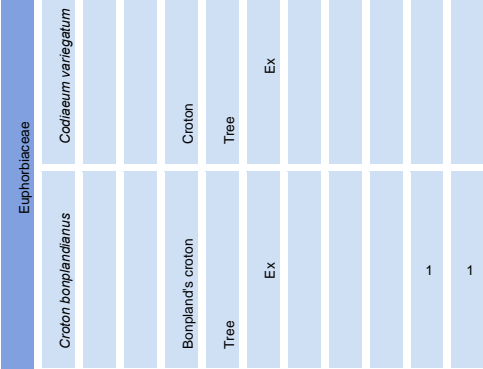

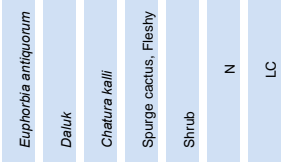




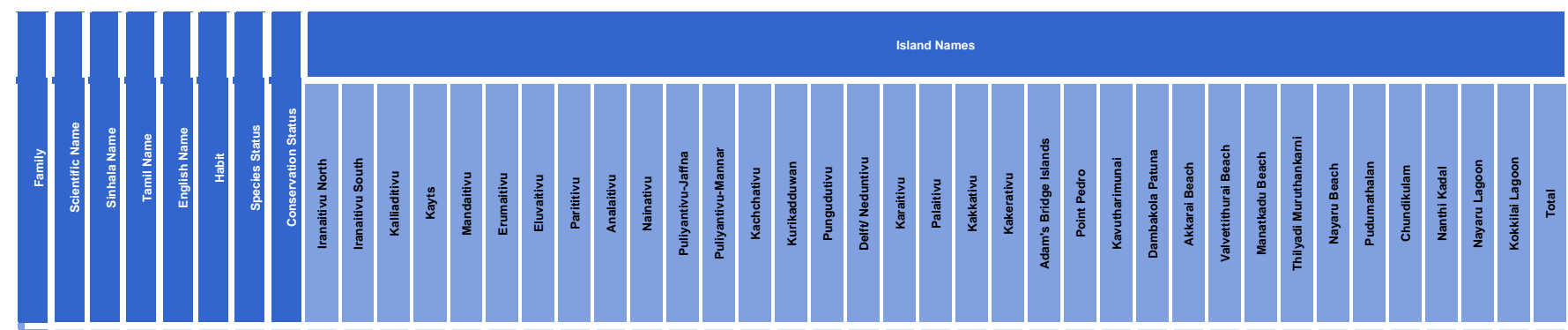

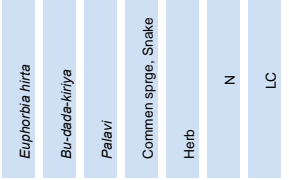

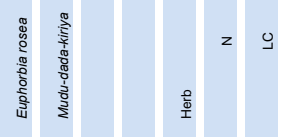

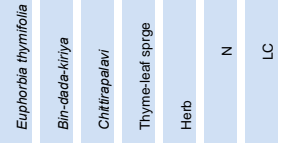

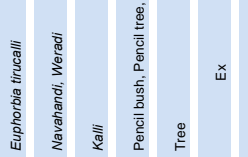

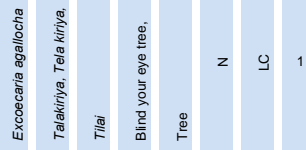

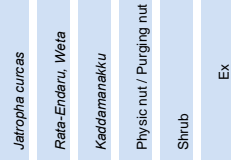

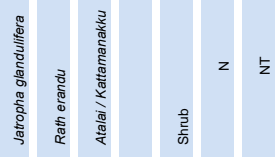

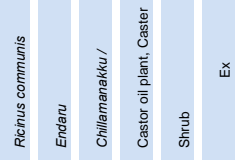

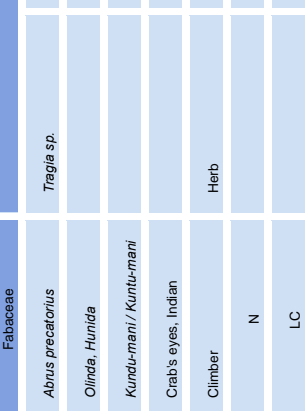




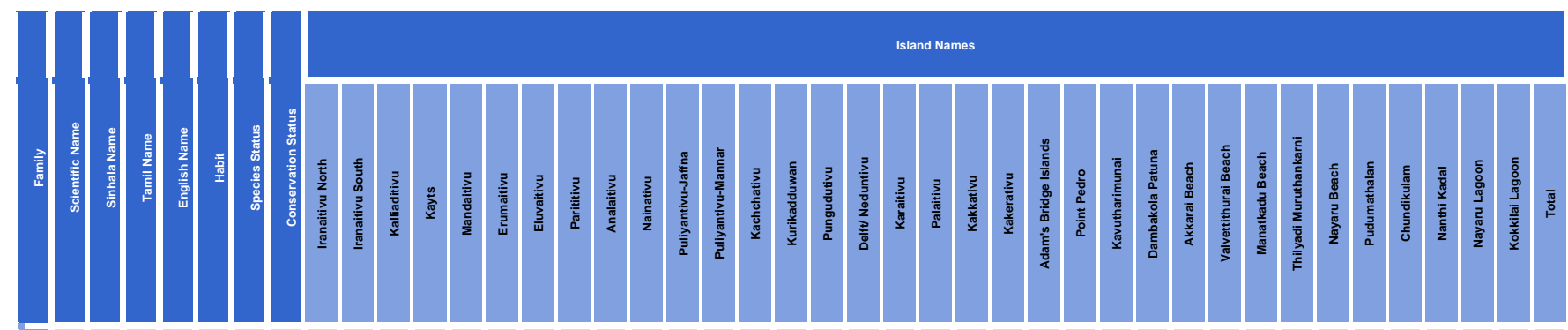

IIII,

IIII.

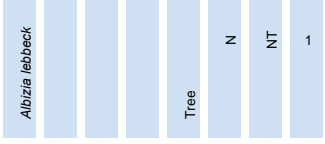

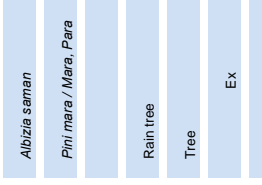

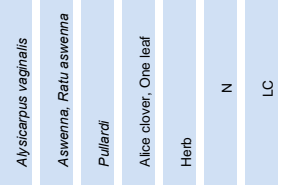

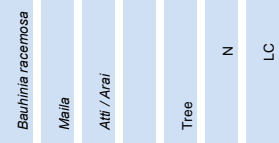

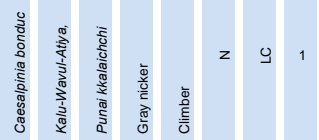

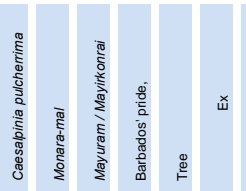

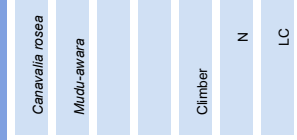

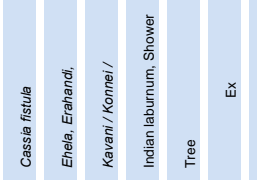



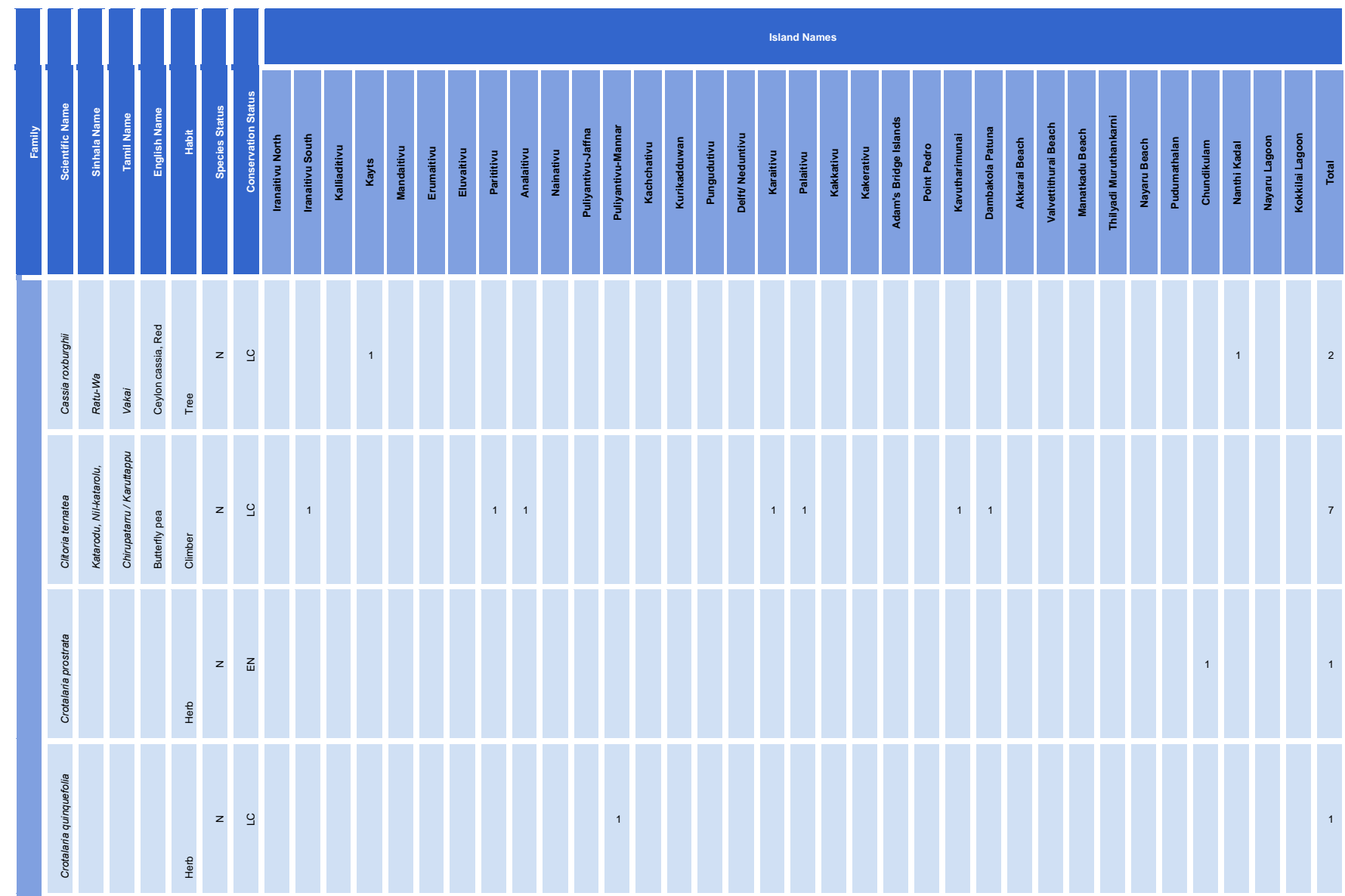

IIII,

I I...

illi.

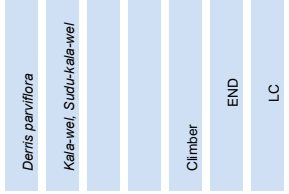

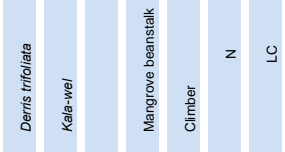

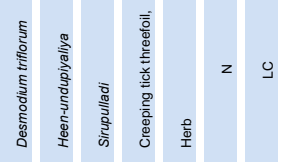




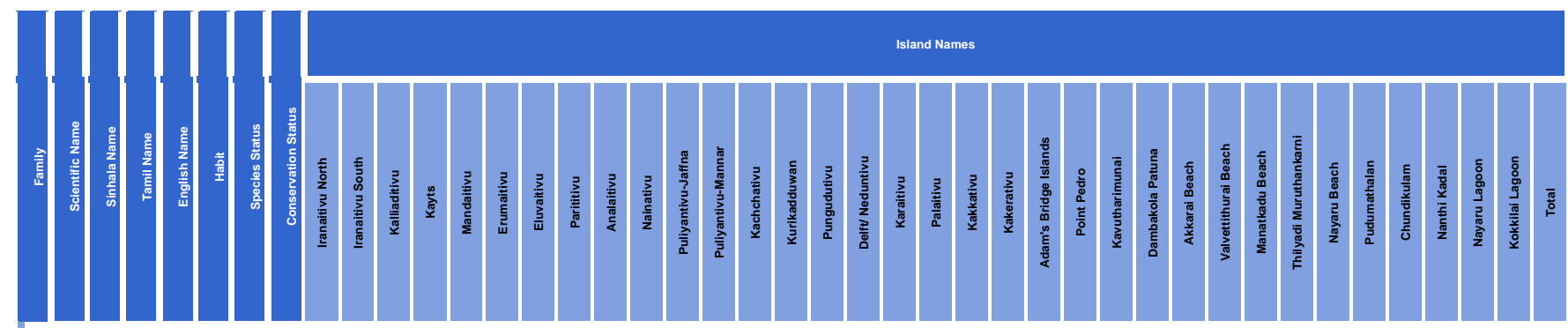

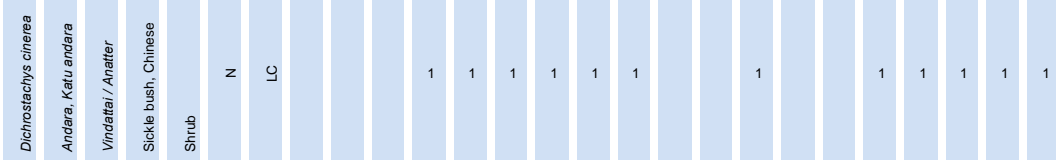

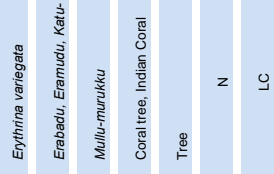

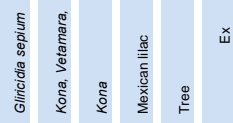

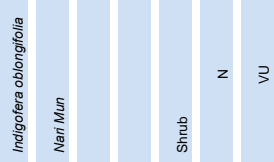

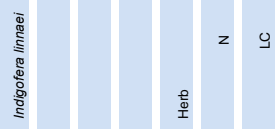

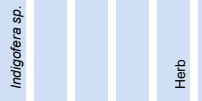

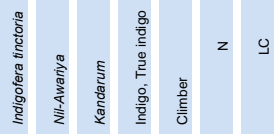

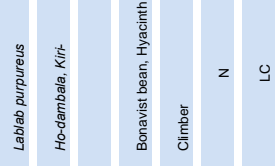

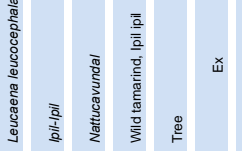

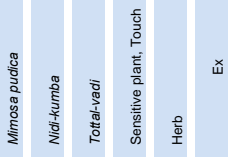



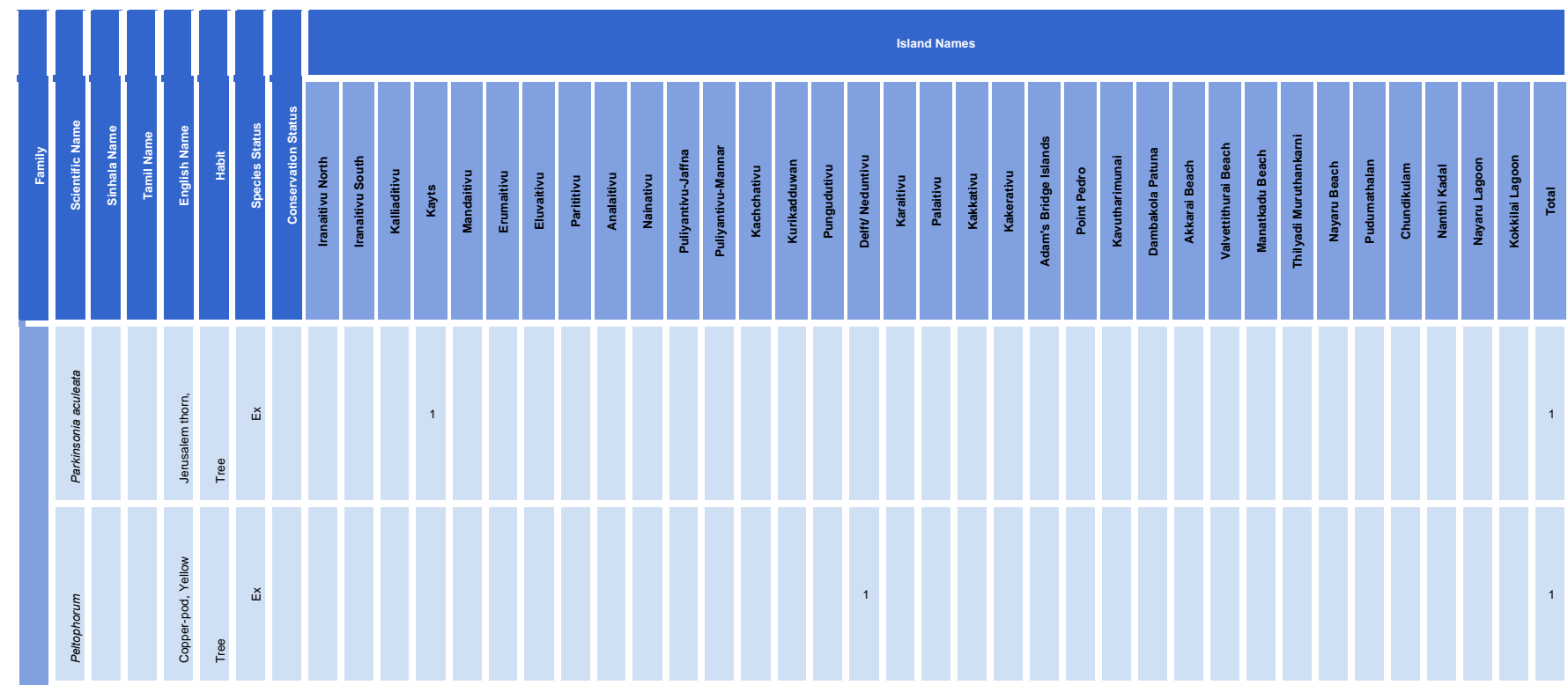

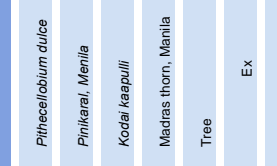

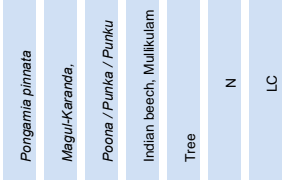

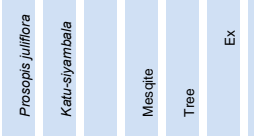

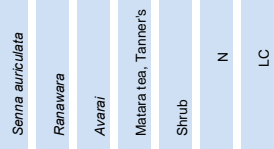

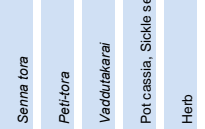

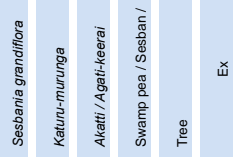

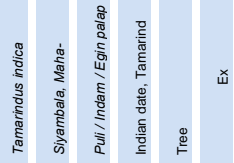

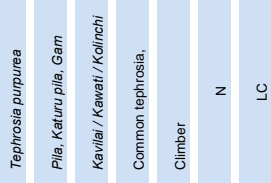




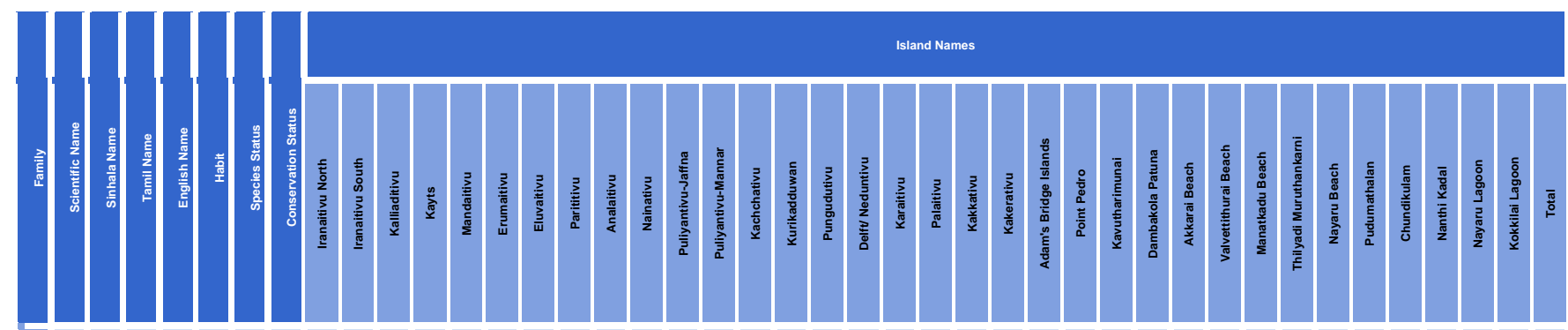

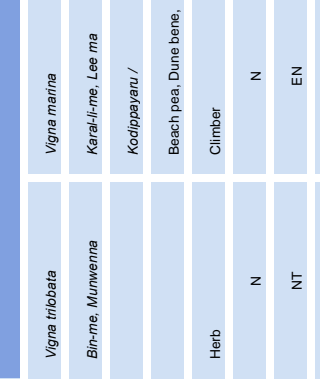

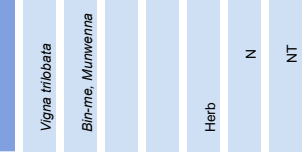

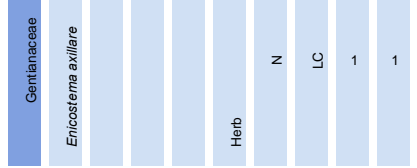
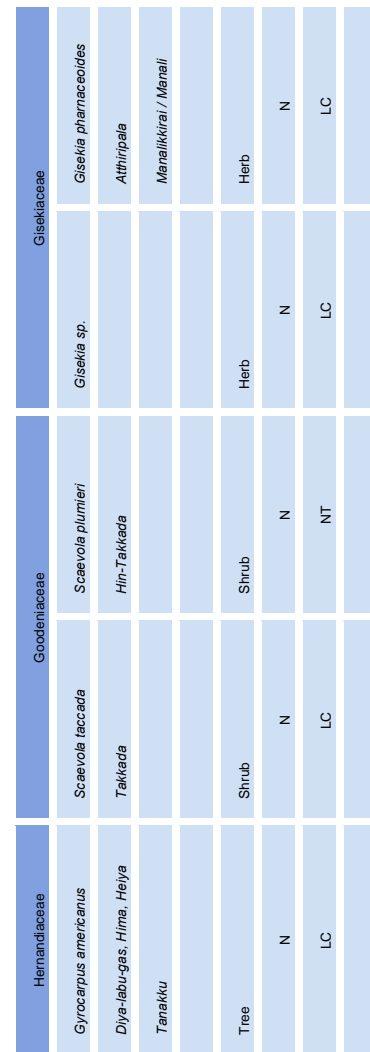

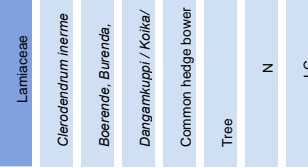




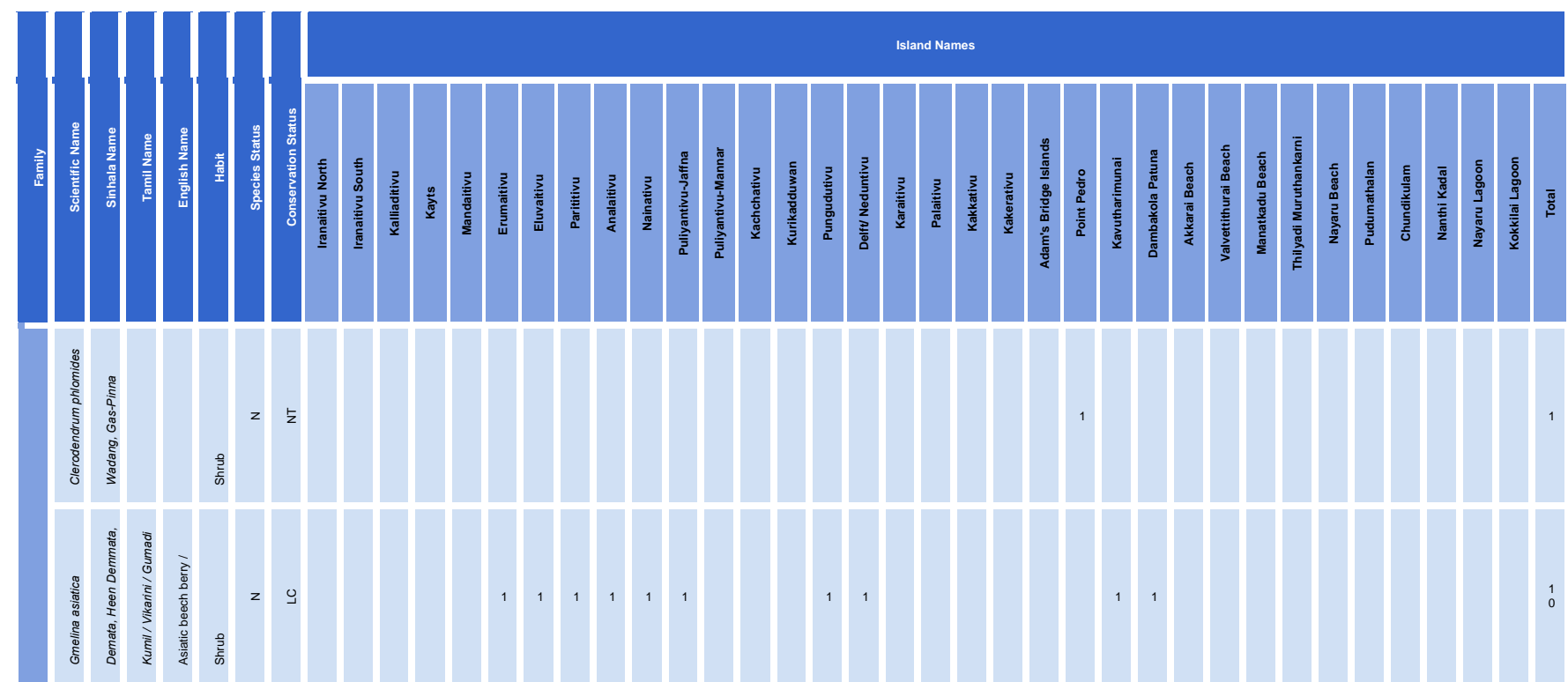

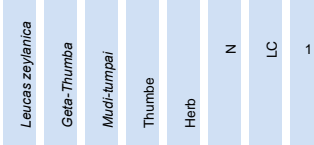

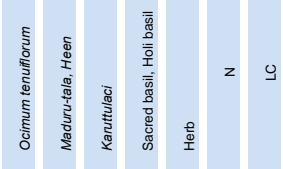

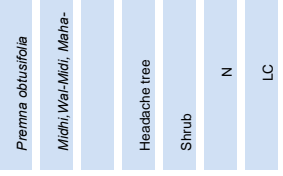

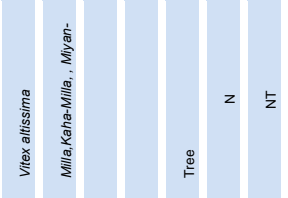

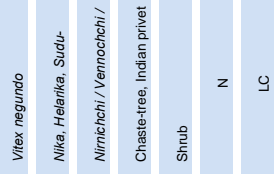

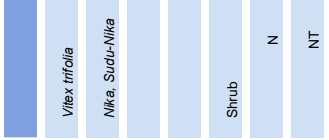

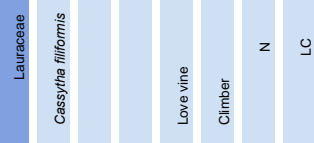




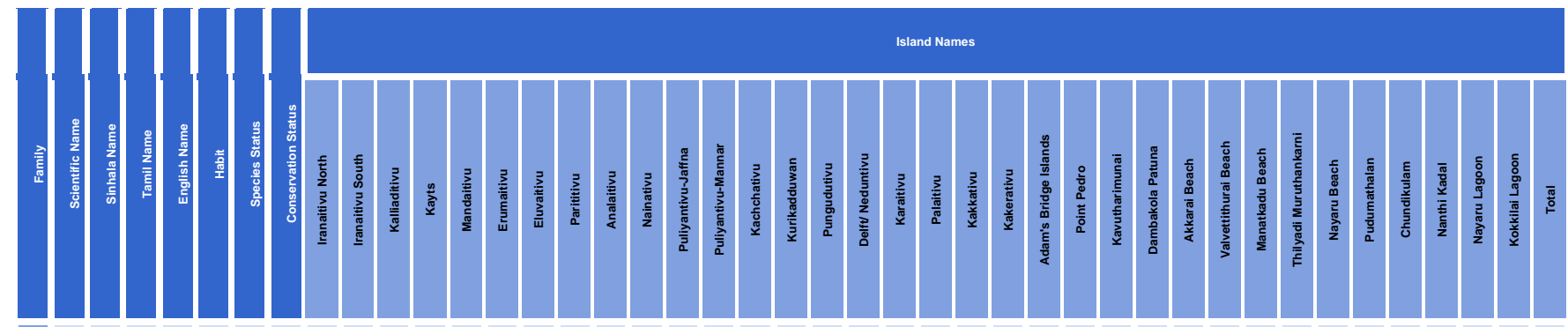

IIII,

(I).

| 1 ,

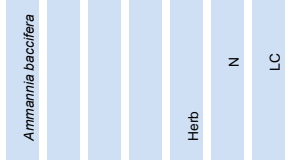

(illi.

II , ......

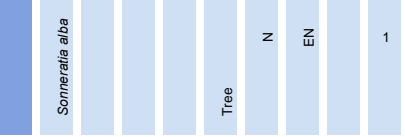

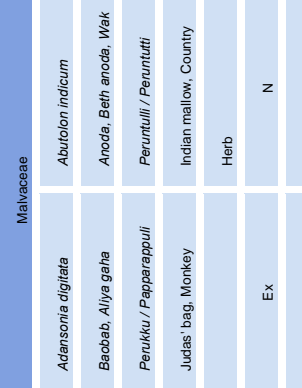



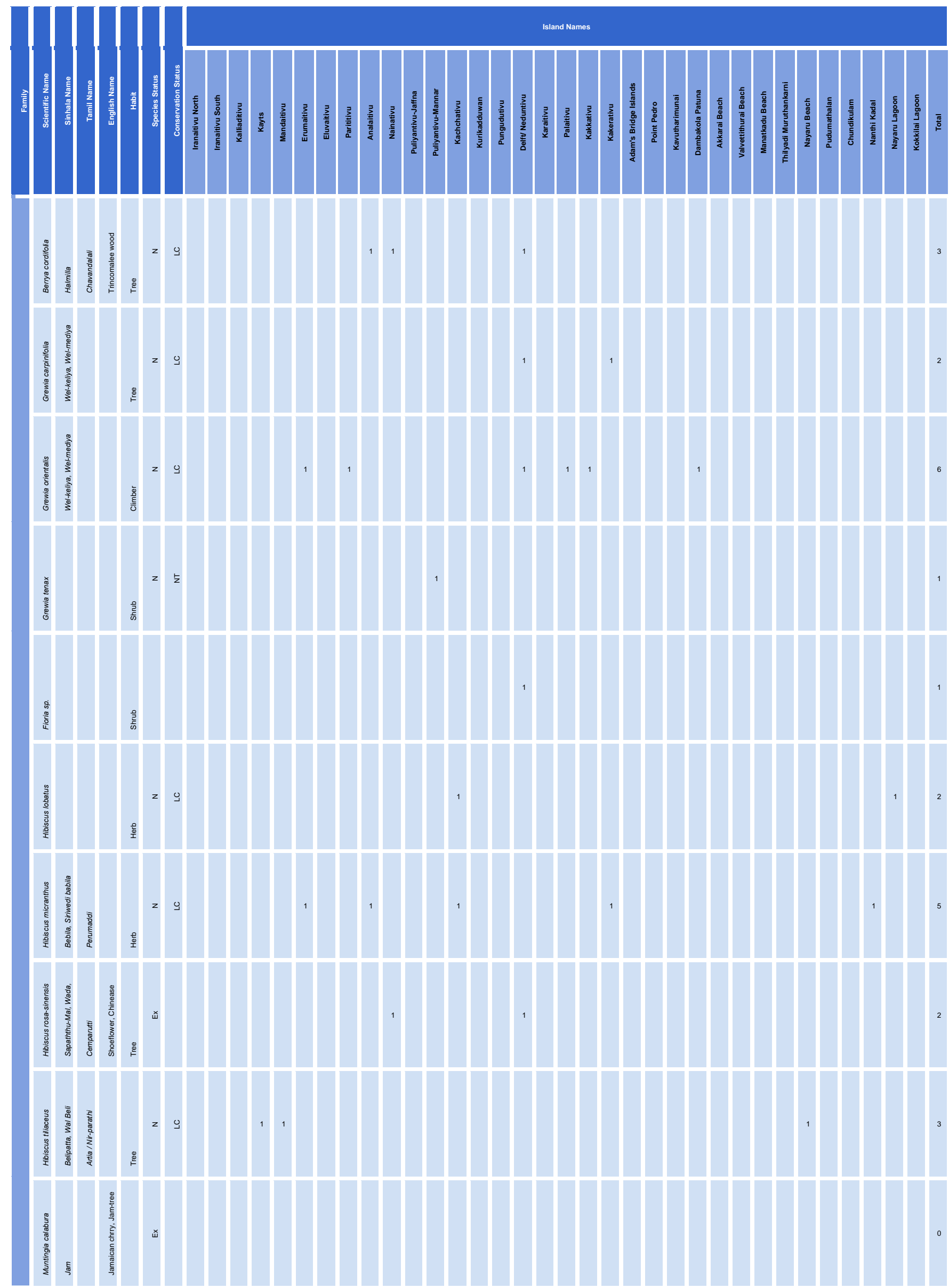


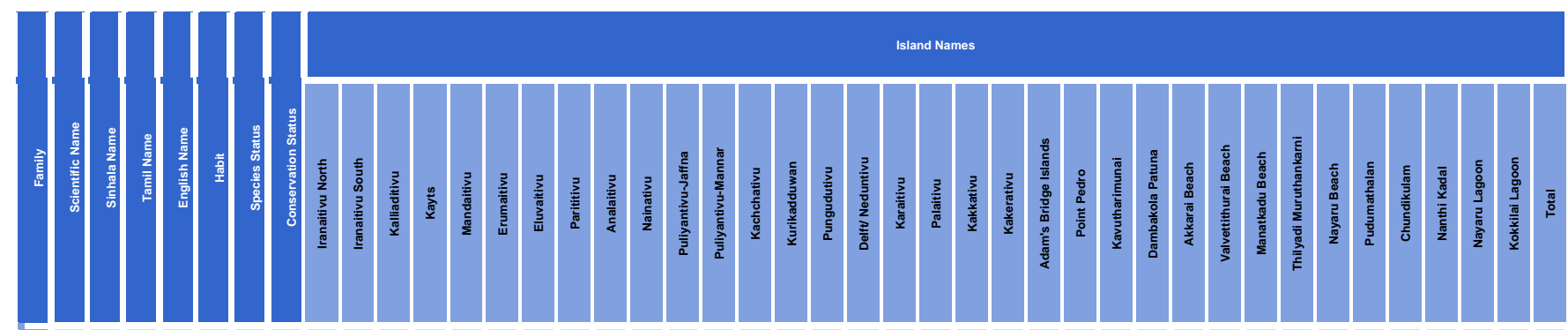

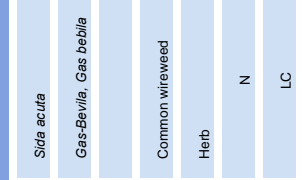

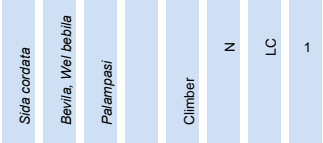

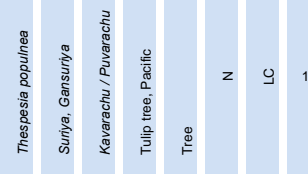

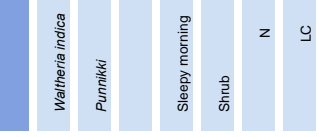

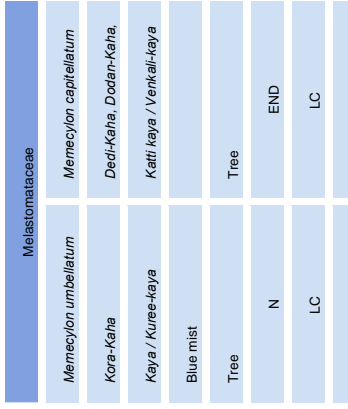

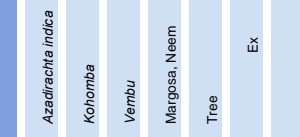

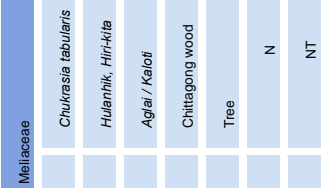

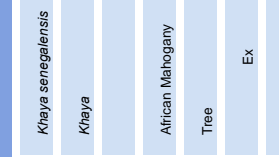

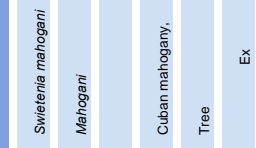



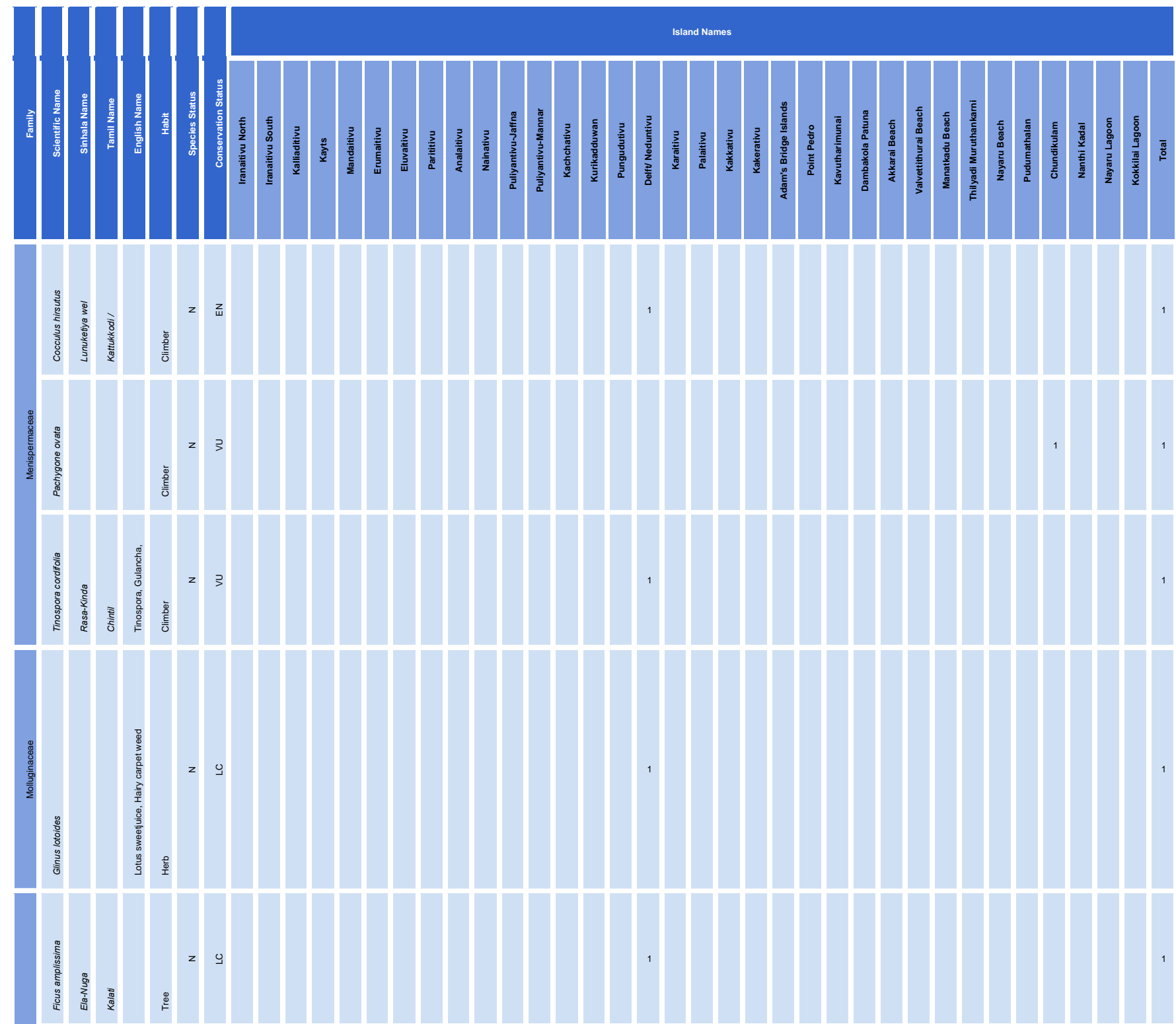

Iin.

lin,

IIII. 

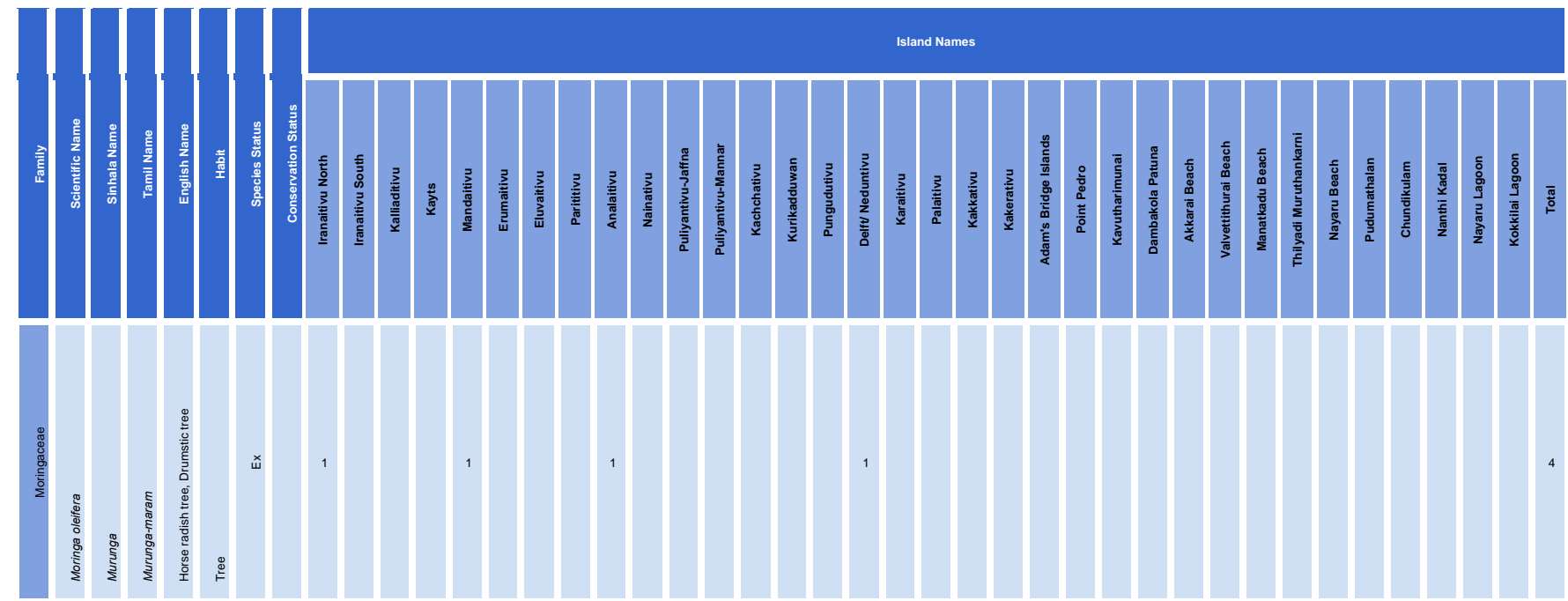

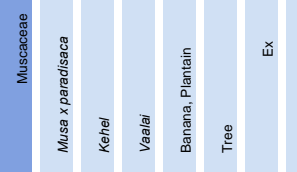

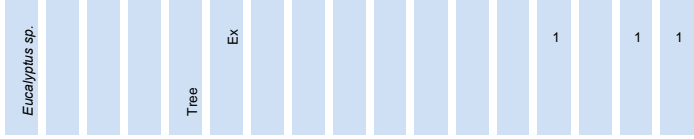

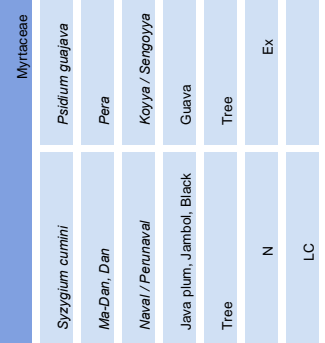

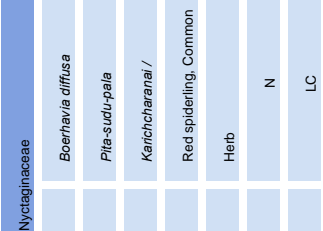

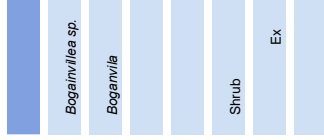

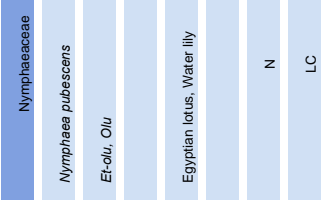



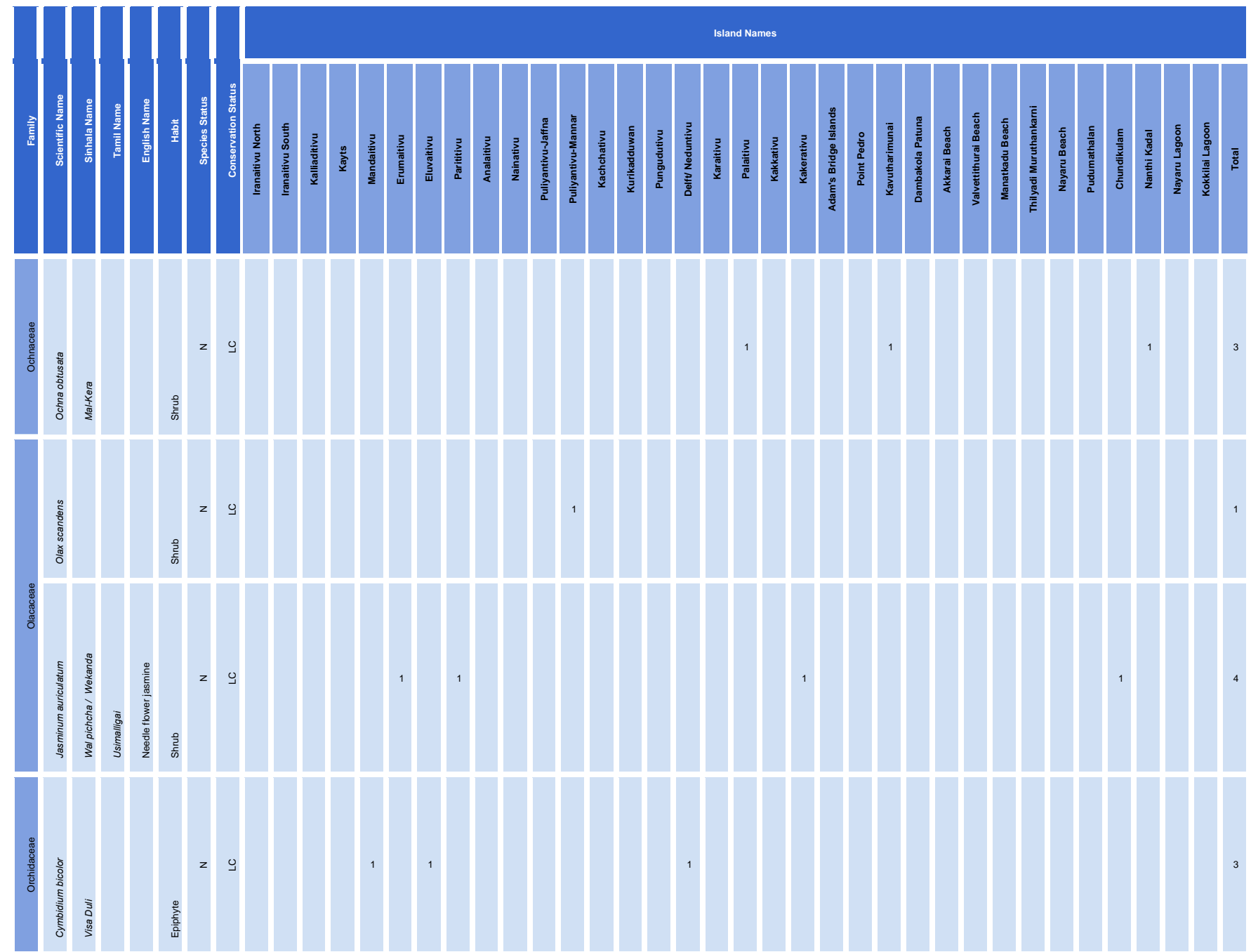

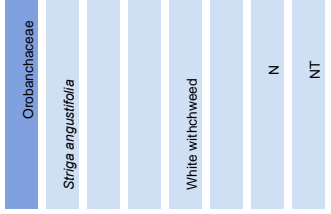

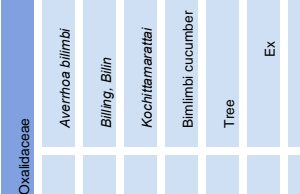

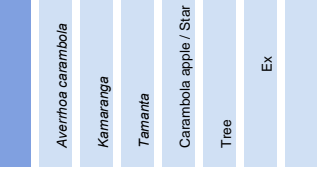

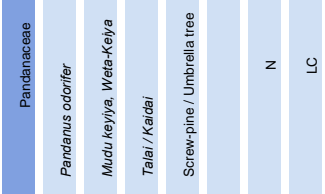



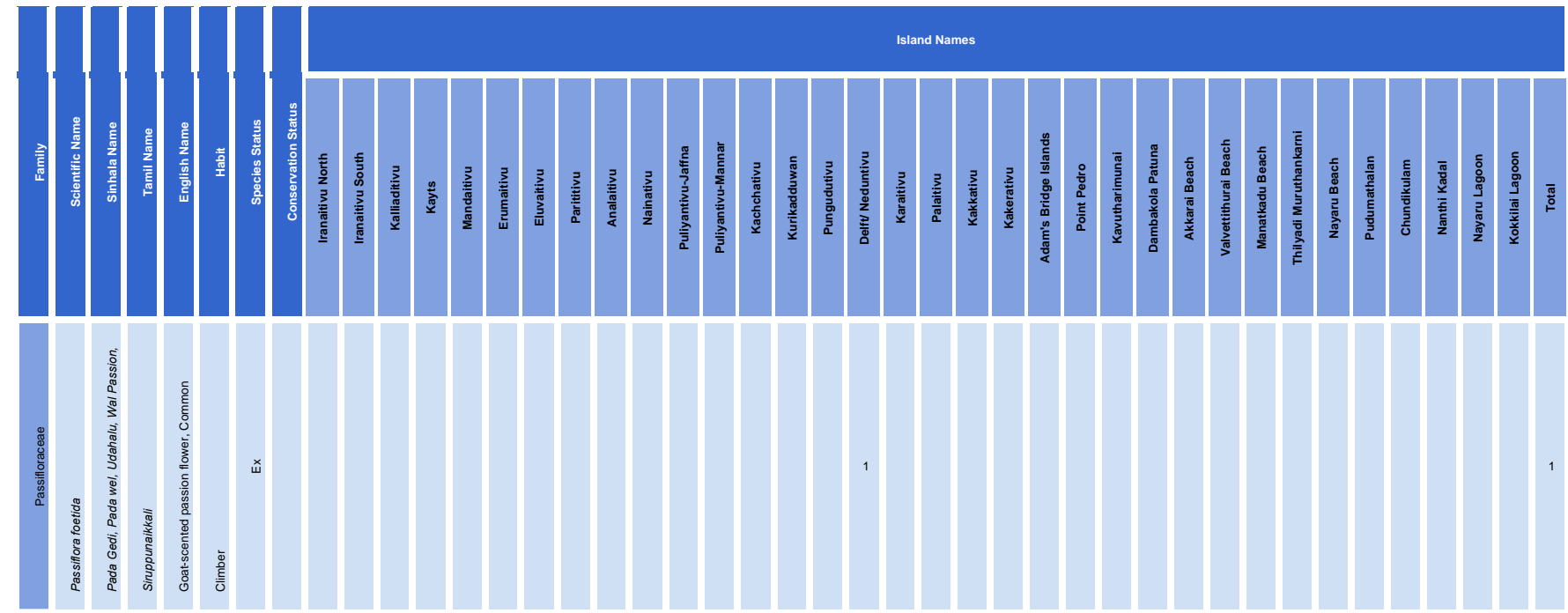

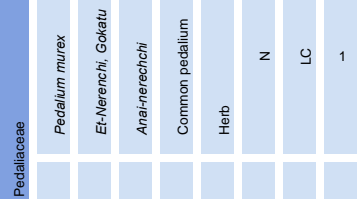
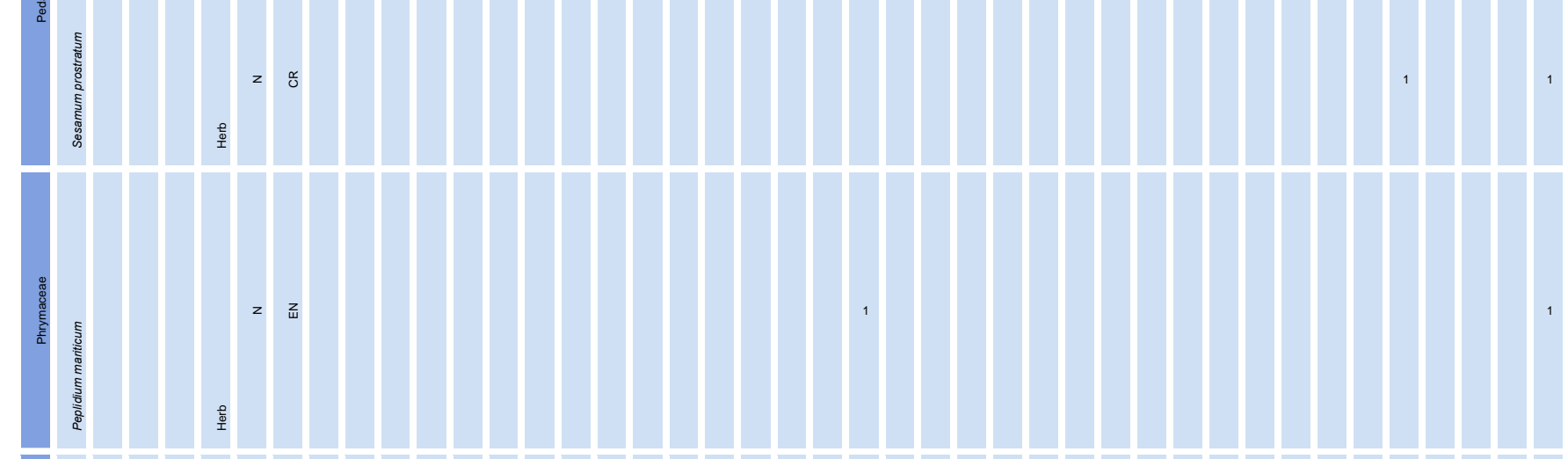

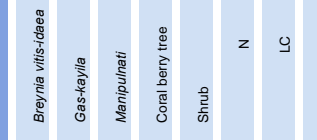

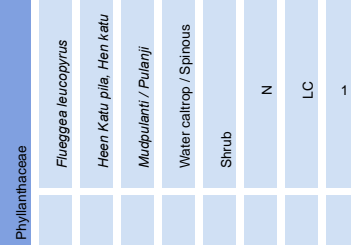

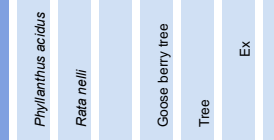

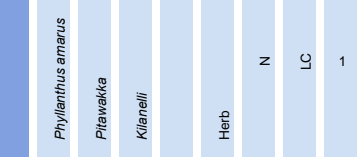



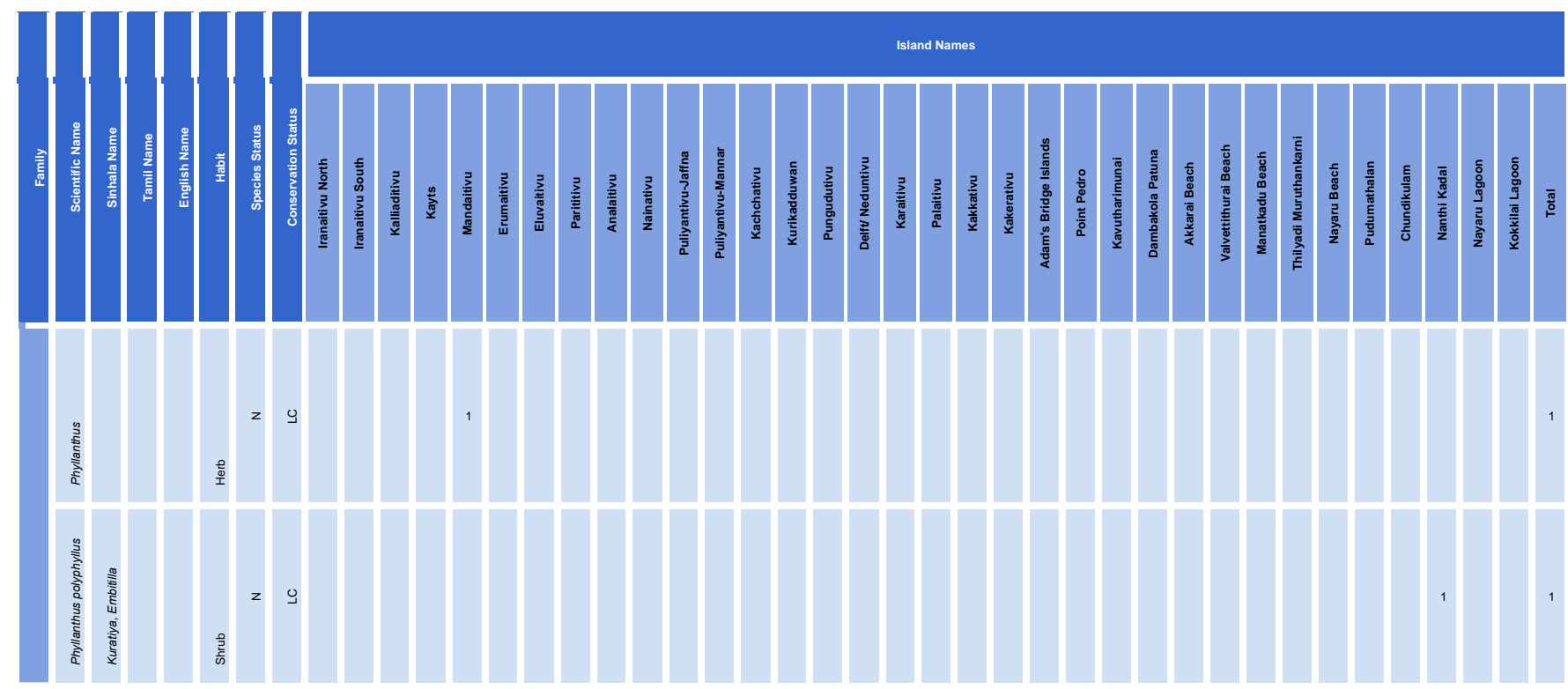

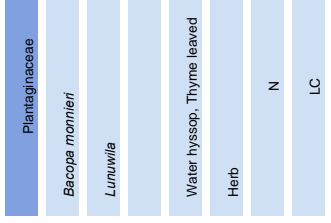
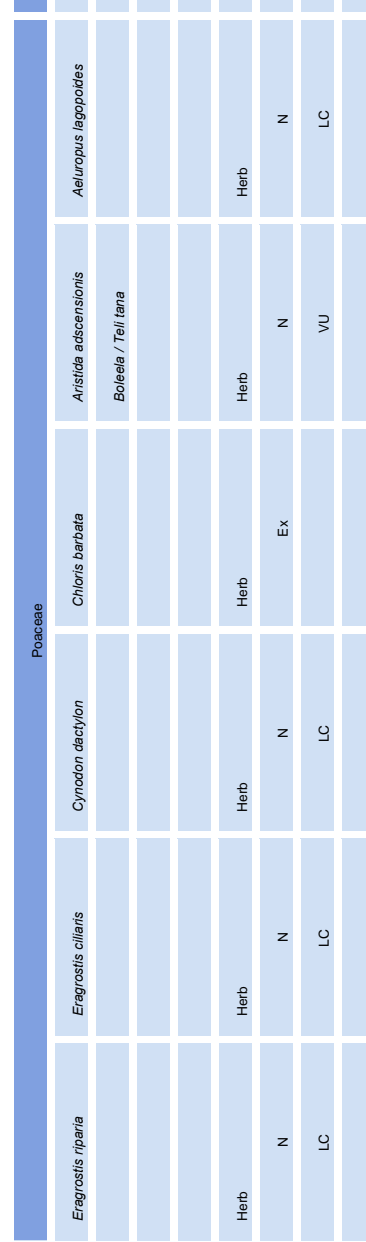

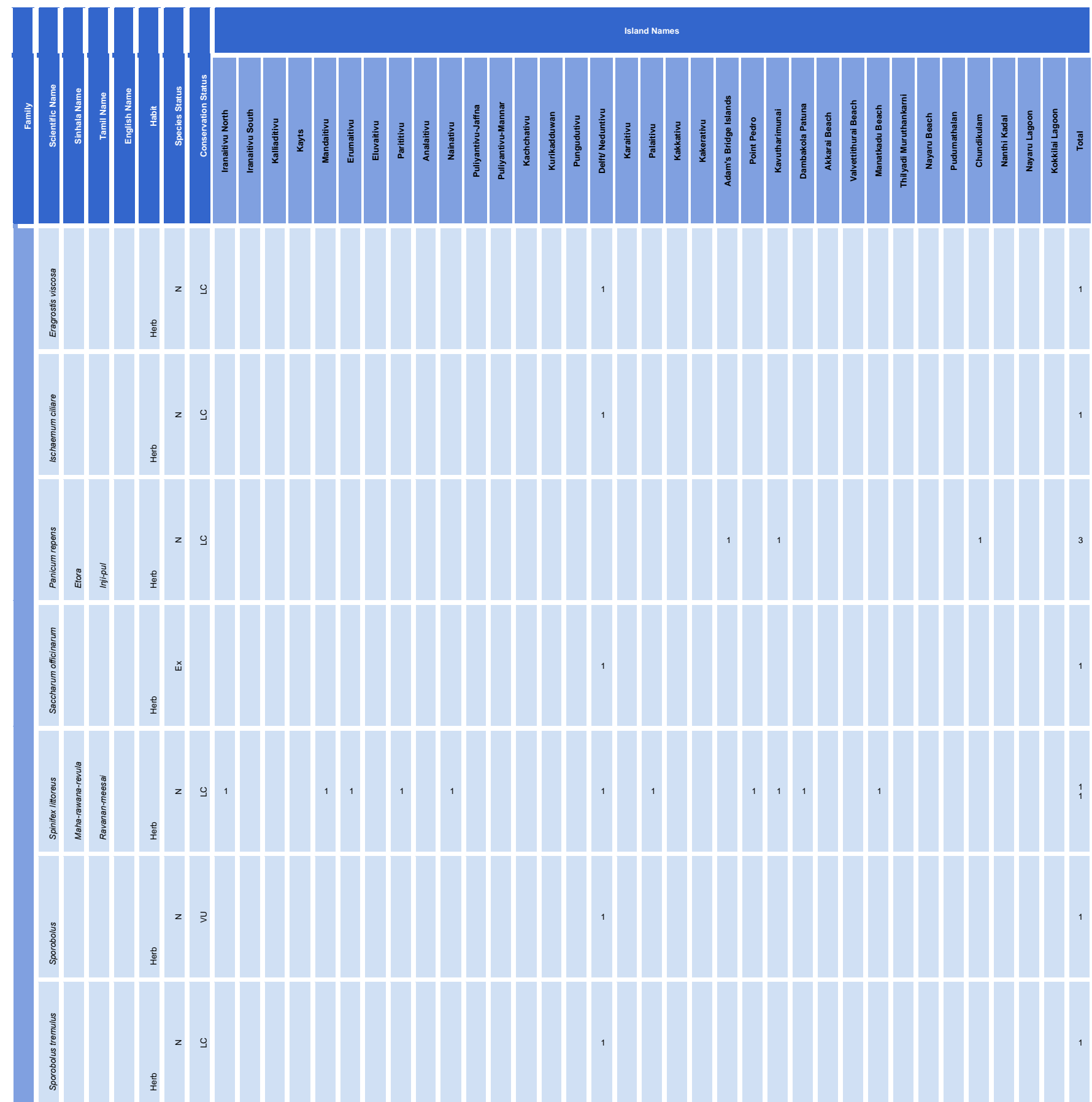

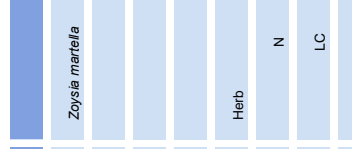

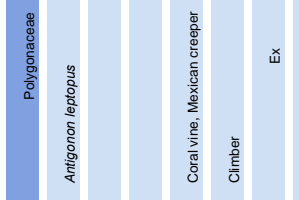




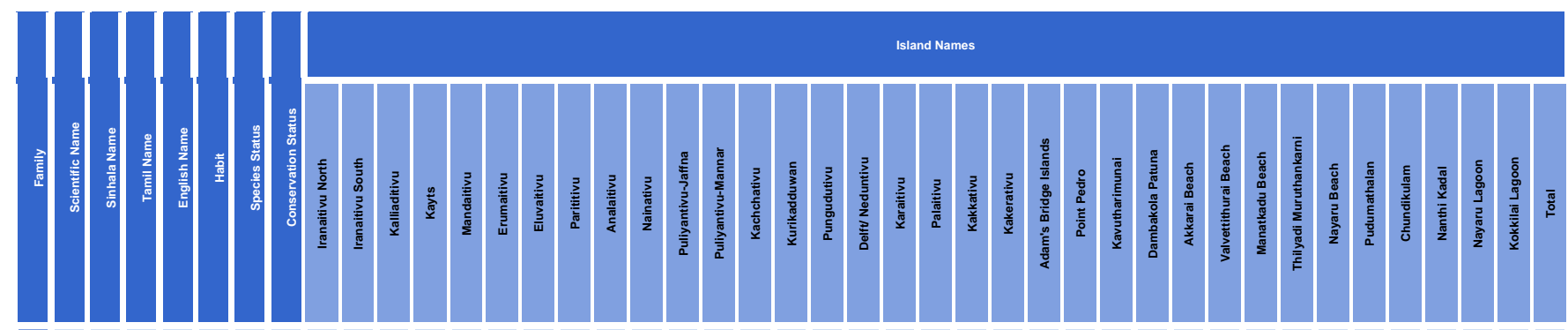

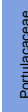

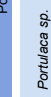

量

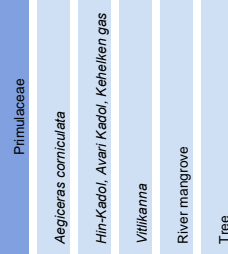

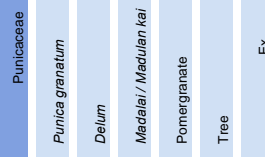

:
:
:

o

袠

รั้ำ

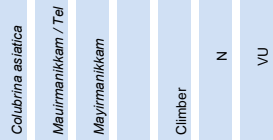

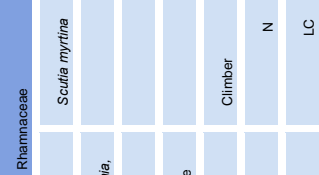

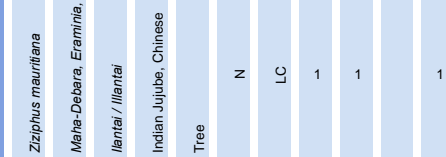

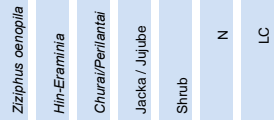




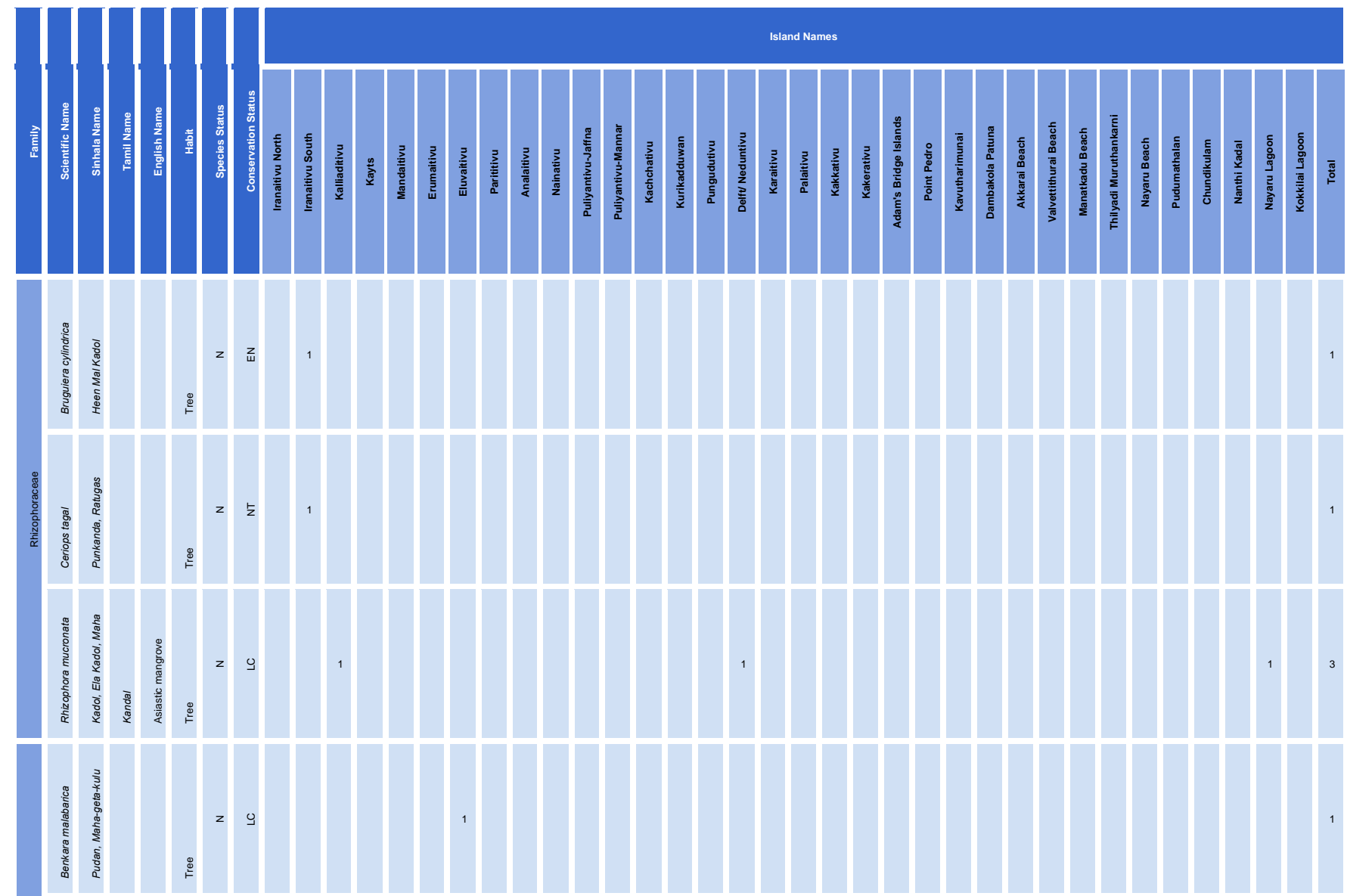

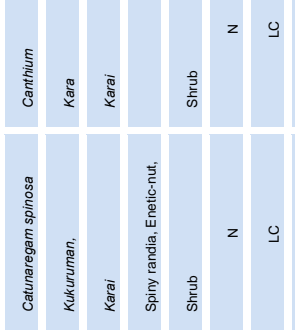

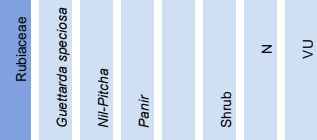

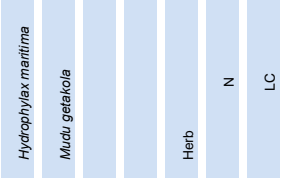

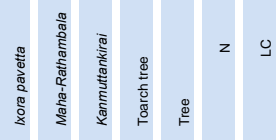

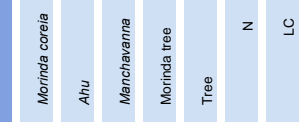



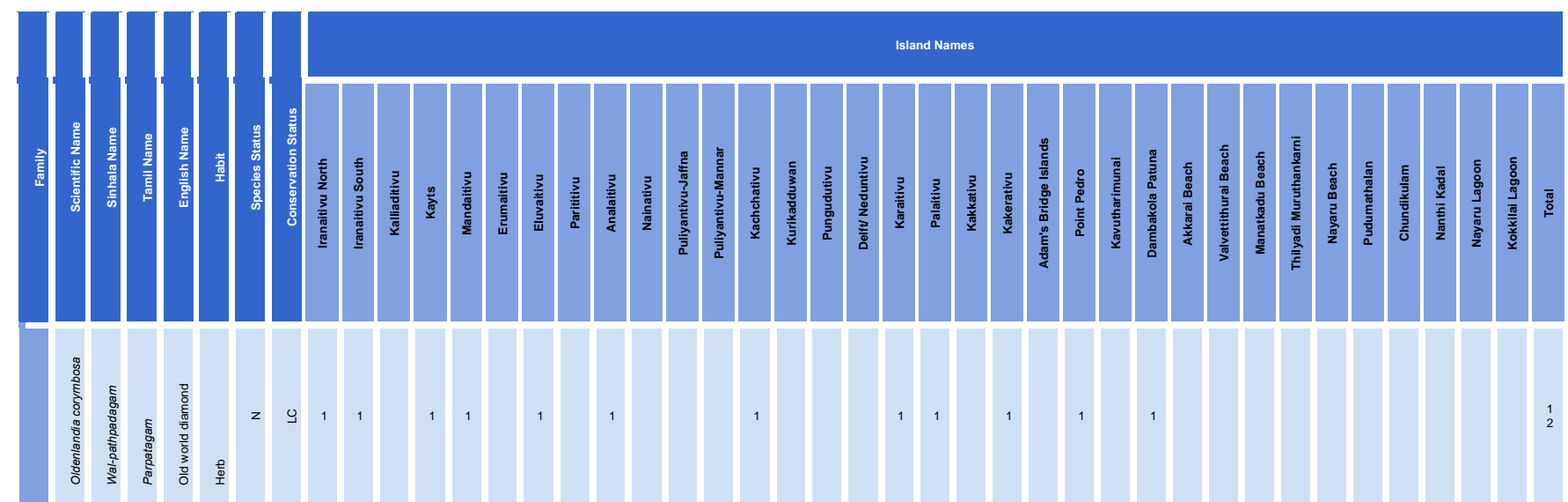

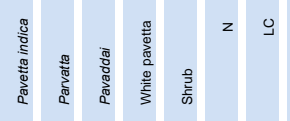

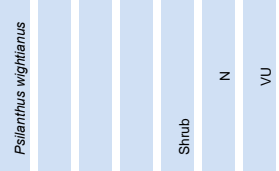

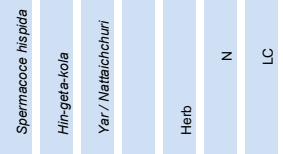

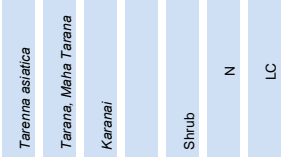

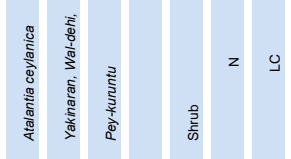

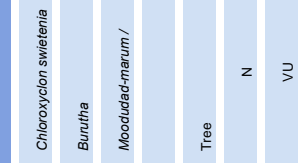

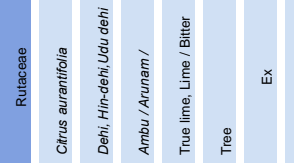

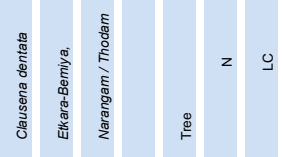

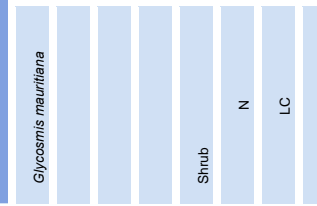



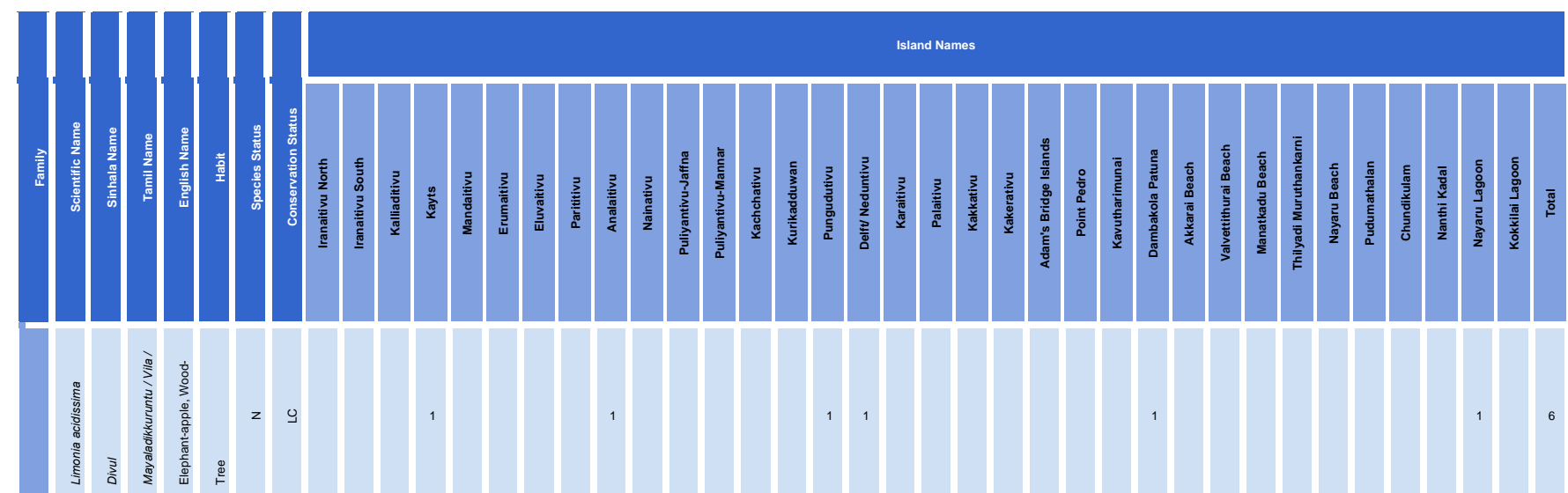

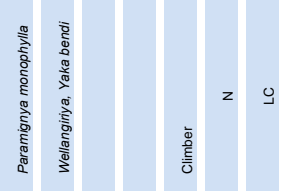

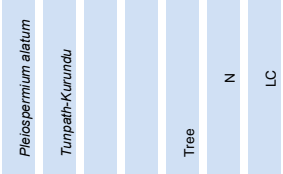

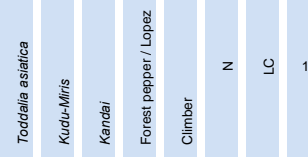

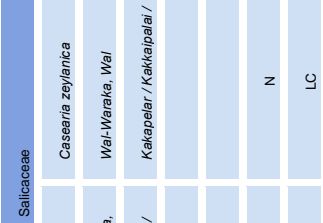

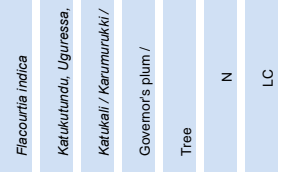

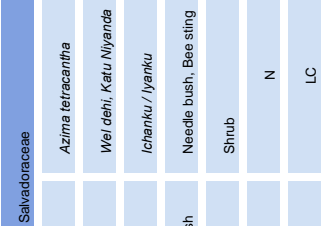

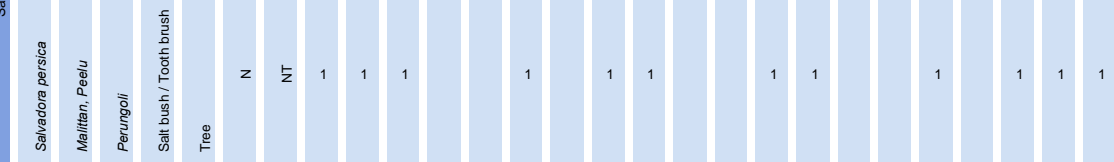

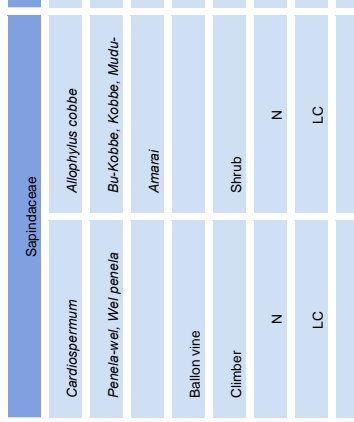




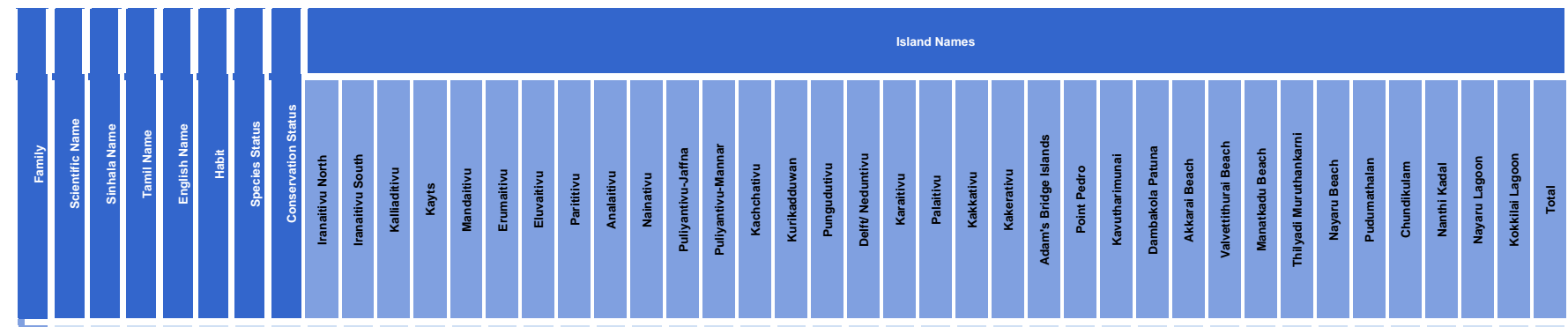

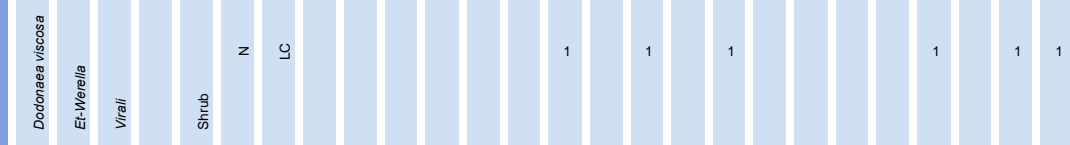

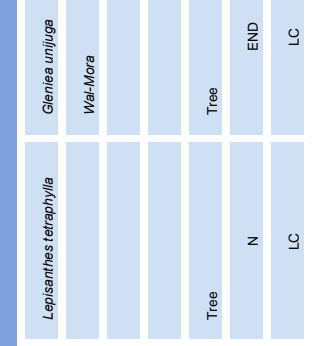

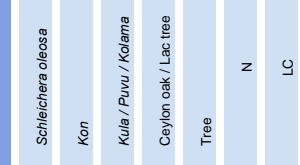

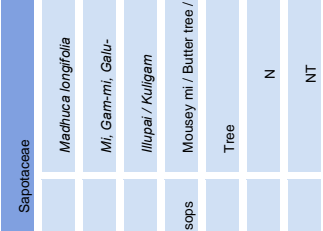

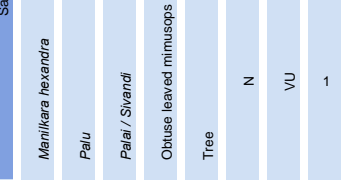

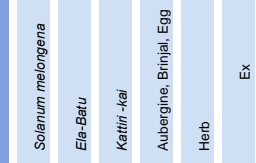

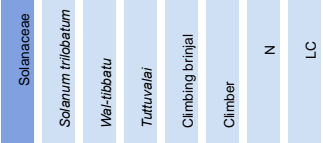

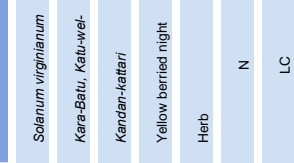

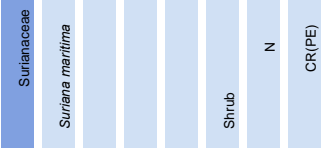



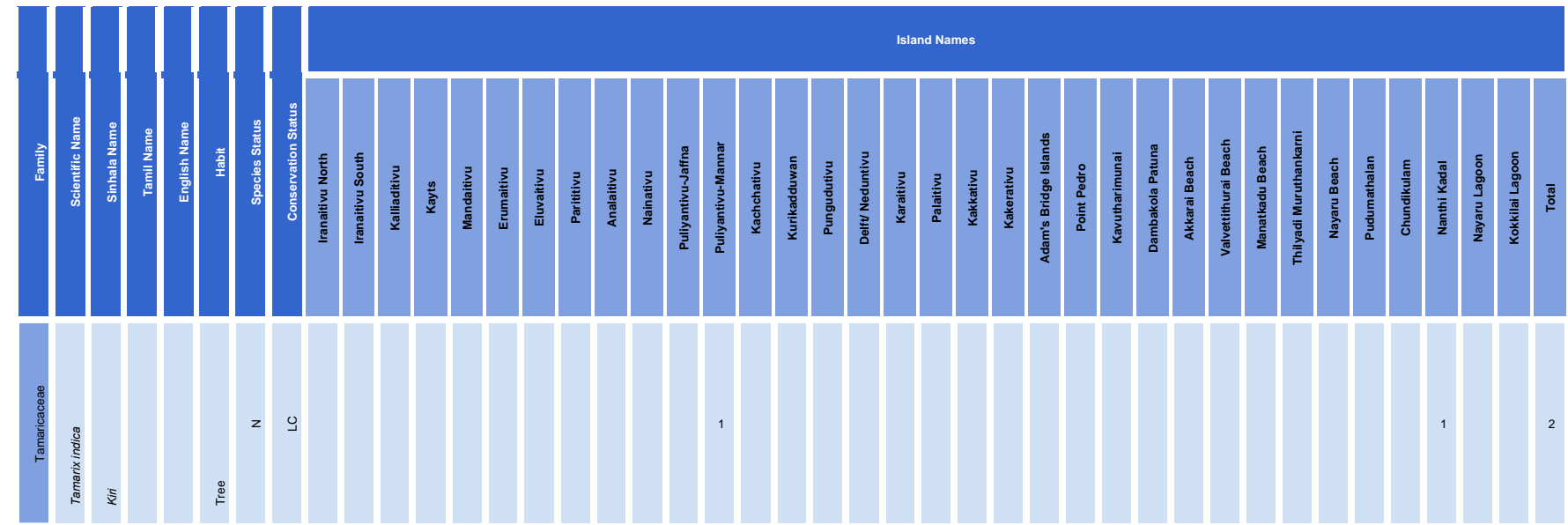

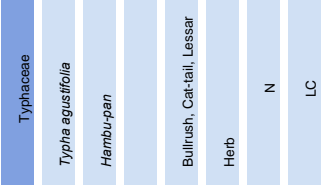

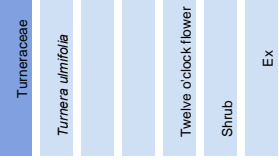

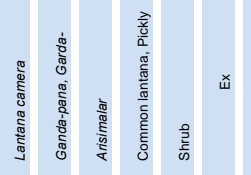

HII:"

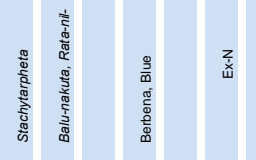

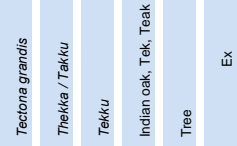

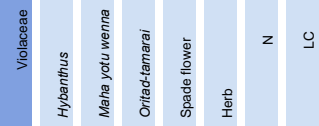

ปูำ

高 


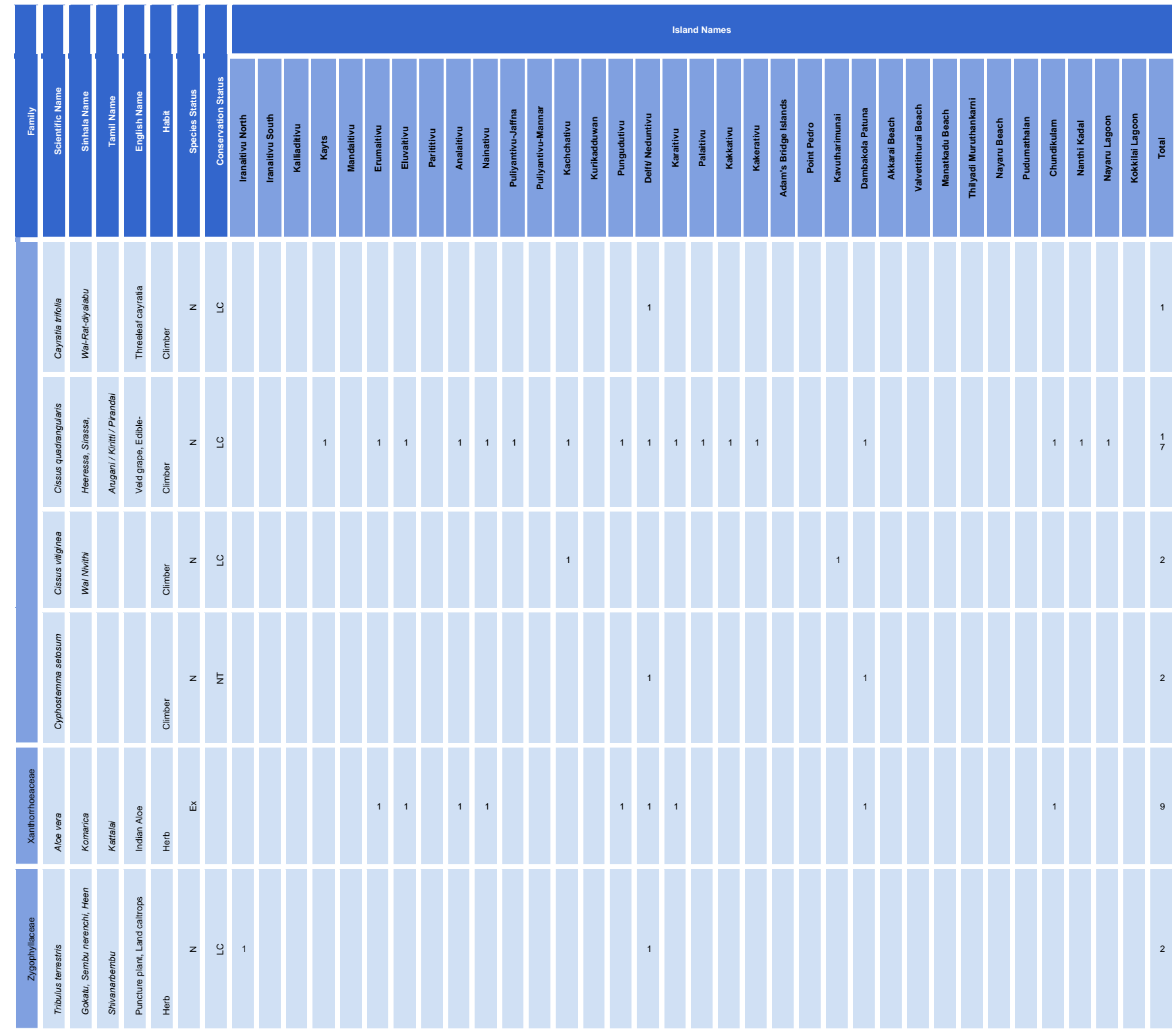

\section{Legend}

\section{Species Status}

\begin{tabular}{|l|l|}
\hline $\mathrm{N}$ & Native \\
\hline Ex & Exotic \\
\hline Ex-N & Exotic, naturalised \\
\hline END & Endemic \\
\hline
\end{tabular}

\section{Conservation Status}

\begin{tabular}{|l|l|}
\hline VU & Vulnerable \\
\hline CR (PE) & Critically Endangered, Possibly Extinct \\
\hline CR & Critically Endangered \\
\hline EN & Endangered \\
\hline VU & Vulnerable \\
\hline NT & Near Threatened \\
\hline LC & Least concern \\
\hline NE & Not evaluated \\
\hline
\end{tabular}




\section{Annex 5. List of Fauna Found in the Study Area}

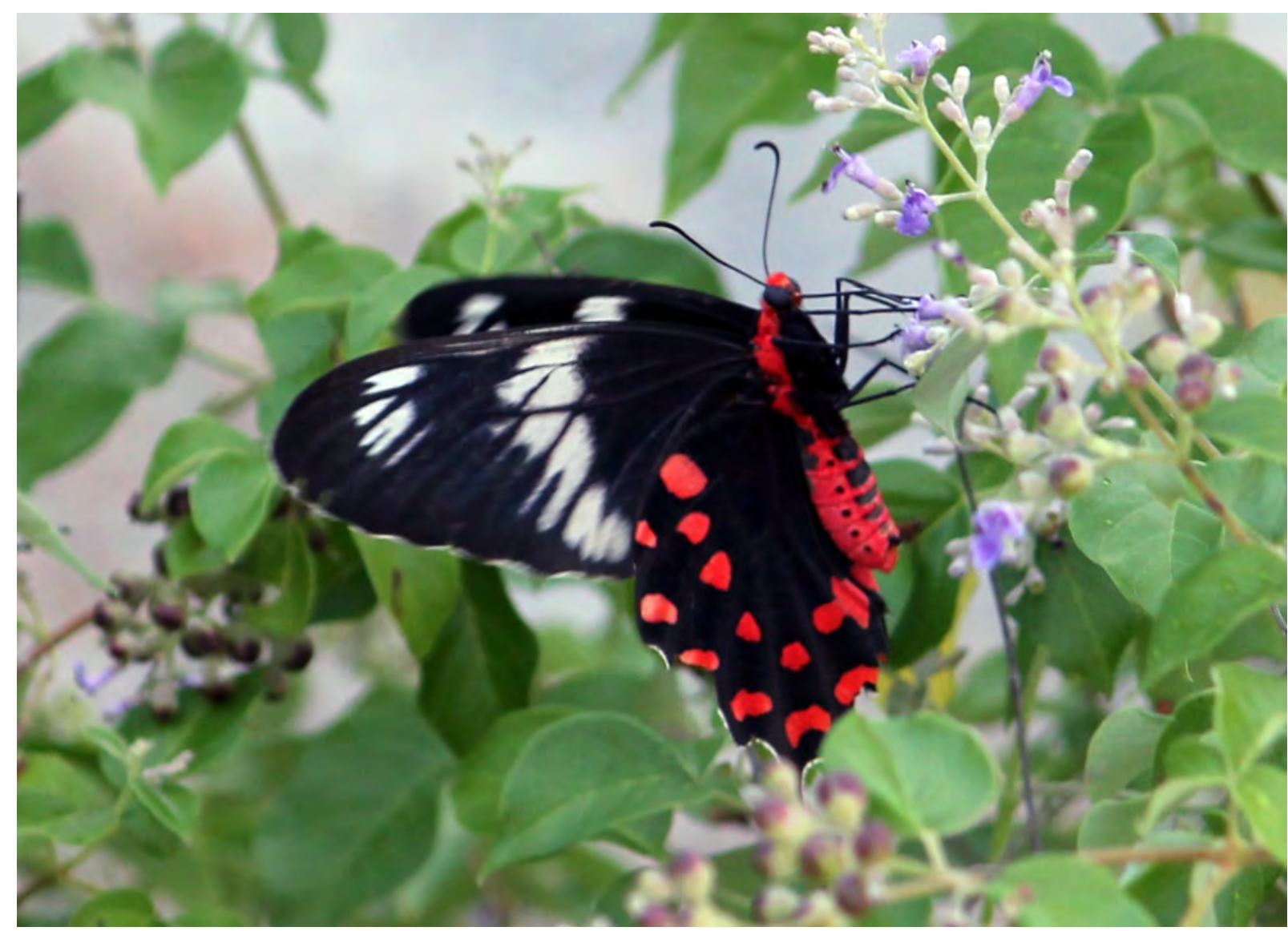

Crimson rose (Pachliopta hector), Karainagar $\odot$ IUCN/Sampath de A. Goonatilake 
(Sources: This study; Abhirami \& Shivashanthini, 2008; Asela et al., 2014; Balasubramaniam et al., 2003; IUCN, 2011b; Karunarathna et al., 2009; Packiyanathan \& Wijesundara, 2014; and Veronika et al., 2013)

\section{a) Snails}

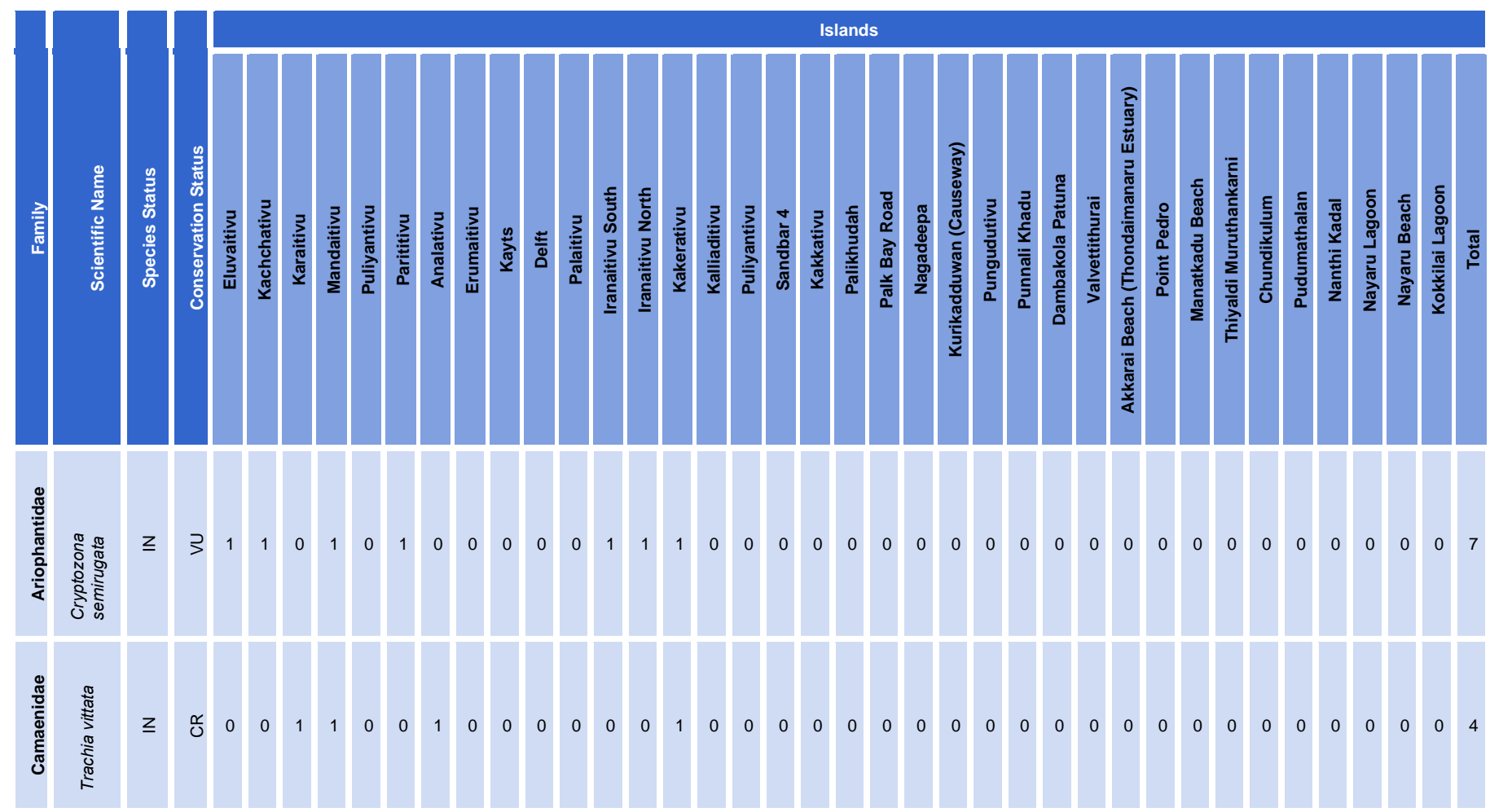

* No common or vernacular names known 


\section{b) Scorpions}
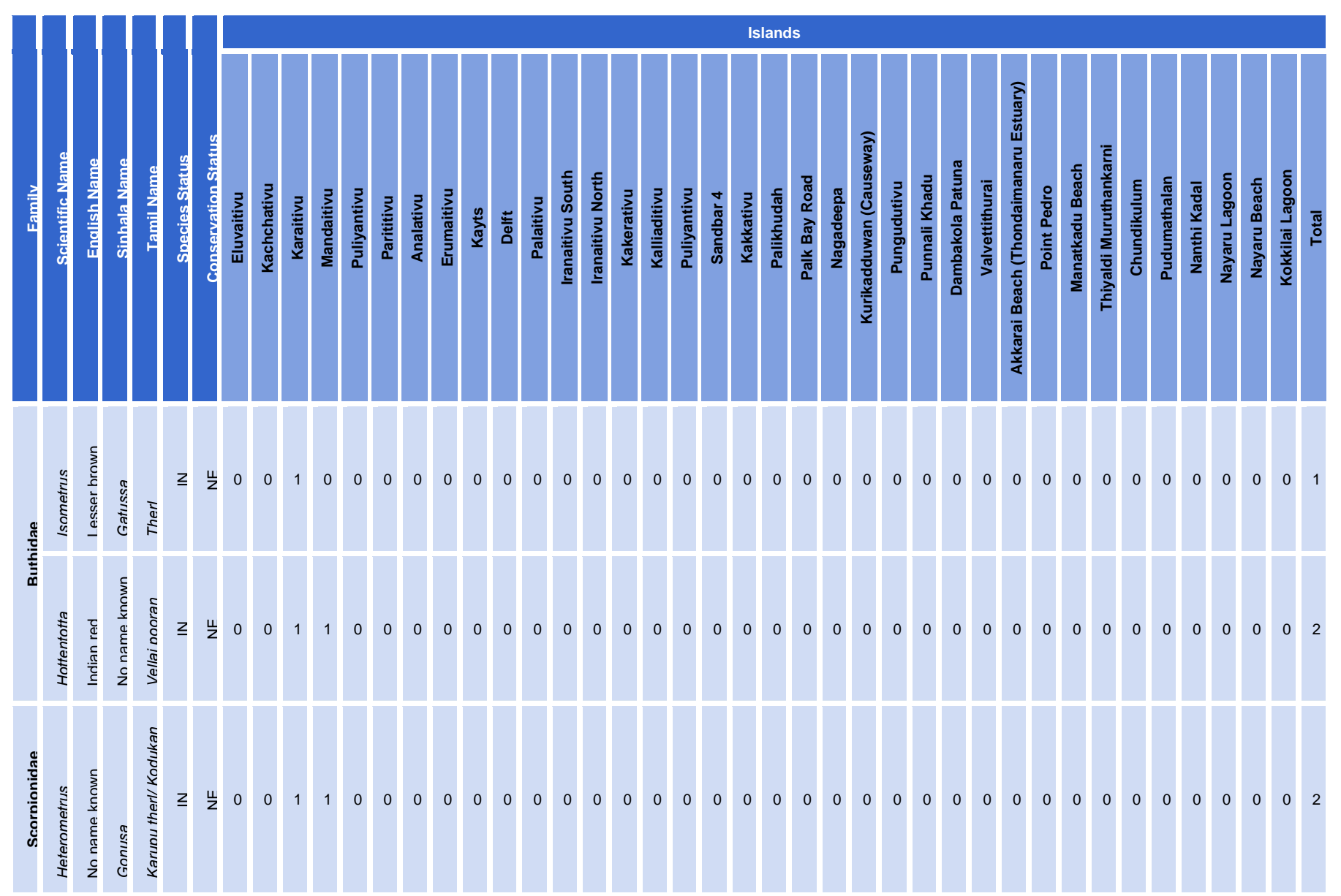


\section{c) Dragonflies}

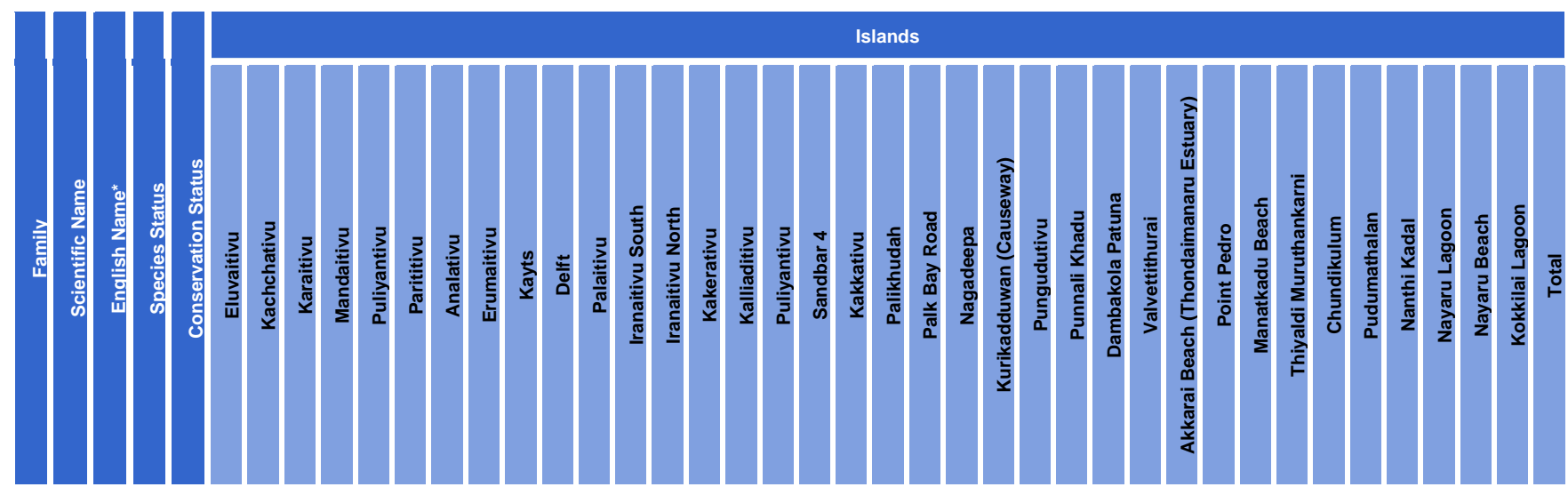

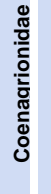

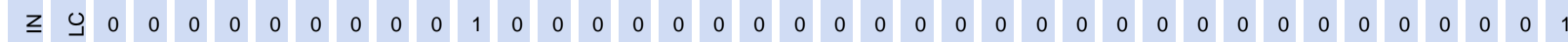

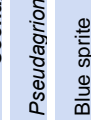

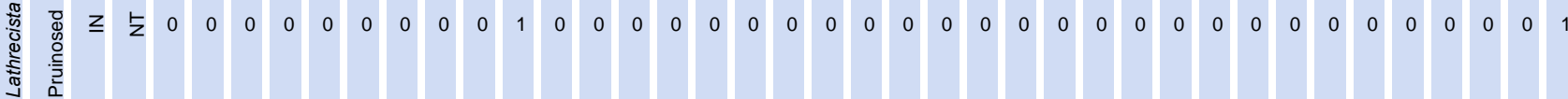

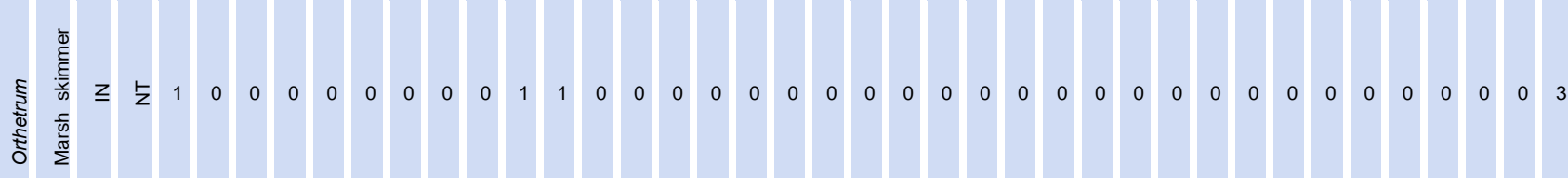
ह 这离

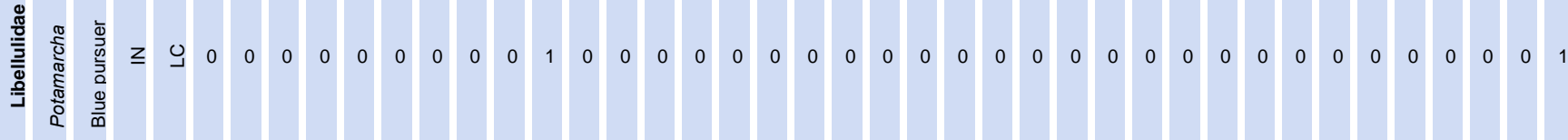

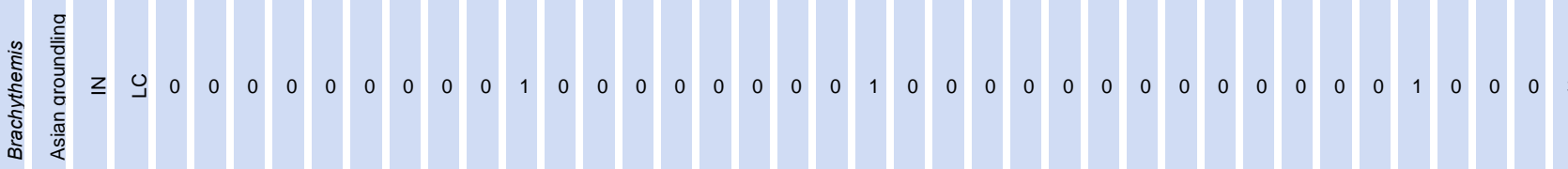

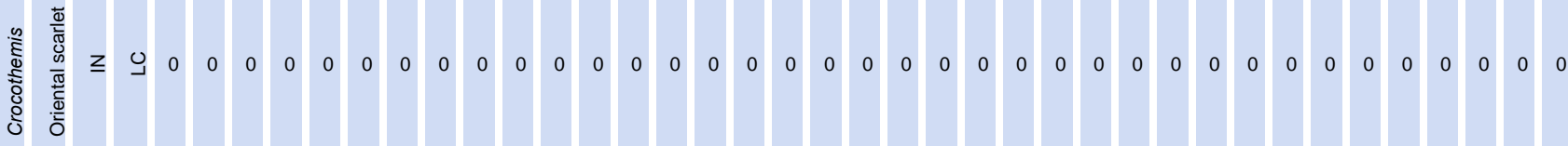

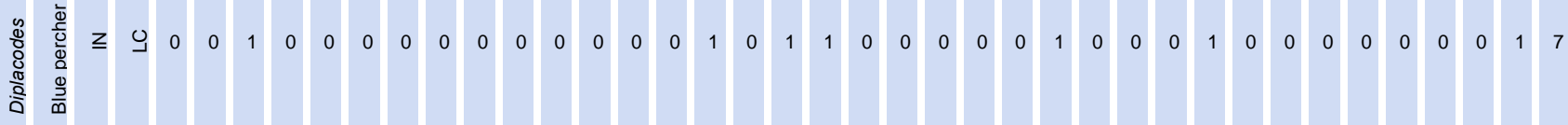




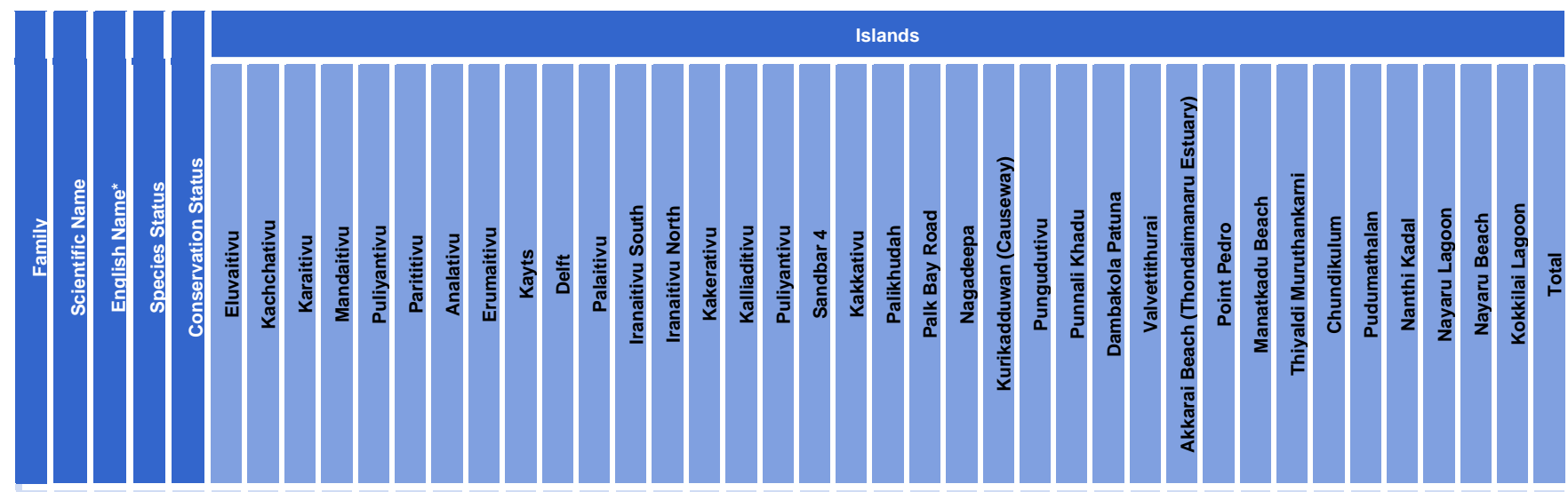

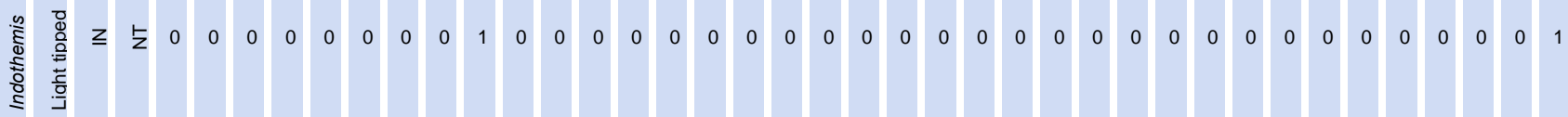

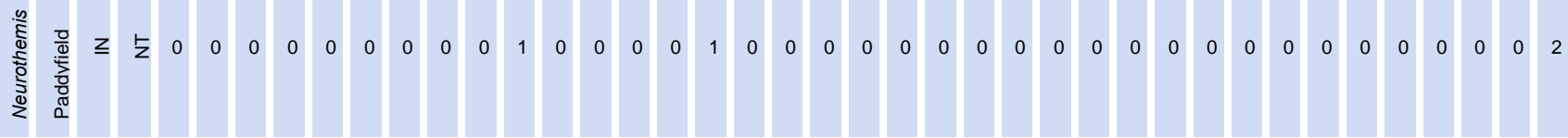

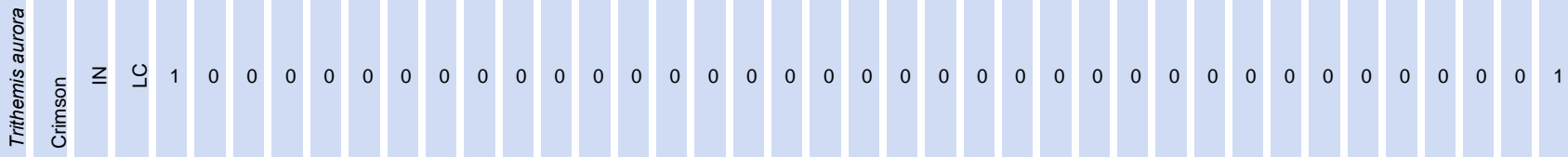

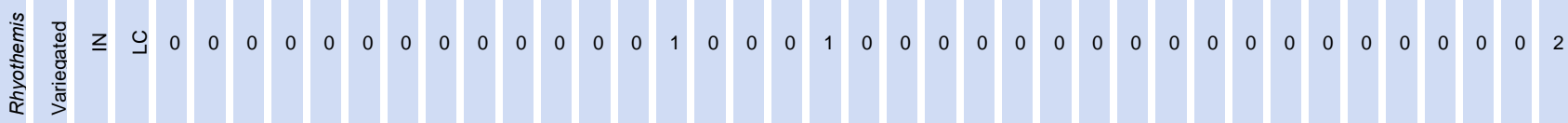

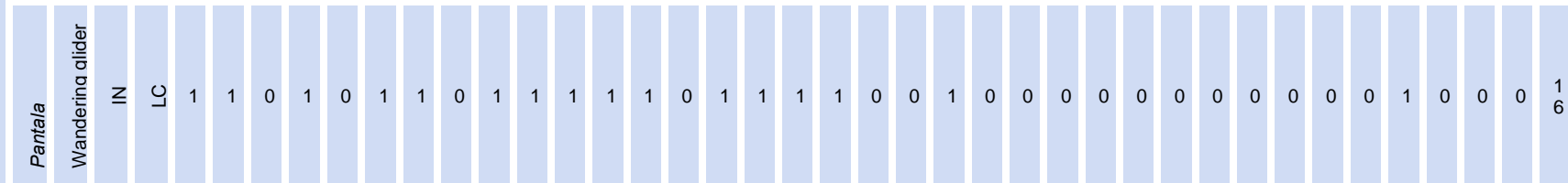

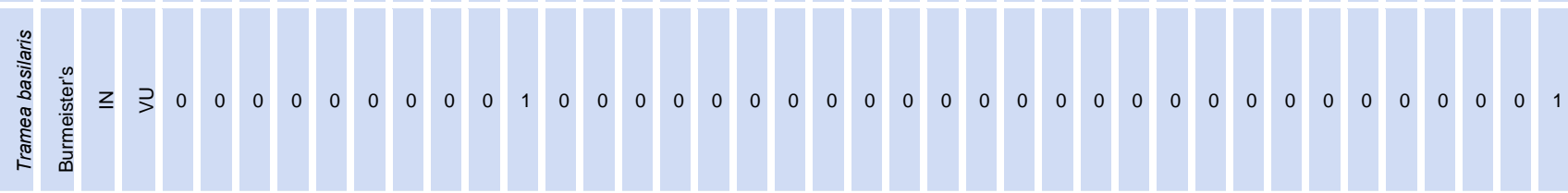

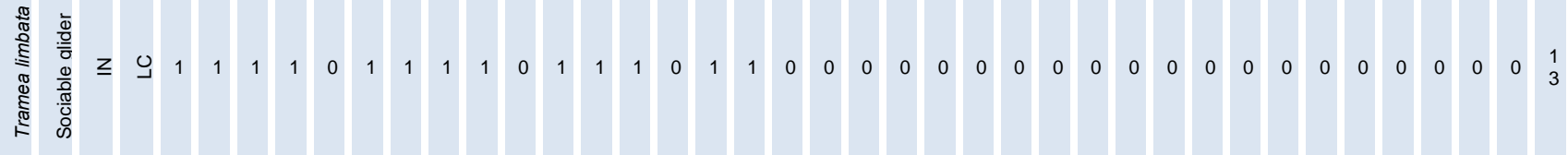
${ }^{*}$ No vernacular names known 


\section{d) Butterflies}

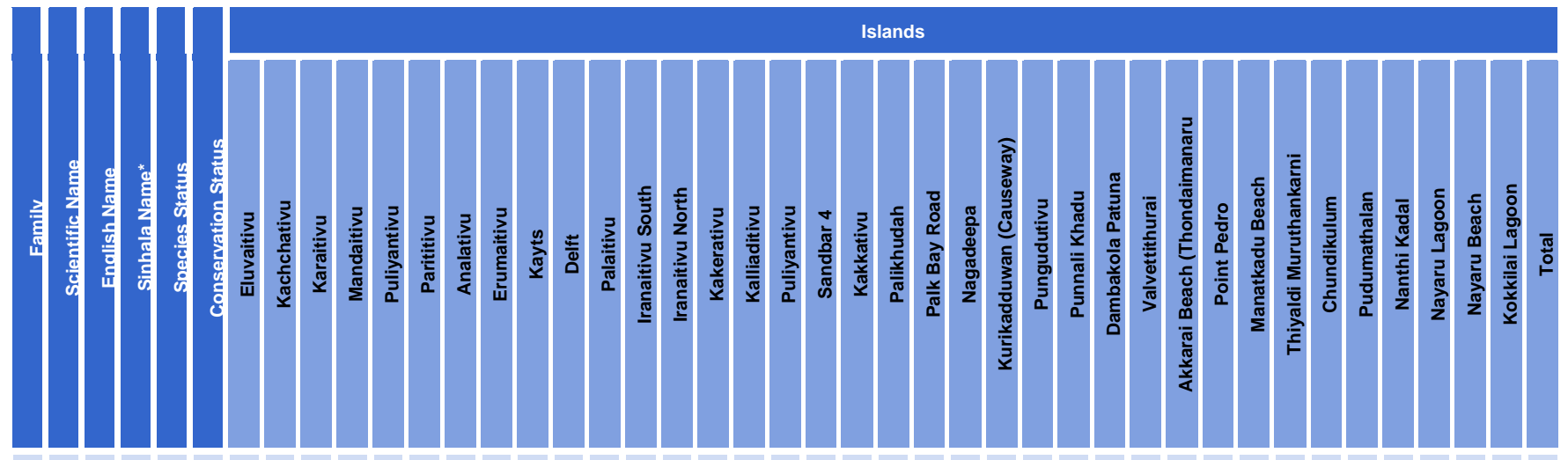

ह

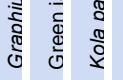

要 ¿

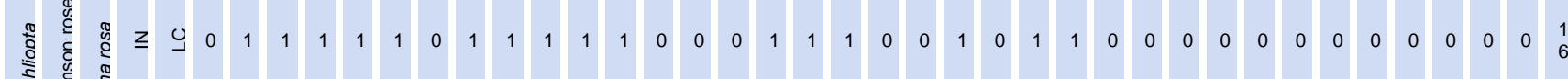
券

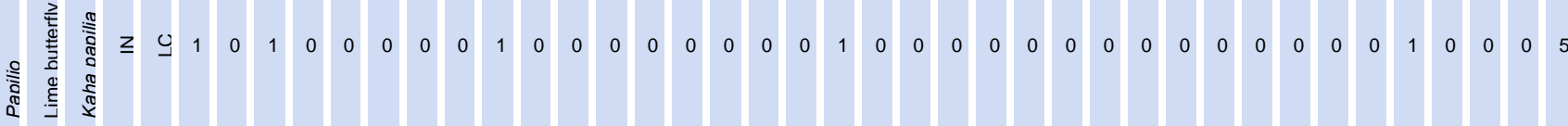

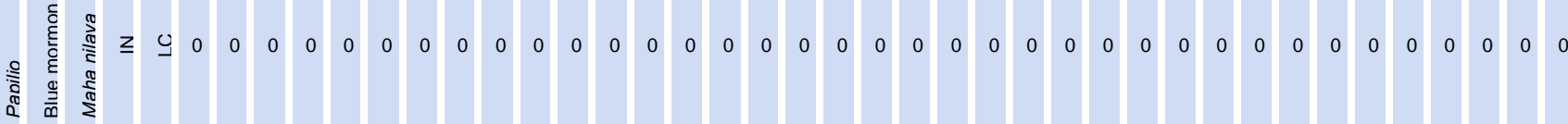

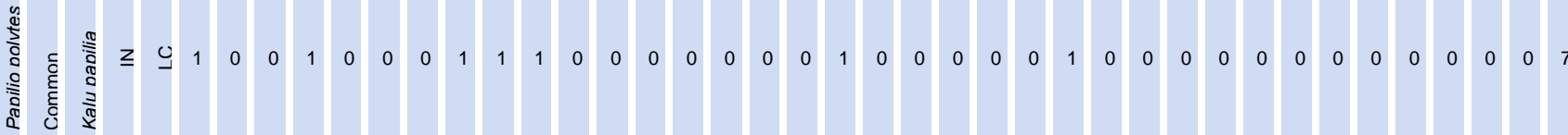

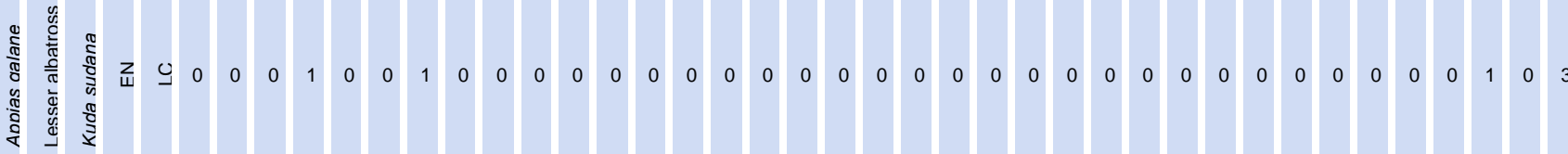

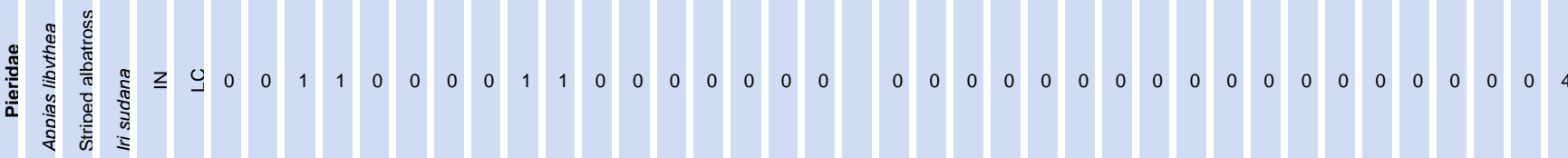

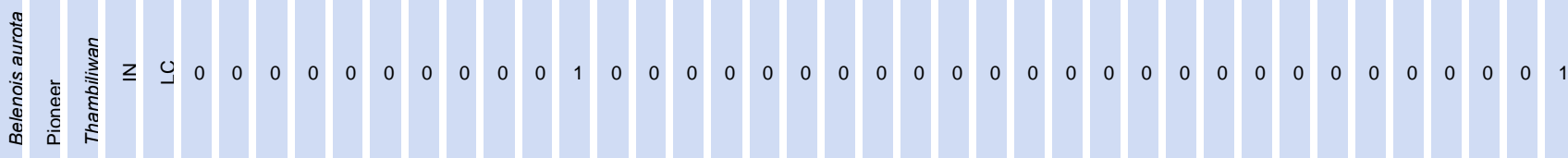




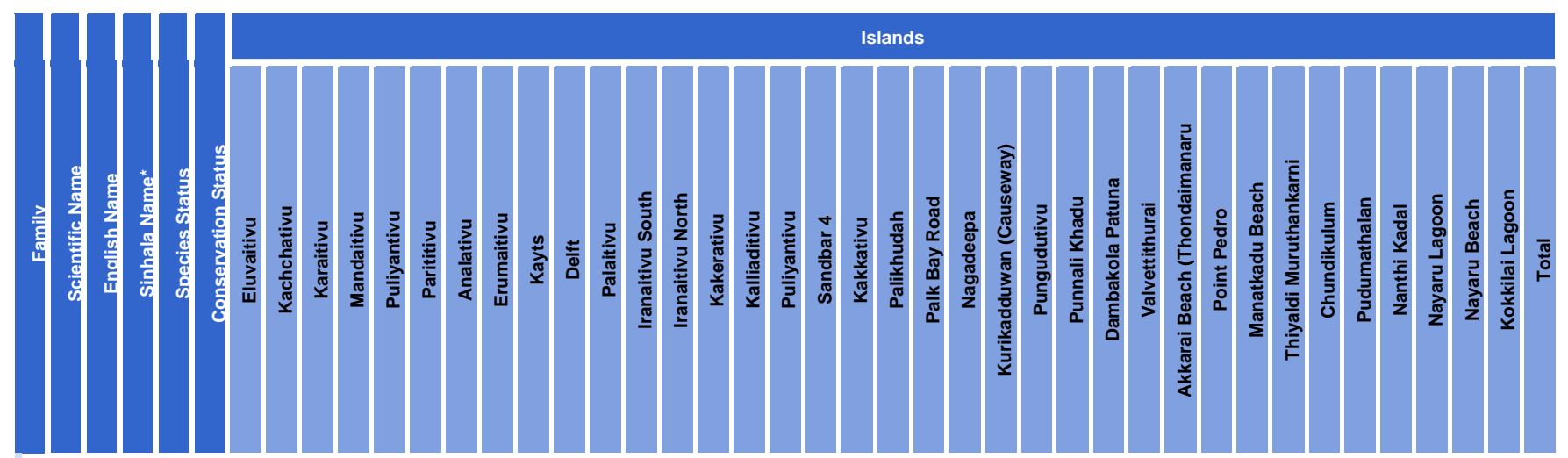

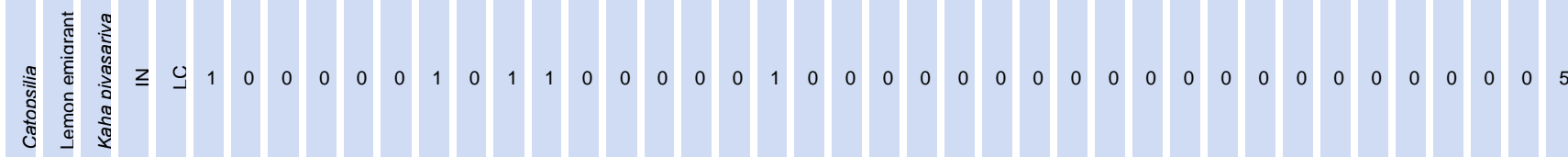

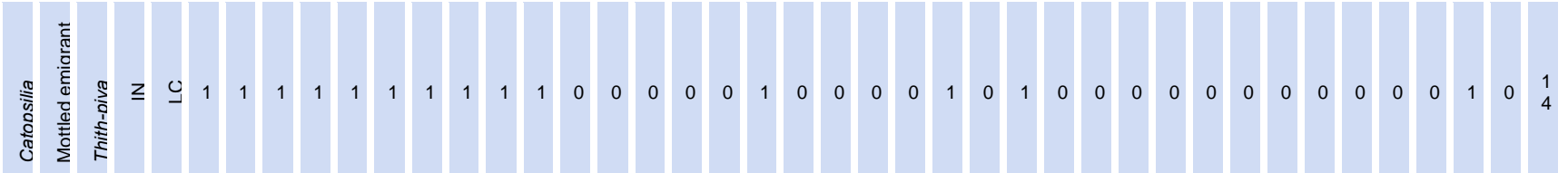

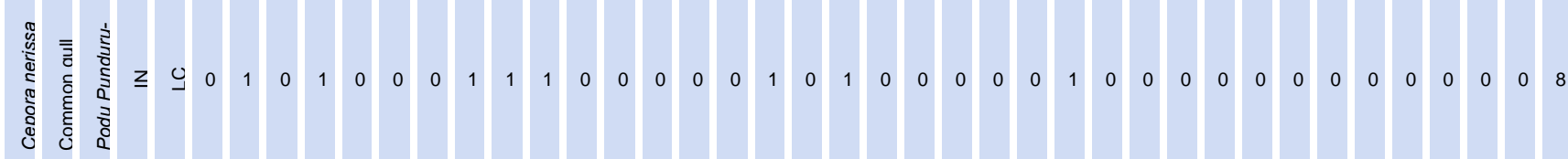

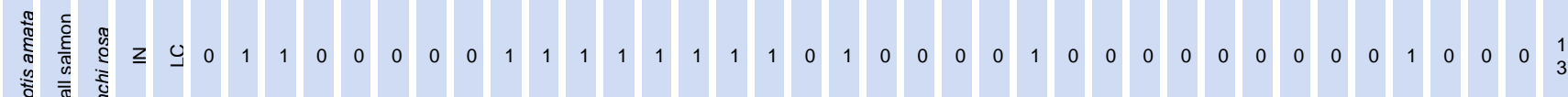

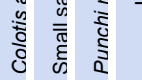

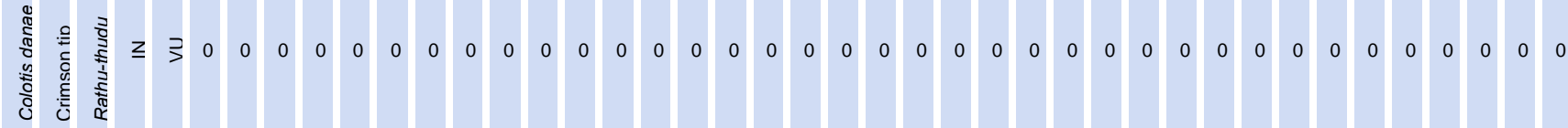

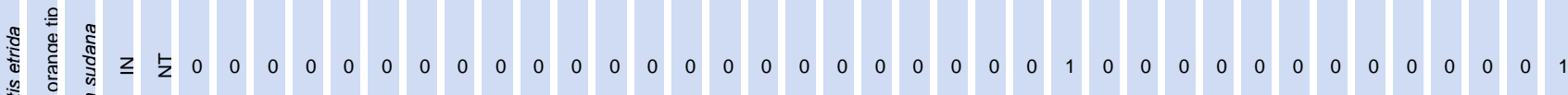

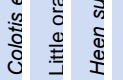

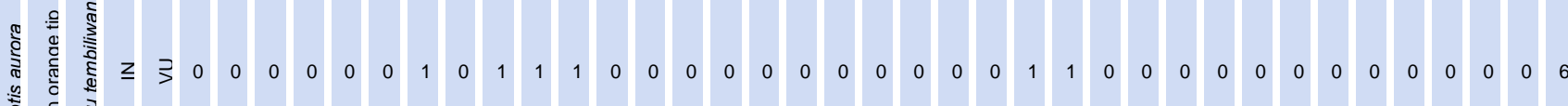

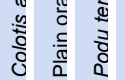

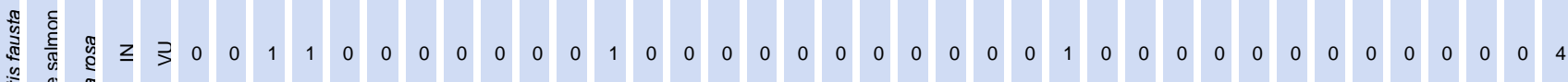
c)

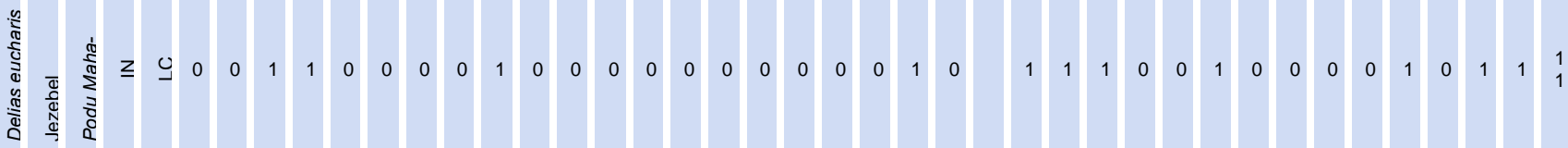




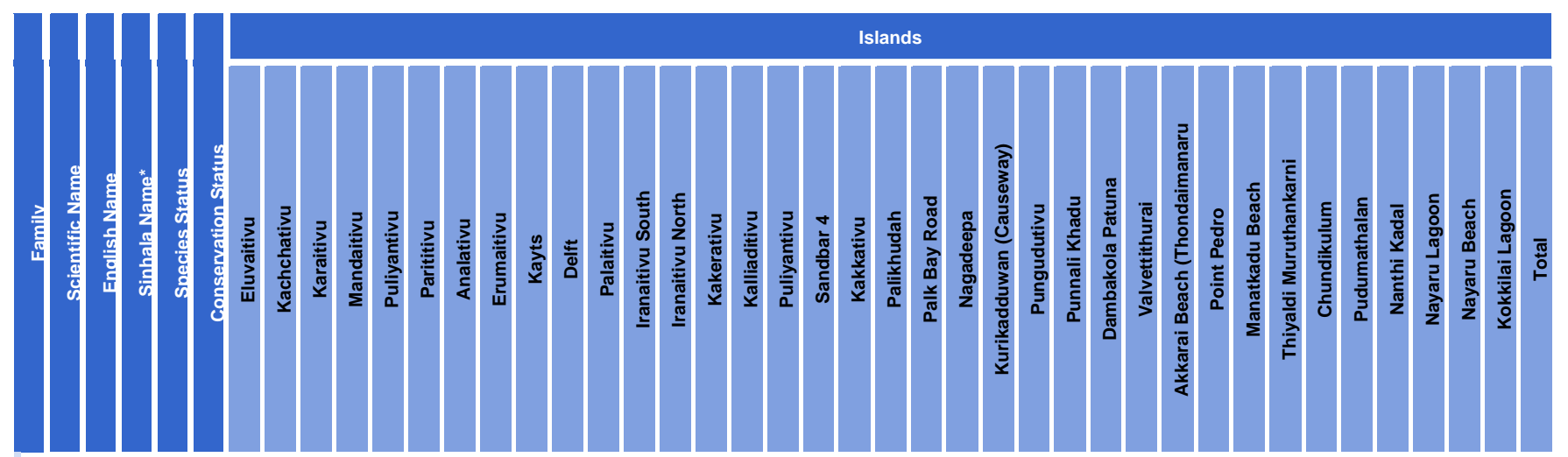

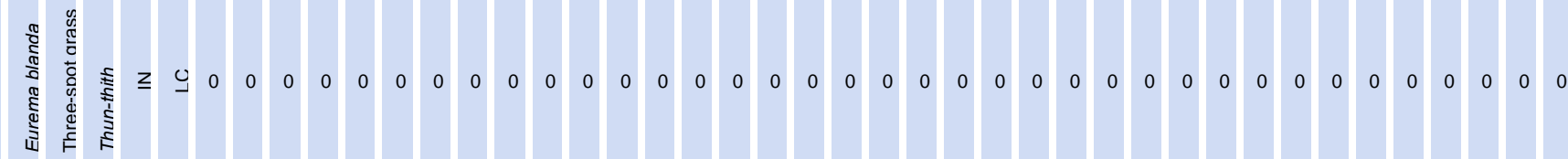

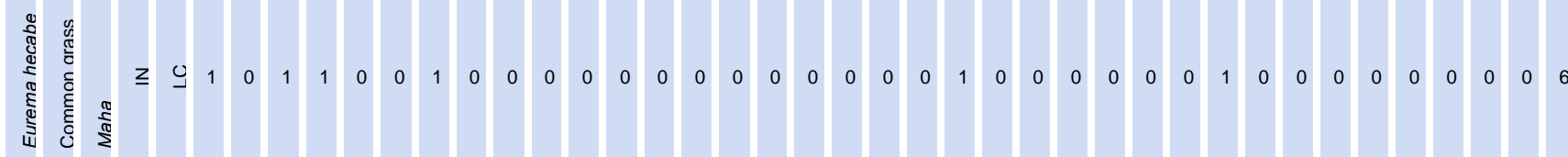

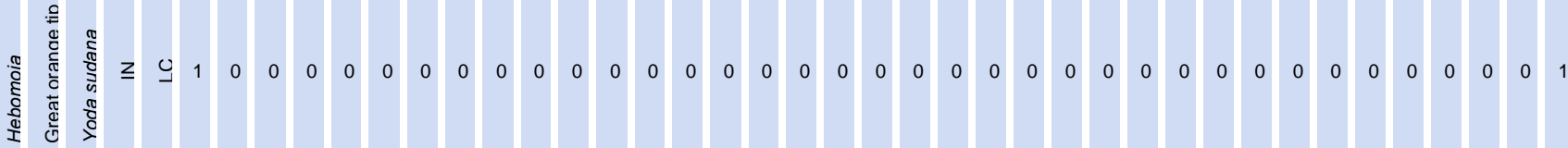

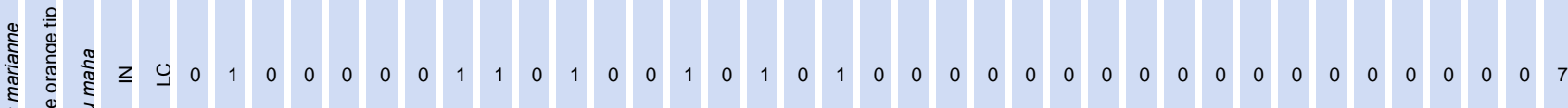
竞

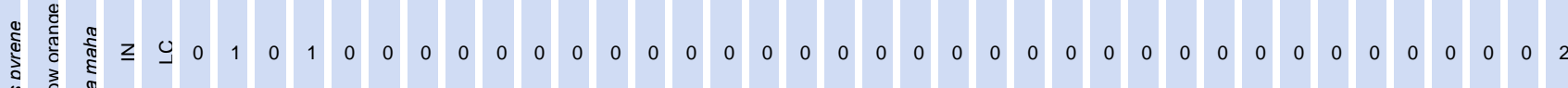
离

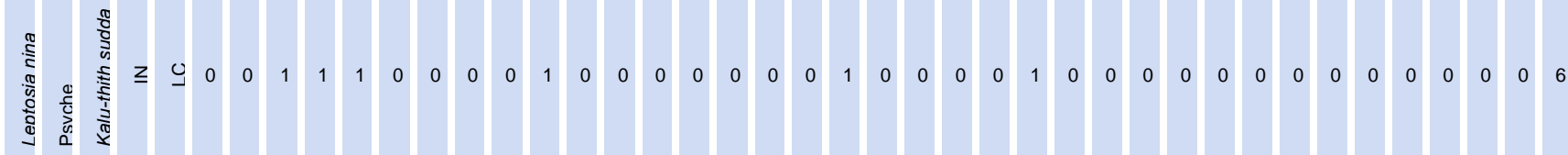

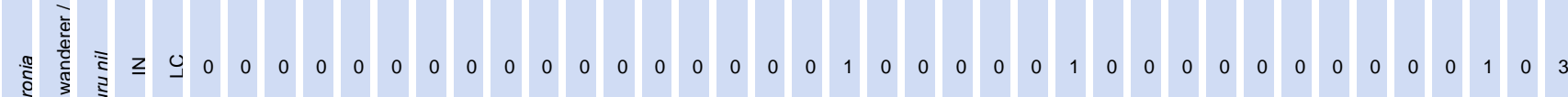
ब苋

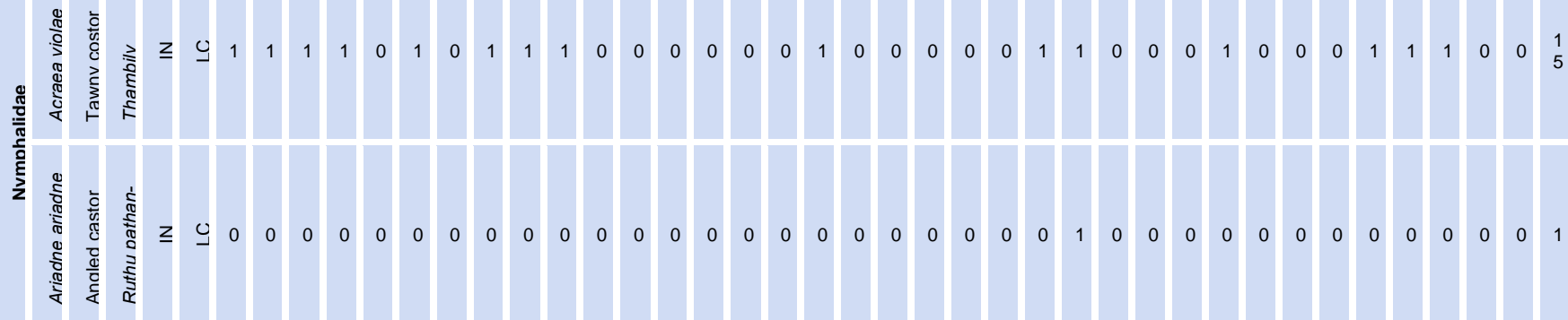




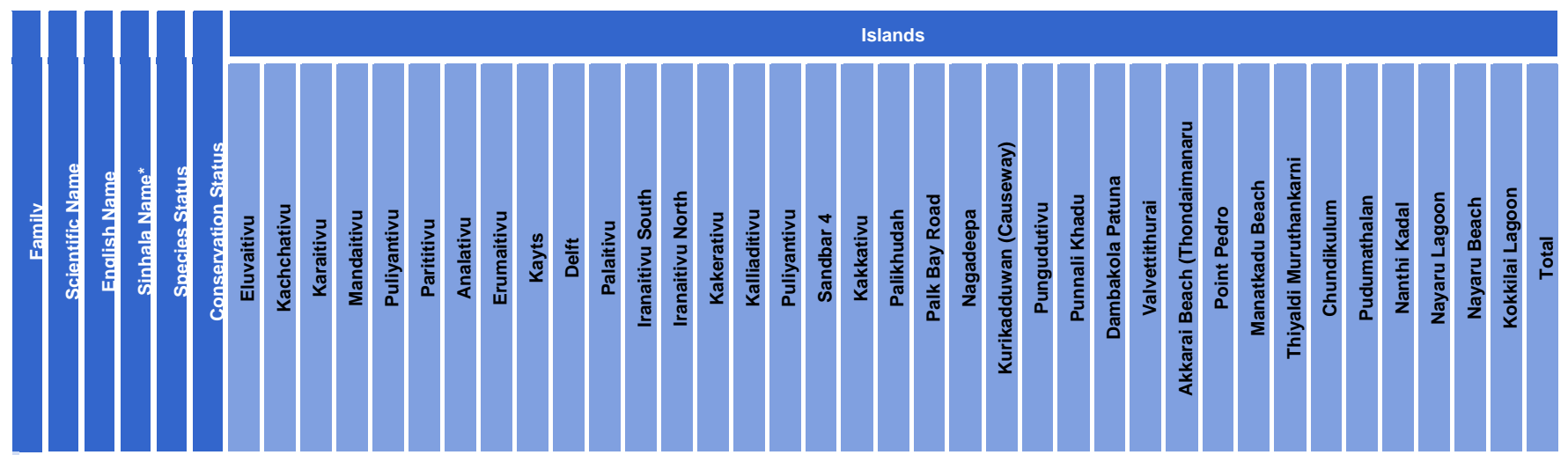

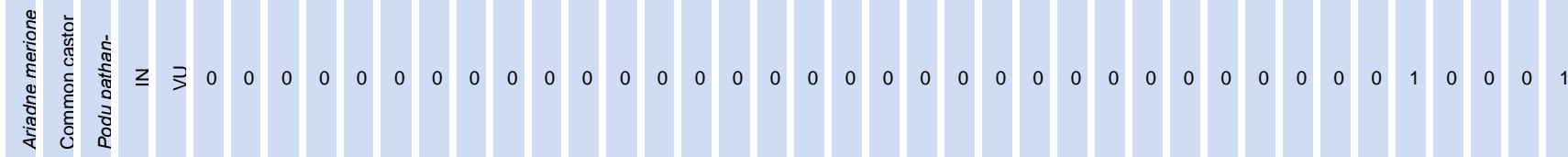

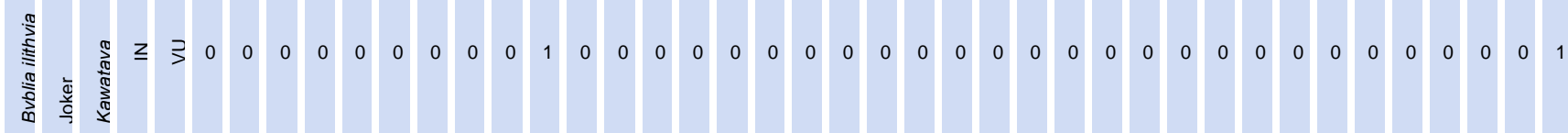

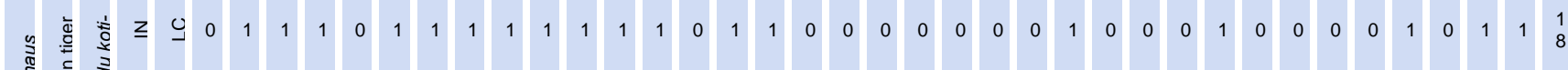

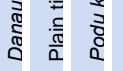

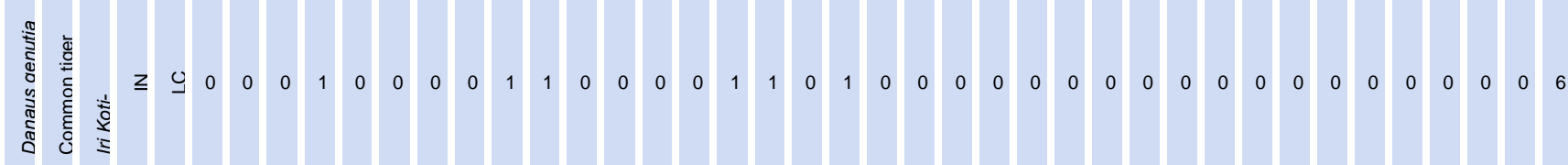<smiles>O=C(O)C(=O)O</smiles>

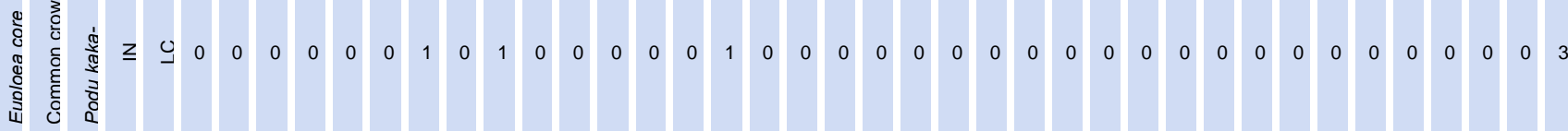

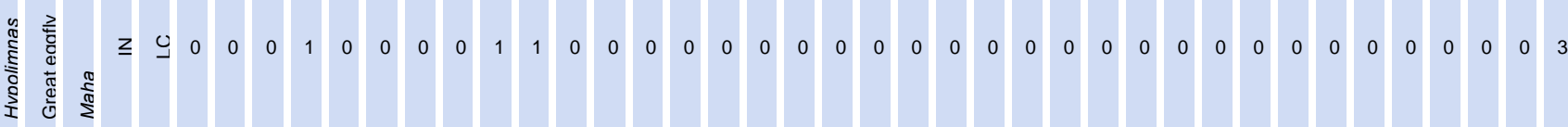

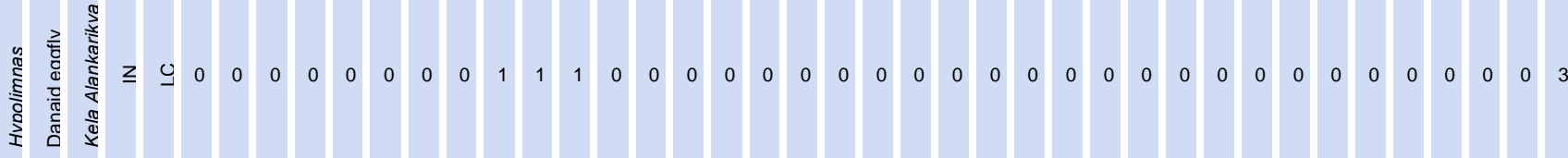

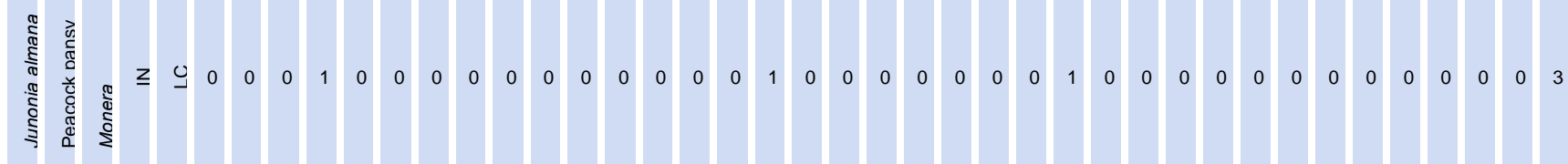




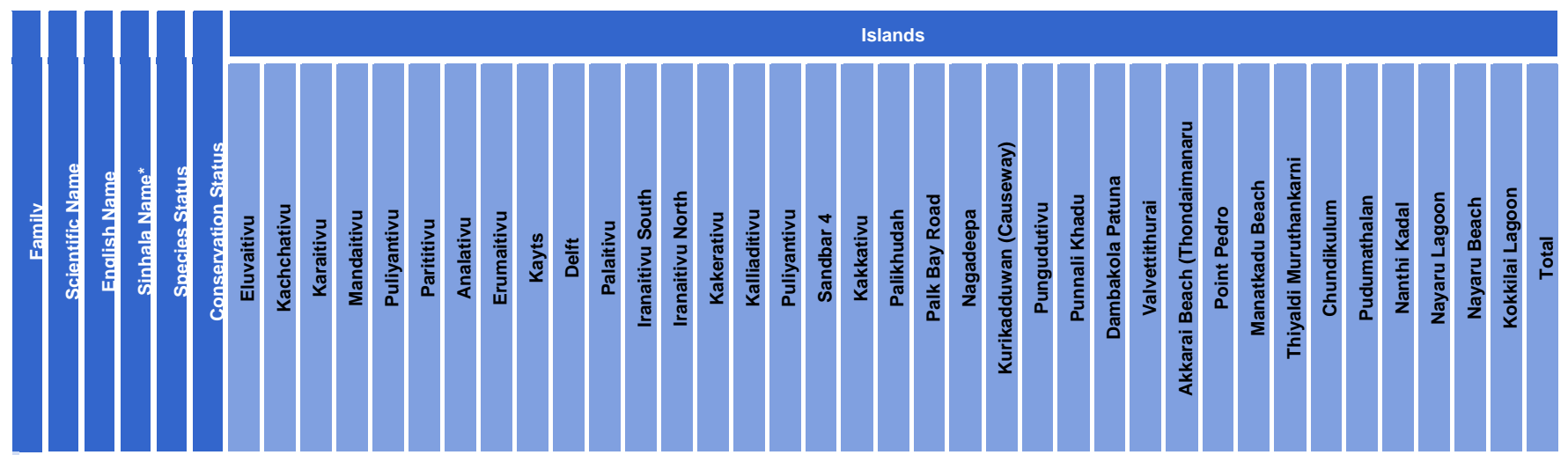

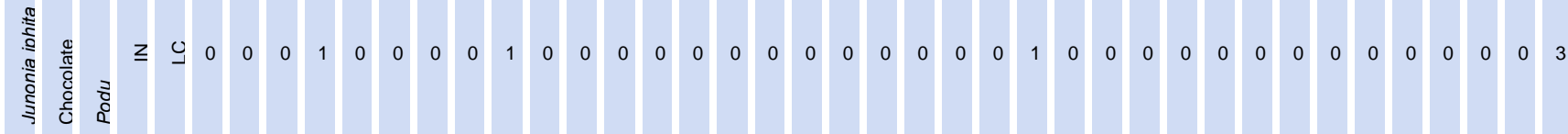

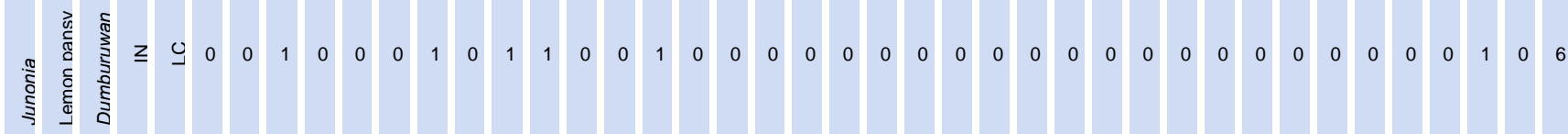

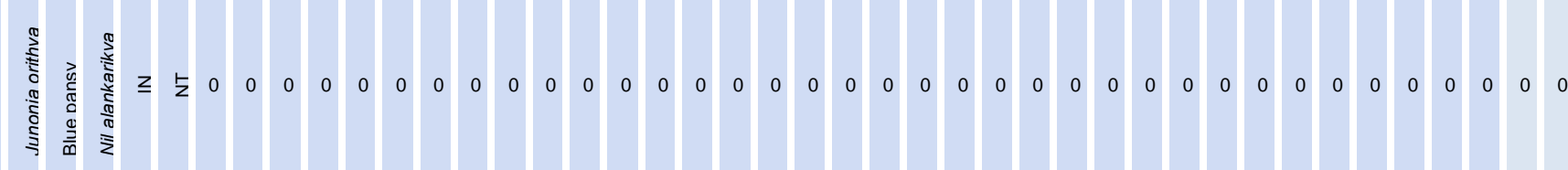

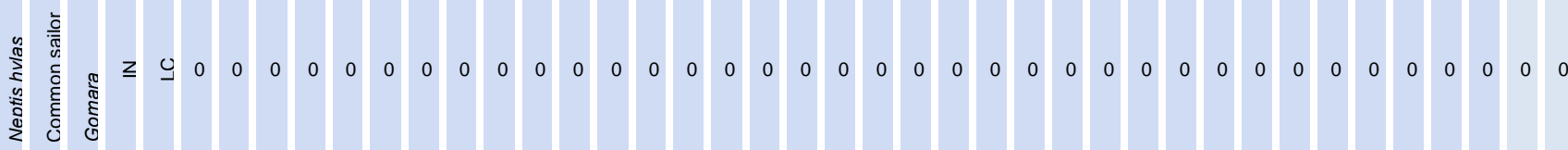

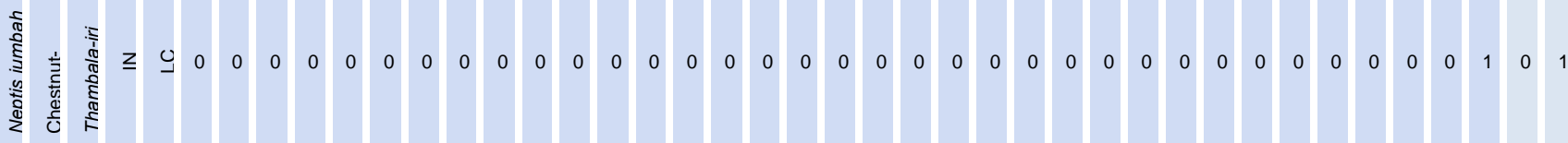

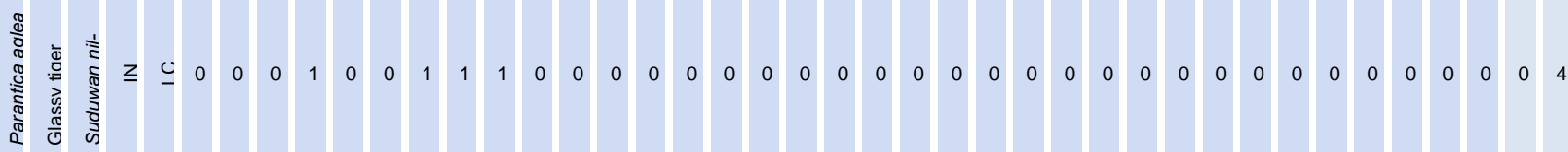

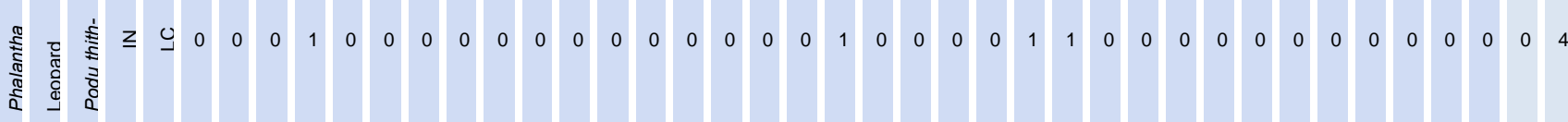

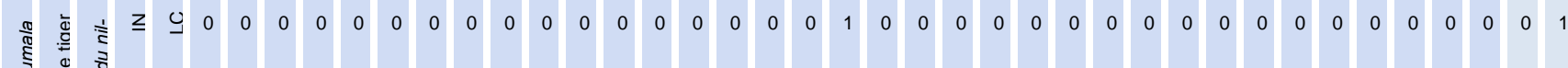

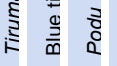

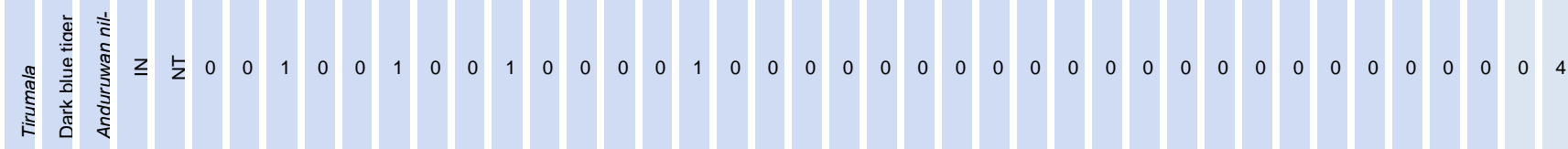




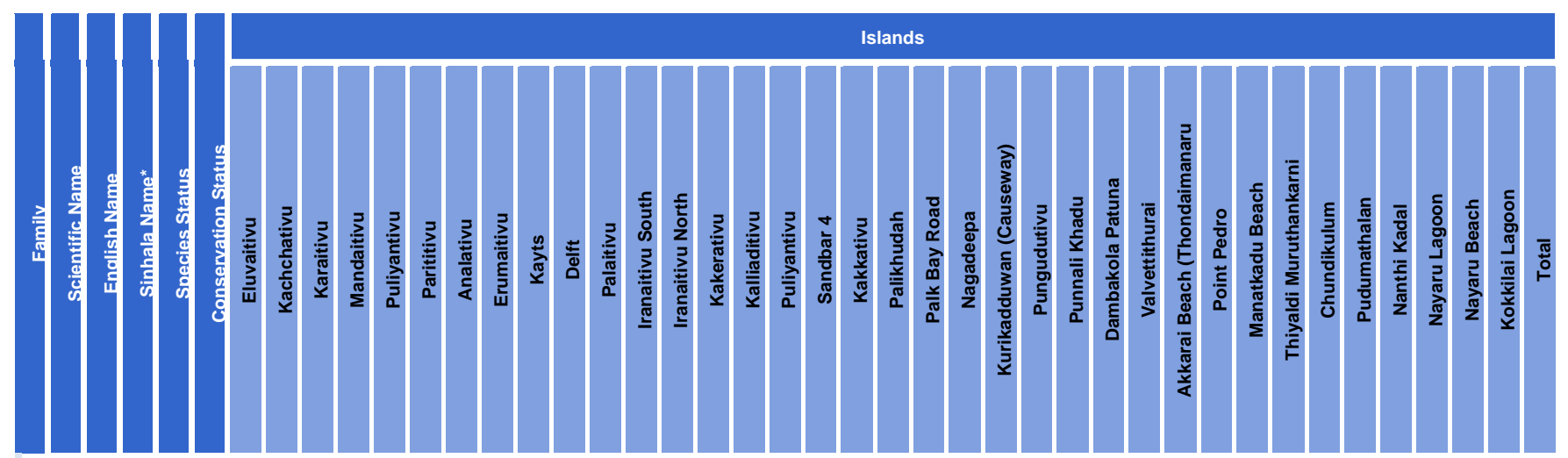

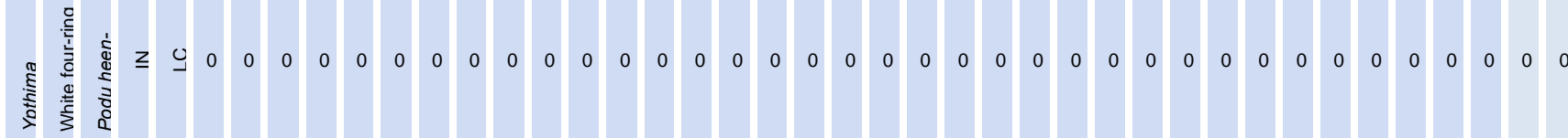

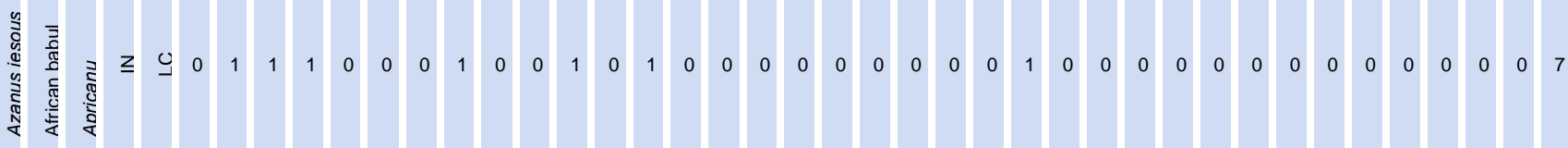

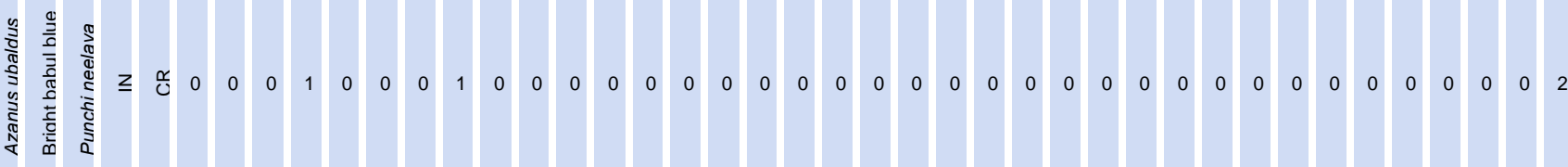

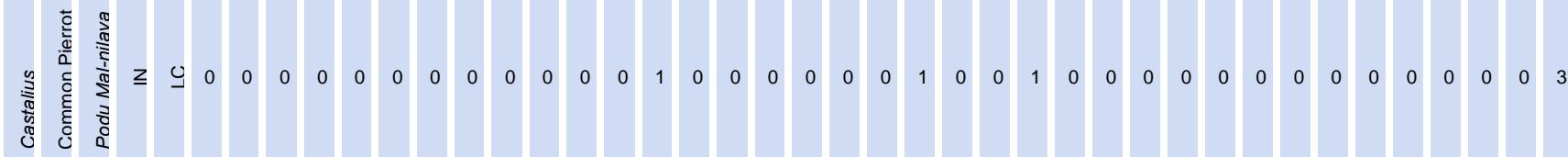
竞 đั.

乌ั

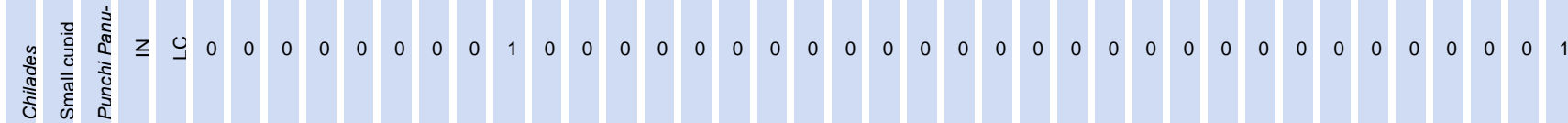
蓄 岗

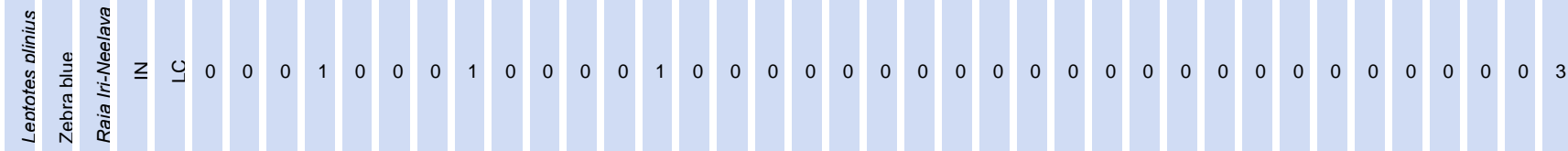

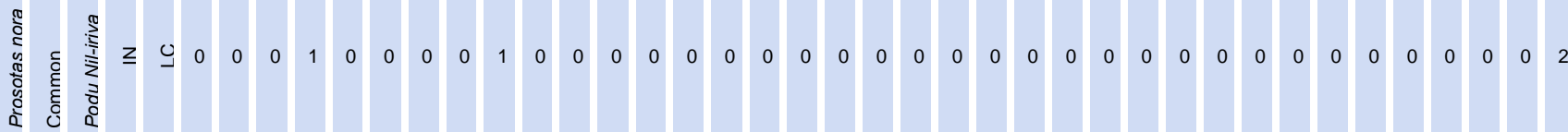




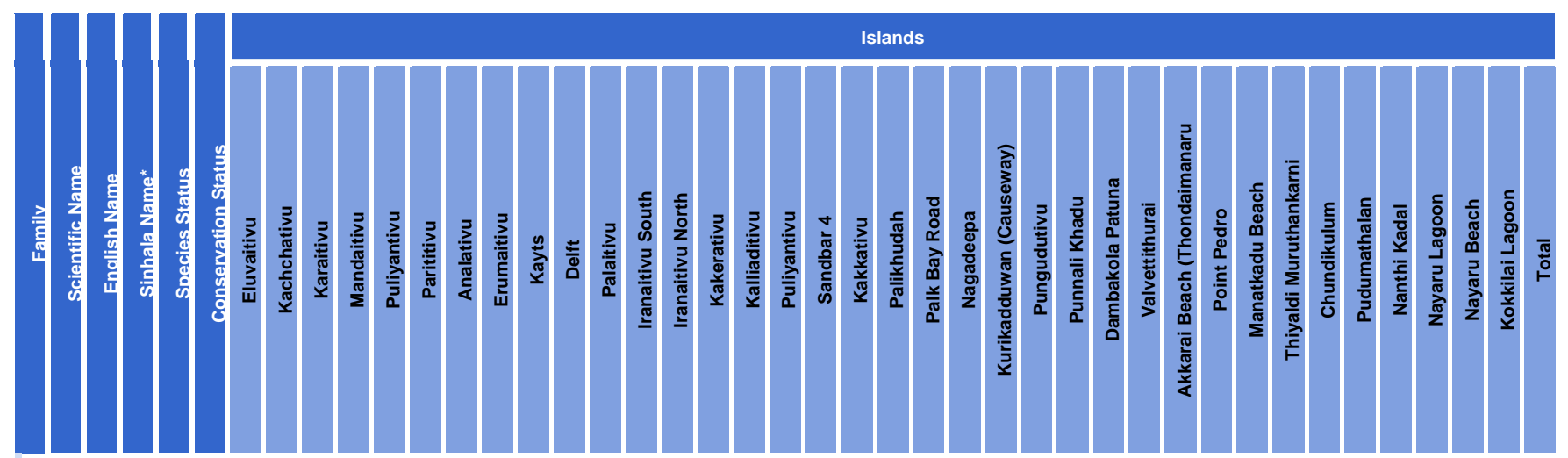

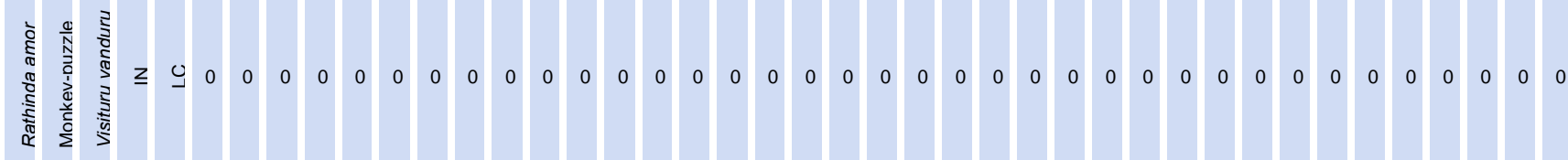

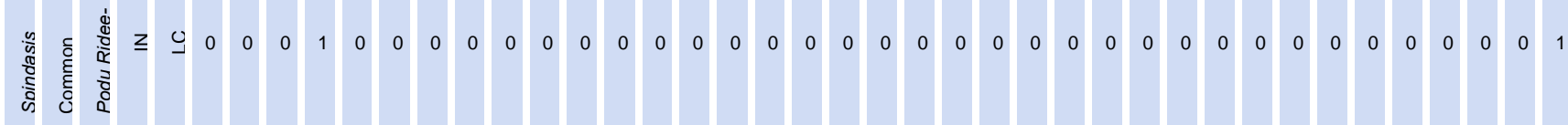

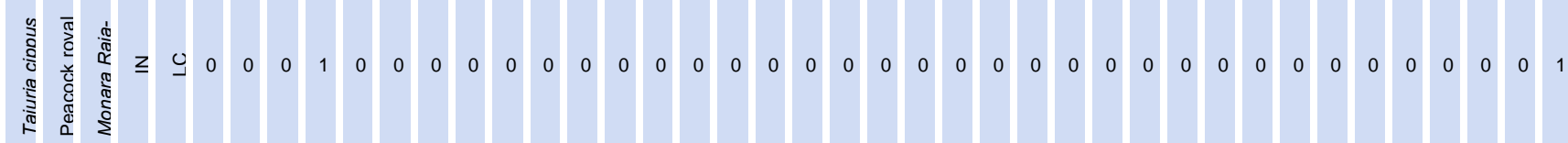

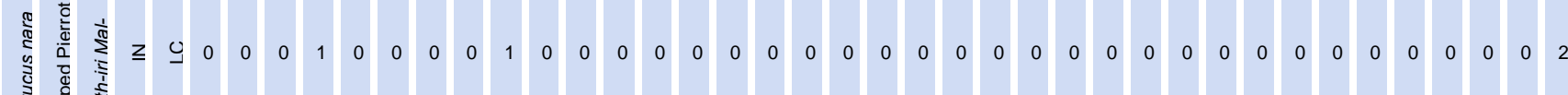

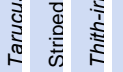

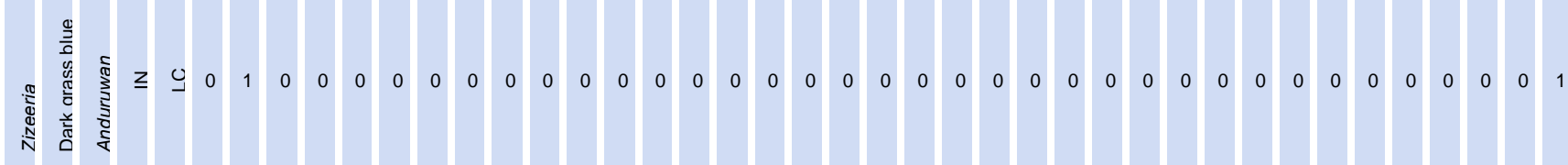

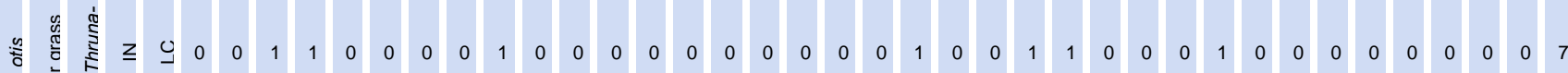

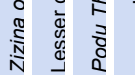

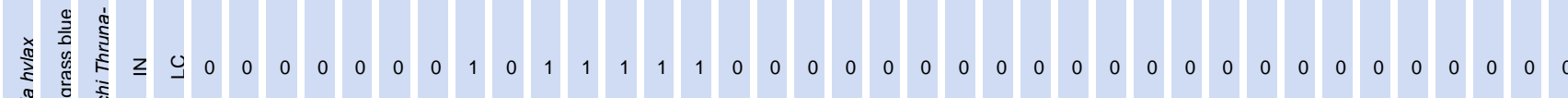
Iㄴ.

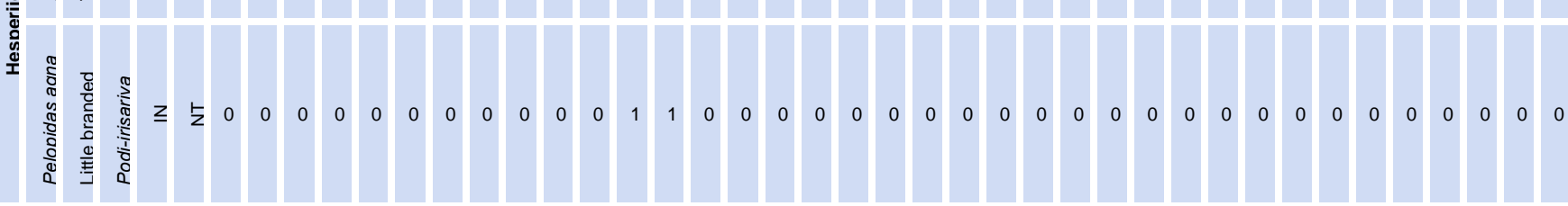




\section{e) Amphibians}

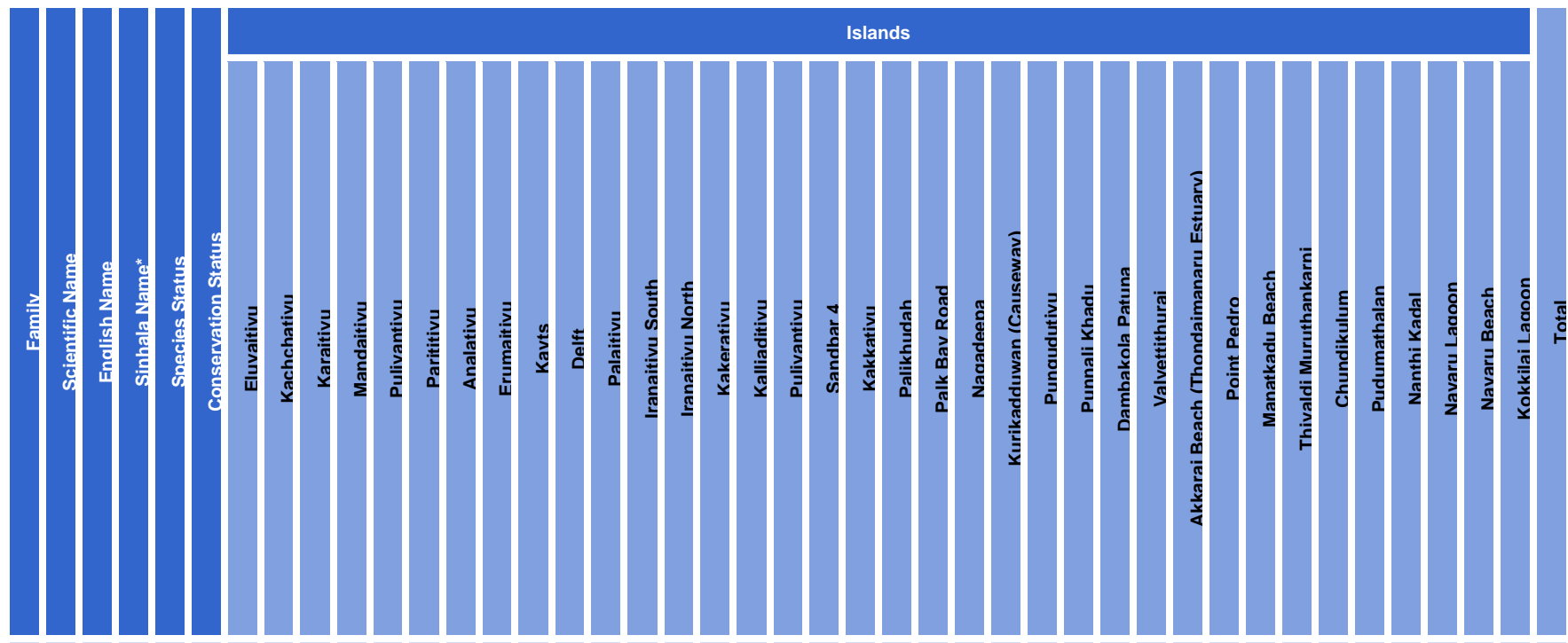

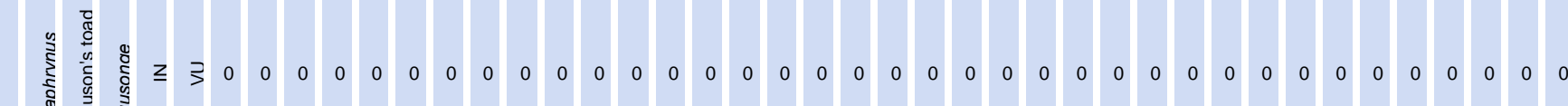
สำ

๓ั

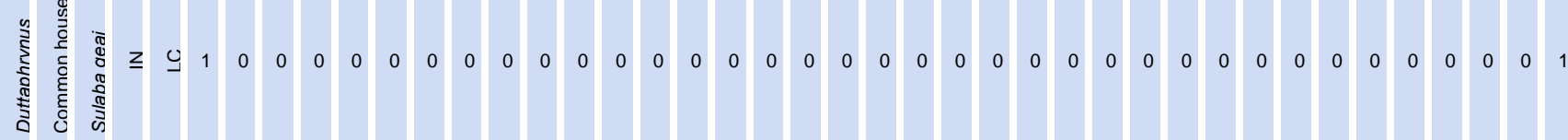

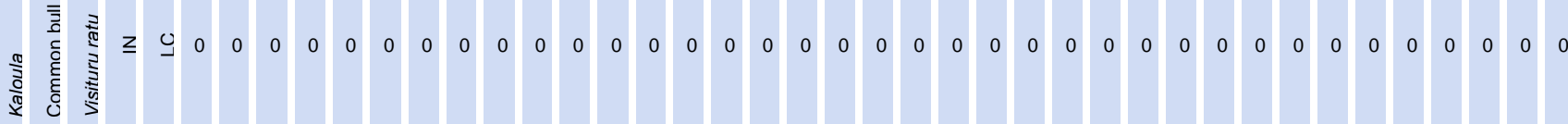

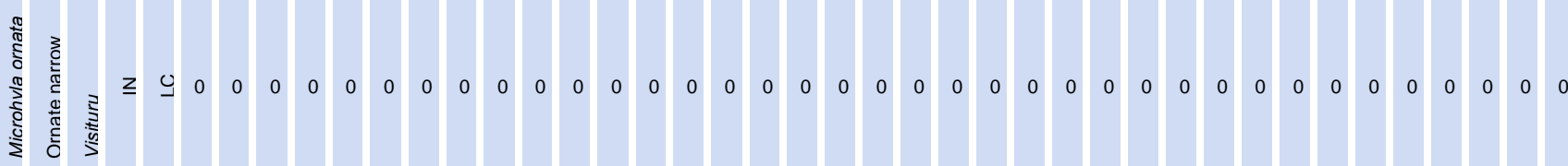

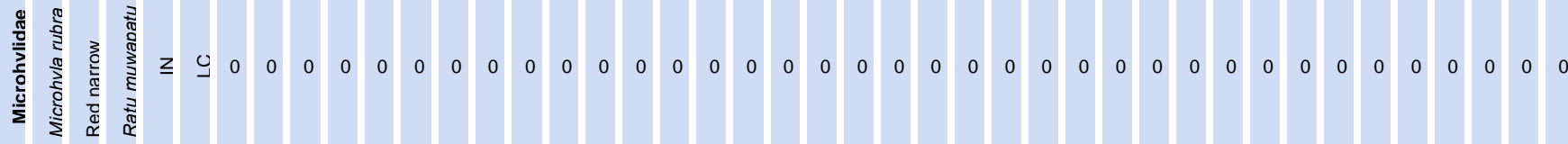

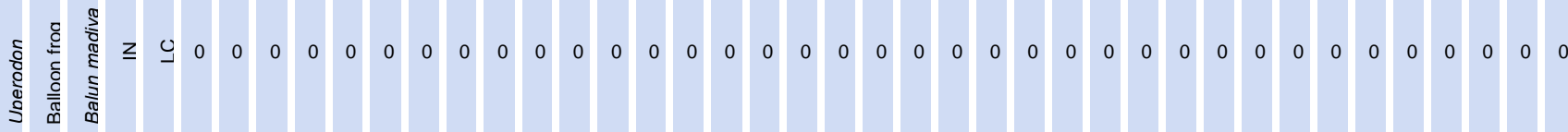

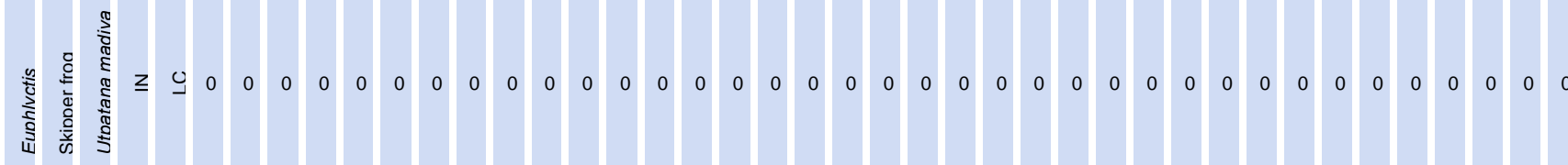

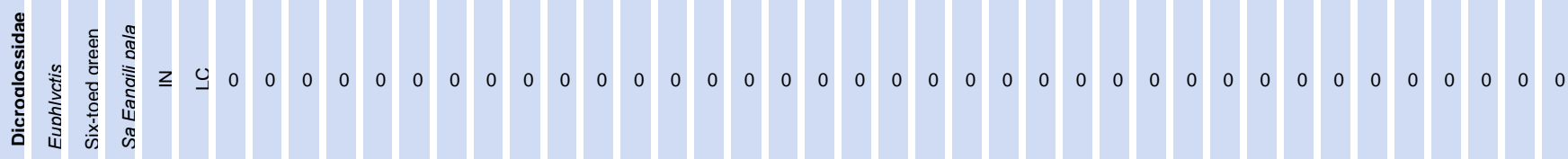



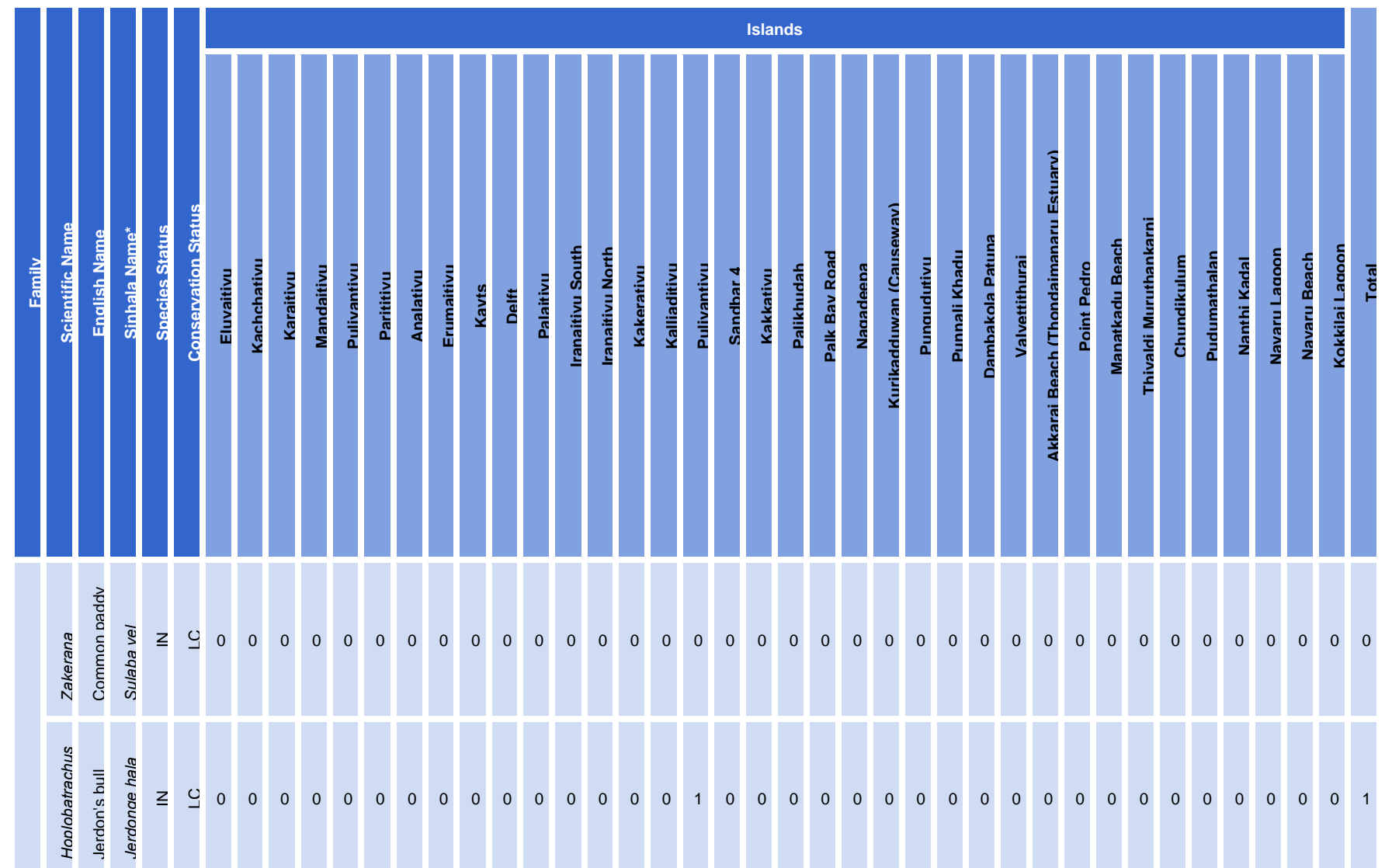

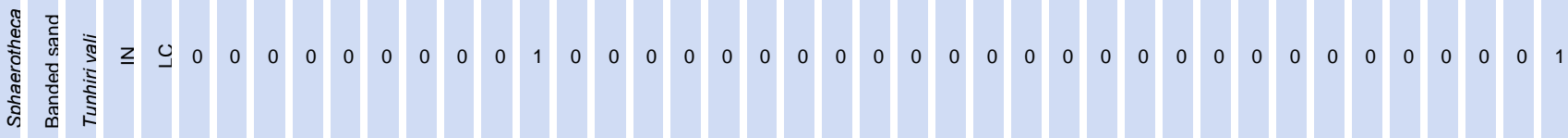

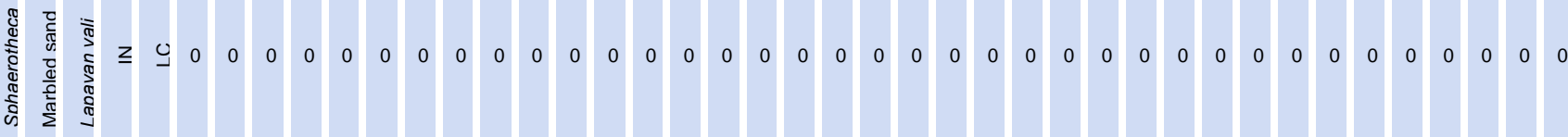

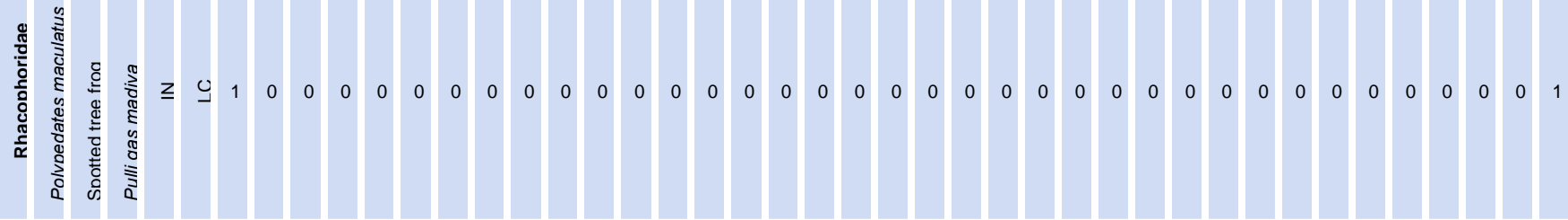

*No specific Tamil names known. 


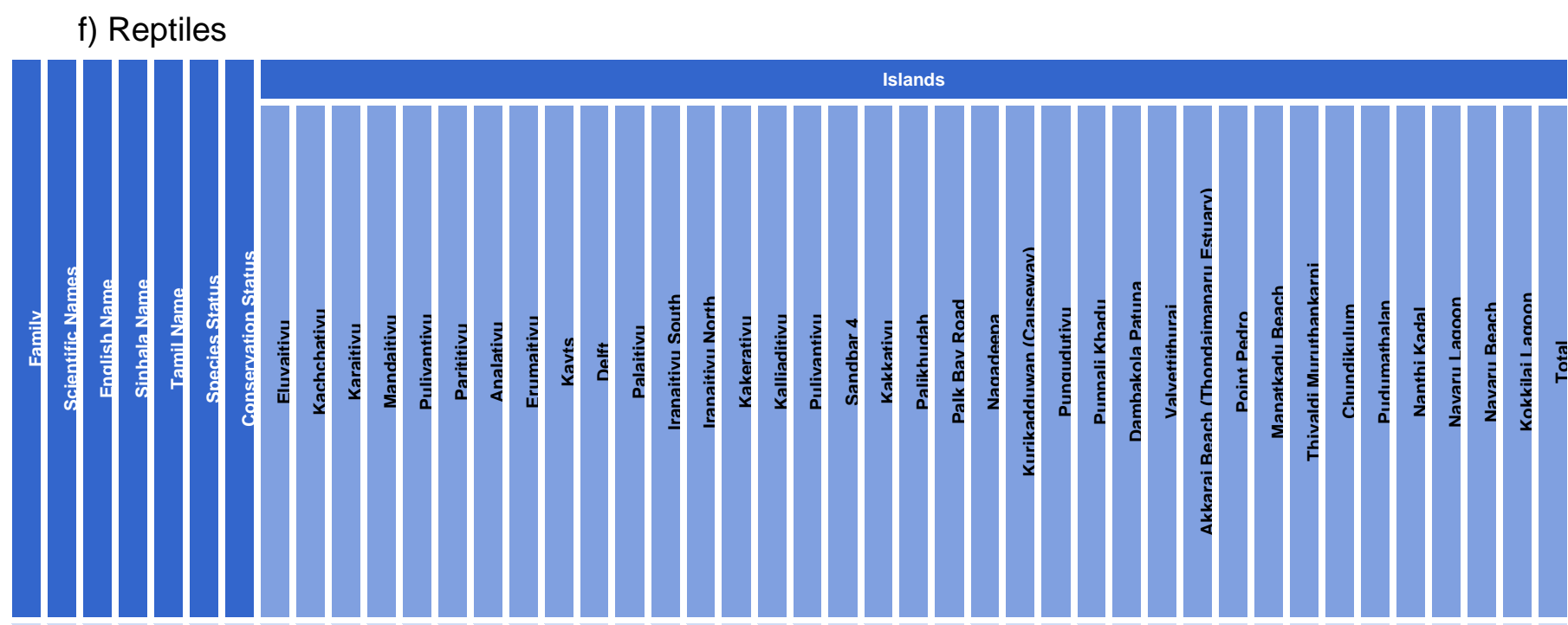

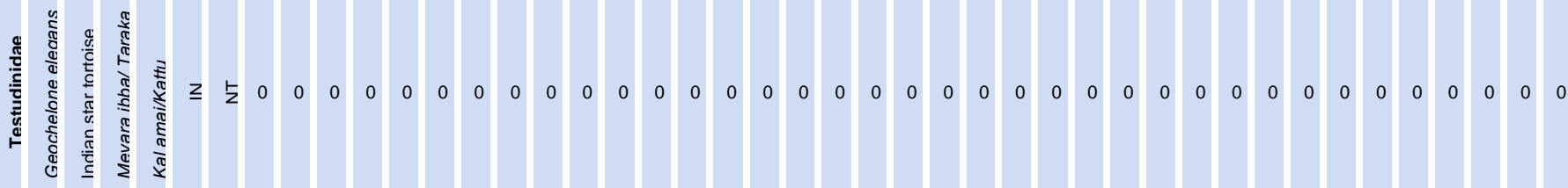

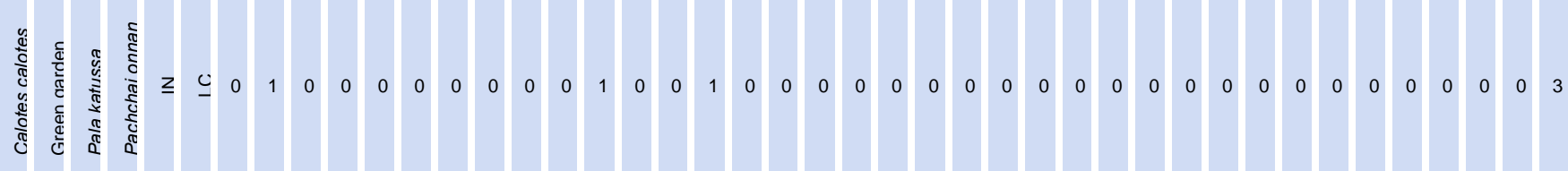

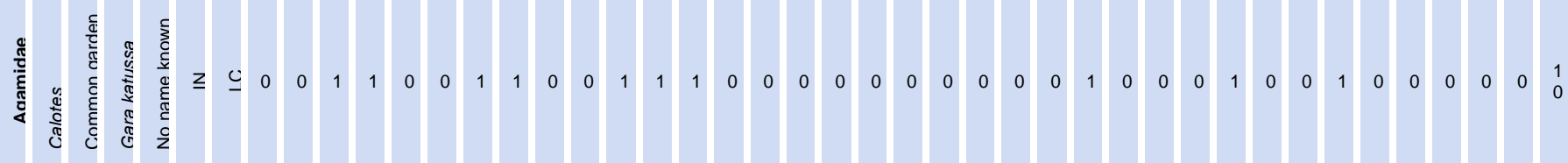

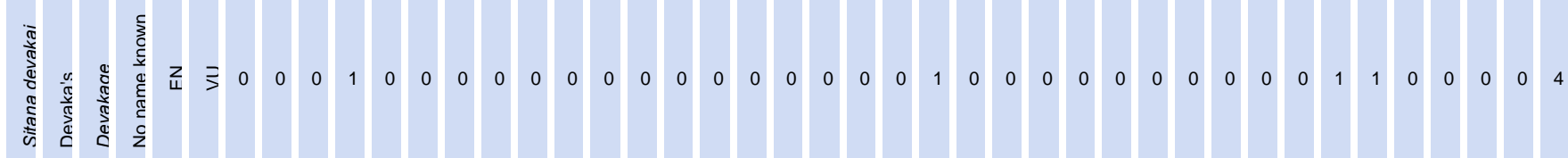

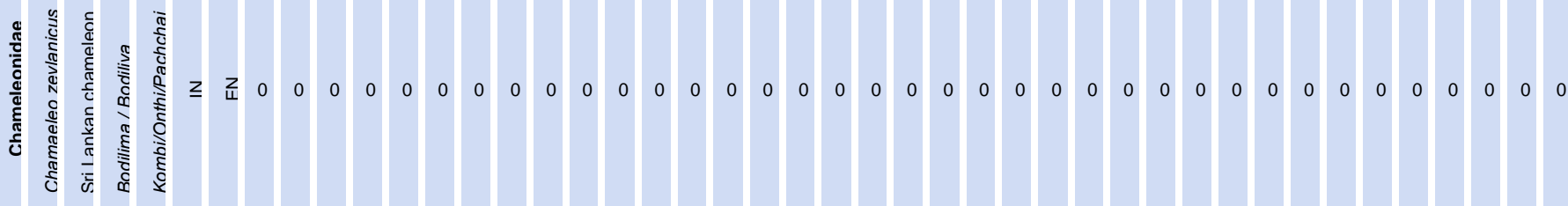

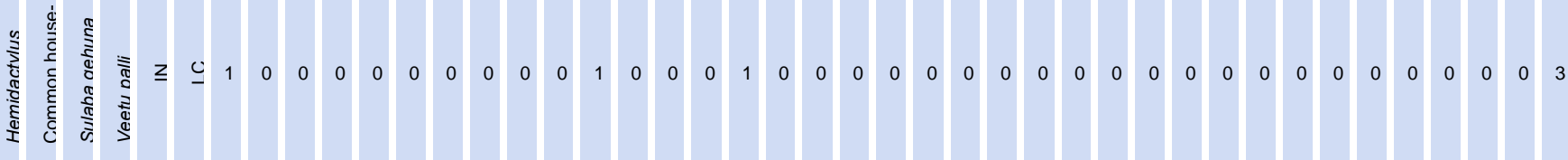

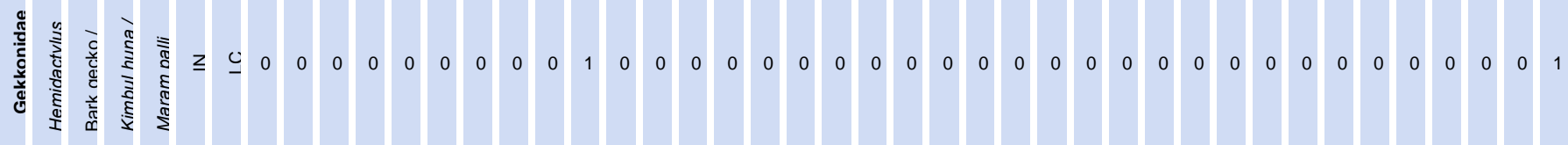

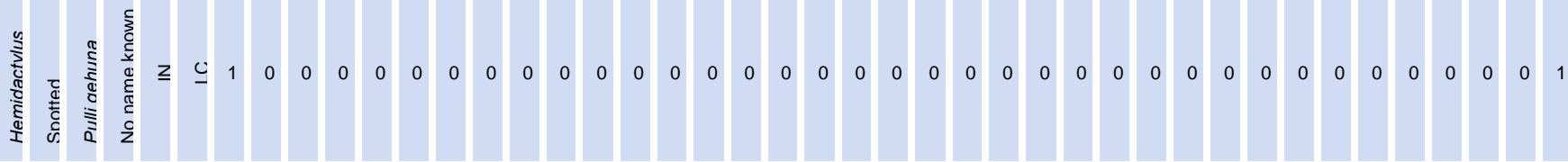




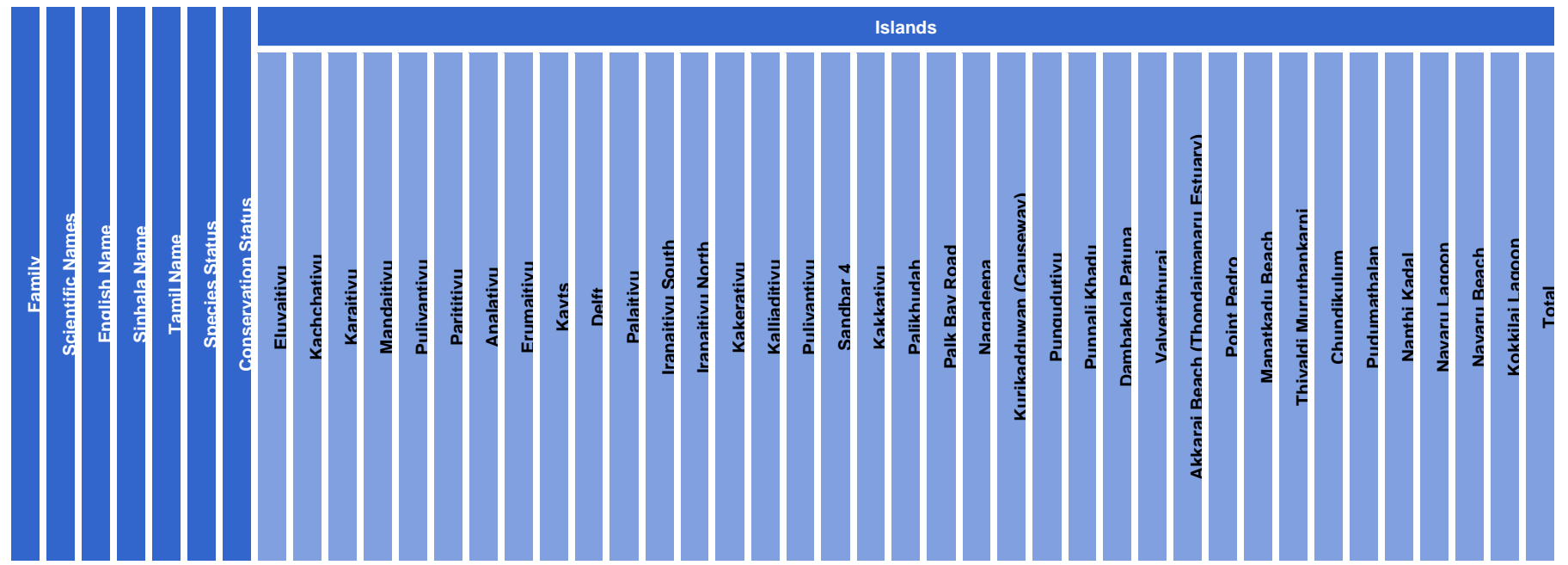

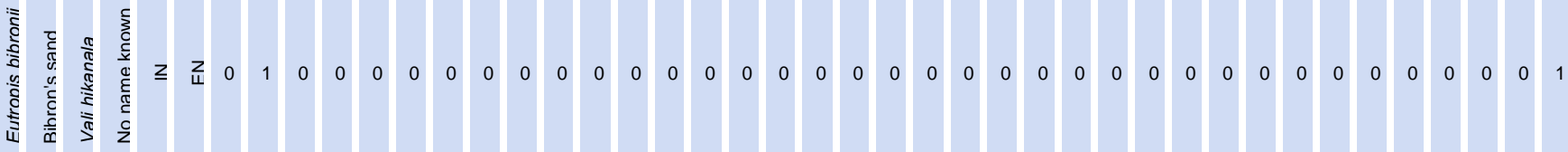

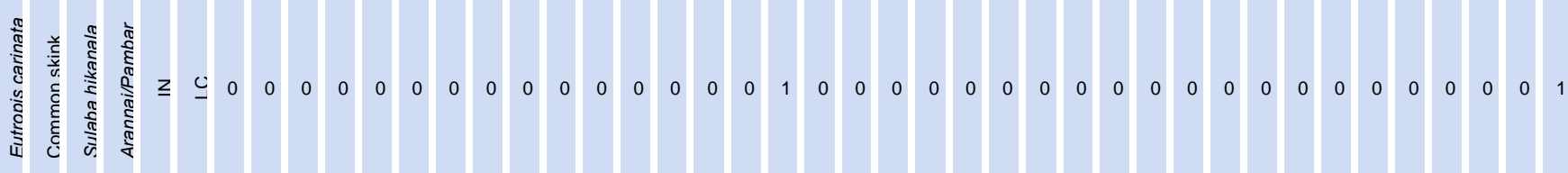

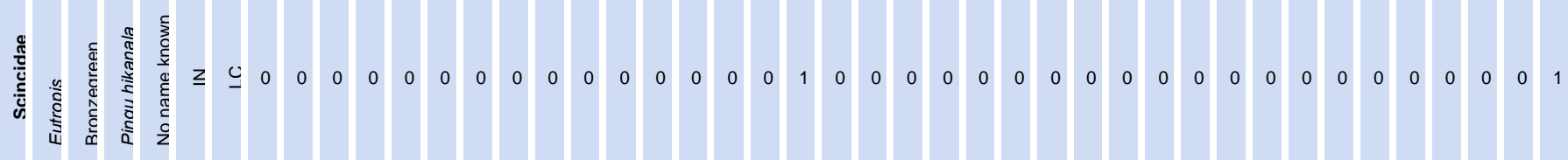

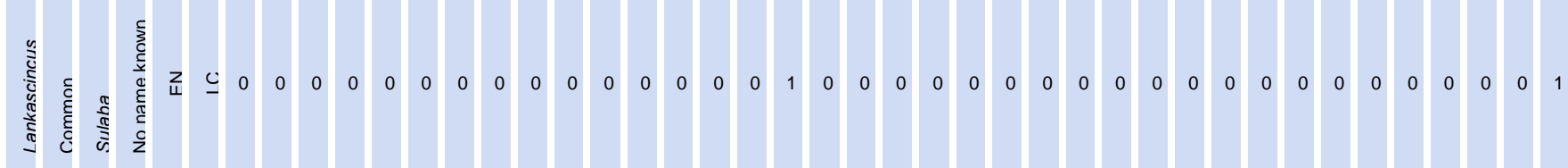

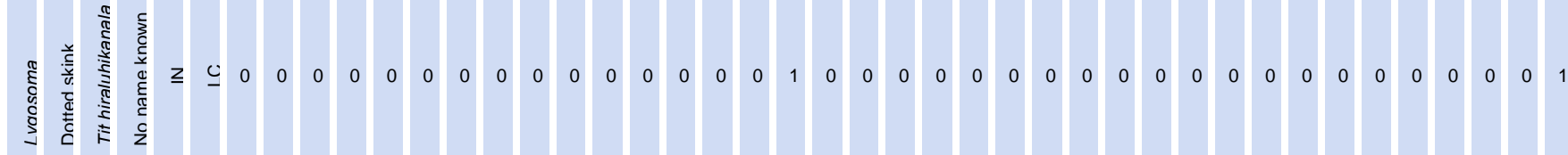

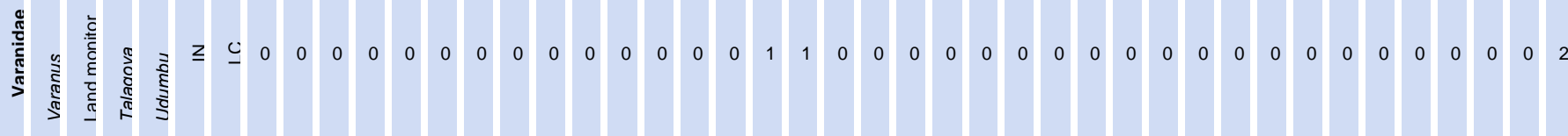

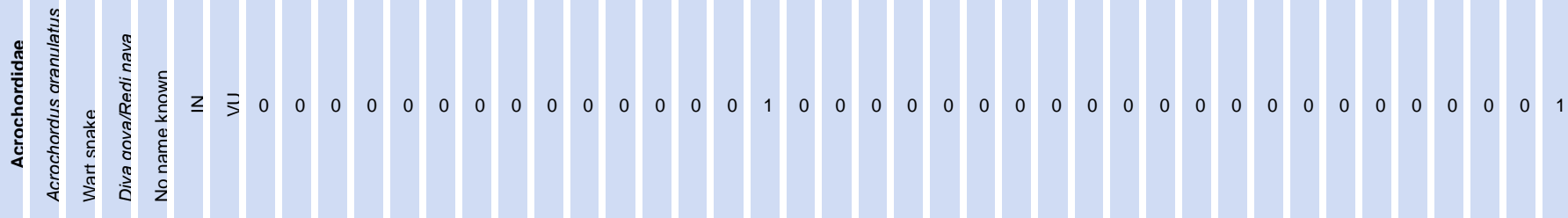

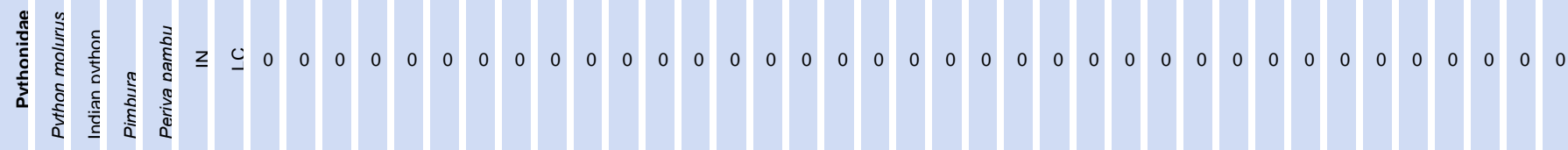




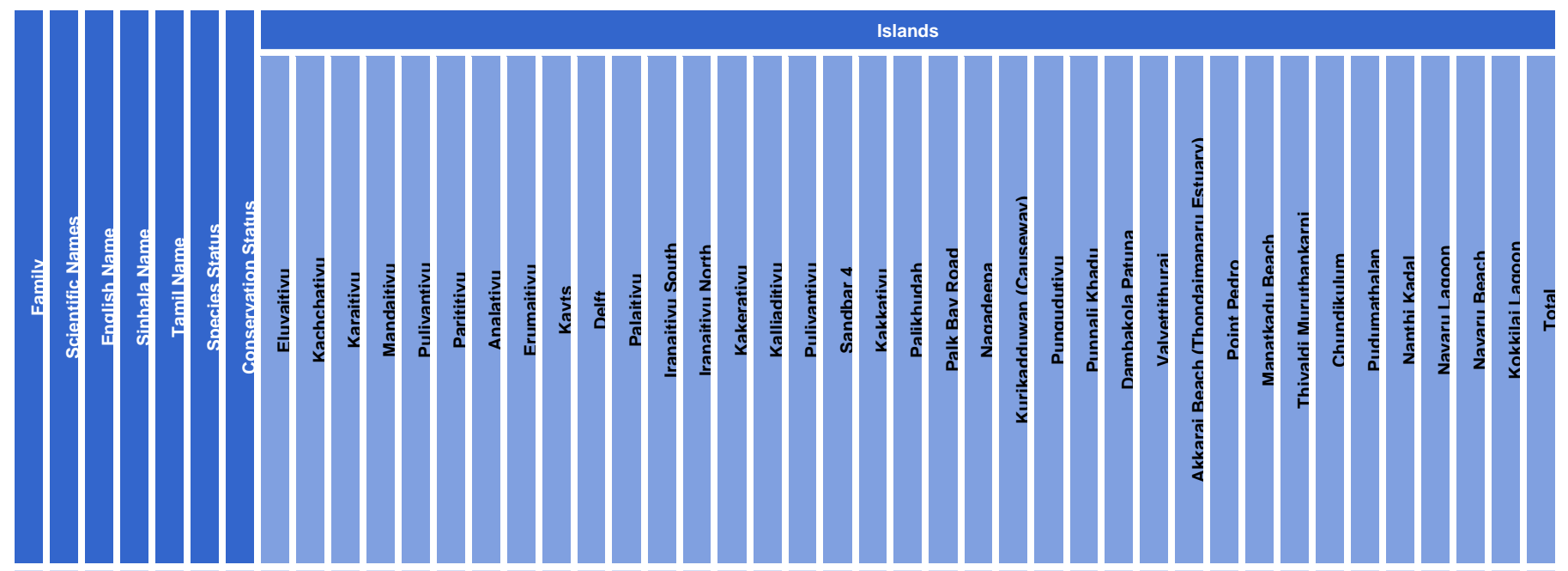

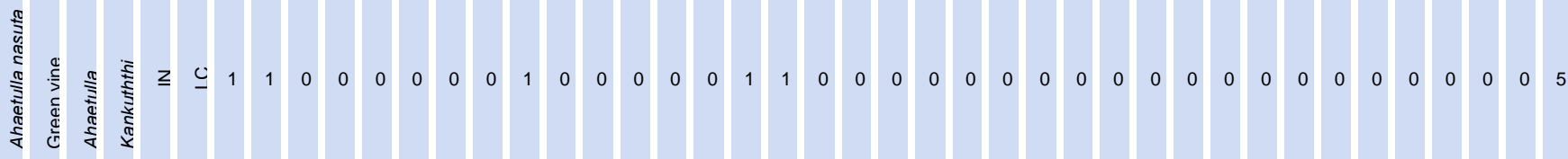

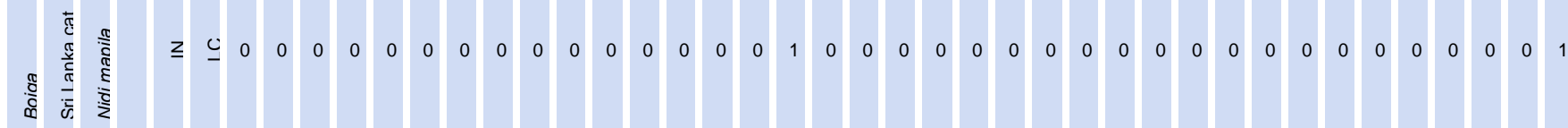

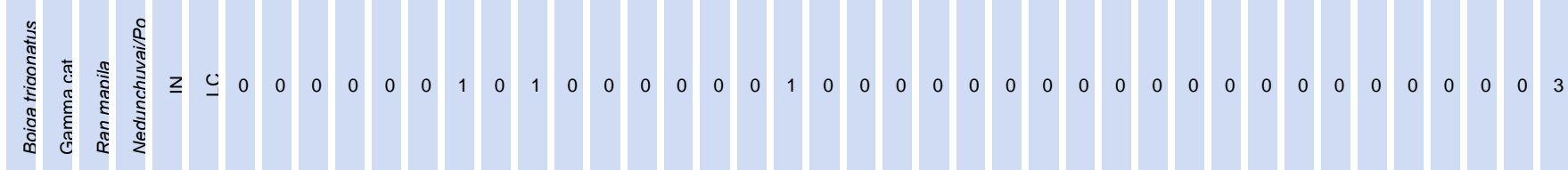

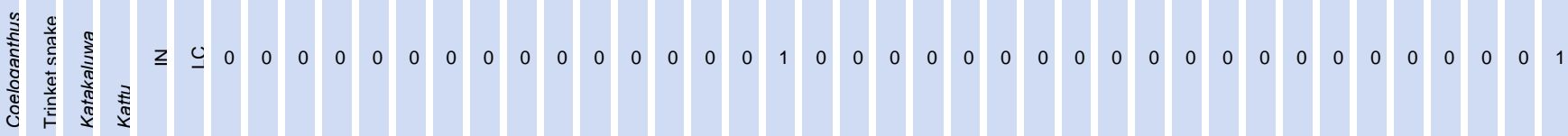

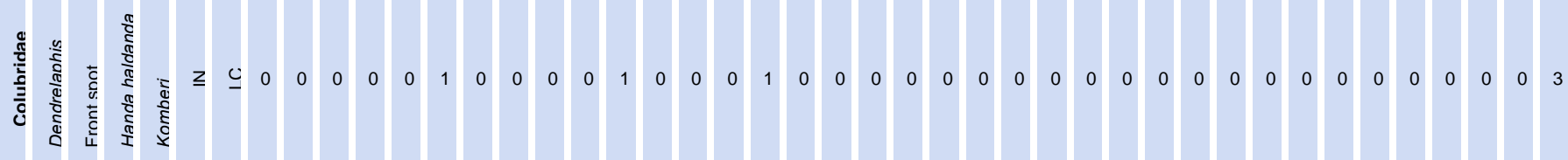

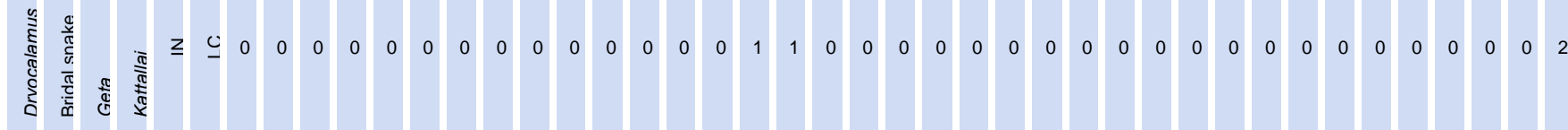

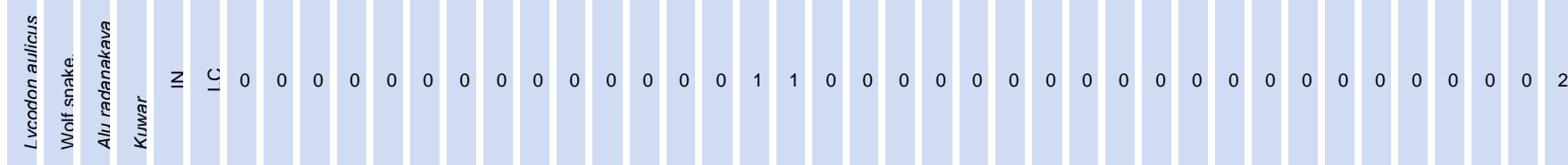

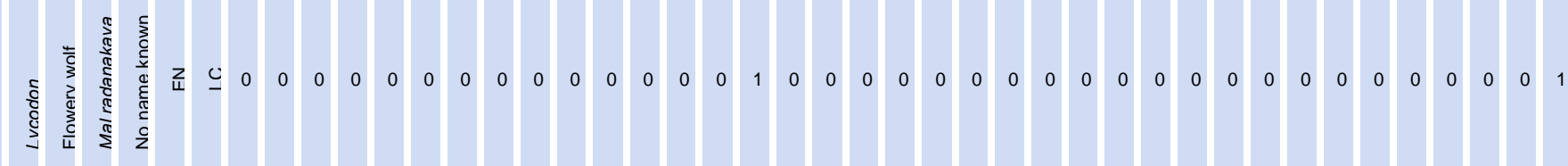

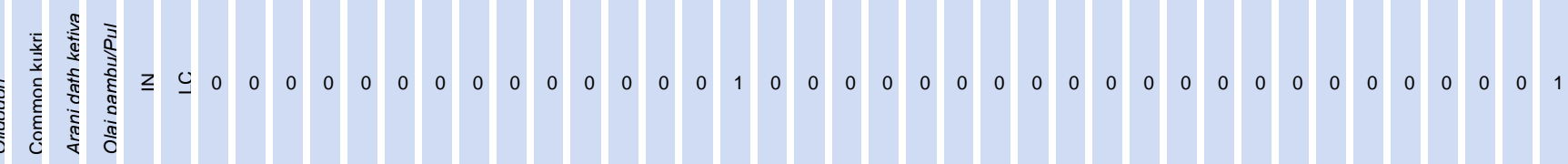




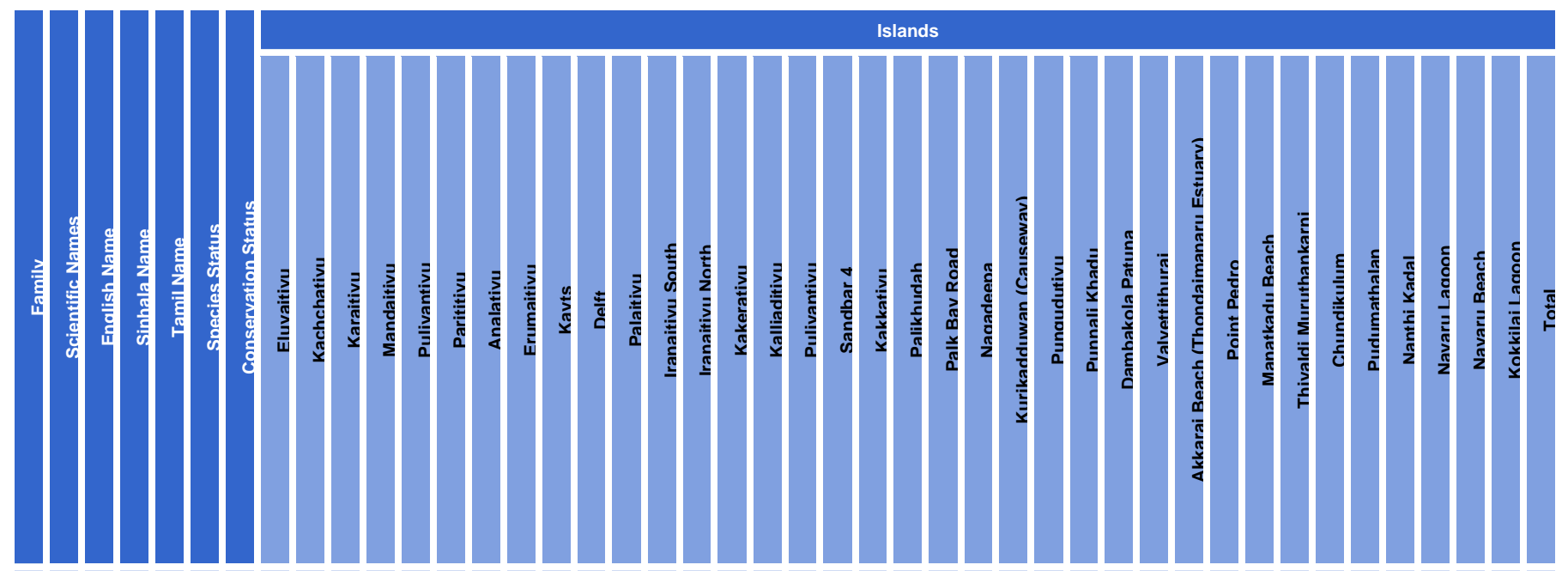

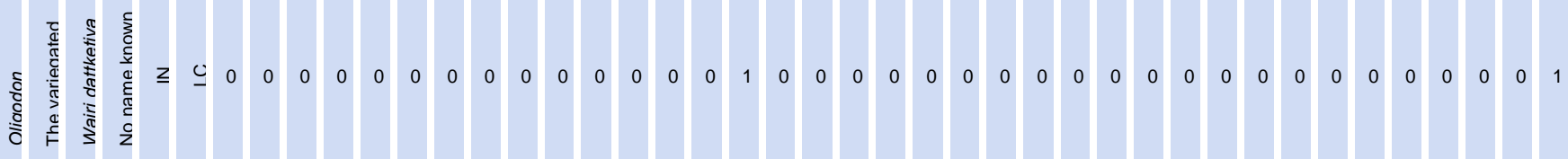

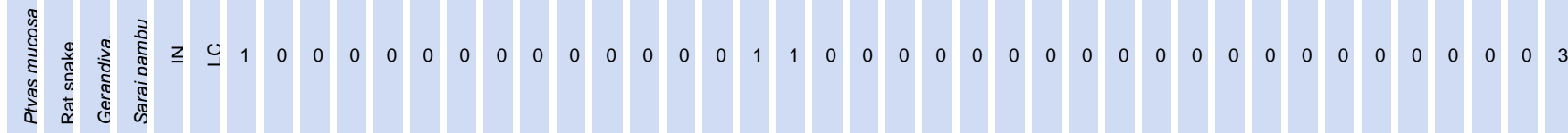

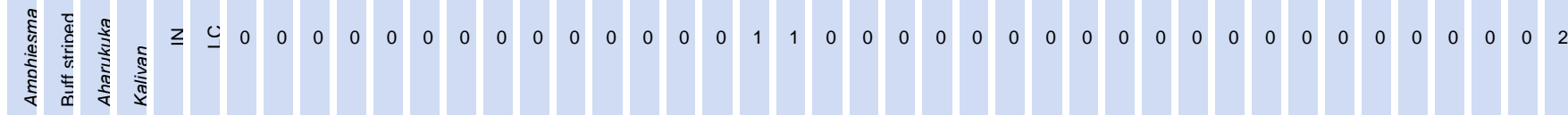

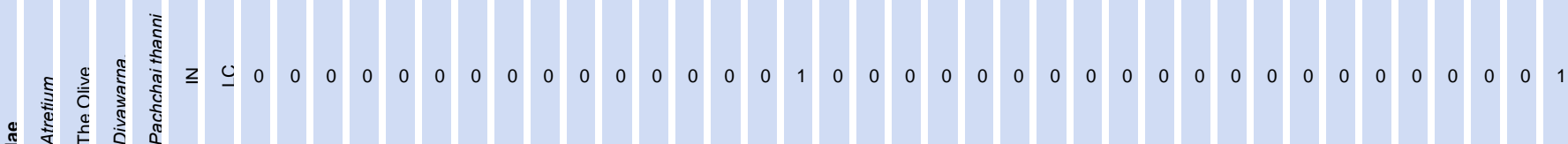

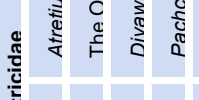

ट च वे है

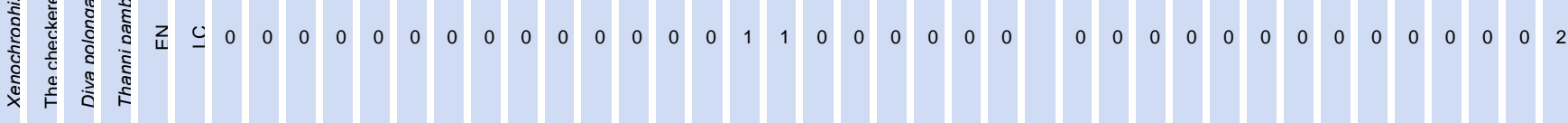

๘ั

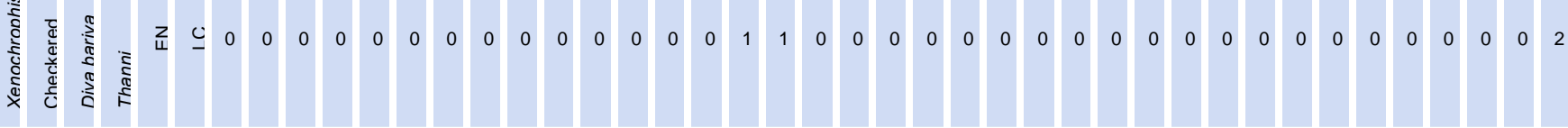

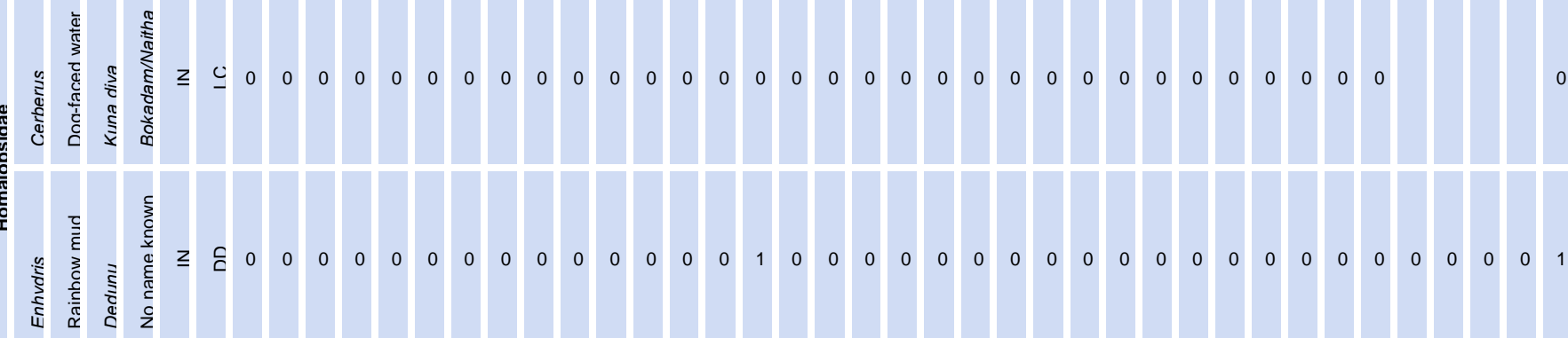

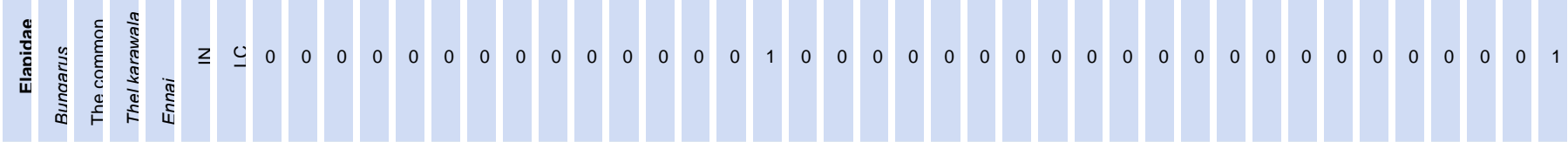




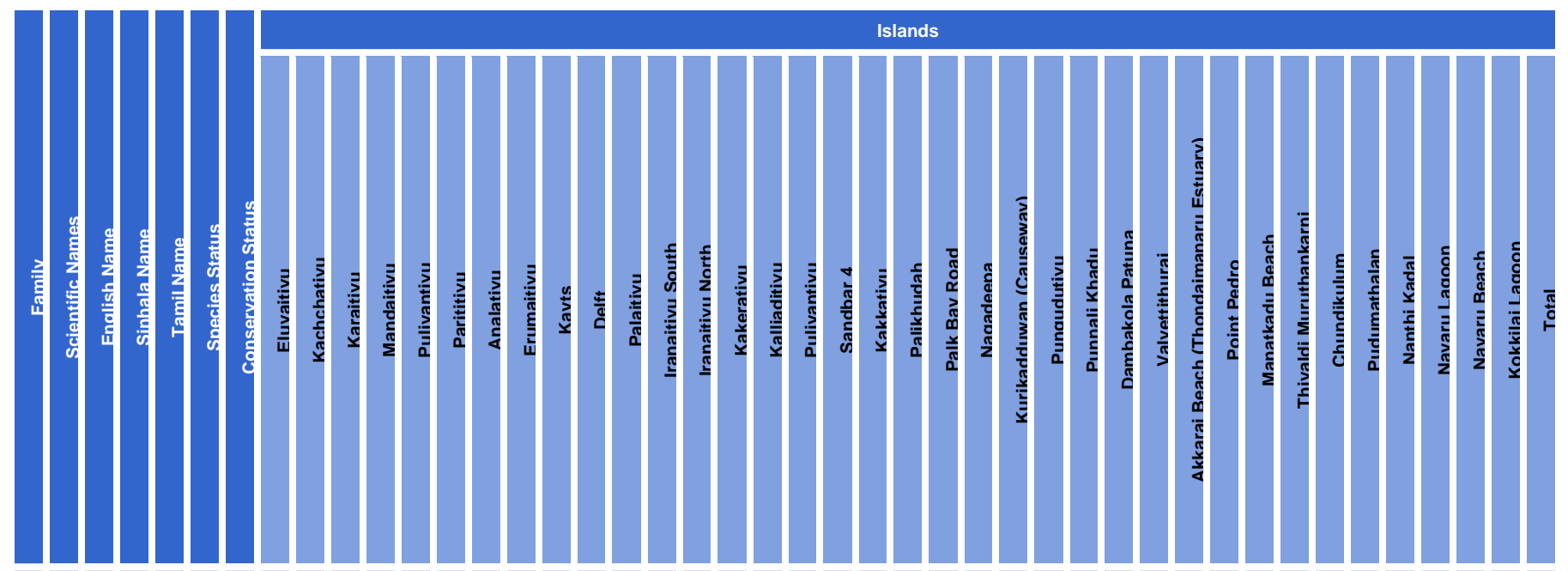

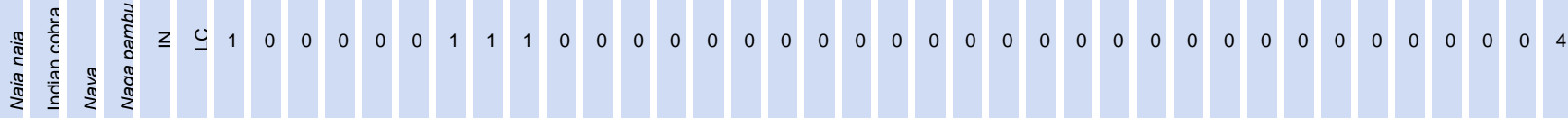

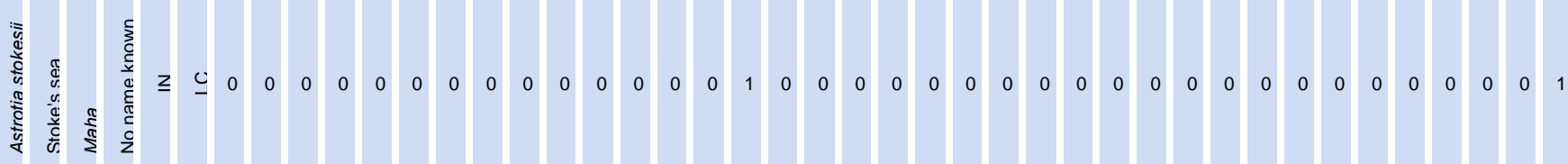

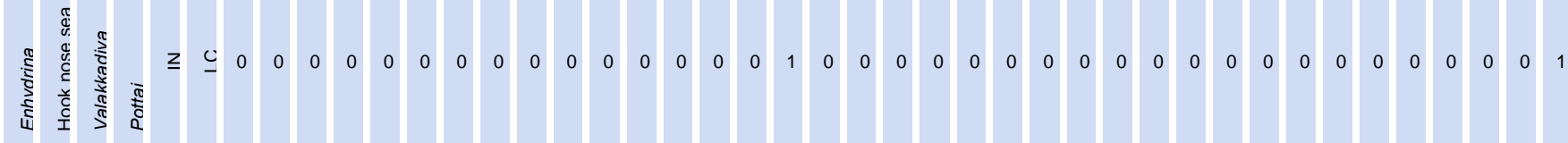

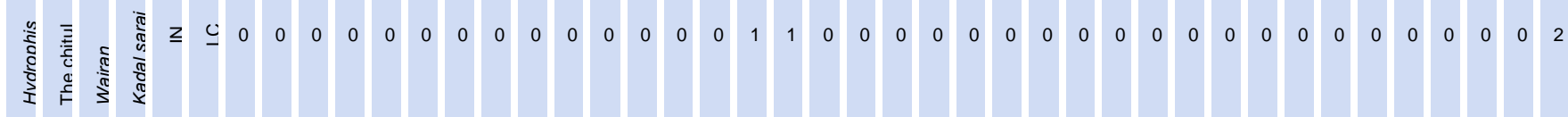

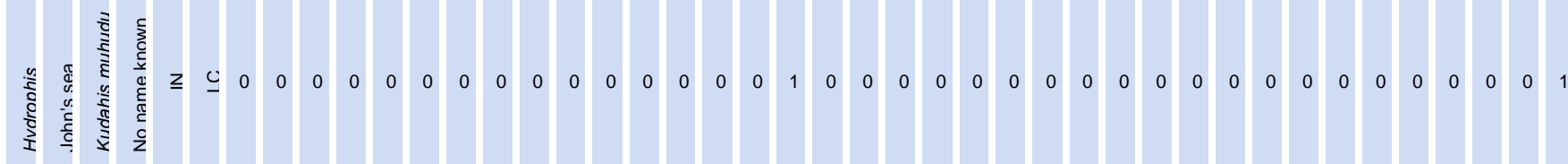

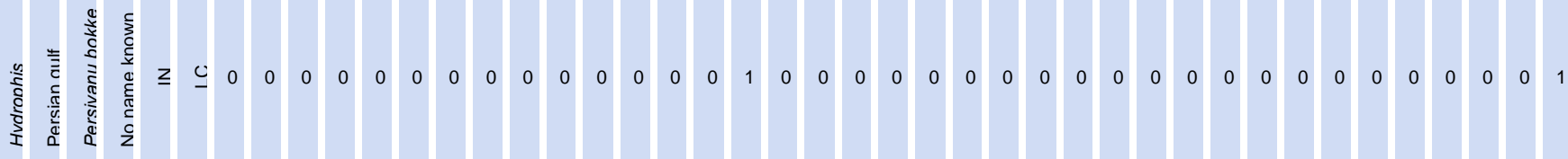
ชู

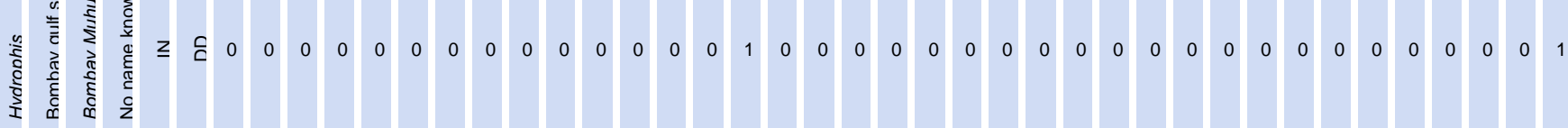

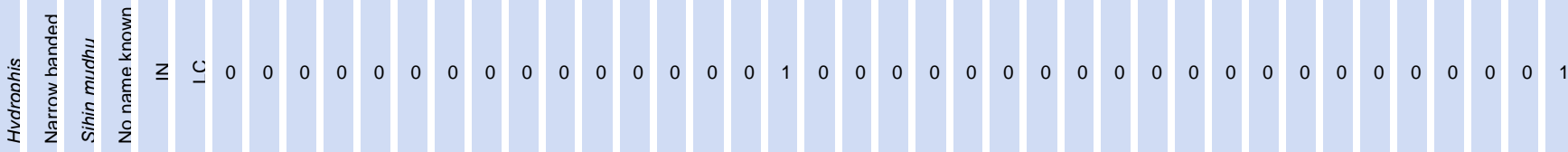

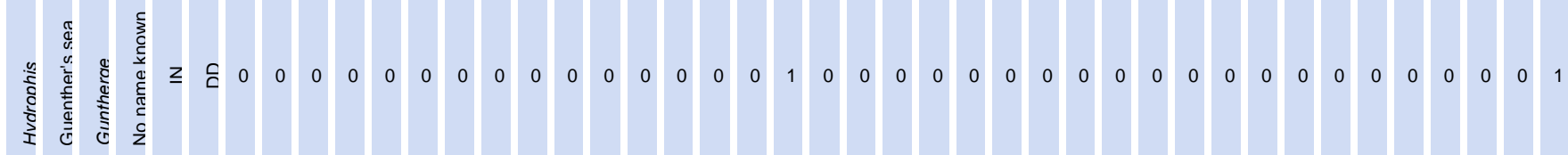




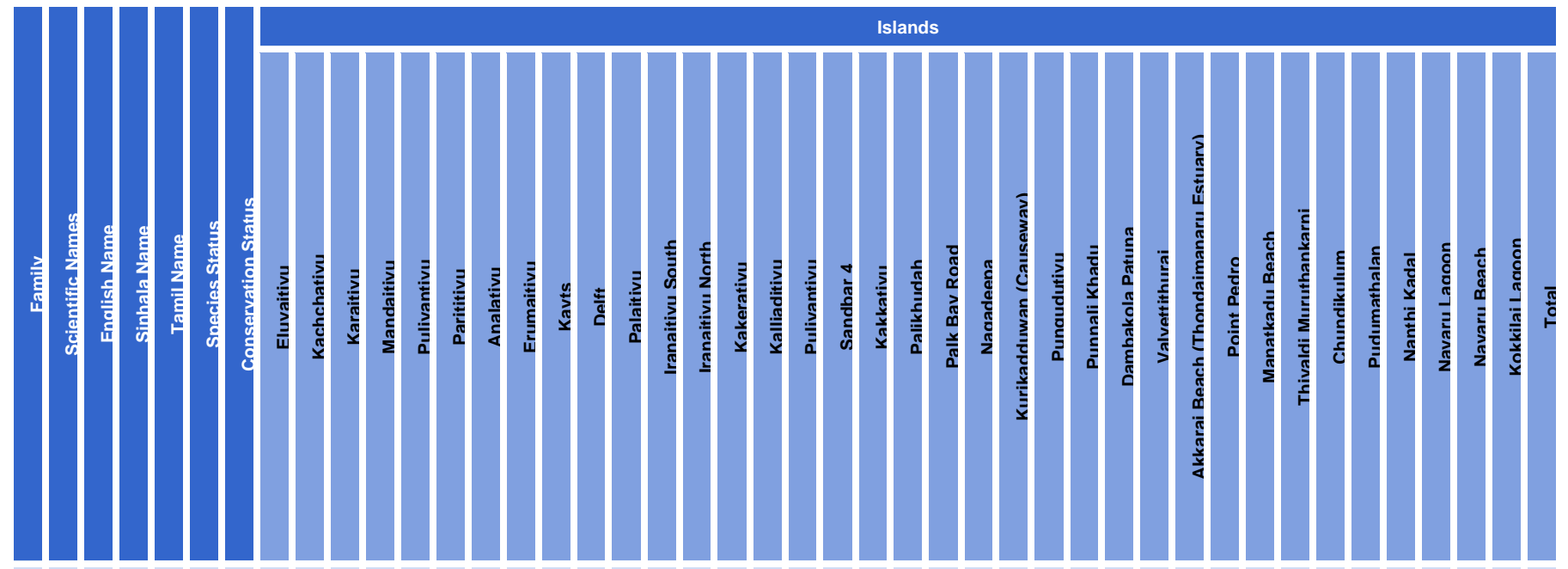

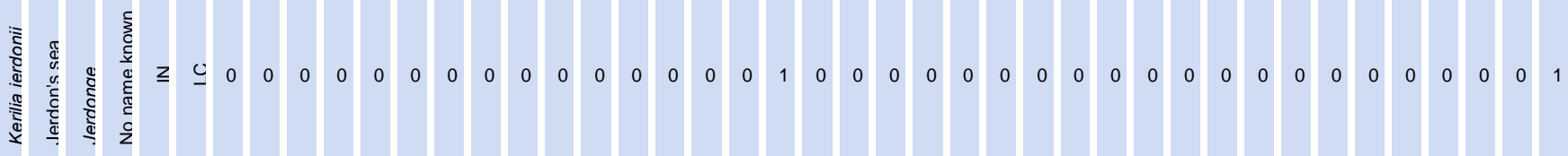

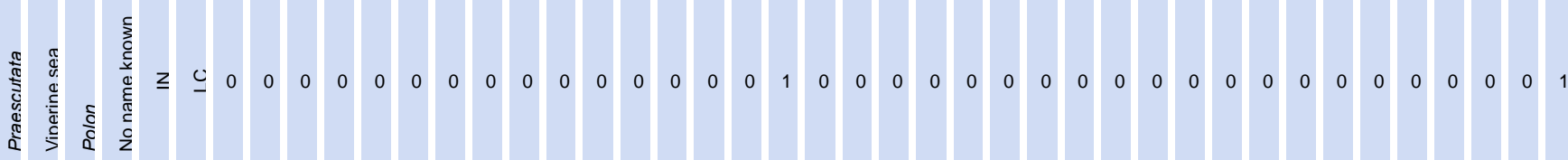

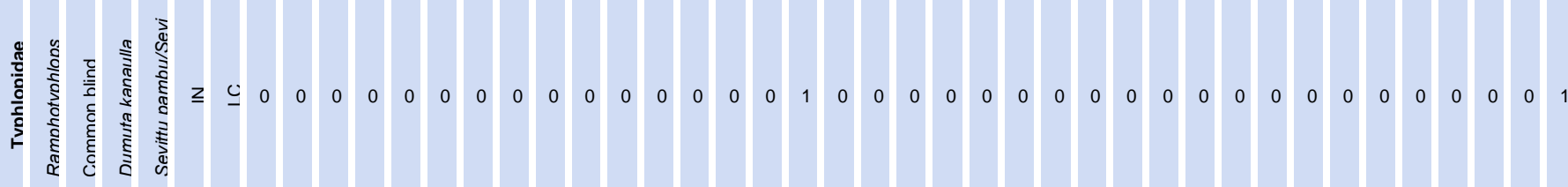

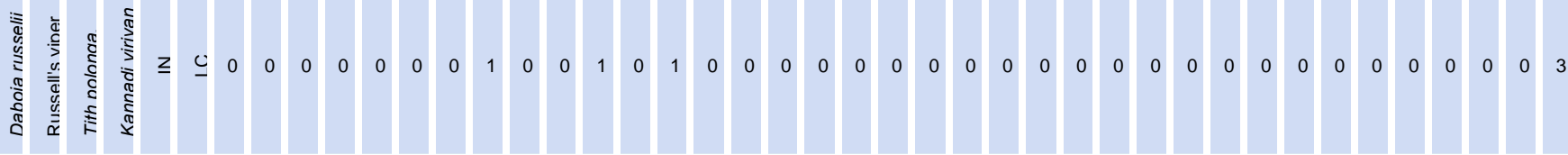

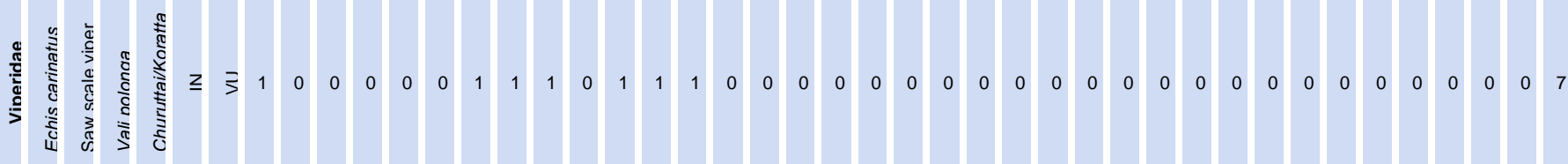

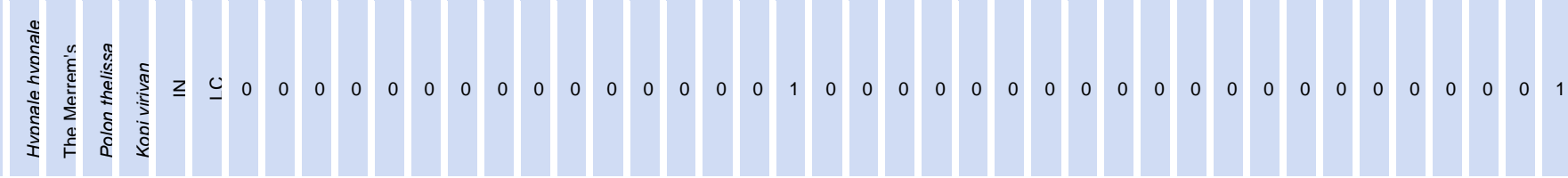




\section{g) Birds}

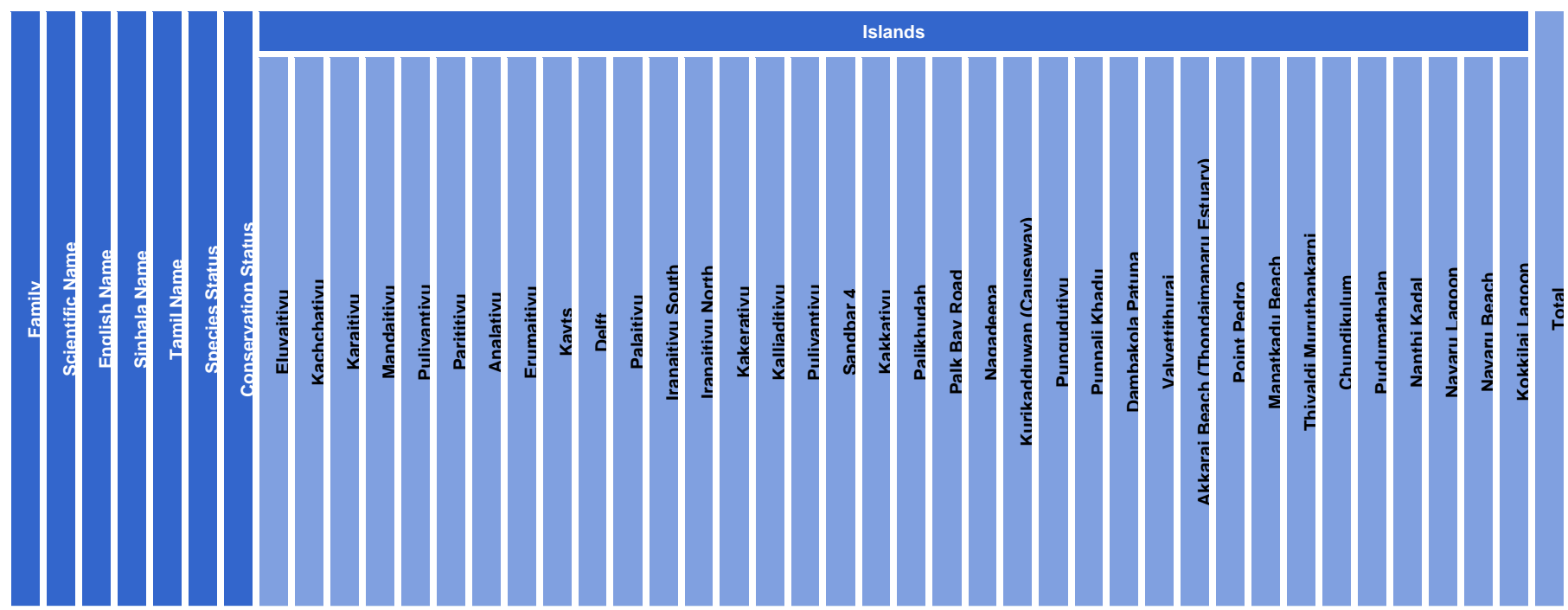

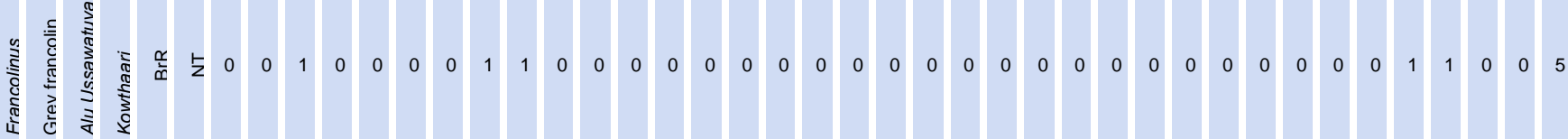

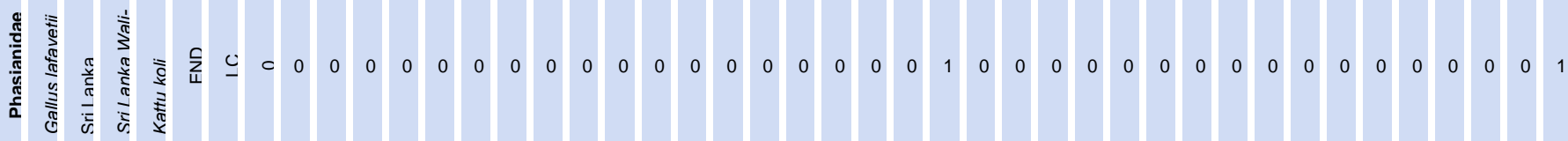

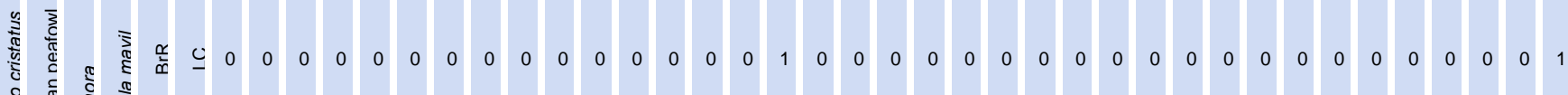

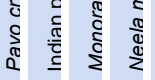

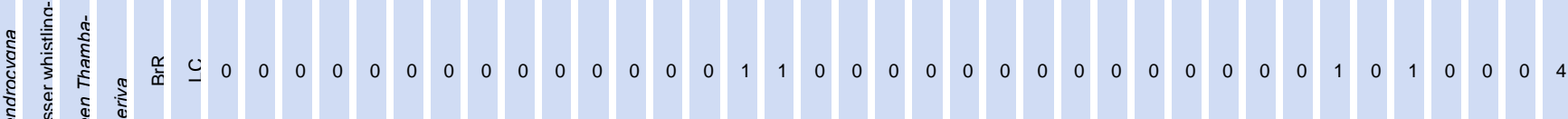

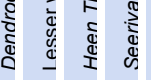

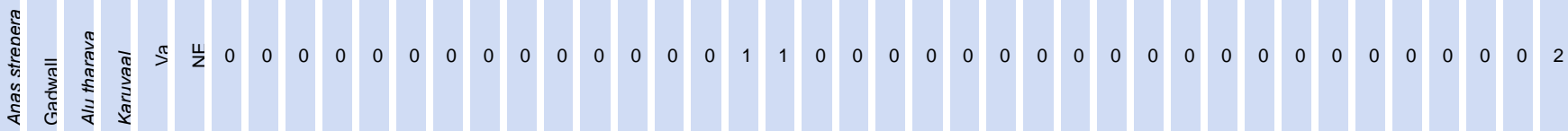

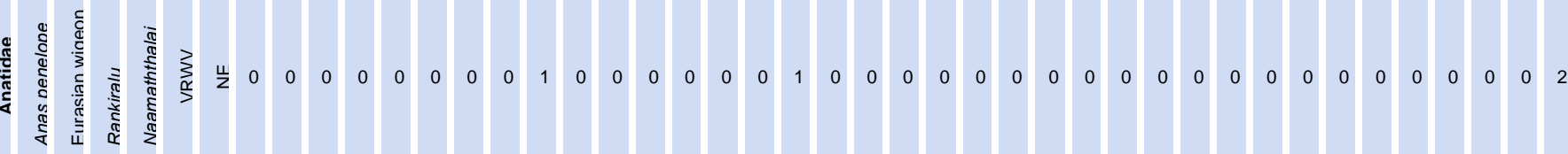

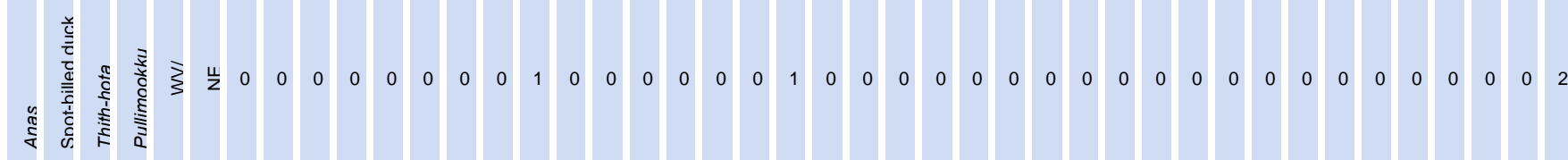

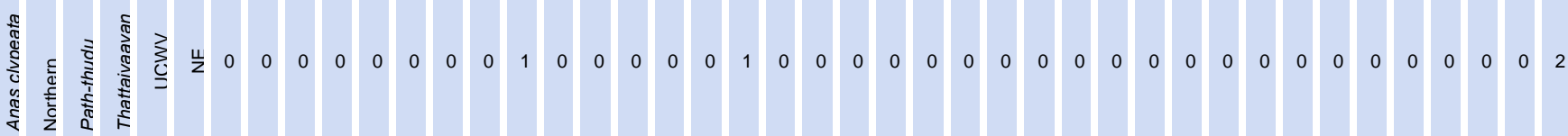




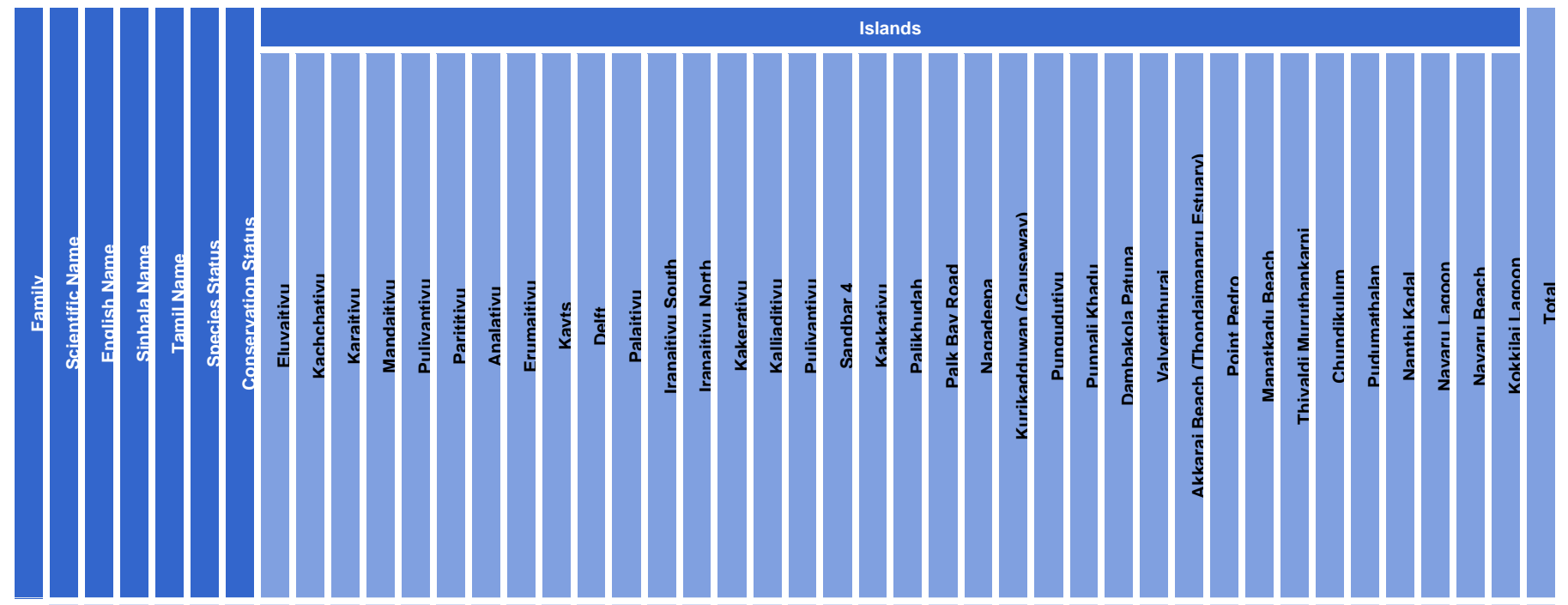

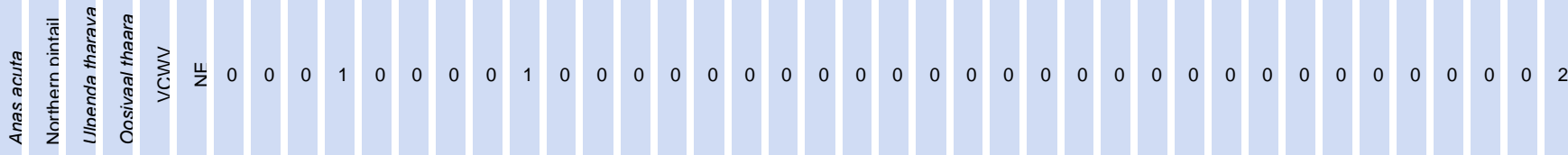

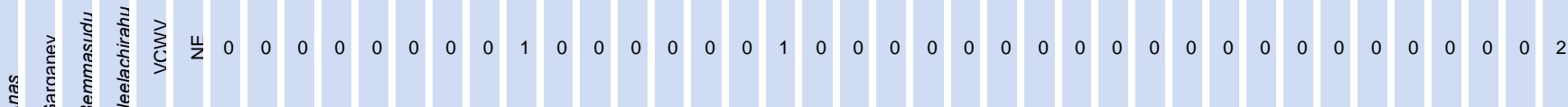

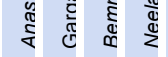

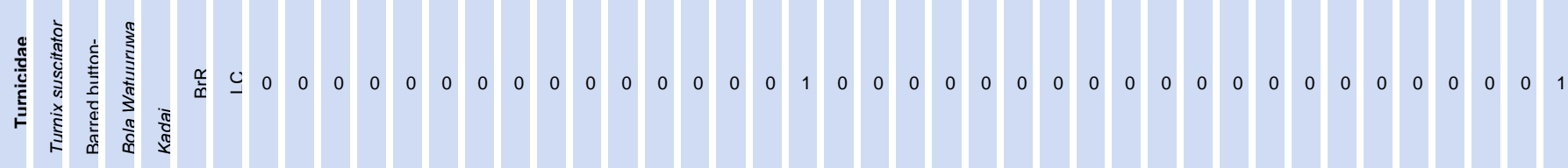

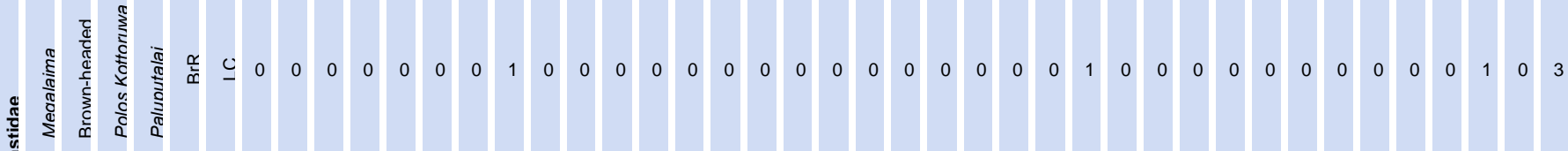

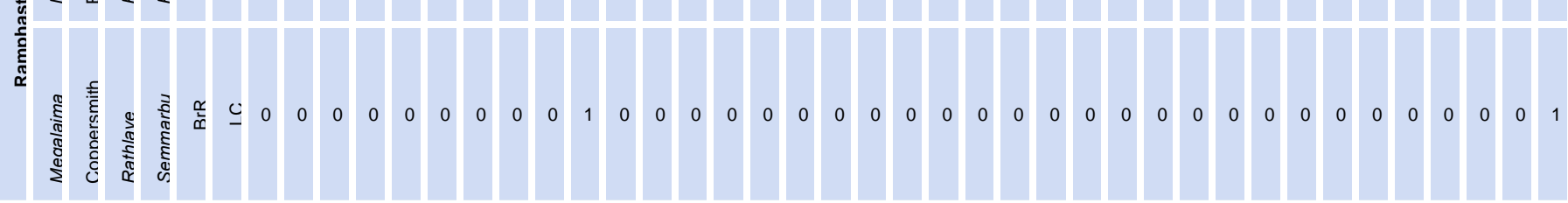

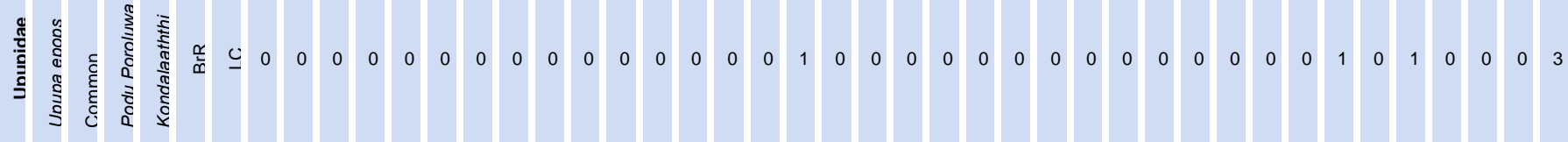

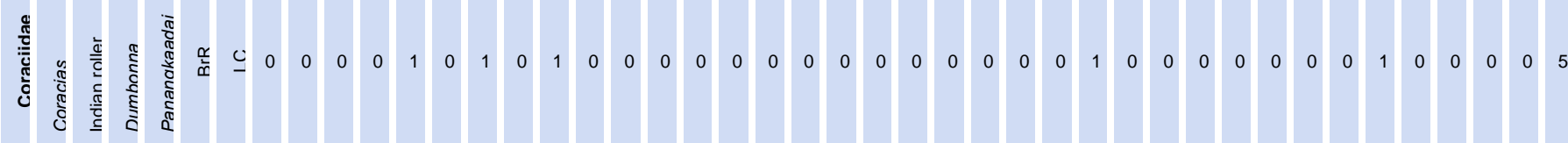

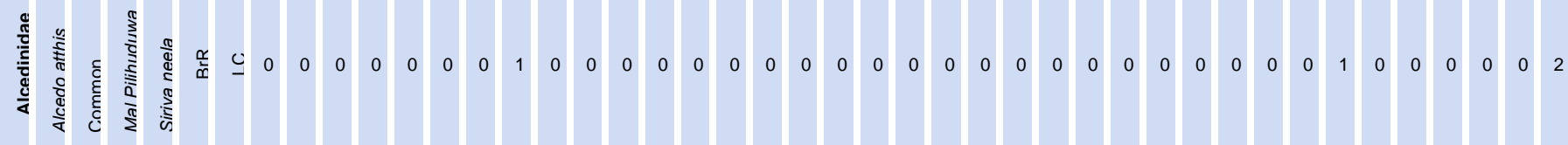




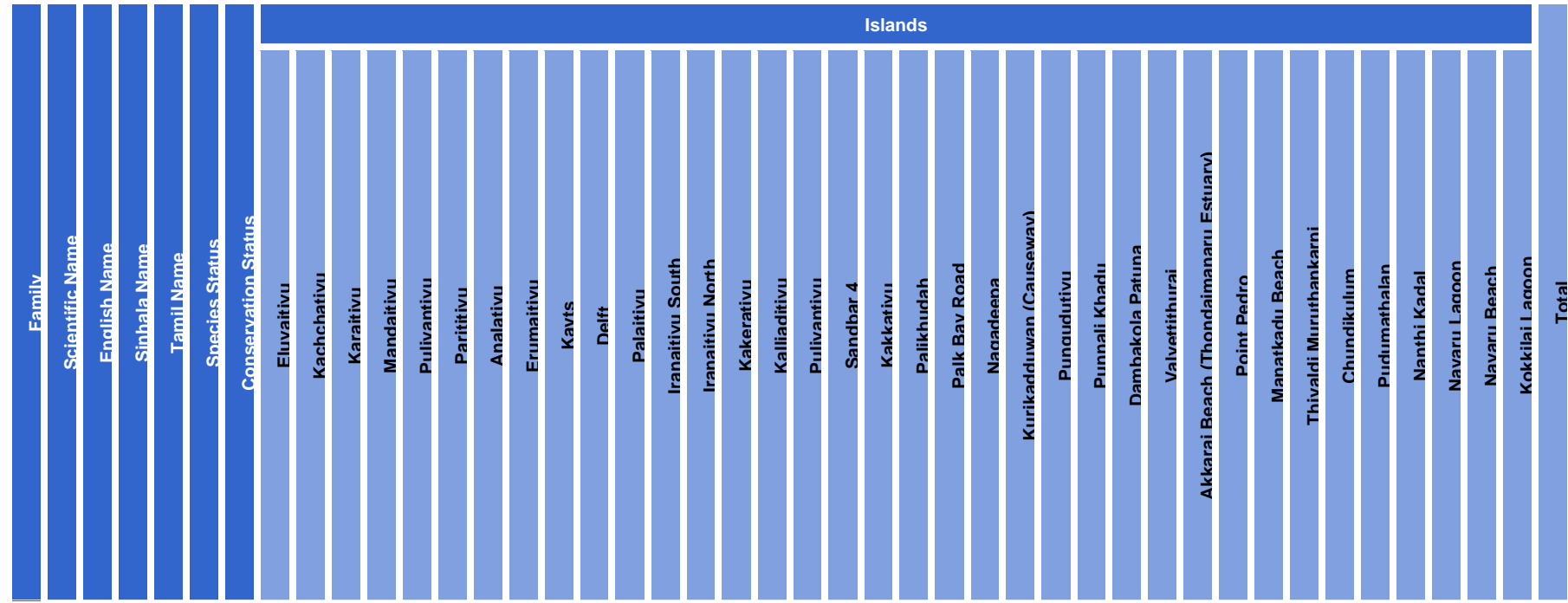

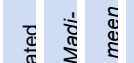

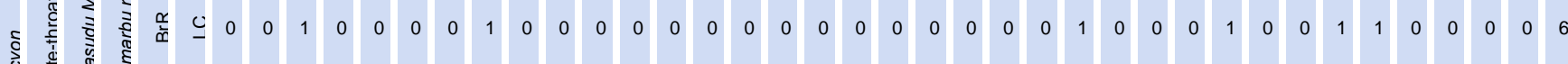

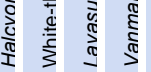

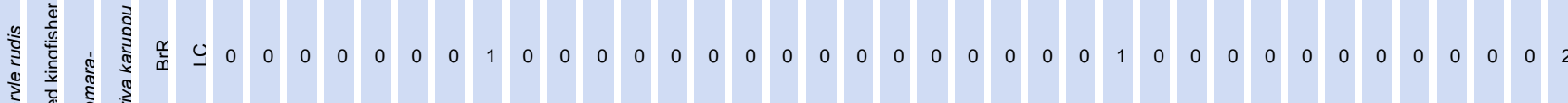

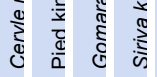

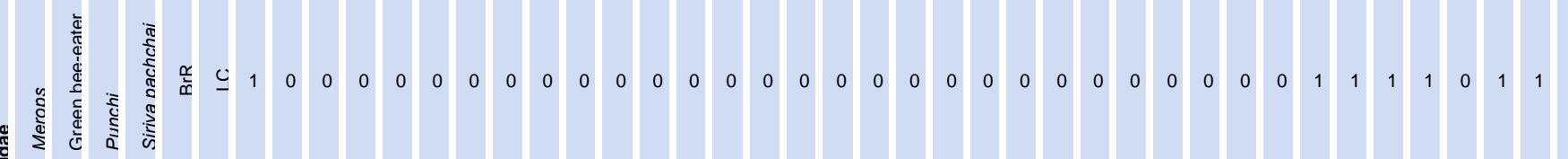

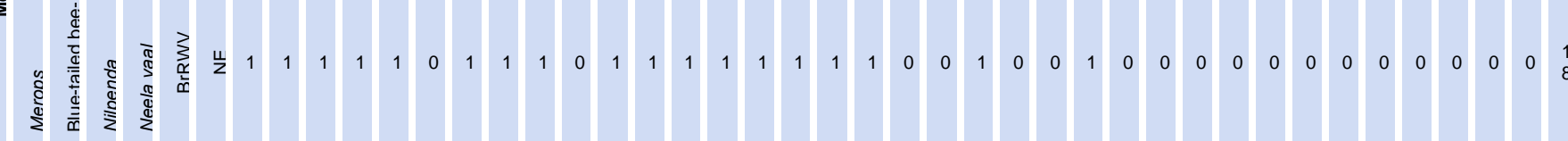

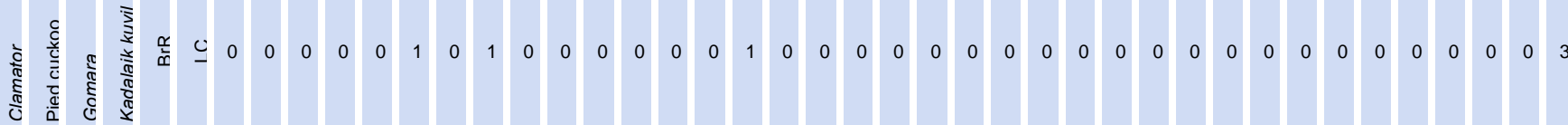

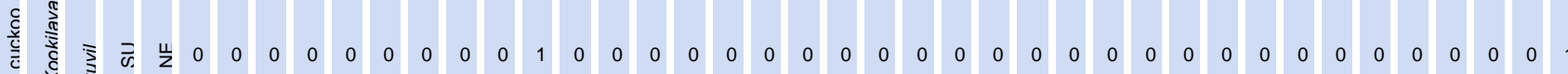

ब

Uั

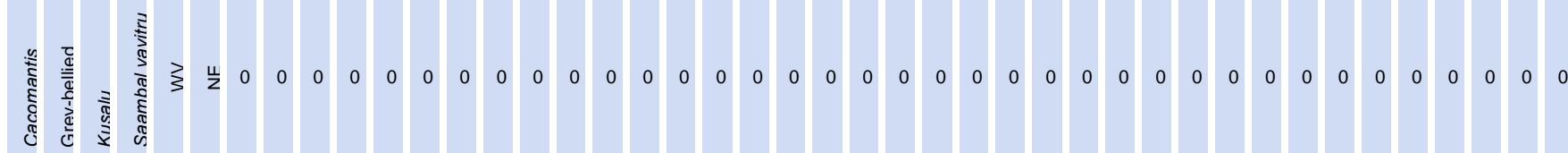

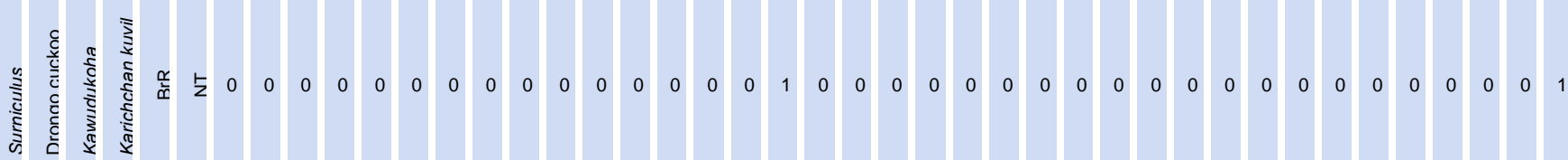




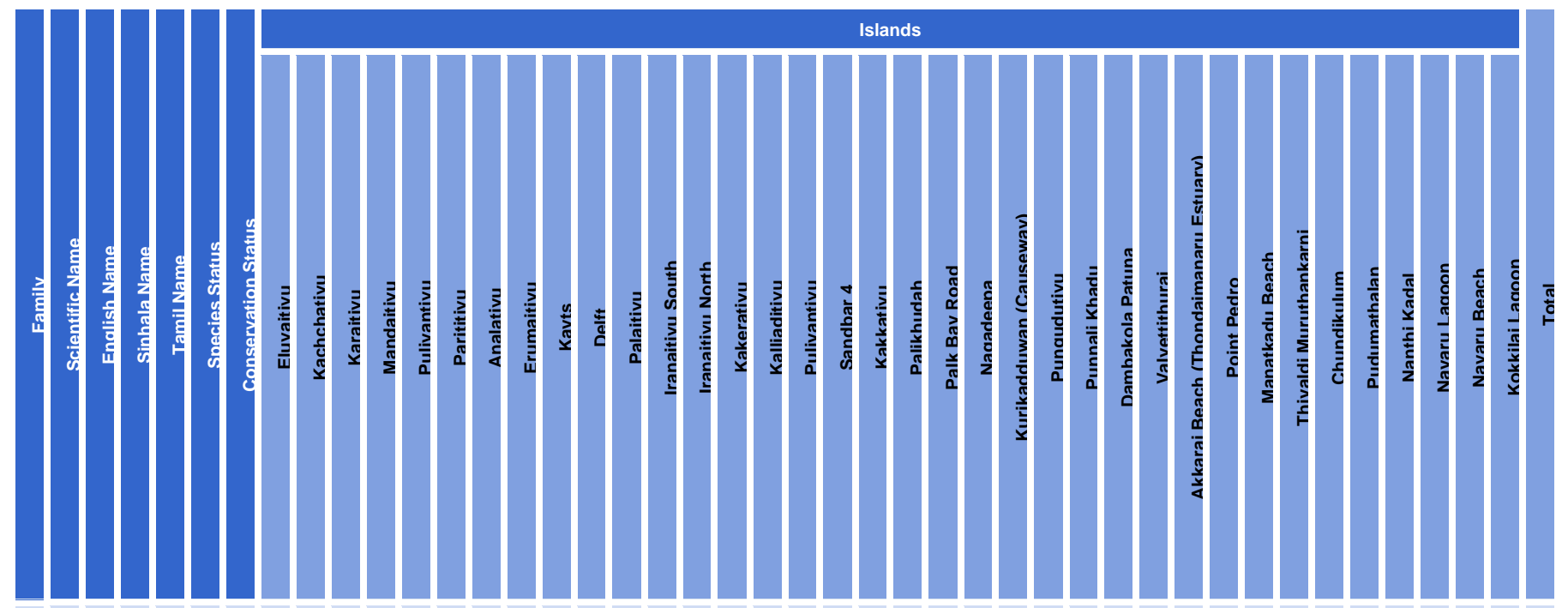

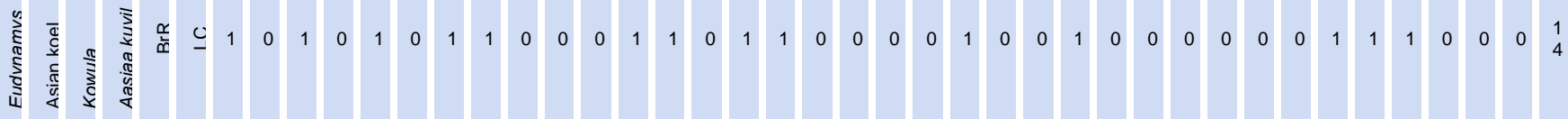

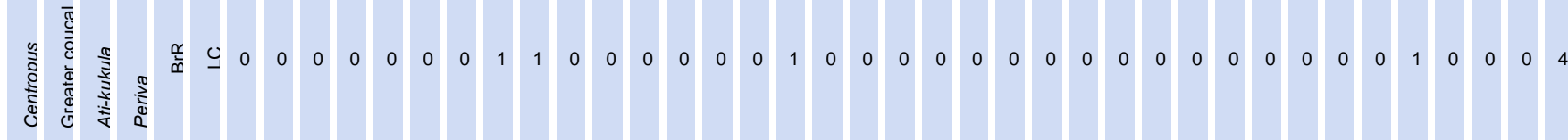

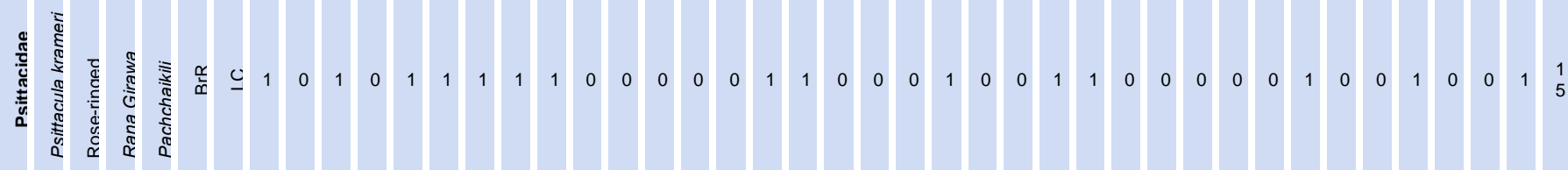

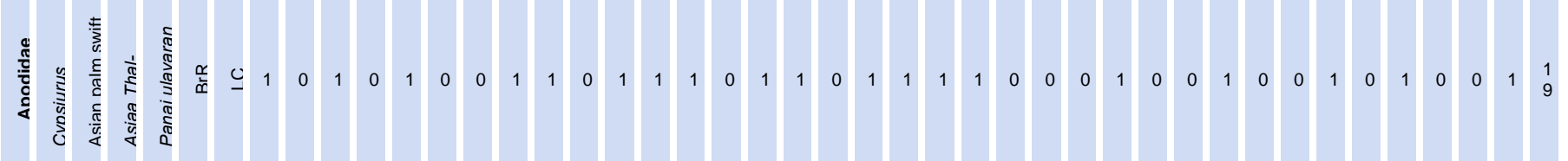

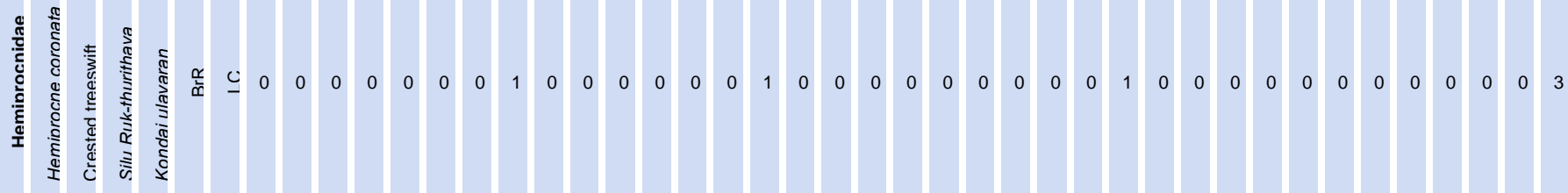

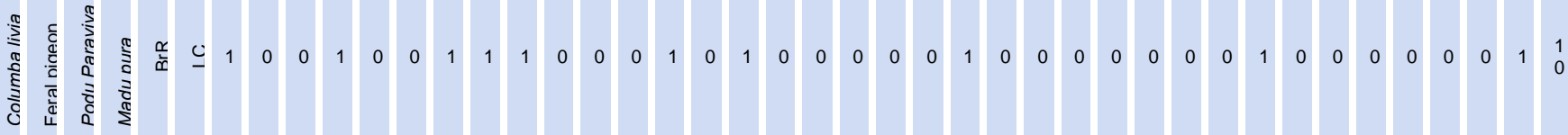

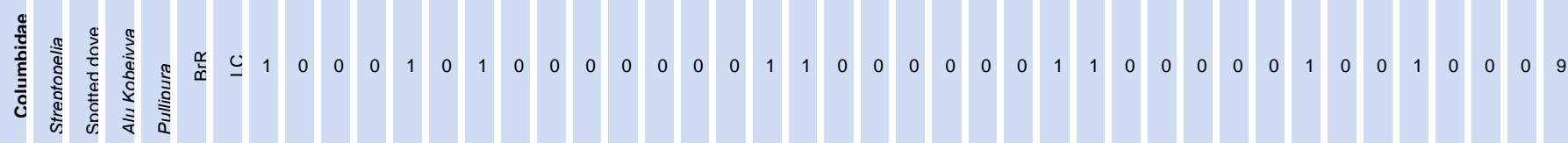

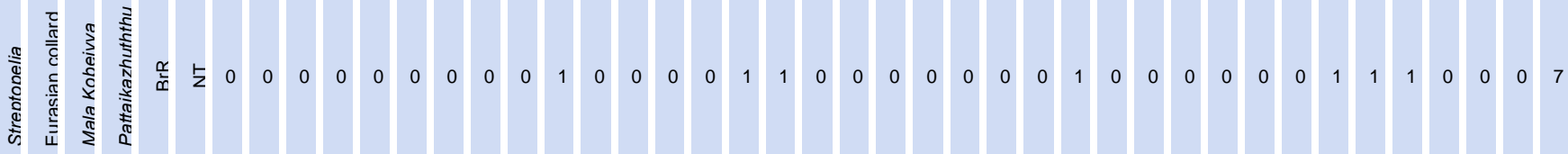




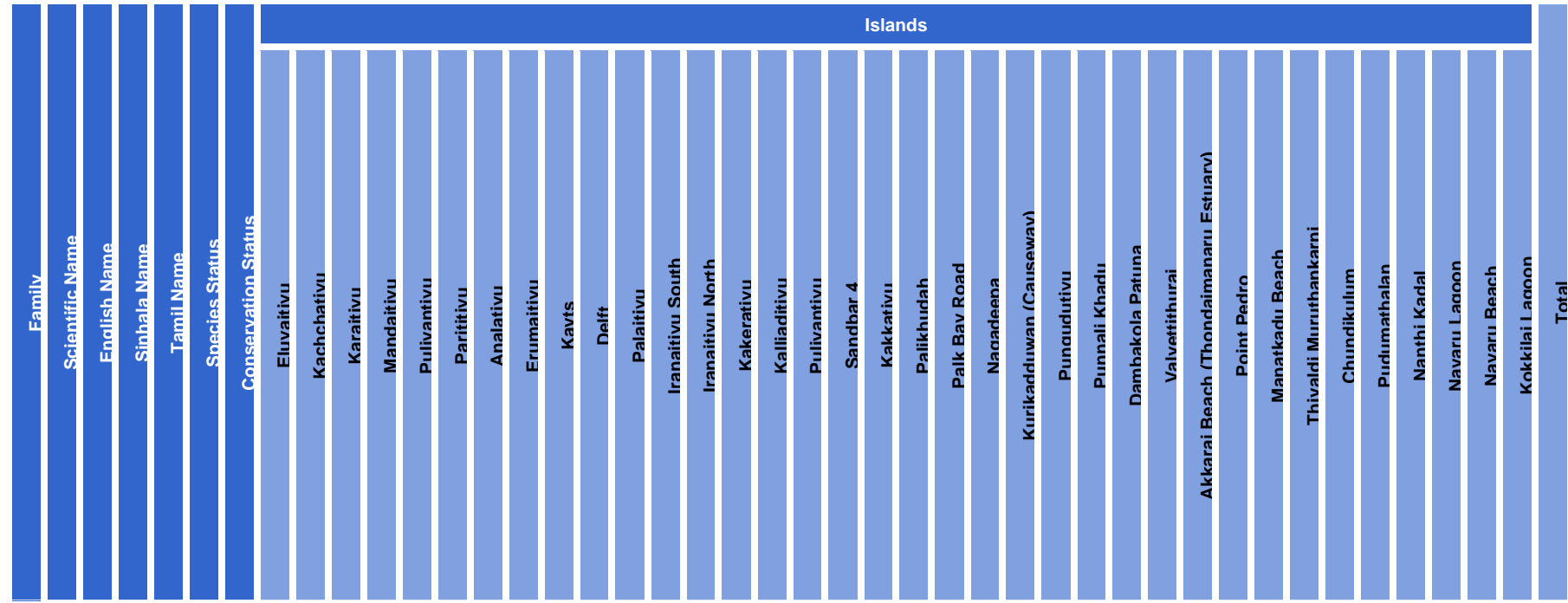

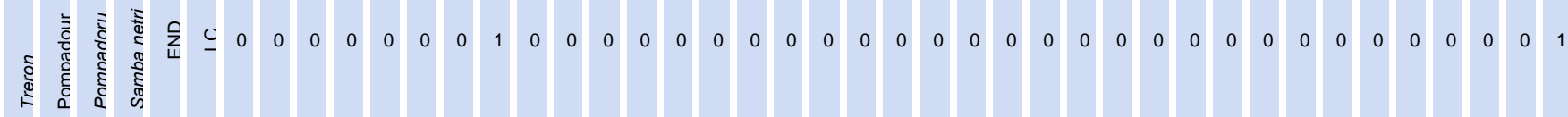

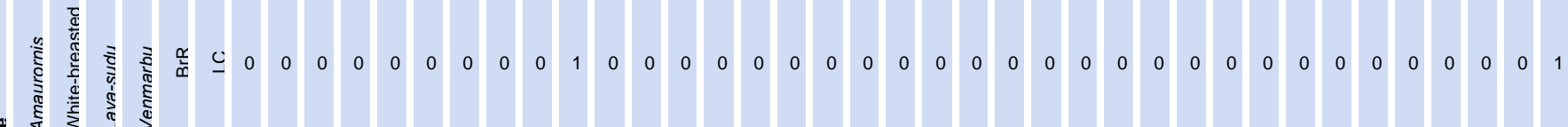
綧

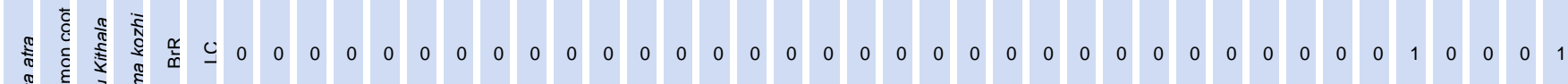

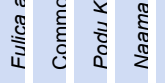

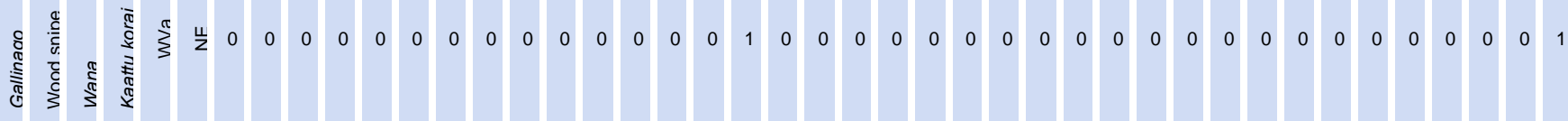

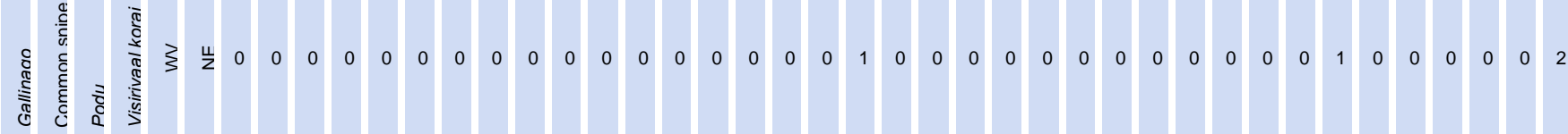

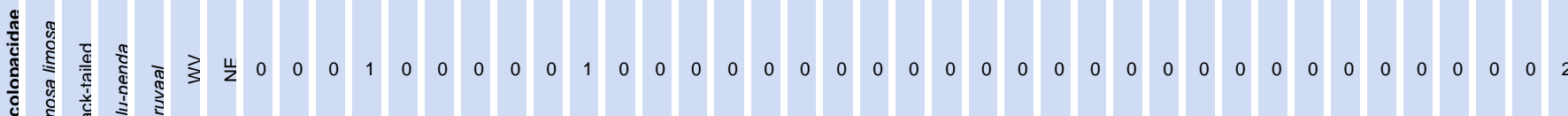
ज.

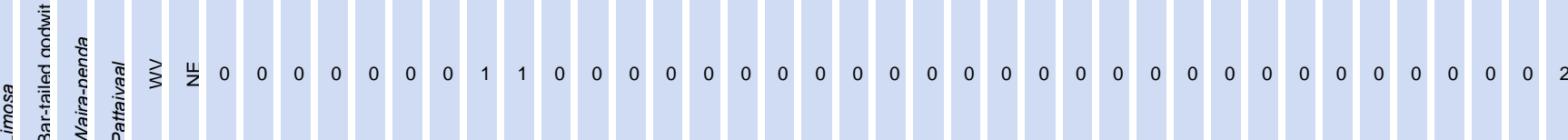

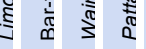

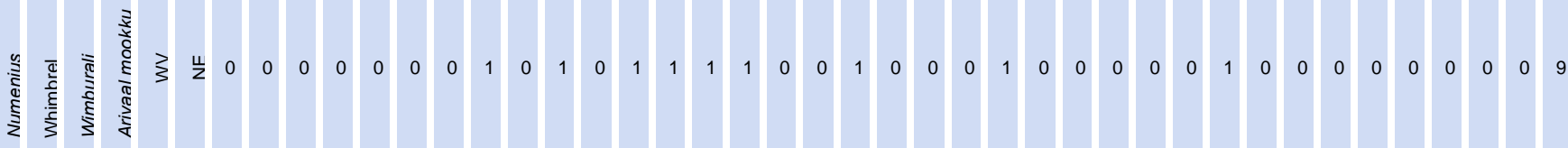




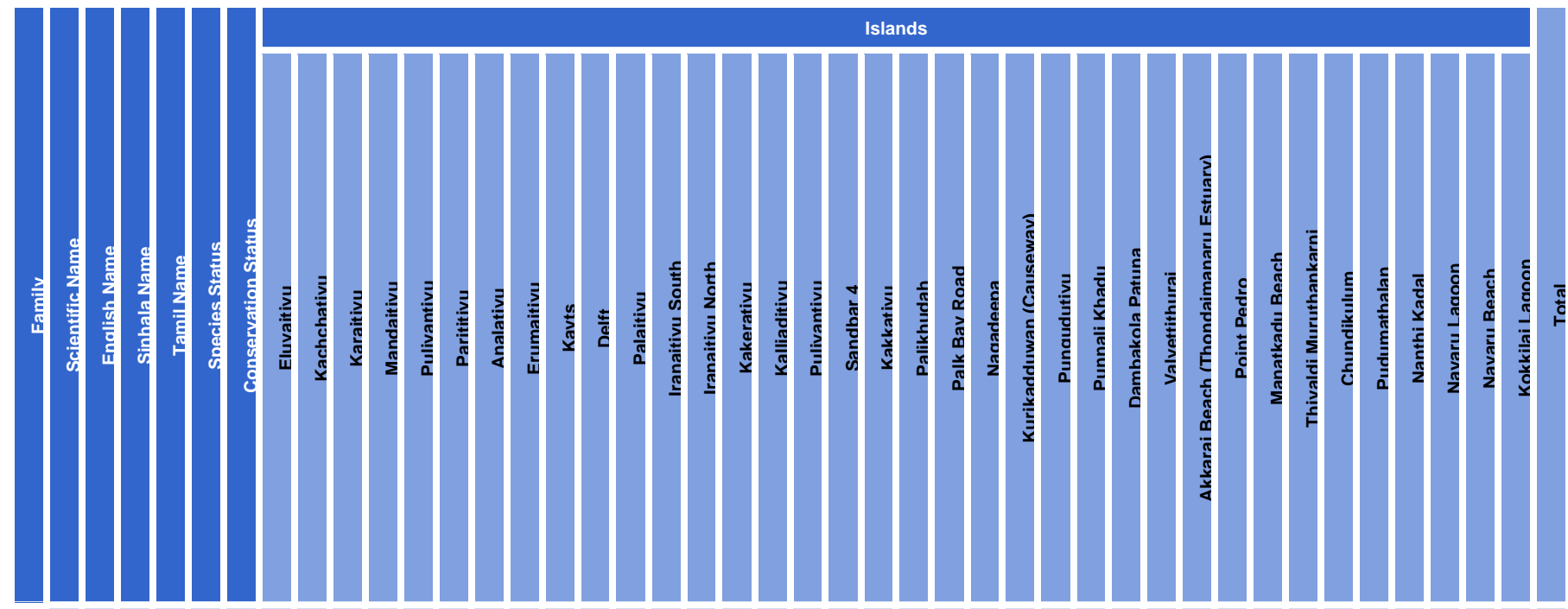

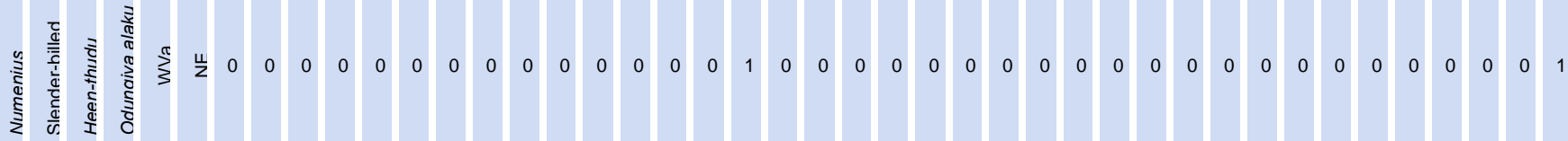

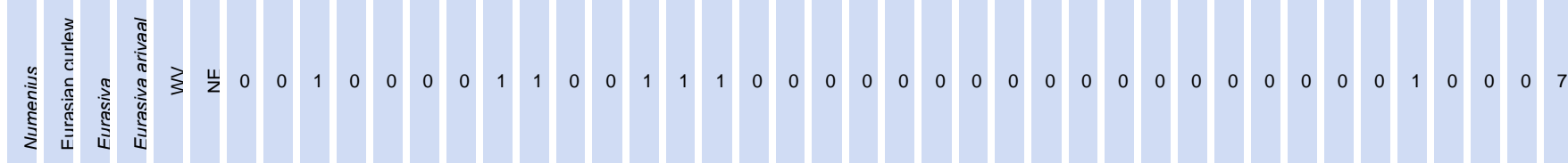

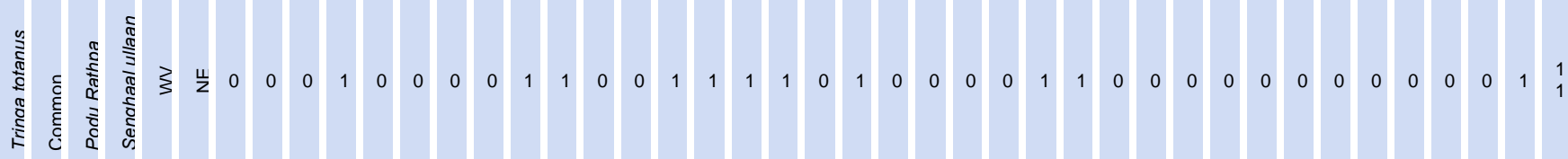

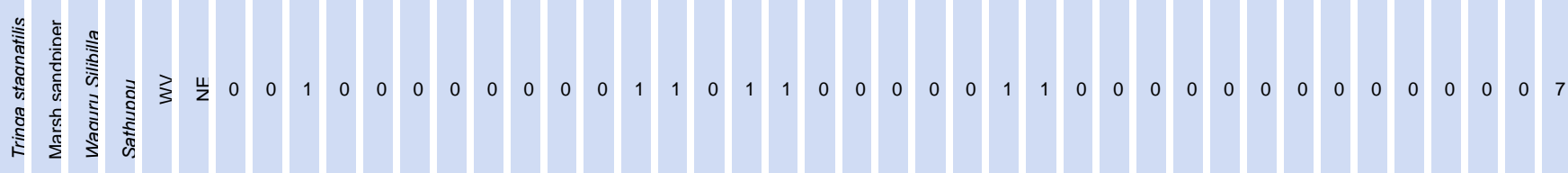

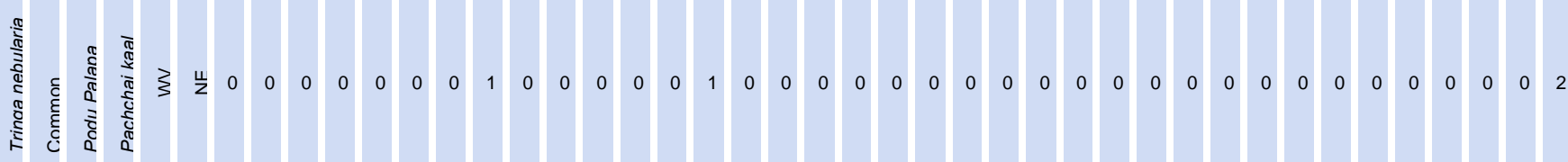

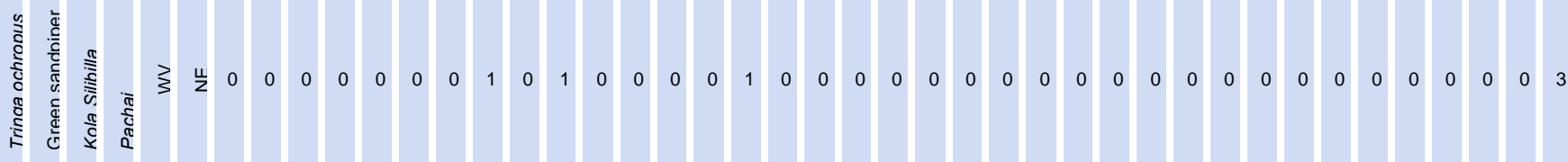

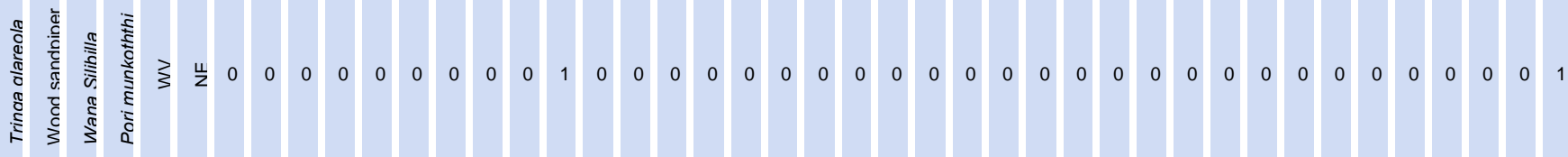

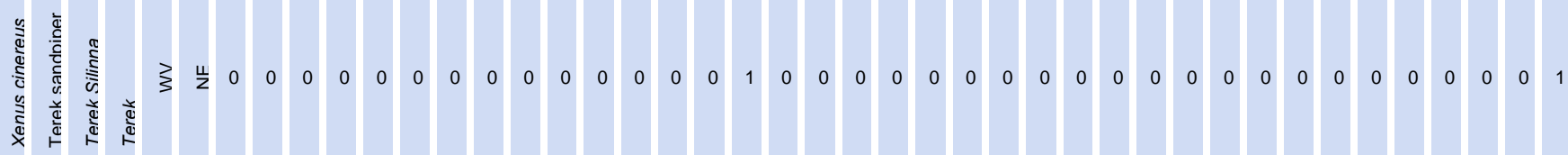




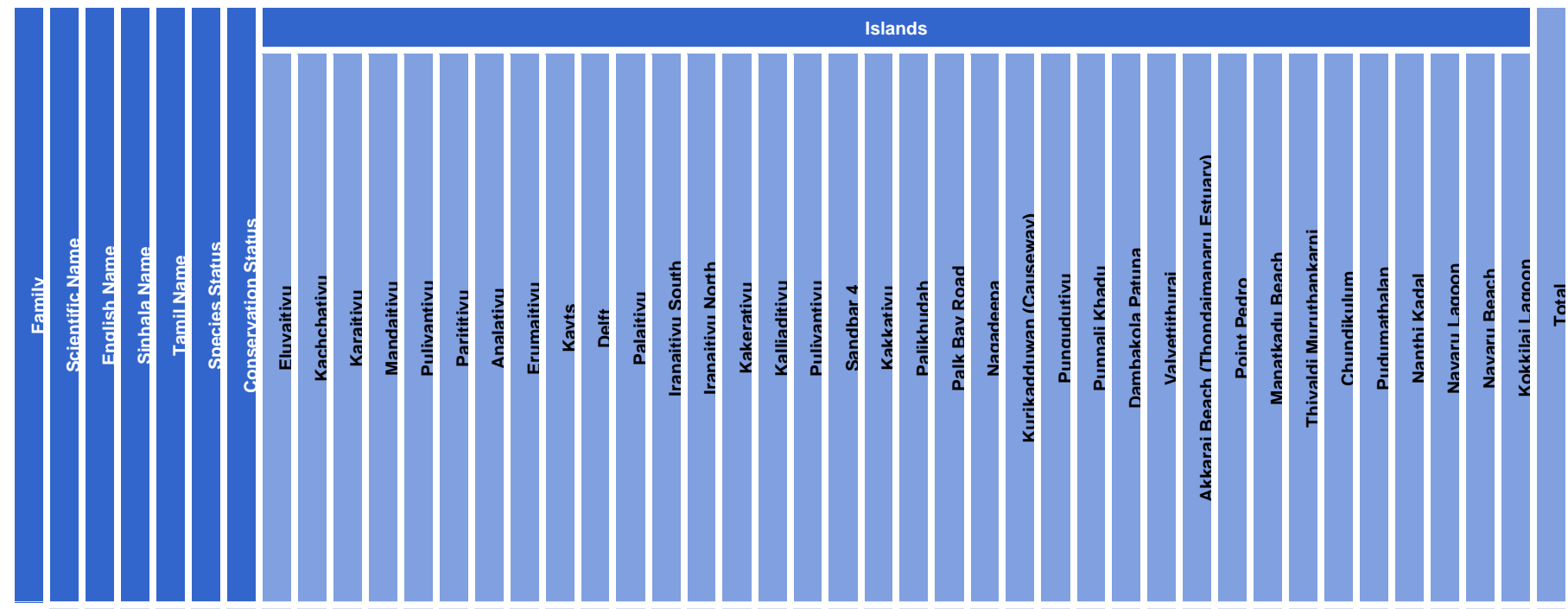

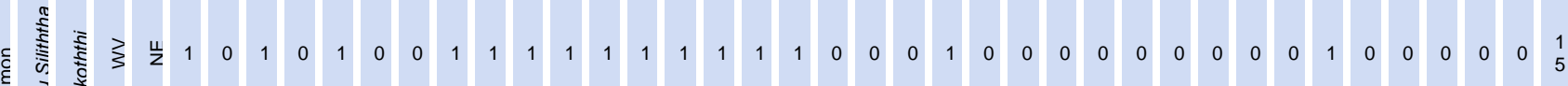

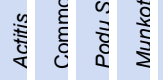

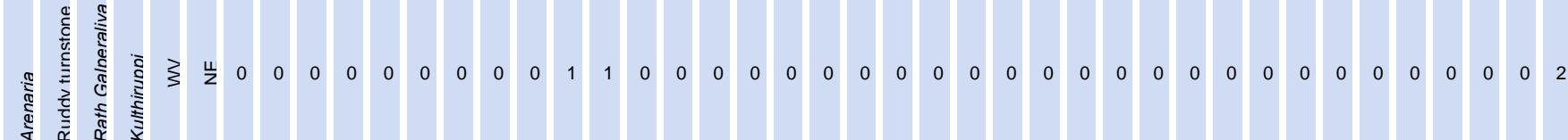

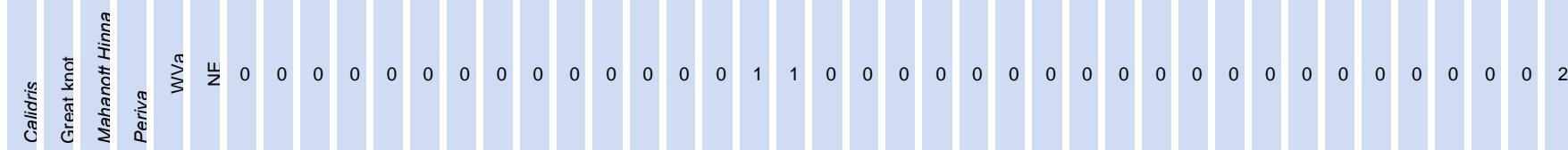

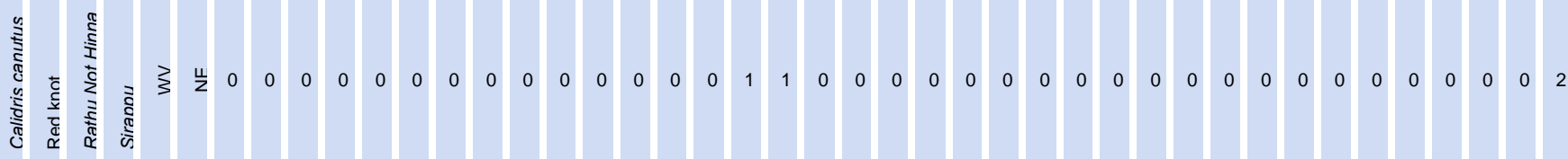

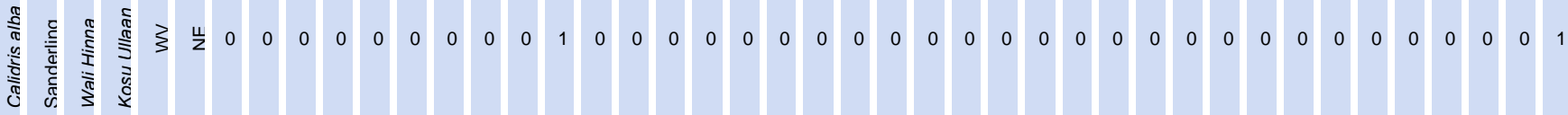

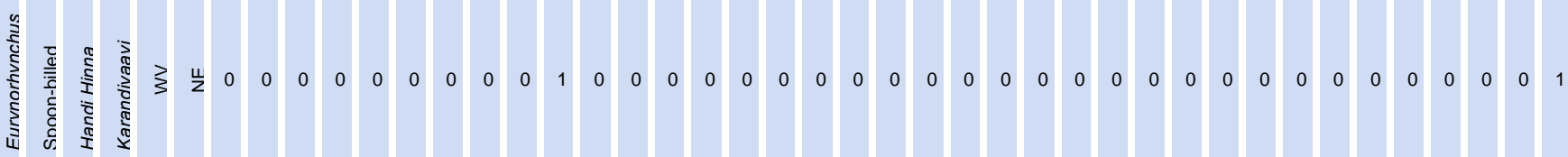

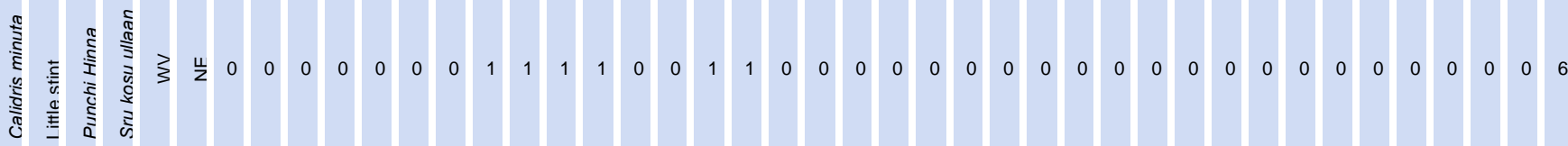

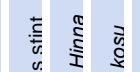

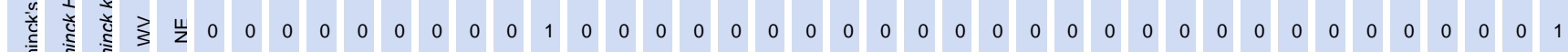

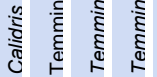




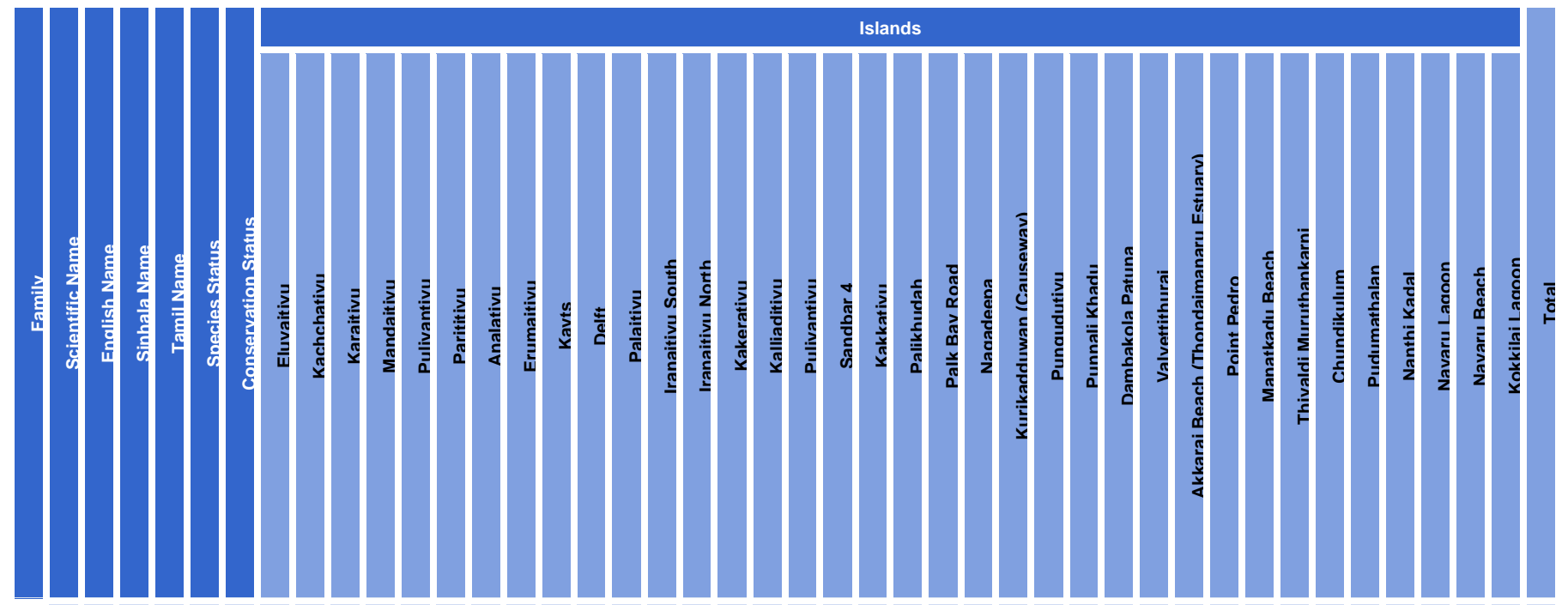

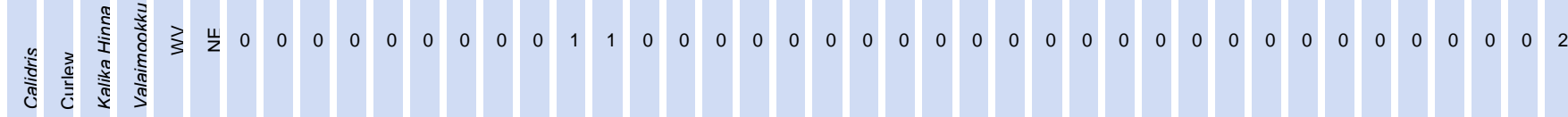

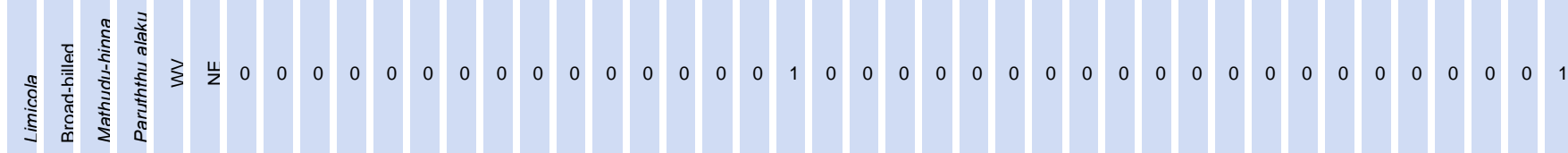

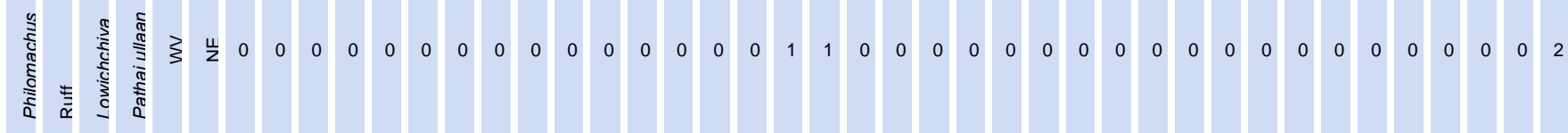

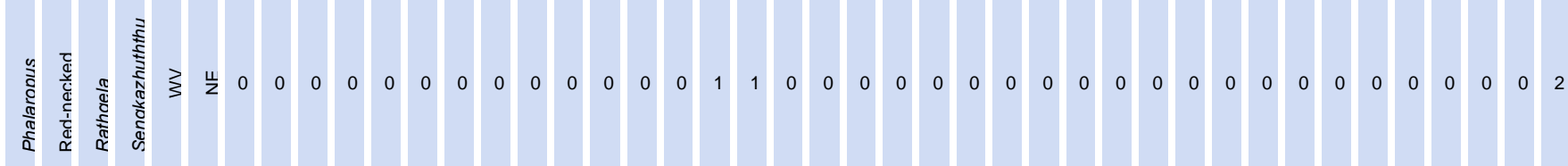

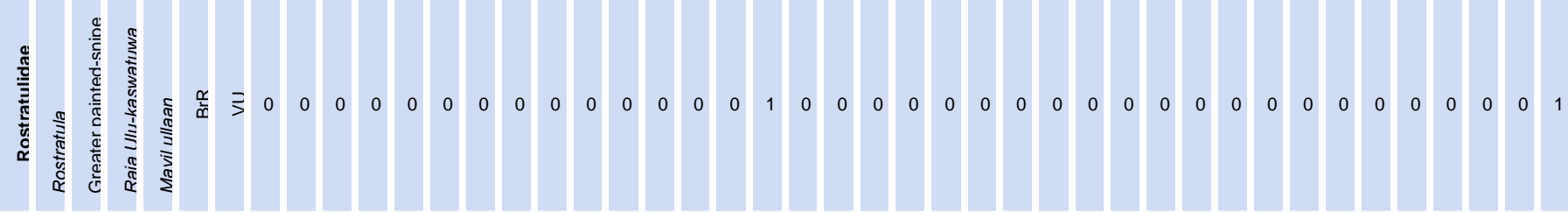

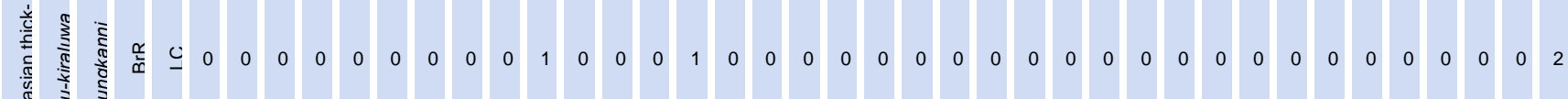
竞:

产

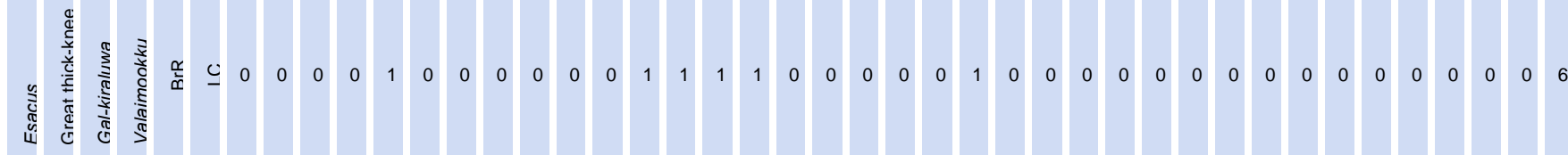

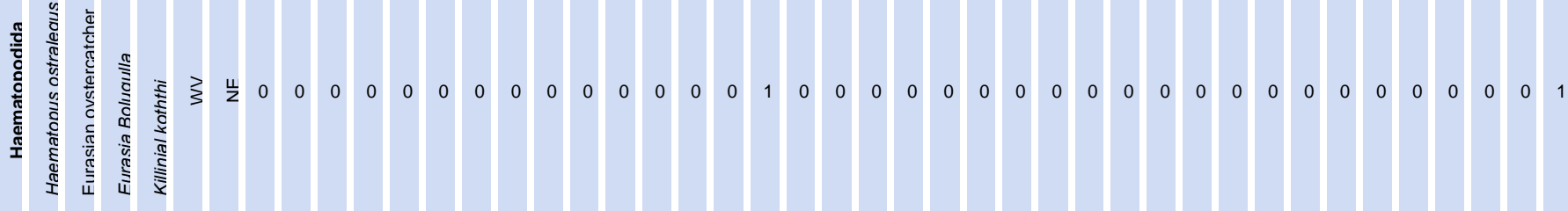




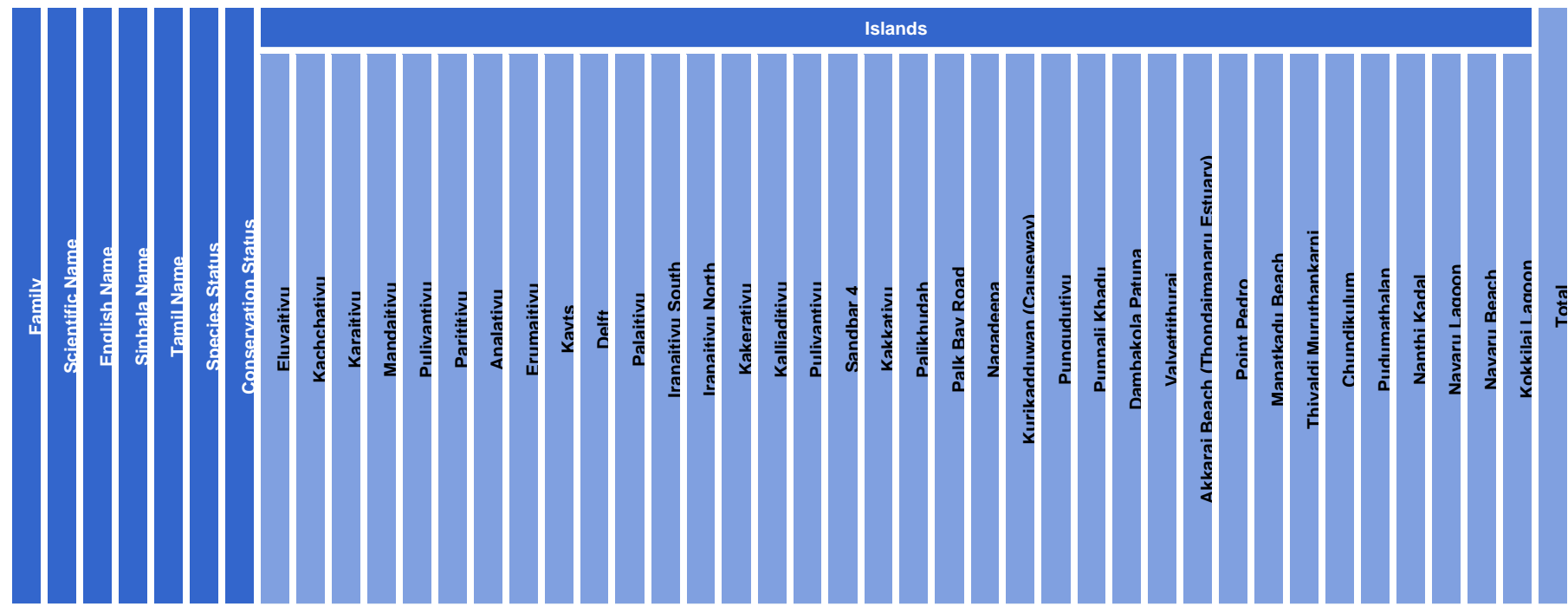

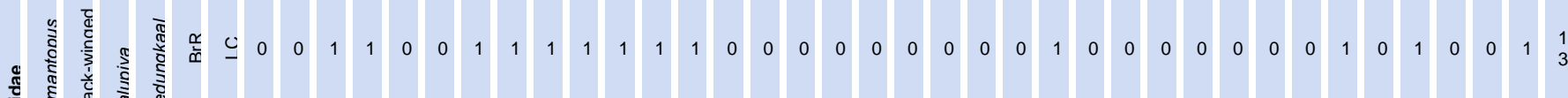

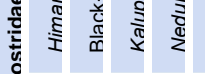

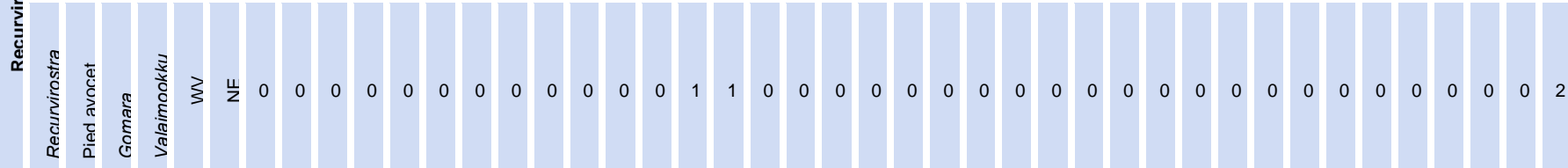

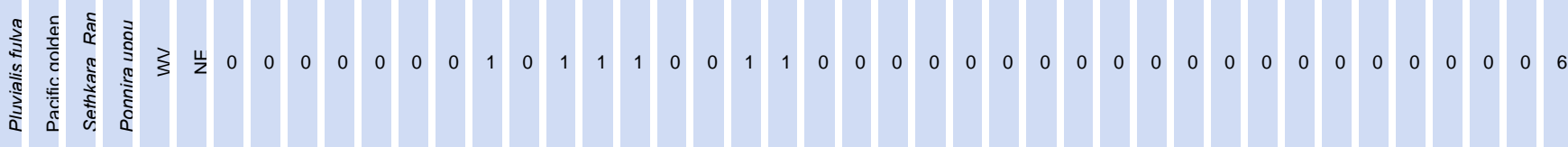

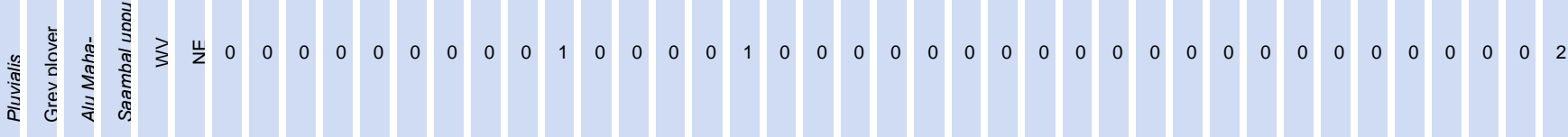

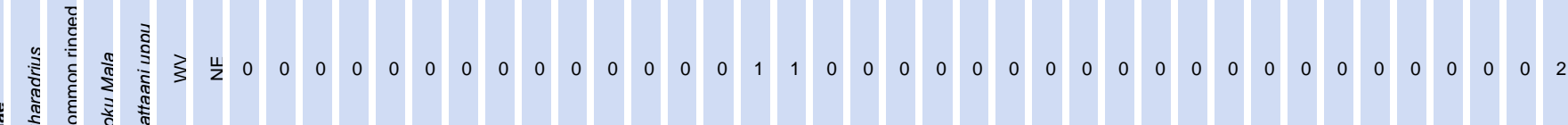

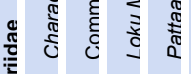

选

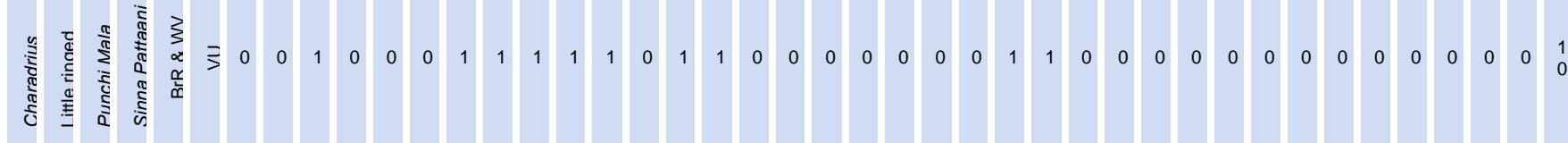

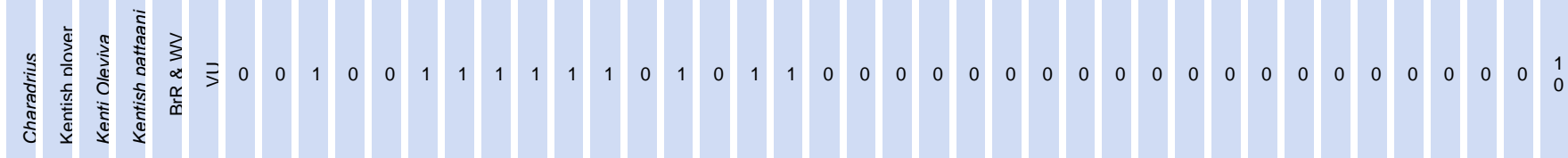

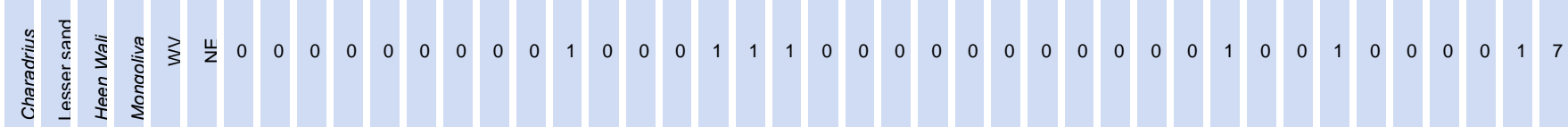




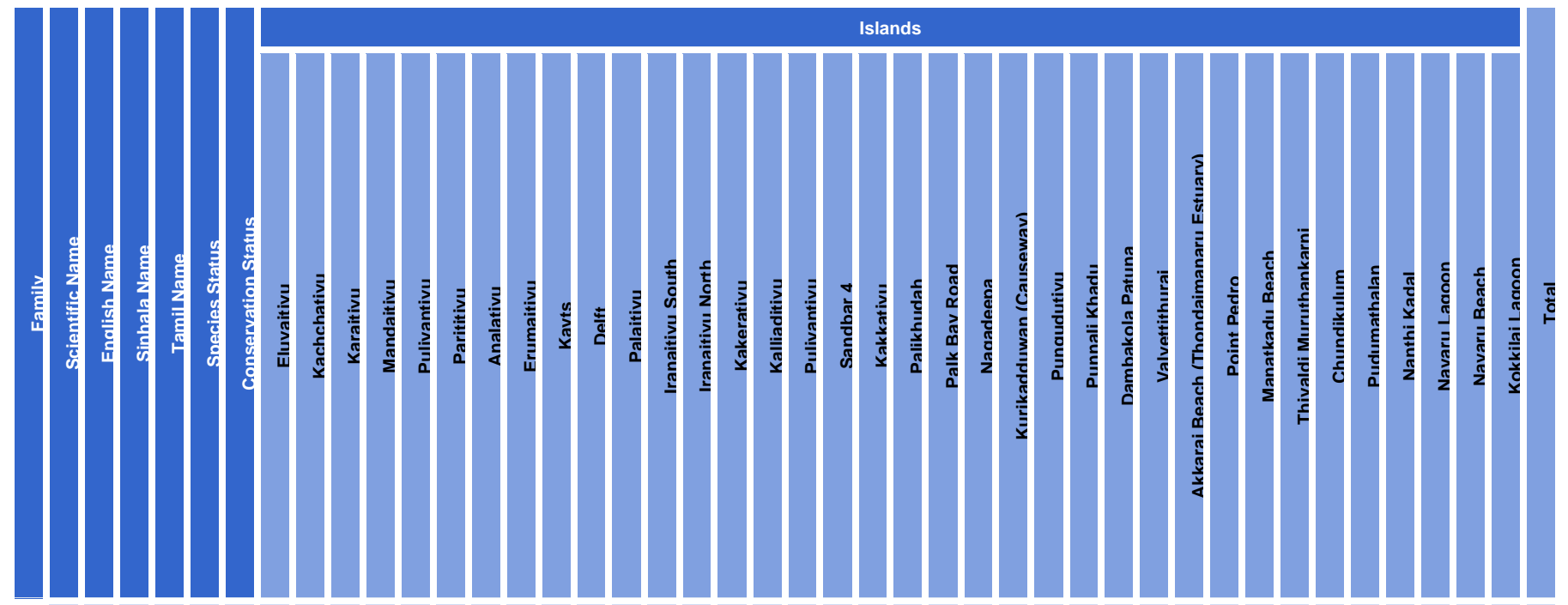

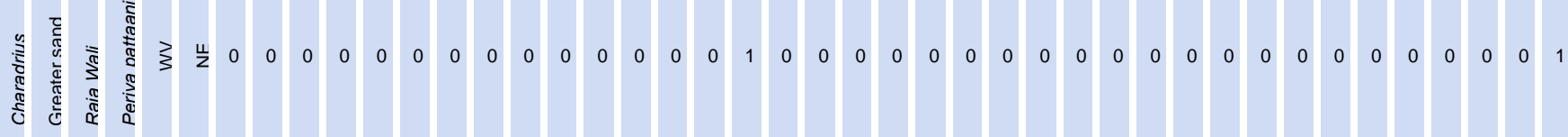

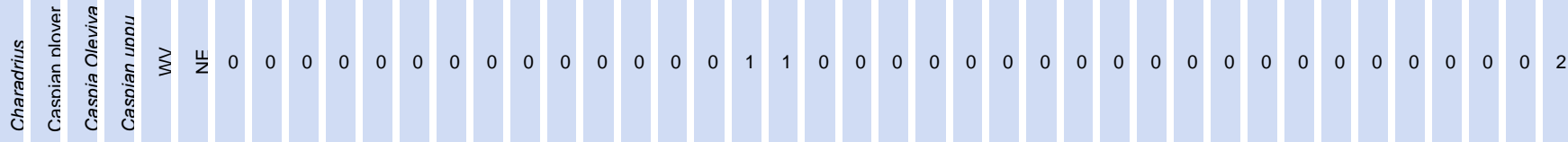

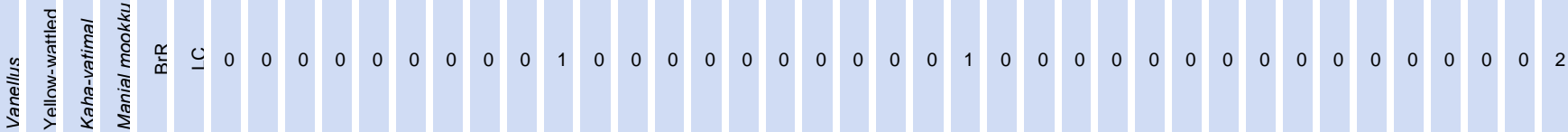
> $>2$

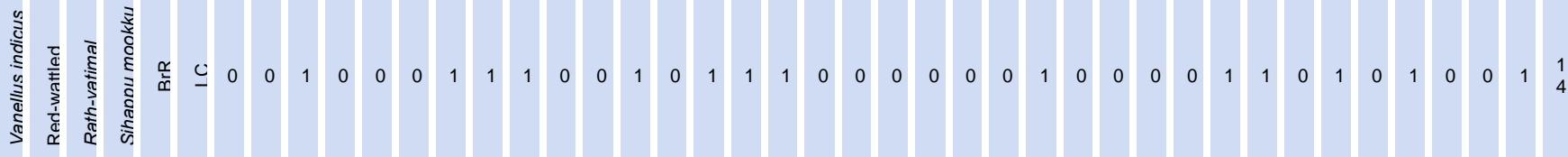

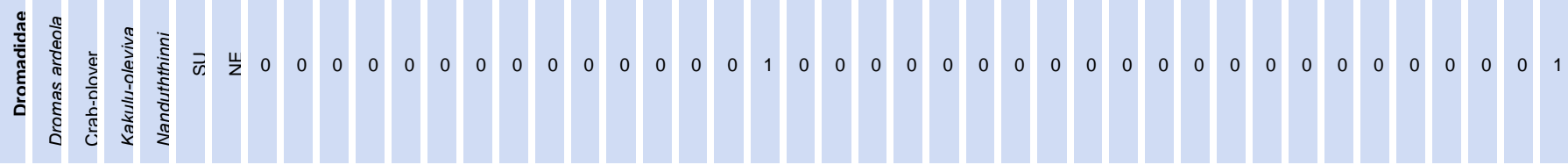

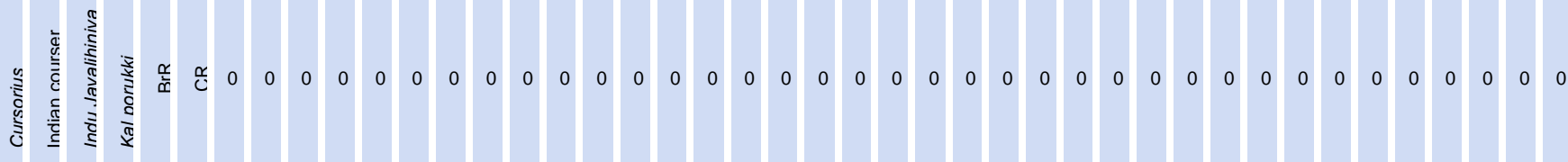

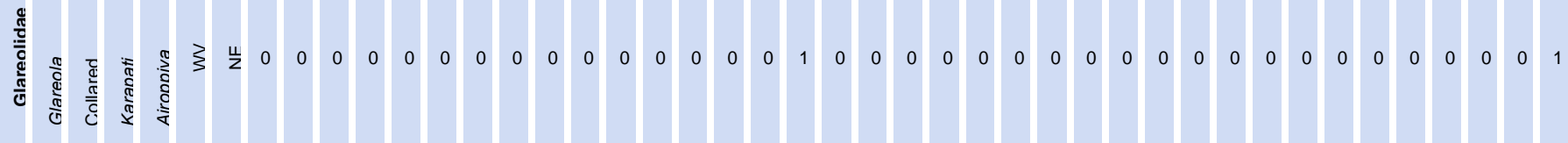

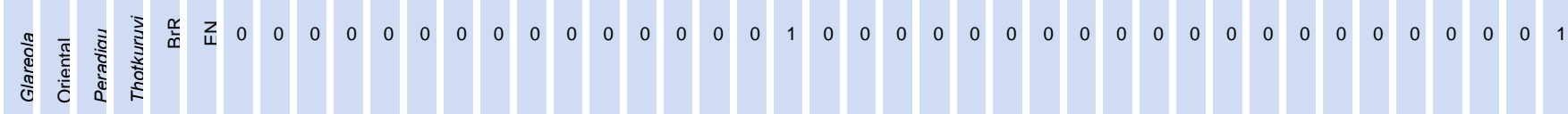




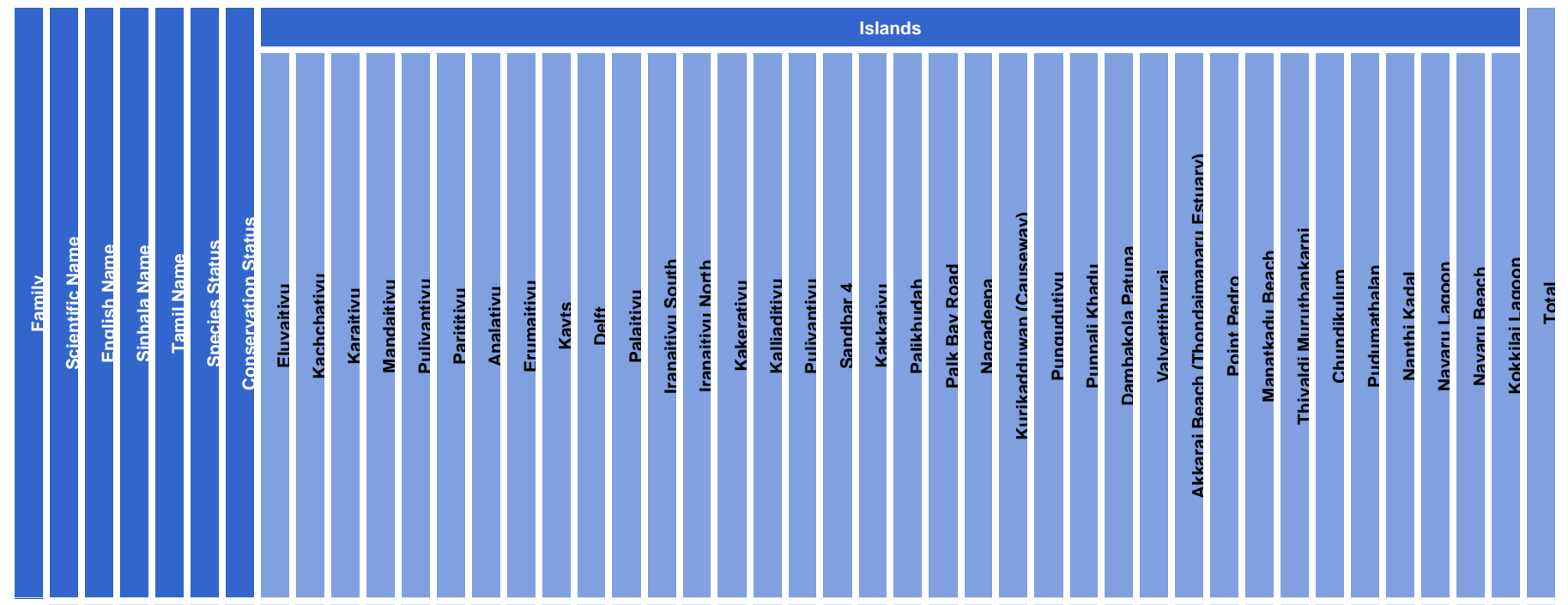

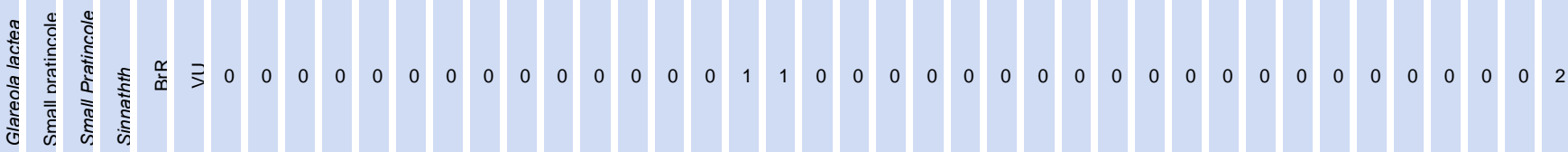

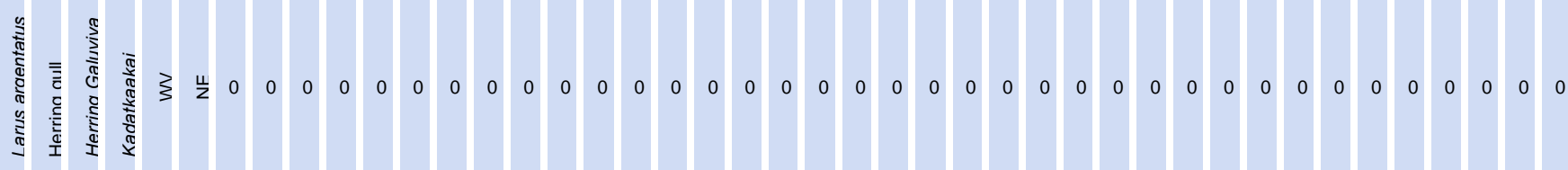

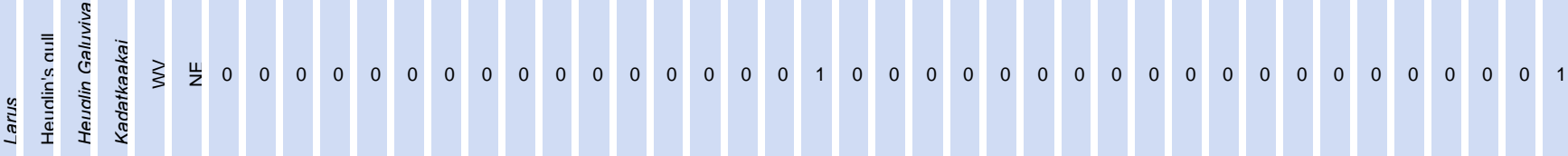

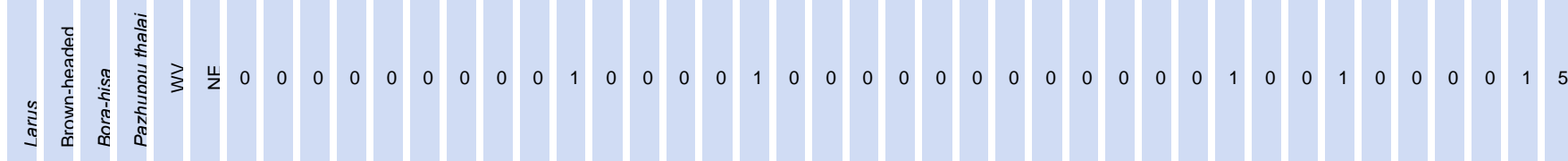

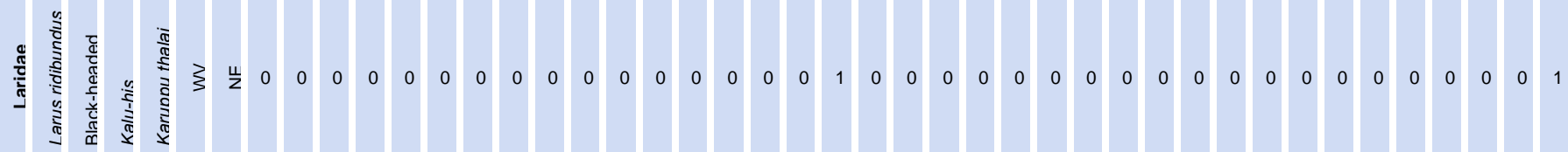

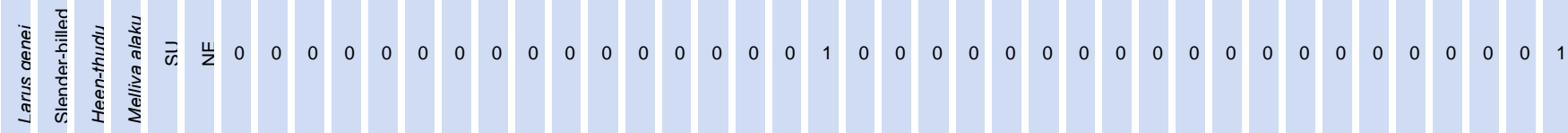

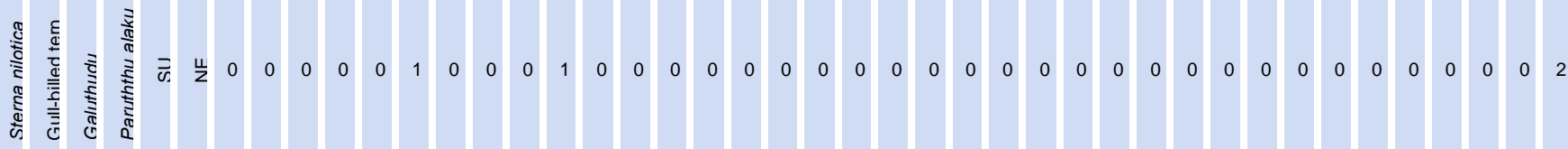

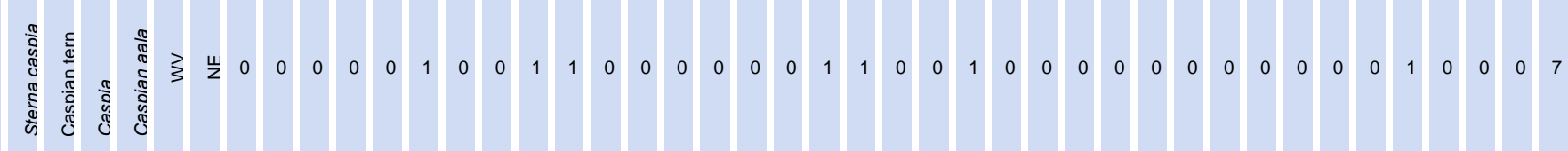




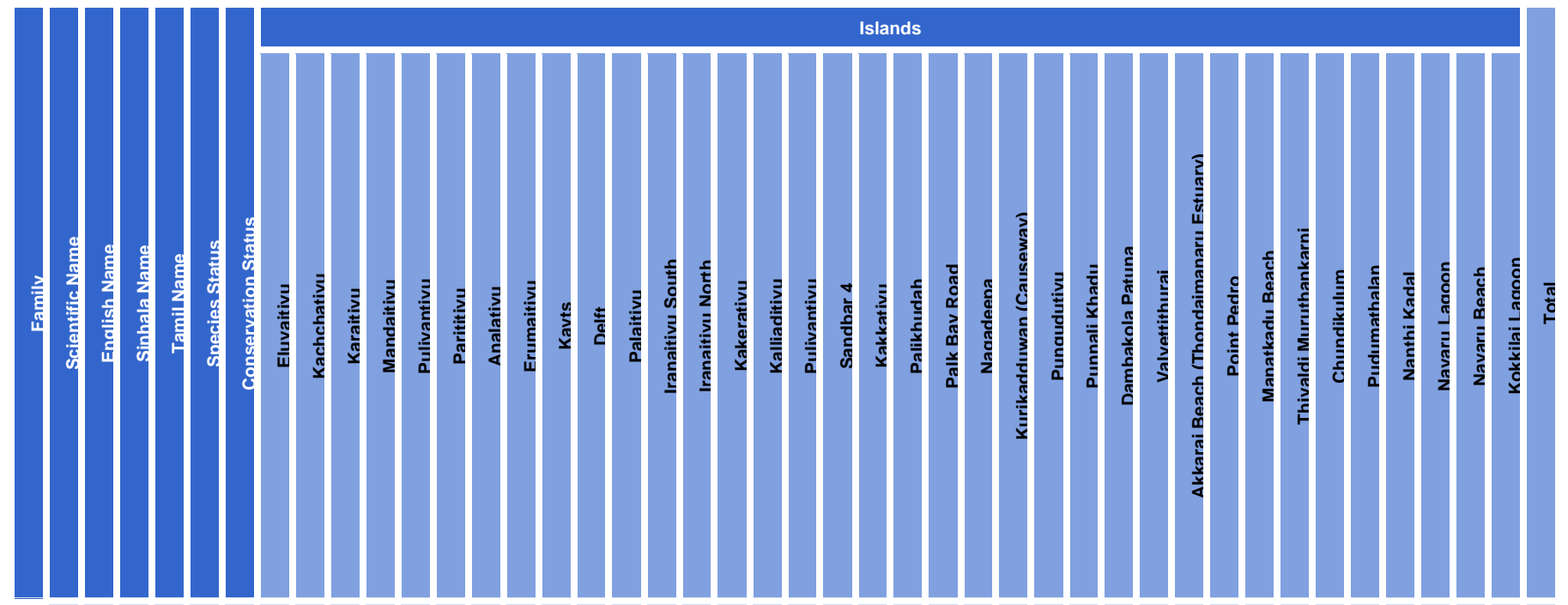

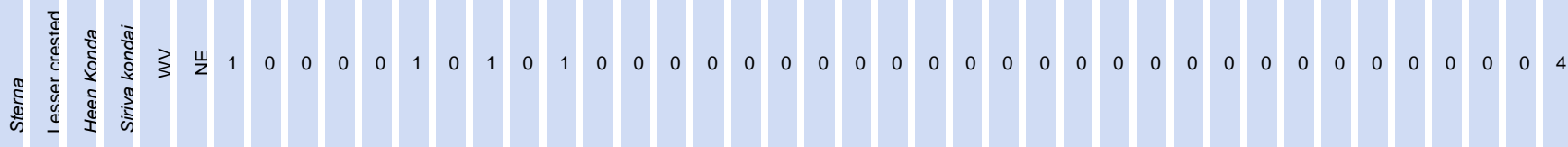

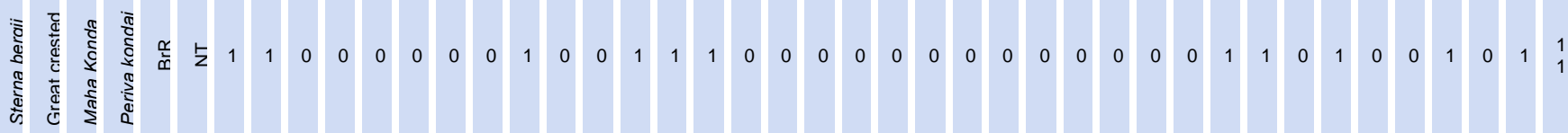

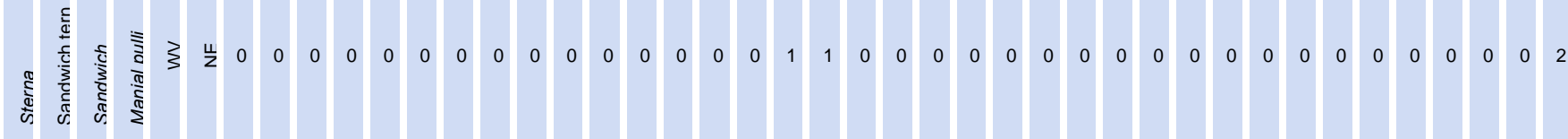

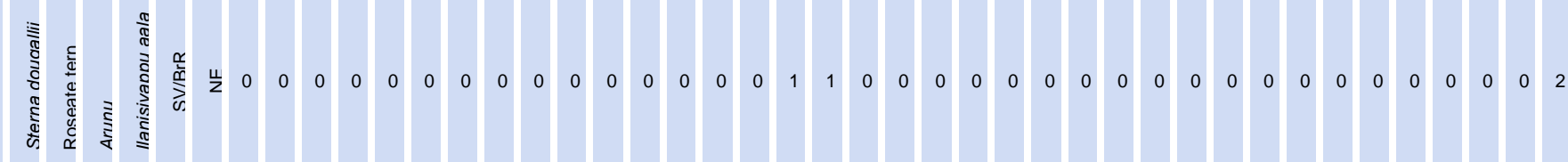

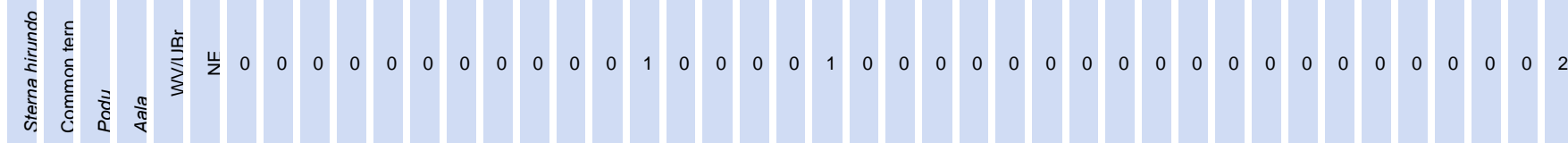

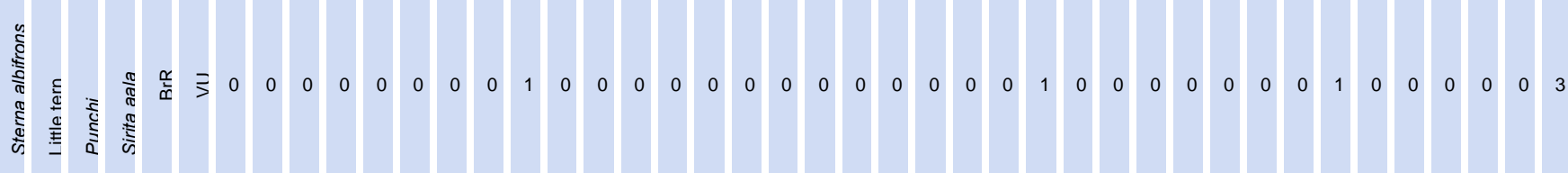

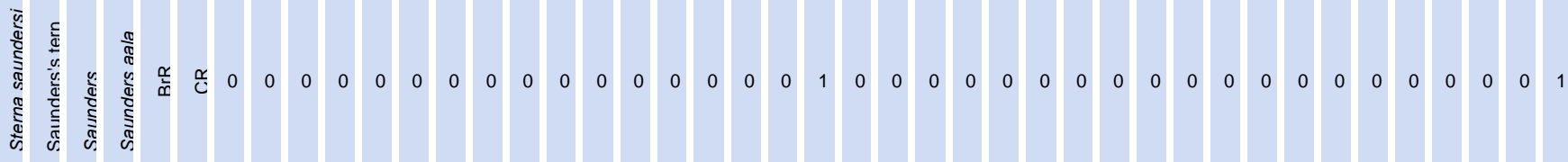

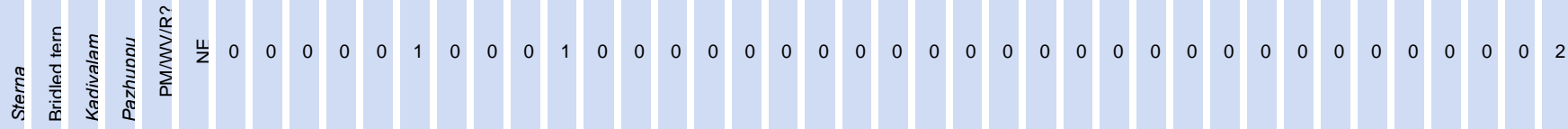




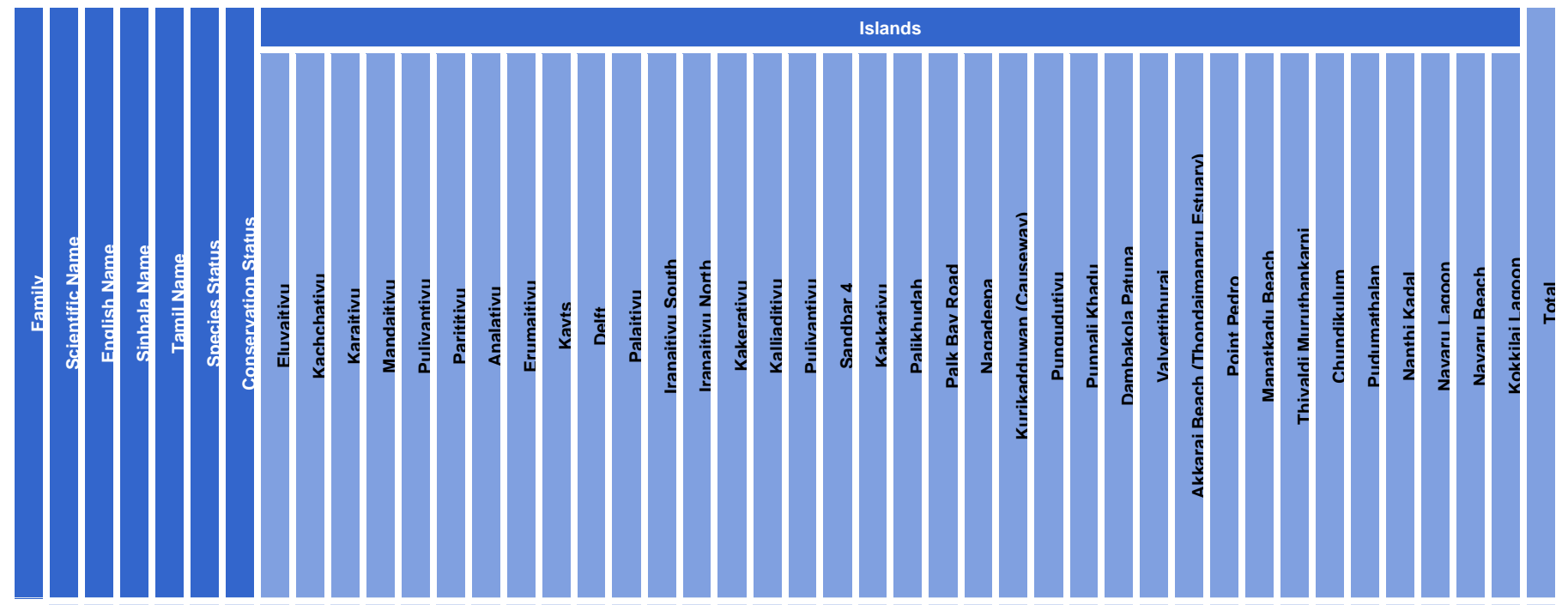

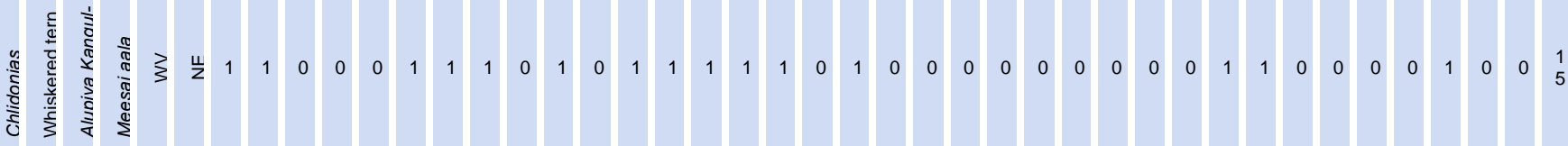

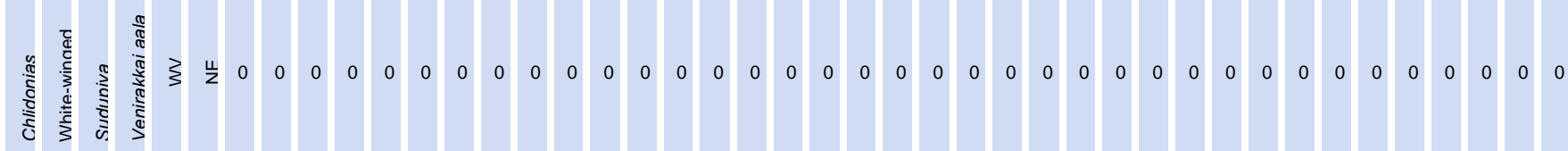

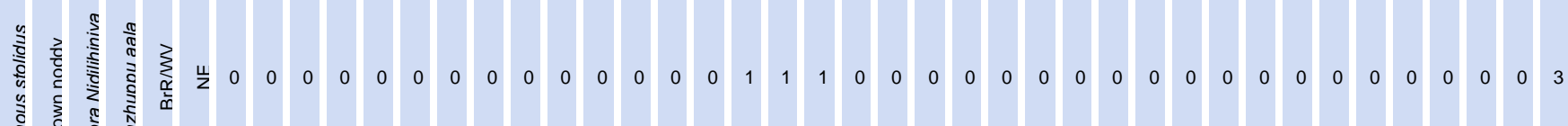

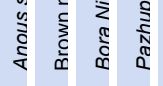

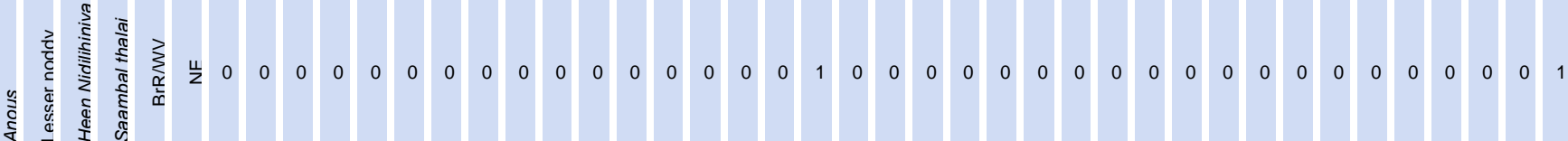

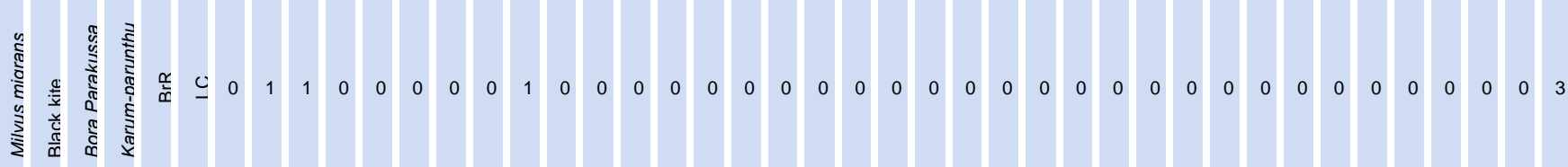

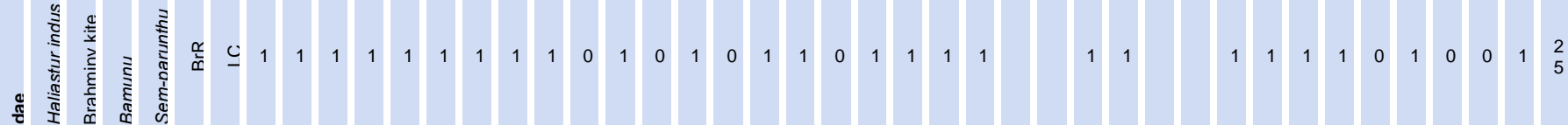
要

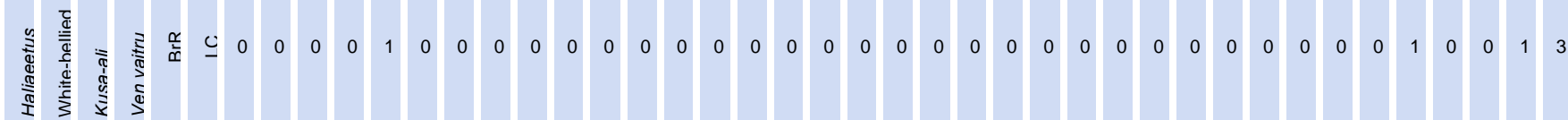

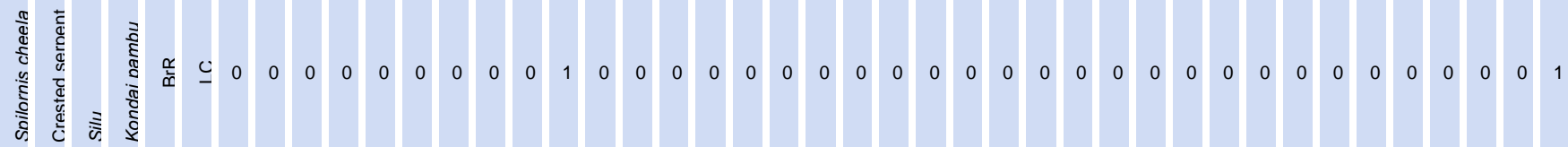




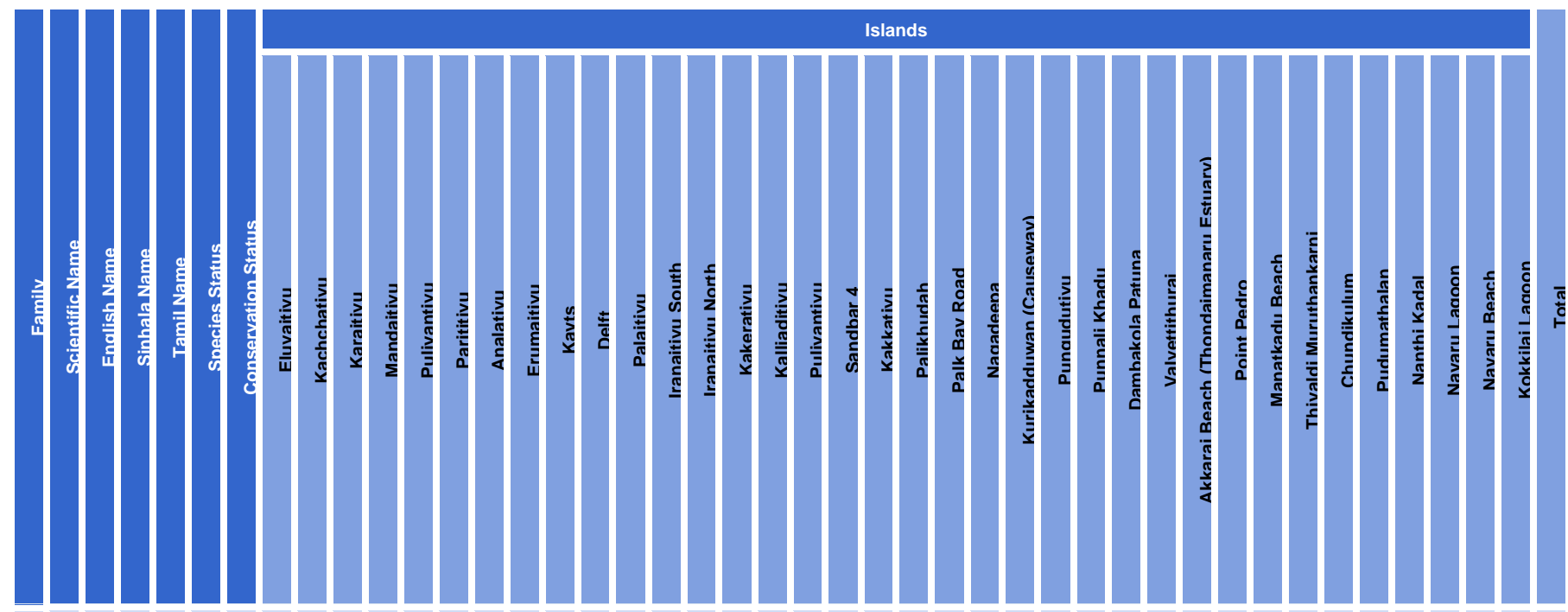

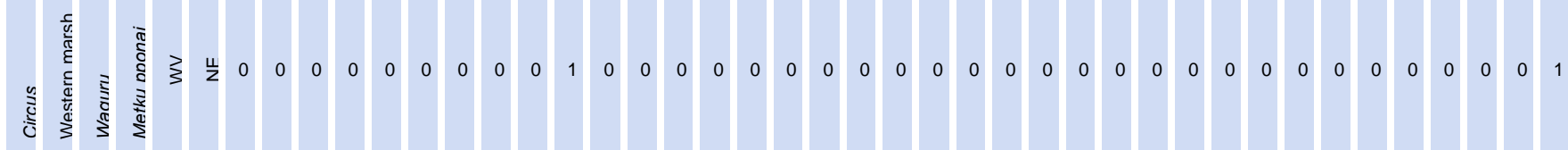

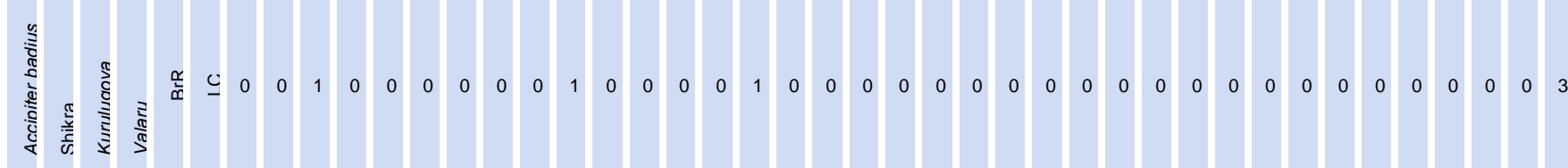

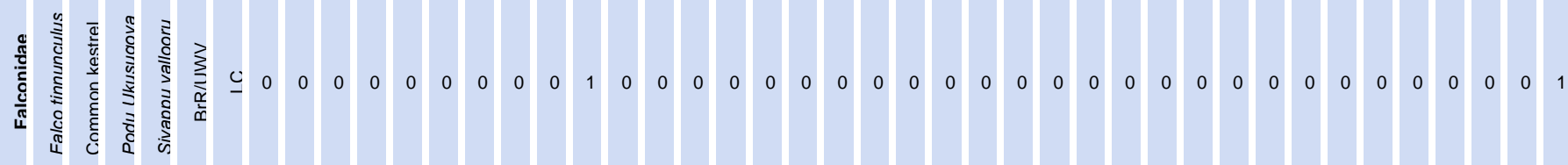

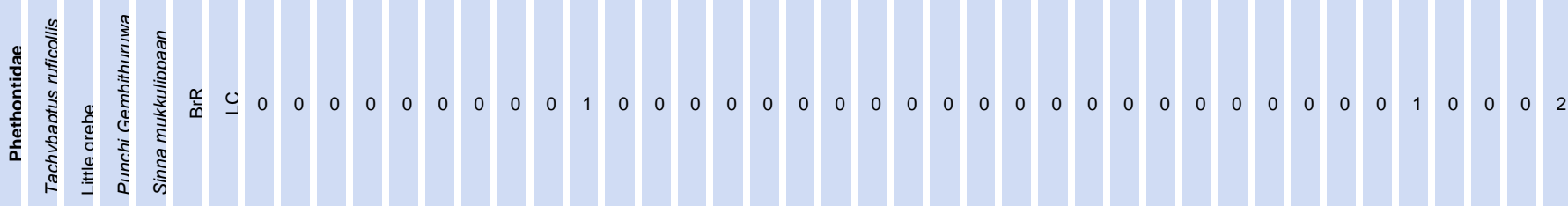

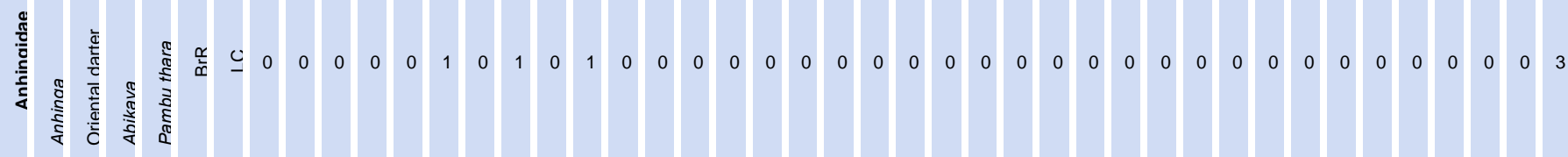

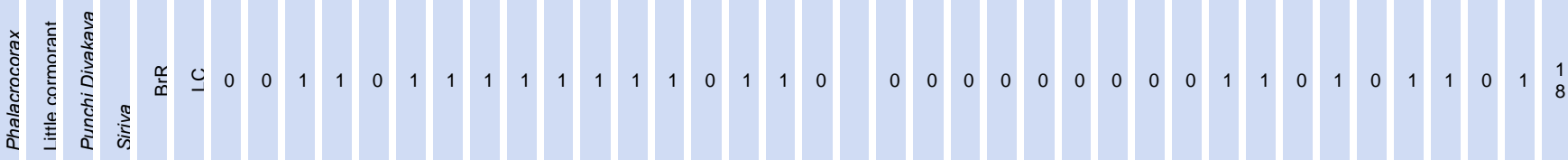

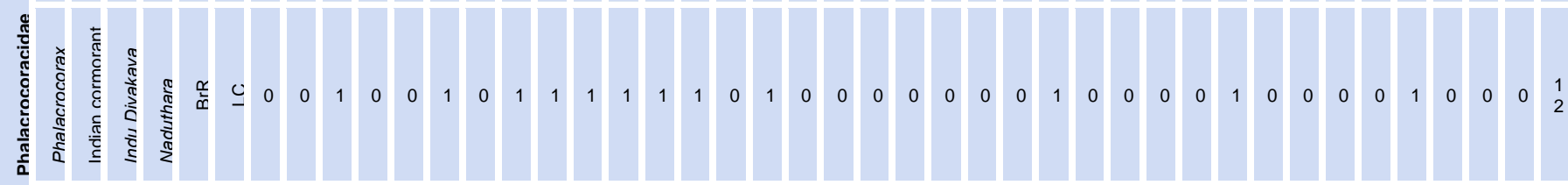

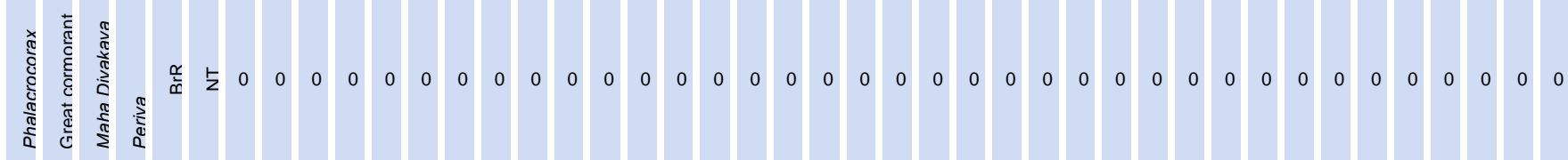




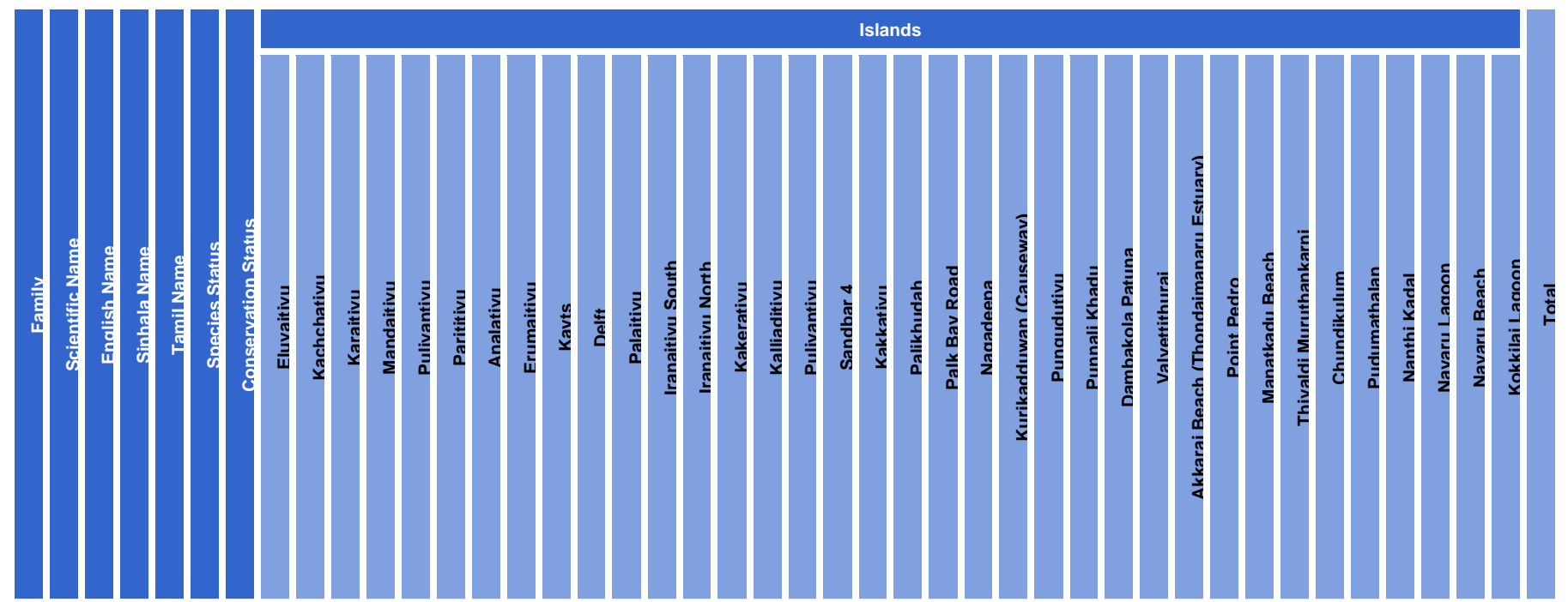

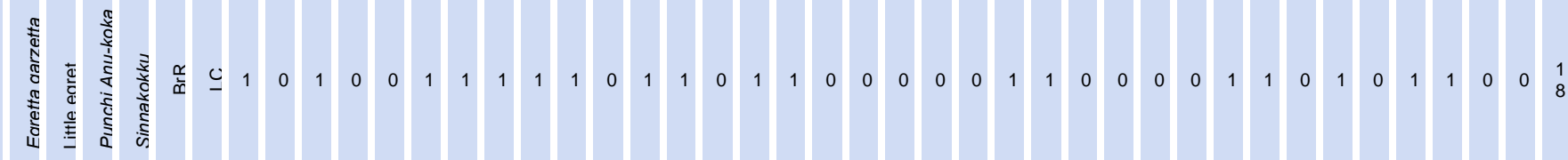

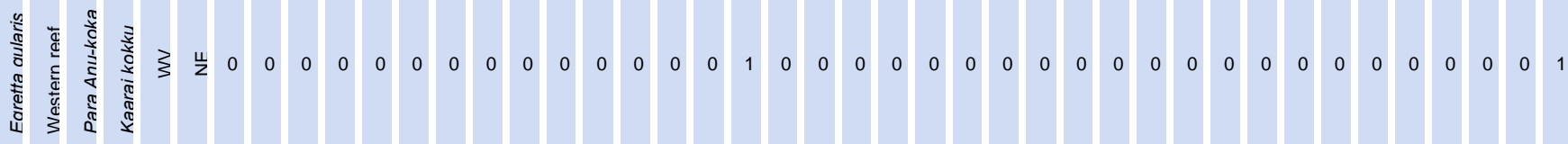

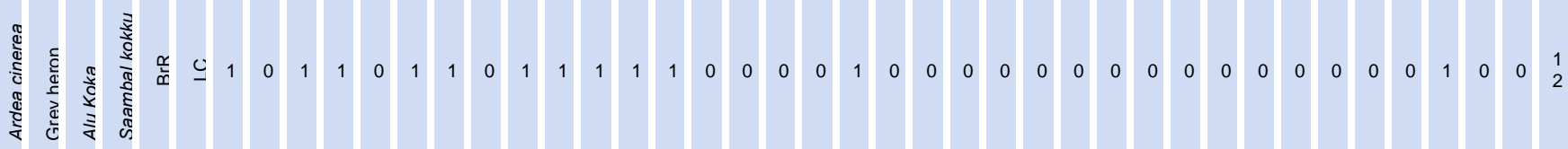

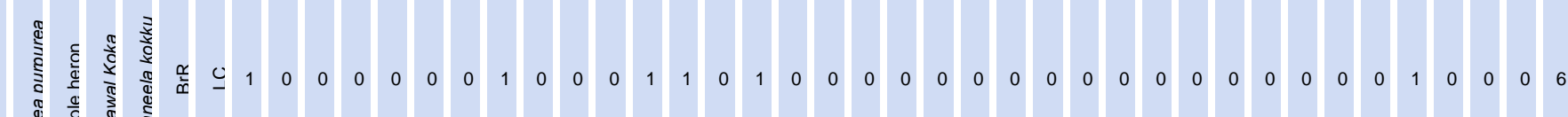

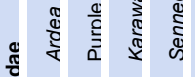

高

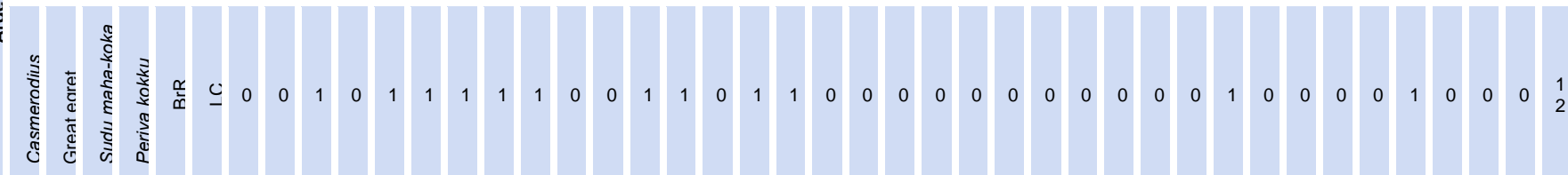

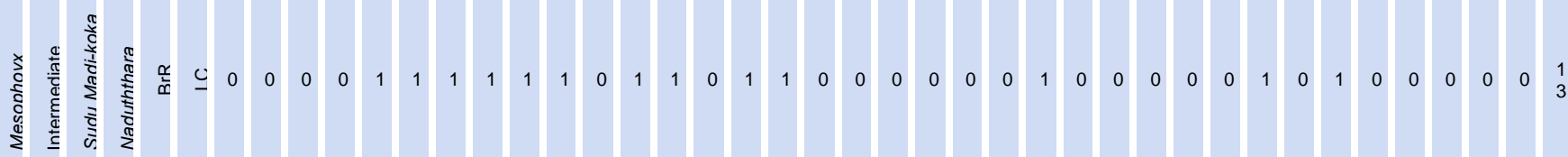

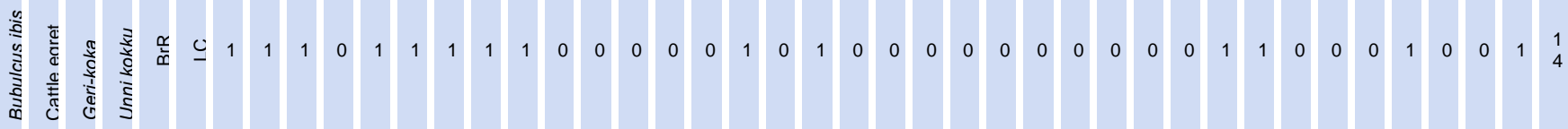

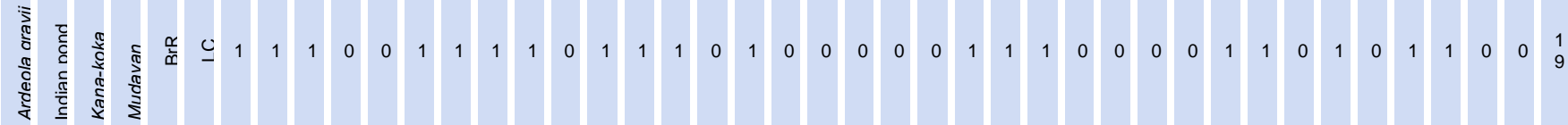




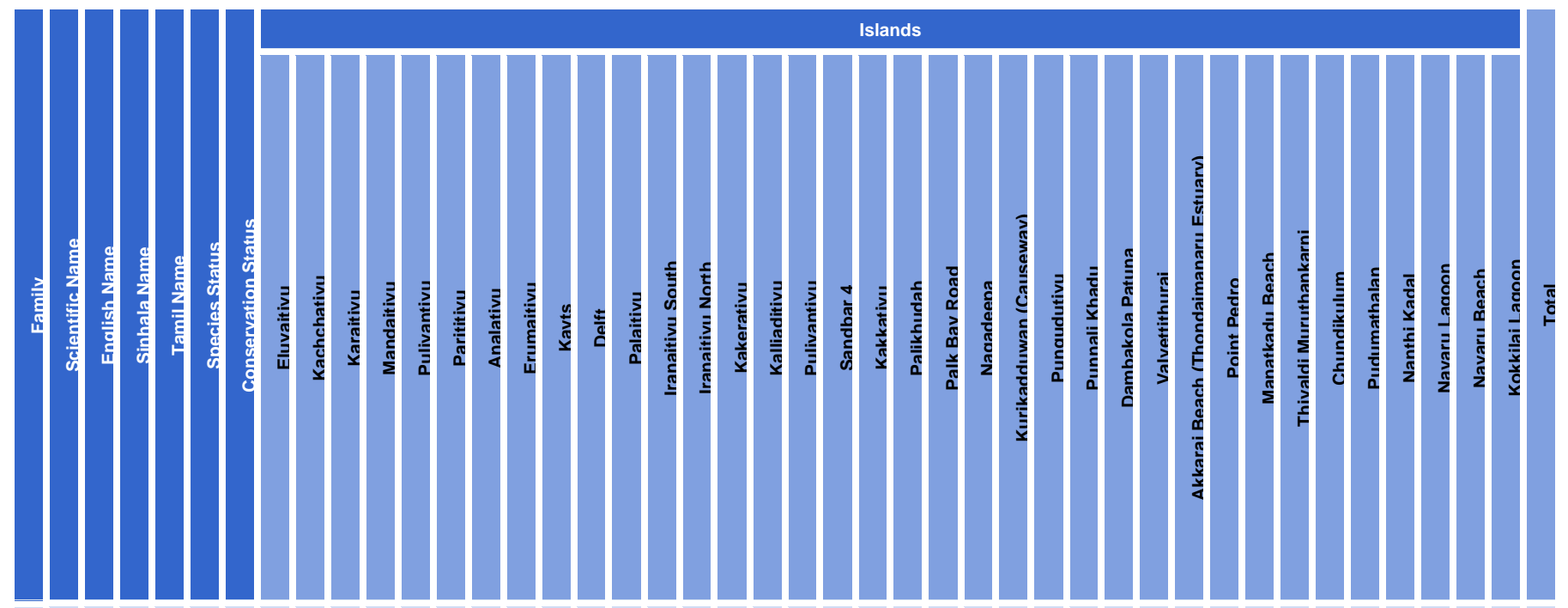

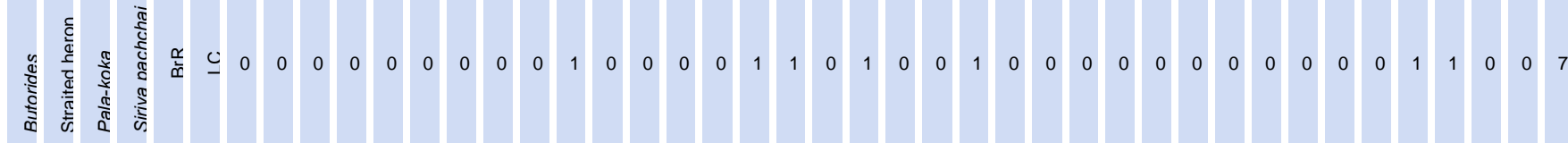

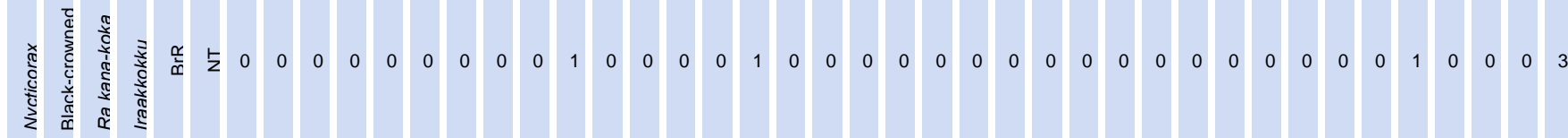

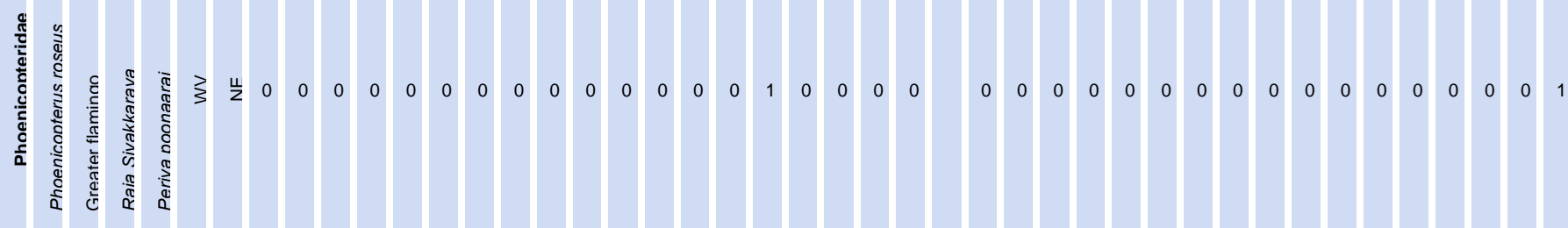

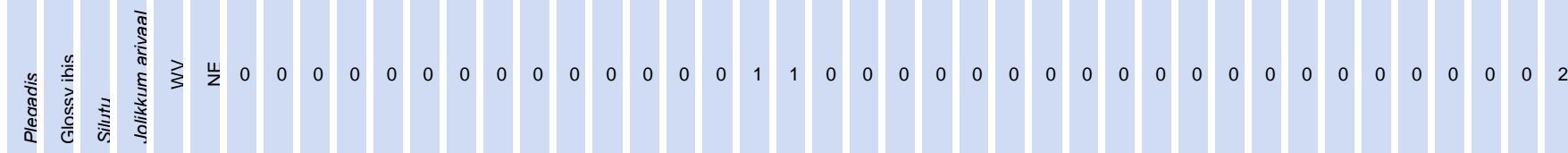

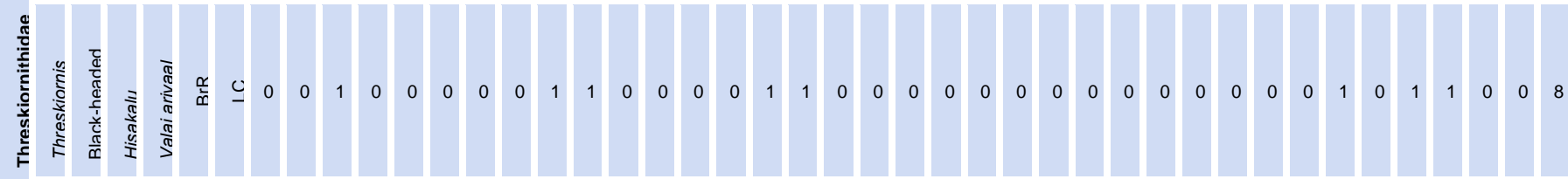

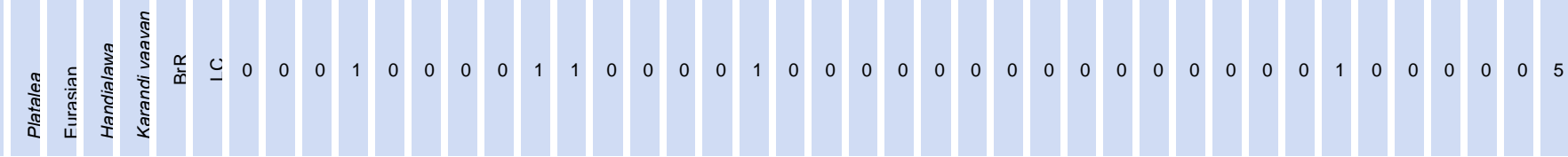

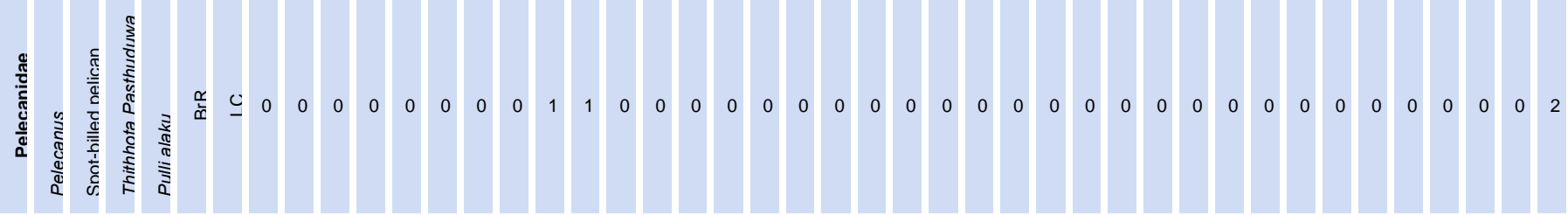

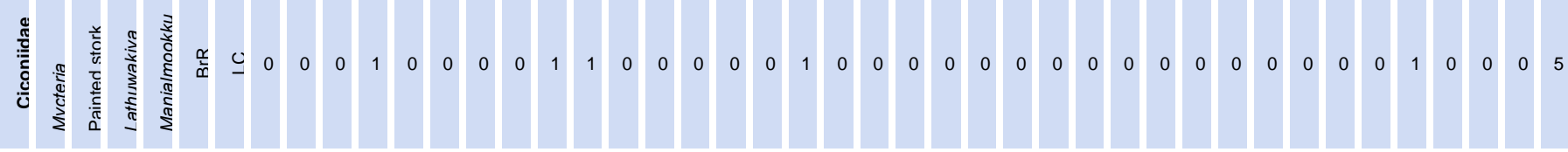




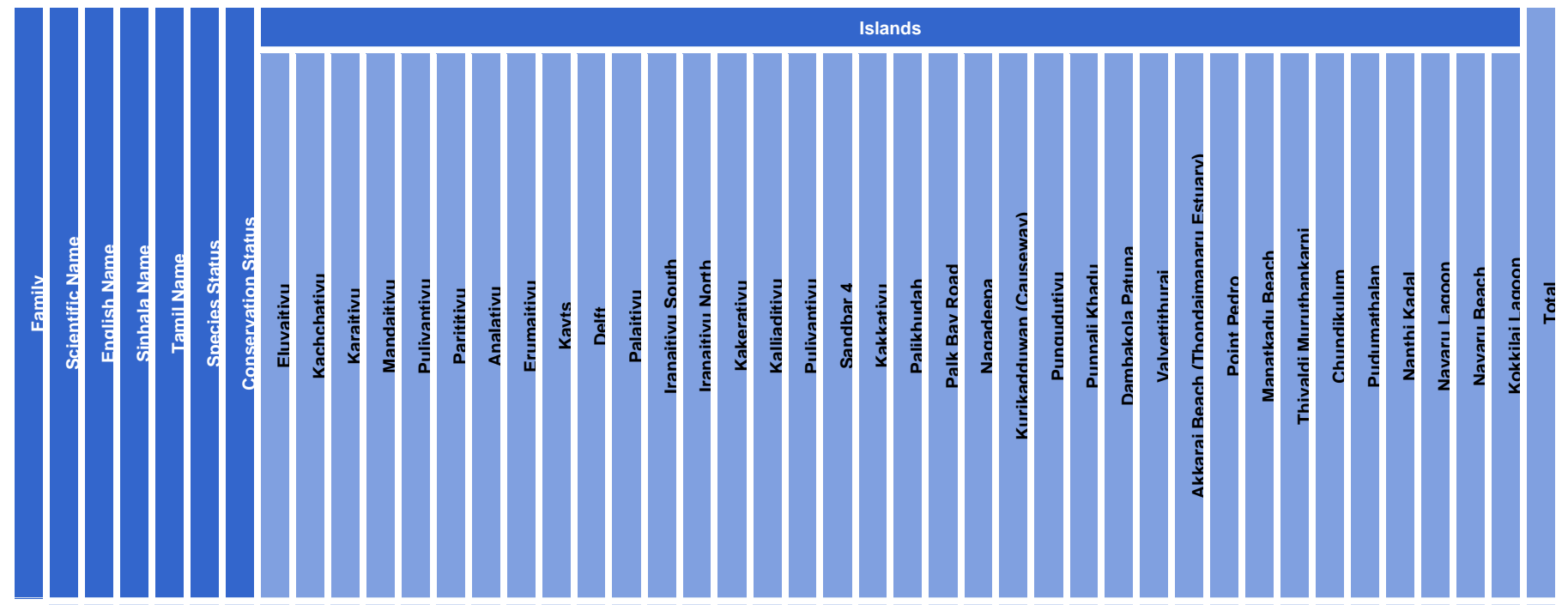

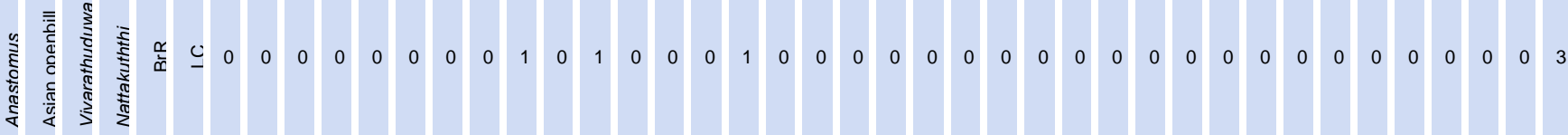

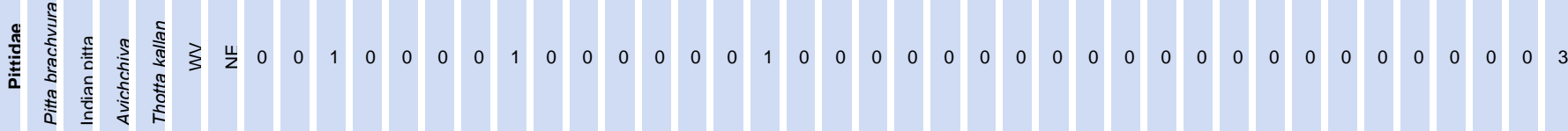

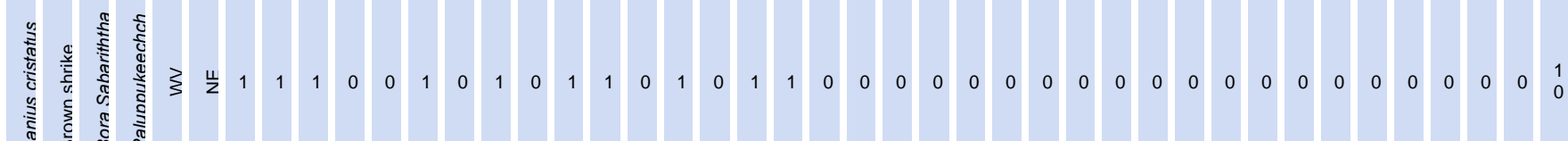

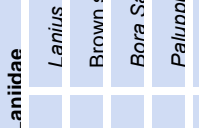

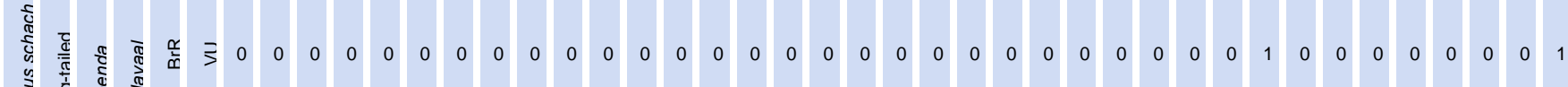

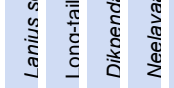

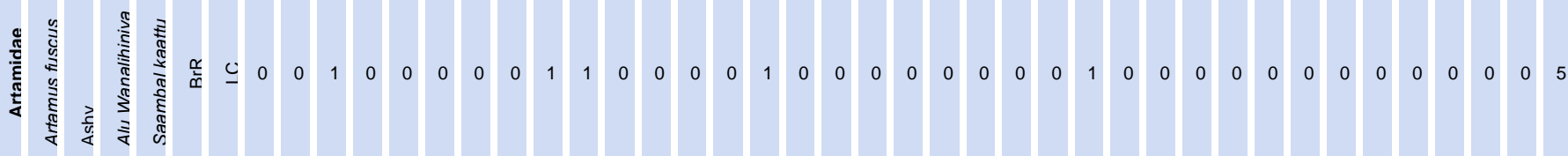

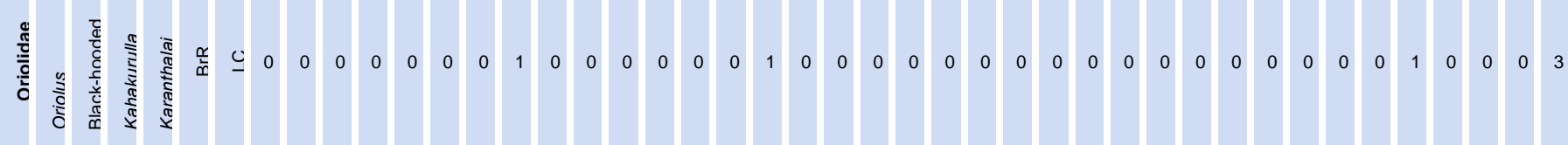

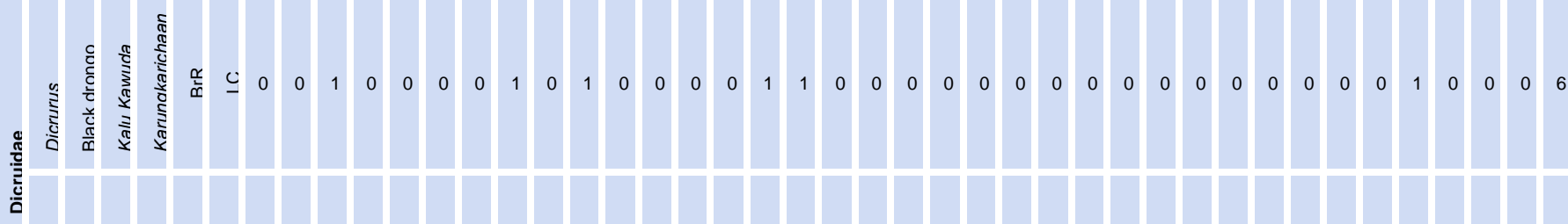

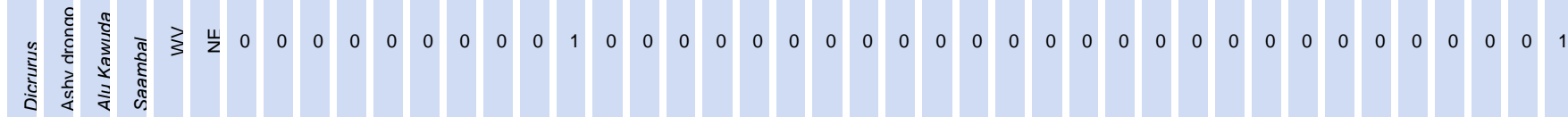




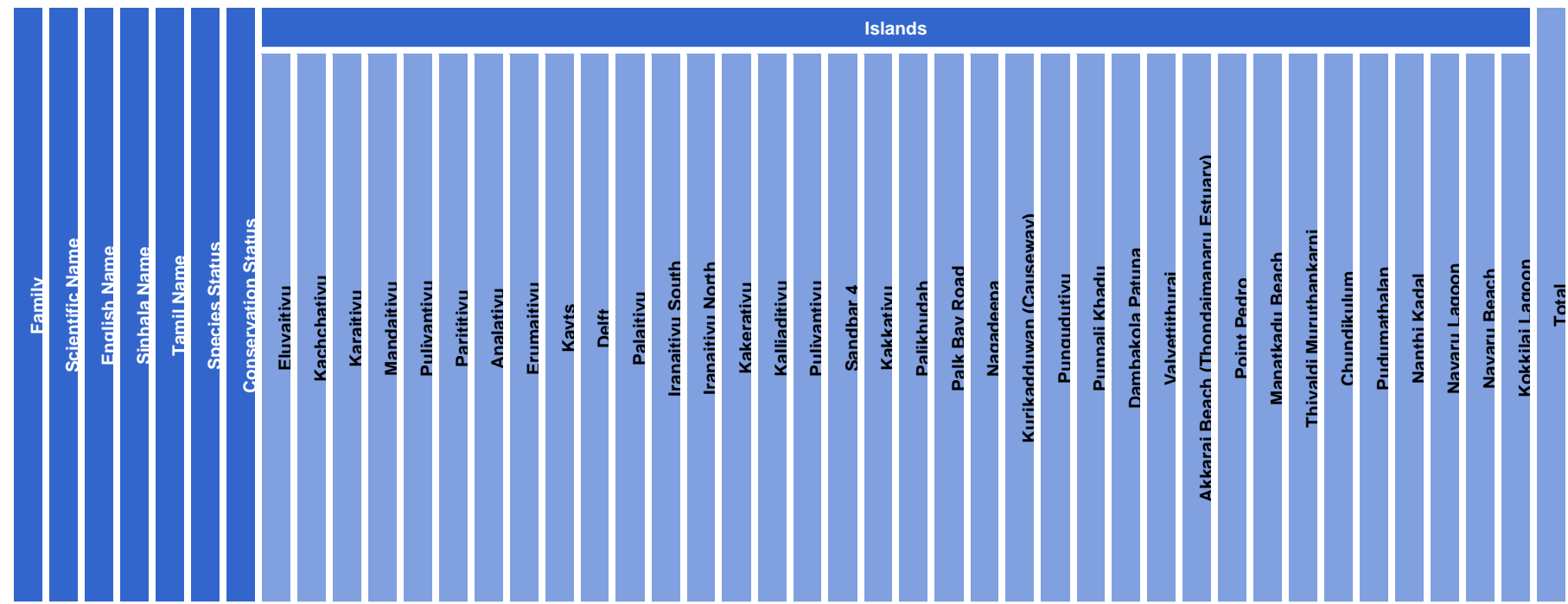

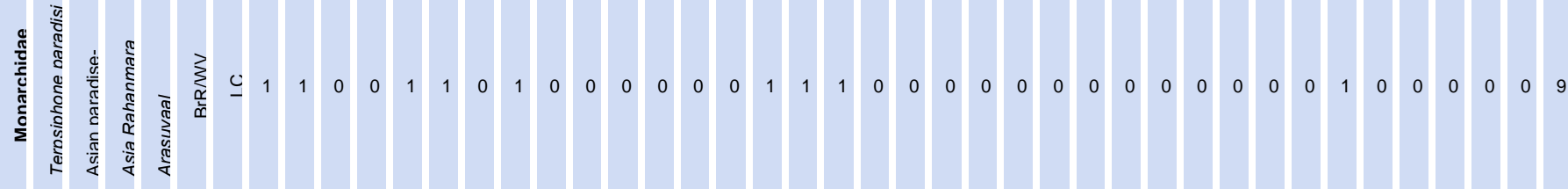

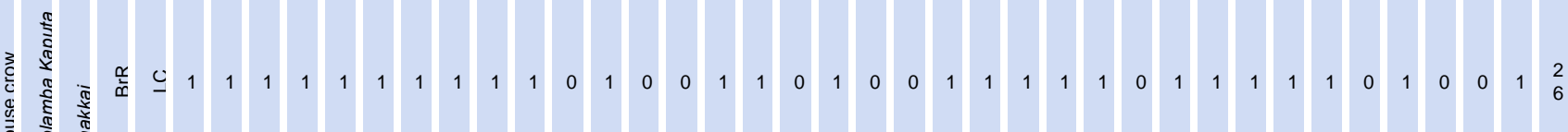
).

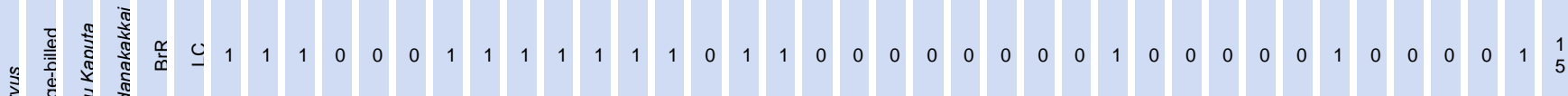
究

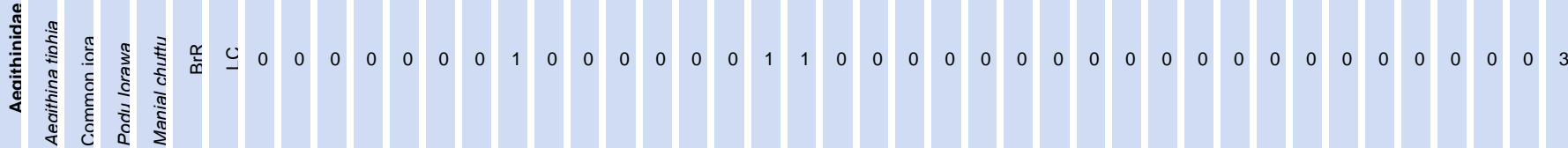

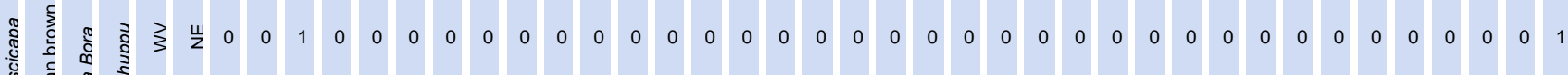

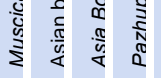

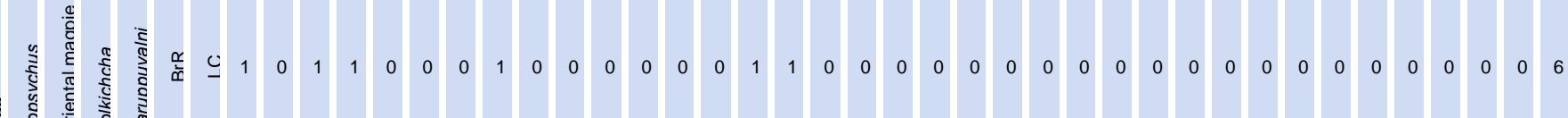
竎

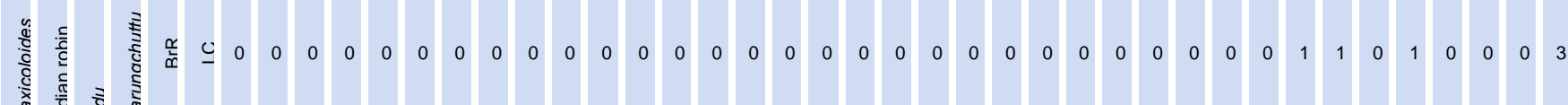

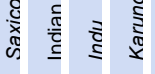

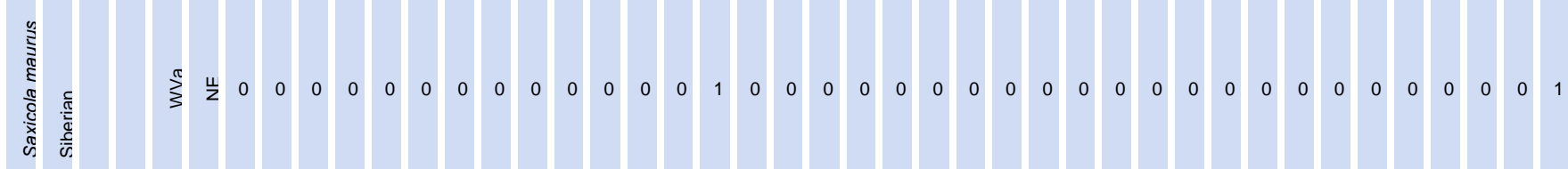




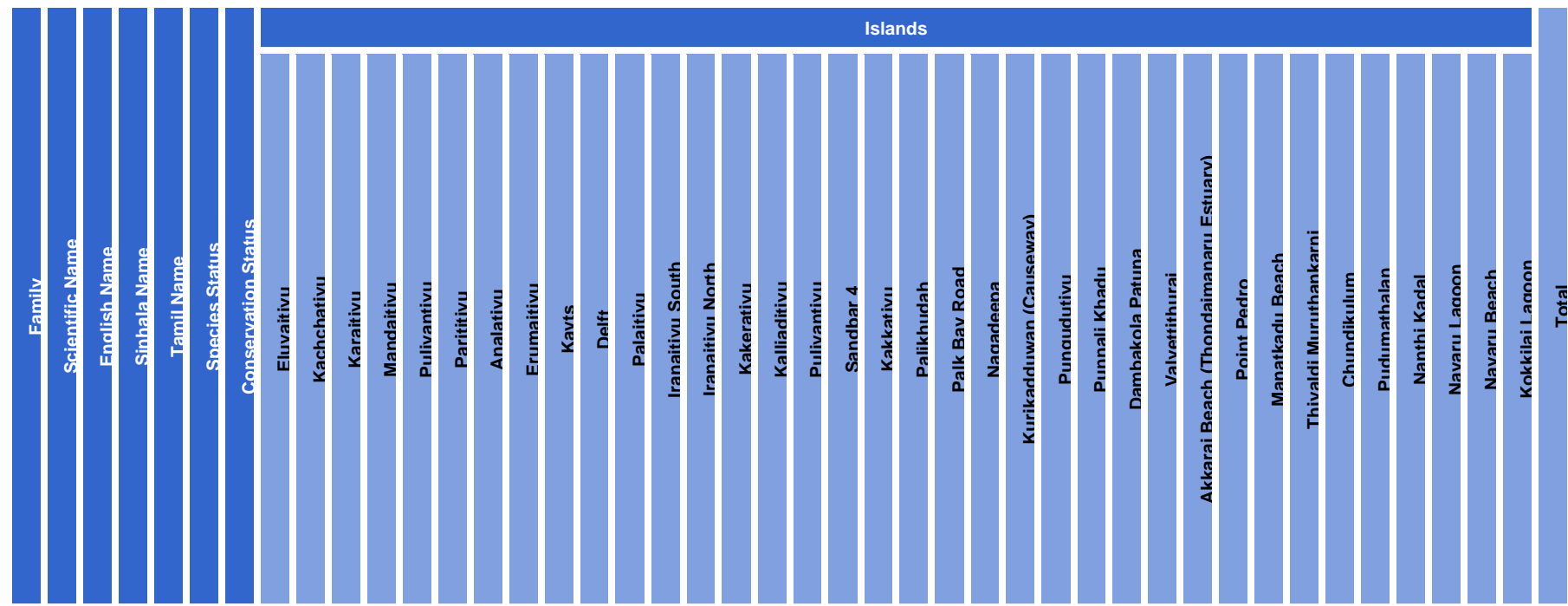

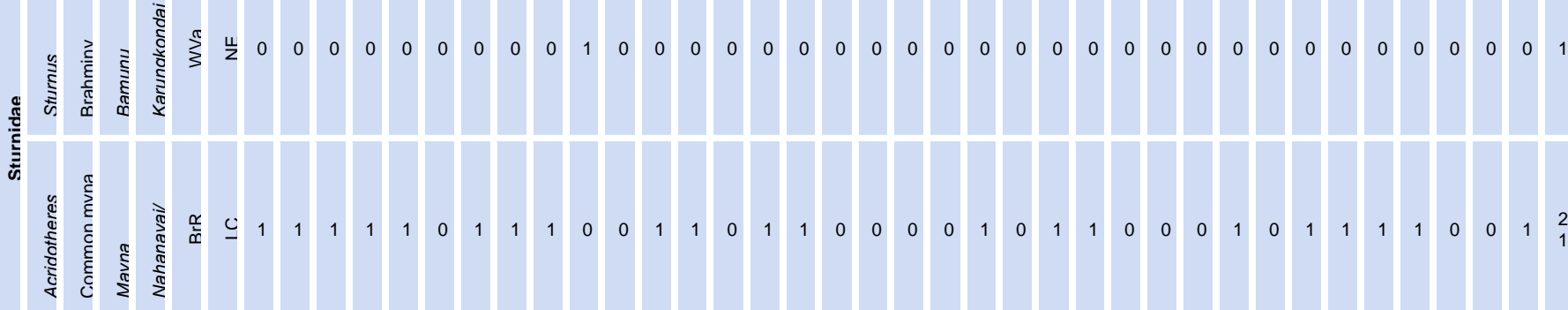

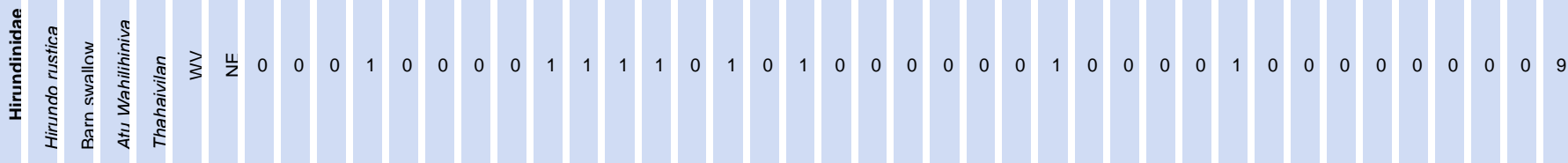

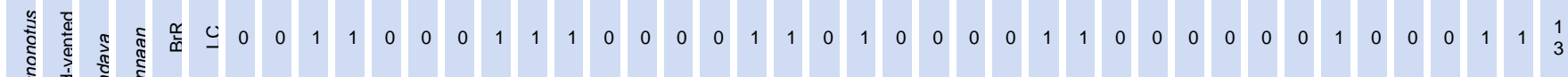

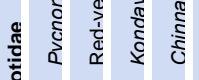

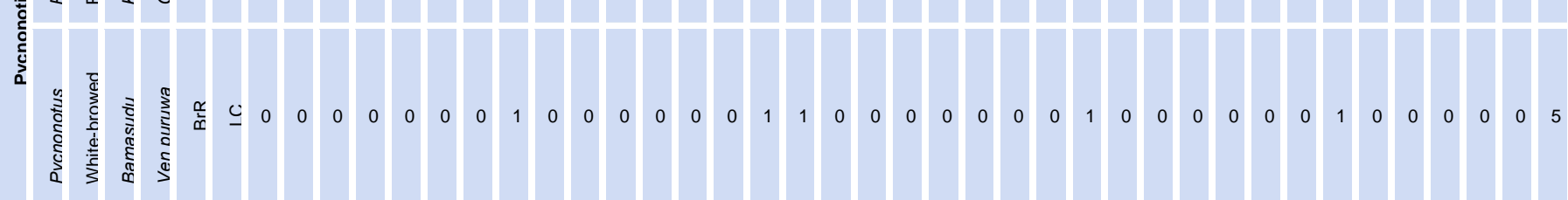

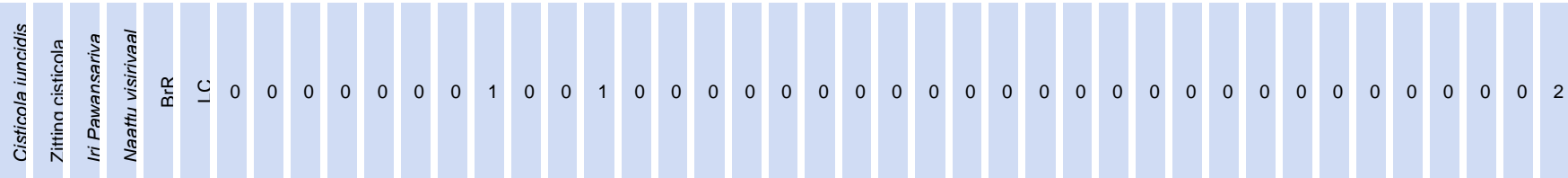

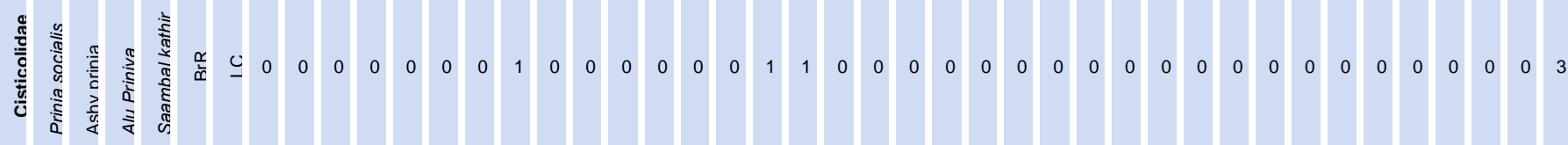

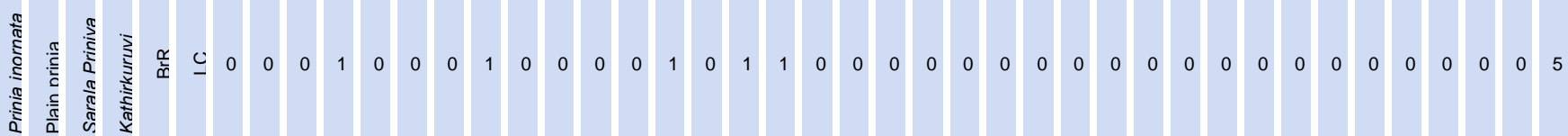




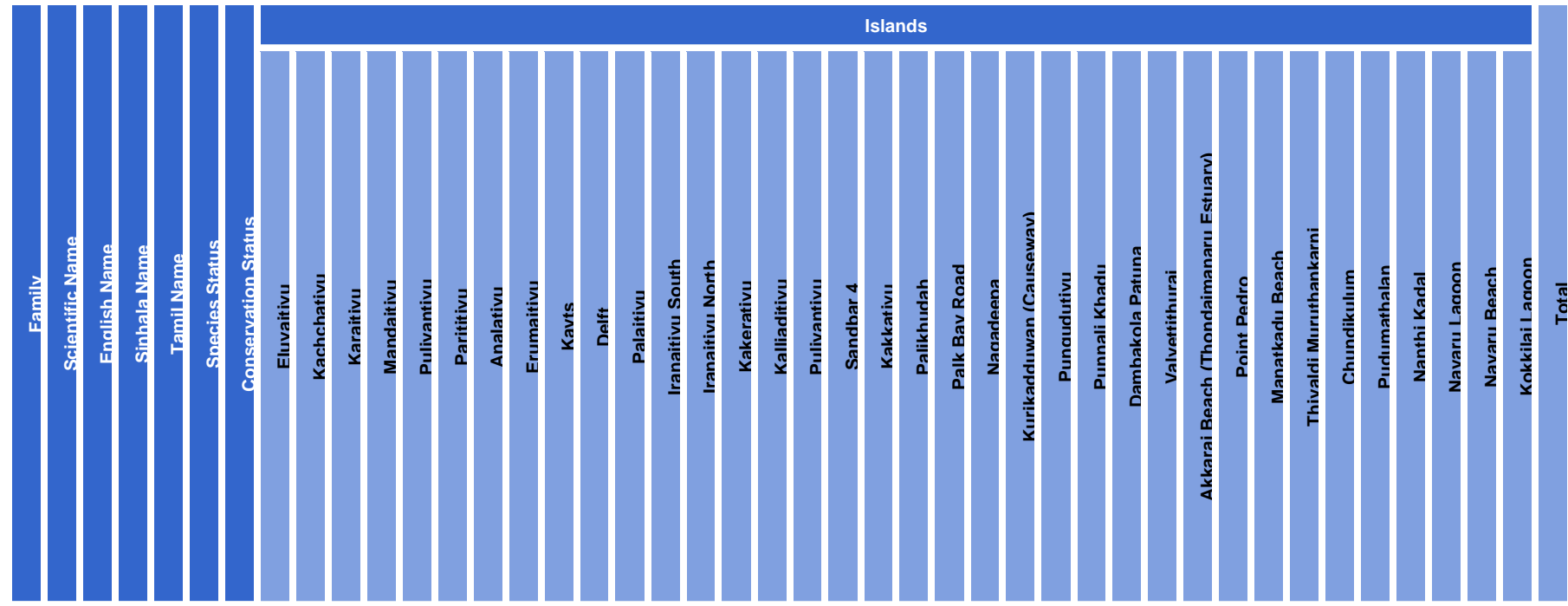

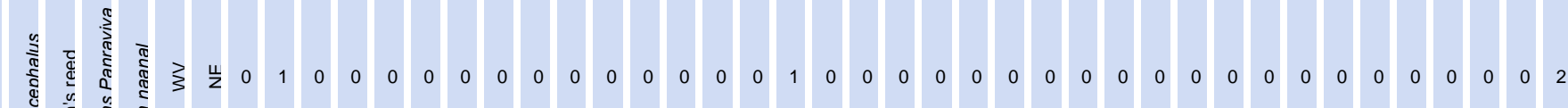
究

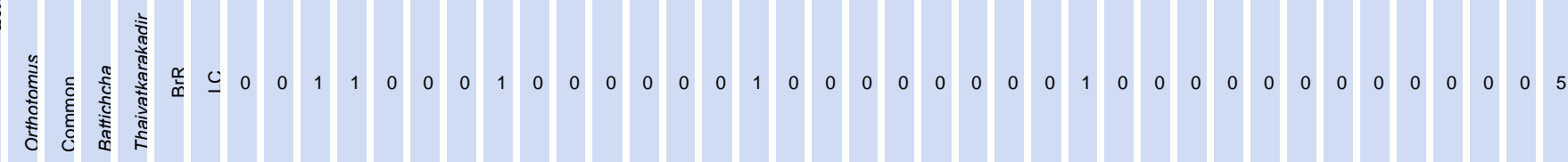

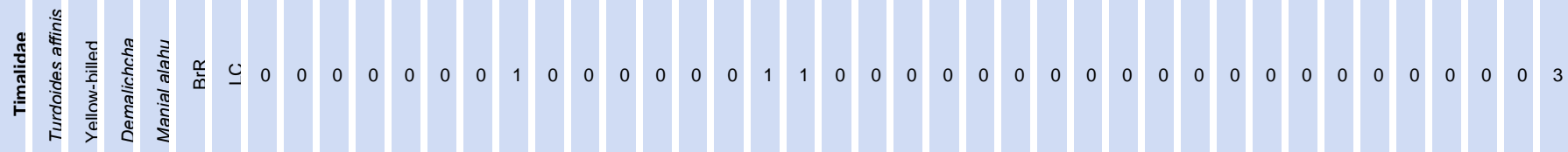

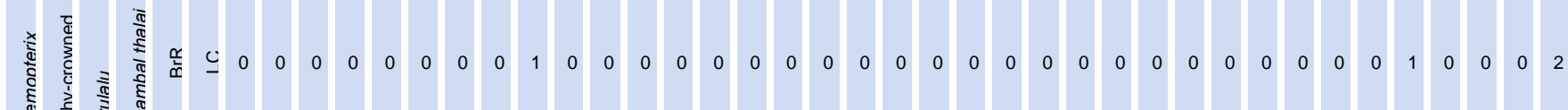

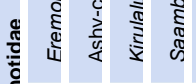

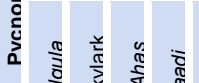

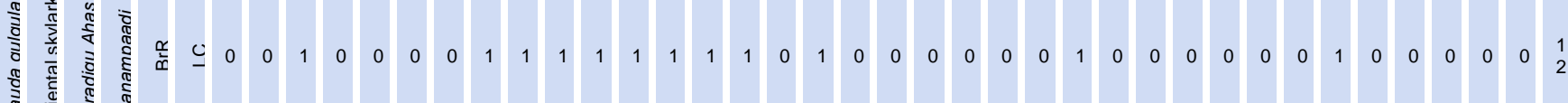

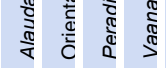

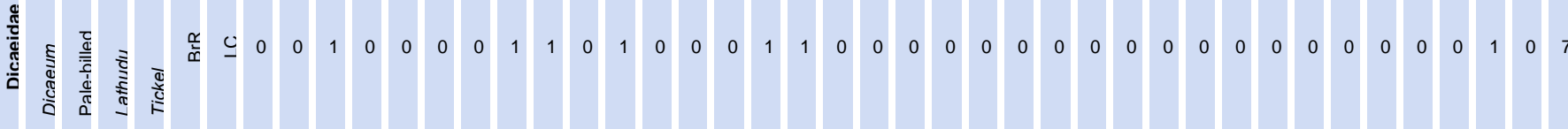

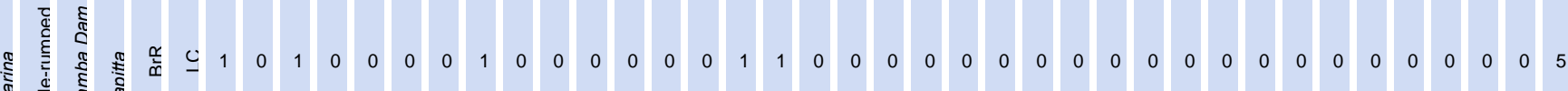

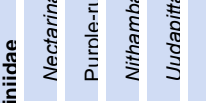

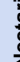

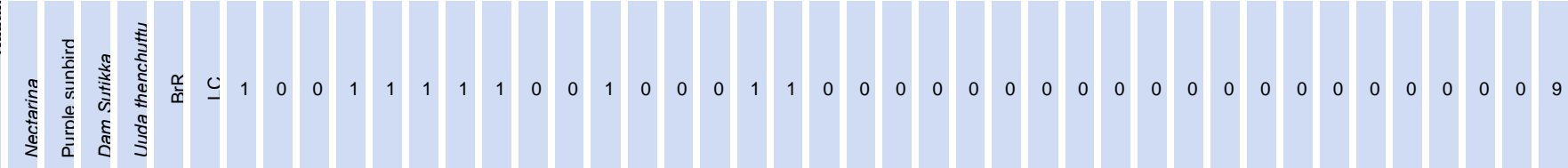




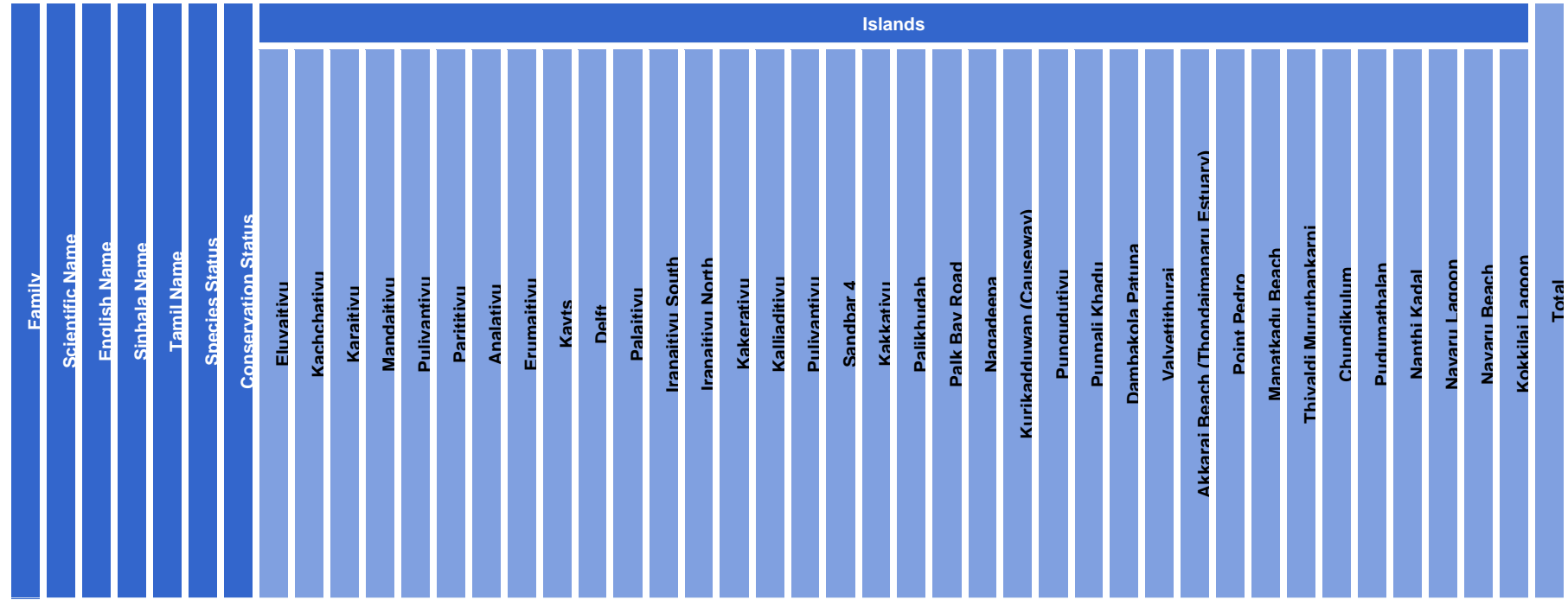

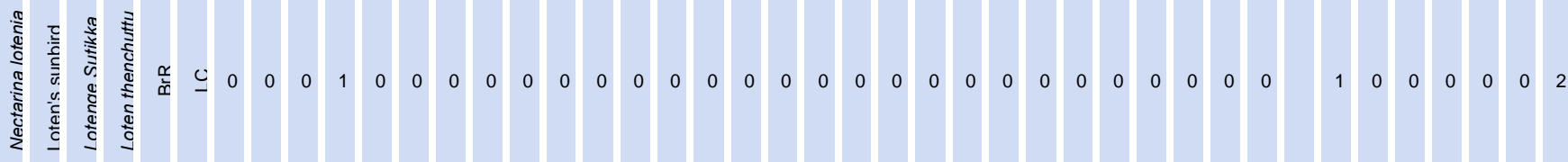

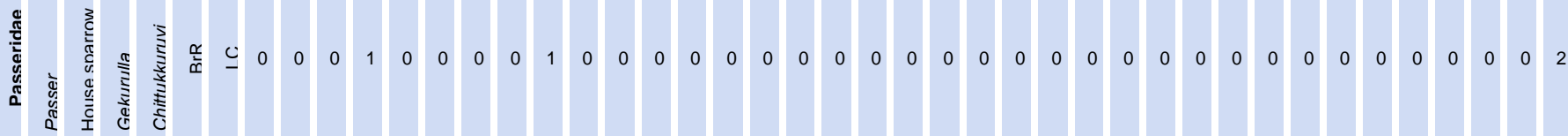

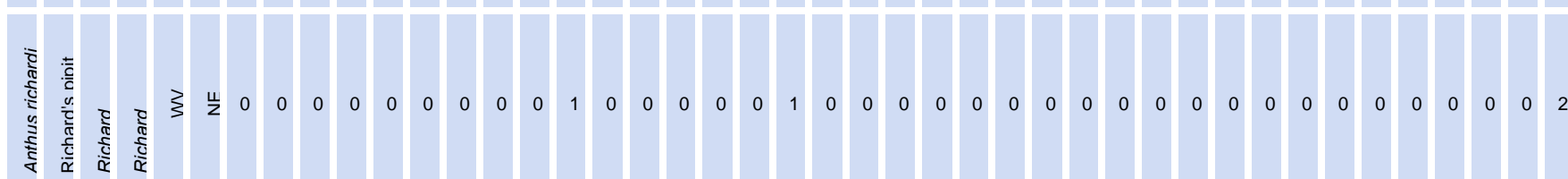

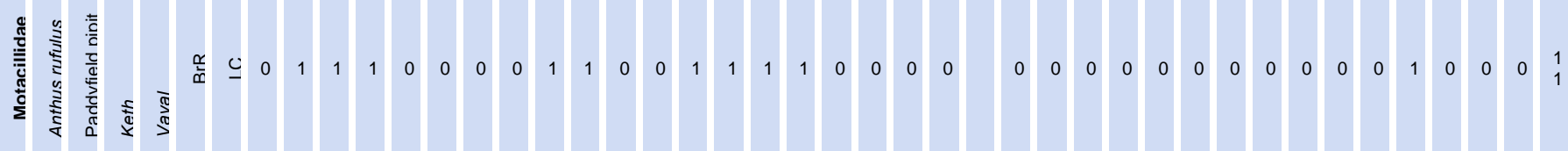

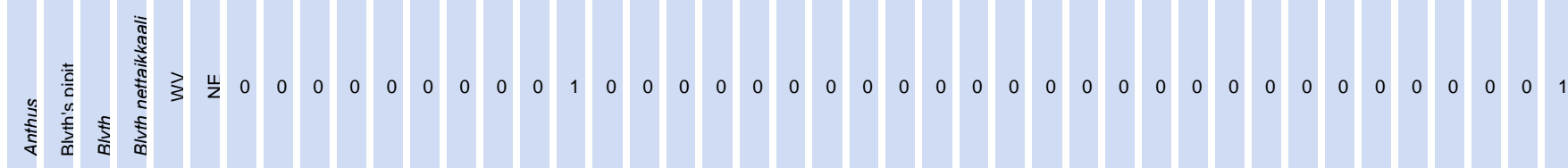

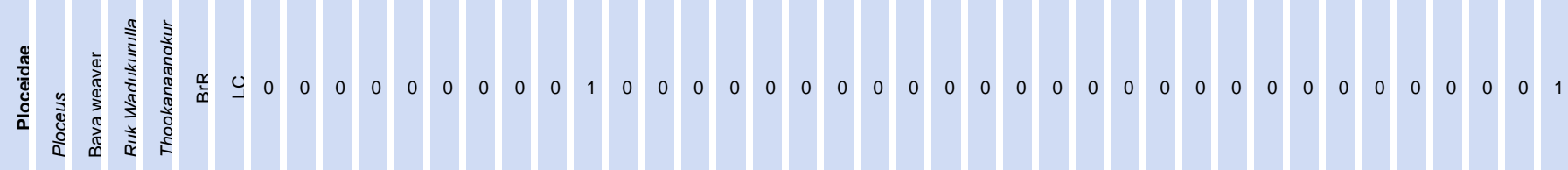

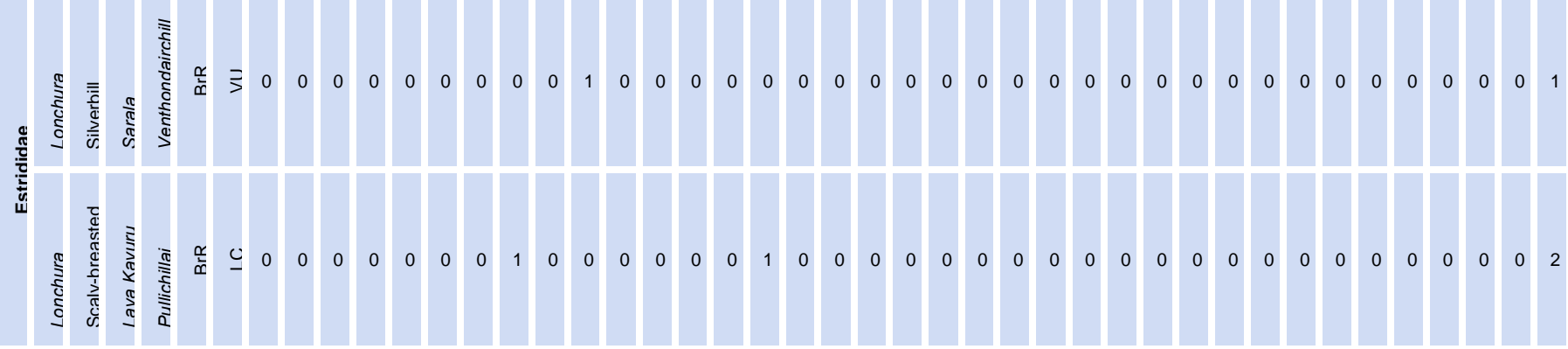




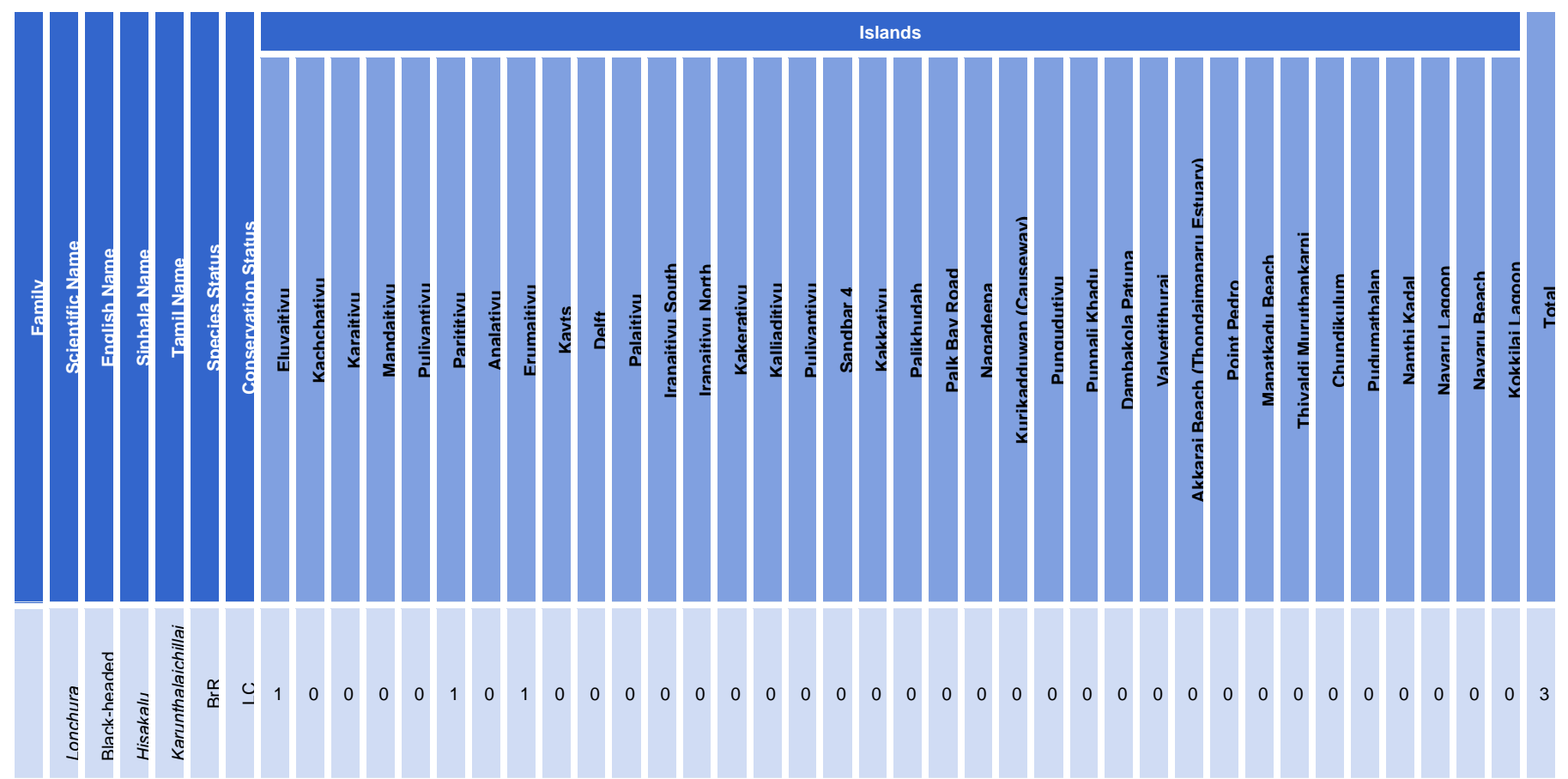


h) Mammals

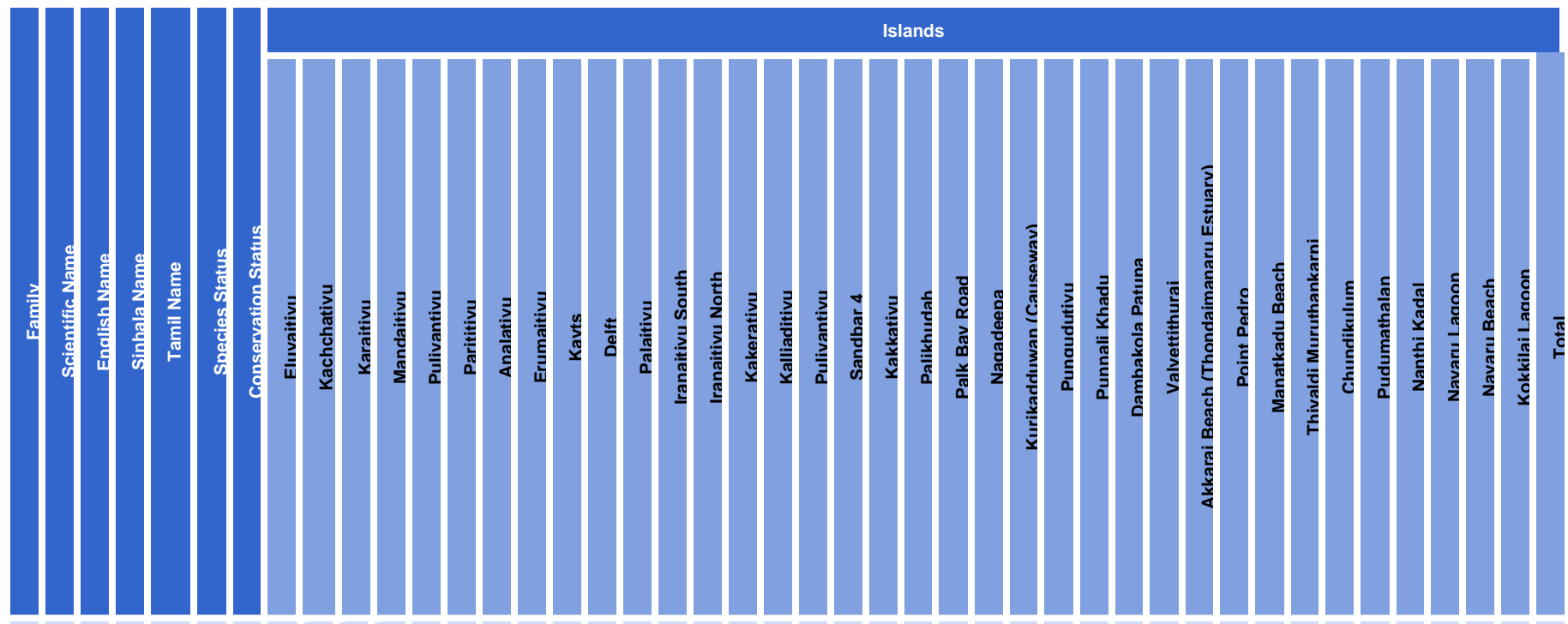

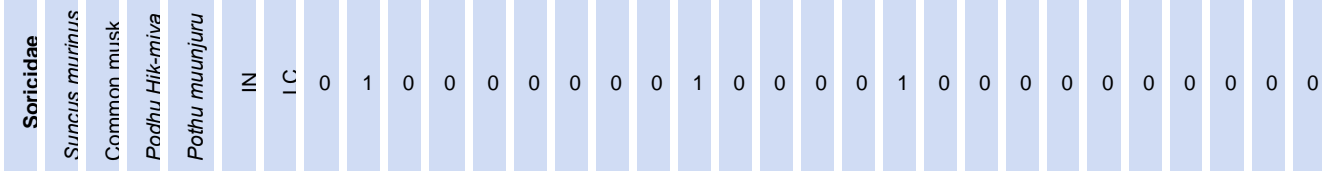

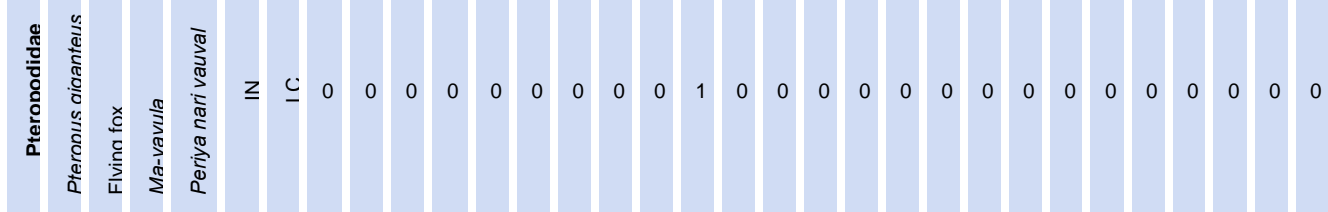

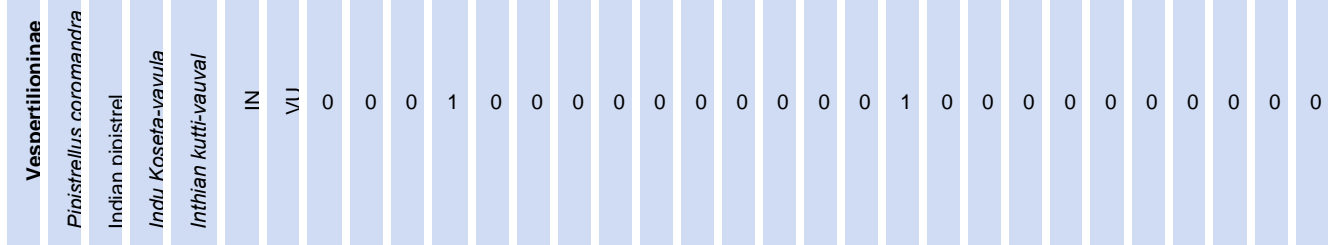

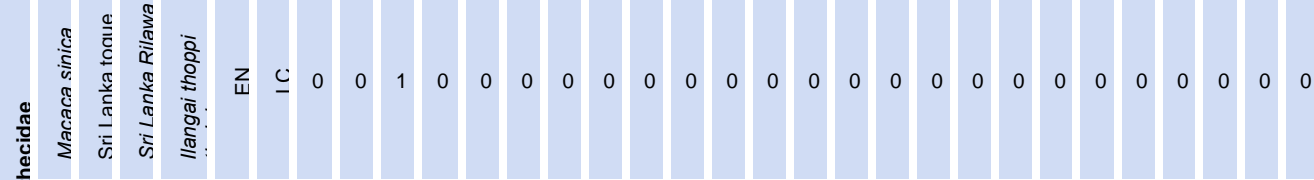

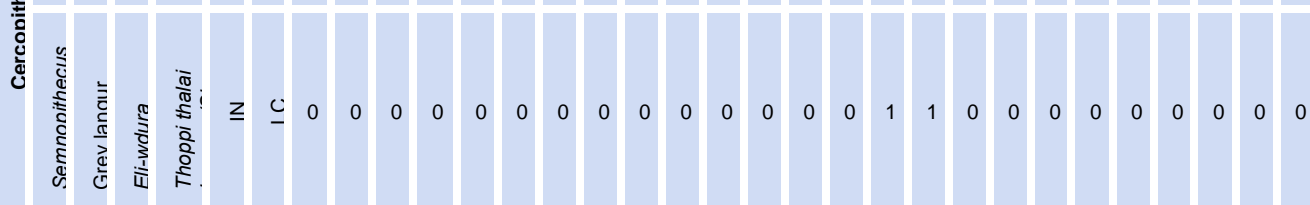

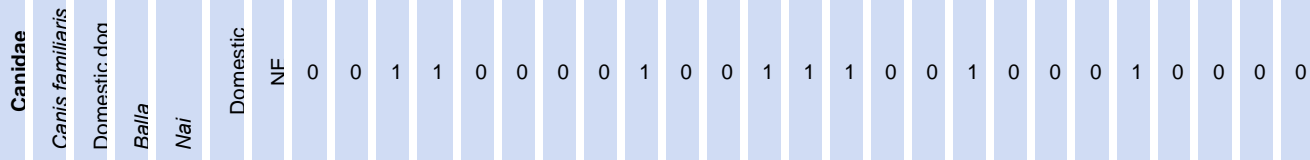

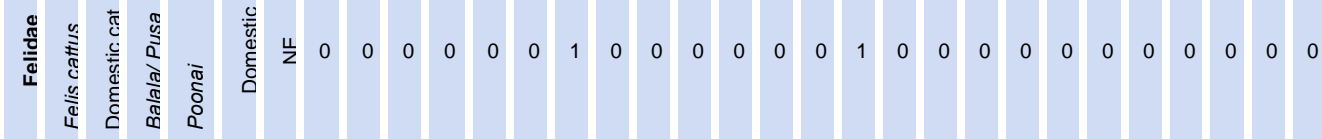




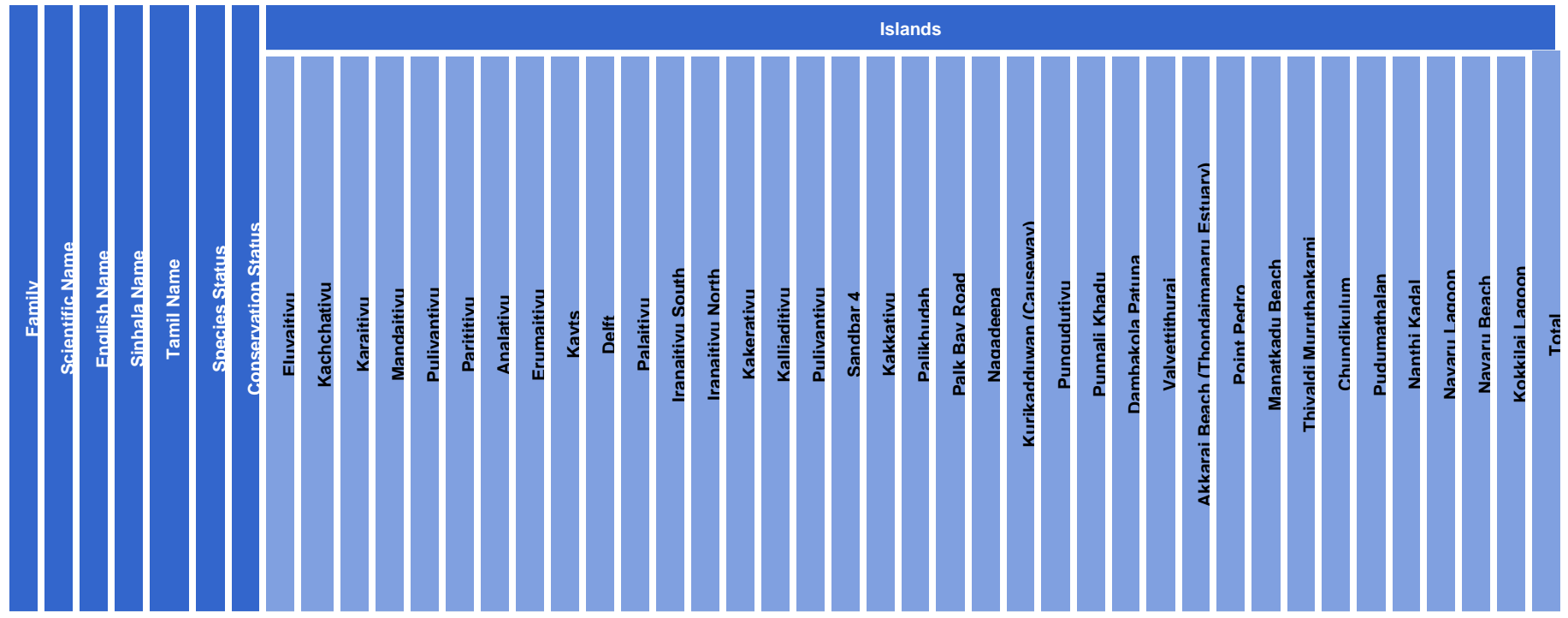

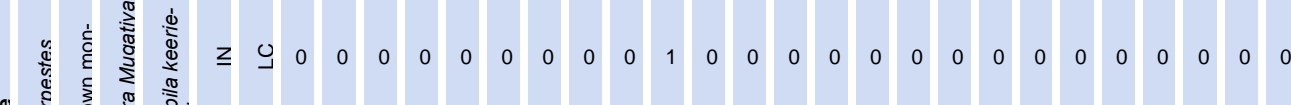

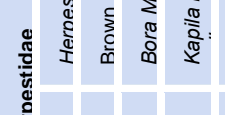

迹

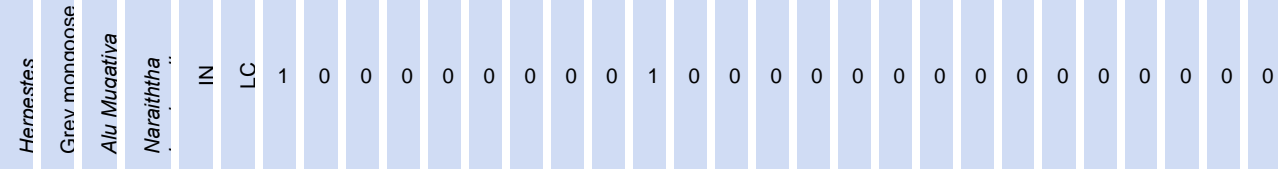

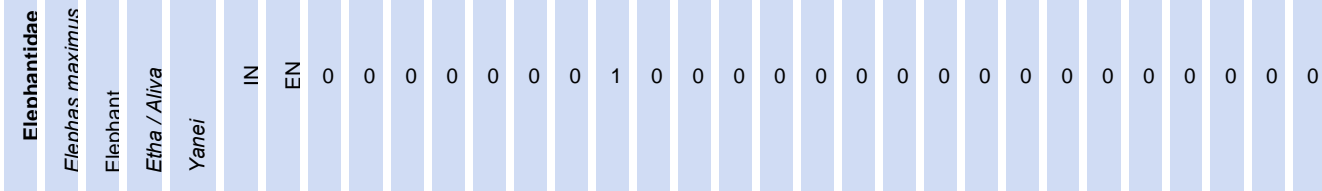

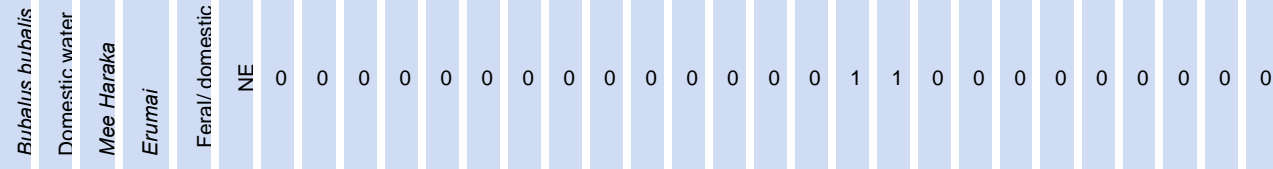

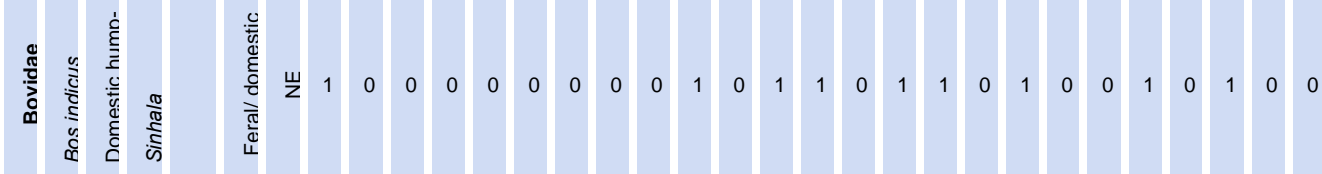

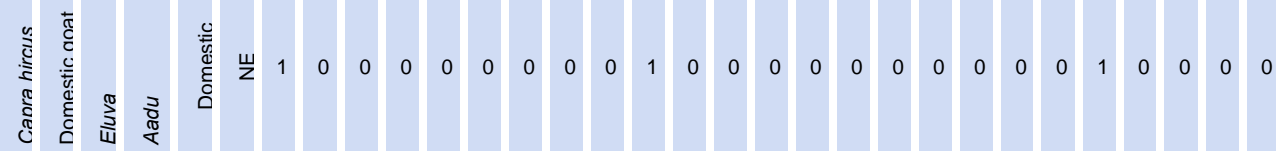

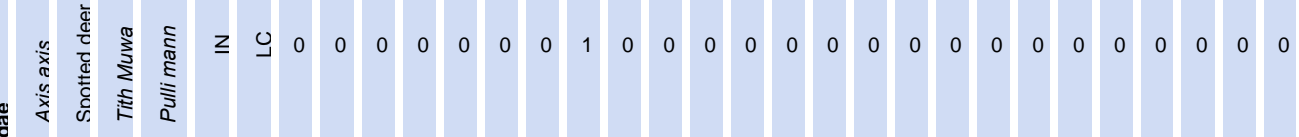

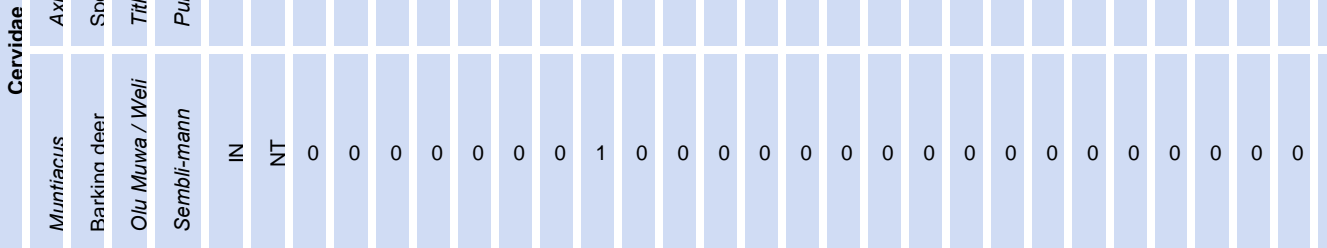




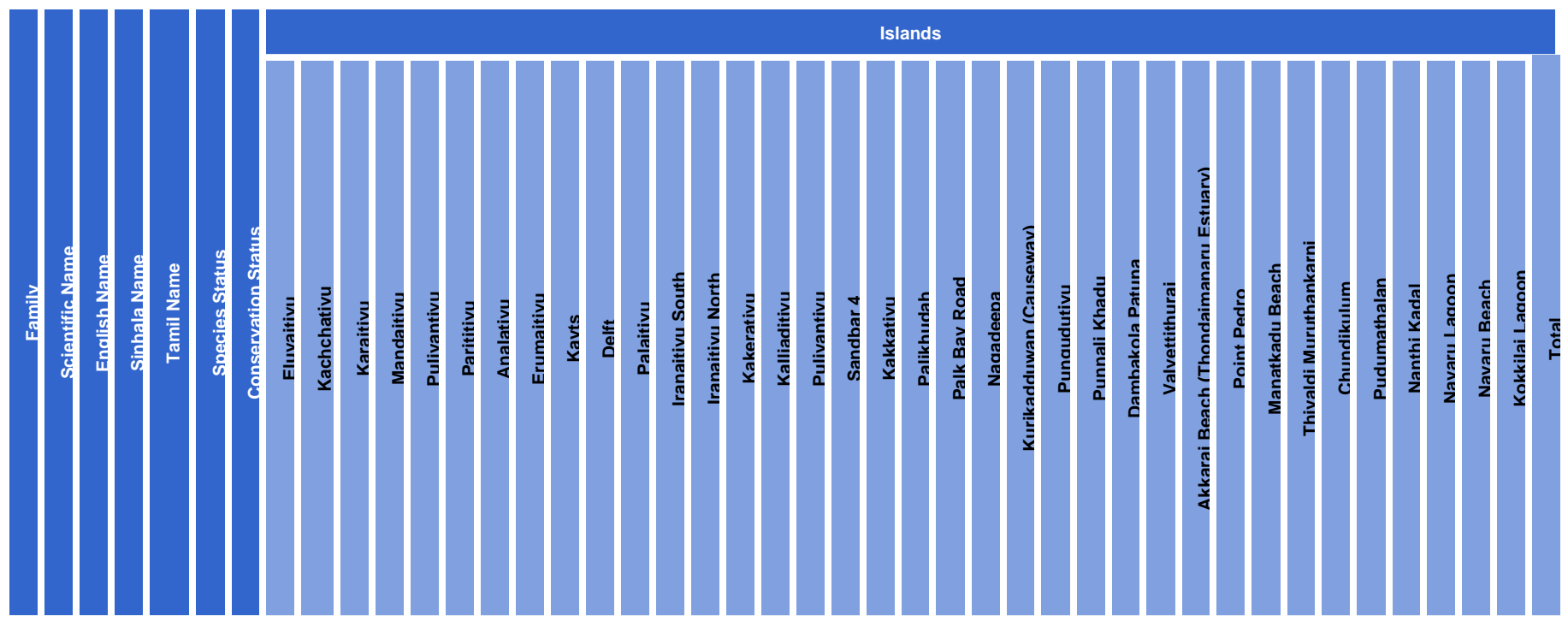

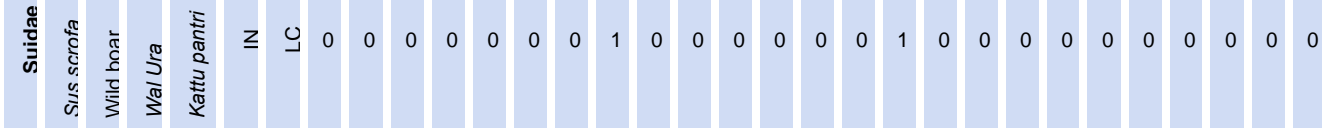

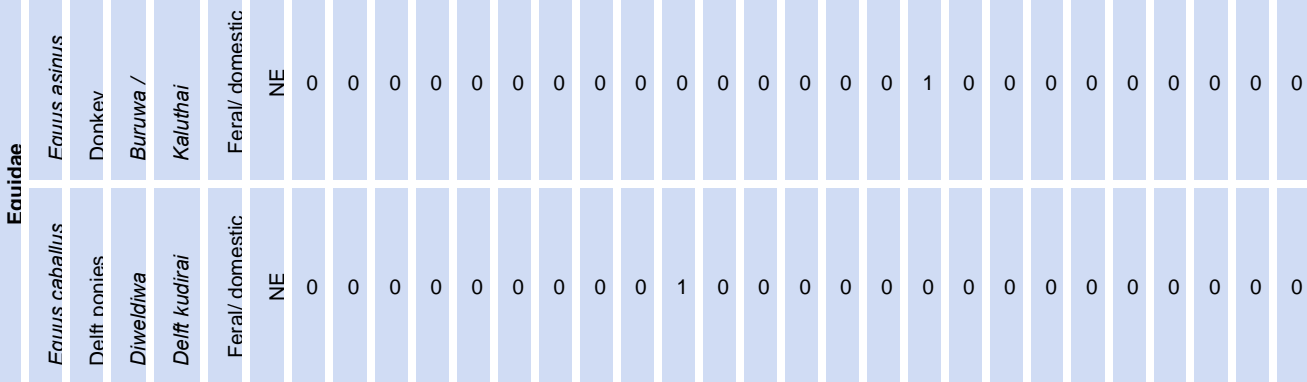

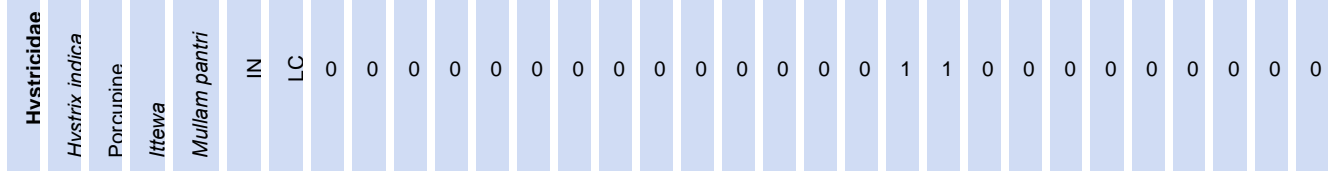

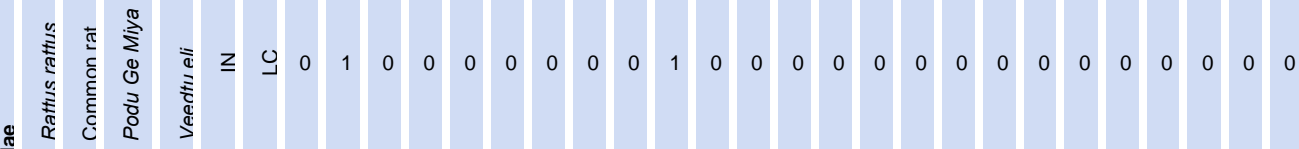

焉

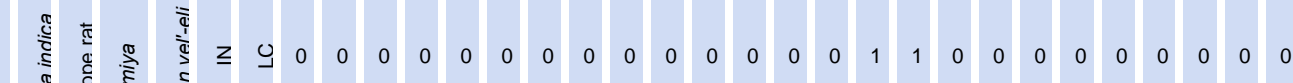

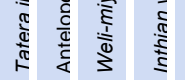

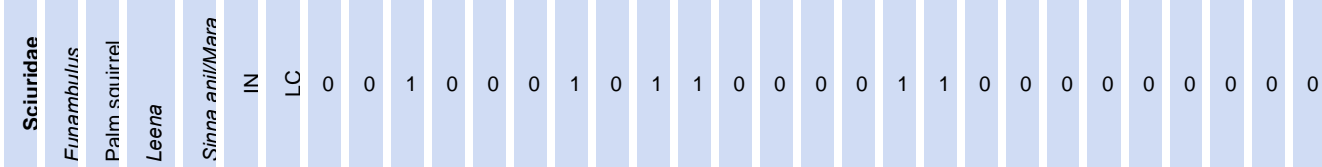

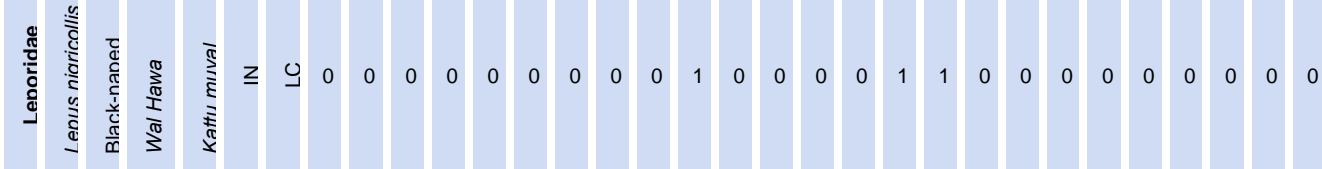




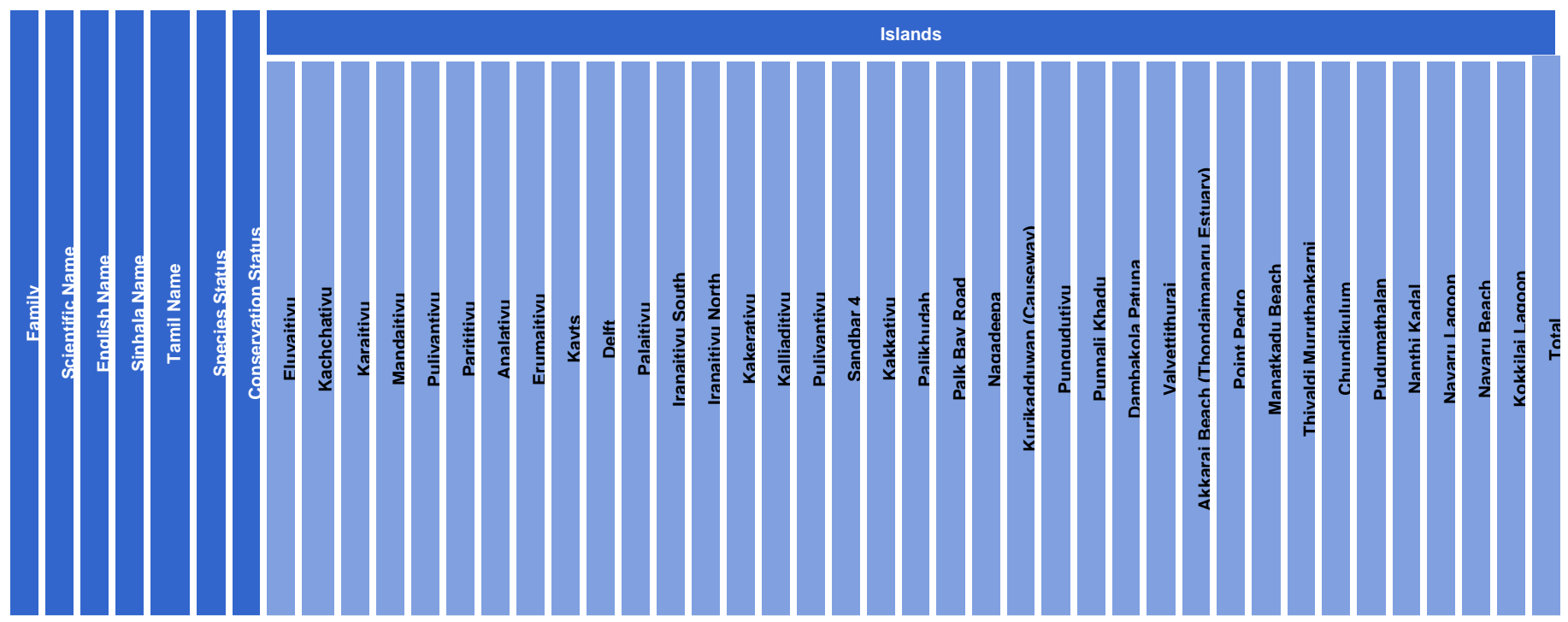

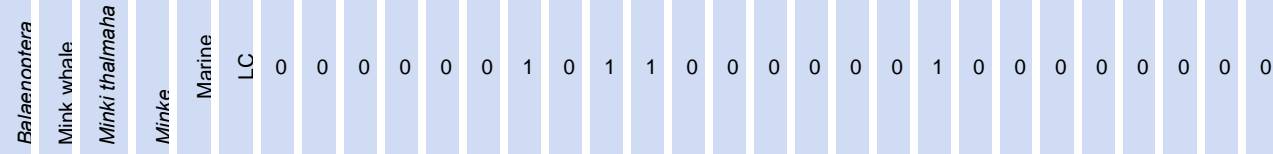

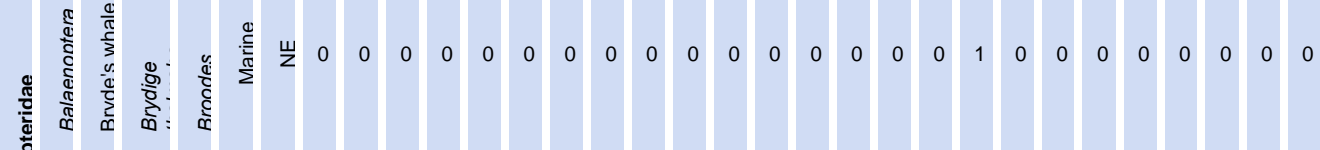

๓ा

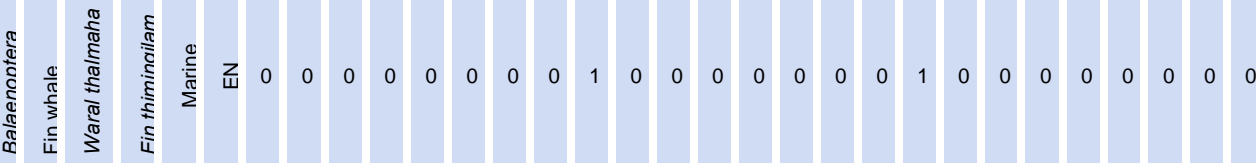

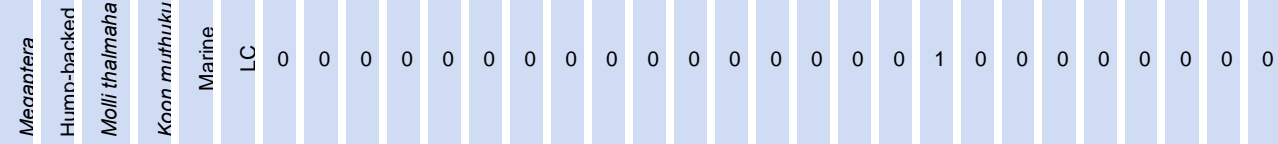

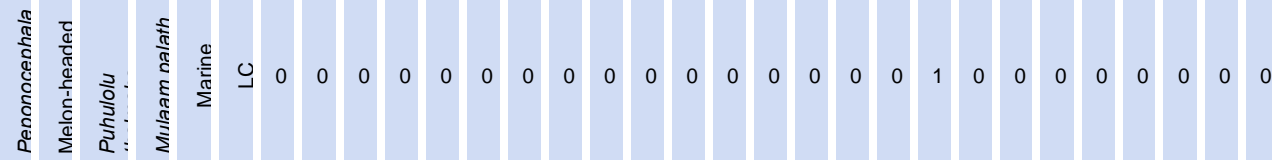

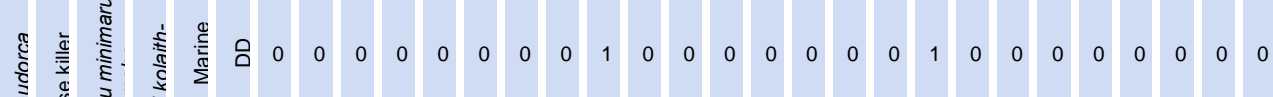

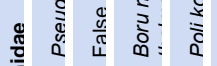

$\frac{d}{d}$

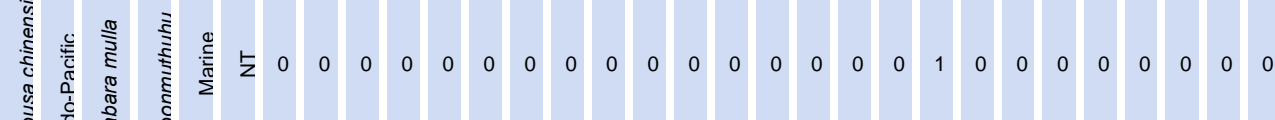

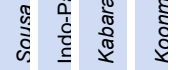

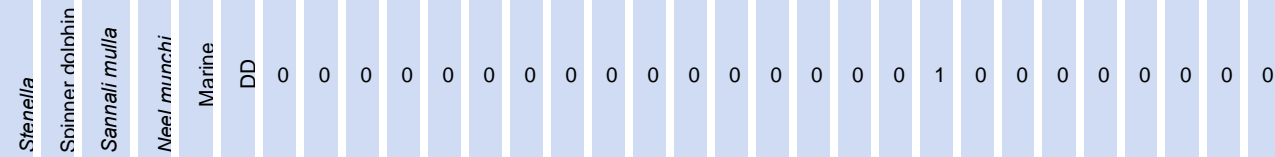




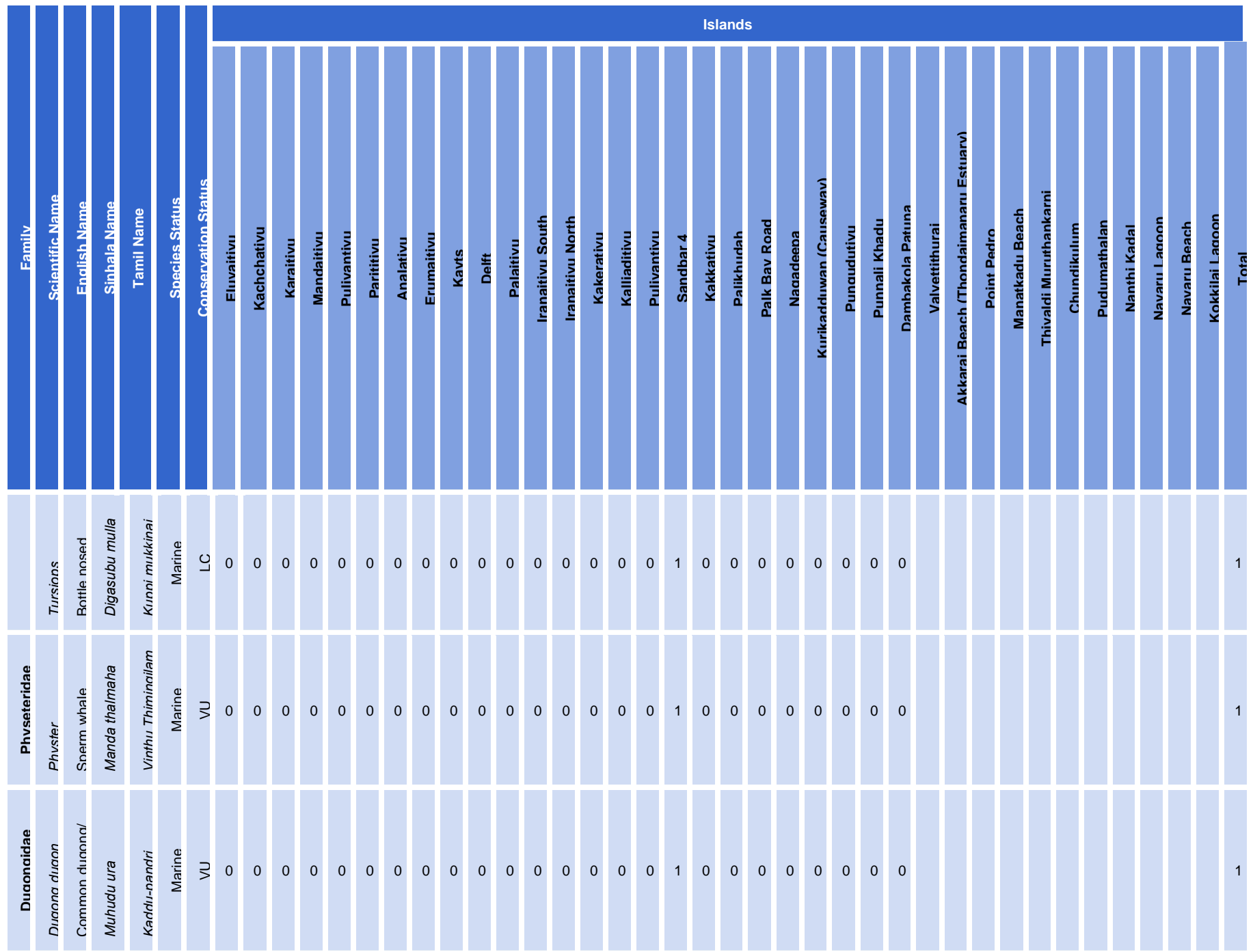

\section{Legend}

\begin{tabular}{|l|l|}
\hline SpS & Species status \\
\hline CoS & Conservation status \\
\hline IN & Indigenous \\
\hline EN & Endemic \\
\hline EX & Exotic \\
\hline$B r R$ & Breeding Resident \\
\hline$W V$ & Winter Visitor \\
\hline$W V a$ & Winter Vagrant \\
\hline$V a$ & Vagrant \\
\hline$S U$ & Status Unknown \\
\hline$S V$ & Summer Visitor \\
\hline$P M$ & Passege Migrent \\
\hline$R$ & Resident \\
\hline$U W V$ & Uncertain Winter Visitor \\
\hline$U B r$ & Uncertain Breeding Resident \\
\hline
\end{tabular}

\begin{tabular}{|l|l|}
\hline CR/PE & Critically Endangered/Possibly Extinct \\
\hline CR & Critically Endangered \\
\hline EN & Endangered \\
\hline VU & Vulnerable \\
\hline NT & Near Threatened \\
\hline DD & Data Deficient \\
\hline LC & Least Conscern \\
\hline NE & Not Evaluated \\
\hline
\end{tabular}




\section{Annex 6. List of coral species found in the study area}

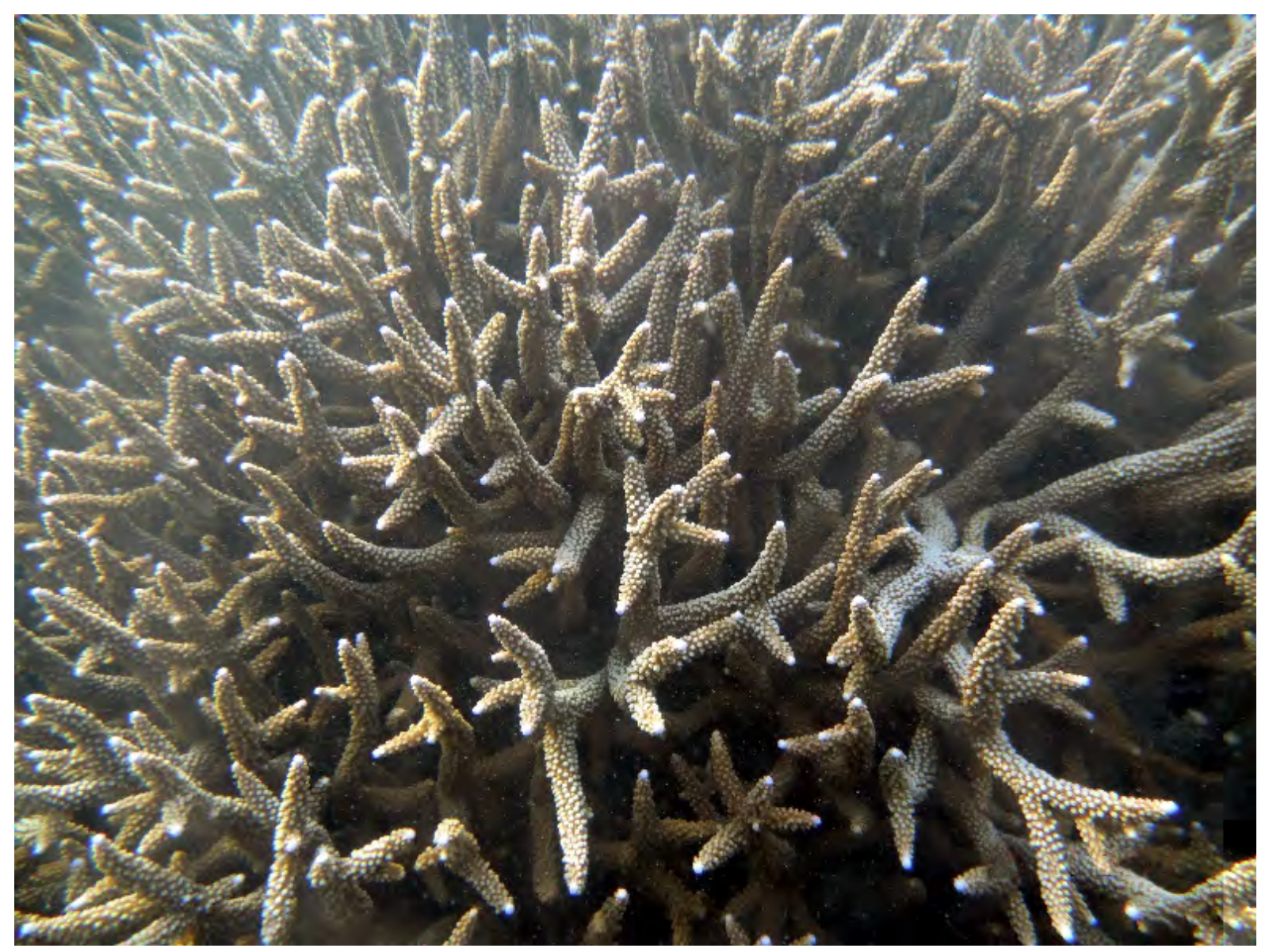

Acropora Formosa, Erumaitivu $\odot$ IUCN/Arjan Rajasuriya 


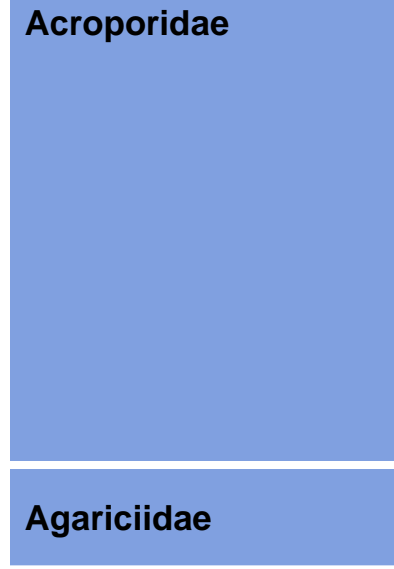

Dendrophyllidae

Faviidae

\section{Merulinidae}

\section{Mussidae}

Acropora aculeus

Acropora anthocercis

Acropora acuminata

Acropora aspera

Acropora cytherea

Acropora divaricata

Acropora digitifera

Acropora hyacinthus

Acropora millepora

Acropora microphthalma

Acropora muricata

Acropora samoensis

Acropora secale

Montipora aequituberculata

Montipora digitata

Montipora foliosa

Montipora verrucosa

Pavona maldivensis

Pavona venosa

Turbinaria mesenterina

Turbinaria peltata

Favia favus

Favia pallida

Favia speciosa

Favites abdita

Favites complanata

Favites halicora

Montastrea curta

Diploastrea heliopora

Goniastrea edwardsi

Goniastrea pectinata

Goniastrea retiformis

Goniastrea aspera

Platygyra lamellina

Platygyra sinensis

Platygyra daedalea

Leptoria phrygia

Leptastrea purpurea

Cyphastrea chalcidicum

Echinopora lamellosa

Podabacia crustacea

Merulina ampliata

Hydnophora microconos

Symphyllia agaricia

Symphyllia radians 


\begin{tabular}{|l|l|}
\multicolumn{1}{|c|}{ Family } & \multicolumn{1}{c|}{ Species } \\
\hline Oculinidae & Galaxea astreata \\
& Pocillopora damicornis \\
\hline \multirow{3}{*}{ Pocilloporidae } & Pocillopora elegans \\
& Pocillopra verrucosa \\
\hline Pocillopora eydouxi & Porites rus \\
\hline Poritidae & Porites lutea \\
\hline Porites lobata \\
\hline Siderastreidae & Goniopora sp \\
\hline
\end{tabular}




\section{Annex 7. List of reef fish species found in the study area}

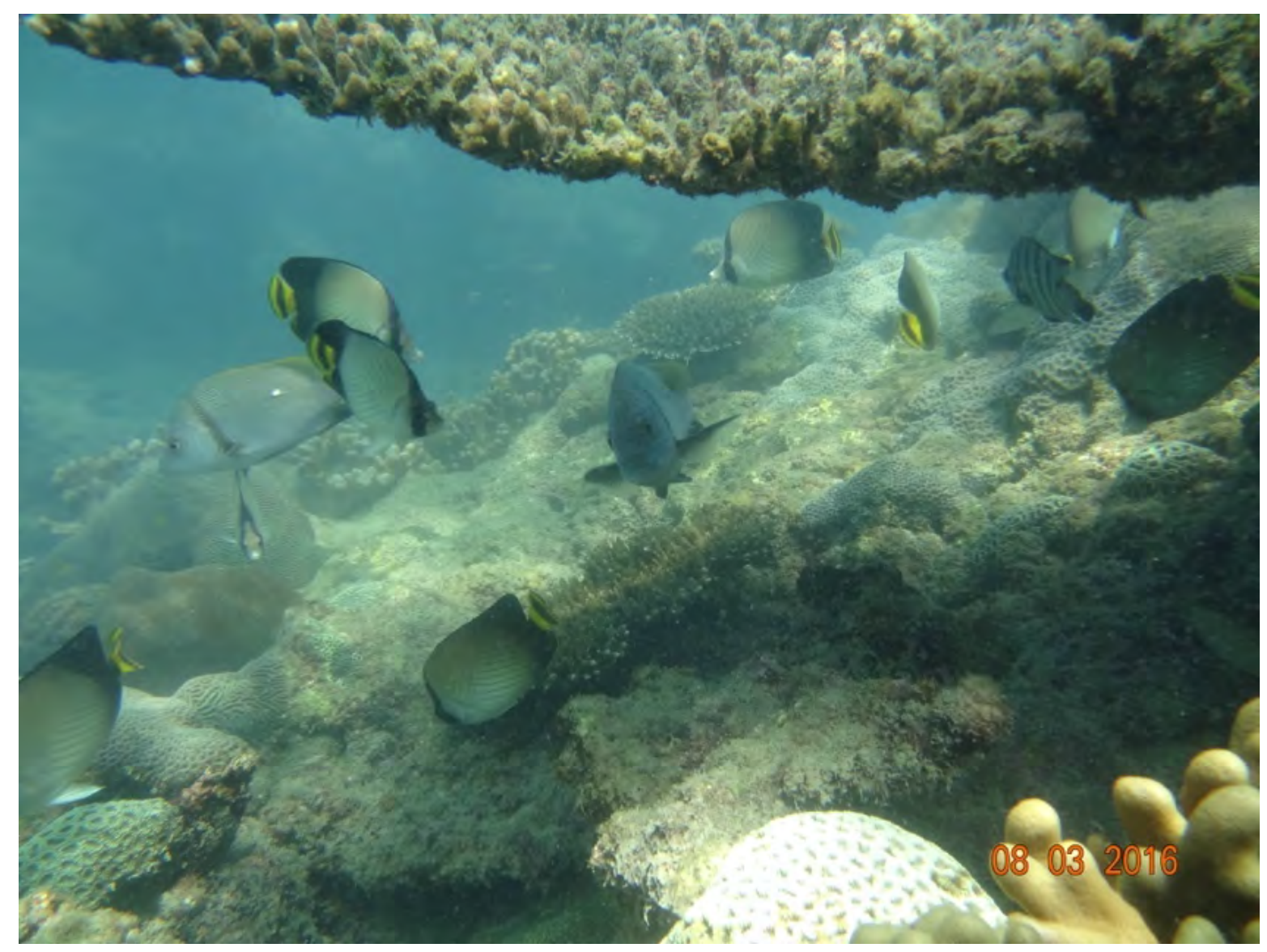

Coral reef, Point Pedro showing two species of butterfly fish

(Chaetodon decussatus and C. andamanensis), a damselfish (Abudefduf vaigiensis) and a snapper (Lutjanus rivulatus) @ IUCN/Arjan Rajasuriya 
The following list draws upon University of Ruhuna (2010).

\begin{tabular}{|c|c|c|c|c|}
\hline Family & Species & $\begin{array}{l}\text { Common name } \\
\text { (English) }\end{array}$ & $\begin{array}{c}\text { Common } \\
\text { name } \\
\text { (Sinhala) }\end{array}$ & $\begin{array}{c}\text { Common } \\
\text { name (Tamil) }\end{array}$ \\
\hline \multirow{10}{*}{ Acanthuridae } & Acanthurus bariene & $\begin{array}{l}\text { Black-spot } \\
\text { surgeonfish }\end{array}$ & & \\
\hline & Acanthurus dussumieri & $\begin{array}{l}\text { Eyestripe } \\
\text { surgeonfish }\end{array}$ & & \\
\hline & $\begin{array}{l}\text { Acanthurus } \\
\text { leucosternon }\end{array}$ & $\begin{array}{l}\text { Powderblue } \\
\text { surgeonfish }\end{array}$ & Nil detha & Nila orandeya \\
\hline & Acanthurus lineatus & Lined surgeonfish & Sevaya & \\
\hline & Acanthurus mata & $\begin{array}{l}\text { Elongate } \\
\text { surgeonfish }\end{array}$ & & \\
\hline & Acanthurus nigricauda & $\begin{array}{l}\text { Epaulette } \\
\text { surgeonfish }\end{array}$ & Kalu orava & \\
\hline & $\begin{array}{l}\text { Acanthurus } \\
\text { xanthopterus }\end{array}$ & $\begin{array}{l}\text { Yellowfin } \\
\text { surgeonfish }\end{array}$ & Orava, Peela & \\
\hline & Ctenochaetus striatus & $\begin{array}{l}\text { Striated } \\
\text { surgeonfish }\end{array}$ & & \\
\hline & Naso brachycentron & $\begin{array}{l}\text { Humpback } \\
\text { unicornfish }\end{array}$ & & \\
\hline & Naso brevirostris & Spotted unicornfish & & \\
\hline \multirow{6}{*}{ Apogonidae } & Ostorhinchus aureus & $\begin{array}{l}\text { Ring-tailed } \\
\text { cardinalfish }\end{array}$ & & \\
\hline & $\begin{array}{l}\text { Ostorhinchus } \\
\text { angustatus }\end{array}$ & $\begin{array}{l}\text { Broadstriped } \\
\text { cardinalfish }\end{array}$ & & \\
\hline & Apogon sp. & - & & \\
\hline & Taeniamia fucata & $\begin{array}{l}\text { Orangelined } \\
\text { cardinalfish }\end{array}$ & & \\
\hline & $\begin{array}{l}\text { Cheilodipterus } \\
\text { macrodon }\end{array}$ & $\begin{array}{l}\text { Large toothed } \\
\text { cardinalfish }\end{array}$ & & \\
\hline & Rhabdamia gracilis & $\begin{array}{l}\text { Luminous } \\
\text { cardinalfish }\end{array}$ & & \\
\hline \multirow{2}{*}{ Blenniidae } & Cirripectes sp & - & & \\
\hline & Salarias $\mathrm{sp}$ & - & & \\
\hline \multirow{5}{*}{ Caesionidae } & Caesio caerulaurea & $\begin{array}{l}\text { Blue and gold } \\
\text { fusilier }\end{array}$ & & \\
\hline & Caesio cuning & $\begin{array}{l}\text { Redbelly yellowtail } \\
\text { fusilier }\end{array}$ & Battalaya & Vaipara \\
\hline & Caesio xanthonota & Yellowback fusilier & & \\
\hline & $\begin{array}{l}\text { Pterocaesio } \\
\text { chrysozona }\end{array}$ & Goldband fusilier & $\begin{array}{l}\text { Hemala, Ilitta, } \\
\text { Illitta }\end{array}$ & Peroomkilche \\
\hline & Pterocaesio tile & $\begin{array}{l}\text { Dark-banded } \\
\text { fusilier }\end{array}$ & & \\
\hline \multirow{3}{*}{ Carangidae } & Caranx heberi & Blacktip trevally & $\begin{array}{l}\text { Atanagul } \\
\text { parava, Guru } \\
\text { parawa, Pareh }\end{array}$ & \\
\hline & Caranx sp & - & & \\
\hline & $\begin{array}{l}\text { Gnathanodon } \\
\text { speciosus }\end{array}$ & Golden trevally & Kabara parava & $\begin{array}{l}\text { Pathi-parah, } \\
\text { Pilli-parah }\end{array}$ \\
\hline
\end{tabular}




\begin{tabular}{|c|c|c|c|c|}
\hline Family & Species & $\begin{array}{l}\text { Common name } \\
\text { (English) }\end{array}$ & $\begin{array}{l}\text { Common } \\
\text { name } \\
\text { (Sinhala) }\end{array}$ & $\begin{array}{c}\text { Common } \\
\text { name (Tamil) }\end{array}$ \\
\hline & Scomberoides lysan & $\begin{array}{l}\text { Doublespotted } \\
\text { queenfish }\end{array}$ & $\begin{array}{l}\text { Gona kattava, } \\
\text { Katta, Katu } \\
\text { bollu kattava, } \\
\text { Nil kattava }\end{array}$ & Katta \\
\hline \multirow{10}{*}{ Chaetodontidae } & Chaetodon auriga & $\begin{array}{l}\text { Threadfin } \\
\text { butterflyfish }\end{array}$ & & \\
\hline & $\begin{array}{l}\text { Chaetodon } \\
\text { andamanensis }\end{array}$ & $\begin{array}{l}\text { Andaman } \\
\text { butterflyfish }\end{array}$ & & \\
\hline & Chaetodon collare & Redtail butterflyfish & & \\
\hline & Chaetodon decussatus & $\begin{array}{l}\text { Indian vagabond } \\
\text { butterflyfish }\end{array}$ & & \\
\hline & Chaetodon lineolatus & Lined butterflyfish & & \\
\hline & Chaetodon Iunula & $\begin{array}{l}\text { Raccoon } \\
\text { butterflyfish }\end{array}$ & & \\
\hline & $\begin{array}{l}\text { Chaetodon } \\
\text { octofasciatus }\end{array}$ & $\begin{array}{l}\text { Eightband } \\
\text { butterflyfish }\end{array}$ & & \\
\hline & Chaetodon trifascialis & $\begin{array}{l}\text { Chevron } \\
\text { butterflyfish }\end{array}$ & & \\
\hline & Chaetodon trifasciatus & Melon butterflyfish & & \\
\hline & $\begin{array}{l}\text { Chaetodon } \\
\text { vagabundus }\end{array}$ & $\begin{array}{l}\text { Vagabond } \\
\text { butterflyfish }\end{array}$ & & \\
\hline Chanidae & Chanos chanos & Milkfish & Vaikkaya & $\begin{array}{l}\text { Pal-kendai, } \\
\text { Palmeen, } \\
\text { Tulucandul }\end{array}$ \\
\hline Cirrhitidae & Paracirrhites forsteri & Blackside hawkfish & & \\
\hline Clupeidae & Unidentified sp & - & & \\
\hline Echeneidae & Echeneis naucrates & Live sharksucker & & \\
\hline Ephippidae & Platax teira & Longfin batfish & & \\
\hline Gerridae & Gerres sp & - & & \\
\hline \multirow{4}{*}{ Gobiidae } & Amblygobius sp & - & & \\
\hline & Amblygobius sphynx & Sphinx goby & & \\
\hline & Salarias sp & - & & \\
\hline & $\begin{array}{l}\text { Valenciennea } \\
\text { sexguttata }\end{array}$ & Sixspot goby & & \\
\hline Kyphosidae & Kyphosus vaigiensis & Brassy chub & & \\
\hline \multirow{4}{*}{ Haemulidae } & $\begin{array}{l}\text { Plectorhinchus } \\
\text { ceylonensis }\end{array}$ & $\begin{array}{l}\text { Sri Lanka } \\
\text { sweetlips }\end{array}$ & Boraluwa & \\
\hline & $\begin{array}{l}\text { Plectorhinchus } \\
\text { gibbosus }\end{array}$ & Harry hotlips & & \\
\hline & Plectorhinchus schotaf & Minstrel sweetlips & $\begin{array}{l}\text { Boraluva, Gal } \\
\text { modha, } \\
\text { Gobeya }\end{array}$ & $\begin{array}{l}\text { Kallu kallewa, } \\
\text { Tholen }\end{array}$ \\
\hline & Pomadasys guoraca & Grunter & & \\
\hline Hemiramphidae & Hemiramphus sp & - & & \\
\hline \multirow{2}{*}{ Holocentridae } & Myripristis sp & - & & \\
\hline & Sargocentron diadema & Crown squirrelfish & & \\
\hline
\end{tabular}




\begin{tabular}{|c|c|c|c|c|}
\hline Family & Species & $\begin{array}{l}\text { Common name } \\
\text { (English) }\end{array}$ & $\begin{array}{c}\text { Common } \\
\text { name } \\
\text { (Sinhala) }\end{array}$ & $\begin{array}{c}\text { Common } \\
\text { name (Tamil) }\end{array}$ \\
\hline & Sargocentron sp & - & & \\
\hline \multirow{5}{*}{ Labridae } & Cheilinus chlorourus & Floral wrasse & $\begin{array}{l}\text { Muthu gireva, } \\
\text { Pothy gireva }\end{array}$ & Kili meen \\
\hline & Halichoeres sp. & - & & \\
\hline & $\begin{array}{l}\text { Halichoeres } \\
\text { margaritaceous }\end{array}$ & Pink-belly wrasse & & \\
\hline & Stethojulis sp & - & & \\
\hline & Thalassoma janseni & Jansen's wrasse & & \\
\hline \multirow[t]{2}{*}{ Latidae } & $\begin{array}{l}\text { Psammoperca } \\
\text { waigiensis }\end{array}$ & Waigieu seaperch & & Chenganni \\
\hline & Lates sp. & - & & \\
\hline \multirow{2}{*}{ Leiognathidae } & Leiognathus sp. & - & & \\
\hline & Karalla daura & Goldstripe ponyfish & & Veri-kare \\
\hline \multirow{3}{*}{ Lethrinidae } & Lethrinus harak & $\begin{array}{l}\text { Thumbprint } \\
\text { emperor }\end{array}$ & & \\
\hline & Lethrinus lentjan & Pink ear emperor & & \\
\hline & Lethrinus $\mathrm{sp}$ & - & & \\
\hline \multirow{6}{*}{ Lutjanidae } & $\begin{array}{l}\text { Lutjanus } \\
\text { argentimaculatus }\end{array}$ & $\begin{array}{l}\text { Mangrove red } \\
\text { snapper }\end{array}$ & $\begin{array}{l}\text { Thambalaya, } \\
\text { Thabalaya, } \\
\text { Adallu, Dhala, } \\
\text { Guru } \\
\text { thambuwa }\end{array}$ & $\begin{array}{l}\text { Adallu, } \\
\text { Antaleyan }\end{array}$ \\
\hline & Lutjanus fulvus & Blacktail snapper & $\begin{array}{l}\text { Pen dhalla, } \\
\text { Padalla }\end{array}$ & \\
\hline & Lutjanus gibbus & $\begin{array}{l}\text { Humpback red } \\
\text { snapper }\end{array}$ & & \\
\hline & Lutjanus johnii & John's snapper & & Parithi \\
\hline & Lutjanus rivulatus & Blubberlip snapper & $\begin{array}{l}\text { Badawa, } \\
\text { Badava, } \\
\text { Kuruviliya, } \\
\text { Rumasse }\end{array}$ & $\begin{array}{l}\text { Kuruvilla, } \\
\text { Baddau cuttu- } \\
\text { pirium }\end{array}$ \\
\hline & Lutjanus russelli & Russell's snapper & & \\
\hline Microdesmidae & Ptereleotris evides & Blackfin dartfish & & \\
\hline Monodactylidae & $\begin{array}{l}\text { Monodactylus } \\
\text { argenteus }\end{array}$ & Silver moony & $\begin{array}{l}\text { Kapu handha, } \\
\text { Kapuwa }\end{array}$ & $\begin{array}{l}\text { Moolen, } \\
\text { Purrandee }\end{array}$ \\
\hline \multirow{3}{*}{ Mugilidae } & Sicamugil cascasia & Yellowtail mullet & & \\
\hline & Mugil cephalus & $\begin{array}{l}\text { Flathead grey } \\
\text { mullet }\end{array}$ & $\begin{array}{l}\text { Is barri godeya, } \\
\text { Kitheya, Thel } \\
\text { godeya }\end{array}$ & $\begin{array}{l}\text { Kasmeen, } \\
\text { Manalei, Manla }\end{array}$ \\
\hline & Mugil sp & - & & \\
\hline \multirow{3}{*}{ Mullidae } & $\begin{array}{l}\text { Parupeneus } \\
\text { barberinus }\end{array}$ & $\begin{array}{l}\text { Dash-and-dot } \\
\text { goatfish }\end{array}$ & & \\
\hline & Parupeneus indicus & Indian goatfish & Gal nagareya & $\begin{array}{l}\text { Kal-nakharai, } \\
\text { Kulnaveri, } \\
\text { Mussara }\end{array}$ \\
\hline & Upeneus tragula & Freckled goatfish & & \\
\hline
\end{tabular}




\begin{tabular}{|c|c|c|c|c|}
\hline Family & Species & $\begin{array}{l}\text { Common name } \\
\text { (English) }\end{array}$ & $\begin{array}{c}\text { Common } \\
\text { name } \\
\text { (Sinhala) }\end{array}$ & $\begin{array}{c}\text { Common } \\
\text { name (Tamil) }\end{array}$ \\
\hline \multirow[b]{2}{*}{ Nemipteridae } & Scolopsis bimaculatus & $\begin{array}{l}\text { Thumbprint } \\
\text { monocle bream }\end{array}$ & Pol ranna & Kundul \\
\hline & Scolopsis vosmeri & $\begin{array}{l}\text { Whitecheek } \\
\text { monocle bream }\end{array}$ & $\begin{array}{l}\text { Andiya, Andiya } \\
\text { Kiri vavoula, } \\
\text { Kiri vavoula }\end{array}$ & $\begin{array}{l}\text { Andiyan, } \\
\text { Kundul, Pal } \\
\text { muta, Pompton }\end{array}$ \\
\hline \multirow{2}{*}{$\begin{array}{l}\text { Ostraciidae } \\
\text { (Boxfish) }\end{array}$} & Ostracion cubicus & Yellow boxfish & & \\
\hline & Ostracion meleagris & $\begin{array}{l}\text { Whitespotted } \\
\text { boxfish }\end{array}$ & & \\
\hline \multirow[b]{2}{*}{ Pempheridae } & Pempheris oualensis & Silver sweeper & & \\
\hline & $\begin{array}{l}\text { Pempheris } \\
\text { vanicolensis }\end{array}$ & Vanikoro sweeper & & \\
\hline Pinguipedidae & Parapercis clathrata & Latticed sandperch & & \\
\hline Plotosidae & Plotosus lineatus & Striped eel catfish & Mudhu hunga & $\begin{array}{l}\text { Irung-keleru, } \\
\text { Kanjakalutti, } \\
\text { Kedal- } \\
\text { changuan }\end{array}$ \\
\hline Pomacanthidae & $\begin{array}{l}\text { Pomacanthus } \\
\text { semicirculatus }\end{array}$ & $\begin{array}{l}\text { Semicircle } \\
\text { angelfish }\end{array}$ & & \\
\hline \multirow{11}{*}{ Pomacentridae } & Abudefduf bengalensis & Bengal sergeant & & \\
\hline & Abudefduf sordidus & Blackspot sergeant & & \\
\hline & $\begin{array}{l}\text { Amblyglyphidodon } \\
\text { leucogaster }\end{array}$ & $\begin{array}{l}\text { Yellowbelly } \\
\text { damselfish }\end{array}$ & & \\
\hline & Amphiprion clarkii & $\begin{array}{l}\text { Yellowtail } \\
\text { clownfish }\end{array}$ & & \\
\hline & Amphiprion sebae & $\begin{array}{l}\text { Sebae } \\
\text { anemonefish }\end{array}$ & & \\
\hline & $\begin{array}{l}\text { Chrysiptera } \\
\text { unimaculata }\end{array}$ & $\begin{array}{l}\text { Onespot } \\
\text { demoiselle }\end{array}$ & & \\
\hline & $\begin{array}{l}\text { Neoglyphidodon } \\
\text { bonang }\end{array}$ & Ocellated damsel & & \\
\hline & $\begin{array}{l}\text { Neopomacentrus } \\
\text { azysron }\end{array}$ & $\begin{array}{l}\text { Yellowtail } \\
\text { demoiselle }\end{array}$ & & \\
\hline & $\begin{array}{l}\text { Neopomacentrus } \\
\text { cyanomos }\end{array}$ & Regal demoiselle & & \\
\hline & Pomacentrus indicus & Indian damsel & & \\
\hline & Stegastes nigricans & Dusky farmerfish & & \\
\hline \multirow[b]{2}{*}{ Pseudochromidae } & Pseudochromis fuscus & Brown dottyback & & \\
\hline & $\begin{array}{l}\text { Pseudochromis } \\
\text { dilectus }\end{array}$ & Dilectis Dottyback & & \\
\hline \multirow{2}{*}{ Scaridae } & Chlorurus rhakoura & $\begin{array}{l}\text { Raggedfin } \\
\text { parrotfish }\end{array}$ & Muli gireva & \\
\hline & Scarus ghobban & $\begin{array}{l}\text { Blue-barred } \\
\text { parrotfish }\end{array}$ & & \\
\hline Scatophagidae & Scatophagus argus & Spotted scat & Ilattiya & \\
\hline
\end{tabular}




\begin{tabular}{|c|c|c|c|c|}
\hline Family & Species & $\begin{array}{l}\text { Common name } \\
\text { (English) }\end{array}$ & $\begin{array}{l}\text { Common } \\
\text { name } \\
\text { (Sinhala) }\end{array}$ & $\begin{array}{c}\text { Common } \\
\text { name (Tamil) }\end{array}$ \\
\hline \multirow{5}{*}{ Serranidae } & $\begin{array}{l}\text { Cephalopholis } \\
\text { boenack }\end{array}$ & Chocolate hind & & Verri-cullawah \\
\hline & Cephalopholis formosa & Bluelined hind & Kangan kossa & Verri kaleva \\
\hline & $\begin{array}{l}\text { Epinephelus } \\
\text { caeruleopunctatus }\end{array}$ & $\begin{array}{l}\text { Whitespotted } \\
\text { grouper }\end{array}$ & & \\
\hline & $\begin{array}{l}\text { Epinephelus } \\
\text { longispinis }\end{array}$ & Longspine grouper & & \\
\hline & $\begin{array}{l}\text { Epinephelus } \\
\text { malabaricus }\end{array}$ & Malabar grouper & $\begin{array}{l}\text { Gal bola, Gal } \\
\text { kossa, Gas } \\
\text { bola }\end{array}$ & $\begin{array}{l}\text { Kalava, Punni- } \\
\text { calawah }\end{array}$ \\
\hline \multirow{5}{*}{ Siganidae } & Siganus argenteus & $\begin{array}{l}\text { Streamlined } \\
\text { spinefoot }\end{array}$ & & \\
\hline & Siganus canaliculatus & $\begin{array}{l}\text { White-spotted } \\
\text { spinefoot }\end{array}$ & & \\
\hline & Siganus javus & Streaked spinefoot & Nava & Ottah \\
\hline & Siganus stellatus & $\begin{array}{l}\text { Brown-spotted } \\
\text { spinefoot }\end{array}$ & & \\
\hline & Siganus virgatus & Barhead spinefoot & & \\
\hline Syngnathidae & Corythoichthys sp & - & & \\
\hline Sparidae & Acanthopagrus berda & & & \\
\hline Sphyraenidae & Sphyraena obtusata & Obtuse barracuda & Theliya, Ulava & \\
\hline Synodontidae & Synodus jaculum & $\begin{array}{l}\text { Lighthouse } \\
\text { lizardfish }\end{array}$ & & \\
\hline \multirow{2}{*}{ Tetraodontidae } & $\begin{array}{l}\text { Arothron } \\
\text { nigropunctatus }\end{array}$ & Blackspotted puffer & Paiththaya & \\
\hline & Canthigaster solandri & Spotted sharpnose & & \\
\hline Zanclidae & Zanclus cornutus & Moorish idol & & \\
\hline
\end{tabular}




\section{Annex 8. List of invertebrates recorded during the survey and beach collection from Kachchaitivu}

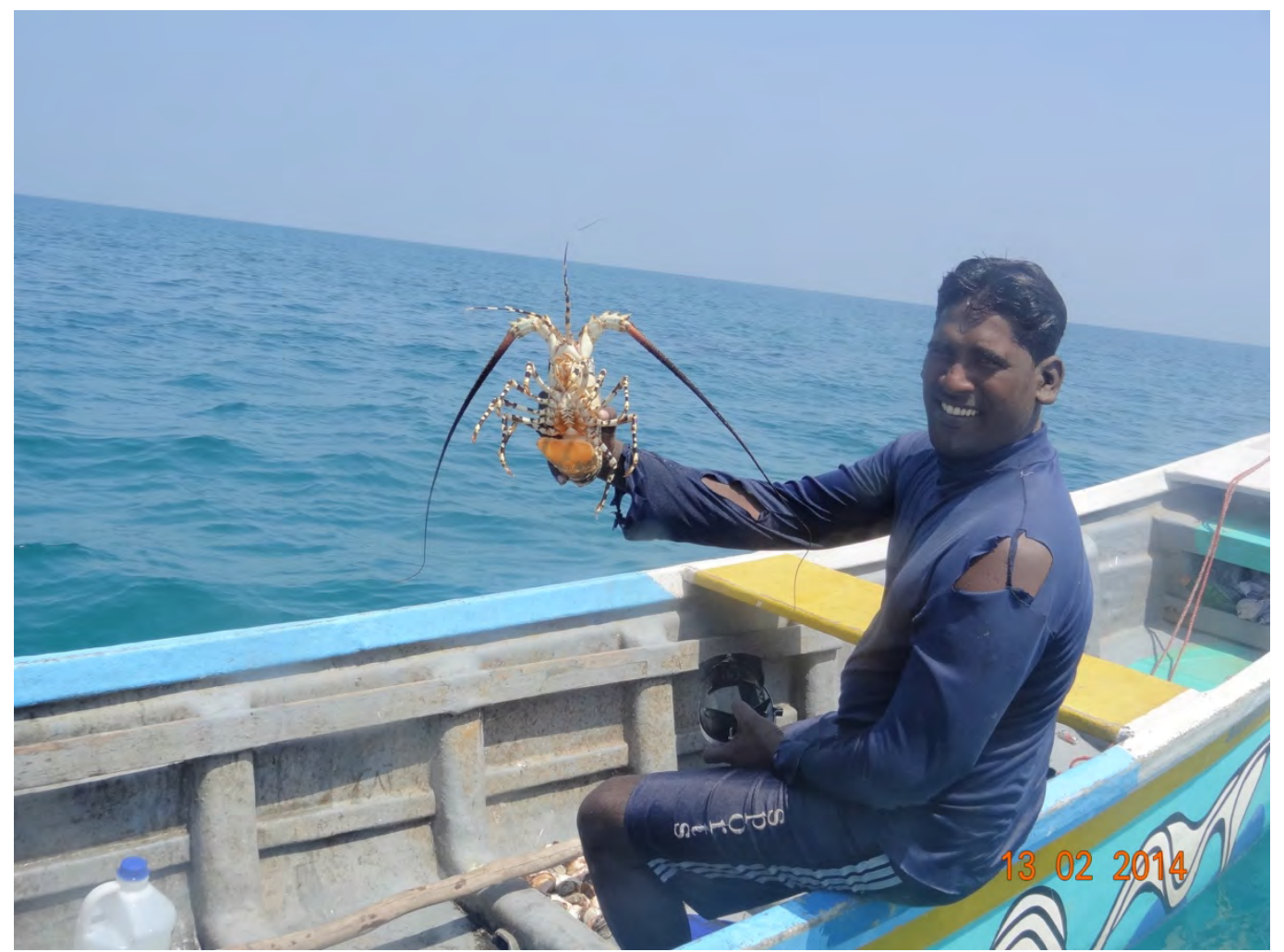

Skin diver with a spiny lobster (Panulirus versicolor), Vankalai Lagoon (c) IUCN/Arjan Rajasuriya 
Species were identified by Dr. Malik Fernando

\begin{tabular}{|c|c|c|c|}
\hline Group & Family & Common name & Species \\
\hline \multirow{12}{*}{ Molluscs } & Cardiidae & Cockles & Unidentified \\
\hline & Fissurellidae & Limpets & Unidentified \\
\hline & Muricidae & Venus comb murex & Murex sp \\
\hline & & Ramose murex & Chicoreus ramosus \\
\hline & Mytilidae & Sea mussels & Unidentified \\
\hline & Olividae & Olive shells & Unidentified \\
\hline & Pectinidae & Scallops & Unidentified \\
\hline & Pteridae & Winged oysters & Unidentified \\
\hline & Strombidae & $\begin{array}{l}\text { Common spider } \\
\text { conch }\end{array}$ & Lambis lambis \\
\hline & & $\begin{array}{l}\text { Chiragra spider } \\
\text { conch }\end{array}$ & Lambis chiragra \\
\hline & Tridacnidae & Fluted giant clam & Tridacna squamosa \\
\hline & Loligonidae & Pharaoh cuttlefish & Sepia pharaonis \\
\hline \multirow{7}{*}{ Crustaceans } & & Painted spiny lobster & Panulirus versicolor \\
\hline & & Mantis shrimp & Squilla sp \\
\hline & & Western king prawn & Penaeus latisulcatus \\
\hline & & Blue swimming crab & Portunus pelagicus \\
\hline & & Giant mud crab & Scylla serrata \\
\hline & & $\begin{array}{l}\text { Mangrove swimming } \\
\text { crab }\end{array}$ & Thalamita crenata \\
\hline & & Barnacles & Unidentified \\
\hline \multirow{4}{*}{ Echinoderms } & $\begin{array}{l}\text { Holothuroidea } \\
\text { (Sea cucumbers) }\end{array}$ & Brown sandfish & Bohadschia marmorata \\
\hline & & Lollyfish & Holothuria atra \\
\hline & & Pinkfish & Holothuria edulis \\
\hline & & Golden Sandfish & Holothuria scabra \\
\hline
\end{tabular}




\section{Annex 9. Legislation related to biodiversity}

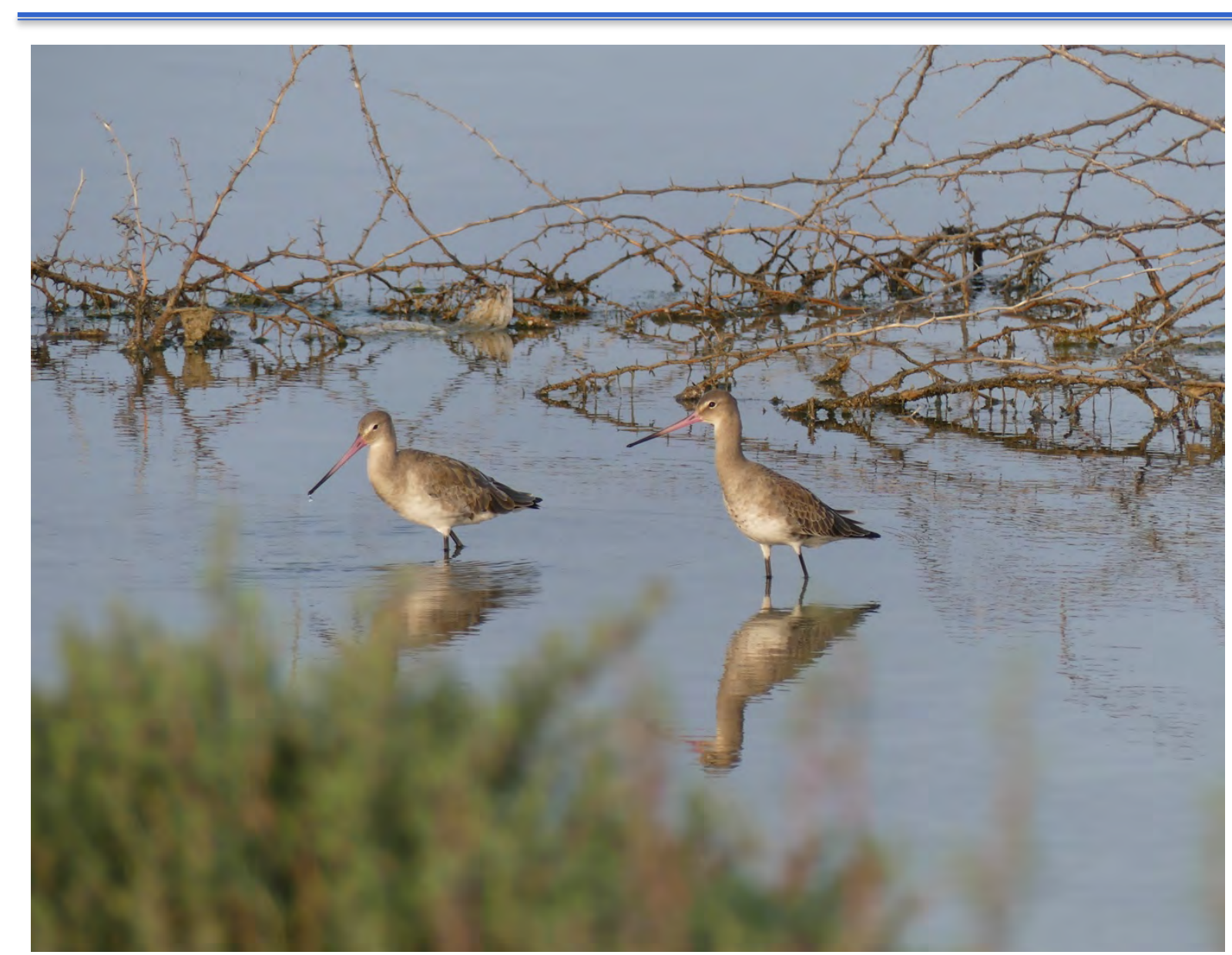

Bar-tailed godwits (Limosa lapponica), winter visitors to Vankalai Nature Reserve $\odot$ Sriyanie Miththapala 


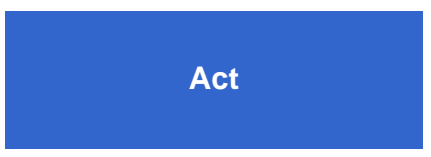

Fauna and Flora

Protection Ordinance, No.

02 of 1937

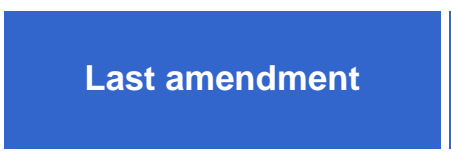

Act No. 22 of 2009

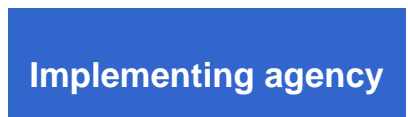

DWC; has empowered

the SLPD and FD also to implement.
Relevance to

biodiversity

conservation

Directly protects habitats and species.

Provisions

This enactment plays the major role in affording protection to indigenous species of animals and plants. It has been amended several times and the latest amendments are by Act No. 22 of 2009. The intention of this enactment are 'to provide for the protection of and conservation of the fauna and flora of Sri Lanka and their habitats, for the prevention of commercial and other misuse of the fauna and flora and their habitats and for the conservation of biodiversity of Sri Lanka'. The provisions of this ordinance are broad and wide, cover the protection of both habitats and species, and also have provisions to regulate the import and export of animals.

The protection of habitats is effected by making them parts of a protected area or declaring the habitat as a protected area. Three types of protected areas, namely National Reserves, Sanctuaries and Managed Elephant Reserves can be declared under this ordinance. The type known as National Reserves can be declared only on state (government) land and the entry in to these areas are restricted according to the category, and there are seven categories under which a National Reserve can be made. These are the Strict Nature Reserves, National Parks, Nature Reserves, Jungle Corridors, Marine National Parks, Refuges and Buffer Zones. The Sanctuaries and Managed Elephant Reserves can have both state and private land within their areas, and there are certain controls and restrictions on activities that are permitted in private lands that fall within these areas. The concept of declaring Managed Elephant Reserves covering both state and private lands is to ensure that both human beings and elephants can live in harmony and not in conflict with each other and is intended to strike a balance between different needs, rather than acquiring such lands to resettle people and declare National Reserves.

The protection of species under this enactment saw a major new development through the latest amendment which brought in a new category of protected species known as Strictly Protected Species for mammals, reptiles and birds. Elephants are provided with a special degree of protection because of their ecological, cultural, social and economic importance and because they are under severe pressure and threat. A special feature in the protection afforded to elephants is the provisions that allow people to keep tame elephants and to keep the tusks of dead elephants in their possession, both being old and traditional practices that are allowed under the law by regulating through a process of registration and permits. There are 20 species of mammals, 16 species of reptiles and 63 species of birds that are listed as Strictly Protected Species. These are given a higher degree of protection by increasing the punishments provided for offences against these species. The protection of birds covers all the migrants (including vagrants and stragglers) that come within the area belonging to Sri Lanka and has been afforded in a manner that any new species that is seen within Sri Lanka will automatically be protected by law. It is noteworthy that all other migrant species belonging to different categories in addition to birds — such as reptiles, mammals and even dragonflies - are enjoying protected status in Sri Lanka.

However, domestic animals are not protected under this ordinance and have been excluded from being provided protection. This enactment also excludes providing protection to exotic or alien species of animals, although the entry of such species is regulated by making it mandatory to import them only under a permit issued by the DWC. 


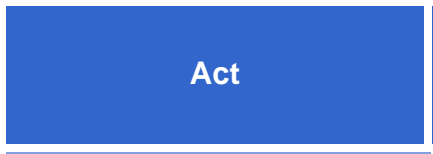

Forest Conservation

Ordinance, No. 16 of 1907
Last amendment

Act No. 65 of 2009. This amendment changed the hitherto used short title of the enactment (Forest Ordinance) to the Forest Conservation Ordinance.

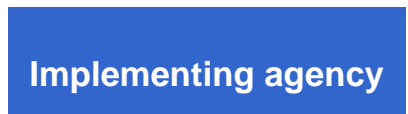

Relevance to biodiversity conservation

The ConservatorGeneral of Forests is responsible for the enforcement of the provisions of the FCO.

\section{Directly protects} forests and species within these forests.

\section{Provisions}

This amendment changed the hitherto used short title of the enactment (Forest Ordinance) to the Forest Conservation Ordinance. The intention of the FCO is to 'Consolidate and amend the law relating to the conservation, protection and the sustainable management of the forest resources and the utilization of forest produce'.

It can be made use of both to provide protection to habitats and regulate and maintain the sustainable use of plant species through a system of permits. This enactment provides for the declaration of three types of protected areas, namely, Conservation Forests, Reserved Forests (Forest Reserves) and Village Forests. All these can be declared on state land only. The Conservation Forests have the highest degree of protection under this enactment and entry is restricted for non-extractive practices only. The type known as Village Forests is declared to cover an area that is used for different purposes by a community or several communities and certain kinds of extractive practices are permitted inside such areas. A very important feature in this enactment is that it provides protection to all state lands within Sri Lanka that are not declared as protected areas by this or by another enactment. Hence, this provision allows these areas to enjoy a certain degree of protection by regulating some of the activities that can be carried out in such lands.

The other important feature in the Forest Conservation Ordinance is that it allows the extractive use of flora under a regulatory system. This is effected through the issue of permits to collect different parts of plants which are grouped under the broad category known as 'Forest Produce'. This category is divided into two, namely Major Forest Products and Minor Forest Products and the former includes timber, while the latter includes parts of plants, as well as medicinal herbs. This system, which has been in place and has been in practice for more than a century, ensures the sustainable use of forest resources. The permit system is geared to ensure the sustainable use of biological material that falls within the category of Forest Products.

According to the Forest Ordinance (Amendment Act, No. 65 of 2009), the Conservator-General of Forests is required to prepare and implement a Management Plan for Reserved Forests, in such manner as may be prescribed, for the purposes of conservation of bio-diversity, soil and water and for the preservation of its unique ecosystem, genetic resources and as a habitat of rare and endemic species of flora and fauna. The Minister shall make regulations applicable either to the whole or any specified area of the Reserved Forests in respect of the administration and management of the Reserved Forests.

In several areas, mangrove forests areas have been brought under the purview of the Forest Department and declared as forest reserves. However, as yet, management plans, as required under the Forest Ordinance, have not yet been prepared.

\begin{tabular}{|c|c|c|c|}
\hline $\begin{array}{l}\text { The National Heritage } \\
\text { Wilderness Areas Act, No. } \\
03 \text { of } 1988\end{array}$ & None & $\begin{array}{l}\text { The Conservator- } \\
\text { General of Forests is } \\
\text { the competent authority }\end{array}$ & $\begin{array}{l}\text { Directly protects } \\
\text { habitats. }\end{array}$ \\
\hline \multicolumn{4}{|c|}{ Provisions } \\
\hline
\end{tabular}

The intention is to provide protection to habitats that are important in terms of biodiversity, as well as for other aspects such as aesthetic values, and geological and hydrological importance of such areas. It does not have provisions to provide any direct protection to species. This enactment is unique in having provisions to afford protected status to an area for reasons other than the value of biodiversity. Therefore, this enactment enables the declaration of areas with special biodiversity values - such as habitats of rare and endangered species - as well as for the protection of wilderness areas for their importance as watersheds and areas that have special aesthetic value. The protection provided to an area declared under this act permits the entry into such areas and allows only non-extractive uses such as tourism and recreational purposes. This act has been made use of to declare only one area as a National Heritage 
Wilderness Area and that is the Sinharaja National Heritage Wilderness Area. However, it has the potential to afford much needed protection to places that have high biodiversity value.

\begin{tabular}{l|l|l} 
& & $\begin{array}{l}\text { Supports biodiversity } \\
\text { conservation by } \\
\text { controlling pollution } \\
\text { and requiring } \\
\text { The National } \\
\begin{array}{l}\text { Environmental Act, No. } 47 \\
\text { of } 1980\end{array}\end{array} \quad \begin{array}{l}\text { Act. No. } 56 \text { of } 1988 \\
\text { Environmental Authority } \\
(\text { CEA) is responsible for } \\
\text { the enforcement of the } \\
\text { provisions of this Act. }\end{array}$ \\
& $\begin{array}{l}\text { for development } \\
\text { projects through } \\
\text { mandatory EIAs. }\end{array}$
\end{tabular}

The intention of this enactment is to provide for the protection, management and enhancement of the environment and for the prevention, abatement and control of pollution of the environment. The main activities under this enactment are the protection of the physical environment by regulating the discharge of substances that may cause pollution to the environment, through a process of licensing. It also has provisions for environmental approval for certain types of new ventures and projects and this approval has to be preceded by an Initial Environmental Examination (IEE) or an Environmental Impact Assessment (EIA) report. The subject matter that is evaluated under these reports includes the biodiversity of the areas that will be affected by the proposed activities and suitable mitigatory measures for the proposed activities. Thus, both the licensing process and the environmental approval have indirect roles in protecting biodiversity. In addition, there are provisions in this act to designate areas as Environmental Protection Areas where the biodiversity value of a particular area merits it to be designated as an Environmental Protection Area. An important feature of this act is that there can be regulations to prohibit, restrict, regulate and approve certain types of activities within such areas and these are effected through regulations.

\begin{tabular}{|c|c|c|c|}
\hline $\begin{array}{l}\text { Coast Conservation Act } \\
\text { No. } 57 \text { of } 1981\end{array}$ & Act No. 64 of 1988 & $\begin{array}{l}\text { The Director of the } \\
\text { CC\&CRMD }\end{array}$ & $\begin{array}{l}\text { Protects biodiversity } \\
\text { in coastal areas. }\end{array}$ \\
\hline
\end{tabular}

The Coastal Zone is defined under this act.

This enactment details regulations related to activities permitted within this zone, as well as those prohibited.

The Director of the CC\&CRMD can request an EIA for development activities in the coastal zone.

The Coast Conservation Amendment Act No. 49 of 2011 provides for the establishment of Special Management Areas (SMAs) and for which regulations can be made with regard to activities, access arrangements and administrative matters. This is an improvement on the earlier Special Area management (SAM) concept which had no legal status. The Coastal Zone and Coastal Resources Management Plan of 2016 has identified a total of 40 SMA sites. SMAs provide a collaborative approach for coastal communities and stakeholders to plan and implement resource management within a defined geographic area of land within the Coastal Zone. A total of 12 SMA sites from Mannar, Jaffna and Mullaitivu have been proposed in the Coastal Zone and Coastal Resources Management Plan of 2016.

SMAs proposed under the Coastal Zone and Coastal Resources Management Plan of 2016 in the study area are: Manatkadu dunes, Jaffna estuary (town area), Thondaimanaru Lagoon, Kankesanthurai and Keeramalai coastal areas, Mandaitivu, Delft, Nainativu, Karainagar (including Casuarina beach) coastal area, Navali coastal area in the Jaffna District; Gulf of Mannar, Thalaimannar coastal area, Silavatturai, Arippu and Aruvi Aru coastal area in the Mannar District and Nanthi Kadal Lagoon and Nayaru Estuary in Mullaitivu (CCZRMP, 2016).

The amended Act No. 49 of 2011 has also extended CC\&CRMD mandate to 100m of the riparian land of the water bodies (rivers/lagoons) within the coastal zone and has also extended CC\&CRMD mandate to implement coastal resources management programs including coordination, information dissemination, research, etc. Therefore, the CC\&CRMD can now be directly and actively involved in natural resources conservation and management, including conservation and management of mangroves and sea grass beds, for example, in the coastal zone. 


\begin{tabular}{|c|c|c|c|}
\hline Act & Last amendment & Implementing agency & $\begin{array}{l}\text { Relevance to } \\
\text { biodiversity } \\
\text { conservation }\end{array}$ \\
\hline $\begin{array}{l}\text { Fisheries and Aquatic } \\
\text { Resources Act, No. } 02 \\
\text { of } 1996\end{array}$ & Act No. 22 of 2006 & $\begin{array}{l}\text { The Director-General of } \\
\text { the Department of } \\
\text { Fisheries and Aquatic } \\
\text { Resources is } \\
\text { responsible for the } \\
\text { enforcement of this } \\
\text { enactment. }\end{array}$ & $\begin{array}{l}\text { Supports biodiversity } \\
\text { conservation by } \\
\text { declaring areas } \\
\text { protected for } \\
\text { regulation of } \\
\text { fisheries, which } \\
\text { supports other } \\
\text { species and habitats } \\
\text { in the area. It also } \\
\text { protects some marine } \\
\text { species. }\end{array}$ \\
\hline
\end{tabular}

Provisions

The objectives of this enactment are to provide for the management, regulation, development and the conservation of the fisheries and aquatic resources of Sri Lanka. This enactment has defined the term 'fish' in a very broad manner and covers not only fish but every species of aquatic fauna from invertebrates to marine and aquatic mammals. The definition of aquatic resources covers every type of aquatic plants including seaweeds and thus, has a broad range of applications. This enactment has provisions to declare protected areas and to declare protected areas and to prohibit the import of any species that can have an adverse impact on aquatic organisms.

There are two types of special areas that can be declared under this enactment, namely the Fisheries Management Areas and Fisheries Reserves. The former are declared for the sustainable management of a particular area and is done through regulations that ensure the sustainable use of fisheries resources and through a process of public participation in decision-making in relation to the area. The type known as Fisheries Reserves is intended to protect a particular resource or the resources that are found in a particular area by restricting and controlling the activities that are allowed in such an area. This provision can be made use of to protect the spawning areas of aquatic animals and to ensure the sustainable use of fisheries resources.

This enactment provides for the declaration of any species from being overexploited and to protect species by restricting or preventing the catching and landing of such species and also through the regulation of exports. Marine mammals and marine turtles and thrasher sharks are protected by prohibition of the catching of these species, while the export trade has been regulated by prohibition of the export of certain species of freshwater and marine species, the mandatory need for permits for the export of yet other species. Another important aspect in this enactment is the powers to prevent the import of any species of aquatic organisms by formulation of regulations. This will help protect biodiversity by preventing the introduction of predators and invasive alien species. The regulations made during the past have prohibited the import of 24 species of fish, which can become either predators or invasive species if released to the water bodies.

Since 2006, the Fisheries Act has been amended in 2013, 2016 and 2017. The Fisheries and Aquatic Resources (Amendment) Act No. 35 of 2013 provides for ecosystem- based collaborative management of designated fisheries/areas through Fisheries Management Coordinating Committees composed of representatives from fishing communities, local administration, local political authority, fisheries agencies (DFAR, NARA, NAQDA), other development (SLTDA, FD, DWC) and regulatory agencies (CC\&CRMD, MEPA, UDA), enforcement authorities, women's groups, etc. These committees are required to develop and implement fisheries management plans in their designated areas, incorporating elements of 
environment/ecosystem conservation. The Fisheries and Aquatic Resources (Amendment) Act No. 11 of 2017 prohibits fishing using bottom trawls.

\begin{tabular}{|c|c|c|c|}
\hline $\begin{array}{l}\text { Marine Pollution } \\
\text { Prevention Act No. } 59 \\
\text { of } 1981\end{array}$ & Act No. 35 of 2008 & $\begin{array}{l}\text { The Marine } \\
\text { Environment Protection } \\
\text { Agency is responsible } \\
\text { for the enforcement of } \\
\text { this enactment. }\end{array}$ & $\begin{array}{l}\text { Supports biodiversity } \\
\text { conservation by } \\
\text { preventing one of the } \\
\text { drivers of its loss, in } \\
\text { the marine sector. }\end{array}$ \\
\hline
\end{tabular}

\section{Provisions}

This enactment mandates the Marine Environment Protection Agency (MEPA) to prevent, control and reduce pollution in the territorial waters of Sri Lanka or any other maritime zone, its fore-shore and the coastal zone of the country.

\begin{tabular}{|c|c|c|c|}
\hline $\begin{array}{l}\text { Antiquities Ordinance } \\
\text { No. } 9 \text { of } 1940\end{array}$ & Act No. 24 of 1998 & $\begin{array}{l}\text { The Director-General of } \\
\text { Archaeology is } \\
\text { responsible for the } \\
\text { enforcement of this } \\
\text { enactment. }\end{array}$ & $\begin{array}{l}\text { Indirectly supports } \\
\text { biodiversity } \\
\text { conservation through } \\
\text { the declaration of } \\
\text { archaeological } \\
\text { reserves which serve } \\
\text { as habitats for } \\
\text { species. }\end{array}$ \\
\hline
\end{tabular}

\section{Provisions}

This ordinance and its amendments provides for the Director General of Archaeology to declare certain areas as Archaeological Reserves, where encroachment of any kind is prohibited. It also empowers the Director General of Archaeology to conduct an Archaeological Impact Assessment of areas that may be affected by development, industrial or other projects proposed by anyone and implement any mitigatory measures that may be required.

\begin{tabular}{|c|c|c|c|}
\hline $\begin{array}{l}\text { Agrarian Development } \\
\text { Act No. } 46 \text { of } 2000\end{array}$ & Act No. 46 of 2011 & $\begin{array}{l}\text { Commissioner General } \\
\text { of Agriculture Agrarian } \\
\text { Development is } \\
\text { responsible for the } \\
\text { enforcement of this } \\
\text { enactment. }\end{array}$ & $\begin{array}{l}\text { Paddy areas are } \\
\text { known to be areas of } \\
\text { high species } \\
\text { richness, so this act } \\
\text { indirectly supports } \\
\text { biodiversity } \\
\text { conservation. }\end{array}$ \\
\hline
\end{tabular}

Provisions

This act prohibits the conversion of paddy land for a purpose other than agricultural cultivation without the written permission of the Commissioner General.

\begin{tabular}{|c|c|c|}
\hline $\begin{array}{l}\text { Plant Protection Act } \\
\text { No. } 35 \text { of } 1999\end{array}$ & $\begin{array}{l}\text { The Director of } \\
\text { Agriculture is } \\
\text { responsible for the } \\
\text { enforcement of this } \\
\text { enactment. }\end{array}$ & $\begin{array}{l}\text { This has direct } \\
\text { bearing on the } \\
\text { spread of invasive } \\
\text { alien species }\end{array}$ \\
\hline
\end{tabular}

Provisions

This act provides for the prevention of wild plants, seeds and plant diseases and controls the introduction of new plant species. 


\begin{tabular}{|c|c|c|c|}
\hline Act & Last amendment & Implementing agency & $\begin{array}{c}\text { Relevance to } \\
\text { biodiversity } \\
\text { conservation }\end{array}$ \\
\hline $\begin{array}{l}\text { Soil Conservation Act } \\
\text { No. } 25 \text { of } 1959\end{array}$ & Act No. 24 of 1996 & $\begin{array}{l}\text { Director of Agriculture, } \\
\text { Ministry of Agricultural } \\
\text { Development is } \\
\text { responsible for } \\
\text { enforcement of this } \\
\text { enactment }\end{array}$ & $\begin{array}{l}\text { Soil erosion damages } \\
\text { water ways that } \\
\text { become sedimented, } \\
\text { thus degrading } \\
\text { aquatic habitats. } \\
\text { This act, therefore, } \\
\text { indirectly supports } \\
\text { biodiversity by } \\
\text { preventing habitat } \\
\text { degradation. }\end{array}$ \\
\hline
\end{tabular}

Provisions

This act and its amendments provide for the conservation of soil resources, mitigation of soil erosion, and protection against floods and drought.

\begin{tabular}{|c|c|c|c|}
\hline $\begin{array}{l}\text { Felling of Trees } \\
\text { (Control) Act No. } 9 \text { of } \\
1951\end{array}$ & Act No. 1 of 2000 & $\begin{array}{l}\text { The Conservator- } \\
\text { General of Forests is } \\
\text { the competent authority }\end{array}$ & $\begin{array}{l}\text { This has a direct } \\
\text { bearing on } \\
\text { threatened species }\end{array}$ \\
\hline
\end{tabular}

Provisions

This act provides for the prohibition and control of the felling of selected tree species.

\begin{tabular}{l|lll}
$\begin{array}{l}\text { State Lands Ordinance } \\
\text { No. } \mathbf{8} \text { of } 1947\end{array}$ & $\begin{array}{l}\text { State lands vested in } \\
\text { Village councils and } \\
\text { Local Authorities- } \\
\text { District Secretary }\end{array}$ & $\begin{array}{l}\text { This act has a direct } \\
\text { bearing on habitat } \\
\text { loss and degradation. }\end{array}$ \\
& Other lands - President
\end{tabular}

This ordinance provides for how state lands and their resources - rivers, streams and reservoirs - should be allocated and managed.

\begin{tabular}{|c|c|c|c|}
\hline $\begin{array}{l}\text { Mahaweli Authority of } \\
\text { Sri Lanka Act No. } 23 \text { of } \\
1979\end{array}$ & Act No. 59 of 1993 & $\begin{array}{l}\text { The Minister of MoMDE } \\
\text { with the approval of the } \\
\text { President }\end{array}$ & $\begin{array}{l}\text { This has a very large } \\
\text { bearing on } \\
\text { biodiversity } \\
\text { conservation the } \\
\text { Mahaweli Basin } \\
\text { covers } 16 \% \text { of the } \\
\text { land area of Sri } \\
\text { Lanka. }\end{array}$ \\
\hline
\end{tabular}

Provisions

This act established the Mahaweli Authority of Sri Lanka and provides for the protection watershed areas and protection of the physical environment of the Mahaweli area.

\begin{tabular}{|c|c|c|c|}
\hline $\begin{array}{l}\text { Urban Development } \\
\text { Authority Law } 1978\end{array}$ & Act No. 41 of 1988 & $\begin{array}{l}\text { Urban Development } \\
\text { Authority }\end{array}$ & $\begin{array}{l}\text { This act has a direct } \\
\text { bearing on habitat } \\
\text { loss and degradation. }\end{array}$ \\
\hline
\end{tabular}

Provisions

This law and its amendments promote integrated planning and implementation of economic, social and physical development in areas declared as urban development areas, all development activity within the said areas fall within the purview of the Urban Development Authority 


\begin{tabular}{|c|c|c|c|}
\hline Act & Last amendment & Implementing agency & $\begin{array}{l}\text { Relevance to } \\
\text { biodiversity } \\
\text { conservation }\end{array}$ \\
\hline $\begin{array}{l}\text { Water hyacinth } \\
\text { Ordinance No. } 9 \text { of } 1909\end{array}$ & No amendment & $\begin{array}{l}\text { Department of } \\
\text { Agriculture }\end{array}$ & $\begin{array}{l}\text { This act has a direct } \\
\text { bearing on the } \\
\text { spread of IAS. }\end{array}$ \\
\hline
\end{tabular}

Provisions

This controls the introduction and proliferation of water hyacinth and other weeds and invasive plants in the country.

\begin{tabular}{|c|c|c|c|}
\hline $\begin{array}{l}\text { The National Zoological } \\
\text { Gardens Act No.14 of } \\
1982\end{array}$ & No amendment & $\begin{array}{l}\text { Department of National } \\
\text { Zoological Gardens }\end{array}$ & $\begin{array}{l}\text { This act has a direct } \\
\text { bearing on } \\
\text { biodiversity } \\
\text { conservation as it } \\
\text { sets up an ex-situ } \\
\text { conservation site. }\end{array}$ \\
\hline
\end{tabular}

Provisions

This Act set governs the management and administration of the National Zoological Gardens.

\begin{tabular}{|c|c|c|c|}
\hline $\begin{array}{l}\text { The Botanic Gardens } \\
\text { Ordinance No. } 31 \text { of } \\
1928 .\end{array}$ & Law No. 32 of 1973 & $\begin{array}{l}\text { Department of National } \\
\text { Botanic Gardens }\end{array}$ & $\begin{array}{l}\text { This act has a direct } \\
\text { bearing on } \\
\text { biodiversity } \\
\text { conservation as it } \\
\text { sets up an ex-situ } \\
\text { conservation site. }\end{array}$ \\
\hline
\end{tabular}

\section{Provisions}

This deals with ex-situ conservation of plants and concerns the management and administration of the National Botanic Gardens.

\begin{tabular}{l|l|l} 
Mines and Minerals Act & Act No. 66 of 2009 & $\begin{array}{l}\text { Board of Management } \\
\text { of the Geological } \\
\text { No. } 33 \text { of } 1992\end{array}$
\end{tabular}

\section{Provisions}

Regulates mining, exploitation, processing, trading and export of minerals.

\begin{tabular}{|c|c|c|c|}
\hline $\begin{array}{l}\text { Irrigation Ordinance } \\
\text { No. } 32 \text { of } 1946 \text { (as } \\
\text { amended) - Part VI. }\end{array}$ & Act No. 13 of 1994 & $\begin{array}{l}\text { Commissioner of } \\
\text { Irrigation }\end{array}$ & $\begin{array}{l}\text { This has a bearing on } \\
\text { e-flows. }\end{array}$ \\
\hline
\end{tabular}

Provisions

Deals with environmental aspects of water, irrigation and land use in irrigated agricultural activities.

\begin{tabular}{|c|c|c|c|}
\hline $\begin{array}{l}\text { Control of Pesticides } \\
\text { Act No. } 33 \text { of } 1980 \text { (as } \\
\text { amended). }\end{array}$ & Act No. 31 of 2011 & Registrar of Pesticides & $\begin{array}{l}\text { This has a direct } \\
\text { bearing on pollution } \\
\text { of soil and water. }\end{array}$ \\
\hline
\end{tabular}

Provides for the licensing and regulation of the import, packing, labelling, storage, formulation, transportation, sale and use of pesticides. 


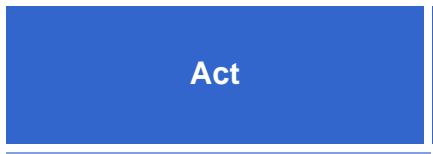

Municipal Councils Ordinance No. 29 of 1947 (as amended).
Implementing agency
Last amendment

Act No. 34 of 2014

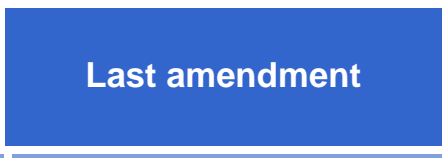

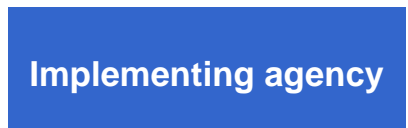

Relevance to biodiversity conservation

This has a direct bearing on solid waste and water pollution.

\section{Provisions}

Provides for the establishment of Municipal Councils and outlines their powers, duties and responsibilities in relation to the built environment and areas such as waste disposal and sanitation.

Urban Councils
Ordinance No. 61 of
1939 (as amended).

\section{Provisions}

Provides for the establishment of Urban Councils and outlines their powers, duties and responsibilities in relation to the built environment and matters such as waste disposal and sanitation.

\begin{tabular}{l|l|l|l}
$\begin{array}{l}\text { Pradeshiya Sabha Act } \\
\text { No. } 15 \text { of } 1987 \text { (as } \\
\text { amended). }\end{array}$ & Act No. 36 of 2014 & Pradeshiya Sabhas & Same as above. \\
\hline & \multicolumn{2}{|c|}{ Provisions }
\end{tabular}

Provides for the establishment of pradeshiya sabhas and outlines their powers, duties and responsibilities in relation to the built environment and matters such as waste disposal and sanitation.

\begin{tabular}{l|l|l|}
$\begin{array}{l}\text { Water Resources Board } \\
\begin{array}{l}\text { Act No. } 29 \text { of } 1964 \text { (as } \\
\text { amended). }\end{array}\end{array}$ & $\begin{array}{l}\text { Act No. } 42 \text { of } 1999 \\
\text { Water Resources }\end{array}$ & $\begin{array}{l}\text { This has a direct } \\
\text { bearing on the } \\
\text { prevention of water } \\
\text { pollution and } \\
\text { attempting to reverse } \\
\text { habitat loss. }\end{array}$ \\
\hline
\end{tabular}

Provisions

Establishes the Water Resources Board and sets out its duties, which include promotion of afforestation, preventing the pollution of rivers, streams and other water courses, and formulation of national policies relating to the control and use of water resources of the country.

\begin{tabular}{|c|c|c|c|}
\hline $\begin{array}{l}\text { Sri Lanka Land } \\
\text { Reclamation and } \\
\text { Development } \\
\text { Corporation Act No. } 15 \\
\text { of } 1968 \text { (as amended) }\end{array}$ & Act No. 49 of 2011 & $\begin{array}{l}\text { Sri Lanka Land } \\
\text { Reclamation and } \\
\text { Development } \\
\text { Corporation }\end{array}$ & $\begin{array}{l}\text { This has direct } \\
\text { bearing on the loss of } \\
\text { wetlands. }\end{array}$ \\
\hline
\end{tabular}

Provisions

Empowers the Sri Lanka Land Reclamation and Development Corporation (SLLR\&DC) to reclaim low-lying lands and wetlands 



\section{IUCN}

INTERNATIONAL UNION FOR CONSERVATION OF NATURE

SRI LANKA COUNTRY OFFICE

53, Horton Place

Colombo 7, Sri Lanka

Tel +94 112682418

Fax +94 1122682470

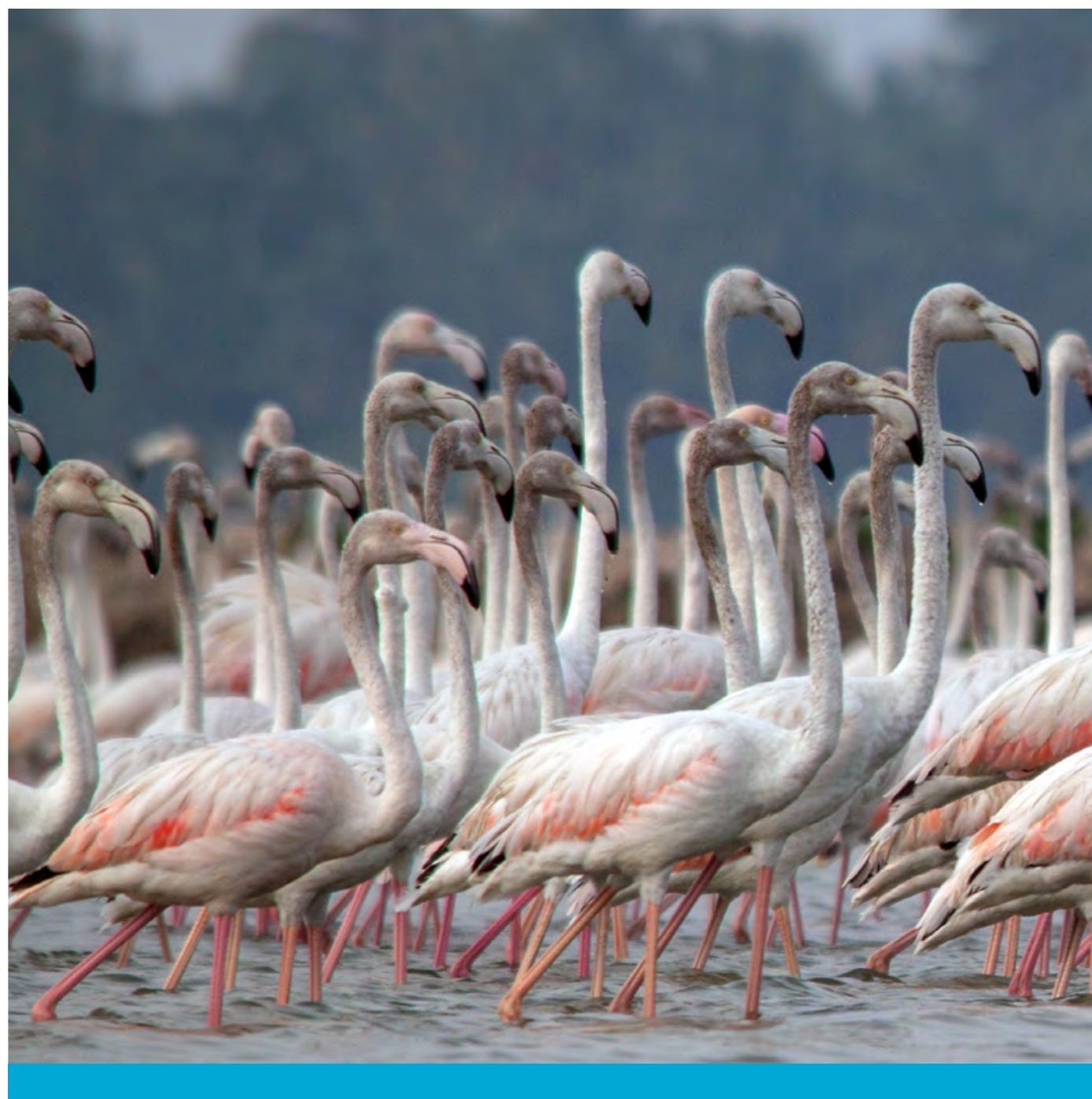

